ANDREA LAURINDVICIUS RIBEIRO

\title{
MÉTODO DE ANÁLISE DE PROJETOS VIÁRIOS PARA MELHORIA DA SEGURANÇA DE PEDESTRES E CICLISTAS EM RODOVIAS CONCESSIONADAS PAULISTAS
}

Dissertação apresentada à Escola Politécnica da Universidade de São Paulo para obtenção do título de Mestre em Engenharia. 


\section{MÉTODO DE ANÁLISE DE PROJETOS VIÁRIOS PARA MELHORIA DA SEGURANÇA DE PEDESTRES E CICLISTAS EM RODOVIAS CONCESSIONADAS PAULISTAS}

Dissertação apresentada à Escola Politécnica da Universidade de São Paulo para obtenção do título de Mestre em Engenharia.

Área de Concentração:

Engenharia de Transportes

Orientador:

Prof. Dr. Hugo Pietrantonio 
Este exemplar foi revisado e alterado em relação à versão original, sob responsabilidade única do autor e com a anuência de seu orientador.

São Paulo, de julho de 2012.

Assinatura do autor

Assinatura do orientador

FICHA CATALOGRÁFICA

Ribeiro, Andrea Laurindvicius

Método de análise de projetos viários para melhoria da segurança de pedestres e ciclistas em rodovias concessionárias paulistas / A.L. Ribeiro. -- ed.rev. -- São Paulo, 2012.

$333 \mathrm{p}$.

Dissertação (Mestrado) - Escola Politécnica da Universidade de São Paulo. Departamento de Engenharia de Transportes.

1. Segurança rodoviária 2. Rodovias (Projeto; Análise; Segurança) I. Universidade de São Paulo. Escola Politécnica. Departamento de Engenharia de Transportes II. t. 


\section{AGRADECIMENTOS}

Primeiramente gostaria de agradecer a Deus, por ele tudo é possível.

Ao professor Hugo Pietrantonio, por toda paciência, dedicação e ensinamento que transmitiu ao longo dessa jornada.

Aos professores da Escola Politécnica que pude ter a honra de conhecer ao longo desses anos, e com que foram de extrema importância no desenvolvimento desse trabalho

Aos colegas da ViaOeste e da EAG que forneceram as informações solicitadas e passaram muito de seu conhecimento em inúmeras conversas.

E finalmente, a minha família que sempre me apoiou incondicionalmente para a realização desse trabalho, sem eles eu não teria conseguido. 


\section{RESUMO}

O objetivo deste trabalho é estudar a segurança de pedestres e ciclistas nas rodovias concessionadas do Estado de São Paulo.

Os conceitos de oportunidade de manobra e oportunidade de conflito de tráfego tem sido usados para obter estimar a segurança em substituição a análise do histórico de acidentes. Estes conceitos têm a vantagem de depender apenas dos dados operacionais do local estudado, como velocidade, fluxo de veículos, fluxo de pedestres, entre outros.

Inicialmente é apresentada a revisão dos dispositivos de segurança para pedestres e ciclistas na literatura nacional e internacional, seus parâmetros de aplicação e projeto.

Com base nessa revisão foi realizado um estudo de campo que buscou formular um modelo de análise para avaliar o nível de segurança de pedestres e ciclistas em rodovias. Este modelo foi validado contra observações de campo (medidas empíricas) e comparação com o histórico de acidentes, com sucesso mas apenas para pedestres. 


\begin{abstract}
The purpose of this work is to study the level of risk for pedestrians and cyclists at highways in São Paulo.

The concepts of maneuver opportunity and conflict opportunity in road traffic have been used to estimate safety in order to replace the accident history. These concepts have the advantage of depend only of traffic data such as, traffic flow and velocity and pedestrian flow, among others.

First, pedestrian and bicycle facilities that improve safety are reviewed in the national and international literature, including applicability and design issues.

Based on this review, the field study was carried-out, indenting to build a model to evaluate the level of risk for pedestrian and cyclists in highways. This model was validated against field observation (empirical measures) and comparison with accident historic, successfully but only for pedestrians.
\end{abstract}




\section{LISTA DE ILUSTRAÇÕES}

Figura 1-1 - Distribuição global de ferimentos mortais por causa (Fonte: Organização Mundial da Saúde - Global Burden of Disease, 2002)

Figura 1-2 - Usuários da via mortos em vários meios de transporte como proporção de todas as mortes de trânsito (Fonte: Organização Mundial da Saúde - Global Burden of Disease, 2002) ......2 Figura 1-3 - Acidentes nas rodovias concessionadas paulistas em 2011 (Dados da ARTESP Agência Reguladora de Transportes do Estado de São Paulo) ......................................................

Figura 2-1 - Sinalização especial de advertência para pedestres.....

Figura 2-2 - Sinalização de indicação para pedestres (Fonte: Código de Trânsito Brasileiro,

Anexo II, 1997)

Figura 2-3 - Sinalização de serviços auxiliares (Fonte: Código de Trânsito Brasileiro, Anexo II, 1997) 20

Figura 2-4 - Faixas de travessia de pedestres (Fonte: Código de Trânsito Brasileiro, Anexo II, 1997)

Figura 2-5 - Marcação de cruzamento rodocicloviários (Fonte: Código de Trânsito Brasileiro, Anexo II, 1997)

Figura 2-6 - Semáforos para pedestres (Fonte: Código de Trânsito Brasileiro, Anexo II, 1997) ...24

Figura 2-7 - Exemplo de semáforo para ciclistas utilizado na cidade de São Paulo .....

Figura 2-8 - Dimensionamento de rampas (Fonte: ABNT NBR9050 Acessibilidade a edificações, mobiliário, espaços e equipamentos urbanos, 2004). 26

Figura 2-9 - Exemplo de interferência do veículo no passeio (Fonte: ABNT NBR9050

Acessibilidade a edificações, mobiliário, espaços e equipamentos urbanos, 2004)

Figura 2-10 - Rampas de acesso provisórias (Fonte: ABNT NBR9050 Acessibilidade a

edificações, mobiliário, espaços e equipamentos urbanos, 2004). .28

Figura 2-11 - Faixa elevada (Fonte: ABNT NBR9050 Acessibilidade a edificações, mobiliário, espaços e equipamentos urbanos, 2004)

Figura 2-12 - Exemplos de rebaixamento de calçada (Fonte: ABNT NBR9050 Acessibilidade a edificações, mobiliário, espaços e equipamentos urbanos, 2004).

Figura 2-13 - Exemplos de rebaixamentos em esquinas (Fonte: ABNT NBR9050 Acessibilidade a edificações, mobiliário, espaços e equipamentos urbanos, 2004). 
Figura 2-14 - Exemplos de rebaixamentos em meio de quadra (Fonte: ABNT NBR9050 Acessibilidade a edificações, mobiliário, espaços e equipamentos urbanos, 2004)

Figura 2-15 - Exemplos com canteiro divisor de pistas (Fonte: ABNT NBR9050 Acessibilidade a edificações, mobiliário, espaços e equipamentos urbanos, 2004).

Figura 2-16 - Elipse corporal do pedestre parado e espaço requerido pelo pedestre andando (Fonte: HCM 2000, TRB, 2001)

Figura 2-17 - Distância de desobstrução visual necessária à frente dependendo de diferentes tipos de movimento (Fonte: Guide for the Planning, Design and Operation of Pedestrian Facilities, America Association of State Highway Transportation Officials, July 2004)..

Figura 2-18 - Gabaritos para pedestres com restrições físicas (Fonte: ABNT NBR9050

Acessibilidade a edificações, mobiliário, espaços e equipamentos urbanos, 2004)

Figura 2-19 - Dimensões de cadeiras de rodas (Fonte: ABNT NBR9050 Acessibilidade a

edificações, mobiliário, espaços e equipamentos urbanos, 2004).

Figura 2-20 - Deslocamento de pessoas em cadeira de rodas e transposição de obstáculos (Fonte: ABNT NBR9050 Acessibilidade a edificações, mobiliário, espaços e equipamentos urbanos, 2004)

Figura 2-21 - Manobras de cadeiras de rodas, sem deslocamento e com deslocamento (Fonte: ABNT NBR9050 Acessibilidade a edificações, mobiliário, espaços e equipamentos urbanos, 2004)

Figura 2-22 - Alcance manual com estação de trabalho: pessoa em cadeira de rodas (Fonte: ABNT NBR9050 Acessibilidade a edificações, mobiliário, espaços e equipamentos urbanos, 2004) ......42 Figura 2-23 - Alcance visual: pessoa em cadeira de rodas (Fonte: ABNT NBR9050 Acessibilidade a edificações, mobiliário, espaços e equipamentos urbanos, 2004). .43

Figura 2-24 - Extensão do trecho com proibição de estacionamento em função da velocidade para travessias em meio de quadra (Fonte: Manual de Segurança de Pedestres, DENATRAN, 1979) 53 Figura 2-25 - Porcentagem de pedestres que utilizam via segura (Fonte: Design and Safety of Pedestrian Facilitys, Institute of Transportation Engeneers, Washington, DC, March 1998. Apud: Guide for the Planning, Design and Operation of Pedestrian Facilities, America Association of State Highway and Transportation Officials, 2004).

Figura 2-26 - Fluxos que justificam a implantação de passarelas (Fonte: Direction des Pontset de la Circulation Routière. Apud: Manual de Projeto Geométrico de Travessias Urbanas, DNIT, 2010) 
Figura 2-27 - Probabilidade de fatalidade de pedestres baseada na velocidade do veículo (Fonte: Pedestrian Facilities User Guide - Providing Safety and Mobility (FHWA-RD-01-102), FHWA, U.S. Department of Transportation, Washington DC, March 2002. Apud: Guide for the Planning, Design and Operation of Pedestrian Facilities, America Association of State Highway

Transportation Officials, July 2004) 68

Figura 2-28 - Distância de estacionamento recomendada e/ou alargamento de calçada (Fonte: Design and Safety of Pedestrian Facilities, ITE, March 1998. Apud: Guide for the Planning, Design and Operation of Pedestrian Facilities, America Association of State Highway Transportation Officials, July 2004)

Figura 2-29 - Velocidade do pedestre em função da declividade da via (Fonte: Manual de Travessias Urbanas, DNIT, 2010).

Figura 2-30 - Relação entre densidade e velocidade de pedestres (Fonte: Manual de Travessias Urbanas, DNIT, 2010).

Figura 2-31 - Dimensionamento de calçadas em função do nível de serviço (Fonte: Manual de Segurança de Pedestres, DENATRAN, 1983)

Figura 2-32 - Raio de curva efetivo (Fonte: Oregon Bicycle and Pedestrian Plan, Oregon Departament of Transportation, 1995. Apud: Guide for the Planning, Design and Operation of Pedestrian Facilities, America Association of State Highway Transportation Officials, 2004 ......80 Figura 2-33 - Pedestrian Design Guidelines Notebook, City of Portland Oregon, Office of Transportation Engineering and Development, 1997. Apud: Guide for the Planning, Design and Operation of Pedestrian Facilities, America Association of State Highway Transportation Officials, 2004).

Figura 2-34 - Exemplo de alargamento de calçada (Fonte: Designing Sidewalks and Trails for Access, Part I, FHWA, 1999. Apud: Guide for the Planning, Design and Operation of Pedestrian Facilities, America Association of State Highway Transportation Officials, 2004).....

Figura 2-35 - Demarcação para faixas de pedestres (Fonte: Guide for the Planning, Design and Operation of Pedestrian Facilities, America Association of State Highway Transportation Officials, 2004)......

Figura 2-36 - Espaço necessário para ciclistas (Fonte: Guide for Development of Bicycle Facilities, AASHTO, 1999)

Figura 2-37 - Seções transversais típicas de ciclofaixas (Fonte: Guide for Development of Bicycle Facilities, AASHTO, 1999). 101 
Figura 2-38 - Sinalização horizontal típica para ciclofaixas em vias de duas mão (Fonte: Guide for Development of Bicycle Facilities, AASHTO, 1999)...... 103

Figura 2-39 - Sinalização horizontal típica em interseções T (Fonte: Guide for Development of Bicycle Facilities, AASHTO, 1999) 104

Figura 2-40 - Ciclofaixas em aproximações de faixas de conversão à direita (Fonte: Guide for Development of Bicycle Facilities, AASHTO, 1999)..... 105

Figura 2-41 - Ciclofaixa em aproximação de interseção com alargamento (Fonte: Guide for Development of Bicycle Facilities, AASHTO, 2004)... 106

Figura 2-42 - Ciclofaixas em aproximações de cruzamentos (Fonte: Bikeway Planning and Design, California State Department of Transportation - Highway Design Manual, HDM. Apud:

Manual de Planejamento Cicloviário, GEIPOT, 2001)... 107

Figura 2-43 - Ciclofaixas em aproximações de cruzamentos (Fonte: Bikeway Planning and Design, California State Department of Transportation - Highway Design Manual, HDM. Apud: Manual de Planejamento Cicloviário, GEIPOT, 2001) 108

Figura 2-44 - Ciclofaixas em aproximações de cruzamentos (Fonte: Bikeway Planning and Design, California State Department of Transportation - Highway Design Manual, HDM. Apud: Manual de Planejamento Cicloviário, GEIPOT, 2001)...... 109

Figura 2-45 - Ciclofaixas em aproximações de cruzamentos (Fonte: Bikeway Planning and Design, California State Department of Transportation - Highway Design Manual, HDM. Apud: Manual de Planejamento Cicloviário, GEIPOT, 2001)...... 110

Figura 2-46 - Distância de visibilidade para ciclovias (Fonte: Guide for Development of Bicycle Facilities, AASHTO, 2004).

Figura 2-47 - Seção transversal de caminho compartilhado bidirecional (Fonte: Guide for Development of Bicycle Facilities, AASHTO, 1999).....

Figura 2-48 - Rampas normais máximas admissíveis em função do desnível a vencer (Fonte:

Manual de Planejamento Cicloviário, GEIPOT, 2001)...... 118

Figura 3-1 - Classificação das oportunidades de travessia e sua relação com a classificação das oportunidades de conflito (Fonte: VASCONCELOS, V.A. - Oportunidades de travessia e oportunidades de conflito para pedestres em interseções semaforizadas, 2004)

Figura 3-2 - Estrutura hierárquica para interseções não semaforizadas. (Fonte: BASILE, O.; PERSIA, L.; USAMI, D.; A Methodology to Assess Pedestrian Crossing Safety, European Transportation Research Review, vol.2, PP. 129-137, 2010) 
Figura 3-3 - Estrutura hierárquica para interseções semaforizadas. (Fonte: BASILE, O.; PERSIA, L.; USAMI, D.; A Methodology to Assess Pedestrian Crossing Safety, European Transportation

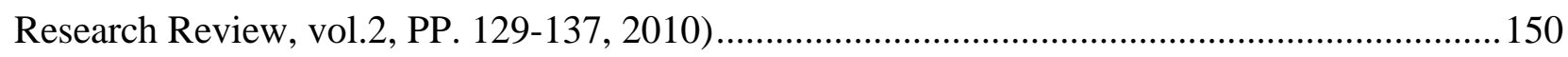

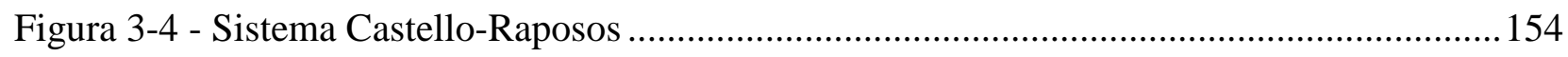

Figura 3-5 - Gráfico de evolução mensal de acidentes envolvendo pedestres e ciclistas na SP 270

Figura 3-6 - Gráfico do comparativo anual de acidentes envolvendo pedestres e ciclistas na SP 270

Figura 3-7 - Gráfico de evolução mensal de acidentes envolvendo pedestres e ciclistas na SP 280

Figura 3-8 - Gráfico do comparativo anual de acidentes envolvendo pedestres e ciclistas na SP 280 . 157

Figura 3-9 - Quadro dinâmico de acidentes - SP 270

Figura 3-10 - Quadro dinâmico de acidentes - SP 280 161

Figura 3-11 - Cronograma de obras concluídas de 2005 a 2010. 163

Figura 3-12 - Cronograma com relação de obras que influenciaram de alguma forma os trechos em estudo.

Figura 3-13 - km 60,5 da SP 270, imagem aérea (Google Earth) e câmera de segurança da concessionária 172

Figura 3-14 - km 60,5 da SP 270, detalhes (Street View - Google Earth).

Figura 3-15 - km 63 da SP 270, imagem aérea (Google Earth) e câmera de segurança da concessionária

Figura 3-16-km 63,5, detalhes

Figura 3-17 - km 29,5 da SP 280, imagem aérea (Google Earth) e câmera de segurança da concessionária 176

Figura 3-18 - km 29,5 da SP 280, detalhes (Street View - Google Earth).

Figura 3-19 - km 30 da SP 280, imagem aérea (Google Earth) e câmera de segurança da concessionária 178

Figura 3-20 - km 30 da SP 280, detalhes (Street View - Google Earth). 179

Figura 3-21 - Diagramas de condição inicial - SP 270 . 184

Figura 3-22 - Diagramas de Condição inicial - SP 280 186 
Figura 3-23 - Evolução anual de acidentes envolvendo pedestres e ciclistas na SP 270, kms 63 e

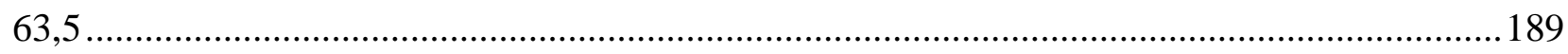

Figura 3-24 - Método proposto para análise de segurança de pedestres e ciclistas .....................235 


\section{LISTA DE TABELAS}

Tabela 1-1 - Evolução dos acidentes nas rodovias concesisonadas paulistas (Dados da ARTESP Agência Reguladora de Transportes do Estado de São Paulo)

Tabela 2-1 - Dimensionamento de rampas (Fonte: ABNT NBR9050 Acessibilidade a edificações, mobiliário, espaços e equipamentos urbanos, 2004).

Tabela 2-2 - Extensão do trecho com proibição de estacionamento em função da velocidade para travessias em meio de quadra (Fonte: Manual de Segurança de Pedestres, DENATRAN, 1979) .53 Tabela 2-3 - Fórmulas para cálculo do atraso sofrido por pedestres em pistas simples e dupla em diferentes tipos de travessia (Fonte: Baseado no Manual de Segurança de Pedestres,

DENATRAN, 1979).

Tabela 2-4 - Fórmulas para cálculo do atraso sofrido por pedestres em pistas simples e dupla em diferentes tipos de travessia (Fonte: Baseado no Manual de Segurança de Pedestres,

DENATRAN, 1979).

Tabela 2-5- Valores recomendados para velocidade de pedestres em rampas (Fonte: manual de Segurança de Pedestres, DENATRAN, 1983)

Tabela 2-6 - - Critério de grade para calçadas (Fonte: Guide for the Planning, Design and Operation of Pedestrian Facilities, America Association of State Highway Transportation Officials, 2004).

Tabela 2-7- Critério de fluxo médio para NS em caminhos e calçadas (Fonte: Special Report 209:

Highway Capacity Manual, TRB. National Research Council, Washington, D.C., 2000)..... 86

Tabela 2-8 - Critério de NS para caminhos e calçadas com o efeito de pelotões (Fonte: Special Report 209: Highway Capacity Manual, TRB. National Research Council, Washington, D.C., 2000)

Tabela 2-9 - Critério de NS para pedestres em caminhos compatilhados (Fonte: Special Report 209: Highway Capacity Manual, TRB. National Research Council, Washington, D.C., 2000)....88 Tabela 2-10 - - Critério de NS para áreas de espera de pedestres (Fonte: Special Report 209: Highway Capacity Manual, TRB. National Research Council, Washington, D.C., 2000)..... 88

Tabela 2-11 - Critério de NS para pedestres em interseções semaforizadas (Fonte: Special Report 209: Highway Capacity Manual, TRB. National Research Council, Washington, D.C., 2000)....89 
Tabela 2-12 - - Critério de NS para pedestres em interseções não semaforizadas (Fonte: Special Report 209: Highway Capacity Manual, TRB. National Research Council, Washington, D.C., 2000).

Tabela 2-13 - - Critério americano de seleção de infra-estrutura para ciclistas no meio urbano

(Fonte: Selecting Roadway Design Treatments to Acommodate Bicycles, FHWA, 1992) .96

Tabela 2-14 - - Critério americano de seleção de infra-estrutura para ciclistas no meio rural (Fonte: Selecting Roadway Design Treatments to Acommodate Bicycles, FHWA, 1992) ..... .96

Tabela 2-15 - Critério inglês de seleção de infra-estrutura para ciclistas no meio urbano (Fonte:

London Cycling Design Standards, 2005)

Tabela 2-16 - - Largura recomendada da faixa de tráfego compartilhado de acordo com AADT

(Fonte: Geometric Design Guide for Canadian Roads, TAC, 1999)

Tabela 2-17 - Largura efetiva de ciclovia unidirecional de acordo com o tráfego horário de bicicletas (Fonte: Manual de Planejamento Cicloviário, GEIPOT, 2001).

Tabela 2-18 - Largura efetiva de ciclovia bidirecional de acordo com o tráfego horário de bicicletas (Fonte: Manual de Planejamento Cicloviário, GEIPOT, 2001).

Tabela 2-19 - Desobstrução lateral (Fonte: Geometric Design Guide for Canadian Roads, TAC, 1999)

Tabela 2-20 - Raio mínimo desejável para ciclovias pavimentadas baseado em ângulo de tombamento de 15o (Fonte: Guide for Development of Bicycle Facilities, AASHTO, 1999).....115 Tabela 2-21 - Raio mínimo desejável para ciclovias pavimentadas baseado em superelevação de $2 \%$ e ângulo de tombamento de 20o (Fonte: Guide for Development of Bicycle Facilities,

AASHTO, 1999) 116

Tabela 2-22 - - Afastamento lateral mínimo para curvas horizontais, em função da distância de visibilidade e raio da curva (Fonte: Guide for Development of Bicycle Facilities, AASHTO, 1999)

Tabela 2-23 - - Grades maiores que 5\% (Fonte: Guide for Development of Bicycle Facilities, AASHTO, 1999)

Tabela 2-24 - comprimentos mínimos de curva vertical necessário para garantir uma distância de visibilidade de parada (Fonte: Guide for Development of Bicycle Facilities, AASHTO, 2004) .119 Tabela 2-25 - Critério de NS para bicicletas em vias exclusivas (Fonte: Special Report 209:

Highway Capacity Manual, TRB. National Research Council, Washington, D.C., 2000). 123 
Tabela 2-26 - Critério de NS para ciclistas em vias de uso compartilhado segregadas do tráfego motorizado (Fonte: Special Report 209: Highway Capacity Manual, TRB. National Research

Council, Washington, D.C., 2000)

Tabela 2-27 - NS para bicicletas em interseções semaforizadas (Fonte: Special Report 209:

Highway Capacity Manual, TRB. National Research Council, Washington, D.C., 2000).... 126

Tabela 3-1 - Oportunidades de conflito em interseções com sinalização de prioridade (Fonte:

MING, S. H. - Oportunidades de Conflito de Tráfego - Modelos de Previsão, 2008),

Tabela 3-2 - Parâmetros (e Erro Padrão) dos Modelos Estimados por DAVIS (2007) para

Severidade dos Acidentes com Pedestres em Função da Velocidade de Impacto (em km/h)

Tabela 3-3 - Escala semântica de Saaty (Fonte: BASILE, O.; PERSIA, L.; USAMI, D.; A

Methodology to Assess Pedestrian Crossing Safety, European Transportation Research Review,

vol.2, PP. 129-137, 2010)

Tabela 3-4 - SP 270 - Acidentes por dia da semana

Tabela 3-5 - SP 270 - Acidentes por gravidade 168

Tabela 3-6 - SP 280 - Acidentes por dia da semana.

Tabela 3-7 - SP 280 - Acidentes por gravidade

Tabela 3-8 - Dados básicos de operação km 60,5 da SP 270. 181

Tabela 3-9 - Dados básicos de operação km 63 da SP 270

Tabela 3-10 - Dados básicos de operação km 29,5 da SP 280

Tabela 3-11 - Dados básicos de operação km 30 da SP 280

Tabela 3-12 - Medidas empíricas de OTs e OCs - km 60,5 da SP 270

Tabela 3-13 - Medidas empíricas de OTs e OCs - km 63 da SP 270 193

Tabela 3-14 - Medidas empíricas de OTs e OCs - km 29,5 da SP 280....................................... 196

Tabela 3-15 - Medidas empíricas de OTs e OCs - km 30 da SP 280 .........................................196

Tabela 3-16 - Cálculo das OTs e OCs teóricas

Tabela 3-17 - Validação das medidas teóricas de oportunidade de manobra (OT) e oportunidade de conflito (OC)

Tabela 3-18 - Análise estatística dos modelos de previsão

Tabela 3-19 - Medidas empíricas de OTs e OCs

Tabela 3-20 - Medidas teóricas de OTs e OCs (1b)

Tabela 3-21 - Análise das obras de melhoria - "antes" e "depois" para cálculos de oportunidade de manobra e de conflito 
Tabela 3-22 - Distâncias de visibilidade considerando obstruções visuais.

Tabela 3-23 - CO/ano e OCE/ano (efetiva) - (Modelo 1b). 


\title{
SUMÁRIO
}

\author{
AGRADECIMENTOS \\ RESUMO \\ ABSTRACT \\ LISTA DE ILUSTRAÇÕES \\ LISTA DE TABELAS
}

\section{INTRODUÇÃO E OBJETIVOS.}

\section{1}

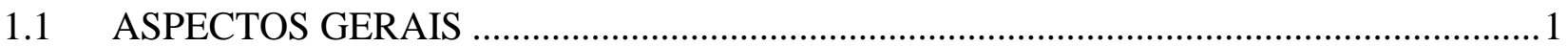

1.2 CONCEITUAÇÃO DOS ACIDENTES COM PEDESTRES E CICLISTAS .....................4

1.3 DISPOSITIVOS DESTINADOS À MELHORIA DA SEGURANÇA DE PEDESTRES E

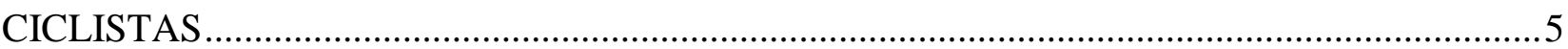

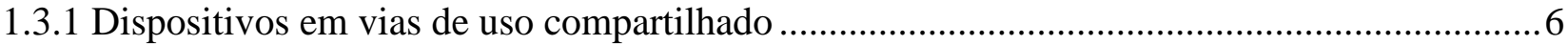

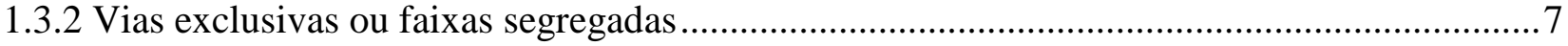

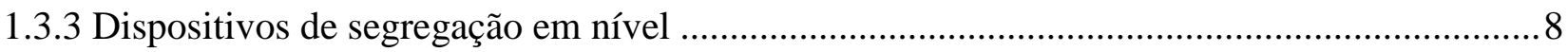

1.4 CONTEXTO URBANO, RURAL E A PECULIARIDADE DAS RODOVIAS .................8

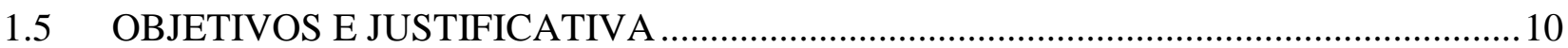

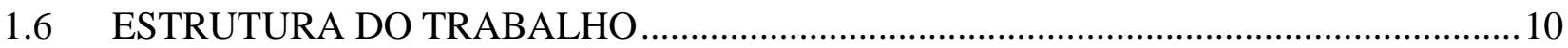

\section{ANÁliSE DOS TRATAMENTOS PARA SEGURANÇA DE PEDESTRES E}

CICLISTAS

2.1 NORMAS LEGAIS RELATIVAS A CIRCULAÇÃO DE PEDESTRES E CICLISTAS NO BRASIL....

2.1.1 Disposições do Código de Trânsito Brasileiro (BRASIL, 1997)

2.1.2 Norma Brasileira ABNT NBR9050: Acessibilidade a edificações, mobiliário, espaços e equipamentos urbanos

2.2 METODOLOGIAS PARA SELEÇÃO E PROJETO DO TRATAMENTO MAIS ADEQUADO 
2.2.2 Referências, Guias e Manuais de Estudos de Acidentes .....................................................35

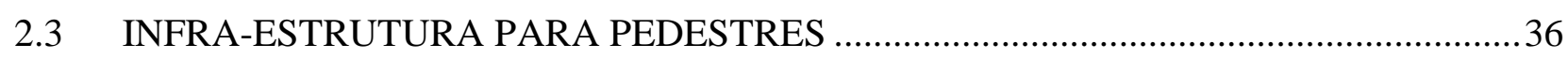

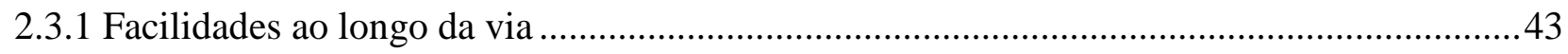

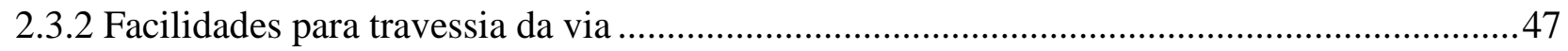

2.4 PARÂMETRO DE PROJETO PARA PEDESTRES .....................................................67

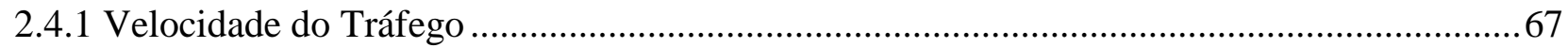

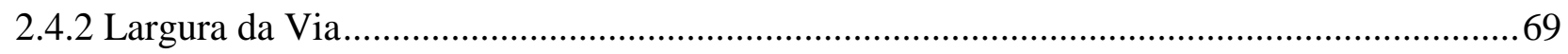

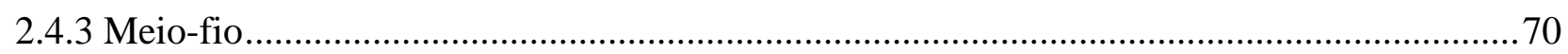

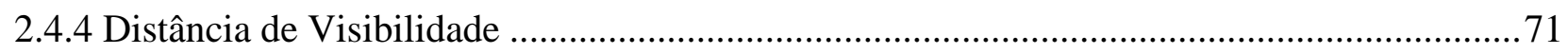

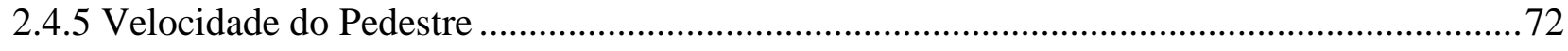

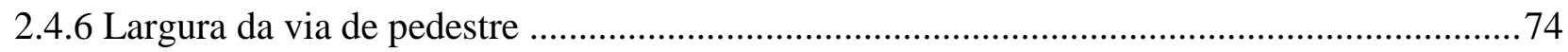

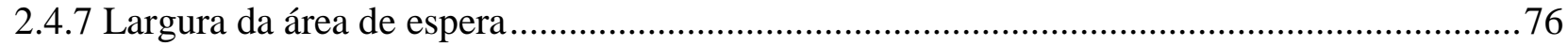

2.4.8 Declividade longitudinal (Grade) e transversal (Cross-Slope) ............................................77

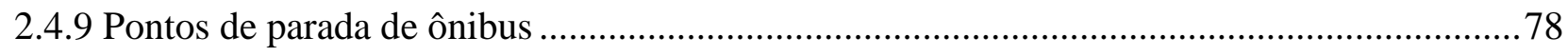

2.4.10 Calçadas para pontes, passarelas e túneis...................................................................... 79

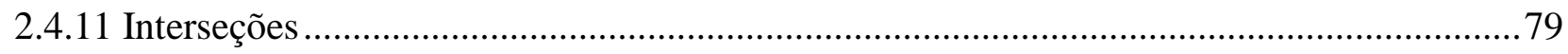

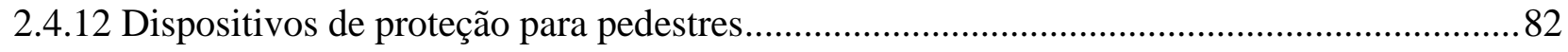

2.5 ANÁLISE DA OPERAÇÃO PARA PEDESTRES ........................................................ 85

2.5.1 Nível de Serviço em Calçadas e Vias Exclusivas para Pedestres ..........................................85

2.5.2 Nível de Serviço em Calçadas Compartilhadas ...................................................................87

2.5.3 Nível de Serviço em Áreas de Espera e Interseções ...........................................................8

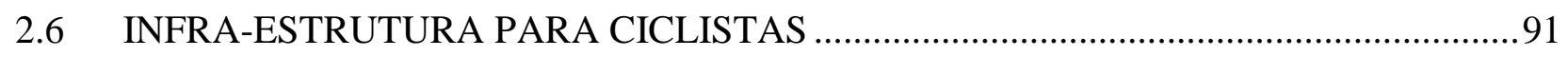

2.6.1 Facilidades para Ciclistas ao Longo da Via ................................................................... 92

2.6.1 Facilidades para Interseções e Travessias com Ciclistas ....................................................98

2.7 PARÂMETROS DE PROJETO PARA CICLISTAS .................................................... 98

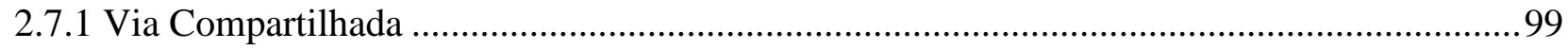

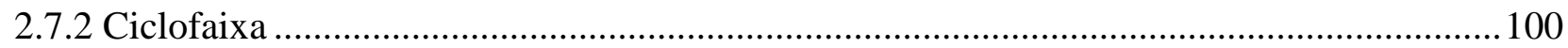

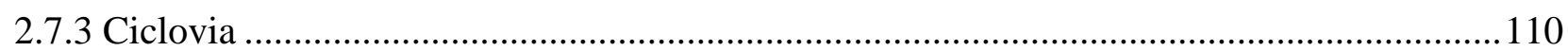

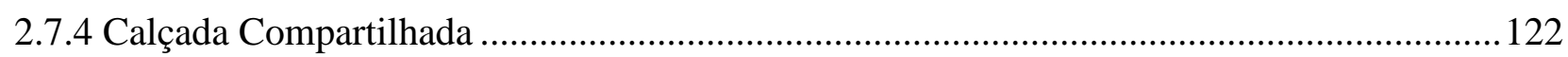

2.8 ANÁLISE DA OPERAÇÃO PARA CICLISTAS......................................................... 122

2.8.1 Nível de Serviço em Vias Exclusivas ............................................................................... 123

2.8.2 Nível de Serviço em Vias de Uso Compartilhado Segregadas do Fluxo Motorizado ..........124 


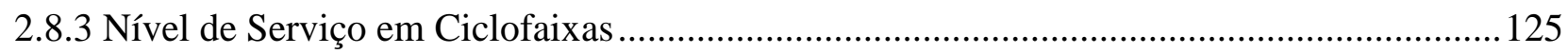

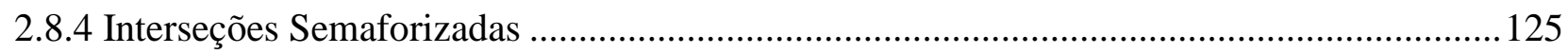

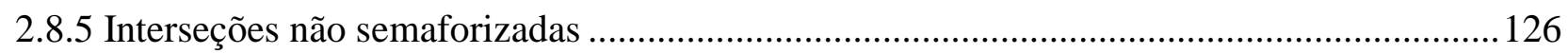

\section{METOdOLOGIA PARA O ESTUdO DE CAMPO E APLICAÇÃO A UM CASO}

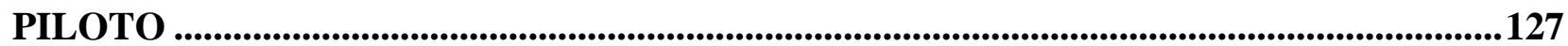

3.1. MÉTODOS DE OPORTUNIDADES DE MANOBRA E CONFLITO ............................128

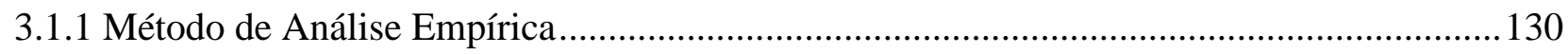

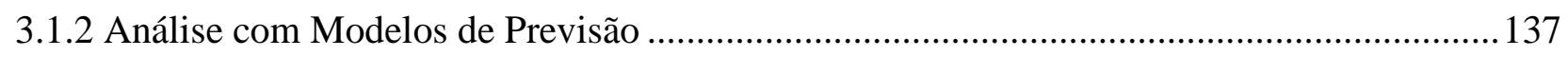

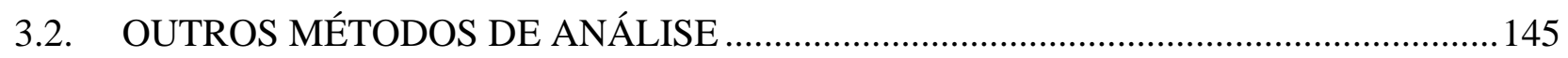

3.2.1 Método de ARAUJO e BRAGA (2008) ........................................................................ 145

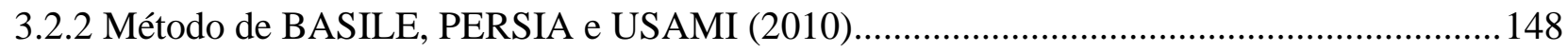

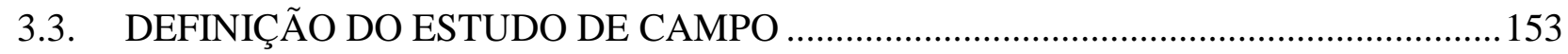

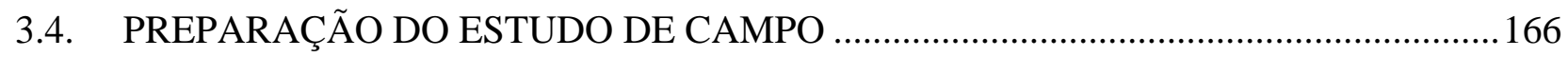

3.4.1. Coleta de Dados sobre Acidentes nos Trechos para Estudo.......................................... 166

3.4.2. Coleta de Dados sobre Operação nos Trechos para Estudo .........................................171

3.4.3. Análise das Condições Locais e dos Acidentes nos Trechos para Estudo .....................183

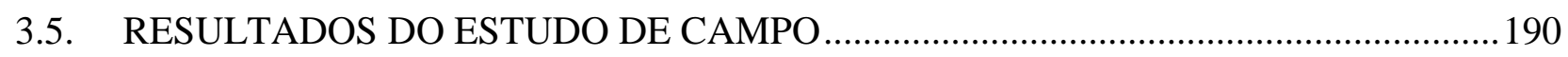

3.5.1 Obtenção e Análise das Medidas de Oportunidades nos Trechos para Estudo ..............190

3.5.2 Análise e validação dos modelos de previsão das medidas de oportunidades ...............214

3.5.3 Comparação do Diagnóstico de Segurança com Medidas de Oportunidades e de Dados

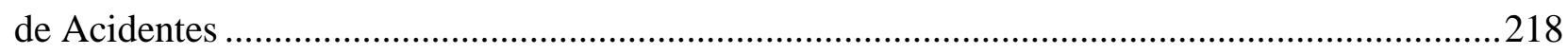

3.6. Método para análise de segurança de pedestres e ciclistas em rodovias...........................235

4 CONCLUSÕES E RECOMENDAÇÕES .........................................................................236

REFERÊNCIAS BIBLIOGRÁFICAS ..........................................................................242

APÊNDICA A - ANÁLISE DA OPERAÇÃO PARA PEDESTRES DO HCM (2000) .........244

A.1. Nível de Serviço em Calçadas e Vias Exclusivas para Pedestres .........................................244

A.2. Nível de Serviço em Calçadas Compartilhadas ..................................................................247

A.3. Nível de Serviço em Áreas de Espera ..........................................................................248

A.4. Nível de Serviço em Travessias Semaforizadas ...............................................................249

A.4. Nível de Serviço em Travessias Não-Semaforizadas .........................................................254

A.5. Nível de Serviço para Pedestres em Vias Urbanas..............................................................256

APÊNDICE B - ANÁLISE DA OPERAÇÃO PARA CICLISTAS DO HCM (2000) ...........257 


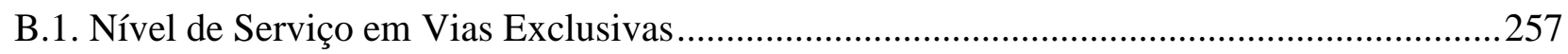

B.2. Nível de Serviço em Vias de Uso Compartilhado Segregadas do Fluxo Motorizado...........258

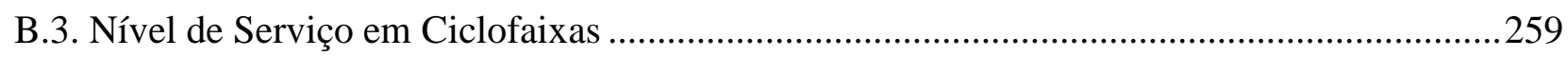

B.4. Nível de Serviço em Interseções Semaforizadas ................................................................259

B.5. Nível de Serviço em Interseções Não Semaforizadas ......................................................260

B.6. Nível de Serviço para Ciclistas em Vias Urbanas ................................................................261

ANEXO A - PLANILHAS DE LEVANTAMENTO DO DADOS OPERACIONAIS .........262

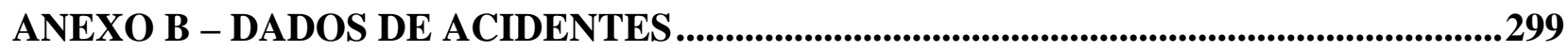




\section{INTRODUÇÃO E OBJETIVOS}

\subsection{ASPECTOS GERAIS}

Segundo a OMS - Organização Mundial de Saúde, acidentes de trânsito são responsáveis pela maior parte das mortes globais, aproximadamente $23 \%$ do total de mortes. Pedestres e ciclistas mortos em acidentes de trânsito chegam a $40 \%$ do total de mortes em países menos desenvolvidos como a Índia. Reduzir a ocorrência desses tipos de acidentes tem sido considerado prioridade atualmente.

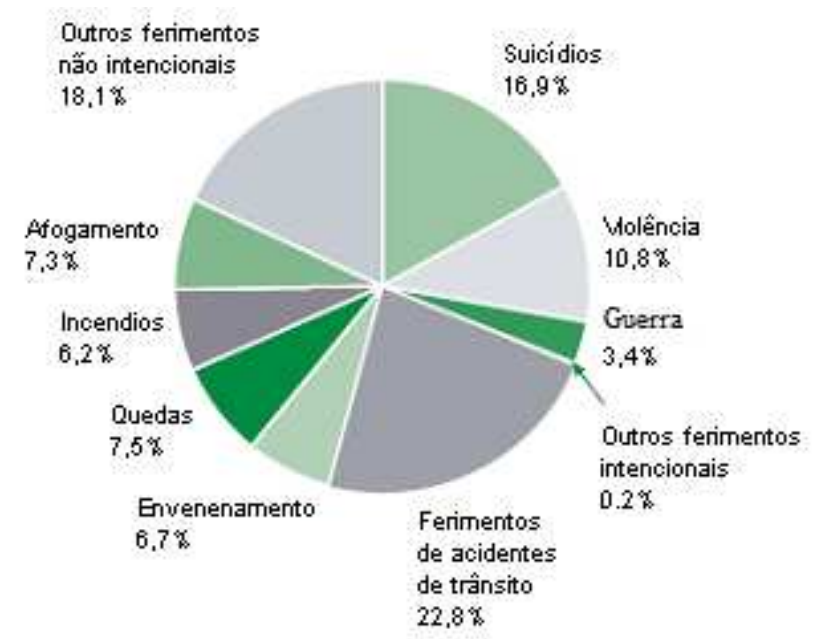

Figura 1-1 - Distribuição global de ferimentos mortais por causa (Fonte: Organização Mundial da Saúde Global Burden of Disease, 2002) 


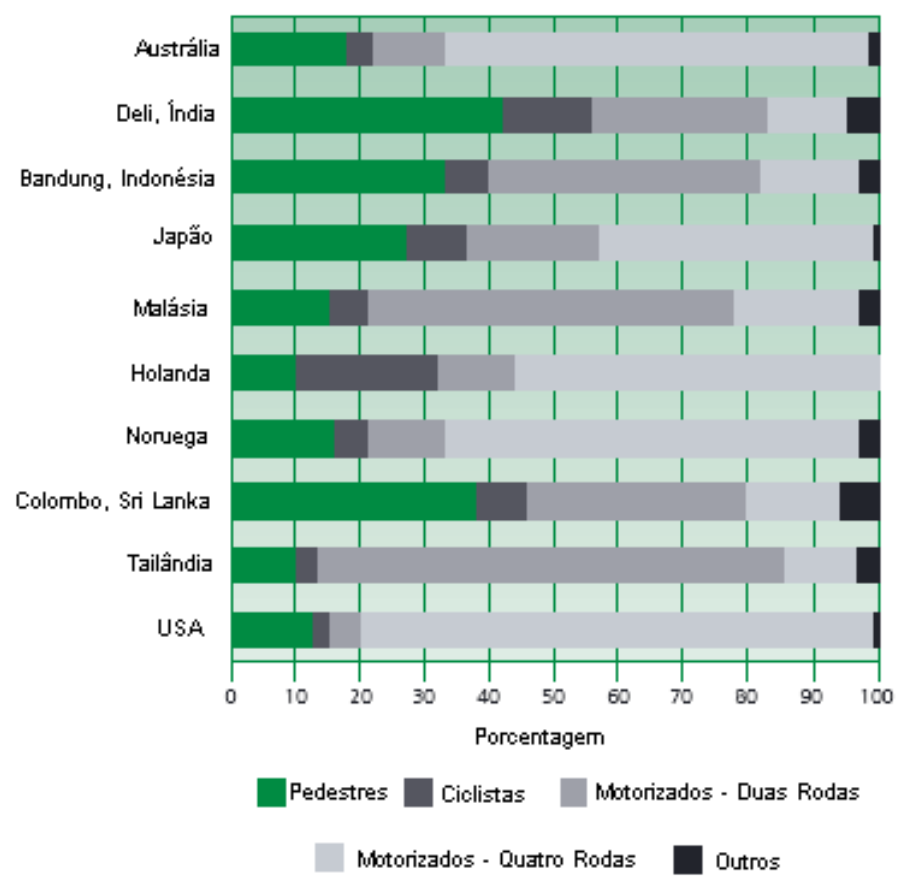

Figura 1-2 - Usuários da via mortos em vários meios de transporte como proporção de todas as mortes de trânsito (Fonte: Organização Mundial da Saúde - Global Burden of Disease, 2002)

A situação no Brasil e, em particular, nas rodovias concedidas do Estado de São Paulo, não é distinta, neste aspecto. O Programa de Concessão Rodoviária do Governo do Estado de São Paulo abriu ao capital privado a oportunidade de prestação de serviços públicos com qualidade e eficiência. Ao longo dos anos, técnicas de engenharia de tráfego têm sido estudadas para redução de acidentes envolvendo pedestres, visto que esse é um problema das rodovias em geral. Segundo a ARTESP (Agência Reguladora de Serviços Públicos Delegados de Transportes do Estado de São Paulo), de janeiro a dezembro de 2010 ocorreram 565 acidentes que resultaram em 189 mortos nas rodovias concessionadas do Estado de São Paulo. O atropelamento é o tipo de acidente que provoca mais vítimas fatais. No ano de 2011 o tipo de acidente atropelamento, representou $1,9 \%$ do total de acidentes, e 25,7\% do total de mortos, como mostra a Figura 1-3. 

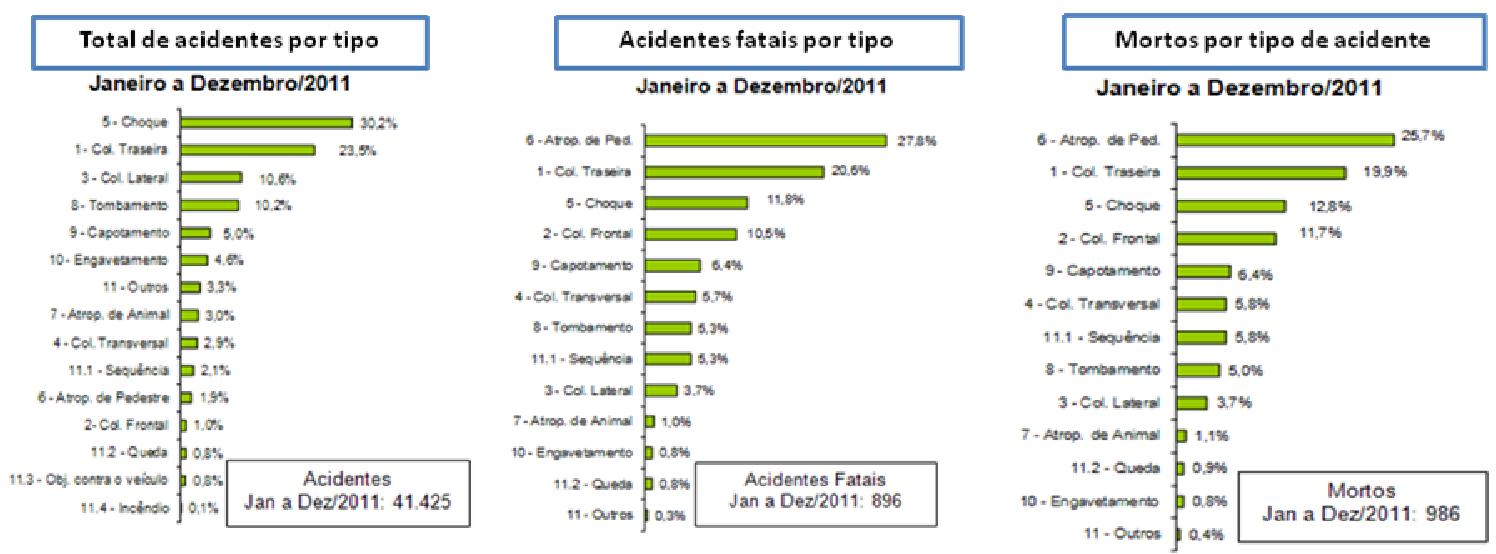

Figura 1-3 - Acidentes nas rodovias concessionadas paulistas em 2011 (Dados da ARTESP - Agência Reguladora de Transportes do Estado de São Paulo)

A Tabela 1-1, na próxima página, mostra a evolução dos acidentes com pedestre nas rodovias concessionadas paulistas desde 2007. Vale ressaltar que até 2009 eram 12 lotes (12L) integrantes da $1^{\text {a }}$ Etapa do Programa de Concessões do Estado de São Paulo. Os anos de 2010 e 2011 contam com os dados de 18 lotes (18L), integrantes da $1^{\mathrm{a}}$ e $2^{\mathrm{a}}$ Etapa do Programa de Concessões.

Tabela 1-1 - Evolução dos acidentes nas rodovias concesisonadas paulistas (Dados da ARTESP - Agência Reguladora de Transportes do Estado de São Paulo)

\begin{tabular}{|l|c|c|c|c|c|}
\hline & $\mathbf{2 0 0 7}(\mathbf{1 2 L})$ & $\mathbf{2 0 0 8}(\mathbf{1 2 L})$ & $\mathbf{2 0 0 9}(\mathbf{1 2 L})$ & $\mathbf{2 0 1 0}(\mathbf{1 8 L})$ & $\mathbf{2 0 1 1}(\mathbf{1 8 L})$ \\
\hline Total de acidentes & 27.874 & 28.407 & 28.037 & 41.557 & 41.425 \\
\hline \%atropelamentos & $\mathbf{2 , 0 0 \%}$ & $\mathbf{2 , 1 0 \%}$ & $\mathbf{2 , 2 0 \%}$ & $\mathbf{1 , 9 0 \%}$ & $\mathbf{1 , 9 0 \%}$ \\
\hline Acidentes fatais & 663 & 593 & 597 & 850 & 896 \\
\hline \%atropelamentos & $\mathbf{2 7 , 8 0 \%}$ & $\mathbf{2 8 , 2 0 \%}$ & $\mathbf{2 7 , 2 0 \%}$ & $\mathbf{2 8 , 8 0 \%}$ & $\mathbf{2 7 , 8 0 \%}$ \\
\hline Mortos & 741 & 665 & 673 & 989 & 986 \\
\hline \%pedestres & $\mathbf{2 3 , 2 0 \%}$ & $\mathbf{2 5 , 4 0 \%}$ & $\mathbf{2 4 , 6 0 \%}$ & $\mathbf{2 5 , 6 0 \%}$ & $\mathbf{2 5 , 7 0 \%}$ \\
\hline
\end{tabular}

No intuito de manter e aprimorar a qualidade dos serviços, as concessionárias vêm ao longo dos anos de concessão, elaborando e implementando o "Plano de Redução de Acidentes PRA", buscando atender ao Edital de Concessão e atingir as metas estipuladas pelo Poder Concedente através da implantação de ações de engenharia, operacionais, fiscalizadoras e 
institucionais visando a redução dos índices de acidentes. Em que pese o esforço dispendido, os problemas com a segurança dos pedestres e ciclistas têm persistido e vêm desafiando os gestores das rodovias. Portanto, parece que faltam mais do que recursos materiais e exigências de resultados para o enfrentamento do problema.

\subsection{CONCEITUAÇÃO DOS ACIDENTES COM PEDESTRES E CICLISTAS}

O DENATRAN como similarmente outros trabalhos, traz definições bastante sumárias de acidentes envolvendo pedestres e/ou ciclistas:

Atropelamento: É o acidente em que um pedestre ou um animal é atingido por um veículo (motorizado ou não-motorizado). Pode ocorrer na pista ou na calçada. No momento do acidente o pedestre pode estar cruzando a pista, andando pela calçada ou pela pista, ou parado.

Colisão com bicicletas: É um sub-tipo particular de colisão entre veículos (Colisão: Choque entre dois ou mais veículos. Bicicleta: Veículo de propulsão humana, dotado de duas rodas, não sendo, similar à motocicleta, motoneta e ciclomotor).

Pode-se ver que, ao contrário dos acidentes veiculares, que são usualmente classificados em função da produção do acidente (choque ou colisão, frontal, angular, lateral, traseira, ...), os acidentes com pedestres são genéricos. Os acidentes com ciclistas, por sua vez, são um subtipo dos acidentes veiculares. Ambas as opções podem ser criticadas por diversos aspectos.

Atropelamentos podem ocorrer na via ou na calçada, sendo eventos bastante distintos. De forma similar, em alguns acidentes os pedestres são lançados para frente, para o lado, por sobre o veículo ou são propriamente atropelados (veículos passam sobre os pedestres). Algo similar pode ocorrer nos acidentes com ciclistas. Embora pedestres e ciclistas estejam em categorias distintas, sendo o ciclista considerado como um veículo, as características de um 
acidente envolvendo um ciclista e um veículo são muito mais semelhantes a um atropelamento do que a uma colisão de dois automóveis de porte similar.

Acidentes com pedestres e ciclistas poderiam ser colocados em um mesmo grupo, com maior razão, falando em atropelamentos de pedestres e atropelamentos de ciclistas (dada sua similaridade) ou distinguidos em categorias específicas, dadas as suas peculiaridades (o que também ocorre em relação aos acidentes com motos).

Desta forma, como em muitos trabalhos recentes, pedestres e ciclistas são considerados em uma categoria similar, os chamados de usuários vulneráveis da via (VRUs-Vulnerable Road Users), considerando que em caso de acidentes ambos são a parte mais prejudicada.

Mesmo com estas mudanças de critério, ainda haveria críticas à tipologia usual de acidentes no Brasil. Muitas vezes uma cadeia de eventos acontece durante um acidente, esse tipo de ocorrência é caracterizado como sequência. Assim, um acidente envolvendo um pedestre ou ciclista pode não ser a causa principal do evento, mas uma saída de pista pode provocar um atropelamento em seguida, por exemplo. Naturalmente, pode também ocorrer o contrário (um atropelamento gerando saídas de pista, por exemplo). Uma conceituação que representasse o acidente como uma sequência de eventos complexa seria mais fidedigna.

\subsection{DISPOSITIVOS DESTINADOS À MELHORIA DA SEGURANÇA DE PEDESTRES E CICLISTAS}

Existe uma ampla gama de tratamentos voltados a melhorar a segurança viária para pedestres e ciclistas, que estão dentro do escopo deste trabalho. Os dispositivos de segurança utilizados para a melhoria da segurança de pedestres e ciclistas encontrados na literatura especializada (que será revisada no capítulo seguinte), podem ser divididos de acordo com diversos atributos como o tipo de via ou a estratégia de ação. Uma classificação e enumeração preliminar, 
definida com o objetivo de estruturar sua análise e dar uma visão ampla do conjunto de tratamentos possíveis, pode ser apresentada conforme segue.

\subsubsection{Dispositivos em vias de uso compartilhado}

- Acostamentos: De acordo com o CTB (BRASIL, 1997), é a parte da via diferenciada da pista de rolamento destinada à parada ou estacionamento de veículos, em caso de emergência, e à circulação de pedestres e bicicletas, quando não houver local apropriado para esse fim. Devem ser projetados e implantados a fim de garantir a segurança e acessibilidade dos pedestres, de forma a não causar riscos de acidentes, minimizando-se as interferências de qualquer natureza e devem ainda possibilitar rotas acessíveis para qualquer usuário, concebidas de forma contínua e integrada por convenientes conexões entre destinos e principalmente aos dispositivos de travessia.

- Canteiros e ilhas divisórias: Dispositivo que proporciona um refúgio para os pedestres, que passam a realizar a travessia em etapas, prestando atenção a um fluxo por vez (a proteção dos pedestres em espera nos canteiros e ilhas é um aspecto complementar). Além disso, diminui o número de colisões frontais, separando os fluxos opostos, e permite a instalação de dispositivos de segregação (dificultando a travessia de pedestres onde ela é indesejada).

- Sinalização e dispositivos de apoio às travessias de pedestres: Medidas para proteger os pedestres e ciclistas podem ser implantadas com o apoio das autoridades de trânsito. Entre elas, a implantação de redutores de velocidade; limites de velocidade mais baixos; vibradores ou sonorizadores; sinais e placas; melhor iluminação; lombadas eletrônicas; radares e câmaras; maior presença policial; melhoria das operações de tráfego (policiais ou civis); e combinações dessas medidas em geral. Os semáforos são ainda mais eficientes e muitos deles incluem estágios 
com verde exclusivo para pedestres. A sinalização deve dar tempo suficiente para que os mais frágeis e lentos concluam a travessia com tranquiilidade.

- Tranquilização de tráfego: Segundo ÁLDUAN (1998), tranquilizar o tráfego é apaziguá-lo, acalmá-lo, diminuir a agitação e o ruído que ele produz. Em outras palavras, tranquilização do tráfego motorizado é reduzir seu volume e sua velocidade até torná-lo compatível com as demais funções da via. Para isso algumas técnicas podem ser utilizadas, entre elas: melhora da mobilidade do pedestre a fim de eliminar conflitos com os veículos; ajuste da velocidade do tráfego (sinalização, ordenação e hierarquização, alinhamento horizontal, alinhamento vertical, interseções). Tranquilização de tráfego tem sido usado principalmente em áreas urbanas, no entanto, com a crescente preocupação de resolver problemas em rodovias, medidas de tranquilização de tráfego estão sendo desenvolvidas. Principais medidas: gateways (combinação de medidas usadas para indicar ao motorista o início de uma área diferente onde o comportamento do motorista deve mudar); placas, linhas, marcas; superfície colorida; superfície texturizada; mudança nos limites de velocidade; câmeras de segurança; redução na largura da via; medidas de regulamentação de tráfego (proibição ou restrição de circulação); facilidades de travessia para pedestres e ciclistas; deflexão horizontal; deflexão vertical.

\subsubsection{Vias exclusivas ou faixas segregadas}

- Calçadas: De acordo com o CTB (BRASIL, 1997) é parte da via, normalmente segregada e em nível diferente, não destinada à circulação de veículos, reservada ao trânsito de pedestres e, quando possível, à implantação de mobiliário urbano, sinalização, vegetação e outros fins. Como dispositivos de segregação podem ser usados gradis e floreiras. A função da calçada é de canalização, ou seja, encaminhar os pedestres para que atravessem em locais mais seguros do que normalmente 
elegeriam. Ciclovias e ciclofaixas: De acordo com o CTB (BRASIL, 1997), ciclofaixa é a parte da pista de rolamento destinada à circulação exclusiva de ciclos, delimitada por sinalização específica e ciclovias, pista própria destinada à circulação de ciclos, separada fisicamente do tráfego comum. Tanto a ciclovia como a ciclofaixa podem ainda ser de uso compartilhado com pedestres.

\subsubsection{Dispositivos de segregação em nível}

- Passarela: Pelo CTB (BRASIL, 1997), obra de arte destinada à transposição de vias, em desnível aéreo, e ao uso de pedestres. Uma passarela com rampas pode também servir aos ciclistas, pedalando ou andando. Alguns técnicos de segurança do trânsito dizem que pedestres não utilizam a passarela voluntariamente e que é muito caro construí-las e mantê-las. Ainda os principais problemas de passarelas são: construídas em lugares errados, mal projetadas, mal construídas, manutenção deficiente, não seguras. Mesmo assim, segundo GOLD (1998), muitos pedestres utilizam a passarela.Passagem inferior (ou subterrânea): Segundo o CTB (BRASIL, 1997), obra de arte destinada à transposição de vias, em desnível subterrâneo, e ao uso de pedestres ou veículos. Naturalmente, também pode estar em nível inferior à via sem ser subterrânea, se a via atravessada for elevada.

\subsection{CONTEXTO URBANO, RURAL E A PECULIARIDADE DAS RODOVIAS}

A fim de estudar os acidentes envolvendo pedestres em rodovias, é necessário levar em conta considerações sobre rodovias em áreas urbanas e seus impactos na percepção dos pedestres. 
O espaço urbano é caracterizado pela intensidade das atividades humanas, sendo que estas, muitas vezes, são permeadas por uma série de conflitos de natureza diversa. Esses conflitos tornam-se mais evidentes quando são observadas as vias de circulação, nas quais veículos motorizados de todo tipo, pedestres e ciclistas disputam o mesmo espaço. A amplitude desses conflitos se deve, em grade parte, à predileção pelos modos motorizados de transporte, notadamente o modo rodoviário, em detrimento dos demais.

Segundo SILVA JÚNIOR (2003), o crescimento populacional aliado à especulação imobiliária da terra urbana e às facilidades associadas à motorização fizeram com que a área urbanizada de diversos municípios fosse incorporando áreas antes isoladas pelas barreiras representadas por cursos d'água, ferrovias e rodovias.

Assim, a rodovia, um dos principais agentes motores do crescimento populacional e desenvolvimento econômico local, tornou-se quase que um empecilho aos deslocamentos intra-urbanos.

A população das cidades passou a conviver com interfaces entre a cidade e a rodovia, que fazem com que os habitantes das regiões lindeiras que realizam atividades em ambos os lados das rodovias tenham que cruzá-la para desempenhar suas funções cotidianas, correndo todos os riscos associados ao tráfego.

Dessa forma a rodovia trouxe à tona a realidade da convivência com os acidentes de trânsito nos trechos onde esta atravessa áreas urbanizadas das pequenas cidades e povoados existentes ao longo de seu traçado e mesmo no acesso às grandes cidades.

Os problemas associados aos acidentes, notadamente atropelamentos, devido ao excesso de velocidade nestas localidades, tem sido uma preocupação para a engenharia de tráfego. Para tanto, essas ações devem ser implantadas de tal forma a não oferecer surpresas ao motorista, no que diz respeito a interferências ou controles de tráfego.

Muito se estuda hoje em dia a respeito de melhoria da segurança de pedestres em meios urbanos, mas não em rodovias, onde apesar de o número de atropelamentos ser menor, é o que causa mais prejuízo às vítimas, sendo na maioria das vezes fatal. Como mencionado 
anteriormente, de acordo com a agência reguladora das rodovias do estado de São Paulo, é o acidente que mais causa vítimas fatais.

\subsection{OBJETIVOS E JUSTIFICATIVA}

Este estudo busca analisar a segurança de trânsito oferecida aos pedestres e ciclistas nos projetos viários, no contexto particular das rodovias concessionadas paulistas, analisando medidas objetivas relacionadas com o risco de acidentes envolvendo usuários vulneráveis da via. Em vista das dificuldades de avaliar a segurança de trânsito em projetos viários com base no potencial de acidentes, a investigação deve incluir outras variáveis.

A fim de medir a segurança das rodovias, serão medidas e avaliadas as oportunidades de manobra e oportunidades de conflito, que são função apenas das características operacionais dos locais como velocidade, fluxo veicular e fluxo de pedestres e ciclistas.

Essas medidas serão comparadas com o histórico de acidentes a fim de serem validadas.

\subsection{ESTRUTURA DO TRABALHO}

O trabalho está estruturado em 4 capítulos.

No capítulo 2 será feita a revisão bibliográfica de princípios e parâmetros de aplicação e projeto de dispositivos para melhoria da segurança de pedestres e ciclistas. 
No capítulo 3 será apresentado o método de estudo proposto, analisando oportunidades de manobra e oportunidades de conflito. Este capítulo conterá os resultados do estudo.

No capítulo 4, estão as conclusões e recomendações obtidas no estudo. 


\section{ANÁLISE DOS TRATAMENTOS PARA SEGURANÇA DE PEDESTRES E CICLISTAS}

O presente capítulo tem por objetivo apresentar a revisão bibliográfica acerca de tratamentos para segurança no trânsito de pedestres e ciclistas.

A revisão feita a seguir buscou analisar detidamente publicações relevantes como:

- as normas legais a respeito de circulação de pedestres e ciclistas no Brasil

- os manuais de projeto viário no que se refere aos pedestres e ciclistas, sejam os internacionais, notadamente da AASHTO (AASHTO 2004a), ou os nacionais, os correspondentes do DNIT/DNER (DNER, 1999; DNIT, 2005 e 2010); incluem-se aqui também os manuais de sinalização viária, precipuamente os aprovados pelo CONTRAN;

- os manuais de análise ou projeto voltados aos usuários não motorizados, internacionais, como os manuais da AASHTO para tratamentos para ciclistas (AASHTO, 1999) e pedestres (AASHTO, 2004b), e nacionais, como do DENATRAN (1983) para pedestres e do GEIPOT (2001) para ciclistas; incluem-se aqui os manuais de análise de operação, especificamente o HCM 2000 (TRB, 2001) nos capítulos dedicados a pedestres e ciclistas; 
- os estudos sobre análise de acidentes, sejam os manuais de análise, como ITE (2000), DENATRAN (1982), DER/PR (1988) ou os trabalhos profissionais, como GOLD (1998) e OGDEN (1996).

A exposição é um esforço de sistematização e comparação das recomendações revisadas.

\subsection{NORMAS LEGAIS RELATIVAS A CIRCULAÇÃO DE PEDESTRES E CICLISTAS NO BRASIL}

Nesse item são revisadas as normas legais para circulação de pedestres e ciclistas no Brasil, uma vez que qualquer indicação contrária deve ser tratada como exceção e somente aplicada com aprovação experimental formalizada pelo CONTRAN.

Foram revistos para isso o Código de Trânsito Brasileiro, CTB1997 (BRASIL, 1997 e suas atualizações até 2008) - Lei n. ${ }^{\circ}$ 9.503, de 23 de setembro de 1977, os manuais de sinalização brasileiros, e a norma de acessibilidade da ABNT NBR9050, de 2004, lei 10098/00, decreto lei 5296 de 2004.

\subsubsection{Disposições do Código de Trânsito Brasileiro (BRASIL, 1997)}

O Anexo I do Código de Trânsito traz conceitos e definições, tendo sido aqui destacados os relacionados a pedestres e ciclistas.

Não há um conceito específico sobre pedestre. Para veículos não-motorizados, os conceitos relevantes são: 
- "BICICLETA - veículo de propulsão humana, dotado de duas rodas, não sendo, para efeito deste Código, similar à motocicleta, motoneta e ciclomotor."

- "CICLO - veículo de pelo menos duas rodas a propulsão humana."

Portanto, Ciclo é a categoria genérica de veículos não-motorizados e Bicicleta é um tipo específico (de duas rodas).

Quanto aos tipos de infra-estrutura utilizadas pelos usuários não motorizados, têm-se:

- "ACOSTAMENTO - parte da via diferenciada da pista de rolamento destinada à parada ou estacionamento de veículos, em caso de emergência, e à circulação de pedestres e bicicletas, quando não houver local apropriado para esse fim."

- “CALÇADA - parte da via, normalmente segregada e em nível diferente, não destinada à circulação de veículos, reservada ao trânsito de pedestres e, quando possível, à implantação de mobiliário urbano, sinalização, vegetação e outros fins."

- "PASSEIO - parte da calçada ou da pista de rolamento, neste último caso, separada por pintura ou elemento físico separador, livre de interferências, destinada à circulação exclusiva de pedestres e, excepcionalmente, de ciclistas."

- "PASSAGEM SUBTERRÂNEA - obra de arte destinada à transposição de vias, em desnível subterrâneo, e ao uso de pedestres ou veículos."

- "PASSARELA - obra de arte destinada à transposição de vias, em desnível aéreo, e ao uso de pedestres."

- "REFÚGIO - parte da via, devidamente sinalizada e protegida, destinada ao uso de pedestres durante a travessia da mesma."

- "CICLOFAIXA - parte da pista de rolamento destinada à circulação exclusiva de ciclos, delimitada por sinalização específica."

- "CICLOVIA - pista própria destinada à circulação de ciclos, separada fisicamente do tráfego comum." 
- "VIAS E ÁREAS DE PEDESTRES - vias ou conjunto de vias destinadas à circulação prioritária de pedestres."

- "FAIXAS DE TRÂNSITO - qualquer uma das áreas longitudinais em que a pista pode ser subdividida, sinalizada ou não por marcas viárias longitudinais, que tenham uma largura suficiente para permitir a circulação de veículos automotores."

- "PISTA - parte da via normalmente utilizada para a circulação de veículos, identificada por elementos separadores ou por diferença de nível em relação às calçadas, ilhas ou aos canteiros centrais."

Portanto, a infra-estrutura destinada aos pedestres é o Passeio implantado nas calçadas (normalmente em nível separado) ou na pista de rolamento (quando delimitada por separadores). As Vias e Áreas de Pedestres também são destinadas prioritariamente aos pedestres. Na falta destes elementos, o acostamento também seria utilizável pelos pedestres.

Já os ciclistas são tratados como veículos e teriam de utilizar a Pista de Rolamento, circulando com o tráfego geral, ou o Acostamento, no caso da sua existência, particularmente em rodovias. A infra-estrutura específica para os ciclistas é constituída pelas Ciclo-faixas (demarcadas na pista de rolamento, de uso exclusivo, para todos os ciclos) e as Ciclovias (fora da pista reservada ao tráfego geral).

Os Passeios e as Vias e Áreas de Pedestres podem ser compartilhadas com ciclistas (conforme sinalização de regulamentação). Entende-se que as Vias e Áreas de Pedestres também podem ser compartilhadas com outros veículos (novamente conforme sinalização de regulamentação, como a circulação de acesso local em vias de pedestres). O mesmo não é claramente estabelecido para o compartilhamento da infra-estrutura destinada aos ciclistas para uso dos pedestres (a sinalização correspondente, no entanto, é prevista).

Quanto às normas gerais de circulação, o CTB1997 (no capítulo III - Das normas gerais de circulação e conduta) estabelece diversas considerações de necessidade dos condutores observarem a segurança de pedestres.

No Art. 38 que trata da entrada à direita ou à esquerda dos veículos, em outra via ou em lotes lindeiros, estabelece que o condutor deverá também “ceder passagem aos pedestres e ciclistas, 
aos veículos que transitem em sentido contrário pela pista da via da qual vai sair, respeitadas as normas de preferência de passagem". A ressalva final (sobre as normas de preferência de passagem), indicaria que os veículos preservam sua preferência (e não precisam ceder preferência) quando esta regra for estabelecida pela sinalização semafórica ou de prioridade (placas de PARE ou DÊ PREFERÊNCIA). Não parece haver consenso a respeito, particularmente no que se refere ao significado concorrente com a sinalização de prioridade.

O Art. 58 regulamenta a circulação de bicicletas, em vias urbanas e rurais, que "deverá ocorrer, quando não houver ciclovia, ciclofaixa, ou acostamento, ou quando não for possível a utilização destes, nos bordos da pista de rolamento, no mesmo sentido de circulação regulamentado para a via, com preferência sobre os veículos automotores." A circulação no sentido contrário do tráfego veicular pode ser autorizada pela autoridade de trânsito, desde que haja ciclofaixa. Portanto, a existência de ciclovia, ciclofaixa ou acostamento desautorizaria o tráfego de bicicletas das demais faixas de tráfego, exceto onde não for possível utilizá-las. A ressalva poderia ser associada a movimentos de conversão em lados opostos ao das ciclovias, ciclofaixas ou acostamentos, entre outros, e seria recomendado sinalizar estas situações.

O Art. 59 regulamenta que os passeios poderão ser compartilhados entre pedestres e ciclistas desde que seja autorizado pelo órgão responsável e sinalizado adequadamente.

No Capítulo IV o CTB 1997 trata especificamente dos pedestres e condutores de veículos não motorizados. Segundo o Art. 68 a utilização de passeios ou passagens apropriadas em vias urbanas e acostamentos em vias rurais pode não ser exclusiva de pedestres, desde que isso não prejudique o fluxo de pedestres, sendo o ciclista desmontado equiparado ao pedestre. A necessidade, ou não, de autorizar estas permissões não é claramente estabelecida (nem a exigência de sinalização como forma), exceto para o ciclista desmontado (onde seria a regra), podendo-se recomendar a prática de sinalizar permissões onde não há prejuízo aos pedestres.

O deslocamento de pedestres pode ser feito na pista de rolamento, com prioridade sobre os veículos, pelos bordos da pista, em fila única, no caso de não haver estrutura adequada (calçadas em vias urbanas e acostamentos em vias rurais) ou não for possível sua utilização, com exceção de locais em que a sinalização proíbe esse deslocamento ou a segurança é comprometida. Em vias rurais os pedestres devem deslocar-se contra o fluxo de veículos. Em 
trechos urbanos de vias rurais e obras de arte devem sempre ser previstos passeios, não devendo ser utilizado o acostamento. Estas exigências legais não são, entretanto, regulamentadas (não há definição de atribuições ou penalidades) de forma específica.

No Art. 69, que diz respeito às travessias, é regulamentado que a travessia de pedestres deve ser feita nas faixas ou passagens de pedestres, sempre que existirem em uma distância de até $50 \mathrm{~m}$, sempre levando em conta a visibilidade, a distância e velocidade dos veículos. Caso não haja faixa de pedestre ou passagem em desnível, o deslocamento deve ser sempre perpendicular ao eixo da via. Em interseções sem faixas de travessia, essa deverá ser feita na continuação da calçada, atentando para não adentrar a via obstruindo o fluxo de veículos, realizar a travessia o mais rápido possível.

O Art. 70 regulamenta a preferência de pedestres que atravessam a via nas faixas de pedestres, exceto onde houver semáforo, devendo mesmo assim ser dada preferência para pedestres que estão concluindo a travessia, mesmo que haja mudança de estágio. No Art. 71, ficam asseguradas as boas condições para uso das faixas e passagens de pedestres: "O órgão ou entidade com circunscrição sobre a via manterá, obrigatoriamente, as faixas e passagens de pedestres em boas condições de visibilidade, higiene, segurança e sinalização".

Examinando os artigos em conjunto, vê-se que as ressalvas introduzem algum grau de ambiguidade. Deve-se também assinalar a falta de uniformidade na interpretação das regras mencionadas e particularmente na sua fiscalização. Haveria a exceção referente aos caso de travessias controladas por semáforos, onde o texto é claro em submeter a preferência à sinalização semafórica. No entanto, mesmo neste caso claramente regulamentado, existe uma dificuldade prática importante dado que na maior parte dos semáforos não é possível aos condutores distinguir à distância se as travessias de pedestres tem focos semafóricos específicos (uma condição que seria necessária para haver regulamentação específica para pedestres), particularmente nas conversões. A desobediência usual à preferência dos pedestres não pode, entretanto, ser atribuída a esta dificuldade prática visto que seria a regra normal no caso das conversões veiculares quando não há focos de pedestres restringindo seu movimento.

O capítulo XV diz respeito às infrações de trânsito. $O$ artigo 214 diz respeito a infração para o motorista que deixar de dar a preferência de passagem a pedestre e a veículo não motorizado, 
caso esteja na faixa de pedestre, ou concluindo a travessia mesmo com mudança de estágio semafórico. Não são distinguidas as diversas situações comentadas anteriormente e mesmo a presença da faixa de pedestre apenas diferencia a gravidade da infração.

Os artigos 254 e 255 regulamentam infrações para pedestres e ciclistas, inclusive com a penalidade de pagamento de multa.

O Art. 254 proíbe o pedestre de:

“I - permanecer ou andar nas pistas de rolamento, exceto para cruzá-las onde for permitido;

II - cruzar pistas de rolamento nos viadutos, pontes, ou túneis, salvo onde exista permissão;

III - atravessar a via dentro das áreas de cruzamento, salvo quando houver sinalização para esse fim;

IV - utilizar-se da via em agrupamentos capazes de perturbar o trânsito, ou para a prática de qualquer folguedo, esporte, desfiles e similares, salvo em casos especiais e com a devida licença da autoridade competente;

V - andar fora da faixa própria, passarela, passagem aérea ou subterrânea;

VI - desobedecer à sinalização de trânsito específica;"

O Art. 255 diz ser infração do ciclista: "Conduzir bicicleta em passeios onde não seja permitida a circulação desta, ou de forma agressiva, em desacordo com o disposto no parágrafo único do art. 59”.

O artigo 59 citado é o que diz respeito à circulação de bicicletas no sentido contrário ao fluxo, desde que na ciclofaixa e autorizado pela autoridade responsável.

Terminadas as citações dos artigos que dizem respeito a circulação de pedestres e ciclistas, o CTB 1997 traz no Anexo II considerações sobre sinalização horizontal e vertical e dispositivos de proteção e canalização de pedestres.

A sinalização de regulamentação relativa aos pedestres é sumária, notando-se os sinais recentemente introduzidos para ordenar o fluxo compartilhado com ciclistas. A sinalização de 
advertência relativa aos pedestres e ciclistas é também sumária, salvo no que se refere aos locais onde há travessias de pedestres, demarcadas ou não, particularmente em áreas escolares. Neste caso, placas de sinalização especial de advertência devem ser utilizadas quando a sinalização de advertência existente não é suficiente ou não pode ser utilizada. A Figura 2-1 mostra exemplos de sinalização especial de advertência para pedestres do Anexo II do CTB:

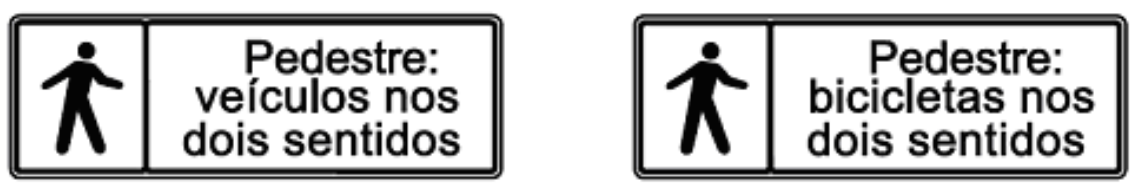

Figura 2-1 - Sinalização especial de advertência para pedestres (Fonte: Código de Trânsito Brasileiro, Anexo II, 1997)

A sinalização de indicação deve identificar as vias, orientar usuários e tem também função educativa. A Figura 2-2 mostra exemplos de sinalizações educativas para pedestres do Anexo II do CTB:
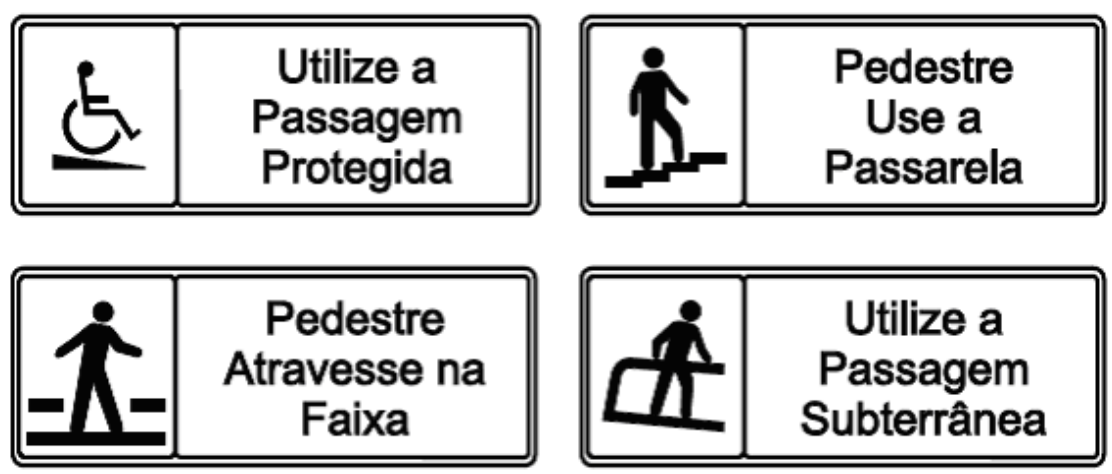

Figura 2-2 - Sinalização de indicação para pedestres (Fonte: Código de Trânsito Brasileiro, Anexo II, 1997)

As placas podem ser ainda de serviços auxiliares, que indicam onde encontrar determinado tipo de serviço. A Figura 2-3 mostra exemplos desse tipo de sinalização para pedestres do Anexo II do CTB: 

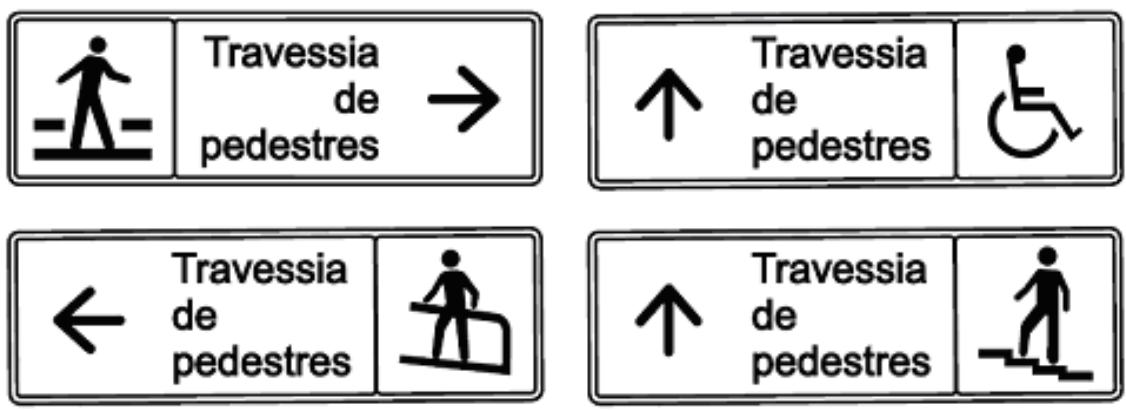

Figura 2-3 - Sinalização de serviços auxiliares (Fonte: Código de Trânsito Brasileiro, Anexo II, 1997)

A sinalização horizontal que diz respeito a pedestres e ciclistas é a de cruzamento e travessia, além de marcação de ciclofaixas ao longo da via.

a) Faixas de Travessia de Pedestres: Regulamentam o local de travessia de pedestres.

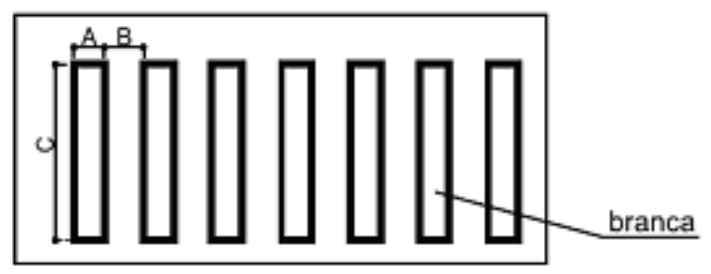

Zebrada

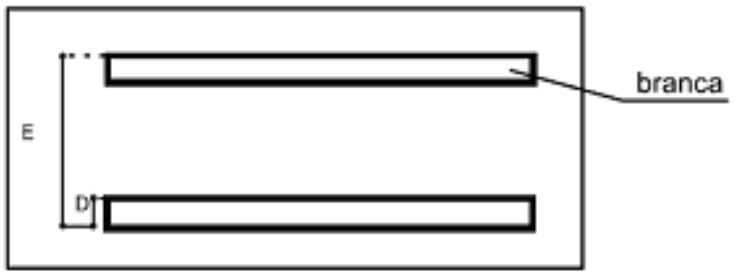

Paralela

Figura 2-4 - Faixas de travessia de pedestres (Fonte: Código de Trânsito Brasileiro, Anexo II, 1997)

Largura da linha - A: mínima 0,30m; máxima 0,40m

- Distância entre as linhas - B: mínima 0,30m; máxima 0,80m

- Largura da faixa - C: (em função do volume de pedestres e da visibilidade) mínima 3,0m; recomendada $4,0 \mathrm{~m}$

- Largura da linha - D: mínima 0,40m; máxima 0,60m

- Largura da faixa - E: mínima 3,0m; recomendada 4,0m

Cor: branca 
No Brasil, o Manual Brasileiro de Sinalização de Trânsito, no volume sobre sinalização horizontal (MBST, 2005), diz que a faixa de travessia de pedestres (FTP) delimita a área destinada a travessia de pedestres e regulamenta a prioridade de passagem dos mesmos em relação aos veículos, nos casos previstos pelo CTB. Compreende dois tipos, conforme a Resolução no 160/04 do CONTRAN: zebrada (FTP-1) e paralela (FTP-2). A cor deve ser branca e as dimensões são as seguintes:

FTP-1: A largura (l) das linhas varia de $0,30 \mathrm{~m}$ a 0,40m e a distância (d) entre elas de $0,30 \mathrm{~m}$ a 0,80m. A extensão mínima das linhas é de 3,00 m, podendo variar em função do volume de pedestres e da visibilidade, sendo recomendado $4,00 \mathrm{~m}$.

FTP-2: A largura (1) das linhas varia de $0,40 \mathrm{~m}$ a 0,60 m. A distância (d) mínima entre as linhas é de 3,00 m, sendo recomendado 4,00 m.

A FTP deve ser utilizada em locais onde haja necessidade de ordenar e regulamentar a travessia de pedestres. A FTP-1 deve ser utilizada em locais, semaforizados ou não, onde o volume de pedestres é significativo, nas proximidades de escolas ou pólos geradores de viagens, em meio de quadra ou onde estudos de engenharia indicarem sua necessidade. A FTP-2 pode ser utilizada somente em interseções semaforizadas. Nos casos em que o volume de pedestres indique a necessidade de uma faixa de travessia com largura superior a 4,00 m, esta deve ser FTP-1.

A locação da FTP deve respeitar, sempre que possível, o caminhamento natural dos pedestres, sempre em locais que oferecem maior segurança para a travessia. Em interseções, deve ser demarcada no mínimo a 1,00 m do alinhamento da pista transversal. Exige-se também o uso de linhas de retenção (LRE) na aproximação das faixas de pedestres, com afastamento mínimo de $1,60 \mathrm{~m}$ (do alinhamento da faixa de pedestre). 
b) Marcação de Cruzamentos Rodocicloviários: regulamenta o local de travessia de ciclistas.

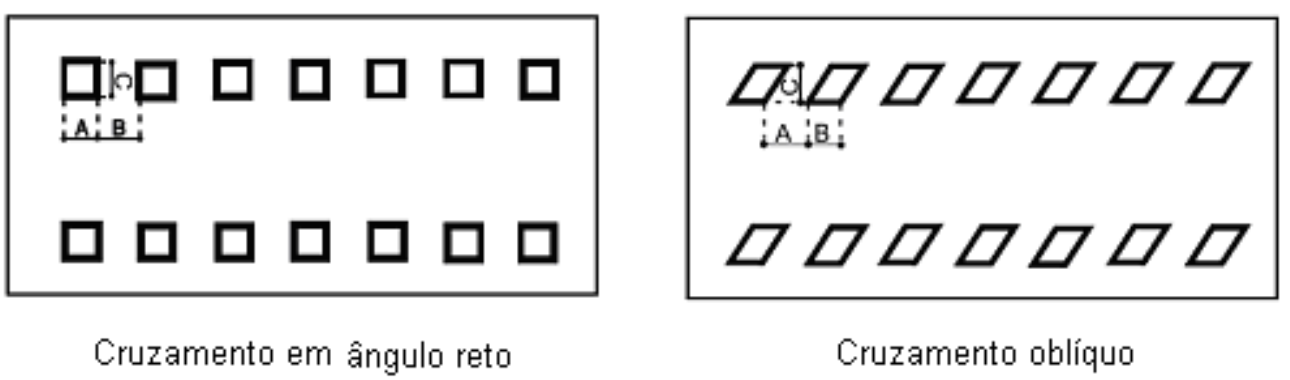

Figura 2-5 - Marcação de cruzamento rodocicloviários (Fonte: Código de Trânsito Brasileiro, Anexo II, 1997)

Lado do quadrado ou losango: mínimo 0,40m; máximo 0,60m

- Relação: $\mathrm{A}=\mathrm{B}=\mathrm{C}$

- Cor: branca

c) Marcação de Ciclofaixas ao Longo da Via (MCI): foi introduzida na atualização do Anexo II do CTB, através da Resolução 160/2004, e regulamentada pelo Manual de Sinalização Horizontal, instituído pela Resolução 236/2007. A Resolução 160/2004 adotou a cor vermelha como padrão definido para marcas relativas à infra-estrutura para ciclistas (sinalizada com a R-34). No entanto, a distinção da MCI foi introduzida apenas no Manual de Sinalização Horizontal, adotando como padrão as seguintes recomendações:

- branca/contínua nos bordos da ciclofaixa; largura: 0,20 a 0,30m; pista interna ou linha; vermelha adjacente (mínimo $0,10 \mathrm{~m}$ ) para contraste

- ciclofaixa: posição lateral na pista recomendada; largura mínima: 1,50m, sentido único; 2,50m, sentido duplo;

- sempre com sinalização vertical de regulamentação R-34 e símbolo "Bicicleta" aplicado ao piso da ciclofaixa; interseções devem ter MCC e transversais com sinalização de advertência A30b; pode-se usar segregadores, retro-refletivos ... 
Ambos os documentos prevêem e exemplificam MCIs somente com linhas longitudinais contínuas (que proibiria a transposição por ciclomotores e automotores). Depreende-se que os demais casos (onde a transposição é permitida) seriam demarcados com linhas longitudinais usuais (LFO, LMS, LCO, LBO, conforme o caso, havendo orientações especificas para marcação orientada aos ciclistas em ciclovias para alguns destes casos). No entanto, uma interpretação mais flexível permitiria utilizar o padrão das MCIs também em outros casos.

Por fim, deve-se mencionar dispositivos de canalização e focos semafóricos específicos:

a) Dispositivos de segurança para pedestres e ciclistas: voltando ao CTB (BRASIL, 1997), as recomendações estão destacadas a seguir:

- Dispositivos de canalização: prismas, para substituir o meio-fio; segregadores, para segregar pistas para uso exclusivo de determinado tipo de veículo ou pedestres.

- Alterações nas características do pavimento: utilizados também para incrementar a segurança e/ou criar facilidades para a circulação de pedestres e/ou ciclistas.

- Dispositivos de proteção contínua: gradis de canalização e retenção com altura máxima de 1,20 m, devem permitir intervisibilidade entre veículos e pedestres.

b) A sinalização semafórica de regulamentação, com a função de efetuar o controle do trânsito num cruzamento ou seção de via, alternando o direito de passagem dos vários fluxos de veículos e/ou pedestres, está definida no Anexo II do CTB.

Para controle de fluxo de pedestres, o vermelho indica que a travessia de pedestres não é permitida; vermelho intermitente indica que a fase em que os pedestres podem atravessar está terminando, mostrando que a travessia já iniciada deve ser concluída o mais rápido possível e não se deve começar nova travessia; verde indica que a travessia de pedestres é permitida.

Os tipos de semáforos para pedestres regulamentados estão na Figura 2-6: 


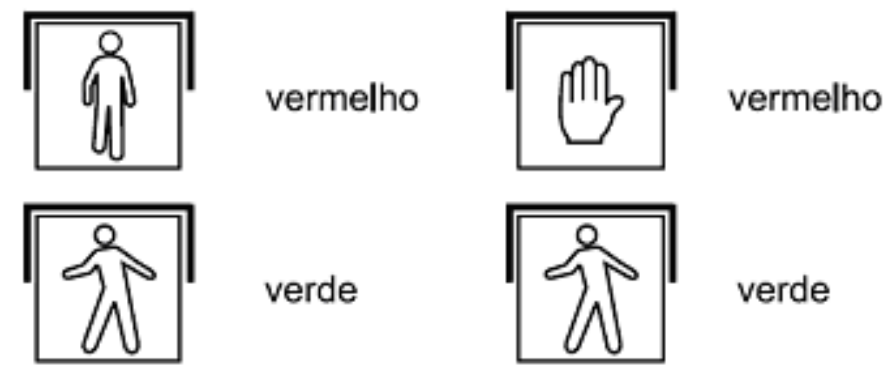

Figura 2-6 - Semáforos para pedestres (Fonte: Código de Trânsito Brasileiro, Anexo II, 1997)

Não há definição correspondente aos semáforos para ciclistas. Exemplo utilizado em São Paulo pode ser apresentado: Figura 2-7, existente na ciclofaixa de lazer da cidade de São Paulo.

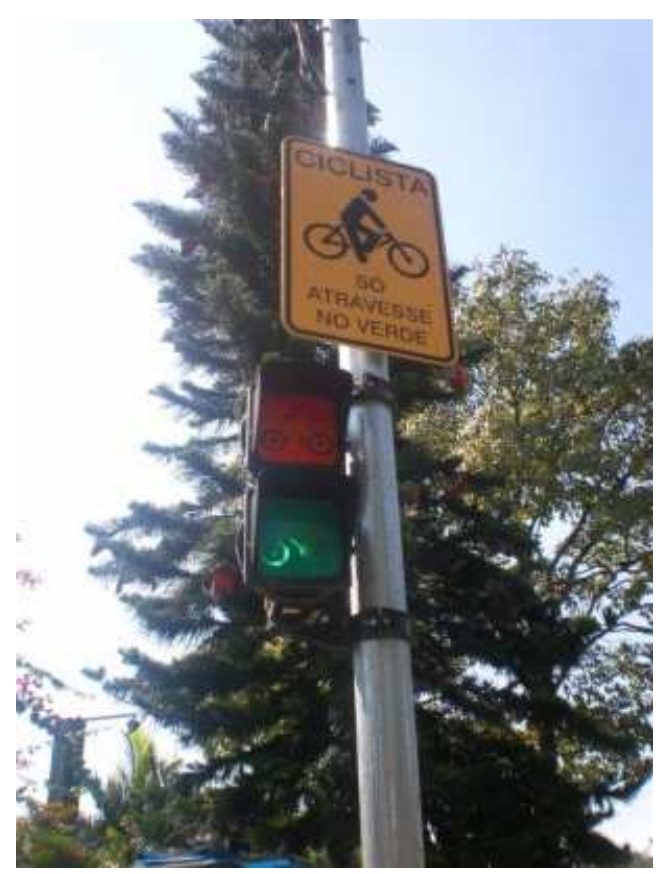

Figura 2-7 - Exemplo de semáforo para ciclistas utilizado na cidade de São Paulo 


\subsubsection{Norma Brasileira ABNT NBR9050: Acessibilidade a edificações, mobiliário, espaços e equipamentos urbanos}

A norma brasileira ABNT NBR9050 traz recomendações a fim de garantir acessibilidade às pessoas com restrições físicas. Para esse trabalho, interessam os itens relativos a circulação em áreas externas.

O item 6 trata de acessos e circulação, estipulando primeiramente condições gerais de circulação, como pisos, que devem: "ter superfície regular, firme, estável e antiderrapante sob qualquer condição, que não provoque trepidação em dispositivos com rodas (cadeiras de rodas ou carrinhos de bebê)." A declividade transversal deve ser no máximo 3\% para calçadas, passeios e vias exclusivas de pedestres. A inclinação longitudinal deve acompanhar as vias lindeiras, sendo recomendado para áreas de circulação exclusivas de pedestres 8,33\% (1:12) no máximo.

São ainda normatizados piso tátil de alerta, utilizado para sinalizar situações que envolvem riscos de segurança; piso tátil direcional, utilizado quando não há uma linha guia ou quando houver caminhos preferenciais de circulação.

Desníveis de 5 a 15mm devem ser tratados como rampas, com inclinação máxima de 1:2. Desníveis superiores a $15 \mathrm{~mm}$ devem ser considerados degraus e sinalizados adequadamente. Grelhas e juntas de dilatação devem ser colocadas transversalmente à via com dimensão máxima de $15 \mathrm{~mm}$. Tampas e caixas de inspeção e de visita devem estar niveladas com o piso e eventuais frestas devem ter no máximo $15 \mathrm{~mm}$.

Ainda no item 6, é recomendado que áreas de descanso sejam previstas a cada 50m para piso com até 3\% de inclinação, ou a cada $30 \mathrm{~m}$ para piso de $3 \%$ a $5 \%$ de inclinação. A referida norma também estabelece limites para inclinação das rampas, reproduzidos na Tabela 2-1. A aplicação dos critérios está ilustrada na Figura 2-8. 


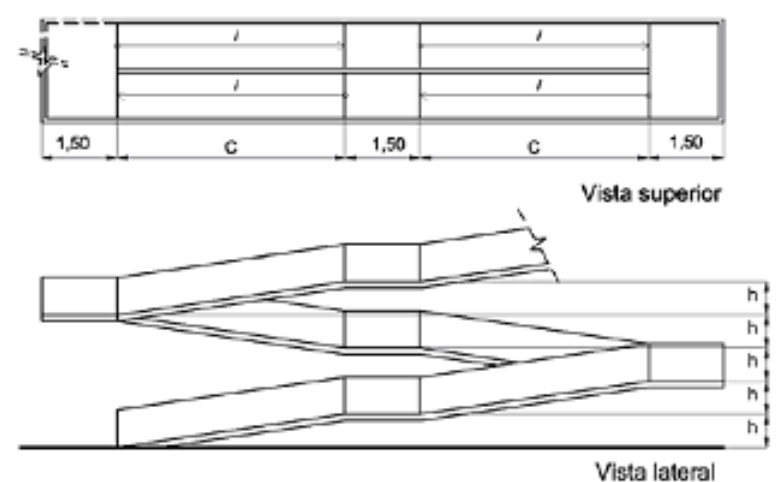

a) Exemplo de dimensionamento de rampas

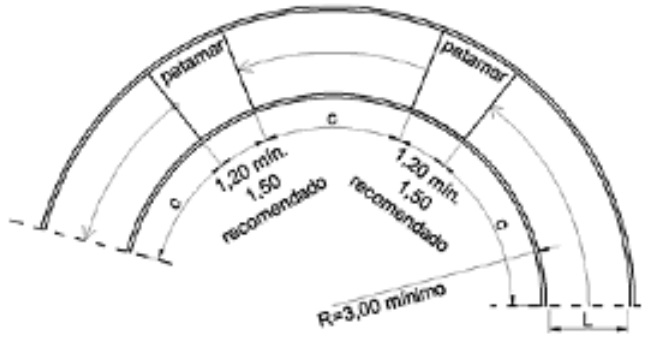

Vista superior

b) Exemplo de rampa em curva

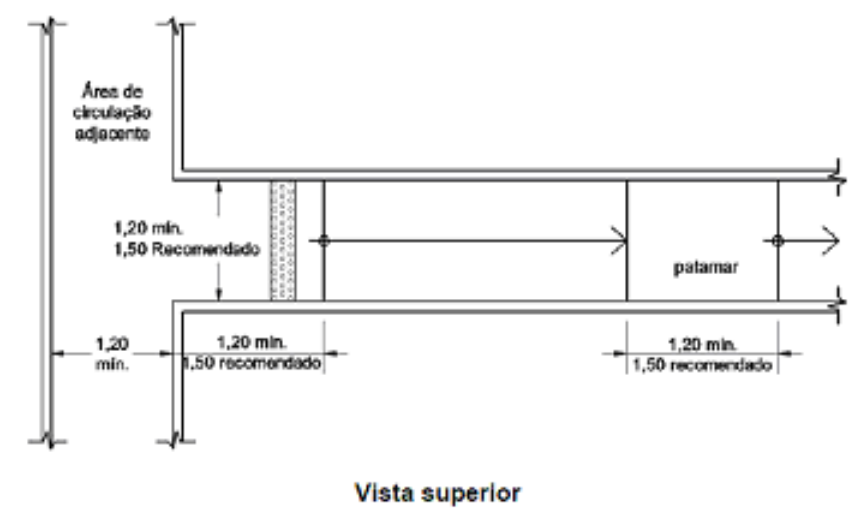

c) Exemplos de patamares de rampas

Figura 2-8 - Dimensionamento de rampas (Fonte: ABNT NBR9050 Acessibilidade a edificações, mobiliário, espaços e equipamentos urbanos, 2004)

Tabela 2-1 - Dimensionamento de rampas (Fonte: ABNT NBR9050 Acessibilidade a edificações, mobiliário, espaços e equipamentos urbanos, 2004)

\begin{tabular}{|c|c|c|}
\hline $\begin{array}{c}\text { Inclinaçäo admissivel em cada } \\
\text { segmento de rampa }\end{array}$ & $\begin{array}{c}\text { Desniveis máximos de } \\
\text { cada segmento de } \\
\text { rampa } \\
\%\end{array}$ & $\begin{array}{c}\text { Número máximo de } \\
\text { segmentos de rampa }\end{array}$ \\
\hline $\begin{array}{c}h \\
\mathrm{~m}\end{array}$ & 1,50 & Sem limite \\
\hline $5,00(1: 20)$ & 1,00 & Sem limite \\
\hline $5,00(1: 20)<i \leq 6,25(1: 16)$ & 0,80 & 15 \\
\hline $6,25(1: 16)<i \leq 8,33(1: 12)$ & & \\
\hline
\end{tabular}


A largura das rampas deve ser estabelecida de acordo com o fluxo de pessoas. A largura livre mínima recomendada pela norma é $1,50 \mathrm{~m}$, sendo admissível 1,20m. As rampas devem ainda ter guias de balizamento com altura mínima de 0,05m. Para rampas em curva, a inclinação máxima admissível é $8,33 \%$ e o raio mínimo, 3,0m, medido no perímetro interno à curva No início e no fim da rampa, assim como entre os segmentos de rampa, devem ser previstos patamares com comprimento longitudinal recomendado de $1,50 \mathrm{~m}$, sendo o admissível 1,20m. É recomendado para calçadas, passeios e vias exclusivas de pedestres uma faixa livre com largura mínima de 1,50m, sendo admissível de 1,20m e altura livre mínima de 2,10 m. Estes aspectos estão ilustrados na Figura 2.6.

Ainda segundo a referida norma, no caso de estacionamento transversal à via de pedestres, os veículos devem estar inteiramente dentro do imóvel de forma a não criar degraus ou desníveis abruptos nos passeios, como ilustrado na Figura 2-8.

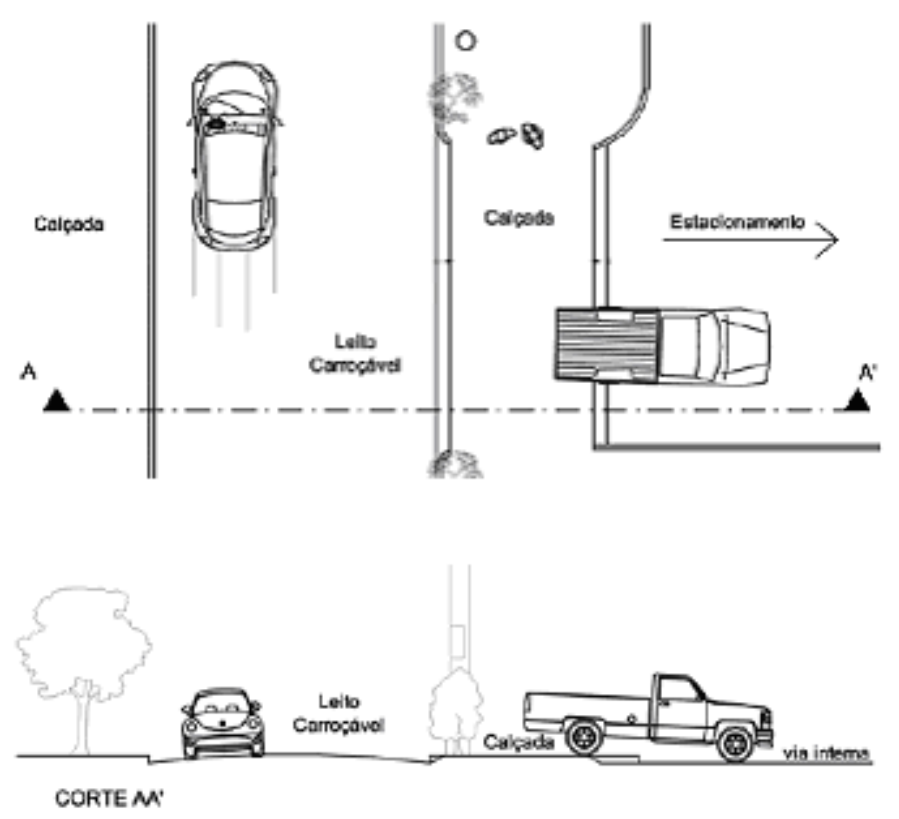

Figura 2-9 - Exemplo de interferência do veículo no passeio (Fonte: ABNT NBR9050 Acessibilidade a edificações, mobiliário, espaços e equipamentos urbanos, 2004)

No caso de obras no passeio, considera de extrema importância que haja sinalização adequada, e que haja uma largura mínima de 1,20m para circulação. Se não houver, deve ser feito desvio 
pelo leito carroçável da via, com rampas provisórias, com largura mínima de 1,0m e inclinação máxima de 10\%, como mostrado na Figura 2-10.

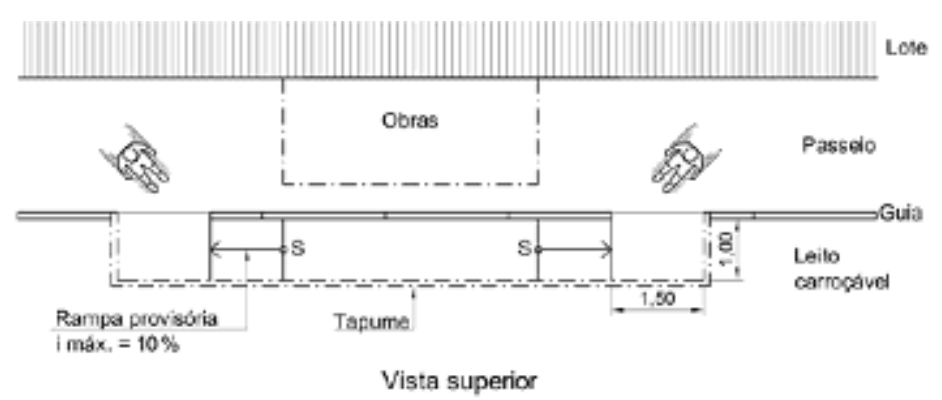

Figura 2-10 - Rampas de acesso provisórias (Fonte: ABNT NBR9050 Acessibilidade a edificações, mobiliário, espaços e equipamentos urbanos, 2004)

Para o dimensionamento das faixas livres, é considerado confortável um fluxo de 25 pedestres por minuto, em ambos os sentidos, a cada metro de largura. Dessa forma, a largura da faixa livre:

$\mathrm{L}=\mathrm{F} / \mathrm{K}+\Sigma \mathrm{i} \geq 1,20$

onde:

L: largura da faixa livre;

F: fluxo de pedestres estimado ou medido nos horários de pico (pedestres por minuto por metro);

$\mathrm{K}: 25$ pedestres por minuto;

$\Sigma$ i: somatório dos valores adicionais relativos aos fatores de impedância.

- 0,45 m junto a vitrines ou comércio no alinhamento;

- 0,25 m junto a mobiliário urbano;

- 0,25 m junto à entrada de edificações no alinhamento.

A NBR9050 recomenda que as faixas de travessia de pedestres sejam executadas de acordo com o CTB1997, devendo ser utilizadas onde houver demanda de travessia, junto a semáforos, 
focos de pedestres, no prolongamento das calçadas e passeios. A largura da faixa de travessia de pedestres é calculada conforme segue:

$\mathrm{L}=\mathrm{F} / \mathrm{K}>4$

onde:

L: largura da faixa (m);

F: fluxo de pedestres estimado ou medido nos horários de pico (pedestres por minuto por metro);

$\mathrm{K}: 25$ pedestres por minuto.

A norma incorpora o uso de faixa elevada (ver Figura 2.9). A faixa elevada, quando instalada no leito carroçável, deve ser sinalizada e dimensionada da mesma forma que a faixa de pedestres, mais as rampas para veículos, com declividade transversal máxima de $3 \%$.

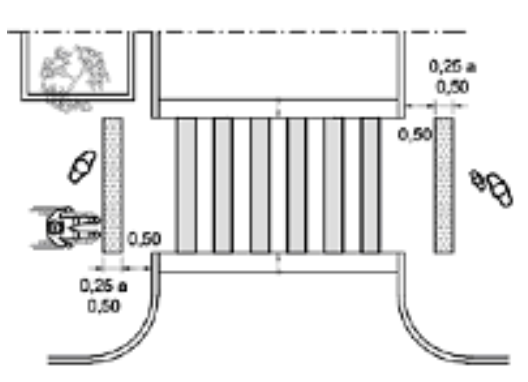

a) Vista superior

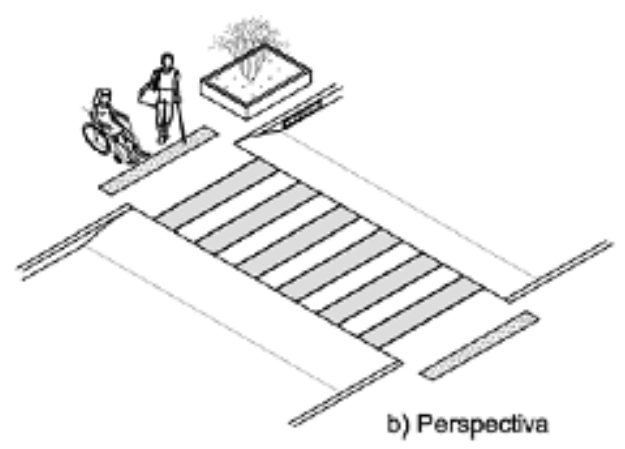

b) Perspectiva

Figura 2-11 - Faixa elevada (Fonte: ABNT NBR9050 Acessibilidade a edificações, mobiliário, espaços e equipamentos urbanos, 2004)

A NBR9050 limita o uso da faixa elevada nas seguintes situações:

“a) em travessias com fluxo de pedestres superior a 500 pedestres/hora e fluxo de veículos inferior a 100 veículos/hora;"

"b) travessia em vias com largura inferior a 6,00 m." 
Nos locais de travessia de pedestres no nível da via as calçadas devem ser rebaixadas, com inclinação constante de no máximo 8,33\% (1:12). Sendo ainda que rebaixamentos em lados opostos da via devem estar alinhados. Quando o fluxo de pedestres for maior ou igual a 25 pedestres/min/m a largura dos rebaixamentos deve ser a mesma das faixas de travessia. Caso contrário, admite-se rebaixamento da calçada em largura inferior, de no mínimo de 1,20m.

Quando a faixa de pedestres estiver alinhada com a calçada da via transversal, deve ser feito o rebaixamento total da calçada na esquina. Se a largura do passeio não for suficiente para acomodar o rebaixamento e a faixa livre (recomendado $1,20 \mathrm{~m}$, aceitável $0,80 \mathrm{~m}$ ), deve ser feito o rebaixamento total da largura da calçada.

Devem ser consideradas abas laterais nos rebaixamentos com projeção horizontal mínima de 0,50m e inclinação máxima recomendada de 10\%. Caso haja obstáculos ao lado dos rebaixamentos, as abas podem ser dispensadas, devendo assim ser garantida uma faixa livre de no mínimo $1,20 \mathrm{~m}$, sendo recomendado $1,50 \mathrm{~m}$.

Diversos exemplos de travessias no nível das ruas da referida norma estão reproduzidos nas Figuras 2-12, 2-13 e 2-14 a seguir. 


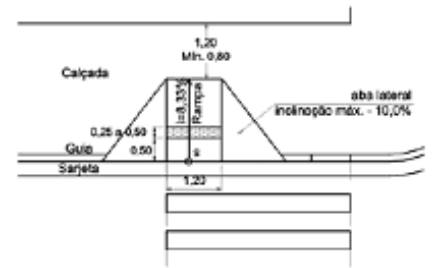

Vista superior

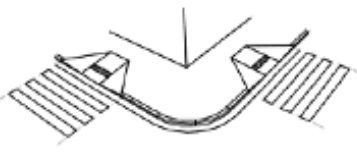

Perspectiva

Rebaixamento $A$

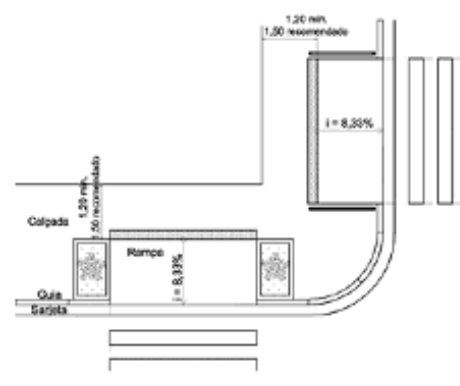

Vista superior

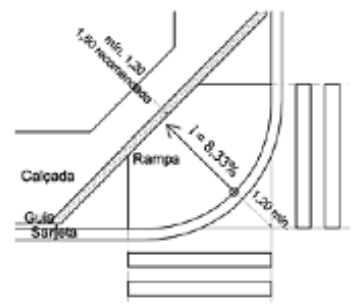

Vista superior

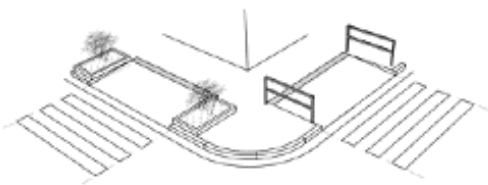

Perspectiva

Rebaixamento $B$

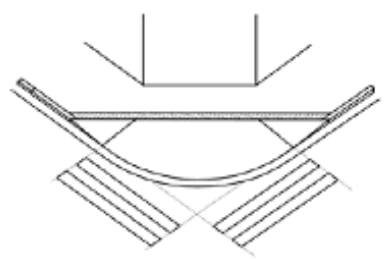

Perspectiva

Rebaixamento C

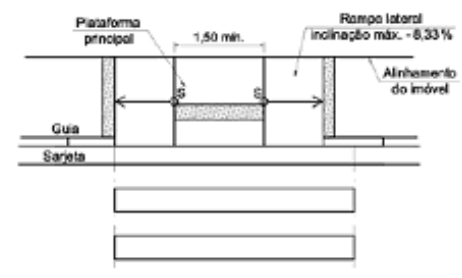

Vista superior

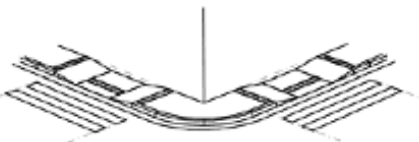

Perspectiva

Rebaixamento $D$

Figura 2-12 - Exemplos de rebaixamento de calçada (Fonte: ABNT NBR9050 Acessibilidade a edificações, mobiliário, espaços e equipamentos urbanos, 2004) 


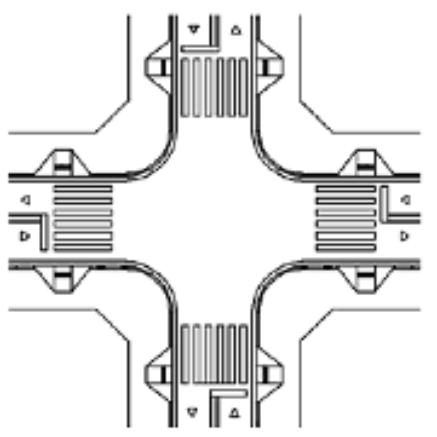

Rebaixamento A

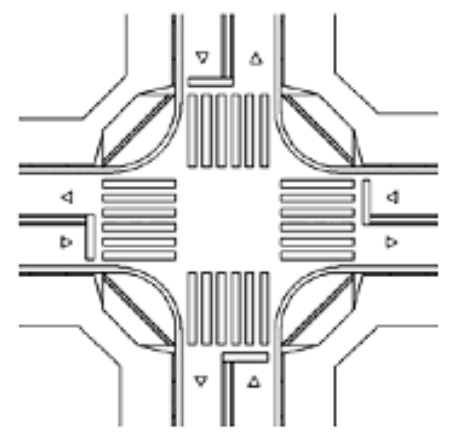

Rebaixamento C

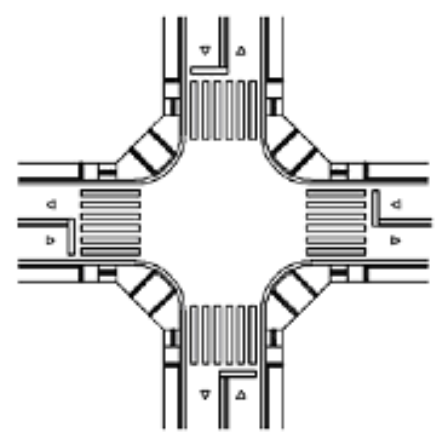

Rebaixamento D

Figura 2-13 - Exemplos de rebaixamentos em esquinas (Fonte: ABNT NBR9050 Acessibilidade a edificações, mobiliário, espaços e equipamentos urbanos, 2004)

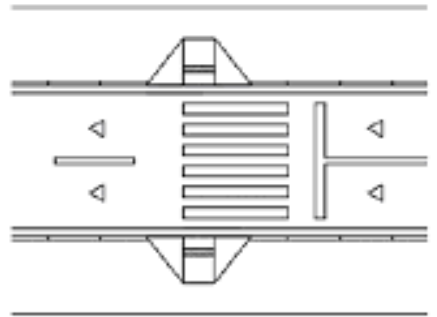

Rebaixamento A

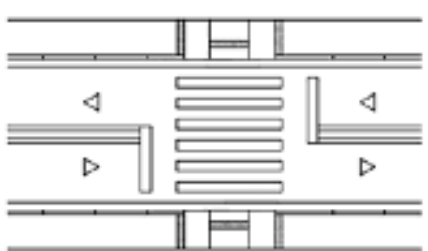

Rebaixamento C

Figura 2-14 - Exemplos de rebaixamentos em meio de quadra (Fonte: ABNT NBR9050 Acessibilidade a edificações, mobiliário, espaços e equipamentos urbanos, 2004) 


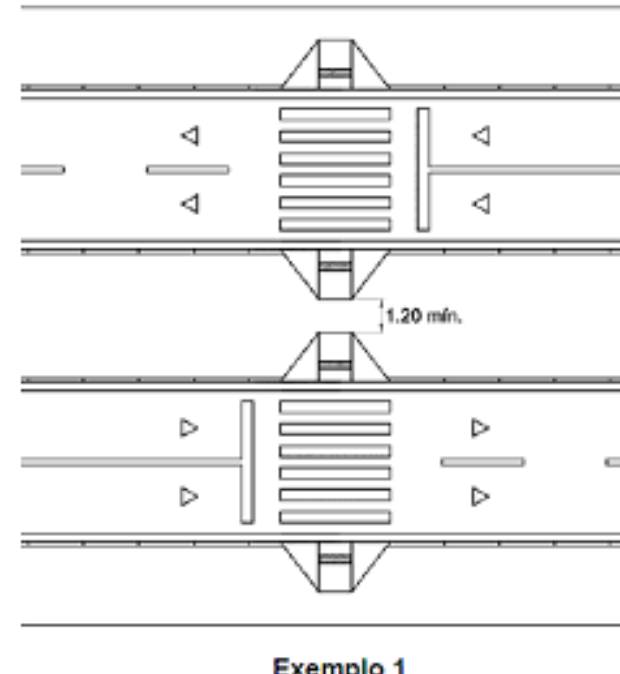

Exemplo 1

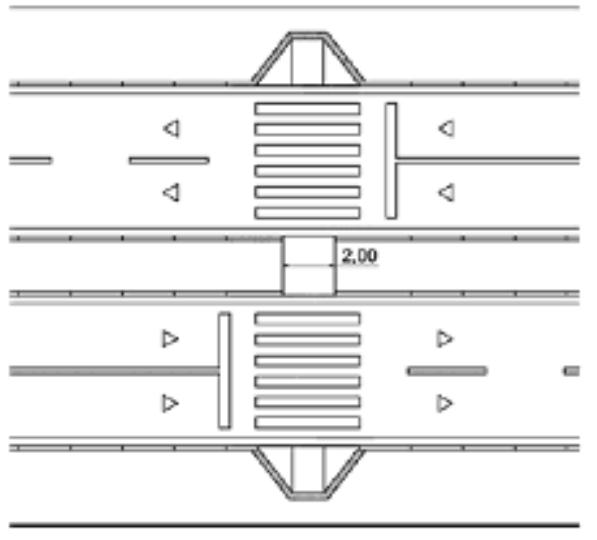

Exemplo 2

Figura 2-15 - Exemplos com canteiro divisor de pistas (Fonte: ABNT NBR9050

Acessibilidade a edificações, mobiliário, espaços e equipamentos urbanos, 2004)

A NBR9050 traz ainda recomendações para passarelas de pedestres, que devem ter rampas e eventualmente elevadores para sua transposição. A largura da passarela deve ser calculada com o mesmo critério recomendado para largura das faixas de travessia.

Para semáforos ou focos de pedestres, caso haja o acionamento manual, o dispositivo de acionamento deve estar a uma altura entre $0,80 \mathrm{~m}$ e 1,20 $\mathrm{m}$ do piso. Se forem instalados em vias de grande volume de tráfego ou concentração de passagem de pessoas com deficiência visual, devem estar equipados com mecanismos que emitam um sinal sonoro entre $50 \mathrm{dBA}$ e $60 \mathrm{dBA}$.

\subsection{METODOLOGIAS PARA SELEÇÃO E PROJETO DO TRATAMENTO MAIS ADEQUADO}

Os seguintes textos foram revisados a fim de esclarecer diferentes aspectos da pesquisa, conforme segue: 


\subsubsection{Manuais de Projeto Viário}

Estes manuais foram analisados para caracterizar quais são as recomendações usuais para projeto de vias e como são considerados os pedestres e ciclistas. As fontes principais foram:

Internacionais:

1. A Policy on Geometric Design of Highways and Streets, AASHTO, 2004a;

2. Guide for Development of Bicycle Facilities, AASHTO, 1999;

3. Guide for the Planning, Design and Operation of Pedestrian Facilities, AASHTO, 2004b;

4. Pedestrian Facilities Users Guide, FHWA, 2002;

5. Manual of Uniform Traffic Control Devices, o MUTCD 2009, FHWA, 2009;

6. Highway Capacity Manual, 2000, o HCM 2000, TRB, 2001;

- Como referência complementar, especificamente sobre ciclistas, foram consultados o relatório do Federal Highway Administration americano, que complementa as recomendações da AASHTO (Selecting Roadway Design Treatments to Acommodate Bicycles; FHWA, 1992), o manual canadense (Geometric Design Guide for Canadian Roads; TAC, 1999) que segue a mesma linha americana, porém com algumas adições interessantes em relação ao manual americano; o manual do Cycling Centre for Excellence de Londres (London Cycling Design Standards; CCE, 2005). 
- Nacionais:

1. Manual de Projeto Viário, DNER, 1999;

2. Manual de Projeto de Interseções, DNIT, 2005;

3. Manual de Travessias Urbanas, DNIT, 2010;

4. Manual Brasileiro de Sinalização de Trânsito, DENATRAN, 2007;

5. Manual de Semáforos, DENATRAN, 1979;

6. Manual de Projeto de Interseções em Nível Não Semaforizadas em Áreas Urbanas, DENATRAN, 1984;

7. Manual de Segurança de Pedestres, DENATRAN, 1983;

8. Manual de Planejamento Cicloviário, GEIPOT, 2001.

Como os manuais nacionais de projeto viário (DNER e DNIT) trazem poucas recomendações específicas de tratamentos para pedestres e ciclistas, em geral seguindo a mesma linha da AASHTO e adotando na maioria das vezes os mesmo critérios, foram aqui destacadas apenas diferenças significativas.

\subsubsection{Referências, Guias e Manuais de Estudos de Acidentes}

Estas referências foram analisadas para caracterizar quais são os aspectos adicionais destacados nos estudos de acidentes, com relação aos pedestres e ciclistas. As fontes principais foram: 
- Internacional:

1. OGDEN, K. W. (1996) - Safer Roads;

2. Manual of Transportation Engineering Studies, ITE, 2000;

- Nacional:

1. GOLD, P. A. (1998) - Segurança de Trânsito;

2. Guia de Redução de Acidentes, DNER, 2007

3. Manual de Identificação, Análise e Tratamento de Pontos Negros, DENATRAN, 1982 ;

4. Manual de Segurança Rodoviária, DER/PR, 1988.

A seguir, inicialmente serão enumerados os tipos de elementos viários projetados para atender os pedestres e para atender os ciclistas. Em sequiência, os parâmetros de projeto recomendados para projetar estes elementos viários serão analisados, também tratando o atendimento aos pedestres e o atendimento aos ciclistas separadamente. Quando existem elementos que buscam atender a ambos, pedestres e ciclistas, conjuntamente (elementos compartilhados entre eles), estes são analisados na discussão relativa aos ciclistas.

\subsection{INFRA-ESTRUTURA PARA PEDESTRES}

A primeira questão geral investigada diz respeito a identificar quais tipos de facilidades podem atender às necessidades dos pedestres. A questão básica complementar é a definição de critérios que recomendam um ou outro tipo de facilidade. Ambas são discutidas a seguir. 
Antes de discutir cada infraestrutura para pedestres, é necessário conhecer as dimensões do pedestre consideradas.

O HCM 2000 (TRB, 2001) apresenta a versão mais clássica (derivada de FRUIN, 1990) sobre a necessidade de espaço dos pedestres, consolidada no conceito de elipse corporal do pedestre e na distinção entre zona de passo e zona sensorial necessárias ao pedestre em caminhada, como ilustradas na Figura 2-16. A elipse corporal do pedestre pode ser descrita pela largura do eixo lateral de 0,60m (a largura da elipse) e do eixo longitudinal de 0,50m (a profundidade da elipse). Desta representação decorreria a necessidade de uma largura útil mínima de $1,20 \mathrm{~m}$ para os passeios de pedestres com fluxos bidirecionais ou com acomodação de pedestres caminhando lado a lado. A largura total necessária deveria acrescentar as exigências adicionais de elementos que causam interferências na largura útil, como fachadas e mobiliário. A zona sensorial não tem a mesma característica física e sua dimensão corresponde aos limites definidos para os diferentes níveis de serviço experimentados pelos pedestres (que variam por tipo de facilidade, entre outros critérios).

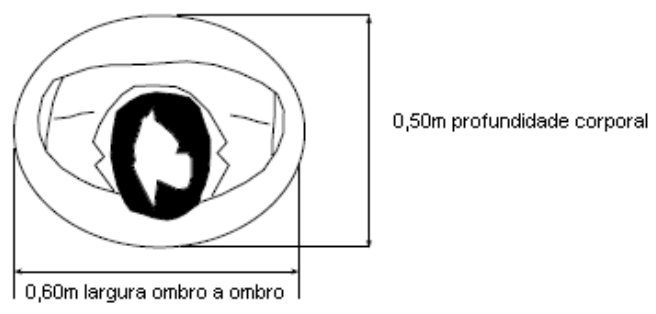

a) Elipse corporal do pedestre

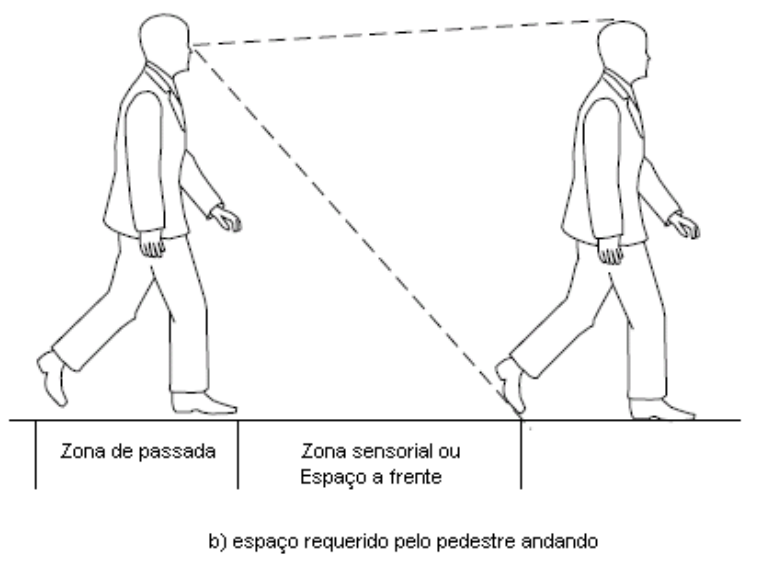

Figura 2-16 - Elipse corporal do pedestre parado e espaço requerido pelo pedestre andando (Fonte: HCM 2000, TRB, 2001) 
O Guia de Pedestres da AASHTO (2004b) também traz considerações a respeito da necessidade espacial. Duas pessoas andando lado a lado geralmente precisam de um espaço de $1,40 \mathrm{~m}$, sendo que duas pessoas em cadeiras de rodas precisam de no mínimo 1,50m para que seja possível realizar a ultrapassagem. O Manual traz ainda o conceito de bolha espacial ( "spatial bubble”), que é a distância de desobstrução visual necessária à frente enquanto anda em diferentes circunstâncias, como mostra a figura 2-17. Portanto, considera um nível de acessibilidade mais amplo (ao incorporar novos tipos de usuários) e recomenda dimensões maiores.

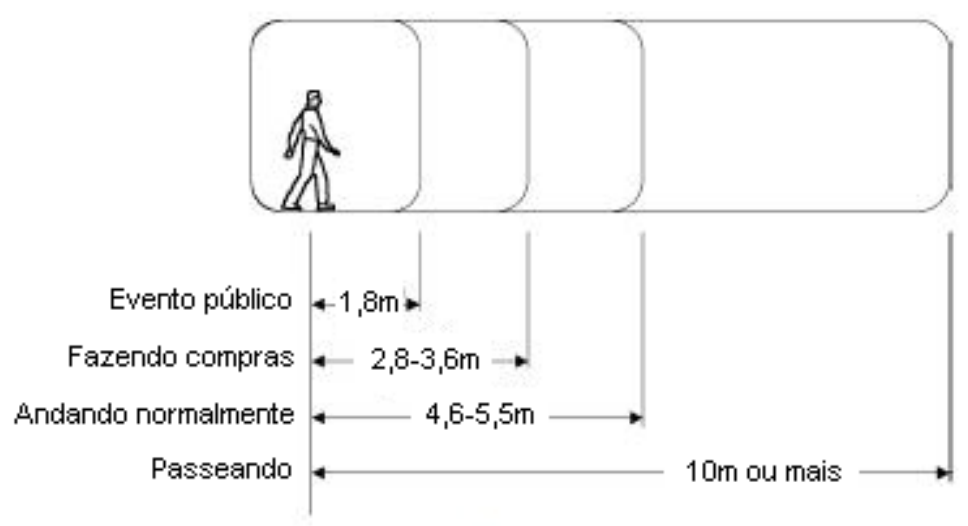

Figura 2-17 - Distância de desobstrução visual necessária à frente dependendo de diferentes tipos de movimento (Fonte: Guide for the Planning, Design and Operation of Pedestrian Facilities, America Association of State Highway Transportation Officials, July 2004)

A norma brasileira de acessibilidade NBR9050 traz diversos gabaritos para pedestres com restrições físicas: pessoas em pé, em diversas condições de mobilidade Figura 2-18a-j, alcance manual frontal: pessoa em pé Figura 2-18k e alcance visual: pessoa em pé Figura 2-181. Podese ver necessidades ainda maiores $(1,80 \mathrm{~m}$ útil, pelo menos se é razoável a frequiência de ter usuários especiais andando lado a lado ou cruzando em uma mesma seção).

Também fornece dados correspondentes às necessidades para cadeiras de rodas e módulo de referência (Figura 2-19), deslocamento e transposição de objetos para pessoa em cadeira de rodas (Figura 2-20), manobra sem deslocamento e com deslocamento (Figura 2-21), alcance manual frontal e lateral (relação entre altura e profundidade) com superfície de trabalho: pessoa em cadeira de rodas (Figura 2-22) e alcance visual: pessoa em cadeira de rodas (Figura 2-23). Portanto, obtém-se valores similares aos requeridos por pedestres com necessidades 
especiais (1,50 a 1,80m útil, pelo menos se é razoável a frequiência de ter cadeirantes andando lado a lado ou cruzando em uma mesma seção).

Pode-se ver que os padrões recomendados pela AASHTO (2004b) devem ser vistos como um mínimo estrito para o contexto de projetos acessíveis e que os padrões clássicos (como os baseados no HCM) consideram o atendimento a pedestres sem necessidades especiais e geram projetos excludentes, quando vistos da ótica de acessibilidade.
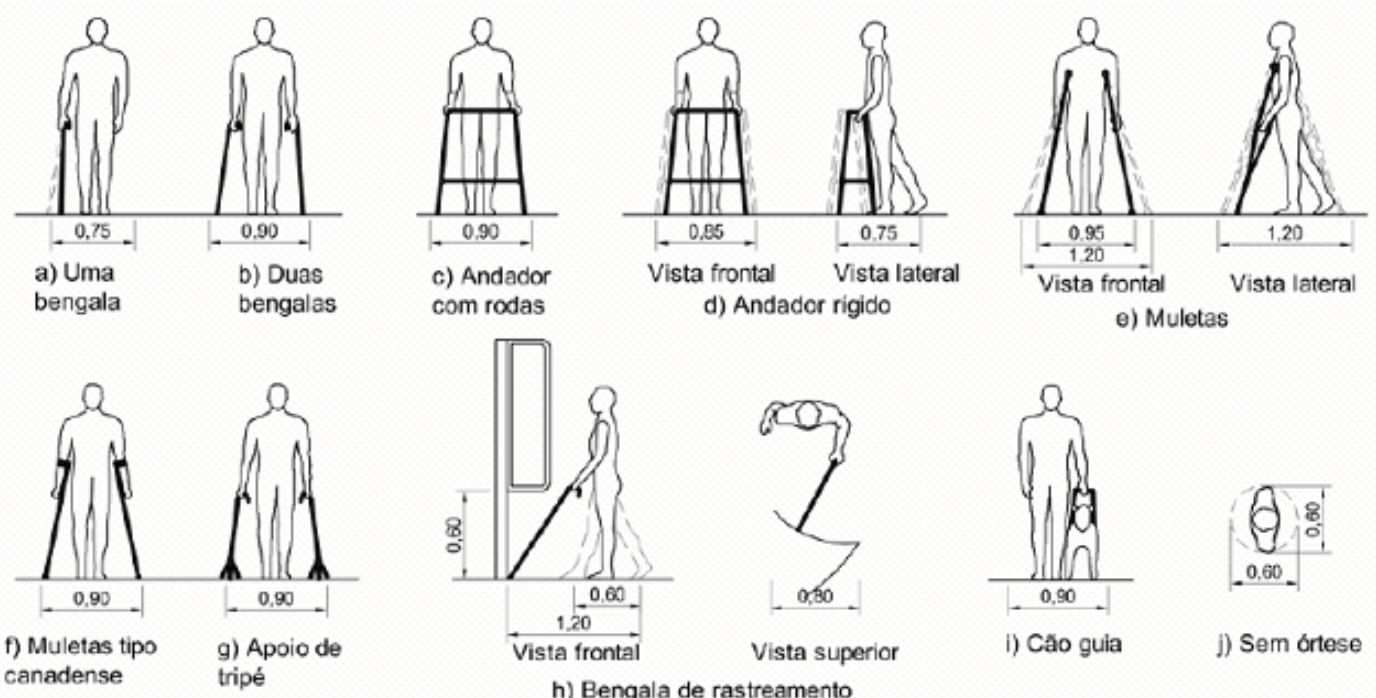

d) Andador rigido

e) Muletas

h) Bengala de rastreamento

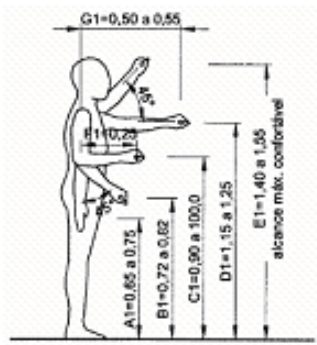

A1 = Atura do centro da maso estendida as longo do ejoo longitudinal do corpo B1 $=$ Altura do piso ate o centro da miso com antebraço formando angulo de $45^{\circ}$ com o tronco

$C 1=$ Atura do centro da maso com antebraço em angulo do $90^{\circ}$ cam o trenco D1 = Altura do centro da maso com braço estendido paralelamente ao piso E1 = Alura do centro da maso com o braço estendido formando $45^{\circ}$ com o piso = alcance máximo contortavel

F1 $=$ Comprimento do artebraço (do contro do cotovelo ao centro da mâ) G1 = Comprimento do braço na horizontal, do ombro so centro da mao

k) alcance manual frontal: pessoa em pé
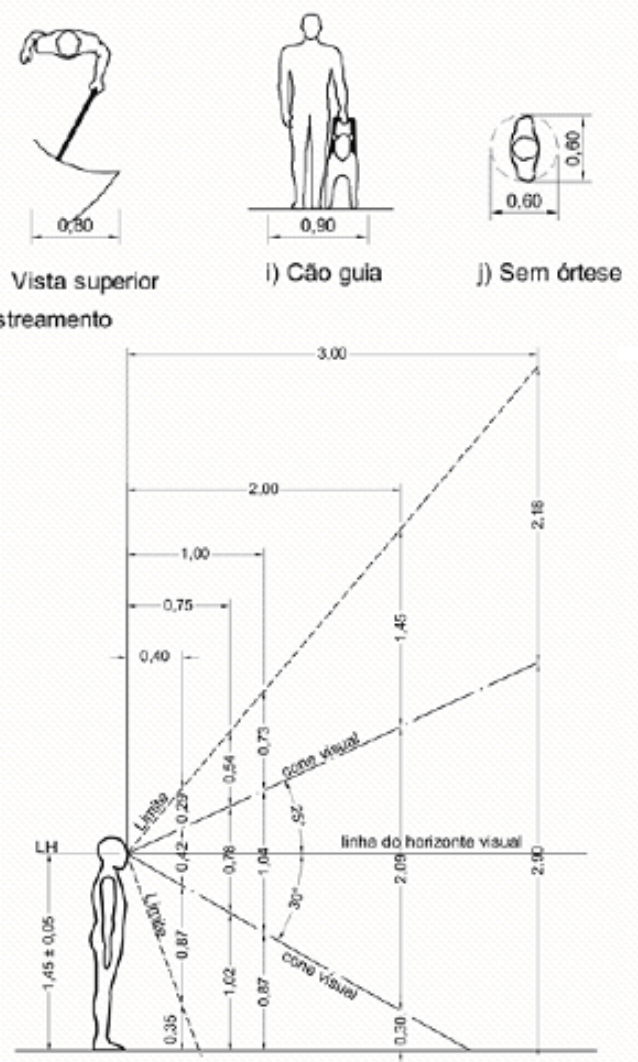

l) alcance visual: pessoa em pé

Figura 2-18 - Gabaritos para pedestres com restrições físicas (Fonte: ABNT NBR9050 Acessibilidade a edificações, mobiliário, espaços e equipamentos urbanos, 2004) 


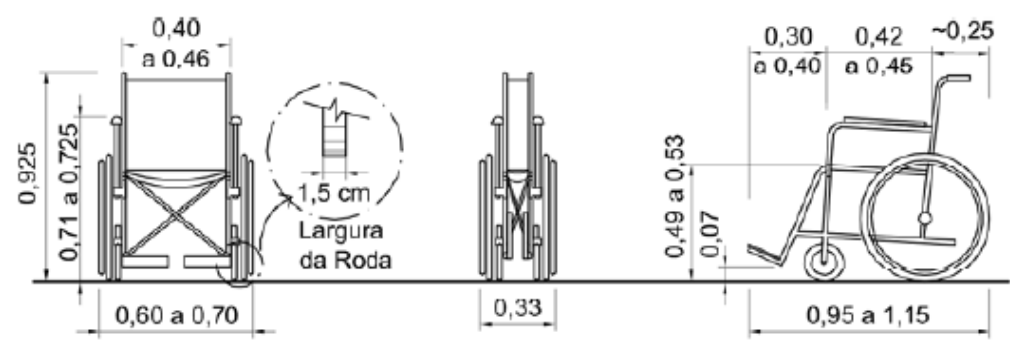

a) Vista frontal aberta

b) Vista frontal fechada

c) Vista lateral

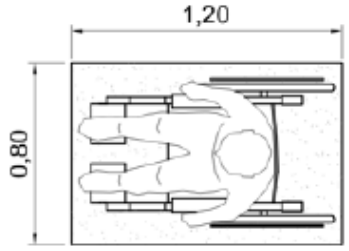

d) Módulo de referêncial (M.R.)

Figura 2-19 - Dimensões de cadeiras de rodas (Fonte: ABNT NBR9050 Acessibilidade a edificações, mobiliário, espaços e equipamentos urbanos, 2004)
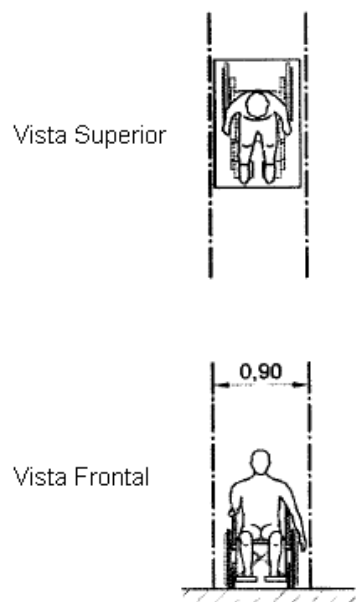

a) Uma pessoa em cadeira de rodas
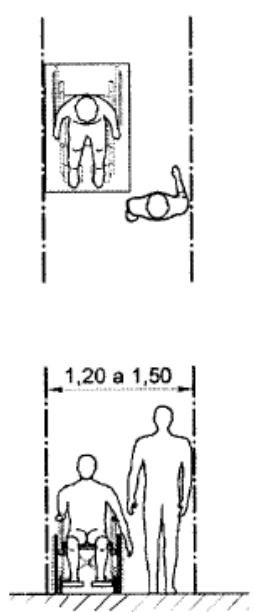

b) Um pedestre e uma pessoa em cadeira de rodas
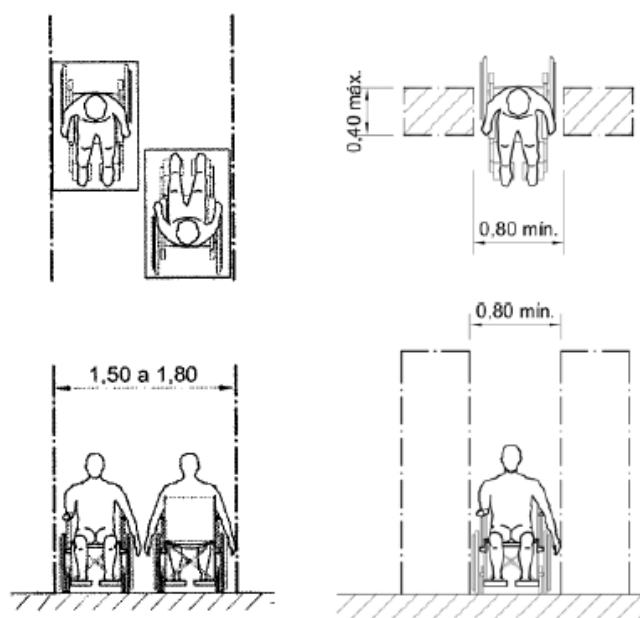

c) Duas pessoas em cadeiras de rodas

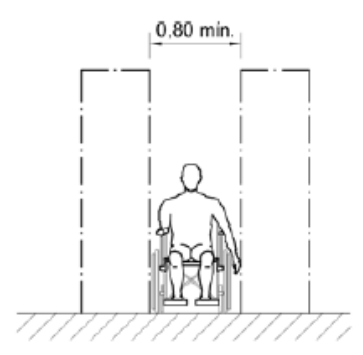

d) Trasposição de obstáculos

Figura 2-20 - Deslocamento de pessoas em cadeira de rodas e transposição de obstáculos (Fonte: ABNT NBR9050 Acessibilidade a edificações, mobiliário, espaços e equipamentos urbanos, 2004) 


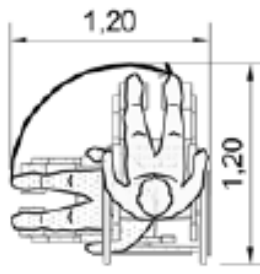

a) Rotaçã̃o de $90^{\circ}$

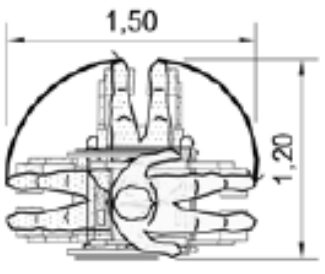

b) Rotaçẫo de $180^{\circ}$

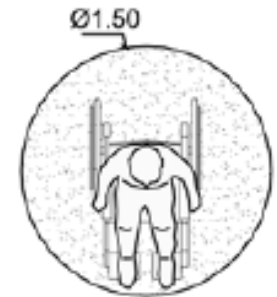

c) Rotaçã̃o de $360^{\circ}$

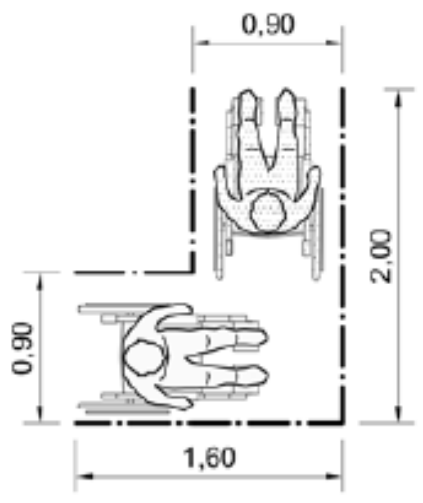

d) Deslocamento de $90^{\circ}$

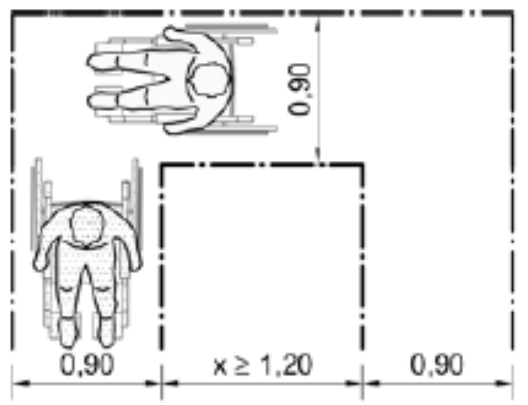

f) Deslocamento consecutivo de $90^{\circ} \mathrm{com}$ percurso intermediário - caso 1

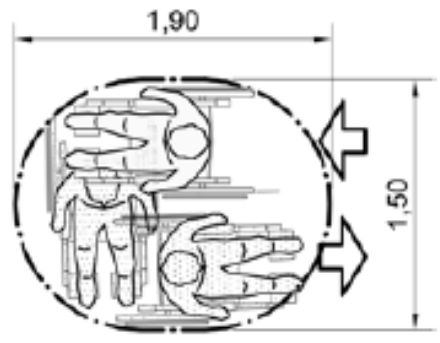

e) Deslocamento de $180^{\circ}$

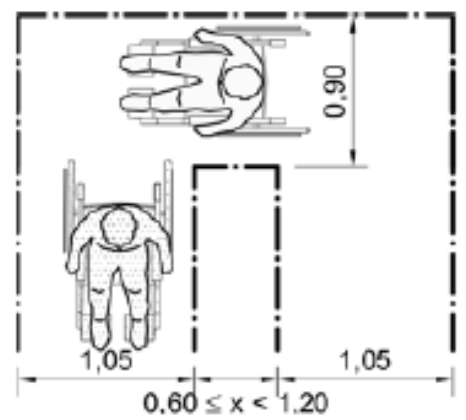

g) Deslocamento consecutivo de $90^{\circ} \mathrm{com}$ percurso intermediário - caso 2

Figura 2-21 - Manobras de cadeiras de rodas, sem deslocamento e com deslocamento (Fonte:

ABNT NBR9050 Acessibilidade a edificações, mobiliário, espaços e equipamentos urbanos, 2004) 


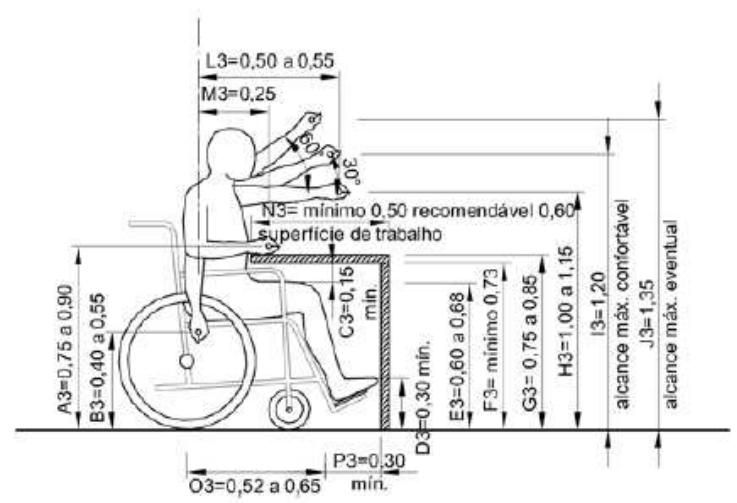

A3 = Altura do centro da mão com antebraço formando $90^{\circ} \mathrm{com}$ o tronco

B3 = Altura do centro da mão estendida ao longo do eixo longitudinal do corpo

C3 = Altura mínima livre entre a coxa e a parte inferior de objetos e equipamentos

D3 = Altura mínima livre para encaixe dos pés

$E 3=$ Altura do piso atè a parte superior da coxa

F3 = Altura mínima livre para encaixe da cadeira de rodas sob o objeto

$\mathrm{G} 3=$ Altura das superficies de trabalho ou mesas

H3 = Altura do centro da mão com braço estendido paralelo ao piso

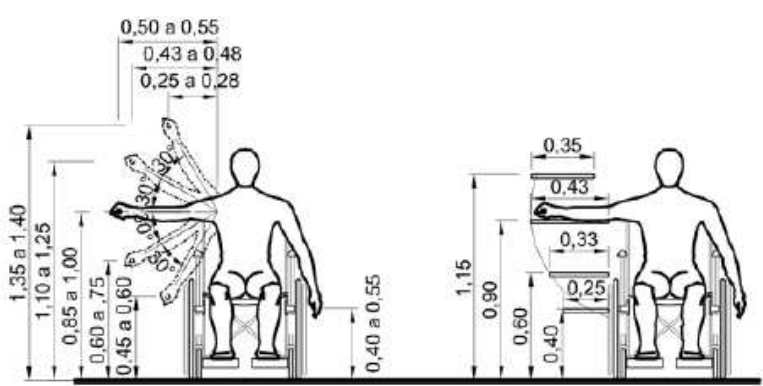

I 3 = Altura do centro da mão com o braço estendido, formando $30^{\circ} \mathrm{com} \circ$ piso $=$ alcance máximo confortável

$\mathrm{J} 3$ = Altura do centro da mão com o braço estendido formando $60^{\circ}$ com o piso = alcance máximo eventual

$\mathrm{L} 3$ = Comprimento do braço na horizontal, do ombro ao centro da mão

M3 = Comprimento do antebraço (do centro do cotovelo ao centro da mão)

N3 = Profundidade da superficie de trabalho necessária para aproximação total

O3 = Profundidade da nádega à parte superior do joelho

P3 = Profundidade minima necessária para encaixe dos pés

Figura 2-22 - Alcance manual com estação de trabalho: pessoa em cadeira de rodas (Fonte: ABNT NBR9050 Acessibilidade a edificações, mobiliário, espaços e equipamentos urbanos, 2004) 


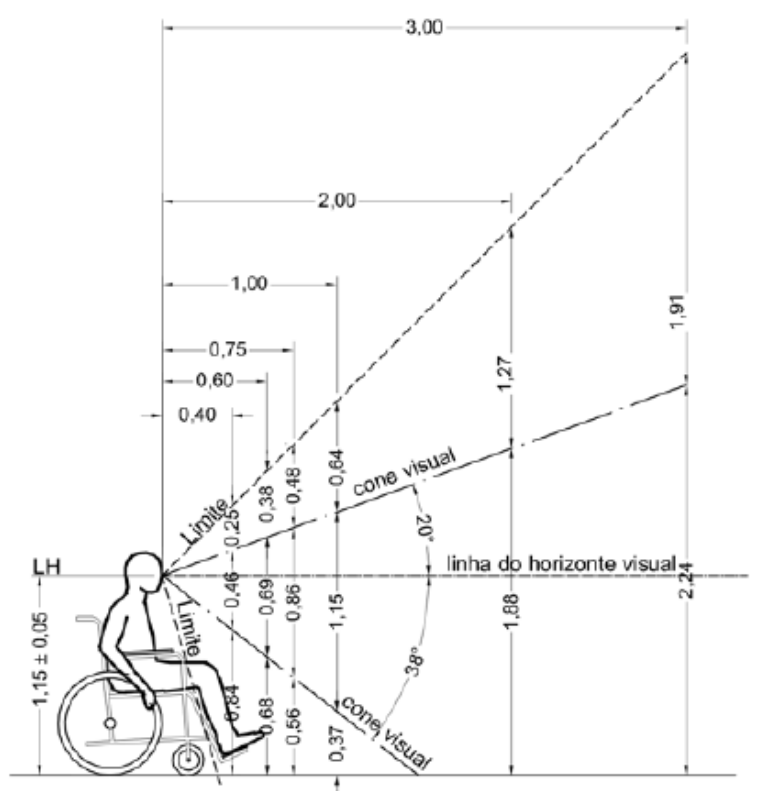

Figura 2-23 - Alcance visual: pessoa em cadeira de rodas (Fonte: ABNT NBR9050 Acessibilidade a edificações, mobiliário, espaços e equipamentos urbanos, 2004)

\subsubsection{Facilidades ao longo da via}

Estas são as facilidades que permitem o deslocamento dos pedestres em trajetos paralelos ao alinhamento das vias que atendem o tráfego em geral. Foram identificados como facilidades ao longo da via os acostamentos e as calçadas (exclusivas ou compartilhadas com outros usuários não motorizados).

Caberia também citar os caminhos de pedestres, que permitem o deslocamento por trajetos distintos das vias que servem o tráfego geral mas não serão discutidos por estarem fora do escopo deste trabalho.

Informalmente, outras duas alternativas ocorrem quando as facilidades específicas não existem ou são inadequadas: o uso das faixas de tráfego geral (compartilhando o espaço com os veículos motorizados) e o uso das áreas adjacentes às vias (distinguidas das calçadas pela falta de tratamento adequado à caminhada). 
$\mathrm{Na}$ maior parte, a discussão a seguir corresponde a decisões do projeto funcional das vias e por isso recorre principalmente aos manuais de projeto viário.

\section{a) Acostamentos}

De acordo com o Green Book (AASHTO, 2004a), o acostamento é a parte da via contígua ao leito carroçável que pode acomodar veículos parados, uso emergencial e em alguns casos, pedestres e ciclistas. E ainda que acostamentos podem mostrar a necessidade de calçadas, se são do tipo que encorajam o uso por pedestres em qualquer clima.

No entanto, segundo o Guia de Pedestres da AASHTO (2004b), a maioria dos acostamentos em rodovias não são dispositivos para pedestres, porém podem acomodar pedestres ocasionais. Onde ciclistas e pedestres serão acomodados no acostamento, a largura mínima livre deve ser de $1,20 \mathrm{~m}$.

O DNIT (2010) define acostamento como: "área da plataforma adjacente à pista de rolamento, destinada a: parada ou estacionamento provisório de veículos, servir de faixa extra de rolamento para emergências, contribuir para proteção da estrutura do pavimento e dos efeitos da erosão e à circulação de pedestres e bicicletas, quando não houver local apropriado para esse fim. Em rodovias de pista dupla, os acostamentos à direita do sentido de tráfego são denominados externos e aqueles à esquerda, internos. Onde acostamentos se aproximam de uma ponte ou viaduto, mesmo para baixo volume de tráfego de pedestres, os acostamentos devem ser mantidos com a mesma largura na travessia da obra de arte, e possivelmente aumentados, para levar em conta a restrição ao tráfego de pedestres, imposta pela obra-de-arte. $\mathrm{O}$ acostamento não deve ser interrompido por um passeio lateral elevado em uma ponte. Onde existir tal condição e não se justificar economicamente sua remoção, os passeios laterais devem ser projetados de modo que concordem com o greide do acostamento, por meio de rampas de 1:20 (ou 5\%).

O Manual de Segurança de Pedestres do DENATRAN (1979) recomenda, em vias rurais, alargamento do acostamento ou sua construção quando inexistente. Ressaltando ainda a 
necessidade de boa iluminação, criação de locais adequados para estacionamento e sinalização adequada para pedestres e ciclistas.

b) Calçadas

Segundo a AASHTO (2004a) as calçadas são parte integral de ruas na cidade, mas são raramente encontradas em áreas rurais. No entanto o potencial de atropelamentos é maior em muitas áreas rurais devido às altas velocidades e pouca iluminação. Os dados disponíveis são limitados, mas sugerem que calçadas em áreas rurais reduzem atropelamentos. Calçadas em áreas rurais são mais freqüentemente justificáveis em pontos de ocupação adjacente, como áreas residenciais, escolas, locais de negócio e indústrias, que resultam em concentração de pedestres próximo ou ao longo de rodovias. Se calçadas são utilizadas, devem ser separadas dos acostamentos. Justificativa para construção de calçadas depende do potencial de conflito entre veículos e pedestres. Volumes de tráfego para necessidade de pedestres não foram ainda estabelecidos. Em geral, sempre que as condições de desenvolvimento do entorno e do solo afetarem o movimento regular dos pedestres ao longo da rodovia, uma calçada deve ser providenciada. Quando duas comunidades estão próximas uma a outra, deve ser providenciada uma calçada para conectar essas comunidades.

O Guia de Pedestres da AASHTO (2004b) acrescenta que, calçadas instaladas nos dois lados da via, são os dispositivos preferidos pelos pedestres.

O HCM 2000 (TRB, 2001) diz que calçadas são dispositivos geralmente de uso exclusivo para pedestres, e dessa maneira dão o melhor nível de serviço para esses usuários. A melhor medida de desempenho da calçada é o espaço, que é o inverso da densidade.

O DNIT (2010) diz que justificativa para a construção de passeios laterais depende do potencial de conflitos com pedestres. Ainda não foram estabelecidas condições para construção de passeios em função dos volumes de tráfego. De um modo geral, sempre que o desenvolvimento lateral produzir movimento regular de pedestres ao longo da rodovia, um passeio lateral deve ser construído, ou área adequada deve ser reservada. Como uma medida de ordem geral, passeios laterais devem ser construídos ao longo de qualquer rua, mesmo que 
o tráfego de pedestres seja pequeno. Onde passeios laterais forem construídos ao longo de rodovias de velocidades elevadas, áreas de proteção devem separá-los da rodovia.

Pode, inicialmente, não haver demanda de pedestres em alguns trechos das vias arteriais urbanas que atravessam áreas pouco desenvolvidas. Passeios laterais podem não ser necessários inicialmente. O projeto, no entanto, deve considerar a possível necessidade futura e reservar área para sua instalação. Contudo, é desejável que todas as vias arteriais que não tenham faixas de acostamento já sejam construídas com passeios laterais, mesmo para baixos volumes de tráfego.

Referências clássicas como OGDEN (1996), também dizem que esse tipo de dispositivo de segurança é geralmente desejável, com exceção de locais onde o fluxo de pedestres é muito baixo; o fluxo de veículos é muito baixo e/ou há uma política bem estabelecida de integração entre veículos e pedestres

c) Método de Seleção de Facilidades para Pedestres ao Longo da Via

Em princípio, o critério básico de seleção é baseado no fluxo mínimo de pedestres que exige a provisão da infra-estrutura. Este é o caso da exigência de calçadas (os parâmetros específicos serão discutidos adiante).

Não foi identificada uma formulação correspondente para o problema de definir a provisão de acostamentos, nem fica claro se a opção à calçada seria admitir as alternativas informais ou outro tratamento (nas rodovias, seriam os acostamentos).

Também não foi identificada uma discussão detalhada de quais seriam as características adequadas à caminhada (que configurariam a área adjacente às vias como calçadas), como terreno nivelado ou com inclinação aceitável, ausência de obstruções no trajeto, calçamento ou outro tratamento superficial, etc... 


\subsubsection{Facilidades para travessia da via}

Estas são as facilidades que permitem o deslocamento dos pedestres em trajetos transversais ao alinhamento das vias que atendem o tráfego em geral. Foram identificados as travessias em nível sem semáforo ou com semáforo em interseções, as travessias em nível sem ou com semáforo em meio de quadra e as travessias em desnível (passarelas elevadas ou passagens subterrâneas). As travessias informais são as de meio de quadra sem sinalização.

Novamente, na maior parte, a discussão a seguir corresponde a decisões do projeto funcional das vias e por isso recorre principalmente aos manuais de projeto viário.

a) Travessias: em interseções sem semáforo

Segundo o Green Book (2004a) quando o pedestre encontra uma interseção, o fluxo de pedestres é interrompido e deve ser providenciada uma área de espera na calçada assim como uma área própria para travessia. Em interseções sem controle, pedestres devem esperar por uma brecha aceitável para a travessia, no tráfego veicular. Quanto mais larga a via, maior deve ser a brecha para que o pedestre consiga realizar a travessia. As interseções não semaforizadas são classificadas em: caso A - sem controle; caso B - com sinal de PARE na via secundária; caso $\mathrm{C}$ - com sinal de DÊ PREFERÊNCIA na via secundária.

O Manual de Pedestres da AASHTO (2004b) divide as interseções não semaforizadas em três grupos: sem sinalização de controle, com sinalização de preferência na via principal, e o controle com Pare para Todos existente nos EUA (All-way Stop Control, que aqui não será considerado). Na maior parte dos casos, em todas estas situações, os pedestres teriam de atravessar nas brechas entre veículos.

Segundo a AASHTO (2004b), garantindo condições adequadas de largura da via, volume de tráfego, velocidade e distância de visibilidade, interseções não semaforizadas podem ser bastante seguras para todos os usuários. 
O Manual do DNIT (2010) diz que "Nas interseções com grande volume de tráfego, os projetistas freqüentemente reduzem o número de travessias marcadas no pavimento, visando diminuir a quantidade de pessoas nas áreas de conflito. As larguras dos canteiros centrais, que contêm faixas de giro à esquerda, devem ser dimensionadas, de modo que a área restante do canteiro ofereça abrigo suficiente para os pedestres que desejam atravessar. Um canteiro central com 5,50 m de largura permite uma faixa de armazenagem de veículos de 3,50 m e uma ilha com 2,00 m de largura, para proteção dos pedestres. Os conflitos de pedestres com veículos ocorrem principalmente nas interseções. Nas vias arteriais de classe inferior, especialmente em cruzamentos com ruas secundárias de menor importância, com poucos movimentos de giros, as travessias de pedestres são geralmente delimitadas por simples marcas no pavimento. Para proteção dos pedestres podem ser incluídos iluminação permanente, ilhas de refúgio, barreiras e sinais luminosos."

Naturalmente, algumas das variáveis mencionadas não são variáveis controladas no projeto, como é o caso do volume de tráfego. Esta observação explica a discussão tradicional sobre a adequação das travessias sem semáforo em função do volume de tráfego.

Outras variáveis são apenas parcialmente controladas, como é o caso da velocidade de tráfego, para manter-se um projeto consistente com as características da via como um todo, em cada contexto percorrido. Além disso, podem existir restrições físicas rígidas que impedem a adequação da visibilidade ou largura das travessias às necessidades dos pedestres.

Portanto, a adequação da travessia sem semáforos pode ser comprometida, o que será considerado na discussão dos tratamentos mencionados a seguir.

b) Travessias: em interseções com semáforo;

Não há uma discussão clara sobre a necessidade deste tipo de tratamento nos manuais de projeto viário como o Green Book (AASHTO, 2004a), onde diz-se sucintamente que as travessias devem ser largas o suficiente para acomodar pedestres nos dois sentidos durante a fase semafórica de pedestres.

O mesmo aplica-se ao DNER (1999). 
Segundo o Guia de Pedestres da AASHTO (2004b), semáforos criam brechas que permitem que os pedestres cruzem a via. Esta observação corresponde mais aos semáforos com estágios de pedestres. Nos semáforos com estágios veiculares, seu efeito é reduzir os fluxos conflitantes em cada estágio.

O Guia de Pedestres da AASHTO (2004b) recomenda, no entanto, que o projeto geométrico considere também a situação sem semáforo mesmo neste caso. Por exemplo, a distância de visibilidade deve ser mantida para que motoristas e pedestres possam ver uns aos outros quando o semáforo não está funcionando.

Diz ainda que estudos mostram que em interseções com menos de 1200 pedestres por dia, não há diferença significativa em acidentes com pedestres havendo ou não semáforo com fase exclusiva de pedestre. Portanto, critérios de volume de tráfego são sugeridos para determinar a adequação do tratamento semafórico dado aos pedestres, sem uma análise sistemática.

Para o Manual de Segurança de Pedestres do DENATRAN (1983), o controle por semáforos nas interseções é a forma mais segura para a travessia de pedestres, devendo ser utilizado semáforo para pedestres em conjunto com semáforo para veículos quando não existem movimentos conflitantes (o tempo de verde para pedestres coincide com o tempo de vermelho para veículos). A consideração provavelmente limita-se aos tratamentos em nível.

Quando existem movimentos conflitantes de pedestres e veículos deve ser feita análise das características do tráfego no local, evitando congestionamento, aumento no tempo de viagem e aumento nos retardamentos. As situações consideradas são:

- Caso A: Criação de refúgios no local de travessia - permitindo que os pedestres estejam seguros durante a espera de uma brecha entre veículos, favorável para a travessia, ou de uma mudança de fase (estágio) do semáforo;

- Caso B: Término antecipado da fase (estágio) do semáforo que permite o movimento conflitante de veículos (em geral conversão), prolongando o verde para pedestres no mesmo tempo; 
- Caso C: Adoção de um tempo de vermelho em conjunto para todos os movimentos de veículos (all red ou estágio geral de pedestres), com duração suficiente para que os pedestres completem a travessia. O fluxo de pedestre deve justificar essa medida;

- Caso D: Proibição do movimento de conversão de veículos, desde que seja possível a adoção de um caminho alternativo que não traga prejuízos ao tráfego.

Recomenda também critérios para a temporização dos tempos semafóricos:

- O tempo de vermelho: depende do tempo de verde para o movimento conflitante, da necessidade de minimizar o retardamento total para os veículos, da frequiência de chegada de pedestres, da inconveniência de ciclos muito longos;

- O tempo de verde constante: Todo o pedestre esperando no meio fio ou chegando ao local, pode iniciar a travessia. Recomendado: 6 segundos, no mínimo.

- O tempo de verde piscando: Pedestre que já iniciou a travessia pode completá-la. É função da largura da via (L) e da velocidade média do pedestre, admitida 1,3 m/seg; tempos de verde piscando: $\mathrm{L} / 1,3$.

O tratamento dos pedestres em semáforos é um tema recorrente nos estudos sobre acidentes (sugerindo a sua importância neste aspecto).

De acordo com OGDEN (1996), há algumas vezes conflitos entre capacidade de tráfego e estágio de pedestres em semáforos. ZEGEER et al. (1982) chamam atenção para que semáforos sem o estágio exclusivo de pedestres não são mais seguros que aqueles com esse estágio. ZEGEER (1993) sugere que estágios exclusivos devem ser previstos quando o semáforo dos veículos não é visível para os pedestres ou há fases exclusivas de conversão, e dessa forma o tempo dos pedestres não é claro; também na travessia de escolas; um estágio de pedestres para movimento em qualquer direção é recomendada.

Para GOLD (1998), a implantação de semáforos para pedestres deve ser precedida de uma avaliação de critérios sobre a necessidade real de sua instalação. 
O tratamento dos pedestres também é parte dos critérios usuais de utilização de semáforos, particularmente em interseções. A referência clássica a respeito é o MUTCD (2009), ou suas sucessivas versões. Esses critérios são reconhecidos também no Brasil embora de forma adaptada. Por exemplo, o Manual de Semáforos (DENATRAN, 1978), embora baseado nos critérios do MUTCD (1968), diverge dele e recomenda os seguintes volumes mínimos: 250 pedestres por hora em ambos os sentidos da travessia; 600 automóveis por hora para via de sentido duplo sem divisor central; 1.000 veículos por hora para via com divisor central. Para ambos, pode haver casos que requeiram a instalação de um semáforo com volumes inferiores, como o caso do volume de veículos contínuo e sem brechas (semáforo atuados por botoeiras).

Muitos dos critérios para definição da necessidade de semaforizar (ou de forma mais geral segregar) para ordenar os conflitos entre veículos e pedestres são propostos sem justificativa ou esclarecimento sobre sua racionalidade. Um histórico interessante sobre os critérios americanos é feita em CARLSON e TURNER (2001), onde se vê que os valores e curvas propostas normalmente decorrem de estimativas empíricas ou teóricas da probabilidade de encontrar uma brecha de travessia adequada ou no atraso médio para travessias para os pedestres na ausência de semáforos (ou outros dispositivos de segregação).

c) Travessias em meio de quadra

O Manual do DNIT (2010) diz que nas travessias das ruas, geralmente são satisfatórias faixas de pedestres com largura de 3,00 m. Devem ser marcadas com pintura todas as faixas situadas nas rotas estabelecidas para acesso às escolas. No entanto a largura da faixa de travessia deve ser suficiente para acomodar o fluxo de pedestres em ambos os sentidos. Distâncias de visibilidade adequadas e visão desimpedida são pontos chaves na localização dessas travessias. Paisagismo, carros estacionados, postes, dispositivos de sinalização e mobiliário urbano podem criar obstruções para a visão do pedestre. Quando esses elementos não podem ser deslocados, alargamentos das áreas livres laterais ou proibição de estacionamento são desejáveis, de modo que os caminhos de pedestres ou suas linhas de visão não sejam bloqueados. Em ruas com velocidades limitadas de 30 a $50 \mathrm{~km} / \mathrm{h}$, deve-se proibir o estacionamento em trecho de $6 \mathrm{~m}$, a partir do local de travessia de pedestre. Para velocidades 
de 55 a $70 \mathrm{~km} / \mathrm{h}$, é desejável prover $15 \mathrm{~m}$. Uma zona de proibição de estacionamento de $9 \mathrm{~m}$ deve ser estabelecida antes de cada sinal de parada ou de indicação de via preferencial. Para velocidades acima de $70 \mathrm{~km} / \mathrm{h}$ não se deve permitir estacionamento lateral.

O Manual de Segurança de Pedestres do DENATRAN (1983) recomenda que em travessias de pedestres fora de interseções sejam utilizadas faixas para pedestres, em locais com pequeno fluxo veicular e fluxo de pedestres intermitente. Onde é necessário interromper o tráfego devese utilizar semáforo com tempo de ciclo fixo ou acionado pelos pedestres.

Como medida de apoio necessária, o estacionamento deve ser proibido nos trechos onde haveria obstrução da visibilidade. Para determinar o comprimento do trecho com proibição, deve-se levar em consideração que o motorista deve ter visibilidade total da faixa a $30 \mathrm{~m}$ desta (em vias de mão única, à esquerda do motorista: $\mathrm{d}=25 \mathrm{~m}$ e em vias de mão dupla, à direita do motorista: $\mathrm{d}=19 \mathrm{~m}$ ) e visibilidade total da faixa de maneira a poder acionar os freios e parar o veículo no limite da faixa. Estas recomendações sobre estacionamento estão reproduzidas na Tabela 2-2 a seguir.

Uma necessidade correspondente existiria também em interseções. O caso não é discutido para interseções e uma opção seria o avanço de calçada. 
Tabela 2-2 - Extensão do trecho com proibição de estacionamento em função da velocidade para travessias em meio de quadra (Fonte: Manual de Segurança de Pedestres, DENATRAN, 1979)

\begin{tabular}{|c|c|c|c|c|}
\hline \multirow{2}{*}{ V (km/h) } & \multicolumn{2}{|c|}{ Pavimento Seco } & \multicolumn{2}{c|}{ Pavimento Molhado } \\
\cline { 2 - 5 } & $\mathrm{d}_{\mathrm{f}}(\mathrm{m})$ & $\mathrm{d}(\mathrm{m})$ & $\mathrm{d}_{\mathrm{f}}(\mathrm{m})$ & $\mathrm{d}(\mathrm{m})$ \\
\hline 30 & 12 & 10 & 15 & 13 \\
\hline 40 & 23 & 19 & 30 & 25 \\
\hline 60 & 38 & 31 & 51 & 42 \\
\hline
\end{tabular}

Obs.: V: velocidade do veículo $(\mathrm{km} / \mathrm{h})$

$\mathrm{d}_{\mathrm{f}}$ : distância necessária para frear o veículo (em metros)

d: comprimento do trecho com proibição

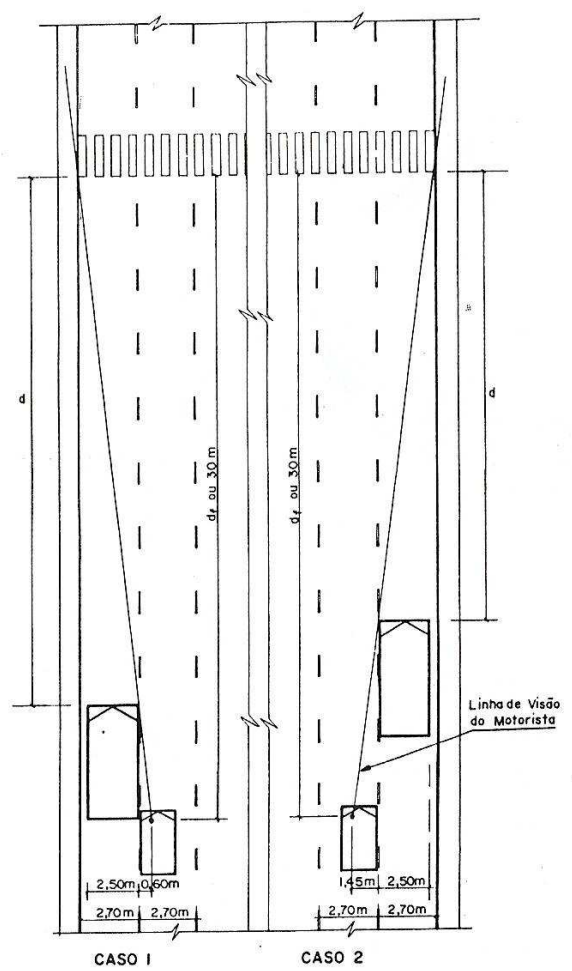

Figura 2-24 - Extensão do trecho com proibição de estacionamento em função da velocidade para travessias em meio de quadra (Fonte: Manual de Segurança de Pedestres, DENATRAN, 1979) 
d) Travessia em desnível: passarelas e passagens subterrâneas

Para a AASHTO (2004a) travessias em desnível devem ser providenciadas onde volume de pedestres, volume de tráfego, capacidade da interseção e outras condições favorecem seu uso, no entanto sua localização específica e projeto requerem estudo individual. Devem ser consideradas onde tem elevados picos de movimentos de pedestres, como em distritos centrais e de negócios, fábricas, escolas, campos de exercício, em combinação com tráfego veicular moderado a alto, ou onde surgiria risco não usual e inconveniência para o pedestre. Códigos e leis federais devem ser consultados para critérios adicionais considerando necessidade, assim como orientação para projeto. Estruturas de travessia de pedestre em desnível não devem ser utilizadas em vias arteriais a menos que seja óbvio para o pedestre que é mais fácil usar a facilidade do que realizar a travessia em nível. Geralmente os pedestres são mais relutantes a utilizar a passagem subterrânea do que a passarela. Um problema sério associado a passarelas em rodovias são vândalos arremessando objetos na pista. Não tem um método ou conselho prático universal a ser utilizado nesse caso. No momento não é prático estabelecer critérios absolutos de quando ou onde barreiras devem ser construídas para evitar o arremesso de objetos da estrutura. Telas devem ser necessariamente colocadas em passarelas: próximas a escolas, playground ou outro lugar que sugere o uso da passarela por crianças desacompanhada de adultos; em grandes áreas urbanas sem constante vigilância da polícia; onde o histórico de incidentes em estruturas próximas indica a necessidade.

Para o Manual de Pedestres da AASHTO (2004b), travessias em desnível são algumas vezes necessárias, mas devem ser bem projetadas e posicionadas de preferência dando continuidade à trajetória normal dos pedestres. Passarelas podem ser mais eficientes onde:

- há uma demanda moderada a alta de pedestres para cruzar uma via expressa;

- há grande número de crianças para atravessar uma via de alta velocidade e volume de tráfego;

- conflitos encontrados por pedestres são inaceitáveis;

- uma ou mais das condições anteriores existe em conjunto com uma rota bem definida de pedestres. 
Ainda segundo a AASHTO (2004b), estudos mostram que o grau de uso de uma passarela ou passagem subterrânea por pedestres, depende da distância percorrida e conveniência do dispositivo. Uma medida de conveniência pode ser, por exemplo, $\mathrm{R}$, a taxa do tempo de travessia na passarela/passagem subterrânea pelo tempo de travessia na via.

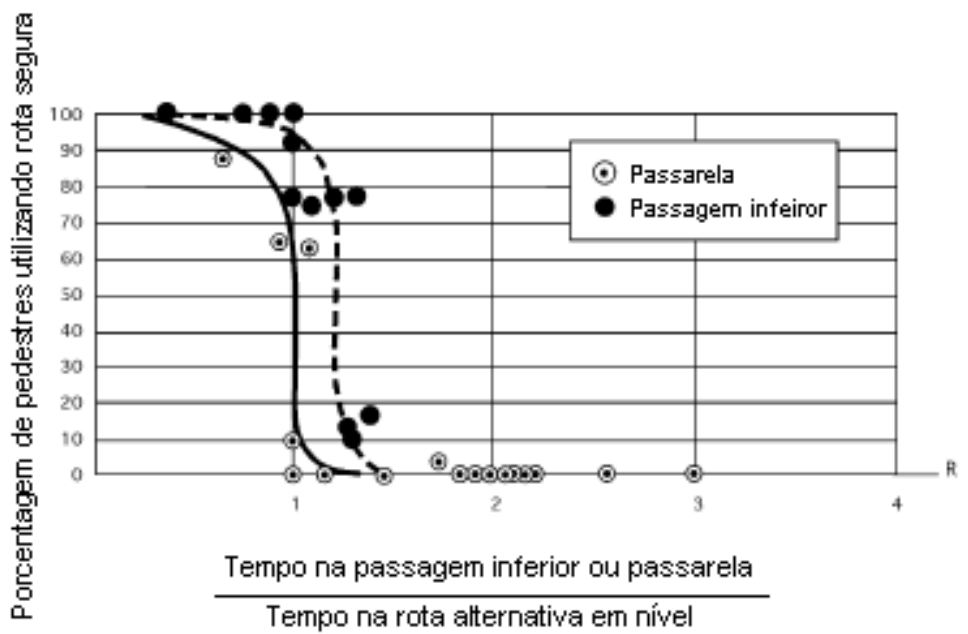

Figura 2-25 - Porcentagem de pedestres que utilizam via segura (Fonte: Design and Safety of Pedestrian Facilitys, Institute of Transportation Engeneers, Washington, DC, March 1998. Apud: Guide for the Planning, Design and Operation of Pedestrian Facilities, America Association of State Highway and Transportation Officials, 2004)

Pelo gráfico, $95 \%$ dos pedestres usariam a passarela e 70\% usariam a passagem subterrânea se o tempo de travessia fosse o mesmo da via, $R=1$. No entanto, se o tempo de travessia pelo dispositivo for $50 \%$ maior $(\mathrm{R}=1,5)$ poucos pedestres utilizaram os dispositivos. A observação mostra que a simples construção do elemento para travessia em desnível, desconsiderando sua conveniência, não é julgada suficiente para atender os pedestres.

O Manual de Travessias Urbanas do DNIT (2010) repete os critérios da AASHTO (2004b) e adiciona um critério preliminar para definir se a travessia de uma via com velocidade de até 60 $\mathrm{km} / \mathrm{h}$ deve ser feita em desnível é apresentado em um gráfico: 


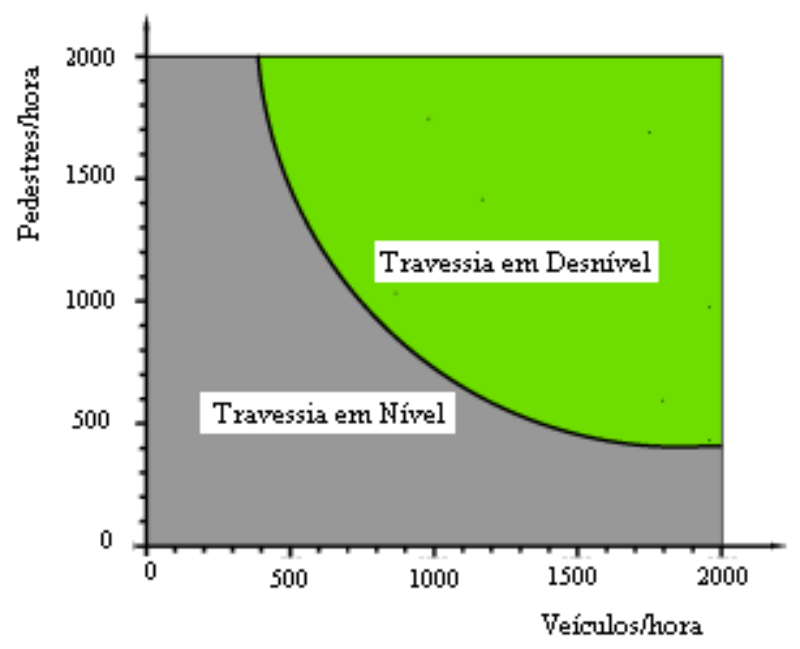

Figura 2-26 - Fluxos que justificam a implantação de passarelas (Fonte: Direction des Pontset de la Circulation Routière. Apud: Manual de Projeto Geométrico de Travessias Urbanas, DNIT, 2010)

O DNIT (2010) menciona ainda que a declividade de acessos por rampas não deve exceder à inclinação de 1:12 (8,33\%), conforme recomendação da NBR 9050 da ABNT, para maior adequação aos deficientes físicos. A altura mínima livre admissível para passagens cobertas ou subterrâneas é de $2,20 \mathrm{~m}$.

Para OGDEN (1996), travessias em desnível são apropriadas quando há alta velocidade e/ou alto fluxo de veículos; onde há atraso considerável de pedestres ou grande problema de acidentes. Sua eficiência depende da escolha dos pedestres em usar ou não o dispositivo. Pesquisa no Estados Unidos (ZEGEER, 1993) mostra que 95\% das pessoas usam a passarela se não há aumento no tempo de viagem e "quase ninguém utiliza" quando há um aumento de $50 \%$ no tempo da viagem. Passagens subterrâneas são menos utilizadas que as passarelas provavelmente devido a percepção de redução de segurança.

Para GOLD (1998), passarelas devem ser consideradas quando há pedestres que precisam cruzar um fluxo perigoso de veículos sem que haja uma alternativa segura; quando ocorreram atropelamentos, mesmo que a análise do fluxo de tráfego não indique que as condições de tráfego são perigosas. Uma passarela deve ser usada quando não há nenhuma alternativa mais barata para proporcionar condições satisfatoriamente seguras ao movimento necessário de pedestres. Como as passagens em desnível geralmente supõem um aumento de tempo de 
percurso dos pedestres, é fundamental que estejam localizadas nas trajetórias desejadas pelos pedestres.

GOLD (1998) compara ainda passarelas com passagens inferiores (subterrâneas):

Vantagens da passarela:

- $\quad$ Não interferem com os serviços públicos subterrâneos

- $\quad$ Para os pedestres, são esteticamente mais agradáveis

- Melhor segurança pessoal

- Mais econômicas que as passagens inferiores (subterrâneas)

Vantagens da passagem inferior (subterrânea):

- Menor desnível a ser percorrido pelo pedestre

- Menores inconvenientes estéticos

- Mais confortáveis em condições climatológicas adversas

e) Método de escolha do tratamento da travessia

Foram selecionados três métodos para a escolha do tratamento a ser utilizado em determinada travessia. O primeiro é o método proposto pelo Manual de Segurança de Pedestres do DENATRAN (1983) baseados no conceito de retardamento sofrido na travessia. Em seguida são apresentados os conceitos de condições básicas e de condições adequadas de travessia expostos por GOLD (1998). 
1. Método do Manual de Segurança de Pedestres do DENATRAN (1983)

O Manual de Segurança de Pedestres do DENATRAN (1983) propõe um método para seleção do tipo de travessia a ser aplicado, conforme segue:

\section{Etapas:}

1)Determina-se características do local a ser estudado através de pesquisas de campo;

2)Calcula-se o retardamento sofrido por pedestre para travessia sem semáforo e com semáforo (pelo volume de pedestres que utiliza a travessia);

3)Calcula-se o retardamento sofrido por veículos para cada tipo de travessia;

4)Taxa média de ocupação de cada veículo passando pelo local (pelos dados coletados);

5)Calcula-se o retardamento sofrido por todos os ocupantes dos veículos;

6)Somando-se 2 e 5, obtêm-se o retardamento sofrido por todas as pessoas que passam pelo trecho, para todos os tipos de travessia;

7)Escolhe-se a travessia com menor retardamento total;

8)No caso em que for escolhida a travessia com semáforo de ciclo fixo, deve-se pesquisar a viabilidade de substituí-la por uma passagem em desnível.

$\underline{\text { Retardamento para pedestres e veículos nos diversos tipos de travessias: }}$

O Manual de Segurança de Pedestres do DENATRAN (1983) traz um método de cálculo da distância da rota principal à escada ou rampa de acesso à passagem em desnível, dp (m).

$$
\begin{gathered}
d_{p}=\frac{V_{p}}{2}\left(a-\frac{2 H}{V_{e} \text { ou } V_{r}}\right) \\
a+t=2 t_{p}+2 t_{h}+t \quad a=2 t_{p}+2 t_{h}
\end{gathered}
$$


Sendo:

$\mathrm{d}_{\mathrm{p}}$ : distância da rota principal à escada ou rampa de acesso à passagem em desnível (m)

a: retardamento sofrido pelo pedestre se escolhida a travessia em nível (segundos)

t: tempo que o pedestre leva para percorrer a distância equivalente à largura da via (seg)

$t_{p}$ : tempo que o pedestre leva para percorrer a distância $d_{p}(s e g)$

$t_{h}$ : tempo que o pedestre leva para subir ou descer a rampa ou escada de acesso à travessia em desnível (segundos)

$\mathrm{V}_{\mathrm{p}}$ : velocidade do pedestre médio no plano $(\mathrm{m} / \mathrm{seg})$

$\mathrm{V}_{\mathrm{e}}$ : velocidade do pedestre médio para descer ou subir uma escada $(\mathrm{m} / \mathrm{seg})$

$\mathrm{V}_{\mathrm{r}}$ : velocidade do pedestre médio para percorrer um rampa $(\mathrm{m} / \mathrm{seg})$

H: desnível entre a via e a travessia (m)

( $H$ mínimo $=5,50 m-A B N T)$

$\underline{\text { Retardamento para pedestres e veículos nos diversos tipos de travessias: }}$

O retardamento médio por pedestres, ap, depende da largura da via a atravessar, das condições de tráfego do local e do fluxo de pedestres no local (no caso de semáforo com botoeira).

O retardamento médio por veículo, av, depende do ciclo do semáforo, do fluxo de veículos no trecho, da capacidade da via no local e da composição do tráfego. 
Tabela 2-3 - Fórmulas para cálculo do atraso sofrido por pedestres em pistas simples e dupla em diferentes tipos de travessia (Fonte: Baseado no Manual de Segurança de Pedestres, DENATRAN, 1979)

\begin{tabular}{|l|c|c|}
\hline & Pista Simples & Pista Dupla \\
\hline $\begin{array}{l}\text { Travessia com faixa, } \\
\text { sem semáforo }\end{array}$ & $a_{p}=\frac{e^{q I}-q I-l}{q}$ & $a_{p}=a_{p I}+a_{p I I}$ \\
\hline $\begin{array}{l}\text { Travessia com } \\
\text { semáforo de tempo de } \\
\text { ciclo fixo }\end{array}$ & $a_{p}=\frac{|C-(P-r)|^{2}}{2 C}$ & $\begin{array}{l}\text { Em vias de mãoúnica ou } \\
\text { dupla existe um único tempo de } \\
\text { ciclo } C\end{array}$ \\
\hline $\begin{array}{l}\text { Travessia com } \\
\text { semáforo acionado pelo } \\
\text { pedestre }\end{array}$ & $a_{p}=\frac{t_{a^{*}} 0,5 \cdot \lambda \cdot t_{b}^{2} \cdot e^{\left(\lambda_{b_{b}}-\hat{\lambda} t_{a}\right)}}{1+\lambda\left(t_{b}+P\right) \cdot e^{\left(\lambda_{b_{b}}-\hat{\lambda_{a}} t_{a}\right)}}$ \\
\hline
\end{tabular}

$a_{p}:$ retardamento médio por pedestre

q: volume de veículos no trecho (veíc/seg)

I: tempo necessário ao pedestre para completar a travessia da rua

I: L/1,3 (seg) (Recomendado)

L: largura da via (metros)

$P:$ duração do período de verde para pedestres

$P: L / 1,3+6=I+6$

$C$ : duração do ciclo do semáforo (seg)

$t_{a}$ : tempo amarelo do semáforo (recomendado $2 \mathrm{seg}$ )

$t_{b}$ : tempo mín de verde para veículos

$(=C$-ta-P $=C$ - $P$ - 2$)$

$\lambda$ : volume de pedestres atravessando a via na secão considerada 
Tabela 2-4 - Fórmulas para cálculo do atraso sofrido por pedestres em pistas simples e dupla em diferentes tipos de travessia (Fonte: Baseado no Manual de Segurança de Pedestres, DENATRAN, 1979)

\begin{tabular}{|c|c|c|}
\hline & Pista Simples & Pista Dupla \\
\hline $\begin{array}{l}\text { Travessia com faixa, } \\
\text { sem semáforo }\end{array}$ & \multicolumn{2}{|c|}{ Nulo } \\
\hline \multirow{2}{*}{$\begin{array}{l}\text { Travessia com } \\
\text { semáforo de tempo de } \\
\text { ciclo fixo }\end{array}$} & $a_{v}-\frac{0,45 \cdot C \cdot(l-g)^{2}}{l-g X}+\frac{1620 \cdot X^{2}}{q \cdot(l-X)}$ & \multirow{2}{*}{$a_{v}=a_{v I}+a_{v I I}$} \\
\hline & $g=\frac{C-P-2}{C}$ & \\
\hline \multirow{3}{*}{$\begin{array}{l}\text { Travessia com } \\
\text { semáforo acionado pelo } \\
\text { pedestre }\end{array}$} & $a_{v}-\frac{0,45 \cdot C \cdot(l-g)^{2}}{l-g X}+\frac{1620 \cdot X^{2}}{q \cdot(l-X)}$ & \multirow{3}{*}{$a_{v}=a_{v I}+a_{v I I}$} \\
\hline & $y-\frac{t_{b}+\frac{1}{\lambda} e\left(\lambda . t_{b}+\lambda \cdot t_{a}\right)}{v\left|t_{b}\right|{ }_{\lambda}^{1} e\left(\lambda \cdot t_{b} \mid \lambda t_{a}\right)}$ & \\
\hline & $\lambda=\lambda_{1}+\lambda_{2}$ & \\
\hline Passagens em desnível & \multicolumn{2}{|c|}{ Nulo } \\
\hline
\end{tabular}

$a_{v}:$ retardamento médio por veículo

$X$ : Grau de saturação $\left(q^{\prime} / q^{S}\right)$

S: fluxo de saturação no trecho $(525 \mathrm{~L} \mathrm{ucp/h})$

$q$ : volume de veículos no trecho (veíc/seg)

$q^{\prime}:$ volume equivalente em veículos de passeio no trecho $(u c p / h)$

$P$ : duração do período de verde para pedestres

g: proporção do ciclo que é efetivamente verde

C: duração do ciclo do semáforo (seg)

$t_{a}$ : tempo amarelo do semáforo (recomendado $2 \mathrm{seg}$ )

$t_{b}$ : tempo mín de verde para veículos

$(=C-t a-P=C-P-2)$

$\lambda$ : volume de pedestres atravessando a via na secão considerada (ped/seg) 
2. Conceito de Condições Básicas e Adequadas de Travessia em GOLD (1998)

GOLD (1998) distingue os conceitos de condições básicas e condições adequadas de travessia. E propõe algumas medidas de melhoria a serem aplicadas a fim de garantir a existência dessas condições.

A apresentação é feita na discussão sobre atropelamentos, sendo baseada na análise dos artigos do Código de Trânsito Brasileiro, CTB1997 (BRASIL, 1997 e suas atualizações até 2008) relacionados ao pedestre; a caracterização do comportamento geral dos pedestres e dos condutores de veículos; e uma discussão sobre aspectos de fluxo de trânsito e da engenharia de tráfego que determinam as condições de travessia.

$\mathrm{O}$ autor ressalta que a maioria dos atropelamentos ocorre pois pedestres e condutores de veículos não seguem o comportamento dos modelos utilizados como base para os projetos do sistema viário e para a sinalização.

Define ainda o comportamento geral dos pedestres e o comportamento geral dos condutores de veículos, que devem ser levados em conta para qualquer análise de fatores que contribuam aos atropelamentos.

\section{Comportamento geral dos pedestres:}

- Pessoas de todas as idades (crianças e adultos);

- Qualquer estado físico/mental;

- Podem não ter recebido educação sobre o trânsito;

- Muitos não sabem ler ou não entendem os sinais,

- Desejam cruzar a rua pelo trajeto mais curto;

- A maioria tem habilidade para driblar os veículos em movimento, podendo passar por diferentes tipos de obstáculos;

- A maioria fica quase invisível, à noite, para os condutores; 
- Consideram que podem cruzar a rua em qualquer local, e em geral podem, a menos que não existam brechas no fluxo de veículos ou existam barreiras eficazes.

Comportamento geral dos condutores de veículos:

- Maiores de 18 anos, normalmente;

- Devem ter passado por um exame médico;

- Devem possuir uma licença para dirigir (alfabetizados, receberam algum tipo de educação para o trânsito);

- Muitas vezes desejam dirigir a uma velocidade mais alta do que a permitida;

- Não desejam fazer paradas desnecessárias e/ou longas;

- Em sua maioria, obedecem à sinalização e aos artigos do código de trânsito apenas quando sua desobediência ameaça a própria segurança ou pode terminar em castigo ou detenção;

- A maioria não se mostra consciente nem dos direitos nem da insegurança que sofrem os pedestres, e atuam com frequiência, contra a sinalização e os regulamentos de trânsito;

- Muitos circulam, à noite, sem faróis ligados, desobedecendo a legislação e ficando sem condições de ver os pedestres a tempo de evitar um atropelamento.

Dessa forma, podem ser analisadas as condições reais da travessia, que determinam a facilidade com que o pedestre atravessa a rua sem entrar em conflito com os veículos.

O autor então apresenta o conceito de condição básica de travessia (sem as quais não haverá possibilidade de travessia segura), como as existentes em um local quando é possível mostrar, para qualquer pedestre que deseje atravessar a rua:

- Local correto: onde pode cruzar com segurança;

- Momento adequado: quando pode cruzar com segurança; e

- Perceptibilidade: como identificar o local correto e o momento adequado. 
A não existência dessas condições básicas de travessia deve-se a alguma deficiência da engenharia de tráfego, e/ou à desobediência da sinalização e das normas de trânsito pelos condutores de veículos.

a. Local com condições básicas de travessia

Linha desejada: AB.

Local seguro: faixa de travessia de pedestres.

Momento adequado: semáforo S1 vermelho e veículos parados atrás da linha de retenção.

Perceptibilidade: faixa de travessia de pedestres, semáforo, veículos parados.

b. Local sem condições básicas de travessia - ausência de local seguro

Linha desejada: $\mathrm{CD}$.

Local seguro: não existe. Não há semáforo e os fluxos geram trânsito contínuo sem brechas. Não há faixa de travessia de pedestres e não há um local alternativo à vista.

c. Local sem condições básicas de travessia - ausência de momento adequado

Linha desejada: EF.

Local adequado: faixa de travessia de pedestres.

Momento adequado: mudança de fase de S1 de verde a vermelho, porém há muitos veículos fazendo a conversão e os condutores não dão preferência aos pedestres. 
d. Local sem condições básicas de travessia - ausência de perceptibilidade

Linha desejada: GH.

Local adequado: GH, sem faixa de travessia de pedestres.

Momento adequado: existem brechas adequadas, porém com freqüência muito baixa e de duração mínima necessária para travessia.

Perceptibilidade: brecha difícil de perceber; mistura de veículos com diferentes velocidades.

O autor introduz então o conceito de condições adequadas, que não são garantidas pela existência das condições básicas: se o tempo de espera e/ou o desvio da trajetória desejada excedem o limite de tolerância dos pedestres, parte deles cruzará em condições de perigo.

As condições adequadas de travessia existem em um local quando, além da existência das condições básicas, é possível constatar um tempo de espera tolerável e um desvio tolerável da trajetória desejada.

O problema é a definição de tolerável, que depende da situação. O pedestre, por exemplo, tem mais paciência para esperar em ruas largas, com muitos movimentos de veículos que em ruas estreitas e calmas.

Finalmente, a travessia fácil e segura de uma rua onde se encontram as condições básicas e adequadas depende de características da via e do fluxo de veículos, que podem ou não ser controladas pela engenharia de tráfego, e que determinam a perceptibilidade do momento adequado para a travessia.

- Distância de travessia: recomenda dividir a travessia para distância maior ou igual a 9 metros;

-Duração das brechas nos fluxos de veículos: no caso de travessias com semáforo, recomendase aumentar o tempo para a travessia; 
- Frequência das brechas adequadas nos fluxos de veículos: também pode ser regulada com ajuste nos tempos do semáforo;

- Velocidade dos veículos: pode ser reduzida com sinais de regulamentação, alargamento de calçada para deixar a via mais estreita e implantação de dispositivos especiais;

- Variações de velocidade dos veículos: a fim de reduzir as variações de velocidades dos veículos, podem ser implantadas as faixas exclusivas para ônibus e locais de confluência de fluxos de veículos com velocidades médias diferentes, por exemplo;

- Sentido de direção dos veículos: no caso de vias de sentido duplo de direção, recomenda-se implantar uma ilha de refúgio entre as faixas, pois a avaliação de brechas é mais simples com um único sentido de fluxo de veículos;

- Número de fontes de fluxos de veículos: nos casos complexo e muito complexo, recomenda a simplificação da travessia com refúgios, implantação de faixas de conversão, semáforo para pedestres;

- Mudança de condições durante a travessia: no caso de muita mudança, os fluxos podem ser separados por pequenos refúgios ou divisores centrais contínuos;

- Visibilidade pedestre/veículo e condutor/pedestre: medidas como a proibição do estacionamento de veículos próximos às esquinas, com ou sem alargamento de calçada (a fim de evitar a transgressão) ajudam a preservar a visibilidade.

$\mathrm{O}$ autor conclui que um ponto crítico de atropelamento requer, pelo menos, a criação das condições básicas, melhorando a perceptibilidade do local correto e do momento adequado. É recomendado também criar as condições adequadas, sem tempos de espera ou desvios excessivos (ou diminuí-los, se for o caso). Finalmente, deve-se buscar facilitar a travessia através de ajustes nos fatores acima descritos.

É fácil ver que este esquema qualitativo pode ser transferido para a análise de facilidades ao longo da via, baseado nos princípios específicos. 


\subsection{PARÂMETRO DE PROJETO PARA PEDESTRES}

A seguir, serão coletadas as recomendações necessárias para o projeto detalhado dos dispositivos destinados a prover uma infra-estrutura adequada aos pedestres. Foram identificados os seguintes aspectos: velocidade na via, largura da via, meio-fio, distância de visibilidade, velocidade do pedestre, largura da via para pedestre, largura da faixa de separação, declividade longitudinal e transversal, além de recomendações específicas para pontos de ônibus, para calçadas em pontos, túneis e passarelas, para interseções, para dispositivos de canalização e proteção.

\subsubsection{Velocidade do Tráfego}

O Green Book (2004a) não traz considerações específicas de escolha da velocidade de projeto do tráfego em relação aos pedestres. Uma velocidade de $100 \mathrm{~km} / \mathrm{h}$ é recomendada em vias expressas e rodovias.

O Manual de Pedestres da AASHTO (2004b) diz que a seleção de uma velocidade de projeto apropriada é um dos passos mais importantes no projeto viário, pois estudos têm indicado que, em acidentes envolvendo pedestres, quanto mais rápido estiver o motorista, maior o risco do acidente ser fatal para o pedestre. 


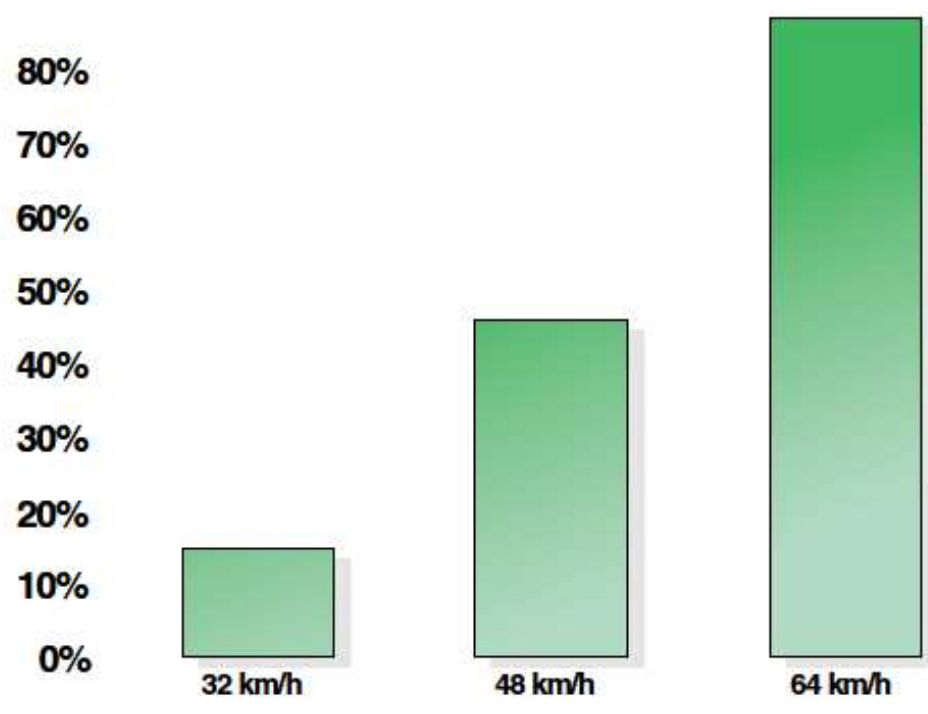

Figura 2-27 - Probabilidade de fatalidade de pedestres baseada na velocidade do veículo (Fonte: Pedestrian Facilities User Guide - Providing Safety and Mobility (FHWA-RD-01-102), FHWA, U.S. Department of Transportation, Washington DC, March 2002. Apud: Guide for the Planning, Design and Operation of Pedestrian Facilities, America Association of State Highway Transportation Officials, July 2004)

Segundo o Manual de Pedestres da AASHTO (2004b), na maioria dos casos, vias urbanas arteriais bem desenvolvidas deve ser projetada, e controles de tráfego empregados, para encorajar velocidade de 50 a $75 \mathrm{~km} / \mathrm{h}$. Vias locais residenciais devem ser projetadas para que a velocidade dos veículos não exceda 30 a $40 \mathrm{~km} / \mathrm{h}$.

De acordo com o Manual de Travessias Urbanas do DNIT (2010), a velocidade diretriz básica recomendada para o projeto geométrico de vias expressas primárias é de $110 \mathrm{~km} / \mathrm{h}$. Nos trechos de transição para uma via de padrão inferior, a velocidade diretriz poderá descer até 80 $\mathrm{km} / \mathrm{h}$, valor que poderá também ser adotado para os trechos onde condicionantes técnicas, econômicas e urbanísticas obrigarem ao emprego generalizado de padrões inferiores de projeto. Essas velocidades podem ser empregadas independente de se tratar de via elevada, enterrada ou ao nível do solo. Velocidades inferiores, de $90 \mathrm{~km} / \mathrm{h}$, ou até mesmo $60 \mathrm{~km} / \mathrm{h}$ em casos extremos, podem ser empregadas em trechos específicos de uma via expressa secundária; por exemplo, na travessia de eventuais interseções em nível. 
Recomenda-se ainda a velocidade diretriz de $80 \mathrm{~km} / \mathrm{h}$ para arteriais em áreas urbanas pouco desenvolvidas ou para vias dotadas de canteiro central, onde a interferência de pedestres e do uso do solo adjacente for pequena e, ainda, a canalização das interseções for adequada. Em condições intermediárias, onde o grau de controle de acesso, bem como as interferências de pedestres e do uso do solo adjacente à via são moderadas e os movimentos de conversão nas interseções são pequenos em relação ao fluxo principal, recomenda-se a velocidade diretriz de $60 \mathrm{~km} / \mathrm{h}$. Finalmente, para as arteriais primárias atravessando zonas de intenso desenvolvimento e com pouca distância entre as interseções, uma velocidade diretriz de 50 $\mathrm{km} / \mathrm{h}$, embora não tão desejável, pode ser a mais apropriada. Isso também se aplica às vias integrantes do Sistema Arterial Secundário.

\subsubsection{Largura da Via}

O número de faixas de uma via é escolhido primeiramente para atender demandas de tráfego veicular para um nível de serviço desejado. No entanto, segundo o Manual de Pedestres da AASHTO (2004b), projetistas devem também considerar os efeitos da largura da via para os pedestres. Quanto mais larga a via, mais difícil para os pedestres atravessarem.

O Green Book da AASHTO (2004a) geralmente permite larguras das faixas de 3,0 a 3,6m. Onde o nível de serviço permite, faixas devem ser suprimidas, deixando inclusive espaço para calçadas ou ciclofaixas/ciclovias. Caso não seja possível, faixas mais estreitas são também uma boa opção para reduzir a travessia do pedestre.

O Manual do DNER (1999) e do DNIT (2010) não trazem recomendações de largura relacionadas aos pedestres.

O DNIT (2010) diz que a largura da faixa de rolamento de um modo geral é obtida adicionando à largura do veículo de projeto a largura de uma faixa de segurança, função da velocidade diretriz, da categoria da via e do nível de conforto que se deseja proporcionar. 
Larguras de faixa de 2,70 a 3,60 m são geralmente adotadas, predominando 3,60 m na maioria das rodovias de alto padrão. A largura da faixa de rolamento de um modo geral é obtida adicionando à largura do veículo de projeto a largura de uma faixa de segurança, função da velocidade diretriz, da categoria da via e do nível de conforto que se deseja proporcionar. Larguras de faixa de 2,70 a 3,60 m são geralmente adotadas, predominando 3,60 m na maioria das rodovias de alto padrão.

\subsubsection{Meio-fio}

Considerações específicas a respeito do uso do meio fio em relação a segurança de pedestres não foram encontradas no Manual da AASHTO (2004a).

Segundo o Manual de Pedestres da AASHTO (2004b) o uso de meio-fio ao longo de uma via aumenta o conforto, segurança de dispositivos para pedestres adjacentes, distinguindo claramente o espaço do veículo e do pedestre. Dois tipos de meio-fio são utilizados: guias com face vertical (vertical curbs) e guias com face inclinada (sloping curbs). Guias com face vertical tendem a desencorajar motoristas a deixar a via e guias com face inclinada são projetados para que motoristas possa traspassá-los facilmente quando necessário. Guias com face vertical são preferíveis onde há calçada ou outro dispositivo para pedestres adjacente à via.

O DNIT (2010) diz que o tipo e a localização dos meio-fios afetam sobremaneira os motoristas e conseqüentemente a segurança e utilização de uma via. São usados com as seguintes finalidades: controle da drenagem, delineamento das vias, proteção de pedestres, redução da faixa de domínio, estética, delineamento dos passeios, redução do custo de manutenção e ordenação do desenvolvimento nas margens da rodovia. Meios-fios intransponíveis e passeios laterais seguros são desejáveis ao longo de túneis e muros de arrimo, principalmente se não se dispõe de acostamentos com largura plena. Esse tipo de meio-fio desencoraja o tráfego próximo à parede, aumentando a segurança dos pedestres. 


\subsubsection{Distância de Visibilidade}

No Manual da AASHTO (2004a) não foi encontrada discussão específica de distância de visibilidade para pedestres especificamente.

Distância de visibilidade é o elemento principal no projeto viário, segundo o Manual de Pedestres da AASHTO (2004b), distinguindo distância de visibilidade de parada, distância de visibilidade de decisão e distância de visibilidade de ultrapassagem. Tão importante quando é para o motorista ver tudo que acontece ao redor, é para o pedestre poder ver e reagir a potenciais conflitos. Distâncias de visibilidade adequadas são considerações chaves para localização de travessias. Paisagem, mobiliário, carros estacionados, postes e dispositivos de controle de tráfego podem criar obstrução visual para os pedestres. Quando não for possível realocar esses elementos, extensão de calçada ou restrições de estacionamento são desejáveis.
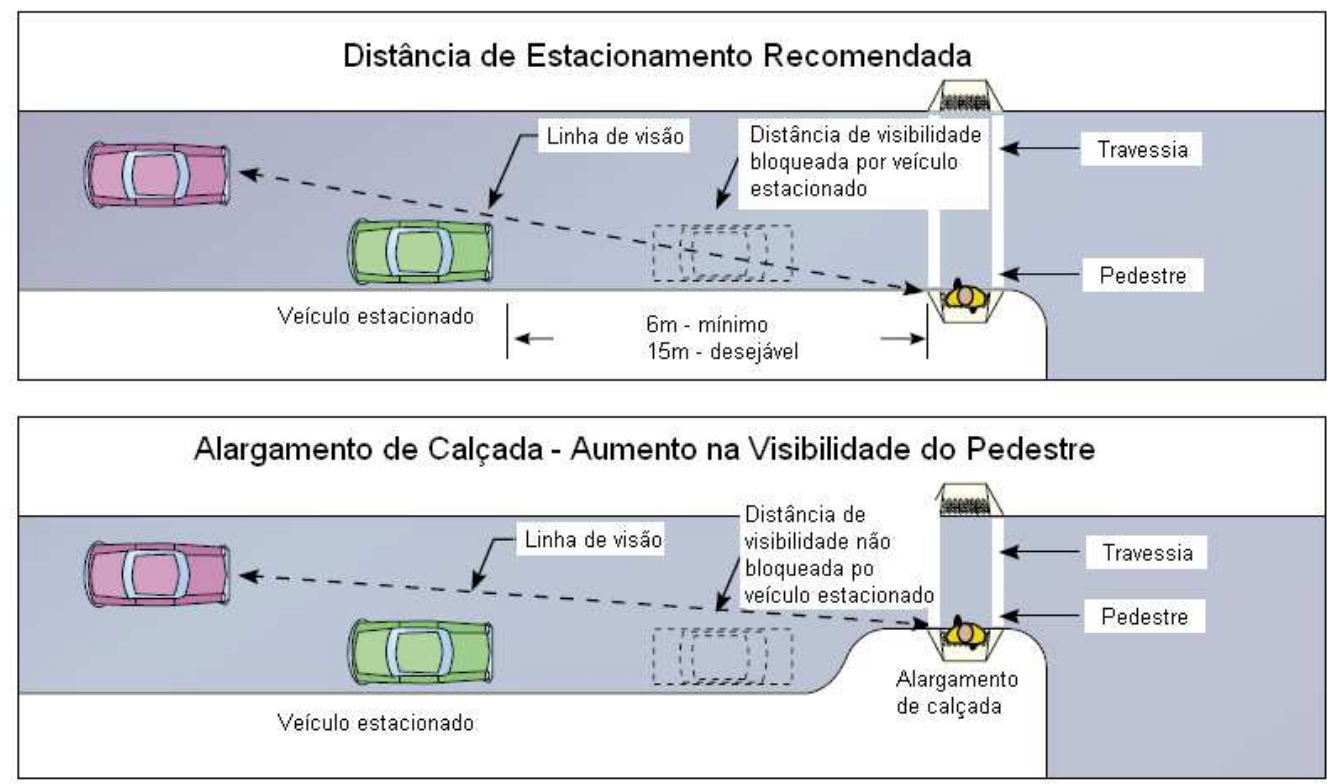

Figura 2-28 - Distância de estacionamento recomendada e/ou alargamento de calçada (Fonte: Design and Safety of Pedestrian Facilities, ITE, March 1998. Apud: Guide for the Planning, Design and Operation of Pedestrian Facilities, America Association of State Highway Transportation Officials, July 2004)

Algumas recomendações usuais dos manuais de projeto viário podem ser consideradas relevantes para os pedestres. Por exemplo, o Green Book da AASHTO (2004a) recomenda que vias devem interceptar-se num ângulo o mais próximo possível de $90^{\circ}$, e não menor que $60^{\circ}$. 
Além disso, recomenda que em vias urbanas com limites de velocidade de 30 a $50 \mathrm{~km} / \mathrm{h}$, o estacionamento deve ser proibido em uma distância mínima de $6 \mathrm{~m}$ da travessia, de ambos os lados do cruzamento. Uma extensão de $9 \mathrm{~m}$ deve ser mantida sem estacionamento caso haja semáforo, sinal de Pare ou Dê Preferência. Onde o limite de velocidade é entre 55 e $70 \mathrm{~km} / \mathrm{h}$, o estacionamento deve ser proibido por uma extensão de $15 \mathrm{~m}$, e onde excede $70 \mathrm{~km} / \mathrm{h}$ deve ser proibido. A posição de um pedestre esperando para realizar a travessia em relação aos carros estacionados é importante para a visibilidade do pedestre.

Os critérios encontrados no DNIT (2010) são similares aos acima descritos.

\subsubsection{Velocidade do Pedestre}

O Green Book da AASHTO (2004a) diz que a velocidade média dos pedestres varia de 0,8 a $1,8 \mathrm{~m} / \mathrm{s}$. Temperatura, hora do dia, motivo da viagem, gelo e neve afetam a velocidade do pedestre, porém a idade é a causa de velocidades mais baixas, e em áreas com pessoas mais velhas uma velocidade de $0,9 \mathrm{~m} / \mathrm{s}$ deve ser considerada para projeto.

Segundo o HCM (2000), depende da proporção de idosos (acima de 65 anos), um aumento de $10 \%$ reduz a velocidade em $0,1 \mathrm{~m} / \mathrm{s}$. De 0 a $20 \%$ utiliza-se $1,2 \mathrm{~m} / \mathrm{s}$; acima de $20 \%, 1,0 \mathrm{~m} / \mathrm{s}$.

De forma semelhante o MUTCD (2009) usa uma velocidade média de 1,2m/s.

O Manual de Travessias Urbanas do DNIT (2010) utiliza as mesmas velocidades da AASHTO (2004a) e traz um gráfico com a variação da velocidade dos pedestres em função da declividade da via, obtido a partir dos estudos de BOVY (1973), mostrado na Figura 2-29. 


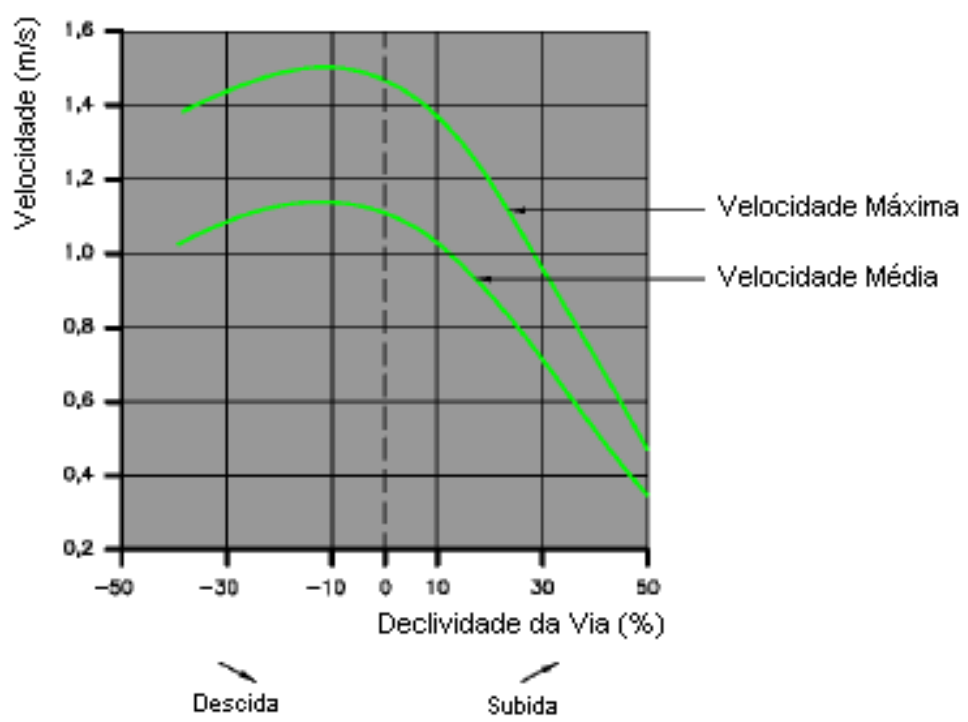

Figura 2-29 - Velocidade do pedestre em função da declividade da via (Fonte: Manual de Travessias Urbanas, DNIT, 2010)

Para o caso de uma interseção que sofra interferência de grande número de pedestres, o gráfico adaptado dos estudos de PUSHKAREV e ZUPAN (Urban Space for Pedestrians MIT Press - 1975), apresenta a velocidade de cada categoria de pedestre como função do nível de aglomeração a que está sujeita, medida pela sua densidade em pessoas por metro quadrado.

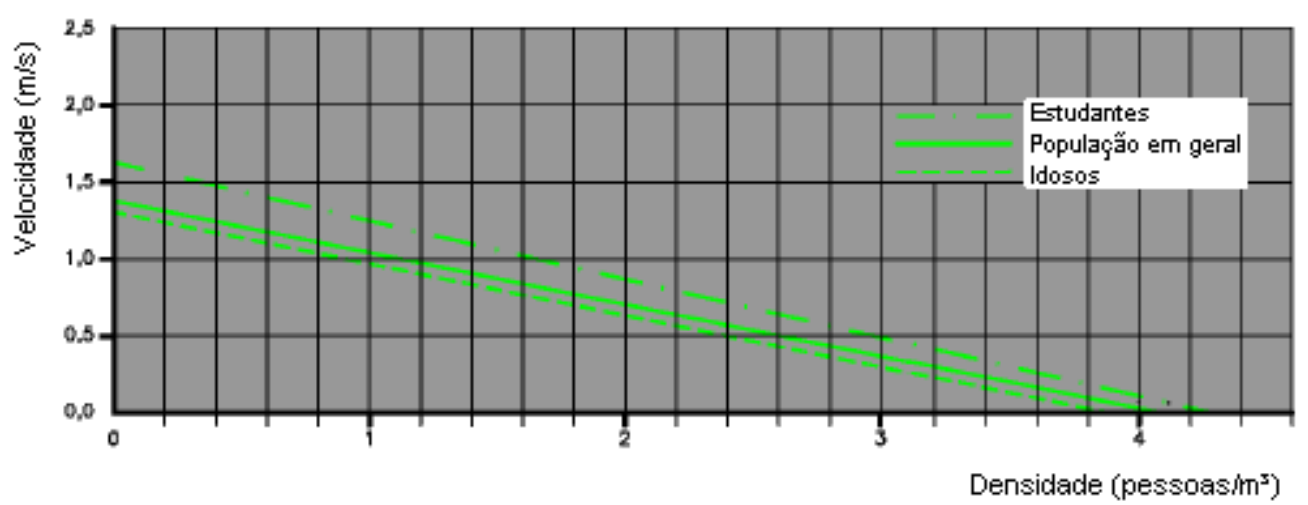

Figura 2-30 - Relação entre densidade e velocidade de pedestres (Fonte: Manual de Travessias Urbanas, DNIT, 2010)

Os valores recomendados pelo Manual de Segurança de Pedestres do DENATRAN (1983) fazem parte do procedimento de seleção do tratamento em travessias. 
Para condições médias, serão utilizados os seguintes valores para velocidade dos pedestres: no plano: $\mathrm{Vp}=1,30 \mathrm{~m} / \mathrm{seg}$; em escadas: $\mathrm{Ve}=0,15 \mathrm{~m} / \mathrm{seg}$ e em rampas:

Tabela 2-5- Valores recomendados para velocidade de pedestres em rampas (Fonte: manual de Segurança de Pedestres, DENATRAN, 1983)

\begin{tabular}{|c|c|}
\hline Inclinação & $\mathbf{V r}$ (m/seg) \\
\hline $2 \%$ & 1,30 \\
\hline $4 \%$ & 1,30 \\
\hline $6 \%$ & 1,26 \\
\hline $8 \%$ & 1,17 \\
\hline $10 \%$ & 1,02 \\
\hline $12 \%$ & 0,93 \\
\hline $14 \%$ & 0,84 \\
\hline $16 \%$ & 0,78 \\
\hline $18 \%$ & 0,72 \\
\hline
\end{tabular}

\subsubsection{Largura da via de pedestre}

Segundo o Green Book da AASHTO (2004a) a largura do acostamento varia de apenas 0,6m em vias rurais pequenas a 3,6m, geralmente pavimentado, em vias principais. Onde ciclistas e pedestres serão acomodados no acostamento uma largura livre mínima de $1,2 \mathrm{~m}$ deve ser utilizada.

Para calçadas, a largura em vias residenciais varia de 1,20 a $2,40 \mathrm{~m}$. Se houver uma faixa de plantas deve ter no mínimo $0,60 \mathrm{~m}$. Caso não haja, ou seja, a calçada seja adjacente ao tráfego veicular, deve ser providenciada uma largura de $0,60 \mathrm{~m}$ a mais.

Passagens em desnível devem ter uma largura mínima de 2,40m, sendo recomendado mais se o volume de pedestres é alto. 
O Manual de Pedestres da AASHTO (2004b) diz que vias de pedestres devem ter no mínimo $1,2 \mathrm{~m}$. Isso vale para acostamentos em que pedestres serão acomodados ou calçadas.

A largura mínima para uma calçada é $1,20 \mathrm{~m}$. Onde as calçadas têm menos de $1,50 \mathrm{~m}$, locais de ultrapassagem com pelo menos $1,50 \mathrm{~m}$ devem ser providenciados em intervalos razoáveis. Tem diversos locais onde larguras maiores são desejáveis. Em vias arteriais, 1,8m a 2,4m é desejável quando há uma linha de plantas entre o meio fio e a calçada. Em áreas centrais, a largura desejável é 3,0m, ou suficientemente larga para providenciar o nível de serviço desejável. Em áreas onde alto volume de pedestres é esperado, pode ser apropriado providenciar calçadas com 3,0 a 4,5m ou mais. Quando a calçada está em frente a lojas, uma largura adicional de $0,6 \mathrm{~m}$ pode ser necessária para manter distância das paredes, pessoas que param para ver vitrines.

O Pedestrian Facilities Users Guide, FHWA (2002) diz que o ITE recomenda largura mínima de $1,5 \mathrm{~m}$, que permite ultrapassagem, ou duas pessoas andando lado a lado, sendo recomendado larguras maiores perto de escolas, pontos de ônibus e em áreas com alta concentração de pedestres.

Segundo o Manual de Segurança de Pedestres do DENATRAN (1983), a largura do passeio deve ser suficiente para acomodar o volume de pessoas que normalmente passa pelo local, andando a velocidade média do pedestre adulto. A largura mínima deve ser $1,80 \mathrm{~m}$ e a superfície deve ser o mais contínua possível. A declividade máxima recomendável é $5 \%$ e o dimensionamento da largura desejável deve ser baseado no cálculo do nível de serviço. 


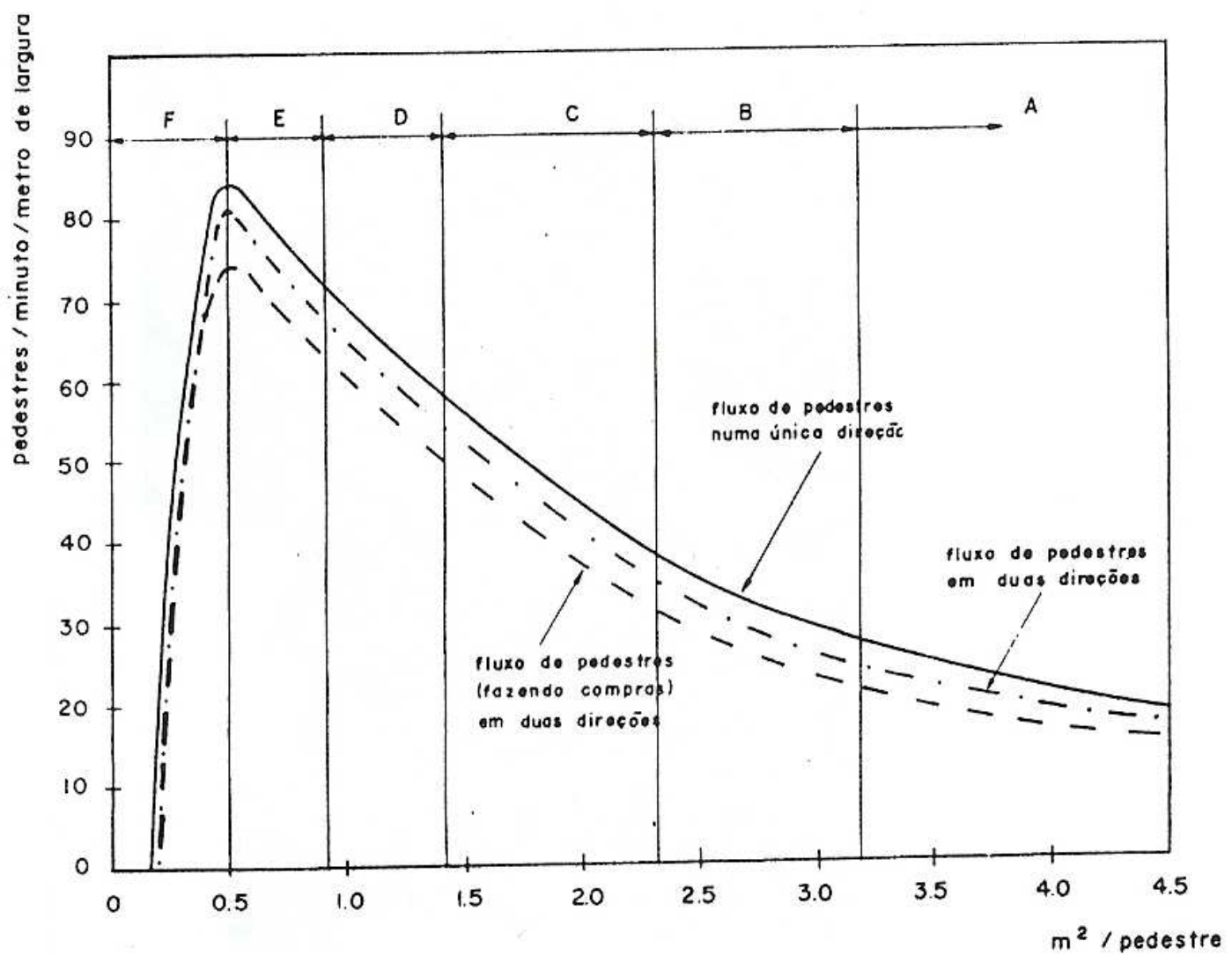

Figura 2-31 - Dimensionamento de calçadas em função do nível de serviço (Fonte: Manual de Segurança de Pedestres, DENATRAN, 1983)

\subsubsection{Largura da área de espera}

Segundo o Manual da AASHTO (2004a) é recomendado providenciar uma faixa de plantas de $0,60 \mathrm{~m}$.

O Manual de Pedestres da AASHTO (2004b) traz ainda considerações sobre a necessidade de haver uma área entre a via e a calçada. Em vias coletoras ou arteriais o ideal é que o "buffer" esteja entre 0,6 e 1,2m. Já em vias arteriais deve estar entre 1,5 e 1,8m. Caso o estacionamento seja permitido na via, ou haja ciclofaixa, essas áreas são consideradas áreas de separação. Em vias onde não há estacionamento ou ciclofaixa, uma faixa de $1,8 \mathrm{~m}$ de floreira é recomendada. 
Se não há floreira, o meio fio adjacente a calçada, em áreas residenciais deve ser no mínimo 1,8m. Em área comerciais, ou ao longo de vias arteriais, a largura recomendada passa a ser $2,4 \mathrm{~m}$.

O Pedestrian Facilities Users Guide, FHWA (2002), recomenda área de separação ("buffer zone”) de 1,2 a 1,8 m (carros estacionados ou ciclovias)

\subsubsection{Declividade longitudinal (Grade) e transversal (Cross-Slope)}

O Manual da AASHTO (2004a) recomenda, de maneira geral, a fim de garantir a drenagem, uma declividade transversal de 2 a $4 \%$ para vias pavimentadas e 4 a $6 \%$ para vias não pavimentadas (6 a $8 \%$ se for gramado).

A fim de atender as pessoas com necessidades especiais, rampas de acesso às calçadas são recomendadas com declividade longitudinal de $8,33 \%$ e transversal de $2 \%$.

O elemento crítico das calçadas de pedestres é o greide. Segundo o Manual de Pedestres da AASHTO (2004b), as calçadas devem apresentar, quando possível, greide inferior a 5\%. Em casos extremos, de greides acima de $8 \%$, guarda-corpos podem ser necessários. Onde a via adjacente não permitir greides menores, o pavimento dos passeios deve ter textura especial, com alto coeficiente de atrito. As declividades transversais dos passeios são necessárias para drenagem. Deve ser adotada uma inclinação máxima de $2 \%$, para que pedestres e usuários de cadeiras de rodas possam transitar e executar manobras com facilidade. Isso é especialmente importante quando os greides são elevados. 
Tabela 2-6 - - Critério de grade para calçadas (Fonte: Guide for the Planning, Design and Operation of Pedestrian Facilities, America Association of State Highway Transportation Officials, 2004)

\begin{tabular}{|l|l|}
\hline \multicolumn{2}{|c|}{ Adjacente a via pública } \\
\hline Grade máximo da calçada adjacente a via & Sem limite se seguir a o grade da via \\
\hline Cross slop máximo & $2 \%(1 \mathrm{~V}: 48 \mathrm{H})$ \\
\hline \multicolumn{2}{|c|}{ Não adjacente a via pública } \\
\hline Grade máximo sem corrimão & $5 \%(1 \mathrm{~V}: 20 \mathrm{H})$ \\
\hline Grade máximo com corrimão & $8,3 \%(1 \mathrm{~V}: 12 \mathrm{H})$ \\
\hline
\end{tabular}

\subsubsection{Pontos de parada de ônibus}

O Manual da AASHTO não traz considerações específicas.

Pontos de paradas de ônibus devem fornecer espaços para embarque e desembarque de passageiros. O recomendado pelo Manual de Pedestres da AASHTO (2004b) é prover um trecho contínuo de calçada, com 2,40m de largura ao longo da parada. Caso não haja meio fio, um acostamento de 2,40 $\mathrm{m}$ deve ser provido para desembarque. Para evitar travessia de pedestres em locais inapropriados, é preferível locar os pontos de ônibus próximos a interseções. Onde for viável, as paradas devem conter abrigos com áreas de espera e assentos para passageiros. Os abrigos devem ter uma área livre de 0,80 por $1,20 \mathrm{~m}$, situada inteiramente dentro do abrigo, ligada à área de embarque e desembarque.

O Manual do DNIT (2010) repete esses mesmos critérios. 


\subsubsection{Calçadas para pontes, passarelas e túneis}

Em obras de arte (pontes, viadutos, passagens inferiores e túneis) que fazem parte de alguma rota de pedestres, calçadas devem ser projetadas. Em pontes e viadutos, o passeio deve ser protegido, tanto quanto possível, por barreiras e guarda-corpos. Segundo o Manual de Pedestres da AASHTO (2004b), as larguras dos passeios ao longo das obras-de-arte devem ser as mesmas ou mais largas que as dos passeios com que se conectam. Em uma ponte ou viaduto, a largura livre mínima é de 1,20 m, sendo desejável 2,40 m. Em passagens inferiores, é recomendável que o passeio fique entre os pilares e a via, para segurança, por aumentar a visibilidade mútua de pedestres e motoristas. Se houver necessidade de colocar os pilares próximos ao meio-fio, o passeio atrás das colunas deve ser tão largo quanto possível e incluir iluminação à prova de vandalismo. Em passagens inferiores longas (maiores que $60 \mathrm{~m}$ ), a iluminação deve ser mantida durante o dia. Normalmente não são permitidos pedestres em túneis longos, mas deve haver espaço para passagem em uma emergência e para atender ao pessoal de manutenção. Passeios mais elevados que os acostamentos ou bordas das vias adjacentes são convenientes, para maior segurança dos pedestres para dificultar que os balanços de veículos desgovernados danifiquem as paredes do túnel e/ou dispositivos de iluminação laterais.

\subsubsection{Interseções}

Pelo Manual de Pedestres da AASHTO (2004b), o raio do meio fio utilizado tanto em interseções semaforizadas como não semaforizadas deve ser selecionado considerando segurança, operação e conveniência para motoristas e pedestres. Deve ser ainda apropriado para que veículos grandes como caminhões e ônibus possam realizar a manobra, no entanto quanto maior o raio mais exposto o pedestre fica (devido ao aumento da distância de travessia e aumento da velocidade dos veículos) e menor o espaço de espera para a travessia. 
Dois raios distintos devem ser considerados. O primeiro é o raio da esquina, e o outro é o raio efetivo de conversão do veículo de projeto de conversão selecionado, que é o raio para o veículo realizar a conversão e retomar o alinhamento da sua trajetória.

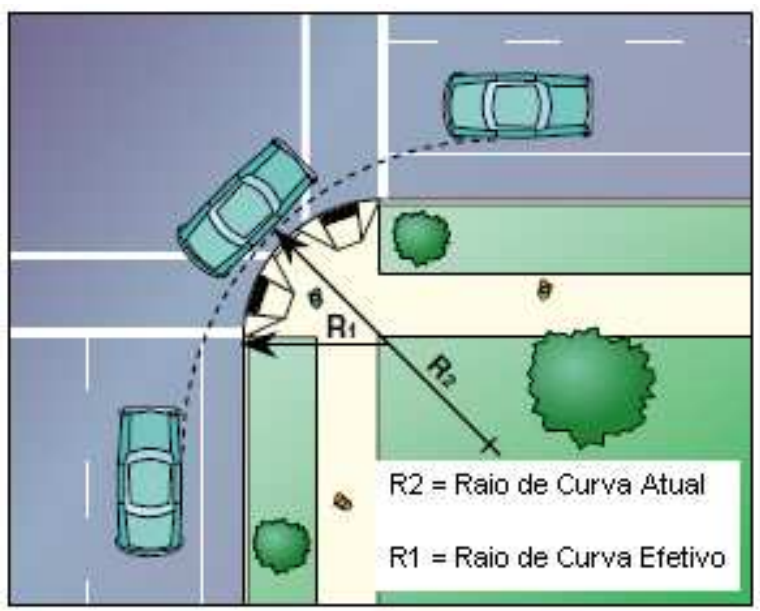

Figura 2-32 - Raio de curva efetivo (Fonte: Oregon Bicycle and Pedestrian Plan, Oregon Departament of Transportation, 1995. Apud: Guide for the Planning, Design and Operation of Pedestrian Facilities, America Association of State Highway Transportation Officials, 2004

O Manual americano traz ainda uma relação mostrando que quanto menor o raio, menor a distância de travessia. 


\begin{tabular}{|c|c|}
\hline Raio de Curvatura, $R$ & Acréscimo na Distância de Travessia* $^{*}$ \\
\hline $5 \mathrm{~m}$ & $1 \mathrm{~m}$ \\
\hline $10 \mathrm{~m}$ & $7 \mathrm{~m}$ \\
\hline $15 \mathrm{~m}$ & $12 \mathrm{~m}$ \\
\hline
\end{tabular}

* Medido a partir da linha de centro da calçadatravessia como comparada a lagura de meio-fio a meio fio

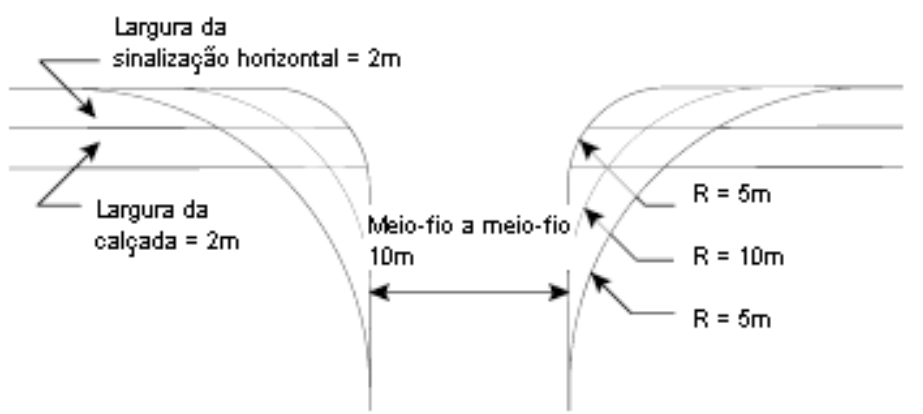

Figura 2-33 - Pedestrian Design Guidelines Notebook, City of Portland Oregon, Office of Transportation Engineering and Development, 1997. Apud: Guide for the Planning, Design and Operation of Pedestrian Facilities, America Association of State Highway Transportation Officials, 2004)

Onde há baixo fluxo de conversão de caminhões é recomendado que o raio na esquina seja de 3 a 4,5m. Onde há altos volumes de caminhões o raio máximo da esquina deve ser aumentado e a faixa de retenção deve ser colocada mais pra traz para que veículos grandes tenham espaço para completar a manobra. O raio mínimo recomendado pelo Manual de Pedestres da AASHTO (2004b) é 1,5m.

Mais uma vez os critérios apresentados pelo DNIT são os mesmos. 


\subsubsection{Dispositivos de proteção para pedestres}

\section{$\underline{\text { Ilha de refúgio }}$}

No Manual de Pedestres da AASHTO (2004b), a largura de uma ilha de refúgio a ser construída deve ser no mínimo 1,80m para que possa acomodar cadeira de roda ou mais de um pedestre esperando. Ilhas existentes com 1,20m podem ser mantidas. Onde possível, uma largura de 2,40m deve ser providenciada para acomodar grupos de pedestres, ciclistas e usuários de cadeira de roda. Para isso as faixas de rolamento podem ser diminuídas para $3,30 \mathrm{~m}$ ou até $3,0 \mathrm{~m}$. As ilhas devem ser sinalizadas $0,60 \mathrm{~m}$ antes e depois.

O Manual de Segurança de Pedestres do DENATRAN (1983) recomenda largura mínima do refúgio: $1,5 \mathrm{~m}$, sendo aceitável $1,2 \mathrm{~m}$ em alguns casos; e proibição de estacionamento ou parada de veículos.

GOLD (1998), diz que a largura mínina deve ser 1,0m com linha de bordo, faixa de segurança de $0,30 \mathrm{~m}$ de cada lado, entre a linha de bordo e o refúgio. Em refúgios espaçados: sinalização contínua entre refúgios, reforçada por tachões.

\section{$\underline{\text { Alargamento de calçada }}$}

O Manual de Pedestres da AASHTO (2004b) diz que, em geral, o alargamento de calçada deve ser uma extensão da faixa de estacionamento, com aproximadamente $1,8 \mathrm{~m}$. 


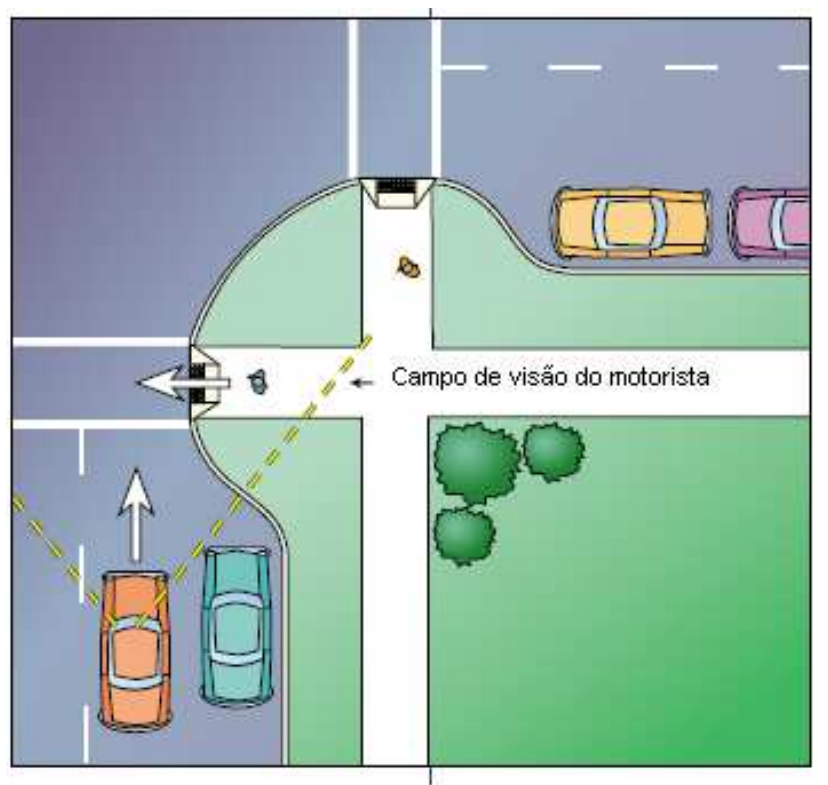

Figura 2-34 - Exemplo de alargamento de calçada (Fonte: Designing Sidewalks and Trails for Access, Part I, FHWA, 1999. Apud: Guide for the Planning, Design and Operation of Pedestrian Facilities, America Association of State Highway Transportation Officials, 2004)

\section{$\underline{\text { Faixa de pedestres }}$}

A largura da faixa de pedestre, segundo o Manual de pedestres da AASHTO (2004b) não deve ser menor que 1,80m (de acordo com o MUTCD). Em centros comerciais ou cidades grandes, o apropriado seria 3,0m ou mais. As faixas podem ser transversais, longitudinais ou diagonais, devendo se extender por toda a extensão da travessia.

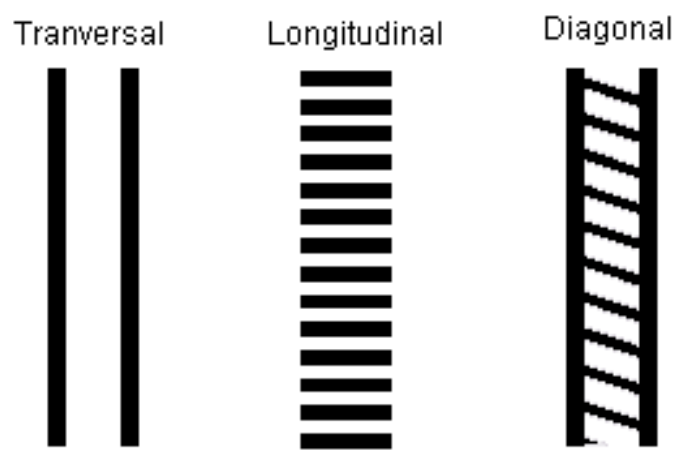

Figura 2-35 - Demarcação para faixas de pedestres (Fonte: Guide for the Planning, Design and Operation of Pedestrian Facilities, America Association of State Highway Transportation Officials, 2004) 
As linhas longitudinais ou diagonais devem ter 0,3 a $0,6 \mathrm{~m}$ de largura e serem espaçadas de 0,3 a 1,5m, sendo que esse espaçamento não deve exceder 2,5 vezes a largura da linha. A largura das linhas transversais deve estar entre 0,60 e $1,50 \mathrm{~m}$.

O Manual de Segurança de Pedestres do DENATRAN (1979), dizia que as faixas devem ser na cor branca, com comprimento mínimo de $2 \mathrm{~m}$, largura de 30 a $60 \mathrm{~cm}$ e o espaçamento deve ser o dobro da largura (60 a $120 \mathrm{~cm}$ ). Estas recomendações eram também menos exigentes, embora estivessem em desacordo com as disposições legais da época.

Vê-se que os valores atualmente adotados no Brasil (revisados anteriormente no item 2.1) são bastante mais exigentes, pelo menos quanto à largura mínima (3,0m para FTP-1 e FTP-2, recomendando-se 4,0m).

No entanto, o aspecto mais importante corresponde a decidir onde as faixas de pedestres devem ser adotadas e onde são efetivas para melhorar a segurança dos pedestres. Não foram encontrados critérios claros sobre esta questão, particularmente considerando as peculiaridades do ordenamento legal e do (des)respeito às regras legais pelos usuários da via.

Existem indicações em manuais estrangeiros. No MUTCD 2009 (FHWA, 2009), faixas de pedestres sem outro dispositivo de controle são proibidas em vias onde o limite de velocidade é superior a $40 \mathrm{mph}(64 \mathrm{~km} / \mathrm{h})$ em vias de 4 ou mais faixas (ambos os sentidos) se o VDMA é superior a 12000 veículos em vias não há canteiro ou refúgio de pedestes ou 15000 veículos em vias onde há canteiro ou refúgio de pedestres. Nestes casos deveriam ser usados dispositivos para reduzir a velocidade, encurtar a travessia, aumentar a percepção da travessia, advertir ativamente sobre a presença dos pedestres, entre outras. Este critério chama a atenção para o fato de que uma faixa de pedestre pode não ser segura para os próprios pedestres. 


\subsection{ANÁlISE DA OPERAÇÃO PARA PEDESTRES}

A seguir, a análise da qualidade do atendimento às necessidades dos pedestres será feita com base nos procedimentos recomendados pelo HCM (2000) apenas. Como discutido anteriormente, o Manual de Segurança de Pedestres do DENATRAN (1983) propõe um procedimento para avaliar a qualidade da operação em travessias, incorporado ao seu método de escolha do tipo de tratamento nas travessias, que é uma fonte suplementar.

A discussão dos critérios recomendados pelo HCM (2000) é feita em termos gerais. Os detalhes do procedimento recomendado estão no Apêndice A.

\subsubsection{Nível de Serviço em Calçadas e Vias Exclusivas para Pedestres}

O cálculo do nível de serviço em calçadas e vias exclusivas para pedestres no HCM (2000) segue os princípios para análise da operação em fluxo contínuo, com base em fluxos de pedestres por unidade de largura efetiva (visto que os pedestres normalmente não seguem a disciplina de utilização de faixas).

O conceito de largura efetiva considera a interferência no uso do espaço lateral da facilidade trazido por elementos que a ocupam (como postes de sinalização, bancos e árvores) ou interferem no seu uso pelos pedestres (como as fachadas e vitrines).

A demanda é medida pelo fluxo de pedestres por unidade de largura, normalmente expressa por minuto (ped/min/m), para um período de pico de 15 minutos, admitindo-se correspondente capacidade $75 \mathrm{p} / \mathrm{min} / \mathrm{m}$. O efeito da formação de pelotões pode também ser considerado transformado o fluxo médio no pico em fluxo em pelotões no pico. 
O critério de nível de serviço é baseado na densidade de pedestres (ped $/ \mathrm{m}^{2}$ ) ou espaço disponível $\left(\mathrm{m}^{2} / \mathrm{ped}\right)$ no fluxo, que pode também ser traduzida em um nível de utilização da capacidade (v/c). Dessa forma, o HCM traz as seguintes tabelas para o nível de serviço:

Tabela 2-7- Critério de fluxo médio para NS em caminhos e calçadas (Fonte: Special Report 209: Highway Capacity Manual, TRB. National Research Council, Washington, D.C., 2000)

\begin{tabular}{c|c|c|c|c}
\hline Nivel de Serviço & Espaço $\left(\mathbf{m}^{2} / \mathbf{p}\right)$ & Fluxo $(\mathbf{p} / \mathbf{m i n} / \mathbf{m})$ & Velocidade $(\mathbf{m} / \mathbf{s})$ & Taxa v/c \\
\hline A & $>5.6$ & $\leq 16$ & $>1.30$ & $\leq 0.21$ \\
B & $>3.7-5.6$ & $>16-23$ & $>1.27-1.30$ & $>0.21-0.31$ \\
C & $>2.2-3.7$ & $>23-33$ & $>1.22-1.27$ & $>0.31-0.44$ \\
D & $>1.4-2.2$ & $>33-49$ & $>1.14-1.22$ & $>0.44-0.65$ \\
E & $>0.75-1.4$ & $>49-75$ & $>0.75-1.14$ & $>0.65-1.0$ \\
F & $\leq 0.75$ & Variável & $\leq 0.75$ & Variável \\
\hline
\end{tabular}

Tabela 2-8 - Critério de NS para caminhos e calçadas com o efeito de pelotões (Fonte: Special Report 209: Highway Capacity Manual, TRB. National Research Council, Washington, D.C., 2000)

\begin{tabular}{c|c|c}
\hline Nivel de Serviço & Espaço $\left(\mathrm{m}^{2} / \mathrm{p}\right)$ & Fluxo $(\mathrm{p} / \mathrm{min} / \mathrm{m})$ \\
\hline A & $>49$ & $\leq 1.6$ \\
B & $>8-49$ & $>1.6-10$ \\
C & $>4-8$ & $>10-20$ \\
D & $>2-4$ & $>20-36$ \\
E & $>1-2$ & $>36-59$ \\
F & $\leq 1$ & $>59$ \\
\hline
\end{tabular}

Nota:

a. Taxas na tabela representam fluxos médios num período de 5-6 min

Critérios específicos são apresentados para fluxo de pedestres em escada, fluxos cruzados, como pode-se ver no Apêndice A (ou no HCM, 2000). 


\subsubsection{Nível de Serviço em Calçadas Compartilhadas}

A análise da operação compartilhada entre pedestres e ciclistas foi introduzida no HCM (2000), com base nos métodos holandeses como os apresentados por BOTMA (1995). O efeito sobre o nível de serviço para os pedestres decorrente da presença de ciclistas é avaliado pelo conceito de impedimento; considerando frequência de ultrapassagens e encontros entre pedestres e ciclistas.

A frequência de encontros ("meetings"), $F m$, e a frequência de ultrapassagens ("passings"), $F p$, são então calculadas em função do fluxo de bicicletas em direção oposta, ou na mesma direção respectivamente; e das velocidades médias dos pedestres e dos ciclistas na via.

$$
\begin{aligned}
& F_{p}=Q_{s b}\left(1-\frac{S_{p}}{S_{b}}\right) \quad \begin{array}{l}
F p=\text { número de eventos de ultrapassagem (eventosih) } \\
F m=\text { número de eventos opostos (eventosih) }
\end{array} \\
& \text { Qsb = taxa de fluxo de bicicletas no mesmo sentido (bicicletas } / h \text { ) } \\
& F_{m}=Q_{o b}\left(1+\frac{S_{p}}{S_{b}}\right) \begin{array}{l}
Q o b=\text { taxa de fluxa de bicicletas no sentido oposto } \\
S p=\text { velocidade média do pedestre na via (m/s) } \\
S b=\text { velocidade média da bicicleta na via }(\mathrm{m} / \mathrm{s})
\end{array}
\end{aligned}
$$

A frequência total de eventos é então calculada considerando que encontros causando geralmente menos impedimento, devido ao contato visual.

$$
F=F_{p}+0.5 F_{m} \begin{aligned}
& \mathrm{F}=\text { número total de eventos na via (eventos } / \mathrm{h} \text { ), } \\
& \mathrm{Fp}=\text { número de eventos de ultrapassagens (eventosih), } \\
& \mathrm{Fm}=\text { número de eventos de encontro (eventos } / \mathrm{h} \text { ) }
\end{aligned}
$$

O HCM (2000) estima estas freqüências considerando velocidade média dos pedestres de 1,5 $\mathrm{m} / \mathrm{s}$ e velocidade média dos ciclistas de $6,0 \mathrm{~m} / \mathrm{s}$, com volume de bicicletas para via bidirecional (50/50). Propõe também uma tabela para cálculo do nível de serviço para uma via bidirecional com largura de 2,4 m: 
Tabela 2-9 - Critério de NS para pedestres em caminhos compatilhados (Fonte: Special Report 209: Highway Capacity Manual, TRB. National Research Council, Washington, D.C., 2000)

\begin{tabular}{c|c|c}
\hline $\begin{array}{l}\text { Nível de Serviço } \\
\text { Pedestres }\end{array}$ & Número de Eventos/h & $\begin{array}{l}\text { Volume de Bicicletas Correspondente } \\
\text { por Direção (bicicletas/h) }\end{array}$ \\
\hline A & $\leq 38$ & $\leq 28$ \\
B & $>38-60$ & $>28-44$ \\
C & $>60-103$ & $>44-75$ \\
D & $>103-144$ & $>75-105$ \\
E & $>144-180$ & $>105-131$ \\
F & $>180$ & $>131$ \\
\hline
\end{tabular}

\section{Notas:}

a. Via de $2,4 \mathrm{~m}$ de largura

b. Um "evento" é uma bicicleta encontrar ou ultrapassar um

pedestre

c. Assumindo divisäo direcional de bicicletas de 50/50

\subsubsection{Nível de Serviço em Áreas de Espera e Interseções}

Novamente, o HCM (2000) baseia a avaliação do nível de serviço para os pedestres com base no conceito de na densidade de pedestres $\left(\mathrm{ped} / \mathrm{m}^{2}\right)$ ou espaço disponível $\left(\mathrm{m}^{2} / \mathrm{ped}\right)$ mas agora na espera.

Em áreas de espera, o nível de serviço para o pedestre é relacionado ao espaço disponível para cada pedestre e ao grau de mobilidade permitido:

Tabela 2-10 - - Critério de NS para áreas de espera de pedestres (Fonte: Special Report 209: Highway Capacity Manual, TRB. National Research Council, Washington, D.C., 2000)

\begin{tabular}{c|c}
\hline Nivel de serviço & Espaço $\left(\mathbf{m}^{2} / \mathbf{p}\right)$ \\
\hline A & $>1.2$ \\
B & $>0.9-1.2$ \\
C & $>0.6-0.9$ \\
D & $>0.3-0.6$ \\
E & $>0.2-0.3$ \\
F & $\leq 0.2$ \\
\hline
\end{tabular}


As estimativas são baseadas nos conceitos e modelos de espaço-tempo usados por FRUIN (1990), que relacionam-se com as medidas de atraso dos pedestres e das dimensões físicas das áreas de espera e de travessia. Este procedimento está detalhado no Apêndice A, com base no $\operatorname{HCM}(2000)$.

Em interseções semaforizadas, o atraso médio sofrido pelo pedestre, calculado em função do tempo de verde efetivo para pedestres e comprimento do ciclo, é:

$$
\mathrm{d}_{\mathrm{p}}=\frac{0.5(\mathrm{C}-\mathrm{g})^{2}}{\mathrm{C}} \quad \begin{aligned}
& \mathrm{dp}=\text { atraso médio do pedestre } \\
& \mathrm{g}=\text { tempo efetivo de verde (para pedestres) }
\end{aligned}
$$

Há um critério específico de nível de serviço baseado no tempo de espera em interseções, observando que para tempos de espera maiores que 30seg, muitos pedestres assumem um comportamento de risco desobedecendo ao semáforo.

Tabela 2-11 - Critério de NS para pedestres em interseções semaforizadas (Fonte: Special Report 209: Highway Capacity Manual, TRB. National Research Council, Washington, D.C., 2000)

\begin{tabular}{c|c|c}
\hline Nível de Serviço & Atraso do Pedestre (s/p) & Probabilidade de Desobediência \\
\hline A & $<10$ & Baixo \\
B & $\geq 10-20$ & Moderado \\
C & $>20-30$ & \\
D & $>30-40$ & Alto \\
E & $>40-60$ & Muito Alto \\
F & $>60$ & . \\
\hline
\end{tabular}


Em interseções não semaforizadas a oportunidade de travessia é função da brecha entre veículos. O atraso médio dos pedestres no HCM (2000) é avaliado por:

$$
\begin{array}{cl}
\mathrm{dp}=\frac{1}{\mathrm{~V}}\left(\mathrm{e}^{\mathrm{VTG}}-\mathrm{VTG}-1\right) & \begin{array}{l}
\mathrm{dp}=\text { atraso médio de pedestres }(\mathrm{s}) \\
\mathrm{v}=\text { taxa de fluxo veicular (veic/s) } \\
\mathrm{tG}=\text { grupo de brechas criticas }
\end{array} \\
\mathrm{d}_{\mathrm{p}}=\frac{1}{\mathrm{v}}\left(\mathrm{e}^{\mathrm{vt}_{\mathrm{G}}}-\mathrm{vt}_{\mathrm{G}}-1\right) & \begin{array}{l}
\mathrm{dp}=\text { atraso médio do pedestres }(\mathrm{s}) \\
\mathrm{v}=\text { taxa de fluxo veicular (vei/s) } \\
\mathrm{tG}=\text { grupo de brechas criticas }
\end{array}
\end{array}
$$

Tabela 2-12 - - Critério de NS para pedestres em interseções não semaforizadas (Fonte: Special Report 209: Highway Capacity Manual, TRB. National Research Council, Washington, D.C., 2000)

\begin{tabular}{c|c|c}
\hline Nível de Serviço & Atraso Médio / Pedestre (s) & Probabilidade de comportamento de Risco $^{\text {a }}$ \\
\hline A & $<5$ & Baixo \\
B & $\geq 5-10$ & \\
C & $>10-20$ & Moderado \\
D & $>20-30$ & \\
E & $>30-45$ & Alto \\
F & $>45$ & Muito Alto \\
\hline
\end{tabular}

Nota:

a. Probabilidade a aceitar brechas curtas

Há novamente um critério específico de nível de serviço baseado no tempo de espera. 


\subsection{INFRA-ESTRUTURA PARA CICLISTAS}

A primeira questão geral investigada diz respeito a identificar quais tipos de facilidades podem atender às necessidades dos ciclistas. A questão básica complementar é a definição de critérios que recomendam um ou outro tipo de facilidade. Ambas são discutidas a seguir.

Também para os ciclistas é importante conhecer o espaço requerido pelos ciclistas. O Manual de Ciclistas da AASHTO (1999) traz o seguinte gabarito da Figura 2-36.

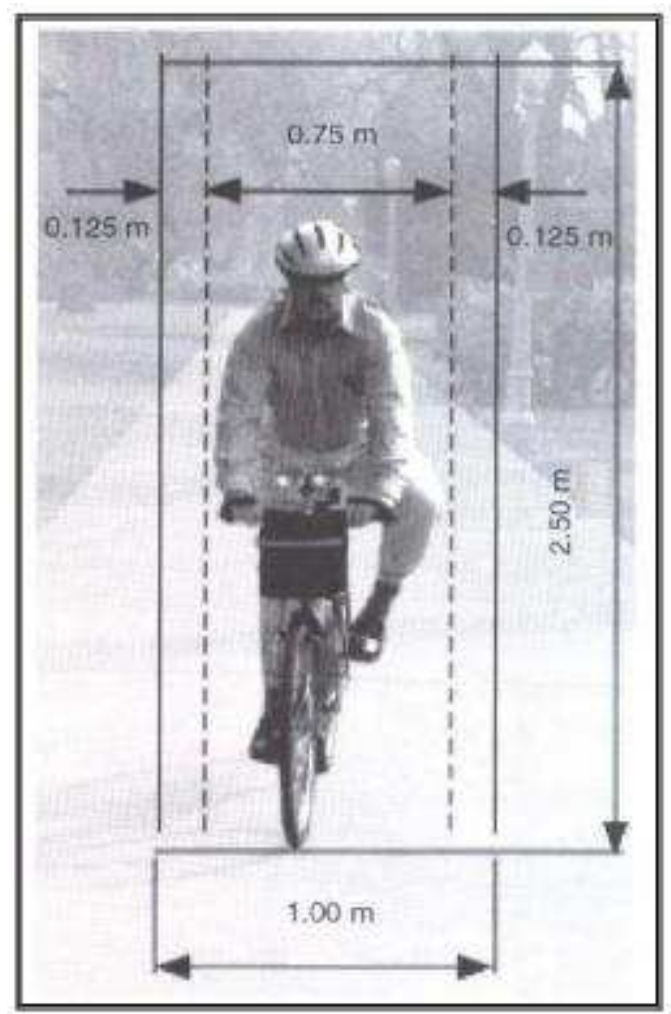

Figura 2-36 - Espaço necessário para ciclistas (Fonte: Guide for Development of Bicycle Facilities, AASHTO, 1999)

O Manual do DNIT (2010) reproduz a mesma figura. 


\subsubsection{Facilidades para Ciclistas ao Longo da Via}

Estas são as facilidades que permitem o deslocamento dos ciclistas em trajetos compartilhados com o tráfego geral ou em trajetos paralelos ao alinhamento das vias que atendem o tráfego em geral. Via compartilhada é a tradução utilizada neste trabalho para o termo shared roadway encontrado na literatura estrangeira revisada, que freqüentemente refere-se ao uso compartilhado das vias com o tráfego geral. Caminho compartilhado é a tradução utilizada para a expressão shared path, também encontrada na literatura estrangeira revisada, para vias compartilhadas por pedestres e ciclistas. Esta terminologia encontra-se, particularmente, no Manual da AASHTO (1999). Desta forma, foram identificadas como facilidades as vias compartilhadas normais (sem sinalização), as ciclofaixas (faixas demarcadas como preferenciais ou exclusivas para os ciclistas), as calçadas compartilhadas (para pedestres e ciclistas) e as ciclovias (segregadas e exclusivas para ciclistas), além dos caminhos compartilhados para pedestres e ciclistas.

a) Acostamento e Acostamentos Compartilhados

No caso das rodovias, em especial, os acostamentos são o espaço destinados à circulação dos ciclistas, além da parada ou estacionamento de veículos em emergências. Na ausência de calçadas, são compartilhados com os pedestres.

b) Via Compartilhada

Segundo o Manual de Ciclistas da AASHTO (1999), bicicletas vão utilizar a via em todo lugar onde não são proibidas, daí a necessidade de promover práticas de projeto de segurança para ciclistas em todas as vias. A AASHTO subdivide as vias compartilhadas em vias compartilhadas e vias compartilhadas sinalizadas. 
Como a maior parte das vias não foi projetada para acomodar ciclistas, algumas melhorias podem tornar o tráfego de ciclistas possível em determinadas vias, incluindo dispositivos de drenagem, juntas de expansão em pontes, superfícies homogêneas, distância de visibilidade adequada e temporização e detecção de semáforos respondendo a bicicletas. Também medidas mais caras, como melhoria no acostamento e faixas mais largas podem ser consideradas. Em certas vias, faixas mais largas à direita podem ser implantadas pela remarcação das faixas (sem necessidade de aumentar a largura da pista), com custo muito menor.

De forma similar, o Manual de Planejamento Cicloviário do GEIPOT (2001) diz, de acordo com o CTB, art. 58, que "nas vias urbanas e nas rurais de pista dupla, a circulação de bicicletas deverá ocorrer onde não houver ciclovia, ciclofaixa ou acostamento, ou quando não for possível a utilização desses, nos bordos da pista de rolamento, no mesmo sentido de circulação regulamentado para a via, com preferência sobre os veículos automotores."

\section{c) Ciclofaixa}

Ciclofaixas são faixas demarcadas nas vias para uso exclusivo de ciclistas. Tanto o Manual de Ciclistas da AASHTO (1999) quanto do GEIPOT (2001) recomendam que as ciclofaixas devem ser dispositivos unidirecionais, com as bicicletas trafegando no mesmo sentido dos veículos. A AASHTO (1999) diz ainda que devem ser colocadas do lado direito da via, pois ciclofaixas do lado esquerdo não são familiares e são inesperadas para os motoristas, devendo ser apenas consideradas quando a ciclofaixa à esquerda reduzirá um número considerável de conflitos. O GEIPOT (2001) também recomenda que as ciclofaixas sejam do lado direito da via, ressaltando que de acordo com o CTB, art. 59, "a autoridade de trânsito com circunscrição sobre a via poderá autorizar a circulação de bicicletas em sentido contrário ao fluxo de veículos automotores, desde que dotado o trecho com ciclofaixa".

\section{d) Ciclovia}

O Manual da AASHTO (1999) não utiliza o termo específico ciclovia, porém a maioria das considerações utilizadas para ciclistas em caminhos compartilhados entre pedestres e ciclistas 
(shared use paths) aplica-se a ciclovias (exclusivas para ciclistas) e foram, portanto, considerados como válidas para ciclovia neste trabalho.

A ciclovia, sendo uma estrutura totalmente segregada do tráfego motorizado, é o dispositivo que apresenta o maior nível de segurança e conforto aos ciclistas. Portanto, a ciclovia distingue-se pela segregação, sendo assim classificada mesmo quando paralela às faixas destinadas ao tráfego geral (caso contrário seriam caminhos para ciclistas, fora do escopo deste trabalho).

Segundo o GEIPOT (2001), os altos custos e necessidade de bastante espaço impedem o uso em maior escala. Diz ainda que a ciclovia deve ser separada da pista de rolamento por um terrapleno com no mínimo $0,20 \mathrm{~m}$ de largura, sendo habitualmente mais elevada do que a pista de veículos motorizados.

e) Caminhos e Calçadas Compartilhadas

Esse dispositivo é totalmente segregado do tráfego de veículos, porém o uso pode ser compartilhado com outros usuários, pedestres, skatistas, entre outros. Quando paralela à via de tráfego geral, pode ser posicionada na área originalmente destinada à calçada, configurando uma calçada compartilhada com ciclistas.

Nada impede, no entanto, que os caminhos compartilhados entre pedestres e ciclistas ocupem outras áreas adjacentes à via (ou não), mantendo-se (ou não) o uso pelos pedestres da área originalmente destinada às calçadas.

O Manual do GEIPOT (2001) não discute estas opções em detalhe.

f) Seleção do tipo de infra-estrutura para ciclistas

Métodos de opção por segregação ou compartilhamento de vias de ciclistas foram encontrados no manual de London, e no relatório FHWA-RD-92-073 (Selecting Roadway Design Treatments to Acommodate Bicycles, FHWA, 1992). 
O relatório da FHWA é um guia para que tipo de dispositivo utilizar, de acordo com: volume de tráfego; velocidade operacional média dos veículos; tráfego misto de automóveis, caminhões, ônibus e/ou veículos recreacionais; estacionamento na via; distância de visibilidade; número de interseções. Para isso é caracterizado o ciclista de projeto, conforme segue:

Grupo A: ciclistas experientes (melhor acomodados em vias de uso compartilhado com faixas mais largas ou acostamento pavimentado);

Grupo B/C: ciclistas comuns / crianças (necessário identificar vias alternativas, arteriais e coletoras, e prover dispositivos para ciclistas nessas vias).

Os dispositivos são divididos em: vias compartilhadas (sl); vias compartilhadas com faixas mais largas, 4,2m (wc); ciclofaixa (bl); acostamento (sh) e ciclovia. As Tabelas 2-13 e 2-14 reproduzem as tabelas desenvolvidas pelo estudo em questão. 
Tabela 2-13 - - Critério americano de seleção de infra-estrutura para ciclistas no meio urbano (Fonte: Selecting Roadway Design Treatments to Acommodate Bicycles, FHWA, 1992)

\begin{tabular}{|c|c|c|c|c|}
\hline \multicolumn{2}{|c|}{ Ciclista A } & \multicolumn{3}{|l|}{ Urbano } \\
\hline & & $<2000$ & $2000-10000$ & $>10000$ \\
\hline \multirow{4}{*}{$\begin{array}{l}\text { Velocidade } \\
\text { média de } \\
\text { operação }\end{array}$} & $<30 \mathrm{mi} / \mathrm{h}$ & $\begin{array}{l}\mathrm{sl} / 3,6 \mathrm{~m} \\
\\
\text { com visibilidade } \\
\text { inadequada } \\
\text { wc / 4,2m } \\
\text { com } \\
\text { estacionamento } \\
\text { wc / 4,2m }\end{array}$ & $\begin{array}{l}\mathrm{sl} / 3,6 \mathrm{~m} \\
\text { com veíc } \\
\text { pesados } \\
\text { wc / 4,2m } \\
\text { com visibilidade } \\
\text { inadequada } \\
\text { wc / 4,2m } \\
\text { com } \\
\text { estacionamento } \\
\text { wc / 4,2m }\end{array}$ & $\begin{array}{l} \\
\text { com estacion. E } \\
\text { veic. pesados } \\
\text { wc / 4,6m }\end{array}$ \\
\hline & $30-40 \mathrm{mi} / \mathrm{h}$ & $\begin{array}{l}\text { wc / 4,2m } \\
\text { com visibilidade } \\
\text { inadequada } \\
\text { wc } 4,6 \mathrm{~m}\end{array}$ & $\begin{array}{l}\text { wc / 4,2m } \\
\text { com veíc } \\
\text { pesados } \\
\text { wc / 4,6m } \\
\text { com visibilidade } \\
\text { inadequada } \\
\text { wc / 4,6m }\end{array}$ & $\begin{array}{l}\text { wc / 4,2m } \\
\text { com veíc } \\
\text { pesados wc / } \\
4,6 \mathrm{~m} \\
\text { com visibilidade } \\
\text { inadequada } \\
\text { wc / 4,6m } \\
\text { com } \\
\text { estacionamento } \\
\text { wc / 4,6m }\end{array}$ \\
\hline & $41-50 \mathrm{mi} / \mathrm{h}$ & $\mathrm{wc} / 4,6 \mathrm{~m}$ & $\begin{array}{l}\text { wc / 4,6m } \\
\text { com visibilidade } \\
\text { inadequada } \\
\text { sh / } 1,8 \mathrm{~m} \\
\text { com estacion. e } \\
\text { veic pesados } \\
\text { wc / 4,9m } \\
\text { com estacion. e } \\
\text { visib. inadequada } \\
\text { wc / 4,9m }\end{array}$ & $\begin{array}{l}\text { wc / 4,6m } \\
\text { com visibilidade } \\
\text { inadequada } \\
\text { sh / } 1,8 \mathrm{~m} \\
\text { com estacion. e } \\
\text { veic pesados } \\
\text { wc / 4,9m } \\
\text { com estacion. e } \\
\text { visib. inadequada } \\
\text { wc / 4,9m }\end{array}$ \\
\hline & $>50 \mathrm{mi} / \mathrm{h}$ & $\begin{array}{l}\text { sh / 1,8m } \\
\text { com } \\
\text { estacionamento } \\
\text { não aplicável }\end{array}$ & \begin{tabular}{|l|}
$\mathrm{sh} / 1,8 \mathrm{~m}$ \\
com \\
estacionamento \\
não aplicável
\end{tabular} & $\begin{array}{l}\mathrm{sh} / 1,8 \mathrm{~m} \\
\text { com } \\
\text { estacionamento } \\
\text { não aplicável }\end{array}$ \\
\hline
\end{tabular}

\begin{tabular}{|c|c|c|c|c|}
\hline \multicolumn{2}{|c|}{ Ciclista B / C } & \multicolumn{3}{|l|}{ Urbano } \\
\hline & & $<2000$ & $2000-10000$ & $>10000$ \\
\hline \multirow{8}{*}{$\begin{array}{l}\text { Velocidade } \\
\text { média de } \\
\text { operação }\end{array}$} & & wc / 4,2m & wc / 4,2m & $\mathrm{bl} / 1,5 \mathrm{~m}$ \\
\hline & $<30 \mathrm{mi} / \mathrm{h}$ & & & \\
\hline & & bl / 1,5m & $\begin{array}{l}\text { bl / } 1,5 \mathrm{~m} \\
\text { com veíc } \\
\text { pesados } \\
\mathrm{bl} / 1,8 \mathrm{~m}\end{array}$ & $\begin{array}{l}\text { bl / 1,5m } \\
\text { com veíc } \\
\text { pesados } \\
\text { bl / 1,8m }\end{array}$ \\
\hline & & & & $\begin{array}{l}\text { com } \\
\text { estacionamento } \\
\text { bl } / 1,8 \mathrm{~m}\end{array}$ \\
\hline & & bl / 1,5m & $\mathrm{bl} / 1,8 \mathrm{~m}$ & bl / 1,8m \\
\hline & $41-50 \mathrm{mi} / \mathrm{h}$ & & & \\
\hline & & $\begin{array}{l}\text { com } \\
\text { estacionamento } \\
\text { bl } / 1,8 \mathrm{~m}\end{array}$ & & \\
\hline & $>50 \mathrm{mi} / \mathrm{h}$ & $\begin{array}{l}\text { bl / 1,8m } \\
\text { com } \\
\text { estacionamento } \\
\text { não aplicável }\end{array}$ & $\begin{array}{l}\text { bl / 1,8m } \\
\text { com } \\
\text { estacionamento } \\
\text { não aplicável }\end{array}$ & $\begin{array}{l}\text { bl / 1,8m } \\
\text { com } \\
\text { estacionamento } \\
\text { não aplicável }\end{array}$ \\
\hline
\end{tabular}

Tabela 2-14 - - Critério americano de seleção de infra-estrutura para ciclistas no meio rural (Fonte: Selecting Roadway Design Treatments to Acommodate Bicycles, FHWA, 1992)

\begin{tabular}{|c|c|c|c|c|}
\hline \multicolumn{2}{|c|}{ Ciclista A } & \multicolumn{3}{|l|}{ Rural } \\
\hline & & $<2000$ & $2000-10000$ & $>10000$ \\
\hline \multirow{4}{*}{$\begin{array}{l}\text { Velocidade } \\
\text { média de } \\
\text { operação }\end{array}$} & $<30 \mathrm{mi} / \mathrm{h}$ & $\begin{array}{l}\text { sl / 3,6m } \\
\\
\text { com visibilidade } \\
\text { inadequada } \\
\text { wc / 4,2m }\end{array}$ & $\begin{array}{l}\text { sl / 3,6m } \\
\text { com veíc } \\
\text { pesados wc / } \\
4,2 \mathrm{~m} \\
\text { com visibilidade } \\
\text { inadequada } \\
\text { wc } 4,2 \mathrm{~m}\end{array}$ & $\begin{array}{l}\text { wc / 4,2m } \\
\\
\text { com visibilidade } \\
\text { inadequada } \\
\text { sh } / 1,2 \mathrm{~m}\end{array}$ \\
\hline & $30-40 \mathrm{mi} / \mathrm{h}$ & $\begin{array}{l}\text { wc / 4,2m } \\
\\
\text { com visibilidade } \\
\text { inadequada } \\
\text { sh / } 1,2 \mathrm{~m}\end{array}$ & $\begin{array}{l}\text { wc / } 4,2 \mathrm{~m} \\
\text { com veíc } \\
\text { pesados wc / } \\
4,6 \mathrm{~m} \\
\text { com visibilidade } \\
\text { inadequada } \\
\text { sh / } 1,2 \mathrm{~m}\end{array}$ & $\mathrm{sh} / 1,2 \mathrm{~m}$ \\
\hline & $41-50 \mathrm{mi} / \mathrm{h}$ & $\mathrm{sh} / 1,2 \mathrm{~m}$ & $\mathrm{sh} / 1,8 \mathrm{~m}$ & $\mathrm{sh} / 1,8 \mathrm{~m}$ \\
\hline & $>50 \mathrm{mi} / \mathrm{h}$ & $\begin{array}{l}\text { sh / 1,2m } \\
\text { com veíc. } \\
\text { pesados sh / } \\
1,8 \mathrm{~m}\end{array}$ & $\mathrm{sh} / 1,8 \mathrm{~m}$ & $\mathrm{sh} / 1,8 \mathrm{~m}$ \\
\hline
\end{tabular}

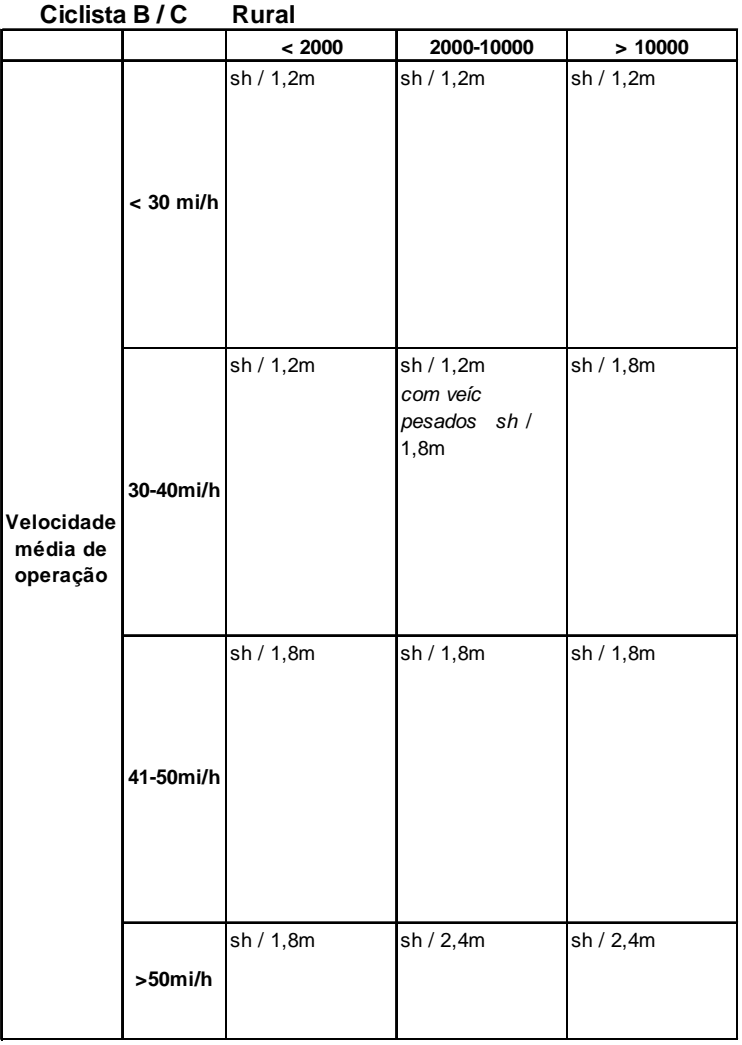


Os critérios acima mencionados não tiveram ampla aplicação, sequer na prática americana.

Internacionalmente, existem critérios mais aplicados que remontam a tradição holandesa. Por exemplo, os critérios ingleses (como os apresentados no London Cycling Design Standards, 2005) recomendam o dispositivo em função do AADT e da velocidade média de operação, conforme a Tabela 2-15.

Tabela 2-15 - Critério inglês de seleção de infra-estrutura para ciclistas no meio urbano (Fonte: London Cycling Design Standards, 2005)

\begin{tabular}{|c|c|c|c|c|c|c|}
\hline \multicolumn{7}{|c|}{ VDM Anual } \\
\hline \multirow{5}{*}{$\begin{array}{l}\text { Velocidade } \\
\text { média de } \\
\text { Operação }\end{array}$} & & $<1500$ & $1500-3000$ & $3000-8000$ & $8000-10000$ & $>10000$ \\
\hline & $<20 \mathrm{mi} / \mathrm{h}$ & & & $\begin{array}{l}\text { Ciclofaixas } \\
\text { podem ser } \\
\text { apropriadas }\end{array}$ & Ciclofaixas & $\begin{array}{l}\text { Ciclofaixas } \\
\text { ou ciclovias }\end{array}$ \\
\hline & $20-30 \mathrm{mi} / \mathrm{h}$ & & & $\begin{array}{l}\text { Ciclofaixas } \\
\text { podem ser } \\
\text { apropriadas }\end{array}$ & Ciclofaixas & $\begin{array}{l}\text { Ciclofaixas } \\
\text { ou ciclovias }\end{array}$ \\
\hline & $30-40 \mathrm{mi} / \mathrm{h}$ & & $\begin{array}{l}\text { Ciclofaixas } \\
\text { ou ciclovias }\end{array}$ & $\begin{array}{l}\text { Ciclofaixas } \\
\text { ou ciclovias }\end{array}$ & $\begin{array}{l}\text { Ciclofaixas } \\
\text { ou ciclovias }\end{array}$ & $\begin{array}{l}\text { Ciclofaixas } \\
\text { ou ciclovias }\end{array}$ \\
\hline & $>40 \mathrm{mi} / \mathrm{h}$ & $\begin{array}{l}\text { Ciclofaixas } \\
\text { ou ciclovias }\end{array}$ & $\begin{array}{l}\text { Ciclofaixas } \\
\text { ou ciclovias }\end{array}$ & Ciclovias & Ciclovias & Ciclovias \\
\hline
\end{tabular}

Neste caso, uma série de critérios complementares também ponderam outros aspectos (como a presença de veículos pesados). 


\subsubsection{Facilidades para Interseções e Travessias com Ciclistas}

Estas são as facilidades que permitem o percurso dos ciclistas em interseções (normalmente compartilhando o espaço com o tráfego geral) ou o deslocamento dos ciclistas em trajetos transversais ao alinhamento das vias que atendem o tráfego em geral (normalmente compartilhando o espaço com os pedestres). Foram identificados os tratamentos em interseções sem semáforo ou com semáforo e os tratamentos em travessias compartilhadas.

A discussão destes tratamentos não será feita aqui porque normalmente deve ponderar aspectos específicos do tipo de infra-estrutura adotada ao longo da via (notadamente a circulação compartilhada com o tráfego geral ou segregada dos veículos). Sua discussão será feita, por este motivo, junto com os aspectos de projeto detalhado de cada tipo de elemento.

\subsection{PARÂMETROS DE PROJETO PARA CICLISTAS}

A seguir, serão coletadas as recomendações necessárias para o projeto detalhados dos dispositivos destinados a prover uma infra-estrutura adequada aos ciclistas. A apresentação está estruturada por tipo de infra-estrutura. Para vias compartilhadas foi identificado um único aspecto: largura da via. Para ciclofaixas foram identificados os seguintes aspectos: largura de faixa, e tratamento em interseções (os demais aspectos são determinados pelo delineamento da via que serve ao tráfego geral). Para ciclovias, foram identificados os seguintes aspectos: velocidade de projeto, distância de visibilidade, largura da via, desobstrução lateral, alinhamento horizontal, alinhamento vertical, e tratamento de interseções. Para caminhos compartilhados, foram identificados os seguintes aspectos: largura da via e tratamento de travessias. 


\subsubsection{Via Compartilhada}

a) Largura

A largura necessária para acomodar veículos e bicicletas numa mesma faixa pode ser alcançada providenciando faixas mais largas ou acostamentos pavimentados.

De acordo com a AASHTO (1999), a largura do acostamento que será utilizado por ciclistas deve ser no mínimo 1,20m, sendo recomendado 1,50m se há barreiras e/ou interferências lateriais. O TAC (1999) sugere um acostamento pavimentado de 1,50m a 3,0m.

A largura mínima recomendada pela AASHTO (1999) para a faixa de tráfego da direita, quando há tráfego compartilhado, é 3,60m, sendo em geral recomendado 4,20m. Quando há maior quantidade de manobras de ciclistas, presença de dispositivos de drenagem e/ou o estacionamento é permitido na via, é preferível adotar 4,50m. O TAC (1999) traz uma tabela (Tabela 2-16) relacionando a largura recomendada de acordo com o volume de tráfego (AADT - Annual Average Daily Traffic). Para AADT de 0 a 3000 faixas de 4,0 a 4,30m podem ser adotadas. Já para volumes de tráfego maiores, recomenda-se faixas mais largas, 4,50m para AADT de até 6000 e 4,80m para AADT maior que 6000.

Tabela 2-16 - - Largura recomendada da faixa de tráfego compartilhado de acordo com AADT (Fonte: Geometric Design Guide for Canadian Roads, TAC, 1999)

\begin{tabular}{|l|l|}
\hline \multicolumn{2}{|c|}{ Ciclovia e Faixa compartilhada a direita (arterial) } \\
\hline AADT 0-1000 & Faixa padrão $-4,0 \mathrm{~m}$ \\
\hline AADT $1000-3000$ & Faixa padrão $-4,3 \mathrm{~m}$ \\
\hline AADT $3000-6000$ & $4,0-4,5 \mathrm{~m}$ \\
\hline AADT $>6000$ & $4,3-4,8 \mathrm{~m}$ \\
\hline
\end{tabular}




\subsubsection{Ciclofaixa}
a) Largura

Segundo a AASHTO (1999), ciclofaixas unidirecionais, com estacionamento proibido, a largura recomendada é $1,50 \mathrm{~m}$ do meio fio à demarcação, sobrando um mínimo de $0,90 \mathrm{~m}$ para o ciclista. Se não houver meio fio e sarjeta, a largura mínima passa a ser $1,20 \mathrm{~m}$. Se o estacionamento é permitido, a ciclofaixa deve estar entre a faixa de estacionamento e o fluxo veicular, com largura mínima de $1,50 \mathrm{~m}$. Onde o estacionamento é permitido, mas não demarcado, a área compartilhada deve ser 3,30m sem meio fio e 3,60 com meio fio. Ainda se o volume de estacionamento é substancial, ou a quantidade de manobras alta, uma largura adicional de 0,30 ou $0,60 \mathrm{~m}$ é desejável. Ciclofaixas bidirecionais não são recomendadas quando resultam em ciclistas trafegando contra os veículos. A Figura 2-37 ilustra essas situações. 


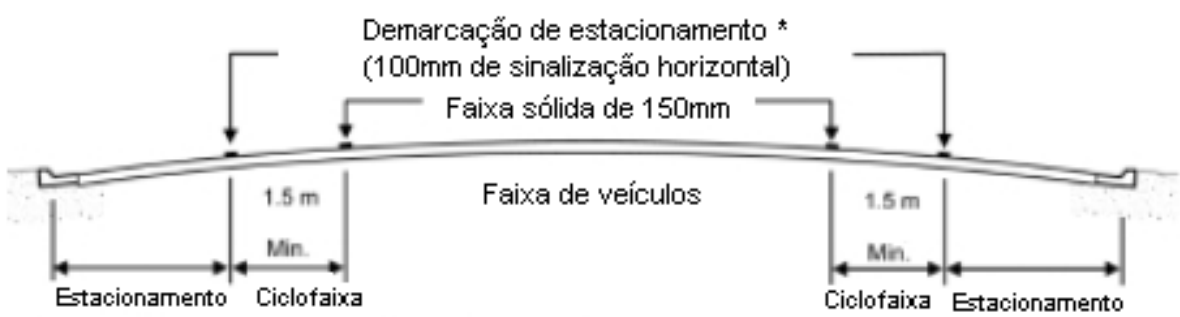

* A sinalizaçẫo horizontal opcional é aconselhável onde o estacionamento é baixo, contudo os motorista podem confundir a ciclofaixa com a via

\section{(1) Estacionamento na via}

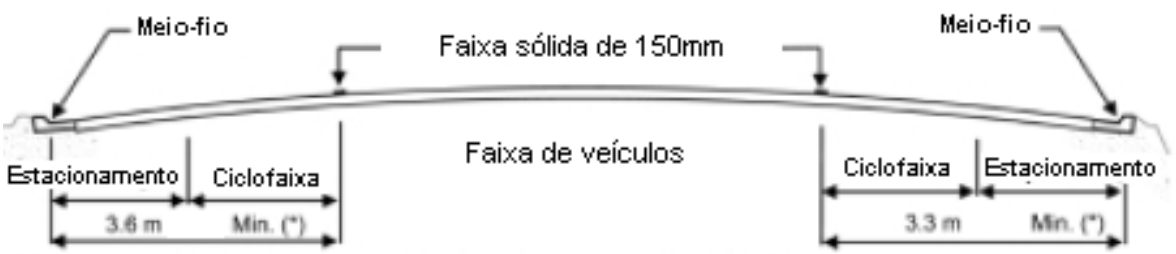

* $3,9 \mathrm{~m}$ é recomendado onde tem um volume substancial de estacionamento ou a quantidade de manobras é grande

(2) Estacionamento permitido sem sinalização horizontal ou barreira

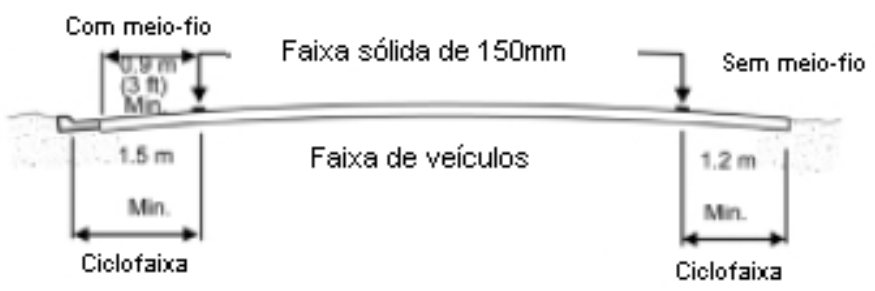

(3) Estacionamento proibido

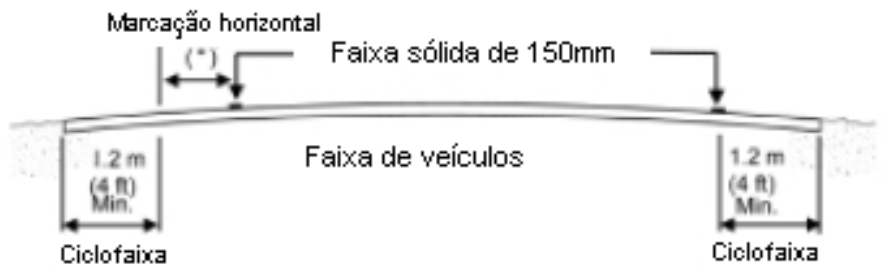

"Mnimo de 1,2m, se existirem marcaçốes horizontais

(4) Via típica em áreas afastadas com estacionamento protegido

Figura 2-37 - Seções transversais típicas de ciclofaixas (Fonte: Guide for Development of Bicycle Facilities, AASHTO, 1999) 
O GEIPOT (2001), de forma similar, recomenda para ciclofaixas unidirecionais, usualmente, 1,40m, sendo: 1,20m (interna) + 0,20m (meio fio), sendo muitas vezes, necessário 1,80m, sendo: $1,20 \mathrm{~m}$ (interna) + 0,40m (zebrado) + 0,20m (meio fio). Quando há estacionamento a ciclofaixa deve estar entre a faixa de estacionamento e a de tráfego, com largura de 2,0m. Ciclofaixas bidirecionais não são recomendadas.

b) Tratamentos nas interseções

As interseções são locais que devem ser tratados com bastante cuidado, pois o número de conflitos entre ciclistas e veículos é grande.

Segundo a AASHTO (1999), na maioria dos casos, a ciclofaixa não deve continuar em interseções. Quando necessário alguns detalhes devem ser observados. A Figura 2-38 ilustra algumas situações.

Em interseções semaforizadas com conversão à direita de veículos, a linha sólida na aproximação deve ser substituída por uma linha seccionada $(0,60 \mathrm{~m}$ o traço e $1,80 \mathrm{~m}$ o espaçamento)., sendo o comprimento da linha seccionada usualmente de $15 \mathrm{~m}$ a $60 \mathrm{~m}$. A ciclofaixa não deve ser colocada em faixas de pedestres. Se não houver faixa de pedestres, a linha da ciclofaixa deve parar antes da interseção e continuar logo após.

Em interseções não sinalizadas, como o volume de conversões à direita é usualmente baixo, a faixa sólida pode continuar por todo o cruzamento. Entretanto, se houver ponto de ônibus, a faixa sólida de $150 \mathrm{~mm}$ deve ser substituída por uma seccionada com $0,60 \mathrm{~m}$ o traço e 1,80m o espaçamento, pelo comprimento do ponto de ônibus. 


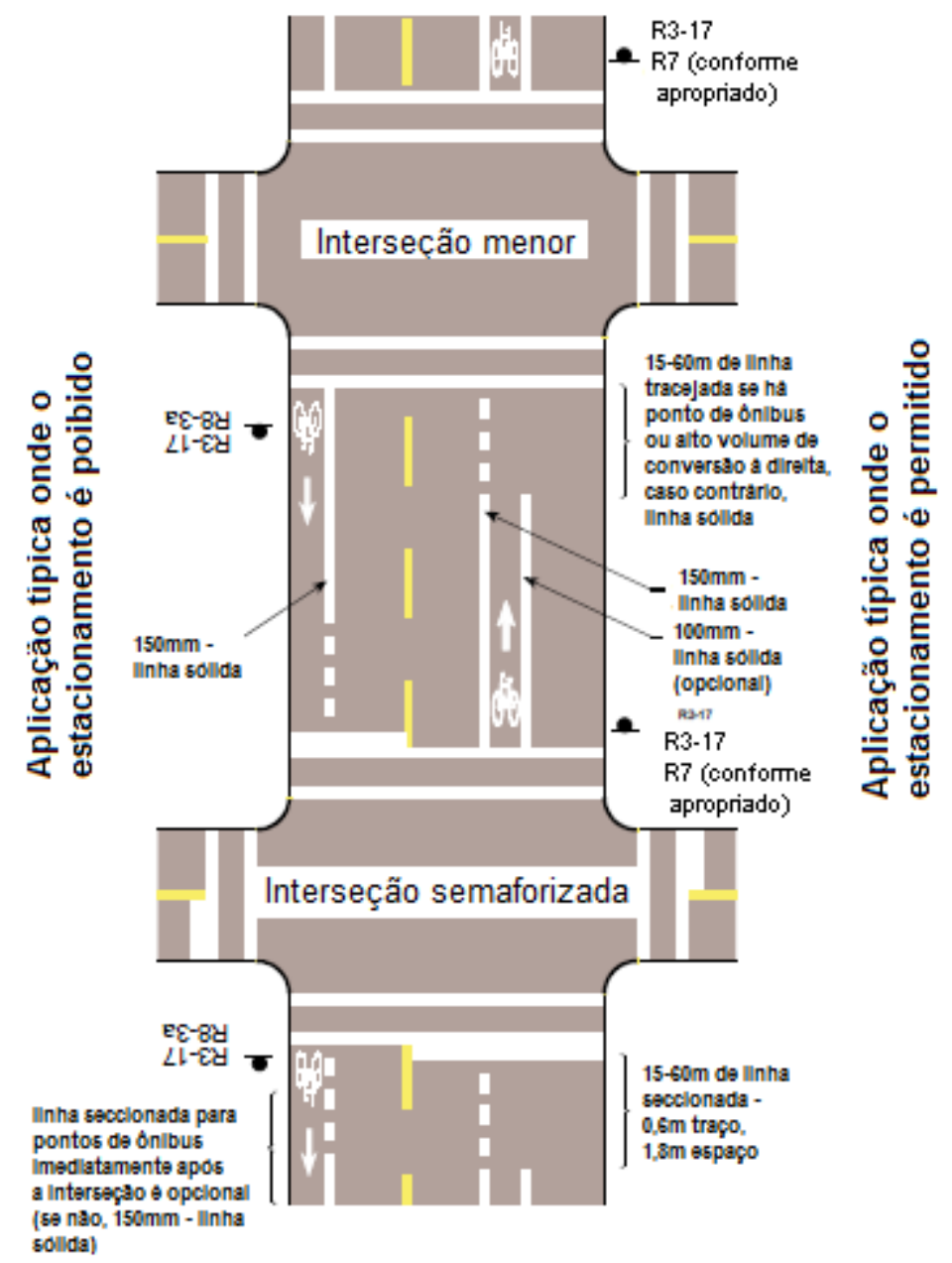

Figura 2-38 - Sinalização horizontal típica para ciclofaixas em vias de duas mão (Fonte: Guide for Development of Bicycle Facilities, AASHTO, 1999)

Em interseções T sem faixa de pedestres, a linha sólida deve continuar sem interrupção na face oposta. Se houver faixa de pedestres pintadas, a faixa na face oposta deve ser interrompida apenas nas travessias, como mostra a Figura 2-39. 

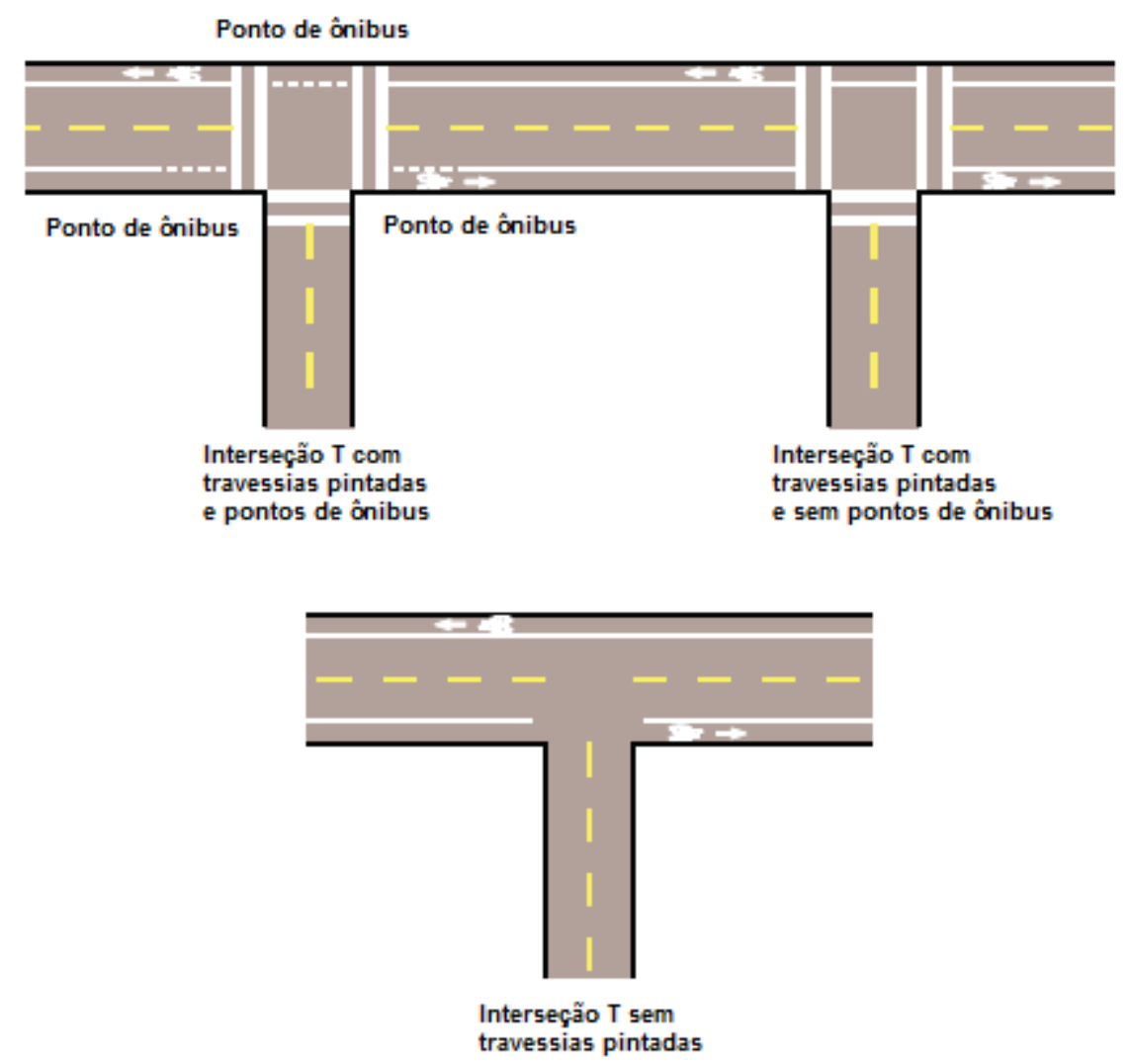

Figura 2-39 - Sinalização horizontal típica em interseções T (Fonte: Guide for Development of Bicycle Facilities, AASHTO, 1999)

Para faixas de conversão à direita e à esquerda, configurações de sinalização que encorajam o entrelaçamento antes do cruzamento são desejáveis. O mesmo é válido para motoristas virando à esquerda, em menor grau, quando também é possível realizar o movimento com a travesssia de pedestres posterior ao cruzamento, como mostrado na Figura 2-40. Orientações gerais para marcação no pavimento seguem o MUTCD. Em interseções com alargamento para acomodar faixas exclusivas de conversão à esquerda e à direita, na falta de espaço para a ciclofaixa, ela deve ser interrompida e o ciclista mesclado com o fluxo de veículos, como na Figura 2-41. 


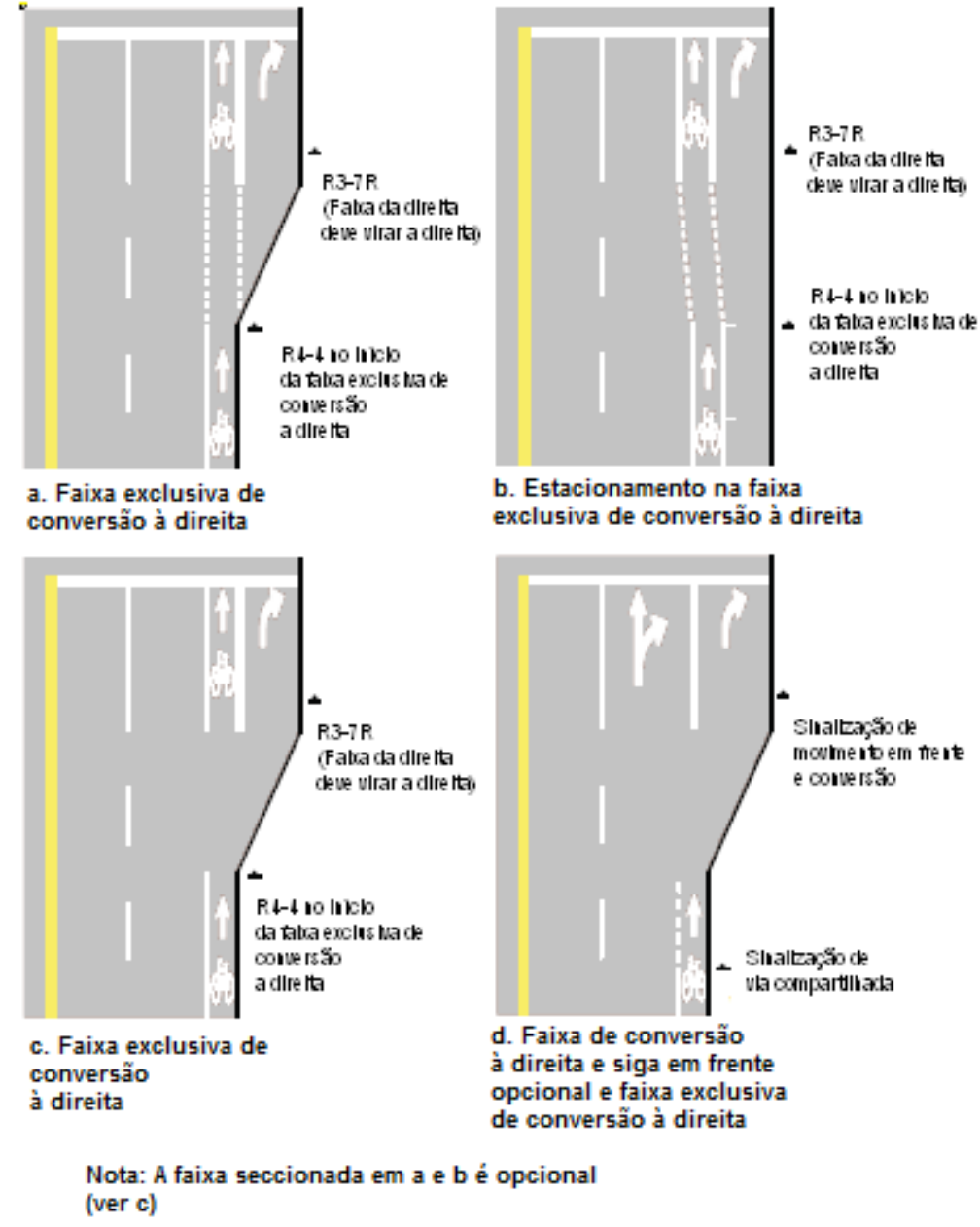

Figura 2-40 - Ciclofaixas em aproximações de faixas de conversão à direita (Fonte: Guide for Development of Bicycle Facilities, AASHTO, 1999) 


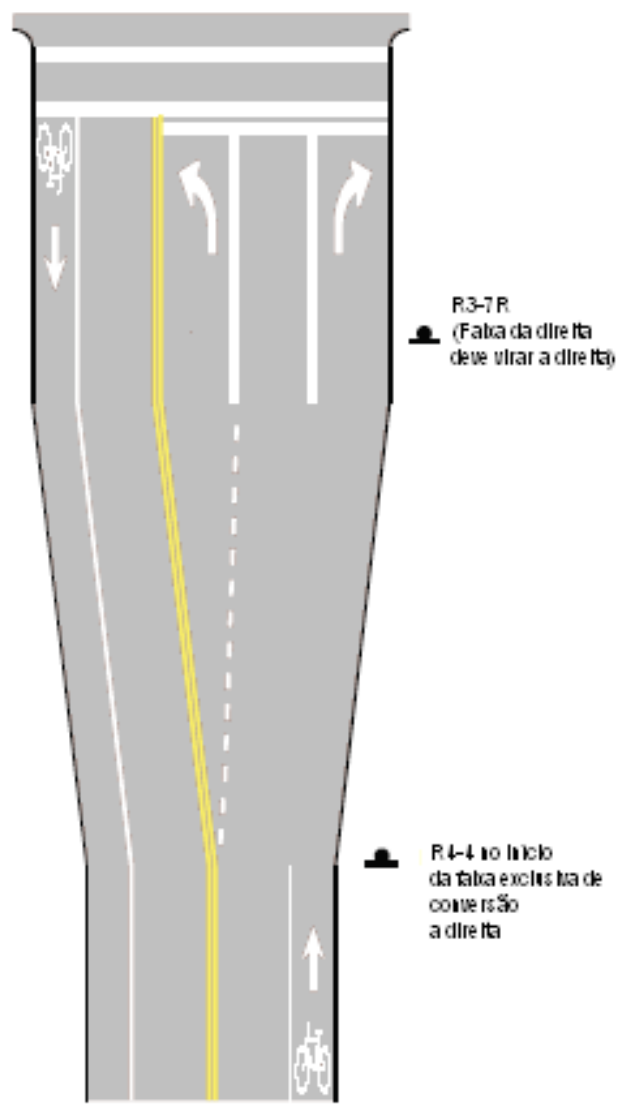

Figura 2-41 - Ciclofaixa em aproximação de interseção com alargamento (Fonte: Guide for Development of Bicycle Facilities, AASHTO, 2004)

O GEIPOT (2001) recomenda, para circulação compartilhada nos cruzamentos, o uso de canalização dos ciclistas onde a área lateral na via é mínima ou há opção por retirar espaço da via destinada ao tráfego geral para se criar ilhas direcionais para os ciclistas.

Princípios Básicos:

a. Diminuição da largura das faixas de tráfego. Em vias de 12m: 2 faixas de 3 $\mathrm{m}$, uma de $3,50 \mathrm{~m}$, ilha de $1 \mathrm{~m}$ e ciclofaixa canalizada de $1,5 \mathrm{~m}$. Onde uma das faixas é usada para estacionamento sua largura pode ter $2 \mathrm{~m}$, e a primeira faixa pode passar a ter $4 \mathrm{~m}$ (as demais $3 \mathrm{~m})$;

b. Aumento no raio de giro na esquina da via, com mínimo de 10m; 
c. Pintura de faixa vermelha, em cruzamentos de ciclovias com faixas de pedestres. Pintura de bicicletas no solo para orientar ciclistas e motoristas; eventualmente pode se estender a pintura de solo na ciclofaixa percorrendo a área interna do cruzamento;

d. No caso de estacionamento permitido, pode ser conveniente o uso de avanço de calçada nas esquinas dos cruzamentos adjacentes à ciclofaixa;

e. Implantação de área de retenção privilegiada para bicicletas à frente da faixa de retenção dos veículos motorizados, com extensão de 3m (estaria implícita a existência de semáforo; eventualmente com estágio exclusivo para conversões à esquerda dos ciclistas).

Em aproximações de cruzamentos, a GEIPOT (2001) reproduz arranjos esquemáticos do documento Bikeway Planning and Design, California State Department of Transportation Highway Design Manual (HDM).

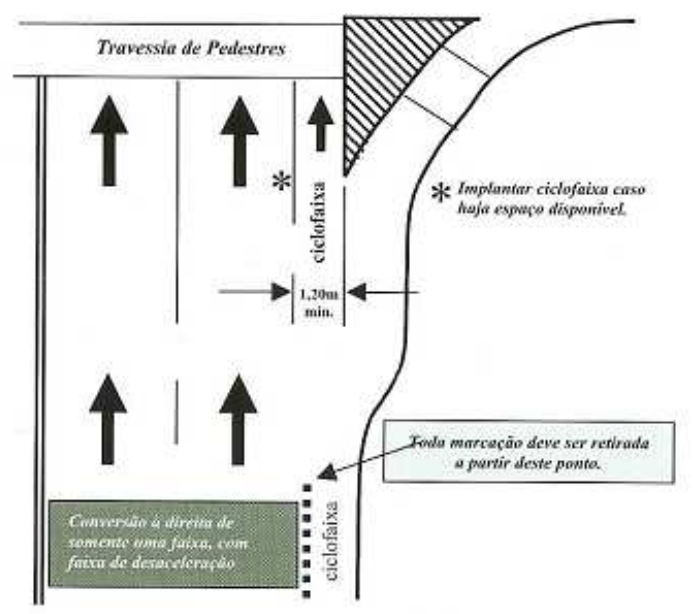

Figura 2-42 - Ciclofaixas em aproximações de cruzamentos (Fonte: Bikeway Planning and Design, California State Department of Transportation - Highway Design Manual, HDM. Apud: Manual de Planejamento Cicloviário, GEIPOT, 2001)

1 - Conversão à direita de somente uma faixa, com faixa de desaceleração

a. Sem deslocamento da trajetória da ciclofaixa; 
b. Interrupção das marcas no pavimento, para que os veículos possam acessar a faixa de desaceleração para realizar conversão para via à direita da via principal;

c. É exigível, para a ciclofaixa, na área imediatamente anterior a faixa de retenção, que ela tenha $1,20 \mathrm{~m}$ de largura.

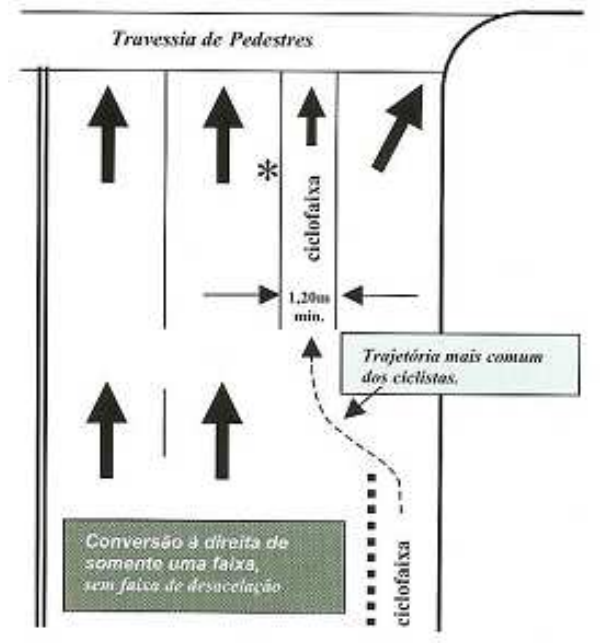

Figura 2-43 - Ciclofaixas em aproximações de cruzamentos (Fonte: Bikeway Planning and Design, California State Department of Transportation - Highway Design Manual, HDM. Apud: Manual de Planejamento Cicloviário, GEIPOT, 2001)

2 - Conversão à direita de somente uma faixa, sem faixa de desaceleração

a. Troca de posição entre a ciclofaixa e a faixa de veículos motorizados;

b. Necessário sobrelargura na faixa da direita do tráfego motorizado. 


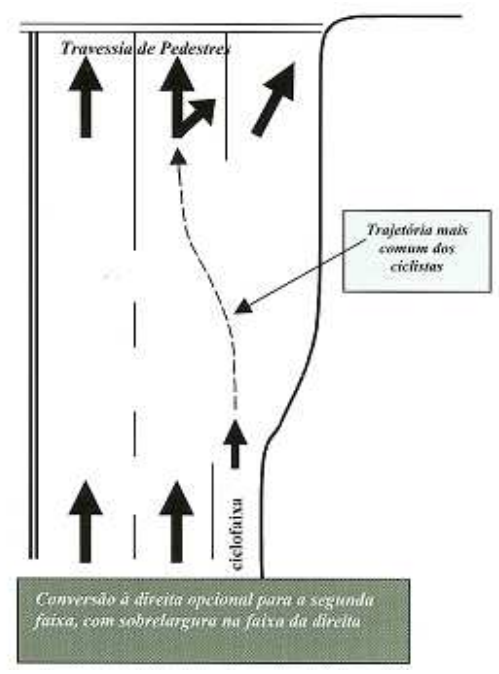

Figura 2-44 - Ciclofaixas em aproximações de cruzamentos (Fonte: Bikeway Planning and Design, California State Department of Transportation - Highway Design Manual, HDM. Apud: Manual de Planejamento Cicloviário, GEIPOT, 2001)

3 - Conversão à direita opcional para a segunda faixa, com sobrelargura na faixa da direita

a. Os ciclistas não tem uma ciclofaixa antes da faixa de rentenção;

b. Estocagem dos ciclistas deve ocorrer na segunda faixa, obrigando-os a trocar de posição com os motoristas que pretendem realizar conversão à direita. 


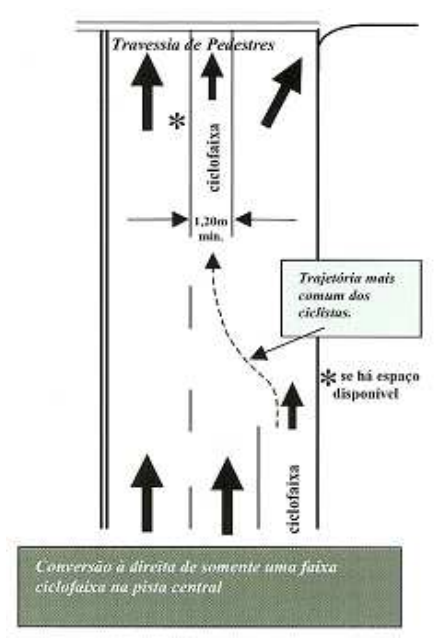

Figura 2-45 - Ciclofaixas em aproximações de cruzamentos (Fonte: Bikeway Planning and Design, California State Department of Transportation - Highway Design Manual, HDM. Apud: Manual de Planejamento

Cicloviário, GEIPOT, 2001)

IV - Conversão á direita de somente uma faixa ciclofaixa na pista central

a. Similar ao II, com menos espaço e menor número de faixas.

\subsubsection{Ciclovia}

a) Velocidade de Projeto

Segundo a AASHTO (1999), a velocidade de projeto depende de diversos fatores: tipo e condição da bicicleta; o motivo da viagem; a condição, localização e grade do caminho; a velocidade e direção do vento; número e tipo de usuários do caminho e das condições físicas dos ciclistas. Em geral, a velocidade mínima que deve ser usada é 30km/h; quando um declive excede $4 \%$, ou onde há ventos fortes, $50 \mathrm{~km} / \mathrm{h}$ ou mais é aconselhável. Em vias não pavimentadas, pode ser usada uma velociade menor, de $25 \mathrm{~km} / \mathrm{h}$; com declives ou presença de vento forte, $40 \mathrm{~km} / \mathrm{h}$. 
O GEIPOT (2001) não discute velocidade de projeto e o TAC (1999) traz os mesmo valores da AASHTO (1999).

b) Distância de Visibilidade

A distância de visibilidade para o ciclista deve ser calculada de acordo com a velocidade de projeto e grade considerando um tempo de ação e reação de $2,5 \mathrm{seg}$ e coeficiente de atrito de 0,25, de acordo com a AASHTO (1999).

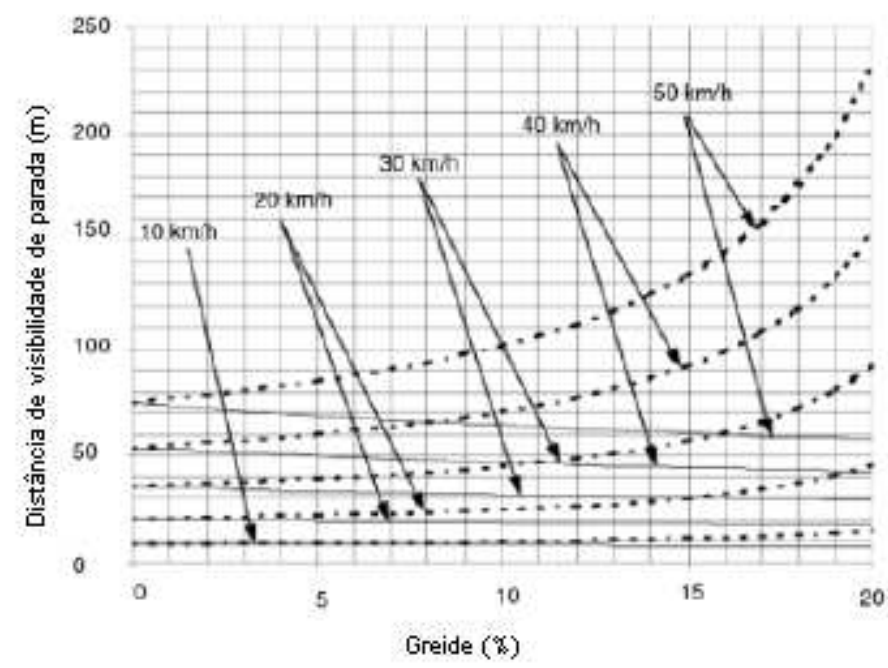

$$
\begin{aligned}
& S-\frac{V^{2}}{254(f \pm G)}+\frac{V}{1.4} \\
& \text { Onde: } S=\text { distância de visibilidade de parada }(\mathrm{m}) \\
& V=\text { velocidade }(\mathrm{km} / \mathrm{h}) \\
& \mathrm{f}=\text { coeficiente de atrito }(0,25) \\
& \mathrm{G}=\text { greide }(\mathrm{m} / \mathrm{m})
\end{aligned}
$$

Figura 2-46 - Distância de visibilidade para ciclovias (Fonte: Guide for Development of Bicycle Facilities, AASHTO, 2004)

O GEIPOT (2001) não discute distância de visibilidade e o TAC (1999) traz os mesmos valores da AASHTO (1999). 
c) Largura

Segundo a AASHTO (1999), ciclovias unidirecionais devem ter uma largura mínima de 1,80m. Para ciclovias bidirecionais, na maioria das condições, a largura recomendada é 3,0m. Raramente, 2,40m aceitável quando tráfego de bicicletas é baixo, bom alinhamento vertical e horizontal. Em certas circunstâncias pode ser necessário aumentar a largura para 3,60m ou 4,20m devido ao grande volume de ciclistas.

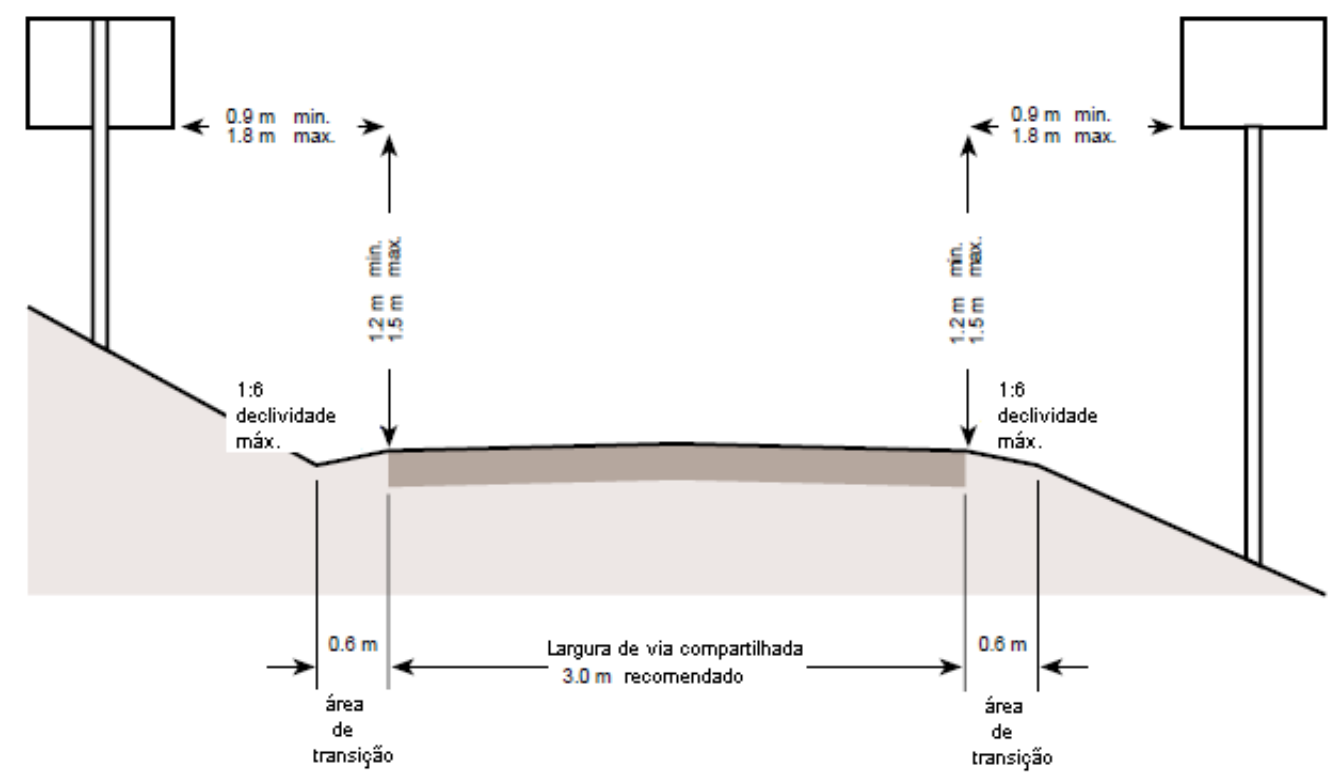

Figura 2-47 - Seção transversal de caminho compartilhado bidirecional (Fonte: Guide for Development of Bicycle Facilities, AASHTO, 1999)

O Manual do GEIPOT (2001) diz que ciclovias unidirecionais são pouco utilizadas no Brasil. Países como França e Holanda adotam 2,0m, acrescendo 0,50m, se o desnível lateral é maior que $0,10 \mathrm{~m}$, acrescendo $0,25 \mathrm{~m}$ se houver arborização lateral. O Manual traz ainda uma tabela que relaciona a largura da ciclovia unidirecional com o fluxo de bicicletas: 
Tráfego horário (bicicletas por hora)

(1) Até 1.000

(2) De 1.000 a 2.500

(3) De 2.500 a 5.000

(4) Mais de 5.000
Largura efetiva

de 2,00 a $2,50 \mathrm{~m}$

de 2,50 a $3,00 \mathrm{~m}$

de 3,00 a $4,00 \mathrm{~m}$

De 4,00 a $6,00 \mathrm{~m}$

Tabela 2-17 - Largura efetiva de ciclovia unidirecional de acordo com o tráfego horário de bicicletas (Fonte: Manual de Planejamento Cicloviário, GEIPOT, 2001)

Para ciclovias bidirecionais, a largura ideal é 3,0m, sendo um mínimo de 2,50m aceitável (devendo-se acrescer $0,50 \mathrm{~m}$ se o desnível for maior que $0,10 \mathrm{~m}$ ). Traz também uma tabela de largura recomendada de acordo com o fluxo de bicicletas:

Tráfego horário Largura efetiva (bicicletas por hora)

(1) Até 1.000 de 2,50 a $3,00 \mathrm{~m}$

(2) De 1.000 a 2.500 de 3,00 a $4,00 \mathrm{~m}$

(3) De 2.500 a 5.000 de 4,00 a $6,00 \mathrm{~m}$

(4) Mais de $5.000 \quad>6,00 \mathrm{~m}$

Tabela 2-18 - Largura efetiva de ciclovia bidirecional de acordo com o tráfego horário de bicicletas (Fonte: Manual de Planejamento Cicloviário, GEIPOT, 2001)

O TAC (1999), muito semelhante ao americano (AASHTO, 1999), recomenda 1,50m a 2,0m para ciclovias unidirecionais e $2,50 \mathrm{~m}$ a $3,0 \mathrm{~m}$ para ciclovias bidirecionais. 
d) Desobstrução Lateral

A AASHTO (1999) diz que uma área de no mínimo 0,6m e declividade máxima 1:6 deve ser mantida de cada lado do caminho, porém, 0,9 ou mais é desejável para manter o caminho afastado de árvores, postes, paredes, cercas, guardrails ou qualquer outra obstrução lateral. Onde o caminho é adjacente a canais, valas ou morros muito acentuados (1:3) uma largura maior deve ser considerada. Uma separação mínima de 1,5m do caminho até o topo do declive é desejável. Dependendo da altura do aterro e de sua condição, uma barreira física pode ser necessária. A desobstrução vertical deve ser no mínimo de 2,5m. Porém pode ser necessário que seja maior para permitir a passagem de veículos de manutenção e emergência. Em passagens subterrâneas e túneis, 3,0m é adequado (Figura 2-22, anterior).

O GEIPOT (2001) não discute e o TAC (1999) traz a seguinte tabela:

Tabela 2-19 - Desobstrução lateral (Fonte: Geometric Design Guide for Canadian Roads, TAC, 1999)

\begin{tabular}{|c|c|}
\hline Elemento & Projeto \\
\hline Desobstruçäo horizontal & $0,6-1,0$ \\
Desobstruçầo vertical & $2,5-3,6$ \\
Altura do parapeito & $1,4-1,6$ \\
\hline Nota: aj Medido da borda do carninho até a tace da \\
obstruçäo
\end{tabular}

\section{e) Alinhamento Horizontal}

i. Raio de curva

De acordo com a AASHTO (1999), o cálculo do raio de curva leva em conta um coeficiente de fricção selecionado baseado no ponto em que a força centrífuga causa desconforto e ação institiva de evitar altas velocidades ao ciclista. O limite de contato dos pedais com o solo varia entre modelos de bicicletas, mas é algo em torno de $25^{\circ}$. Porém, geralmente ciclistas não gostam de se inclinar tanto e aceitam como ângulos de tombamento máximos $15^{\circ}-20^{\circ}$. Assumindo que o ciclista está reto na bicicleta, o raio de curva pode ser calculado da seguinte maneira: 


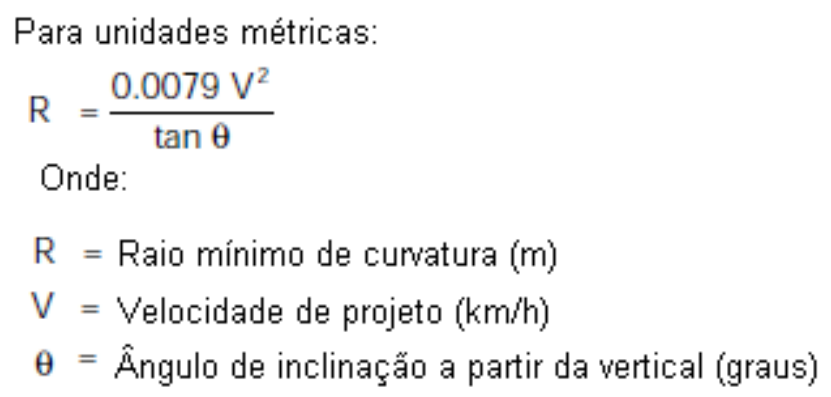

Quando o ângulo do pedal chega próximo de $20^{\circ}$, o raio se torna função da superelevação, do coeficiente de atrito entre os pneus da bicicleta e o pavimento e da velocidade:

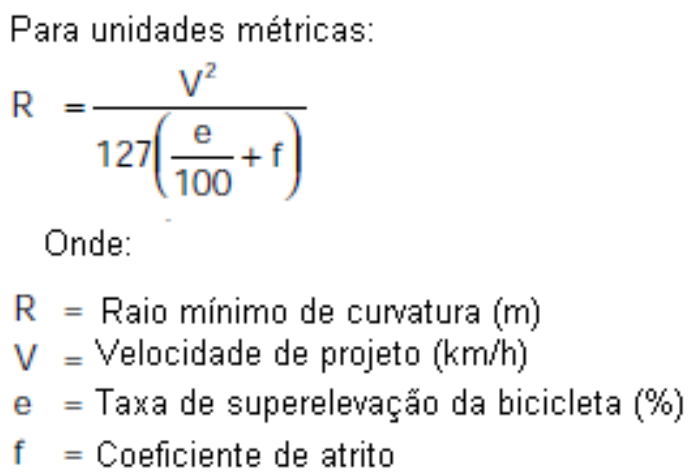

A superelevação máxima é de 3\% para atender ADA (American with Disability Act); neste caso a distância mínima entre duas curvas reversas deve ser 7,50m.

O coeficiente de atrito depende da velocidade; tipo, rugosidade e condição da superfície; tipo e condição do pneu; e se a superfície está molhada ou seca. Sendo a seguinte condição implícita: $\mathrm{f}=\min \{\operatorname{tg} \theta, \mu$ máx $\}$, as tabelas mostram raios de curva mínimos, em função da velocidade:

Tabela 2-20 - Raio mínimo desejável para ciclovias pavimentadas baseado em ângulo de tombamento de 150 (Fonte: Guide for Development of Bicycle Facilities, AASHTO, 1999)

\begin{tabular}{ccccc}
\hline \multicolumn{2}{c}{ Velocidade de Projeto $(\mathbf{V})$} & & \multicolumn{2}{c}{ Raio mínimo (R) } \\
\cline { 1 - 2 } $\mathbf{k m} / \mathbf{h}$ & $(\mathbf{m p h})$ & $\mathbf{m}$ & $(\mathbf{f t})$ \\
20 & $(12)$ & 12 & $(36)$ \\
30 & $(20)$ & 27 & $(100)$ \\
40 & $(25)$ & 47 & $(156)$ \\
50 & $(30)$ & 74 & $(225)$
\end{tabular}


Tabela 2-21 - Raio mínimo desejável para ciclovias pavimentadas baseado em superelevação de $2 \%$ e ângulo de tombamento de 200 (Fonte: Guide for Development of Bicycle Facilities, AASHTO, 1999)

\begin{tabular}{ccccc}
\hline \multicolumn{2}{c}{$\begin{array}{l}\text { Velocidade de } \\
\text { Projeto }(\mathbf{M})\end{array}$} & $\begin{array}{c}\text { Fator de atrito (f) } \\
\text { (superficie pavimentada) }\end{array}$ & \multicolumn{2}{c}{ Raio mínimo (R) } \\
\hline $\mathbf{k m} / \mathbf{h}$ & $(\mathbf{m p h})$ & & $\mathbf{m}$ & $(\mathrm{ft})$ \\
20 & $(12)$ & 0.31 & 10 & $(30)$ \\
30 & $(20)$ & 0.28 & 24 & $(90)$ \\
40 & $(25)$ & 0.25 & 47 & $(155)$ \\
\hline 50 & $(30)$ & 0.21 & 86 & $(260)$ \\
\hline
\end{tabular}

O GEIPOT (2001) diz muito pouco sobre raio de curva. Apenas que deve ser o mesmo da via que a ciclovia margeia, e que para reduzir a velocidade dos ciclistas nas aproximações de cruzamentos: 3,00 a 5,00m, com placas de sinalização adequadas.

O TAC (1999) utiliza os mesmos coeficientes de atrito utilizados para gerar as tabelas acima, variando de 0,3 a $25 \mathrm{~km} / \mathrm{h}$ a 0,22 a $50 \mathrm{~km} / \mathrm{h}$. Para projeto de superfícies não pavimentadas, o coeficiente de atrito é reduzido em 50\%. Diz ainda que para a maioria das condições a superelevação varia de um mínimo de 0,02 a $0,05 \mathrm{~m} / \mathrm{m}$.

ii. O afastamento lateral mínimo para curvas horizontais, em função da distância de visibilidade e raio da curva

A AASHTO (1999) traz ainda o modo de calcular e uma tabela com o afastamento lateral mínimo para curvas horizontais, em função da distância de visibilidade e raio da curva. 
Tabela 2-22 - - Afastamento lateral mínimo para curvas horizontais, em função da distância de visibilidade e raio da curva (Fonte: Guide for Development of Bicycle Facilities, AASHTO, 1999)

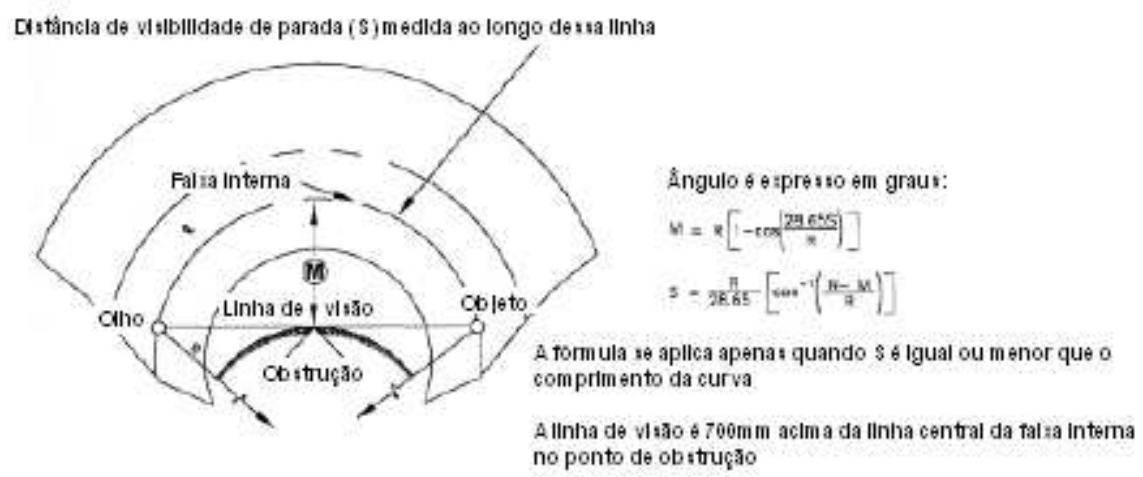

Para unidades metticas:

$S=$ Clstâncla de visibilldade de parada (m)

$R=$ Ralo da llnha central da tal:a $(m)$

$M=$ Cistâncla da llnha central da talsa para a ob struçåo (m)

\begin{tabular}{|c|c|c|c|c|c|c|c|c|c|c|c|c|c|c|c|c|c|c|c|}
\hline \multirow[t]{2}{*}{$\begin{array}{c}\mathrm{R} \\
(\mathrm{m})\end{array}$} & \multicolumn{19}{|c|}{$s=$ Clstâncla de vislbilldade de parada (m) } \\
\hline & 10 & 15 & 20 & 25 & 90 & 35 & 40 & 45 & 50 & 55 & $\infty 0$ & 65 & 70 & 75 & 80 & 85 & 90 & 95 & 100 \\
\hline to & 1.2 & 2.7 & 1.8 & 8.8 & 93 & & & & & & & & & & & & & & \\
\hline 15 & B.8 & 1.8 & 32 & 49 & 59 & 4.1 & $\pi$ & 14 & & & & & & & & & & & \\
\hline 20 & 0.5 & 1.4 & 24 & 38 & 5.4 & 7.2 & 9.7 & $n$ & 14 & 16 & 19 & & & & & & & & \\
\hline 25 & 0.5 & 1,1 & $z$ & 3.1 & 4.4 & 5.9 & 7.6 & 9.5 & 11 & 14 & 16 & 18 & 21 & 23 & & & & & \\
\hline 50 & 0.3 & 0.6 & 1 & 16 & 22 & 3 & 39 & 5 & E:T & 7.4 & 9.7 & 10 & 12 & 13 & 15 & 17 & 19 & 21 & 23 \\
\hline 75 & 0.2 & 0.4 & 0.7 & 1 & 15 & 2 & 2.7 & 3.4 & 4.1 & 5 & 59 & 6.9 & $B$ & 9.2 & 70 & 12 & 13 & 15 & 16 \\
\hline 100 & 0.1 & 0.3 & 0.5 & 0.8 & 1.1 & 1.5 & 2 & 2.5 & 31 & 3.8 & 45 & 5.2 & E.1 & 7 & 7.9 & $B . F$ & 10 & 11 & 12 \\
\hline 125 & 12.1 & 10.2 & 12.4 & 0.6 & 09 & 1.2 & T.F & 2 & 2.5 & 3 & 3.6 & 4.2 & 4.9 & 5.5 & 6.3 & 7.2 & 8 & g. & $g .9$ \\
\hline 150 & & 0.2 & 0.3 & 0.5 & 0.1 & 1 & 1.3 & 1.7 & 23 & 25 & 3 & 35 & 4,1 & 4.7 & 5.3 & 6 & 6.1 & 73 & a.3 \\
\hline 175 & & 0.2 & 123 & 0.4 & 0.5 & 0.9 & 1.1 & 1.4 & $1 B$ & 22 & 2.5 & 3 & 3.5 & 8 & 4.6 & 5.1 & 5.8 & 6.4 & 7.1 \\
\hline 200 & & D.1 & D. 3 & 0.4 & 0.6 & 0.8 & 1 & 1.3 & 1.6 & 19 & 22 & 26 & 3.1 & 3.5 & 4 & 4.5 & 5 & 5.5 & 6.2 \\
\hline 225 & & 0.1 & 02 & 0.3 & 0.5 & 0.7 & 0.9 & 1.1 & 1.4 & 1.7 & 2 & 2.3 & 2.7 & 3.1 & 3.5 & 4 & 4.5 & 5 & 5.5 \\
\hline 250 & & 10.1 & 0.2 & 0.3 & 0.5 & 0.5 & o.n & 1 & 12 & 1.5 & 13 & 21 & 2.4 & 2.8 & $3 z$ & 3.8 & 4 & 4.5 & 5 \\
\hline 275 & & 1.1.1 & D. 2 & 0.3 & 0.4 & 0.6 & 0.7 & 0.9 & 1.1 & 1.4 & 1.5 & 1.9 & 2.2 & 2.5 & 2.9 & 3.3 & $3 \mathrm{~J}$ & 4.1 & 45 \\
\hline 300 & & & 0.2 & 03 & 0.4 & 0.5 & 0.7 & 0.8 & 1 & 1.3 & 1.5 & 1. $\mathrm{B}$ & 2 & 2.3 & 27 & 3 & 3.4 & 38 & 4.2 \\
\hline
\end{tabular}

f) Alinhamento Vertical

i. Grade

A AASHTO (1999) diz que o grade deve ser mínimo, e grades maiores de 5\% são indesejáveis pois é difícil para alguns ciclistas subir e na descida pode levar alguns ciclistas a desenvolver altas velocidades. Caso seja necessário devido a condições do terreno: 
Tabela 2-23 - - Grades maiores que 5\% (Fonte: Guide for Development of Bicycle Facilities, AASHTO, 1999)

$$
\begin{aligned}
5-6 \% & \text { maior que } 240 \mathrm{~m} \\
7 \% & \text { maior que } \mathbf{1 2 0} \mathbf{~ m} \\
8 \% & \text { maior que } 90 \mathrm{~m} \\
9 \% & \text { maior que } 60 \mathrm{~m} \\
10 \% & \text { maior que } 30 \mathrm{~m} \\
11+\% & \text { maior que } \mathbf{1 5} \mathrm{m}
\end{aligned}
$$

Quando utilizar um grade mais elevado, acrescentar 1,20 a 1,80m de largura, para permitir que ciclistas mais lentos andem desmontados.

O GEIPOT (2001) da mesma forma diz que é importante buscar atenuar as rampas, observando-se as relações apresentadas na Figura 2-48.

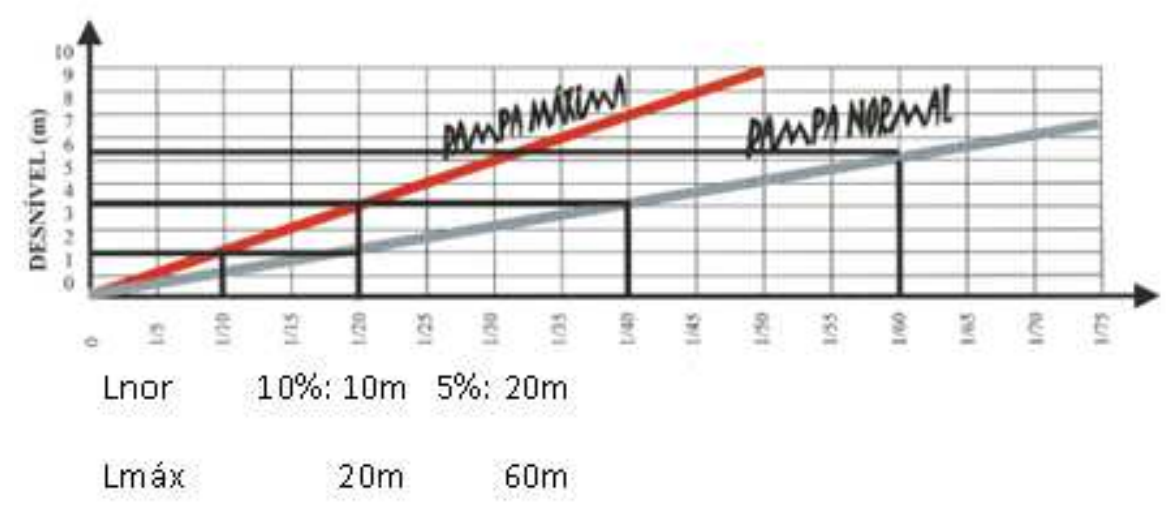

Figura 2-48 - Rampas normais máximas admissíveis em função do desnível a vencer (Fonte: Manual de Planejamento Cicloviário, GEIPOT, 2001)

E ainda, quando for possível deve-se adotar rampas escalonadas, para que não seja uma rampa muito longa.

ii. Comprimento mínimo de curva vertical necessário para garantir uma distância de visibilidade de parada 
O Manual da AASHTO (1999) traz ainda uma tabela com comprimentos mínimos de curva vertical necessário para garantir uma distância de visibilidade de parada para várias velocidades, considerando a altura do olho do ciclista é considerada $1400 \mathrm{~mm}$ e do objeto $0 \mathrm{~mm}$.

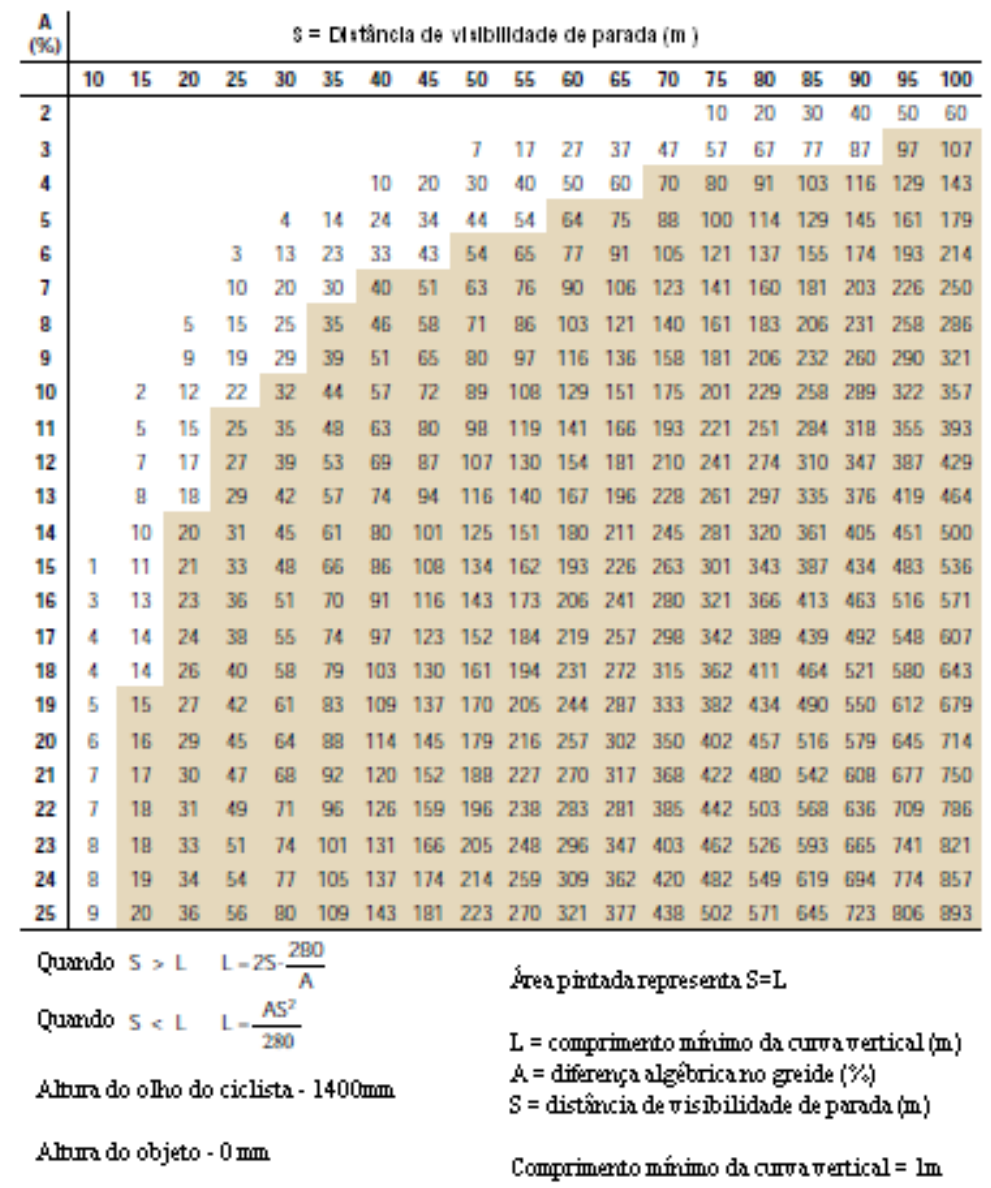

Tabela 2-24 - comprimentos mínimos de curva vertical necessário para garantir uma distância de visibilidade de parada (Fonte: Guide for Development of Bicycle Facilities, AASHTO, 2004)

b. Tratamentos nas Interseções

A AASHTO (1999) classifica as interseções entre vias e ciclovias em três grupos: meio de quadra, adjacentes e complexas. 
As interseções de meio de quadra são aquelas que acontecem longe de cruzamentos. Nesse caso o ideal é que seja em um ângulo de $90^{\circ}$, podendo ser aceito um ângulo mínimo de $45^{\circ}$. Sinalização e semaforização deve ser de acordo com MUTCD.

O critério para semaforização de pedestres é 60 brechas adequadas por hora, em áreas escolares segundo o MUTCD de 2009. O critério foi introduzido pelo MUTCD de 1988 também para áreas escolares e depois foi estendido a todos os semáforos implantados para o atendimento aos pedestres no MUTCD de 2000 e 2003, voltando a ser específico para áreas escolares no MUTCD de 2009.

As interseções adjacentes acontecem quando a ciclovia cruza a via em um cruzamento existente. Nesse caso é necessário: proibir conversão à esquerda veicular com fluxo oposto quando há alto volume de veículos e/ou bicicletas; para a saída da conversão à direita, reduzir o raio da curva a fim de reduzir a velocidade dos veículos; para a entrada da conversão à direita, é recomendado não permitir conversão no vermelho; para entrada da conversão à direita e movimento direto é recomendado usar uma linha de retenção antes do cruzamento com ciclistas; uma fase de vermelho total para proteger os usuários da via.

Interseções complexas são os demais tipos de interseções e deve ser analisado caso a caso. Algumas alternativas: mover travessia, instalar semáforo, mudar o tempo do semáforo, utilizar ilha de refúgio.

Alguns problemas relativos aos três tipos de interseções, citados pelo manual estão listados a seguir:

Controle de Tráfego: Semáforos / Sinais de Pare ou Dê Preferência: Não se deve considerar somente as necessidades do tráfego veicular, mas também o conforto e conveniência dos usuários da ciclovia (tolerância ao atraso, desejo de manter movimento, desconhecimento do tráfego, desrespeito à regulamentação); todos os cruzamentos com ciclovias devem ter sinalização de controle seguindo os critérios usuais do MUTCD para decidir sobre a semaforização; semáforo atuado deve ser colocado em local de fácil acesso, $1,20 \mathrm{~m}$ do solo (não há necessidade do ciclista desmontar); sinais de pare devem ser colocados o mais próximo possível do local e complementados com uma linha de retenção ("stop bar"); sinais de Dê Preferência são aceitáveis em locais com baixo volume de 
tráfego, baixa velocidade nas vias adjacentes; deve-se ter cuidado para que os motoristas não sejam confundidos com os sinais para ciclistas.

Zonas de transição: Visam integrar os caminhos de uso compartilhado ao sistema viário existente; devem haver sinalização adequada das transições e dos extremos das ciclovias, para ciclistas, pedestres e motoristas; cada interseção deve ser considerada como um potencial local de entrada/saída de ciclistas.

Distância de visibilidade: É o elemento mais importante de interseções. Pode-se citar três tipos de distância de visibilidade: distância de visibilidade de parada, distância de visibilidade da interseção, e distância de visibilidade de decisão. A distância de visibilidade de parada visa melhorar a condição usando um tempo de percepção e reação maior que $2,5 \mathrm{seg}$ ou a distância de visibilidade de decisão apropriada de acordo com o Green Book. Não discute especificamente a distância de intervisibilidade das interseções com ciclistas.

Tratamentos de aproximação: As aproximações devem ser preferencialmente niveladas; a sinalização de advertência adequada a distância de visibilidade existente para permitir a parada dos ciclistas especialmente em declives e deve-se pavimentar pelo menos $3 \mathrm{~m}$ na aproximação de interseções, para ciclovias não pavimentadas.

Largura das rampas: A largura das rampas nas interseções deve ser pelo menos a mesma da ciclovia; um raio ou alargamento de $1,5 \mathrm{~m}$ deve ser considerado para facilitar as conversões.

Ilha de refúgio: Deve ser considerada quando há: alto volume de tráfego ou velocidade dos veículos; largura excessiva da via dado o tempo disponível para travessia; travessia será feita por pessoas mais lentas (próximo a escolas, deficientes). Largura da ilha de refúgio na área de espera (Y): 2m-pouco; 2,5m-satisfatório; 3m-bom. Comprimento da ilha de refúgio lateral (X): Maior ou igual a $2 \mathrm{~m}$ (marcação paralela). Comprimento de transição (L): $0,62 \times \mathrm{VxW}, \mathrm{V}$ em $\mathrm{km} / \mathrm{h}, \mathrm{W}=\mathrm{Y} / 2$ 


\subsubsection{Calçada Compartilhada}
a) Largura

Da mesma forma que o mencionado acima para ciclovias, a AASHTO (1999) recomenda 1,8m para caminhos unidirecionais e para caminhos bidirecionais, que seja utilizado $3,0 \mathrm{~m}$, sendo aceitável 2,4m quando tráfego de bicicletas é baixo, uso de pedestres ocasional, bom alinhamento vertical e horizontal. Em certas circunstâncias pode ser necessário aumentar a largura para 3,60m ou 4,20m devido ao grande volume de ciclistas, pedestres, skatistas.

Segundo o GEIPOT (2001), em calçadões de pedestres, unidirecionais, pode ser utilizada uma largura de 1,20m (pois a velocidade dos ciclistas é menor devido ao grande número de pedestres), sendo que a faixa separadora pode ser feita internamente, restando 1,0m de área útil para o ciclista.

\subsection{ANÁLISE DA OPERAÇÃO PARA CICLISTAS}

A seguir, baseado nos procedimentos recomendados pelo HCM (2000) será feito a avaliação da capacidade e nível de serviço de dispositivos para usos de bicicletas. A classificação utilizada é, como no caso dos pedestres, vias de fluxo contínuo (vias exclusivas e de uso compartilhado com pedestres, separados fisicamente do fluxo de veículos) e fluxo descontínuo (faixas de bicicletas que passam por interseções, semaforizadas e não semaforizadas).

Novamente, a discussão dos critérios recomendados pelo HCM (2000) é feita em termos gerais. Os detalhes do procedimento recomendado estão no Apêndice B. 


\subsubsection{Nível de Serviço em Vias Exclusivas}

Os procedimentos adotados pelo HCM (2000) novamente tomaram como base os métodos holandeses, como apresentado por BOTMA (1995), baseados no conceito de impedimento e na freqüência de encontros e passagens.

Assumindo distribuição normal da velocidade das bicicletas com velocidade média de 18 $\mathrm{km} / \mathrm{h}$ e desvio padrão de $3 \mathrm{~km} / \mathrm{h}$, a freqüência de encontros, $f_{m}$, e de ultrapassagens $f_{p}$, é calculada conforme segue:

$$
\begin{gathered}
F_{p}=0.188 v_{s} \\
F_{m}=2 v_{o} \\
F=0.5 F_{m}+F_{p}
\end{gathered}
$$

$F_{p}=$ número de eventos de ultrapassagem (com ciclistas na mesma direção) (eventos/h);

$F_{m}=$ número de eventos opostos (com ciclistas na direção oposta) (eventos/h);

$F=$ número total de eventos na via (eventos $/ \mathbf{h}$ ), com um fator de peso de 0,5 para eventos de encontro;

$v_{s}=$ taxa de fluxo de bicicletas na direção avaliada (bicicletas/h);

$v_{0}=$ taxa de fluxo de bicicletas na direção oposta (bicicletas $/ \mathbf{h}$ )

Com base nestas medidas de interação entre ciclistas, a tabela traz o critério de NS para bicicletas em vias exclusivas:

Tabela 2-25 - Critério de NS para bicicletas em vias exclusivas (Fonte: Special Report 209: Highway Capacity Manual, TRB. National Research Council, Washington, D.C., 2000)

\begin{tabular}{c|c|c}
\hline Nivel de Serviço & $\begin{array}{c}\text { Frequência de Eventos, 2 sentidos, 2 faixas } \\
\text { (eventos/h) }\end{array}$ & $\begin{array}{c}\text { Frequência de Eventos, 2 sentidos, 3 faixas } b \\
\text { (eventos/h) }\end{array}$ \\
\hline A & $\leq 40$ & $\leq 90$ \\
B & $>40-60$ & $>90-140$ \\
C & $>60-100$ & $>140-210$ \\
D & $>100-150$ & $>210-300$ \\
E & $>150-195$ & $>300-375$ \\
F & $>195$ & $>375$ \\
\hline
\end{tabular}

Notas:

a. vias de $2,4 \mathrm{~m}$ de largura. Também utilizado para bicicletas na via

b. vias de $3,0 \mathrm{~m}$ de largura 


\subsubsection{Nível de Serviço em Vias de Uso Compartilhado Segregadas do Fluxo Motorizado}

Os mesmos procedimentos adotados pelo HCM (2000) na análise do fluxo compartilhado para pedestres são utilizados para avaliar o ponto de vista dos ciclistas, novamente com base nos métodos holandeses, como apresentado por BOTMA (1995), no conceito de impedimento e na freqüência de encontros e passagens.

Mantendo a suposição de distribuição normal com médias de $18 \mathrm{~km} / \mathrm{h}$ para pedestres e de 4,5 $\mathrm{km} / \mathrm{h}$ para ciclistas, as estimativas de interação são:

$$
\begin{gathered}
F_{p}=3 v_{p s}+0.188 v_{b s} \\
F_{m}=5 v_{p o}+2 v_{b o} \\
F=0.5 F_{m}+F_{p}
\end{gathered}
$$

$$
\begin{aligned}
& F, F_{p}, F_{m} \text { definidos anteriormente } \\
& v_{p s}=\text { taxa de fluxo de pedestres na direcão analisada }(\mathrm{p} / \mathrm{h}) \\
& v_{b s}=\text { taxa de fluxo de bicicletas na direção analisada (bicicletas/h) } \\
& v_{p o}=\text { taxa de fluxo de pedestres na direção oposta }(\mathrm{p} / \mathrm{h}) \\
& v_{b o}=\text { taxa de fluxo de bicicletas na direção oposta (bicicletas/h) }
\end{aligned}
$$

Com base nestas medidas de interação entre ciclistas e pedestres, a tabela traz o critério de NS para bicicletas em vias compartilhadas: 
Tabela 2-26 - Critério de NS para ciclistas em vias de uso compartilhado segregadas do tráfego motorizado (Fonte: Special Report 209: Highway Capacity Manual, TRB. National Research Council, Washington, D.C., 2000)

\begin{tabular}{c|c|c}
\hline Nivel de Serviço & $\begin{array}{c}\text { Frequência de Eventos, 2 sentidos, 2 faixas }{ }^{a} \\
\text { (eventos } h \text { ) }\end{array}$ & $\begin{array}{c}\text { Frequência de Eventos, 2 sentidos, } 3 \text { faixas } \\
\text { (eventos } h \text { ) }\end{array}$ \\
\hline A & $\leq 40$ & $\leq 90$ \\
B & $>40-60$ & $>90-140$ \\
C & $>60-100$ & $>140-210$ \\
D & $>100-150$ & $>210-300$ \\
E & $>150-195$ & $>300-375$ \\
F & $>195$ & $>375$ \\
\hline
\end{tabular}

Notas:

a. vias de $2,4 \mathrm{~m}$ de largura. Também utilizado para bicicletas na via

b. vias de $3,0 \mathrm{~m}$ de largura

\subsubsection{Nível de Serviço em Ciclofaixas}

No HCM (2000), não há um procedimento detalhado para analisar ciclofaixas e, por extensão, acostamentos (considerado um contex to similar), ponderando o efeito do tráfego adjacente de veículos motorizados, tráfego de veículos pesados, estacionamento, entre outros.

\subsubsection{Interseções Semaforizadas}

O procedimento adotado pelo HCM (2000) trata o fluxo de bicicletas de forma similar ao fluxo veicular em interseções semaforizadas. A capacidade e o atraso são calculados conforme segue:

$$
\mathrm{C}_{\mathrm{b}}=\mathrm{s}_{\mathrm{b}} \frac{\mathrm{g}}{\mathrm{C}}=2000 \frac{\mathrm{g}}{\mathrm{C}} \quad \begin{aligned}
c_{b} & =\text { capacidade da ciclofaixa (bicicletas/h) } \\
s_{b} & =\text { tluxo de saturação da ciclofaixa (bicicletas; } \mathbf{h}) \\
\mathrm{g} & =\text { verde efetivo para a ciclofaixa } \\
\mathrm{C} & =\text { tempo de ciclo do semáforo }
\end{aligned}
$$




$$
\begin{aligned}
d_{\mathrm{b}} & =\frac{0.5 \mathrm{C}\left(1-\frac{\mathrm{g}}{\mathrm{C}}\right)^{2}}{1-\left[\frac{\mathrm{g}}{\mathrm{C}} \min \left(\frac{\mathrm{v}_{\mathrm{b}}}{\mathrm{C}_{\mathrm{b}}}, 1.0\right)\right]} \\
d_{b} & =\text { atraso (seg/bicicleta) } \\
v_{b} & =\text { taxa de fluxo na ciclofaixa unidirecional (bicicletas/h) }
\end{aligned}
$$

Tabela 2-27 - NS para bicicletas em interseções semaforizadas (Fonte: Special Report 209: Highway Capacity Manual, TRB. National Research Council, Washington, D.C., 2000)

\begin{tabular}{c|c}
\hline Nivel de Serviço & Atraso (seg/bicicleta) \\
\hline A & $<10$ \\
B & $\geq 10-20$ \\
C & $>20-30$ \\
D & $>30-40$ \\
E & $>40-60$ \\
F & $>60$ \\
\hline
\end{tabular}

Também de forma simular, o NS para ciclistas em interseções semaforizadas é definido em função do atraso em espera no semáforo:

\subsubsection{Interseções não semaforizadas}

Também em interseções não semaforizadas, o procedimento adotado pelo HCM (2000) trata o fluxo de bicicletas de forma similar ao fluxo veicular. O HCM (2000) recomenda fórmula poissoniana para capacidade, mas não fornece brechas críticas.

Para atraso, recomenda usar as mesmas expressões adotadas para veículos, advertindo que ciclistas não formam fila nas aproximações. É recomendado desprezar atrasos nas conversões à direita e usar critério de nível de serviço de interseção semaforizada. Adverte ainda sobre as manobras com entrelaçamento com veículos. 


\section{METODOLOGIA PARA O ESTUDO DE CAMPO E APLICAÇÃO A UM CASO PILOTO}

O estudo de campo buscará medir a segurança de trânsito para pedestres e ciclistas em rodovias, tanto no deslocamento longitudinal como em travessias.

A metodologia a ser utilizada inicialmente é a da análise de oportunidade de manobra e oportunidade de conflito. A seguir, as características principais dos métodos de análise, empírico e teórico, baseados nestes conceitos são apresentadas. As oportunidades de conflito são eventos similares aos conflitos de tráfego, mais extensamente estudados (também mencionados adiante). A discussão inicial também analisa outros métodos recentemente propostos para análise de travessias de pedestres, de forma a incorporar pontos de interesse.

Em seguida, é apresentado o estudo de campo incluindo:

- seleção de trechos para análise (nas rodovias gerenciadas pela ViaOeste, para as quais obteve-se dados para aplicação) e descrição das características da operação e dos acidentes no trecho selecionado que envolvem pedestres e ciclistas (o escopo do trabalho);

- investigação do diagnóstico dos problemas de segurança para pedestres e ciclistas obtidos com a análise das oportunidades de manobra ou de conflito (estendida convenientemente para 
contextos ainda não considerados atualmente) e comparação com o diagnóstico obtido da análise da segurança viária local, particularmente com os acidentes correspondentes.

\subsection{MÉTODOS DE OPORTUNIDADES DE MANOBRA E CONFLITO}

Este estudo busca analisar a segurança de trânsito oferecida aos pedestres e ciclistas nos projetos viários, no contexto particular das rodovias concessionadas paulistas, analisando medidas objetivas relacionadas com o risco de acidentes envolvendo usuários vulneráveis da via. Em vista das dificuldades de avaliar a segurança de trânsito em projetos viários com base no potencial de acidentes, a investigação deve incluir outras variáveis.

Os dados ou as estatísticas de acidentes revelaram-se um instrumento inadequado para efeitos de análise e projeto de segurança, pois:

- levam um longo tempo para serem acumulados, o que inclusive pode comprometer simples avaliações do tipo "antes-depois" em função da ocorrência de alterações durante o período de avaliação (sem mencionar os vieses decorrentes dos critérios de escolha dos locais);

- não são passíveis de observação direta, o que torna a informação imprecisa e dificulta as inferências sobre a relação entre os fatores intervenientes;

- não permitem ação preventiva, uma vez que a insegurança somente será detectada após a ocorrência dos acidentes.

Em face da dificuldade de coletar dados suficientes sobre acidentes (o dado usual para análise de segurança), da importância de ter um método preventivo (tanto aplicável às fases iniciais da operação quanto às etapas de projeto) e da necessidade de considerar as especificidades das formas alternativas de tratamento em um determinado local, por tudo isso, seria desejável que essa medida pudesse ser estimada em função de dados de tráfego fáceis de coletar, como 
volumes de tráfego e de pedestres, dados físicos dos locais e decisões de tratamento, como geometria, estágios/tempos semafóricos, etc.

A evolução dos conceitos ou parâmetros que medem a segurança de um local a partir de medidas mais operacionais, em complementação ou substituição (conforme a disponibilidade) aos dados de acidentes de trânsito, pode ser resumida no desenvolvimento dos conceitos e técnicas de análise de medidas correlatas de segurança, de análise de conflitos de tráfego e de análise de medidas de oportunidades de conflito de tráfego.

A técnica de conflitos de tráfego supre as deficiências características dos dados de acidentes apontadas acima. Contudo, a sua pesquisa em campo exige um esforço adicional para estabelecer a relação intrínseca entre as variáveis envolvidas, sendo suspeitos de não ter resultados transferíveis de um local para outro.

Para suprir a dificuldade de obtenção direta de dados de acidentes e conflitos de tráfego seria necessário um método de obtenção indireta desses dados através de um modelo matemático que permita estimá-los usando dados mais fáceis de serem obtidos e que pudesse ser deduzido diretamente de variáveis físicas e de tráfego dos locais, de forma a contornar a principal desvantagem em usar os dados de acidentes ou mesmo de conflitos de tráfego (como medida operacional para determinar o grau de segurança).

Para este fim, o conceito de oportunidade de manobra e de conflito tem sido proposto para obter medidas analíticas de segurança. Essa abordagem permite o desenvolvimento de métodos para fazer estimativas de oportunidades de manobra e de conflito, o que torna este parâmetro uma medida potencialmente adequada para determinar o nível de segurança de um determinado local ou fazer projeções sobre a efetividade de projetos de segurança.

Medidas de segurança explorando o conceito de oportunidade de manobra e de conflito são encontradas em VASCONCELOS (2004) no contexto empírico, aplicada a pedestres em uma interseção semaforizada. Modelos analíticos de previsão foram também desenvolvidos em MING (2008), para oportunidades de conflito de tráfego, incluindo pedestres e veículos, em interseções semaforizadas ou não. 
O desenvolvimento destes conceitos e técnicas têm motivações diversas. De maneira geral, tem-se percebido a necessidade de um meio de medir o nível/grau de segurança de uma forma que possibilite uma hierarquização entre diversos locais ou a seleção de tratamentos em um determinado local. Este trabalho visa aplicar estes conceitos e técnicas e contrastá-los com observações de campo e dados de acidentes, como forma de contribuir para sua validação.

Serão aqui revisados os seguintes trabalhos:

1. VASCONCELOS, V. M. A. - Oportunidades de Travessia e Oportunidades de Conflito para Pedestres em Interseções Semaforizadas - Dissertação apresentada à Escola Politécnica da Universidade de São Paulo, São Paulo, Brasil, 2004.

2. MING, S. H. - Oportunidades de Conflito de Tráfego - Modelos de Previsão Dissertação apresentada à Escola Politécnica da Universidade de São Paulo, São Paulo, Brasil, 2008.

\subsubsection{Método de Análise Empírica}

O objetivo da análise empírica das oportunidades de manobra e das oportunidades de conflito é o de mensurar a sua ocorrência (frequência) nos locais em estudo.

VASCONCELOS (2004) avaliou a segurança nas travessias dos pedestres, com um método empírico, evidenciando-se os conceitos de oportunidade de travessia e oportunidades de conflito entre pedestres e veículos.

Em VASCONCELOS (2004), o conceito de oportunidade de travessia a ser utilizado é definido com evento elementar em que o pedestre aceita atravessar a via. As brechas são o aspecto básico primeiro, mas outros aspectos devem ser também considerados. 
Na opção metodológica adotada, as oportunidades de travessias são inicialmente classificadas pelo grau de risco objetivo oferecido ao pedestre.

Oportunidades de travessia (OT): situação em que ocorrem condições que proporcionam ao pedestre a possibilidade de atravessar a via. Esta situação deve ser identificada pela probabilidade de concluir a travessia eventualmente com algum risco objetivo ao pedestre. Este risco eventual pode causar dúvida sobre a aceitação da situação pelos pedestres em alguma condição para travessia. Este conceito deve ser aplicado para cada categoria de pedestres e inclui as oportunidades ideais de travessia.

Oportunidades de travessia ideal (OTI): situação em que ocorrem condições de travessia 'ideais' para os pedestres que proporcionam a possibilidade ao atravessar a via sem arriscar-se. Esta situação deve ser identificada pela probabilidade muito baixa de ocorrer algum risco objetivo ao pedestre diante da travessia e pela ampla aceitação pelos pedestres desta condição para travessia. Este conceito também deve ser aplicado para cada categoria de pedestres.

Nas travessias efetivas, pode haver risco mesmo numa OTI se o pedestre atravessa no seu início ou término. No primeiro caso (travessia no início), o risco é provavelmente controlado, mas no segundo caso (travessia no final) pode não sê-lo quando a chegada do pedestre ocorre com um tempo restante ("lag") reduzido.

As demais oportunidades de travessia são 'não ideais' e serão ainda sub-divididas em dois grupos:

- as oportunidades de travessia com risco aceitável (OTRA), e

- as com risco inaceitável (OTRI).

As brechas nunca utilizadas (pela duração reduzida ou outra característica) definiriam as nãooportunidades de travessia (NOT).

São ainda definidos quatro tipos de brechas: 
(1) as brechas próximas às "mínimas de separação" entre veículos (intervalo de tempo no pelotão) e conseqüentemente o pedestre nem cogitaria em atravessar;

(2) "brechas reduzidas" (tempo mínimo, próximo, porém abaixo do necessário para a travessia) nas quais poucos pedestres aceitariam atravessar e em que a existência de risco objetivo é certa e significativa;

(3) brechas intermediárias, próximas do tempo de travessia, em que o pedestre ficará em dúvida sobre a existência de risco objetivo (o que normalmente depende da posição dos veículos nas faixas e do sentido da travessia do pedestre); e

(4) brechas amplamente maiores do que os tempos de travessia, nas quais há a situação de segurança ideal (também é a situação nos estágios exclusivos de pedestres ou estágios com movimentos de pedestres protegidos).

A caracterização das oportunidades de travessia para um local de travessia, considerando as diferentes categorias de pedestres e tipos de fluxo conflitante ou conflito envolvido, pode ser feita através de diversas variáveis. Entre estas estão:

(1) Duração média da oportunidade de travessia (seg/OT ou seg/OTRA);

(2) Freqüência de oportunidades de travessia (OT/hora ou OTRA/hora);

(3) Duração total das oportunidades de travessia (horaOT/hora ou horaOTRA/hora); e

(4) Tempo normal de travessia (seg, estimado como L/Vp, onde: L é a largura da via a ser transposta pelo pedestre e Vp é a velocidade do pedestre em questão).

(5) Intervalo médio entre oportunidades de travessia (seg/OT ou seg/OTRA);

(6) Tempo de espera médio pela oportunidades de travessia (seg/OT ou seg/OTRA);

(as quatro primeiras foram propostas por VASCONCELOS (2004), enquanto as duas outras variáveis foram aqui propostas).

Na proposta de VASCONCELOS (2004), cada uma das diferentes caracterizações das oportunidades de travessias é distinta para as diferentes categorias de pedestres: 
- o pedestre com passo normal ou moderado (algo como 1,4 m/s) que é prudente na aceitação das situações de risco (não aceita veículos a menos de 2 segundos de separação, seja na travessia ou na espera na via, e considera aceitável uma separação maior que 2 segundos enquanto considera ideal uma separação superior a 5 segundos);

- o pedestre com passo rápido (algo como 2,0 m/s) e comportamento ousado diante das situações de risco (não aceita apenas ser atropelado e admite mesmo a espera entre faixas de tráfego, considerando aceitável uma separação maior que 1 segundo e ideal uma separação superior a 3 segundos);

- o pedestre vagaroso (algo como 0,8 m/s) e comportamento conservador diante das situações de risco (não aceita veículos a menos de 3 segundos de separação e nunca inicia uma travessia com espera na via, considera aceitável uma separação maior que 3 segundos e ideal uma separação superior a 6 segundos).

VASCONCELOS (2004) também investiga a caracterização das Oportunidades de Conflito (OC), entendidas genericamente como situações nas quais existem certas pré-condições para a ocorrência das situações de risco.

Para cada pedestre o número de oportunidades de conflitos é dado pela quantidade de vezes que ele se depara com veículos conflitantes e, eventualmente, com brechas de magnitude insuficiente até encontrar uma brecha adequada. O tempo em que os pedestres expõem-se a estes eventos pode também ser um aspecto relevante.

Os conceitos de oportunidades de conflito investigados por VASCONCELOS (2004) são:

(1) oportunidades de conflito OC1 medidas pelo produto dos fluxos conflitantes:

- OC1a, utilizando os fluxos de tráfego médios,

- OC1b, utilizando os fluxos de tráfego médios de cada estágio,

- outros critérios de fluxo, por exemplo diferenciando fluxos por faixas ou fluxos nos verdes e entreverdes nos estágios; 
(2) oportunidades de conflito OC2 medidas apenas pela coexistência, com o pedestre esperando/atravessando e o veículo conflitante deslocando-se ou eventualmente desacelerando/parando:

- OC2a, sem distinguir os valores das brechas entre veículos ou as velocidades de veículos ou pedestres, considerando apenas o veículo passando e o pedestre esperando,

- OC2b-3, desprezando as brechas veiculares menores que Tn-3 seg, (ou outra margem de tempo) considerando os tempos de travessia compatíveis com as velocidades usuais dos pedestres,

- outros critérios de coexistência, por exemplo considerando as velocidades específicas dos pedestres e os requisitos de espera na calçada, fila de veículo parada ou outros.

(3) oportunidade de conflito OC3 medidas pela travessia na presença de veículos, com o pedestre atravessando e os veículos deslocando-se ou desacelerando/parando diante do pedestre na mesma faixa de tráfego:

- OC3a-3, distinguindo apenas as brechas em que a travessia ocorre com duração tempo livre em relação ao veículo adiante de até $3 \mathrm{seg}$, (ou outra margem de tempo), considerando os tempos de travessia compatíveis com as velocidades usuais dos pedestres,

- OC3b-3, distinguindo apenas as brechas em que a travessia ocorre com duração tempo livre em relação ao veículo adiante de até $3 \mathrm{seg}$, (ou outra margem de tempo), considerando os tempos de travessia e as velocidades específicas dos pedestres,

- outros conceitos de travessia, como os correspondentes a brechas potencialmente utilizáveis (mesmo quando rejeitadas pelos pedestres);

(4) oportunidade de conflito OC4, medidas pelo conflito efetivo, com o pedestre atravessando diante de veículos em curso de acidente (exigindo manobra evasiva):

- OC4a, com movimentação veicular em desaceleração ou desvio;

- OC4b,: com movimentação veicular em desaceleração ou desvio ou pedestres alterando seu percurso na travessia, 
- ou outro contexto similar, ponderando a gravidade do conflito potencial.

A Figura 3-1 mostra a classificação utilizada das oportunidades de travessia e sua relação com a classificação das oportunidades de conflitos:

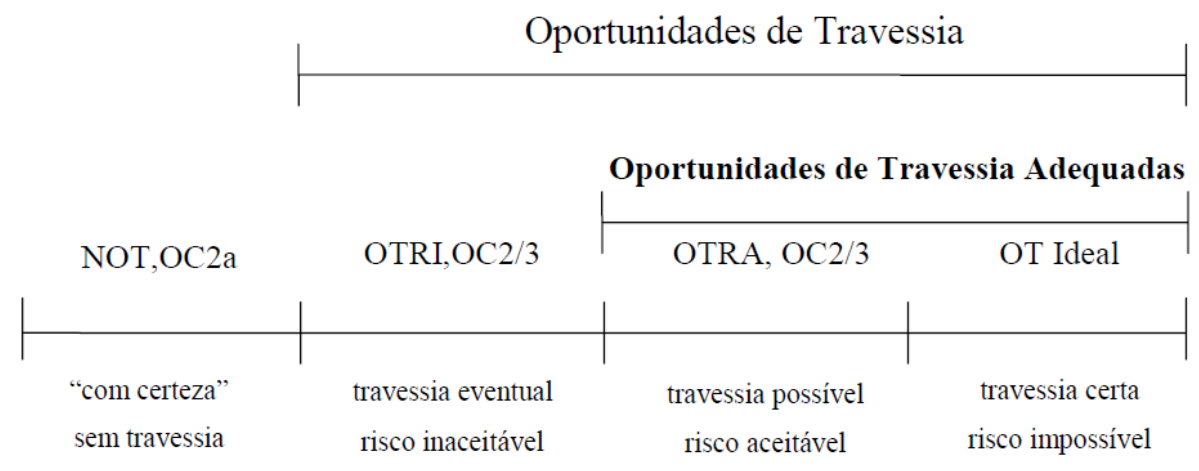

Figura 3-1 - Classificação das oportunidades de travessia e sua relação com a classificação das oportunidades de conflito (Fonte: VASCONCELOS, V.A. - Oportunidades de travessia e oportunidades de conflito para pedestres em interseções semaforizadas, 2004)

Como critério de validação, o estudo de VASCONCELOS (2004) analisou a adequação das medidas alternativas propostas avaliando sua correlação com a segurança das travessias efetivamente observadas, avaliadas subjetivamente.

As travessias efetivas dos pedestres foram qualificadas em:

- travessias ideais (TI): nas quais as esperas ocorrem nas calçadas ou em faixas adjacentes sem veículos, com tempo livre de pelo menos 4 segundos diante do veículo na posição crítica da travessia (de menor tempo livre);

- travessias de risco aceitável (TRA): nas quais as esperas na mesma faixa do veículo em movimento ocorrem durante 1 segundo no máximo (a resolução da medida de tempo) e o tempo livre diante do veículo na posição crítica da travessia é maior do que 1 segundo, mas menor do que 4 segundos (da travessia ideal);

- travessia de risco inaceitável (TRI): nas quais as esperas na mesma faixa do veículo em movimento ocorrem por mais de um segundo ou o tempo livre diante do veículo na posição 
crítica da travessia é de 1 segundo ou nenhuma (isto é, pedestre e veículo ocupam o mesmo trecho da via em segundos consecutivos); e

- não travessia (NT): nas quais o pedestre abandonou o desejo inicialmente manifestado de realizar a travessia no local em avaliação.

A análise da correlação com dados de acidentes de trânsito será uma adição ao trabalho de VASCONCELOS (2004). No entanto, o trabalho citado é especialmente relevante pelo desenvolvimento da metodologia de observação empírica dos conceitos.

Na metodologia de campo e de análise adotaram-se as seguintes definições:

Unidade de tempo na observação: tanto as oportunidades de travessia quanto as oportunidades de conflitos serão medidas/computadas como uma variável de tempo. Durante as observações houve dificuldade em decidir qual seria a unidade de medição.

Anotação da movimentação veicular e de pedestres: O detalhe da movimentação dos veículos e pedestres em cada faixa de tráfego foi registrada. A metodologia busca analisar as brechas na travessia de cada faixa (que corresponde à travessia em etapas, com eventual espera nas faixas de tráfego adjacentes).

Seleção das Travessias Críticas: Decidiu-se focar a análise apenas nas travessias críticas de uma dada interseção. O critério utilizado para caracterizar uma interseção como crítica foi a ausência de tempo específico para a travessia de pedestres nas saídas e existência de travessias concorrentes de pedestres com movimentos veiculares.

A fonte de dados para o estudo de campo foi obtida através de filmagem. Os critérios utilizados para interpretação dos vídeos estão descritos em detalhe no trabalho de VASCONCELOS (2004).

De forma resumida, o estudo concluiu que as oportunidades de conflito foram melhores como medida explicativa para as travessias com risco inaceitável, provavelmente devido ao efeito da interação do tráfego veicular com os pedestres que é contemplada pelas oportunidades de conflito. Já a variação percebida pode estar relacionada com a omissão de algumas variáveis, como a composição do tráfego, as manobras de conversão e as velocidades. No entanto as 
oportunidades de travessia se mostraram importantes por apresentarem o perfil das condições de travessia.

A análise proposta está baseada na contagem direta das oportunidades de travessia e de conflito e na comparação com os conflitos ou com as travessias efetivamente realizadas segundo a avaliação da sua segurança.

Em VASCONCELOS (2004), estes dados primários foram correlacionados entre si e a relação entre as contagens obtidas e as variáveis de tráfego e de controle semafórico ou sua correlação com as variáveis de comportamento e de aceitação de brecha foi investigada. Propõe-se adicionar a análise da correlação com os acidentes.

Deve-se observar que o escopo deste trabalho também inclui os movimentos de pedestres ao longo da via e os movimentos de pedestres de travessia e ao longo da via. Portanto, novos conceitos e procedimentos podem ser necessários.

\subsubsection{Análise com Modelos de Previsão}

O objetivo da análise baseada em modelos das oportunidades de manobra e das oportunidades de conflito é o de prever a sua ocorrência (freqüência) em locais em estudo.

MING (2008) estudou e desenvolveu modelos matemáticos que possam avaliar a segurança viária usando o conceito de oportunidades de conflito de tráfego em interseções semaforizadas ou não, buscando obter a precisão necessária para efeitos de aplicação prática.

Os contextos analisados por MING (2008) foram:

a) Movimento veicular em interseções com sinalização de prioridade;

b) Movimento veicular em interseções semaforizadas, incluindo: 
i. movimentos veiculares protegidos;

ii. movimentos veiculares permitidos;

iii. entreverdes.

c) Movimento de pedestres em interseções com sinalização de prioridade;

d) Movimento de pedestres em interseções semaforizadas, incluindo:

i. movimentos de pedestres protegidos;

ii. movimentos de pedestres permitidos;

iii. entreverdes.

Neste trabalho interessam os modelos propostos por MING (2008) para oportunidades de conflitos envolvendo pedestres em interseções semaforizadas ou não. MING (2008) não desenvolveu modelos correspondentes às oportunidades de manobra (travessia) mas estes podem ser considerados similares aos desenvolvidos.

O objetivo buscado com a aplicação dos modelos de oportunidades de conflito foi o uso do conceito de oportunidade de conflito de tráfego buscando permitir o desenvolvimento de métodos analíticos que dependam apenas de dados de tráfego e de parâmetros relacionados à geometria e ao tipo de controle.

MING (2008) ressalta que existe a dificuldade de considerar a preferência entre veículos e pedestres, definida pelas regras gerais de circulação. Face à ambiguidade existente na legislação e à inobservância da preferência dos pedestres em São Paulo, este aspecto é difícil de analisar.

No caso de travessias em interseções não semaforizadas, a hipótese adotada para o desenvolvimento do modelo é que não há acúmulo de pedestres (os pedestres chegam e atravessam um a um). Sem distinguir as faixas, o tempo de exposição de cada pedestre é seu tempo de travessia na zona de conflito e a probabilidade de uma chegada conflitante define 
uma oportunidade de conflito com pedestres correspondente. As expressões desenvolvidas para o modelo de previsão para este caso foram as seguintes:

Tabela 3-1 - Oportunidades de conflito em interseções com sinalização de prioridade (Fonte: MING, S. H. Oportunidades de Conflito de Tráfego - Modelos de Previsão, 2008),

a. Modelos de Previsão

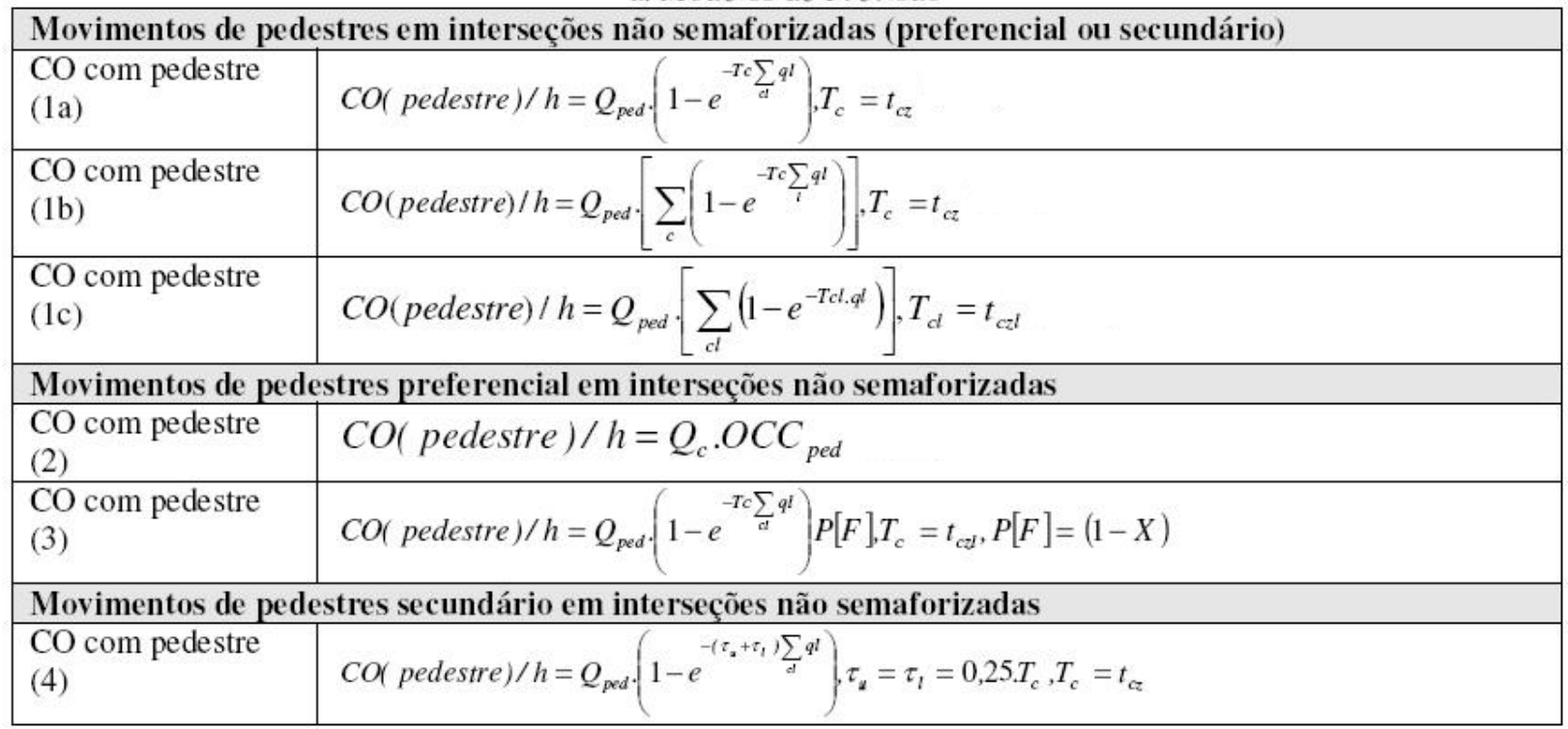

b. Expressões Auxiliares

\begin{tabular}{|l|l|}
\hline Interseções não semaforizadas \\
\hline$T_{i}=t_{z c i}$ & $t_{z c i}=\frac{W_{z c}}{v_{p e d}}$ \\
\hline$O C C_{\text {ped }}=O C C_{\text {pedg }}$ & $O C C_{p e d g}=\left\{\begin{array}{c}Q_{\text {pedg }} / 2000 \text { se } Q_{\text {pedg }} \leq 1000 \\
Q_{\text {pedg }} / 10000+0,4 \text { se } Q_{p e d g}>1000\end{array}, Q_{\text {pedg }}=Q_{\text {ped }}\right.$ \\
\hline
\end{tabular}


Sendo:

$O C C_{p e d}$ : Oportunidade de conflito pedestre

$t_{i}$ : tempo integral de travessia de pedestre

$q_{c l}$ : fluxo do movimento $\ell$ (por fluxo e/ou faixa) da zona de conflito c

$Q_{\text {ped }}$ : travessia do fluxo de pedestres

$t_{c}$ : tempo de travessia do pedestre na zona de conflito c (que pode ser levantado em campo)

$q_{l}$ : fluxo do movimento $\ell$ (por fluxo e/ou faixa), conflitante com a zona de conflito c,

$T_{c}$ : tempo de ocupação de cada zona de conflito

$T_{c l}$ : tempo de ocupação de cada faixa de tráfego

$v_{\text {ped }}$ : velocidade do pedestre

$P[F]$ : probabilidade de não ter fila ao chegar, aproximada por $(1-\mathrm{X}) ; \mathrm{X}=\mathrm{q} / \mathrm{C}$ é a razão fluxo/capacidade veicular;

$\tau_{u}, \tau_{l}$ : limites de tolerância para os intervalos entre veículos nas brechas que delimitam oportunidades de conflito relevantes

MING (2008) apresenta um método para conversão das oportunidades por hora, em oportunidades anuais. É um método bastante simples que adota um fator de conversão F para obter o valor referente ao dia todo a partir da estimativa feita na hora pico. Tendo essa estimativa diária, basta multiplicar pela quantidade de dias do ano para obter a estimativa anual. Portanto, tem-se:

COANUAL $=$ COhora $* D / F$

Sendo:

COANUAL: Oportunidades de conflito anual 
COhora: Oportunidades de conflito em 1 hora

$D$ : Quantidade de dias no ano $(\mathrm{D}=365)$

$F$ : Fator de conversão de hora-pico para dia $(\mathrm{F}=0,10)$

Outros aspectos também podem ser incorporados no esquema básico proposto. MING (2008) também apresenta formulações para conflitos com pedestres em interseções semaforizadas e para conflitos veiculares em interseções com ou sem semáforos.

MING (2008) aplicou estes modelos a duas interseções urbanas típicas e analisou a correspondência entre o diagnóstico obtido com seus resultados numéricos e a análise técnica subjetiva. Propõe-se novamente adicionar a análise da correlação com os acidentes.

Novamente deve-se observar que o escopo deste trabalho também inclui os movimentos de pedestres ao longo da via e os movimentos de pedestres de travessia e ao longo da via. Portanto, novos conceitos, modelos e procedimentos podem ser necessários. Nota-se que as variáveis utilizadas para caracterizar o nível de serviço no HCM (2000), encontros e passagens são similares a COs (oportunidades de conflito).

MING (2008) discute um aspecto específico, relacionado com a evitabilidade da oportunidade de conflito, que parece particularmente relevante.

A condição é uma manobra evasiva destinada à evitar um risco de acidente pode decorrer de diversos aspectos como restrições à visibilidade (por obstruções visuais ou por falta de iluminação) ou falha humana no julgamento da situação de risco (por erro ou falta de atenção). Em um dos esquemas propostos, MING (2008) traduz a probabilidade de falha em evitar o acidente em uma comparação entre o tempo de reação disponível e necessário, expresso como:

$P_{s v}=P\left[D_{p}>D_{v}\right] \Leftrightarrow P_{s v}=P\left[\delta_{R}>\delta_{A}\right] \delta_{A}=\frac{D_{v}}{V}-\frac{V}{2 . b}$

Onde

$D_{p}$ é a distância requerida para parada $D_{p}=\delta_{R} \cdot V+\frac{V^{2}}{2 . b}$, 
$D_{v}$ é a distância de visibilidade existente ou efetiva

$\delta_{R}$ é o tempo de reação do condutor (função do tipo de evento)

$\delta_{A}$ é o tempo de reação disponível para o condutor $\delta_{A}=\frac{D_{v}}{V}-\frac{V}{2 . b}$

onde a probabilidade é calculada a partir de uma aproximação de momentos de segunda ordem para velocidades aleatórias (os demais parâmetros assumem valores típicos, embora sua aleatoriedade também possa ser considerada de forma similar) e da hipótese de distribuição logística $\quad\left(P[X>x]=1-P[X \leq x], P[X \leq x]=\frac{1}{1-e^{-\frac{(x-m)}{a}}}, m=E[X], a=\frac{\sqrt{3}}{\pi} \cdot \sqrt{V[X]}, \quad\right.$ com fórmula analítica e parâmetros dados em função dos momentos da variável considerada).

Este termo incorpora o efeito da velocidade dos veículos, um aspecto relevante mas ausente dos demais termos nos modelos propostos por MING (2008). Naturalmente, existem outros efeitos relevantes da velocidade dos veículos, como a gravidade do acidente potencial, que também seria importante incorporar em versões futuras dos modelos de previsão.

A mesma formulação pode ser traduzida em uma probabilidade de acidente dada por

$P_{s v}=P\left[D_{p}>D_{v}\right] \Leftrightarrow P_{s v}=P\left[V>V_{A}\right], V_{A}=\sqrt{b^{2} \cdot \delta_{R}^{2}+2 \cdot b \cdot D_{v}}-b \cdot \delta_{R}$

onde $V_{A}$ é a velocidade que corresponde a $D_{p}=D_{v}$ para $\delta=\delta_{R}$ (e também $\delta_{A}=\delta_{R}$ ). Quando apenas a velocidade é considerada aleatória, esta expressão é colocada diretamente em função da distribuição da variável aleatória $V$ e $P_{s v}=P\left[V>V_{A}\right]=1-F\left[V_{A}\right]$, dada a função de distribuição acumulada $F$ para as velocidades dos veículos (simplificadamente, pode-se admitir distribuição normal ou logística com um coeficiente de variação de $10 \%$ a $20 \%$ ).

Ainda melhor, a expressão pode ser traduzida em uma velocidade de impacto. Dado $\delta=\delta_{R}$, tem-se $V_{I}=\sqrt{V^{2}-2 \cdot b \cdot\left(D_{V}-\delta_{R} \cdot V\right)}$ se $V>V_{A}$ (caso contrário $V_{I}=0$ pois não há acidente) e 
$\frac{D_{v}}{V}>\delta_{R} \quad$ (ou $\quad V<\frac{D_{v}}{\delta_{R}}, \quad$ caso contrário $\left.\quad V_{I}=V\right)$. Generalizando, tem-se $V_{I}=\min \left\{\sqrt{V^{2}-2 \cdot b \cdot\left(D_{V}-\delta_{R} \cdot V\right)} ; V\right\}$ se $V>V_{A}$ e $V_{I}=0$ se $V \leq V_{A}$. Invertendo a relação, obtém-se $V=\operatorname{máx}\left\{\sqrt{V_{I}^{2}+2 \cdot b \cdot D_{V}+\left(b \cdot \delta_{R}\right)^{2}}-b \cdot \delta_{R} ; 0\right\}$ se $V>V_{A}$.

Segundo DAVIS (2007), a velocidade de impacto pode ser relacionada com a severidade dos acidentes com pedestres por um modelo de distribuição logística dado por

$P_{a c}[$ Leve $]=\frac{e^{\alpha_{1}-\beta . V_{I}}}{1-e^{\alpha_{1}-\beta . V_{I}}}$

$P_{a c}[$ Sério $]=\frac{e^{\alpha_{2}-\beta . V_{I}}}{1-e^{\alpha_{2}-\beta . V_{I}}}-\frac{e^{\alpha_{1}-\beta . V_{I}}}{1-e^{\alpha_{1}-\beta . V_{I}}}$

$P_{a c}[$ Fatal $]=1-\frac{e^{\alpha_{2}-\beta . V_{I}}}{1-e^{\alpha_{2}-\beta . V_{I}}}$

onde os parâmetros calibrados estão resumidos na Tabela 3-2.

Tabela 3-2 - Parâmetros (e Erro Padrão) dos Modelos Estimados por DAVIS (2007) para Severidade dos Acidentes com Pedestres em Função da Velocidade de Impacto $(\mathrm{em} \mathrm{km} / \mathrm{h})$

\begin{tabular}{|c|c|c|c|}
\hline Grupo de Idade da Vítima & $\beta$ & $\alpha_{1}$ & $\alpha_{2}$ \\
\hline Crianças (até 14 anos) & $0,120(0,019)$ & $4,678(0,543)$ & $8,846(0,809)$ \\
\hline Adultos (15 a 59 anos) & $0,127(0,018)$ & $4,970(0,531)$ & $8,866(0,822)$ \\
\hline Idosos (mais de 60 anos) & $0,204(0,035)$ & $5,290(0,811)$ & $9,728(1,433)$ \\
\hline
\end{tabular}

Preliminarmente, o critério pode ser aplicado em função da distribuição aleatória de velocidades, a partir dos valores limites das faixas de velocidade. 
Como aproximação, pode-se admitir gravidade leve se $P_{a c}[$ Leve $]>50 \%$ (ou, correspondentemente, $\left.\quad V_{I}<V_{I 1}=\frac{\alpha_{1}}{\beta}\right)$ e gravidade fatal se $P_{a c}[$ Fatal $] \geq 50 \% \quad$ (ou, correspondentemente, $V_{I} \geq V_{I 2}=\frac{\alpha_{2}}{\beta}$ ), admitindo-se gravidade intermediária caso contrário (ou $V_{I 1}=\frac{\alpha_{1}}{\beta} \leq V_{I}<V_{I 2}=\frac{\alpha_{2}}{\beta}$ ), se forem casos de acidentes.

Traduzindo em termos da velocidade inicial, se $V>V_{A}$, tem-se acidente leve se $V<V_{1}=\operatorname{máx}\left\{\sqrt{V_{I 1}^{2}+2 \cdot b \cdot D_{V}+\left(b \cdot \delta_{R}\right)^{2}}-b \cdot \delta_{R} ; 0\right\} \quad$ e $\quad$ acidente fatal se $V \geq V_{2}=\operatorname{máx}\left\{\sqrt{V_{I 2}^{2}+2 \cdot b \cdot D_{V}+\left(b \cdot \delta_{R}\right)^{2}}-b \cdot \delta_{R} ; 0\right\}$, tendo-se acidente grave em caso contrário.

A distribuição de gravidade dos acidentes seria obtida como $P_{a c}=P\left[V>V_{A}\right]$, $P_{a c}[$ Leve $]=P\left[V<V_{1} / V>V_{A}\right], \quad \quad P_{a c}[$ Fatal $]=P\left[V \geq V_{2} / V>V_{A}\right]$ $P_{a c}[$ Grave $]=1-P_{a c}[$ Leve $]-P_{a c}[$ Fatal $]=1-P\left[V<V_{1} / V>V_{A}\right]-P\left[V \geq V_{2} / V>V_{A}\right], \quad$ onde $P\left[V<V_{1} / V>V_{A}\right]=\frac{P\left[V_{A}<V<V_{1}\right]}{P\left[V>V_{A}\right]}=\frac{F\left[V_{1}\right]-F\left[V_{A}\right]}{1-F\left[V_{A}\right]} \quad\left(0 \quad\right.$ se $\left.\quad V_{1}<V_{A}\right) \quad$ e $P\left[V \geq V_{2} / V>V_{A}\right]=\frac{P\left[V \geq V_{2}>V_{A}\right]}{P\left[V>V_{A}\right]}=\frac{1-F\left[V_{2}\right]}{1-F\left[V_{A}\right]}\left(1\right.$ se $\left.V_{2}<V_{A}\right)$. Estes valores são relativos à probabilidade de acidente $P_{s v}=P\left[V>V_{A}\right]=1-F\left[V_{A}\right]$. Em termos da ocorrência das oportunidades de conflito, os valores correspondentes seriam $P_{a c}[$ Leve $]=F\left[V_{1}\right]-F\left[V_{A}\right](0 \mathrm{se}$ $\left.V_{1}<V_{A}\right), P_{a c}[$ Fatal $]=1-F\left[V_{2}\right]\left(P_{a c}\right.$ se $\left.V_{2}<V_{A}\right)$ e $P_{a c}[$ Grave $]=P_{a c}-P_{a c}[$ Leve $]-P_{a c}[$ Fatal $]$, onde $P_{a c}=P_{s v}$ (condicionada à ocorrência da oportunidade de conflito).

Alternativamente, estas probabilidades poderiam ser obtidas diretamente pela integração das expressões propostas por DAVIS (2007) em função da distribuição de velocidades. 


\subsection{OUTROS MÉTODOS DE ANÁLISE}

Alguns autores utilizam métodos distintos para avaliar a segurança de pedestres.

A seguir são apresentados os seguintes trabalhos, que apresentam métodos de avaliação da segurança:

1. ARAUJO, G.P.; BRAGA, M.G.C. - Methodology for the Qualitative Evaluation of Pedestrian Crossings at Road junctions with Traffic Lights, in Transportation, vol.35, pp.539-557

2. BASILE, O.; PERSIA, L.; USAMI, D. - A Methodology to Assess Pedestrian Crossing Safety, in European Transportation Research Review, vol.2, pp.129-137; 2010

\subsubsection{Método de ARAUJO e BRAGA (2008)}

O trabalho de ARAUJO e BRAGA (2008) tem como objetivo do trabalho testar a aplicação de um método para avaliar qualitativamente a travessia de pedestres, baseado na metodologia de KHISTY (1994). O artigo em questão analisou quatro travessias na cidade de SP e os resultados dos níveis de serviço qualitativos obtidos foram comparados com os níveis de serviço calculados pelo HCM 2000.

O passo preliminar é definir a importância relativa, no ponto de vista do pedestre, das medidas de desempenho empregadas. Então, o nível de serviço, percebido pelos usuários, é determinado para cada travessia estudada. A metodologia de KHISTY (1994) torna possível relacionar o nível de satisfação geral com um nível de serviço qualitativo para o dispositivo de 
pedestre em análise. A metodologia sugerida é simples e rápida de aplicar, além de relativamente barata, compreendendo os seguintes passos:

1. Escolher uma lista de Medidas de desempenho ("Performance Measures" - PMs) que distingue o dispositivo em análise (no máximo 10 PMs)

2. Aplicar procedimentos psicométricos (Paired comparison, Constant sum) num estudo de campo com pedestres, para obter pesos para cada PM considerada

3. Examinar os resultados obtidos e montar uma lista final com as PMs a serem utilizadas, mostrando a importância relativa de cada uma

4. Medir o nível de satisfação ou insatisfação para cada PM, correlacionando esta medida com 6 níveis de serviço (de A a F)

5. Determinar o nível de serviço qualitativo resultante para cada dispositivo analisado.

KHISTY (1994) analisou o nível de serviço para calçadas. A fim de selecionar as PMs, KHISTY (1994, apud ARAUJO e BRAGA, 2008) revisou a literatura e consultou especialistas na esfera da análise da segurança de trânsito do pedestre. Os seguintes PMs foram selecionados: atratividade, conforto, conveniência, segurança, coerência e continuidade do sistema.O método de ponderação foi uma combinação do método de comparação par-a-par (paired comparison) e do método de soma constante (Constant Sum), a fim de estabelecer uma ordem de importância para os pedestres. ARAUJO e BRAGA (2008) e KHISTY (1994) fornecem uma breve descrição dos métodos mencionados.

ARAUJO e BRAGA (2008) adaptaram a metodologia para o Brasil, buscando determinar o nível de serviço para travessias de pedestres semaforizadas. Foram estudados 4 cruzamentos na cidade de São Paulo e um corpo técnico de 17 especialistas trabalharam na determinação das PMs. Diferente do estudo original, em que os atributos eram específicos dos locais estudados, nesse caso os atributos escolhido foram mais gerais no intuito de serem utilizados na análise de qualquer travessia semaforizadas, independente da sua localização. As PMs selecionadas foram: conforto, conveniência, segurança, continuidade do sistema e economia. 
O próximo passo foi coletar os dados a fim de obter os atributos que melhor descrevem as medidas acima mencionadas. Isso foi feito da seguinte maneira:

- Passo 1: O corpo técnico de especialistas desenhou um esboço de um cruzamento conhecido, com movimento intenso de pedestre e veículos, mostrando as características do cruzamento, em termos de infra-estrutura e condições operacionais.

- Passo 2: Os especialistas listaram então os atributos que poderiam influenciar a percepção do pedestre considerando o nível de risco e a qualidade do cruzamento em questão.

- Passo 3: Os autores analisaram as listas resultantes, unificaram eliminando repetições existentes e classificaram os atributos restantes de acordo com as seguintes categorias: (a) operação viária, (b) pedestres, (c) veículos, (d) sinalização horizontal e vertical, (e) semáforos, (f) calçadas, (g) outros.

- Passo 4: Os atributos classificados foram então mostrados aos especialistas, num grupo de discussão, a fim de estabelecer em consenso quais seriam realmente considerados. A tabela inicial mostrava 60 atributos, um número considerado alto e foi decidido reduzi-lo inicialmente por ordem de relevância e frequência. Finalmente 38 atributos foram mantidos.

- Passo 5: Como o número continuou alto (38), 3 especialistas analisaram a lista a fim de escolher 5 atributos para cada PMs, número considerado razoável para o estudo de campo. Para facilitar a redução foi eliminada a PM Economia, já que poucos atributos foram relacionados a ela e geralmente atributos repetidos em outras PMs. Além disso as PMs conveniência e conforto foram considerados num mesmo item considerando que a distinção nas duas definições dificilmente poderia ser percebida pelos pedestres.

Finalmente, as 3 medidas selecionadas, com os respectivos atributos estão abaixo relacionadas:

- Conforto: tempo de espera, espaço disponível enquanto espera a travessia, número de pedestres, via de mão única/dupla, estado da superfície da via;

- Segurança: largura da via, velocidade dos veículos, visibilidade, luz, defensas; 
- Continuidade do sistema: ausência de obstáculos, estado de conservação das calçadas, guias rebaixadas, semáforos de pedestres, canteiro central.

Foi então aplicado um questionário para pedestres nos quatro cruzamentos em estudo a fim de medir o grau de satisfação/insatisfação de cada medida, e consequentemente o nível de serviço qualitativo. Foi utilizada a escala diferencial semântica bi-polar linear para escolher a medida de satisfação do pedestre em relação aos atributos definidos anteriormente.

O resultado dos 424 questionários aplicados determinou os seguintes pesos: Segurança, 38; Continuidade do Sistema, 32 e Conforto, 30; mostrando que o pedestre prioriza fatores relacionados a Segurança, como largura da via, velocidade dos veículos, visibilidade, condições da iluminação e existência de defensa.

Percebe-se que o método é totalmente subjetivo, não tendo sido apresentadas comparações com a realidade (particularmente quanto ao risco de acidentes).

\subsubsection{Método de BASILE, PERSIA e USAMI (2010)}

BASILE et al. (2010) procuraram medir a segurança de pedestres em interseções, semaforizadas ou não, em áreas urbanas. Para isso relacionaram fatores que consideravam importante para a segurança do pedestre na travessia e a contribuição relativa de cada fator foi determinada através da metodologia de AHP (Analytic Hierarchy Process) proposta por Saaty.

Esse método é geralmente utilizado para comparar diferentes alternativas e avaliar qual é a que melhor satisfaz o objetivo inicial. No trabalho, AHP é utilizado para agregar a opinião de diferentes especialistas sobre cada aspecto de segurança da travessia de pedestres.

A metodologia proposta foi utilizada para avaliar a segurança de 215 travessias de pedestres em 17 cidades europeias. 
Os principais aspectos considerados, baseados em opiniões de especialista e em resultados de estudos anteriores, foram: projeto espacial e temporal; visibilidade diurna; visibilidade noturna; e, acessibilidade.

As Figuras 3-2 e 3-3 mostram esses macros critérios aplicados para interseções não semaforizas e semaforizadas respectivamente.

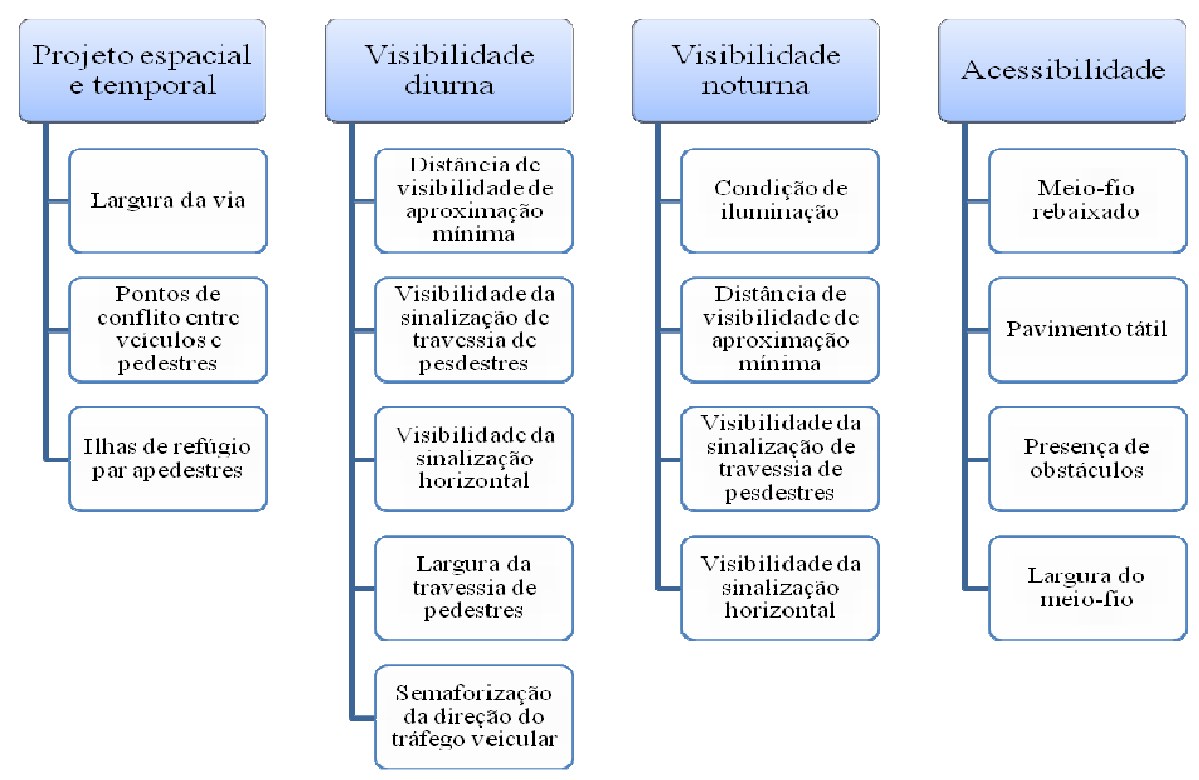

Figura 3-2 - Estrutura hierárquica para interseções não semaforizadas. (Fonte: BASILE, O.; PERSIA, L.; USAMI, D.; A Methodology to Assess Pedestrian Crossing Safety, European Transportation Research Review, vol.2, PP. 129-137, 2010) 


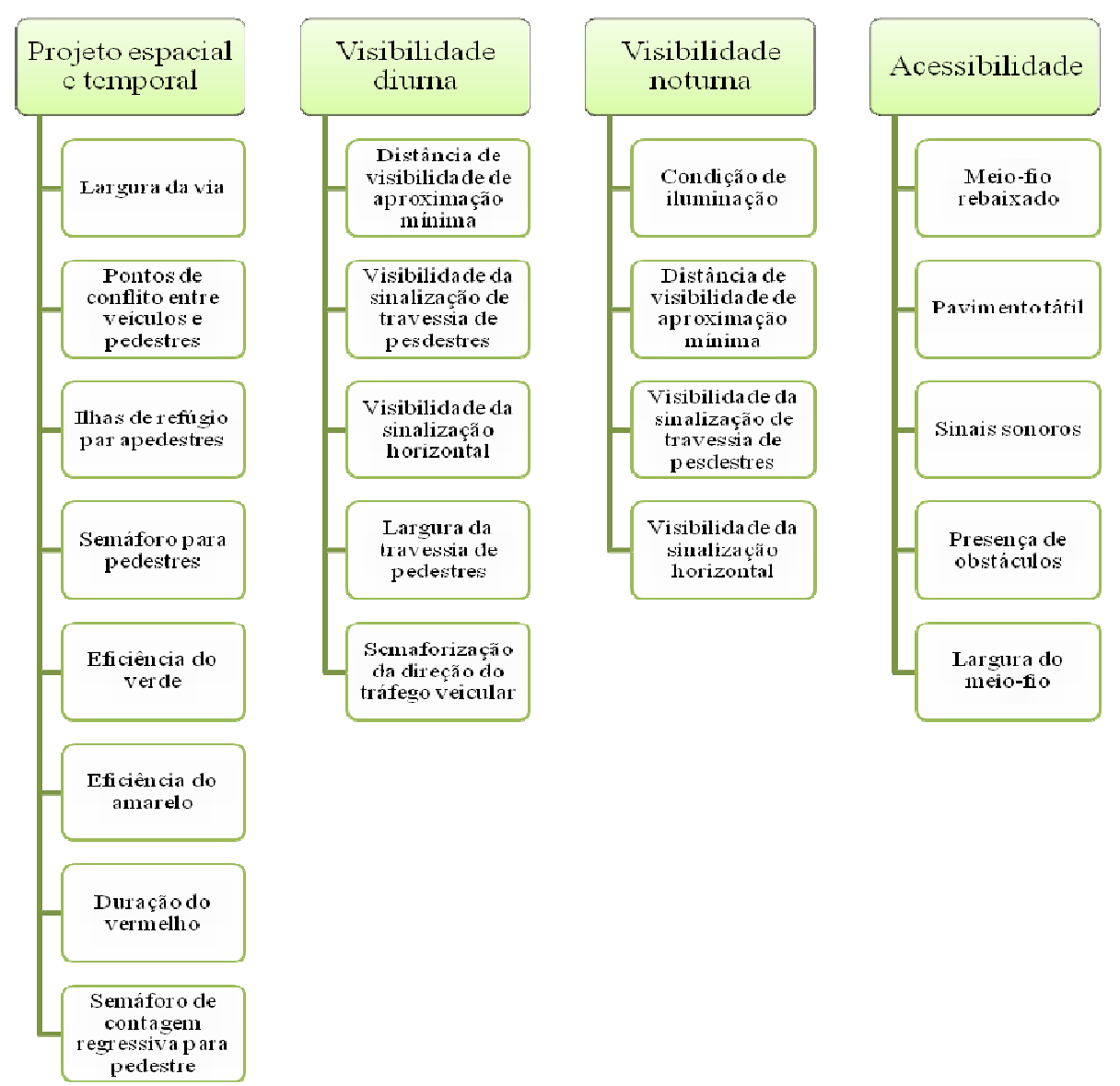

Figura 3-3 - Estrutura hierárquica para interseções semaforizadas. (Fonte: BASILE, O.; PERSIA, L.; USAMI, D.; A Methodology to Assess Pedestrian Crossing Safety, European Transportation Research Review, vol.2, PP. 129-137, 2010)

Características de projeto espacial e temporal levam em conta a exposição dos pedestres ao tráfego, conflitos e fatores de tempo de acesso da facilidade pelo pedestre, incluindo dispositivos que facilitam ou minimizam o tempo de travessia.

A visibilidade diurna e noturna avalia a visibilidade dos pedestres nos cruzamentos para os motoristas, visibilidade da travessia para os motoristas e visibilidades dos veículos que se aproximam para os pedestres.

O critério de acessibilidade leva em conta a possibilidade de acesso para todos os usuários, com ou sem desabilidades, sem obstáculos e possíveis perigos. 
Para cada macro critério foram então estabelecidos indicadores que foram escalados a fim de ter uma medida comum $(0,1)$. Um valor próximo a 0 indica um situação mais segura enquanto um valor próximo a 1 é associado a situações de risco.

Uma vez definido o problema, o AHP foi utilizado para achar um peso para cada critério presente no modelo teórico. De acordo com esse método, no caso de estrutura hierárquica com três níveis, definido pelo critério J, macro-critério $\mathrm{M}$ e um objetivo, é necessário avaliar:

Tabela 3-3 - Escala semântica de Saaty (Fonte: BASILE, O.; PERSIA, L.; USAMI, D.; A Methodology to Assess Pedestrian Crossing Safety, European Transportation Research Review, vol.2, PP. 129-137, 2010)

\begin{tabular}{ll}
\hline Aij & Julgamento \\
\hline 1 & Igual importância \\
3 & Fraca importância \\
5 & Forte importância \\
7 & Muito forte importância \\
9 & Importância absoluta \\
$2,4,6,8$ & Valores intermidiários \\
\hline
\end{tabular}

O peso $\mathrm{w}_{\mathrm{mj}}$ do critério geral $\mathrm{A}_{\mathrm{j}}$ associado ao macro-critério geram $\mathrm{C}_{\mathrm{m}}$;

$\mathrm{O}$ peso $\mathrm{w}_{\mathrm{m}}$ do macro-critério geral $\mathrm{C}_{\mathrm{m}}$ contribuindo para o objetivo geral (nível de segurança).

Foram criadas matrizes para cada macro-critério, onde o elemento $\mathrm{a}_{\mathrm{ij}}$ (coeficiente dominante) da matriz representa a prevalência do critério $A_{i}$ sobre o critério $A_{j}$.

A prevalência é por sua vez medida qualitativamente, usando um escala semântica que associa um valor numérico (de 1 a 9) para um julgamento expressando um resultado possível da comparação, como na seguinte tabela.

Um grupo de 15 especialistas foi então selecionado para fazer as comparações entre os critérios de segurança adotados.

Assumindo $a_{j k}=w_{j} / w_{k}$, com $w_{j}$ sendo o peso associado ao critério j e $w_{k}$ o peso do critério $\mathrm{k}$, o seguinte é valido: 
$a_{j j}=1$

$a_{k j}=1 / a_{j k}$

$a_{j i}^{*} a_{i k}=a_{j k}$

O peso para cada critério foi então obtido agregando os coeficientes dominantes resultantes das matrizes de comparação, obtendo então a matriz agregada de comparação A, que deve ser quadrada, positiva, simétrica e consistente.

Um conjunto de 15 travessias foi avaliado e foi criado um ranking considerando o nível de segurança. Foram ainda realizadas análises na alteração do ranking, removendo cada macrocritério utilizado. A maior mudança foi observada na remoção do macro-critério de acessibilidade.

A análise final permite obter uma lista de melhorias potenciais que acarretarão no aumento da segurança para o pedestre. Dados de 215 travessias de 17 cidades européias mostrou que os principais problemas encontrados foram: ausência de ilha de refúgio para pedestres, ciclos de semáforos inadequados, carros estacionados bloqueando a visibilidade e problemas freqüentes de acessibilidade com obstáculos nas travessias de pedestres.

A proposta da metodologia é principalmente a obtenção de medidas de segurança sem a necessidade de se conhecer dados do tráfego, porém o método é totalmente subjetivo, não tendo sido apresentada a validação contra dados de acidentes ou diagnóstico com dados de acidentes. 


\subsection{DEFINIÇÃO DO ESTUDO DE CAMPO}

Esse item apresenta a discussão relativa à seleção dos trechos para estudo.

\subsubsection{Análise Geral e Seleção dos Trechos para Estudo}

Atualmente, o Programa de Concessões Rodoviárias de São Paulo conta com dezenove Lotes contratados. Dos Lotes contratados, doze correspondem à $1^{\text {a }}$ Etapa do Programa, iniciada em meados de 1998, seis correspondem à $2^{\text {a }}$ Etapa, com contratos assinados entre junho/2008 e junho/2009 e um corresponde à $3^{\text {a }}$ Etapa, com contrato assinado em março/2011 (lote 25 Rodoanel Mário Covas - Trechos Sul e Leste).

A atuação na área de segurança de trânsito tem como instrumento fundamental o PRA, Plano de Redução de Acidentes, elaborado pelas concessionárias anualmente, a fim de estudar e tratar problemas de segurança nas rodovias concedidas. A Secretaria de Transportes estabeleceu como meta obter, até o final do período de Concessão, o Índice de Mortos menor que 2,5 em todo o Sistema de Rodovias Concedidas. Para atingir este objetivo a ARTESP estabelece metas anuais que são discutidas e acordadas com as concessionárias:

- META 1: Índice de Mortos

- META 2: Redução da quantidade de mortos do(s) principal(ais) tipo(s) de acidente(s) fatal (ais)

- META 3: Pontos Críticos

A concessionária ViaOeste administra o Lote 12, com 168 quilômetros de rodovias por onde trafegam diariamente mais de 500 mil veículos. O Sistema Castello-Raposo integra as rodovias Castello Branco, Raposo Tavares, Sen. José Ermírio de Moraes (Castelinho), além da 
rodovia Dr. Celso Charuri, beneficiando mais de 2 milhões de habitantes, moradores da região. Essas rodovias constituem a principal ligação entre a Capital e o Oeste paulista.

A Ffigura 3-4 a seguir ilustra a configuração espacial do sistema Castello-Raposo.

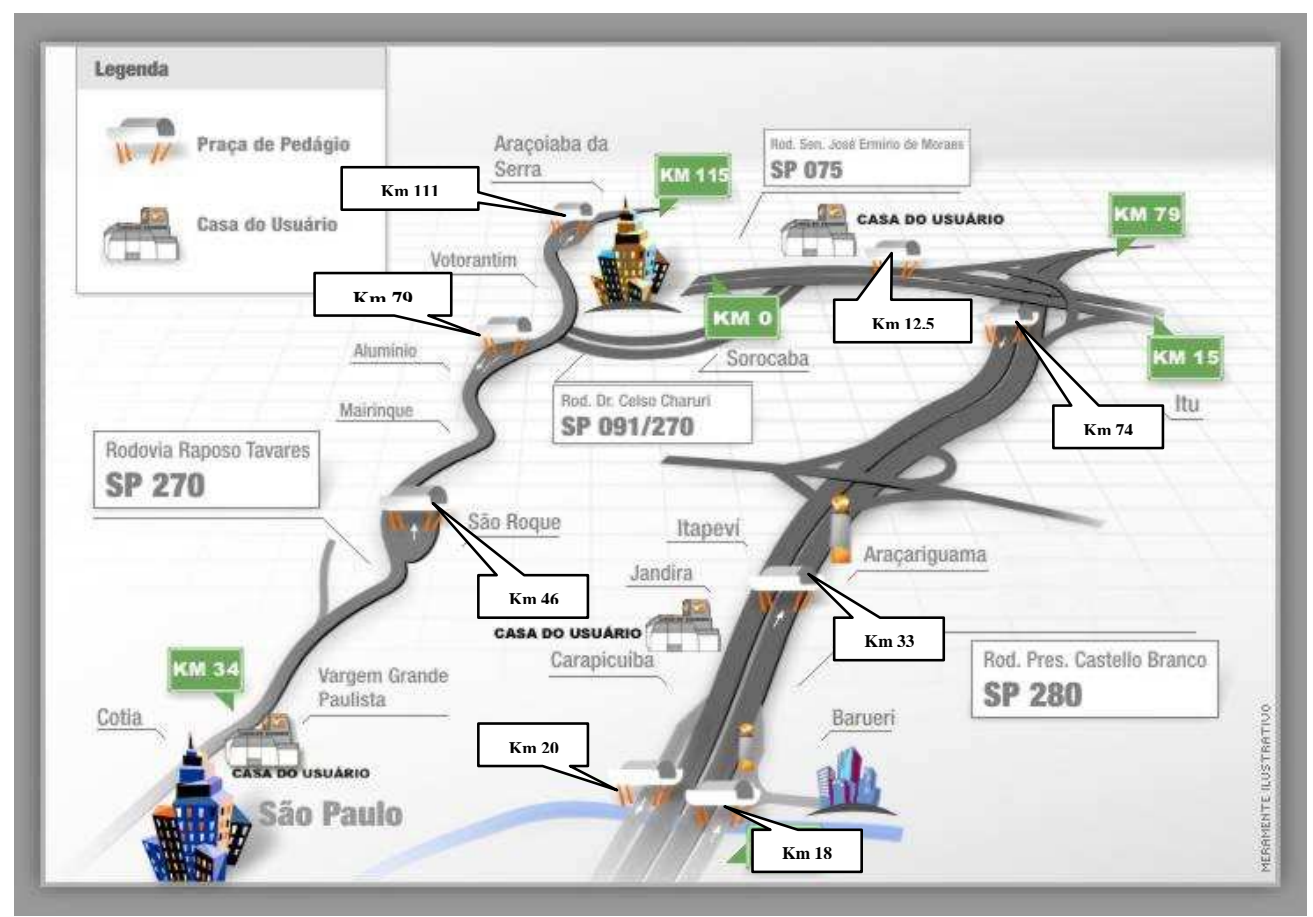

Figura 3-4 - Sistema Castello-Raposos

- Rodovia Presidente Castello Branco (SP 280) - trecho do km 13,46 (Osasco) ao km 79,38 (Itu) - $(65,92 \mathrm{~km})$

- Rodovia Raposo Tavares (SP 270) - trecho do km 34,0 (Cotia) ao km 115,5 (Araçoiaba da Serra) - $(81,5 \mathrm{~km})$

· Rodovia Senador José Ermírio de Moraes (SP 075) - do km zero ao km 15 - (15km)

· Rodovia Dr. Celso Charuri (SP 091/270) - do km zero ao km 6,2 - (6,2 km)

As rodovias SP 270 (Raposo Tavares) e SP 280 (Castello Branco) foram analisadas para seleção de locais para estudo por serem as mais extensas e por reunirem características típicas de distintos contextos de operação. 
A SP 270 apresenta trechos em pista simples (com ou sem terceira faixa) e trechos em pista dupla (com duas ou três faixas), tanto em áreas urbanas (incluindo grandes aglomerações e ocupações médias ou pequenas) quanto rurais (incluindo condições de relevo variado).

A SP 280 apresenta-se totalmente duplicada e tem 3 ou mais faixas ao longo de todo seu trajeto, percorrendo trechos altamente adensados (sem controle total de acesso) e trechos rurais com ocupação variável.

Para este trabalho, buscou-se analisar os trechos críticos específicos para pedestres e/ou ciclistas no sistema concedido. Foram analisados os dados de 2005 a 2011.

Primeiramente, pode-se ver a distribuição mensal desses acidentes, e o comparativo anual, mês a mês, considerando os dados da Rodovia Raposo Tavares (SP 270), nas Figuras 3-5 e 3-6, e da Rodovia Presidente Castello Branco (SP 280), nas Figuras 3-7 e 3-8.

Posteriormente, analisou-se a distribuição desses acidentes por $\mathrm{km}$, sentido e gravidade do acidente, tanto para a SP 270, na Figura 3-9a para acidentes com ciclistas e Figura 3-9b para acidentes com pedestres, quanto para a SP 280, na Figura 3-10a para acidentes com ciclistas e Figura 3-10b para acidentes com pedestres. 
- SP 270: Rodovia Raposo Tavares

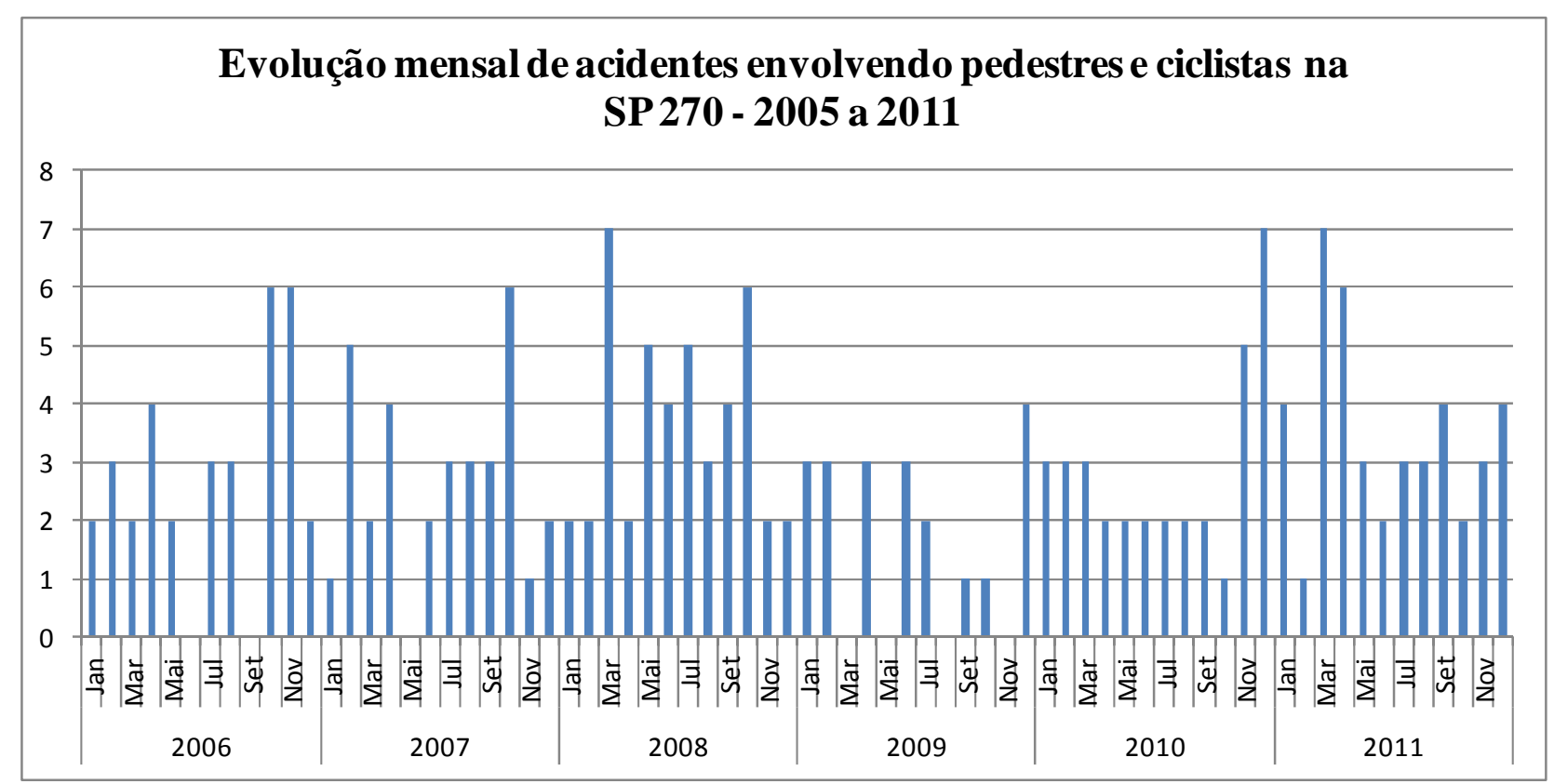

Figura 3-5 - Gráfico de evolução mensal de acidentes envolvendo pedestres e ciclistas na SP 270

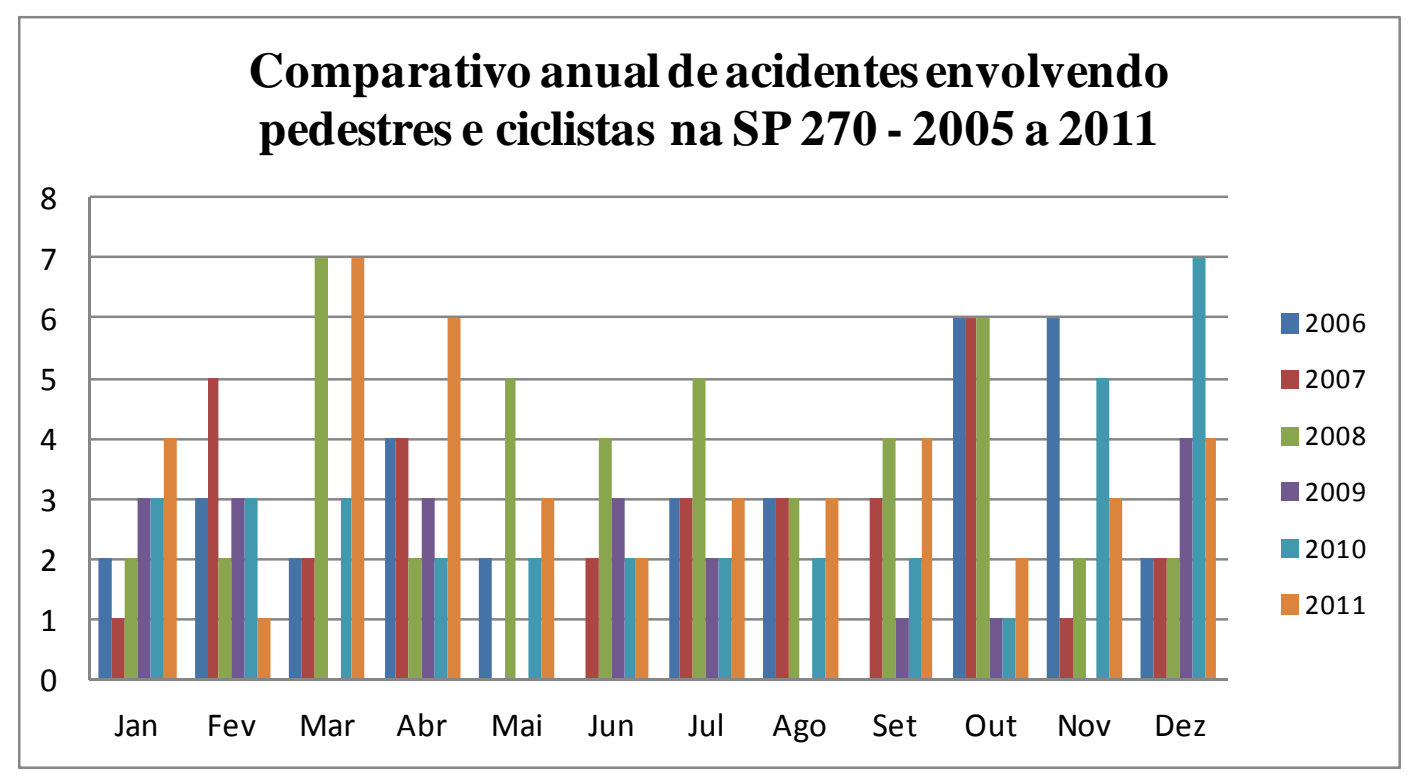

Figura 3-6 - Gráfico do comparativo anual de acidentes envolvendo pedestres e ciclistas na SP 270 
- SP 280: Rodovia Castello Branco

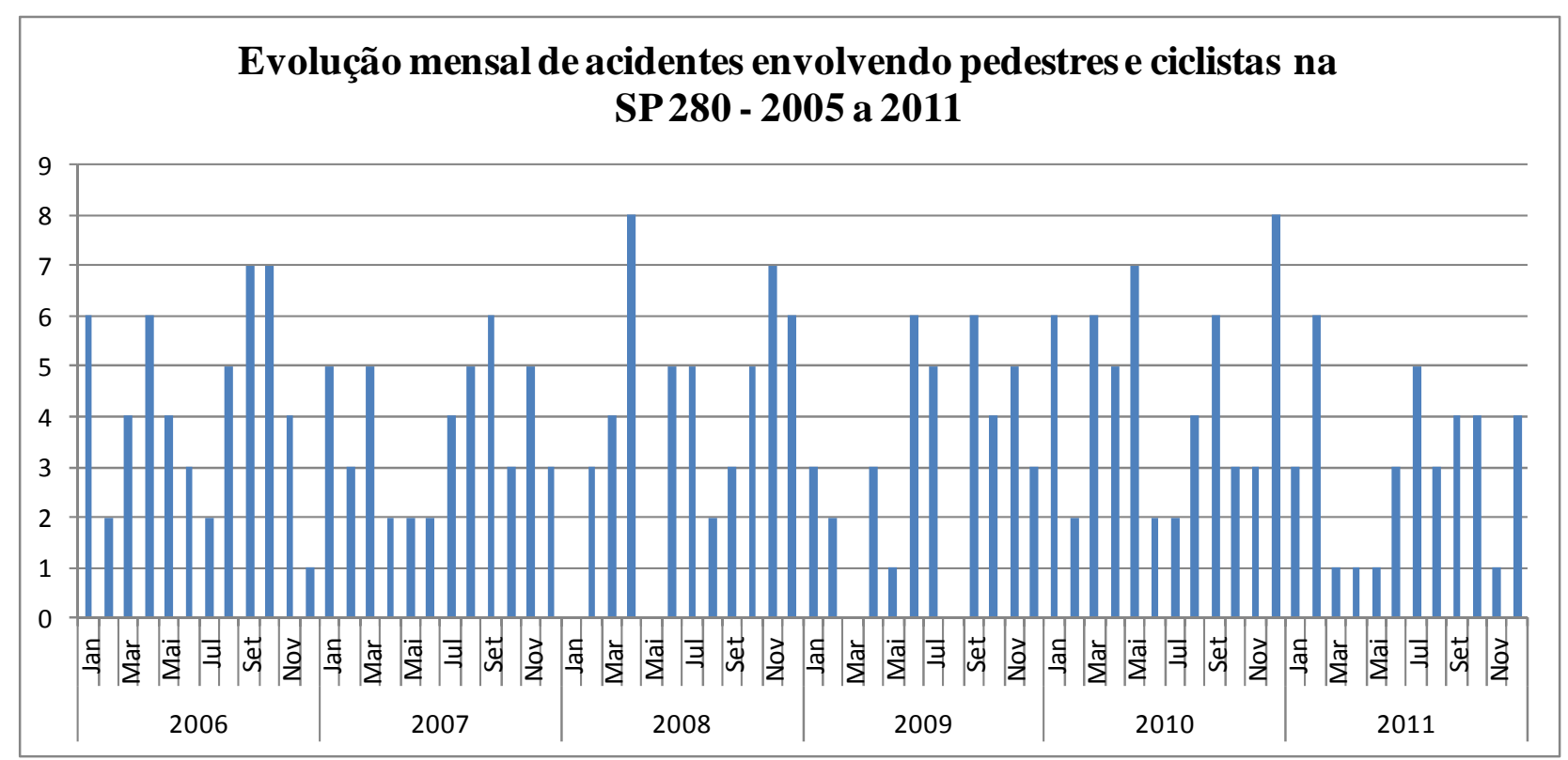

Figura 3-7 - Gráfico de evolução mensal de acidentes envolvendo pedestres e ciclistas na SP 280

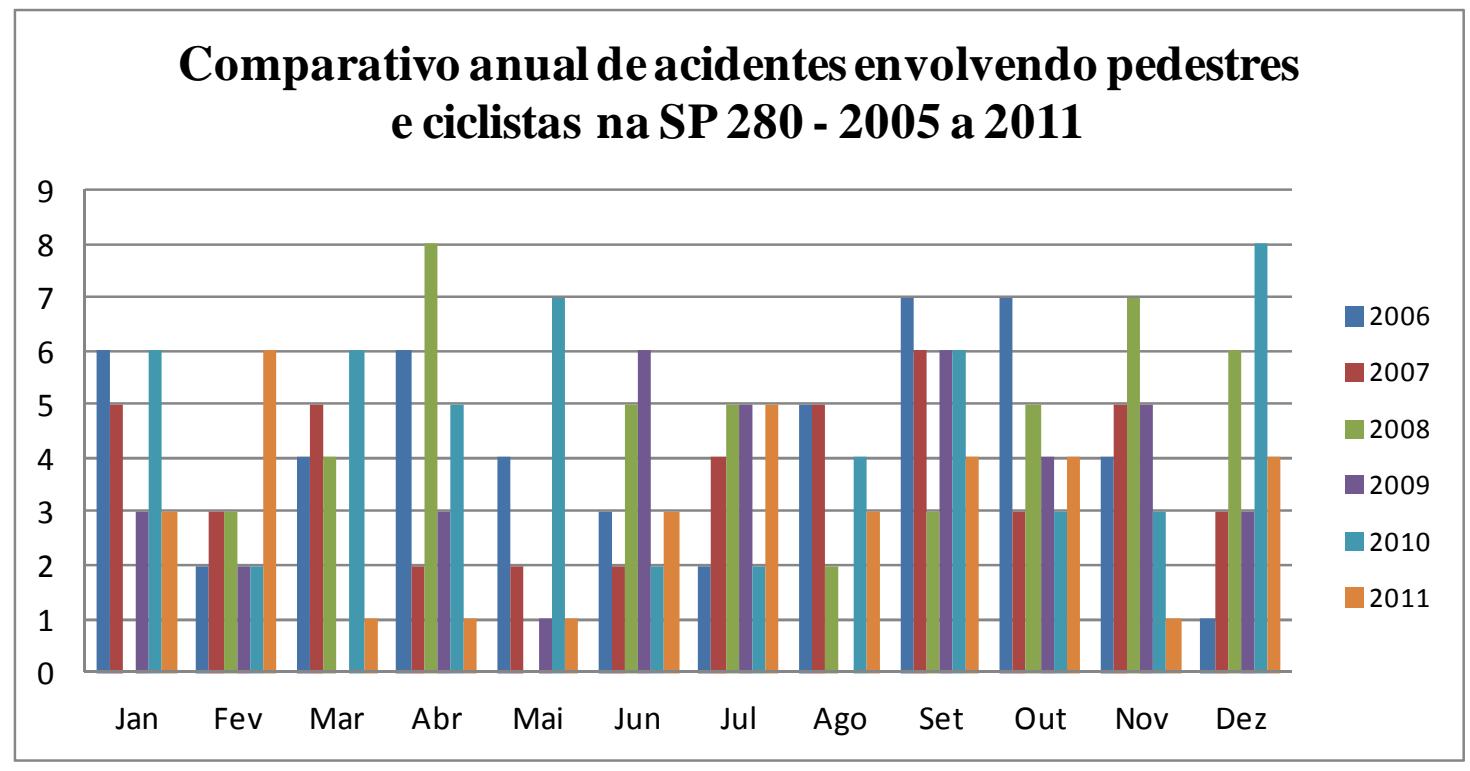

Figura 3-8 - Gráfico do comparativo anual de acidentes envolvendo pedestres e ciclistas na SP 280 


\section{- SP 270: Raposo Tavares}

\section{a) Acidentes com ciclistas}

Pisa Leste (>Capital)

Pista Oeste (>Interior)
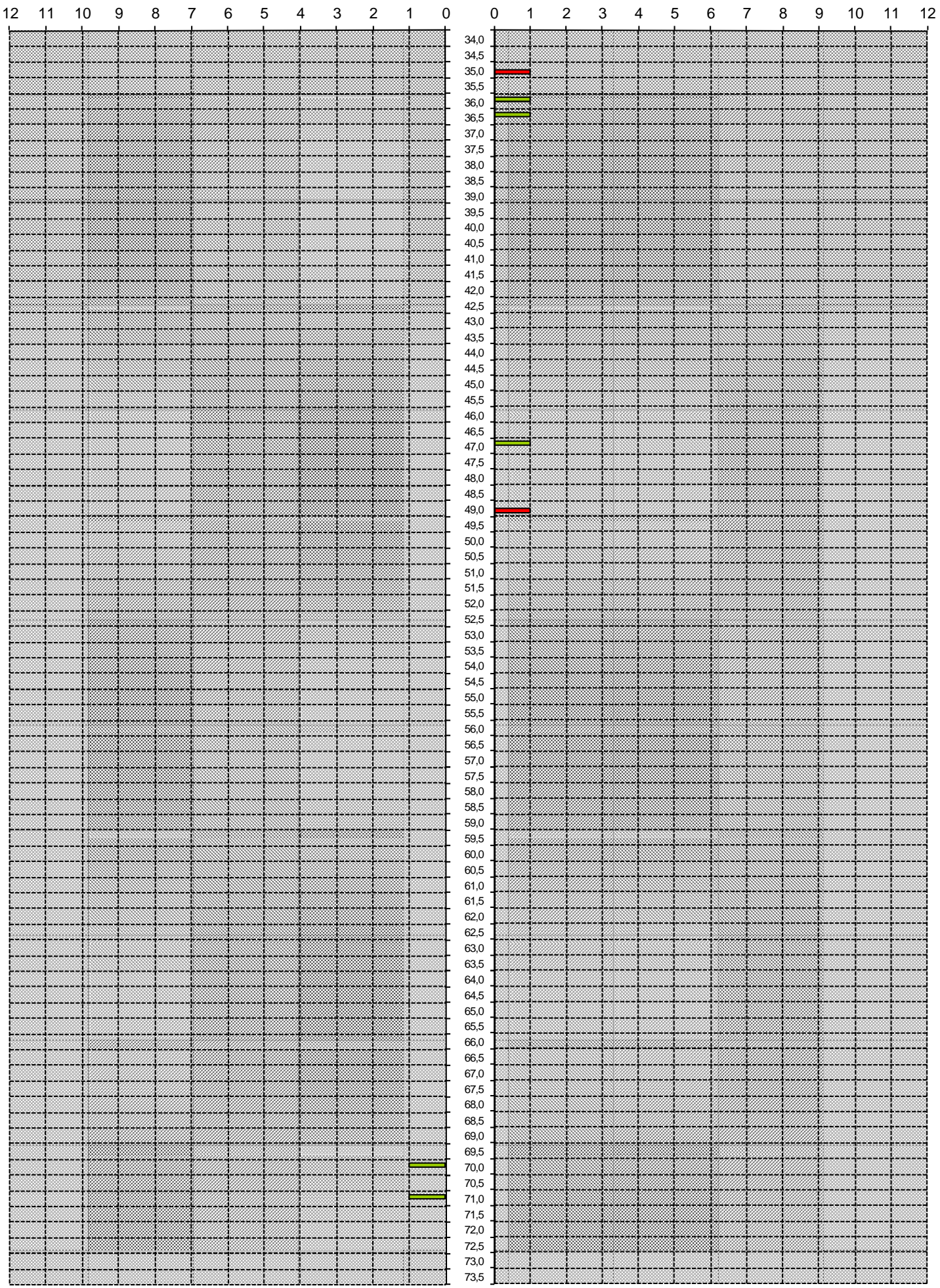
b) Acidentes com pedestres

Pisa Leste (>Capital)

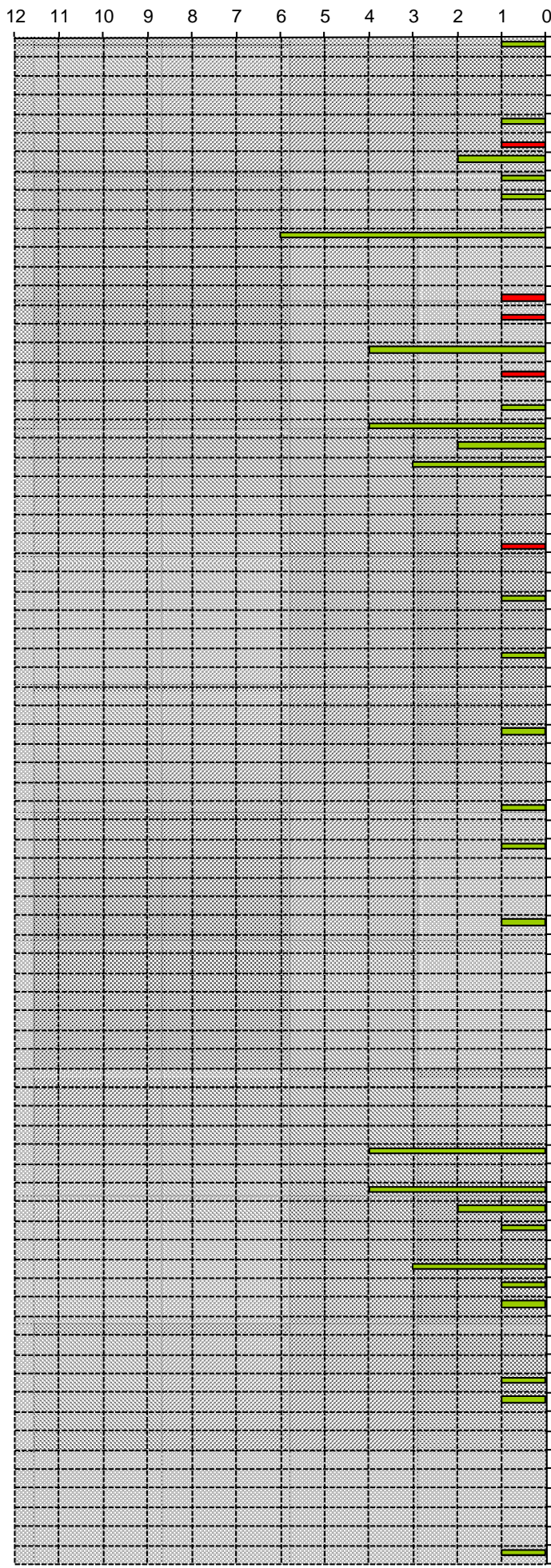

Pista Oeste (>Interior)

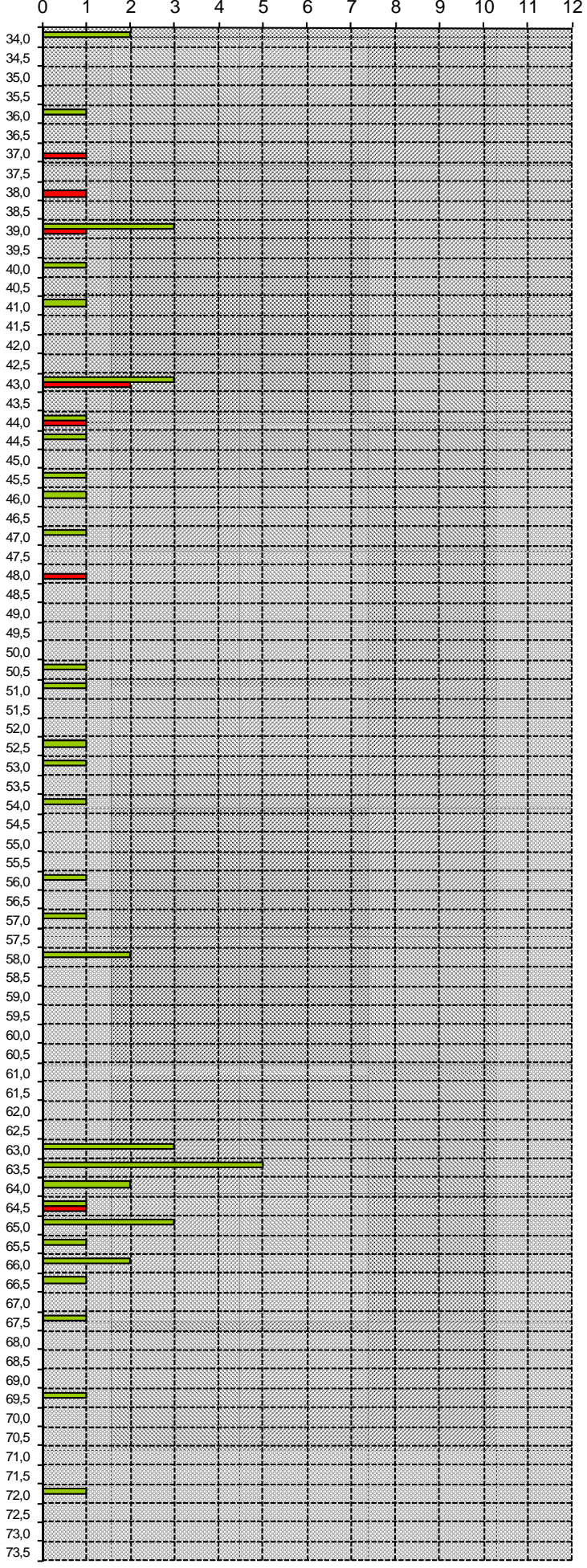

Figura 3-9 - Quadro dinâmico de acidentes - SP 270 


\section{- SP 280}

\section{a) Acidentes com ciclistas}
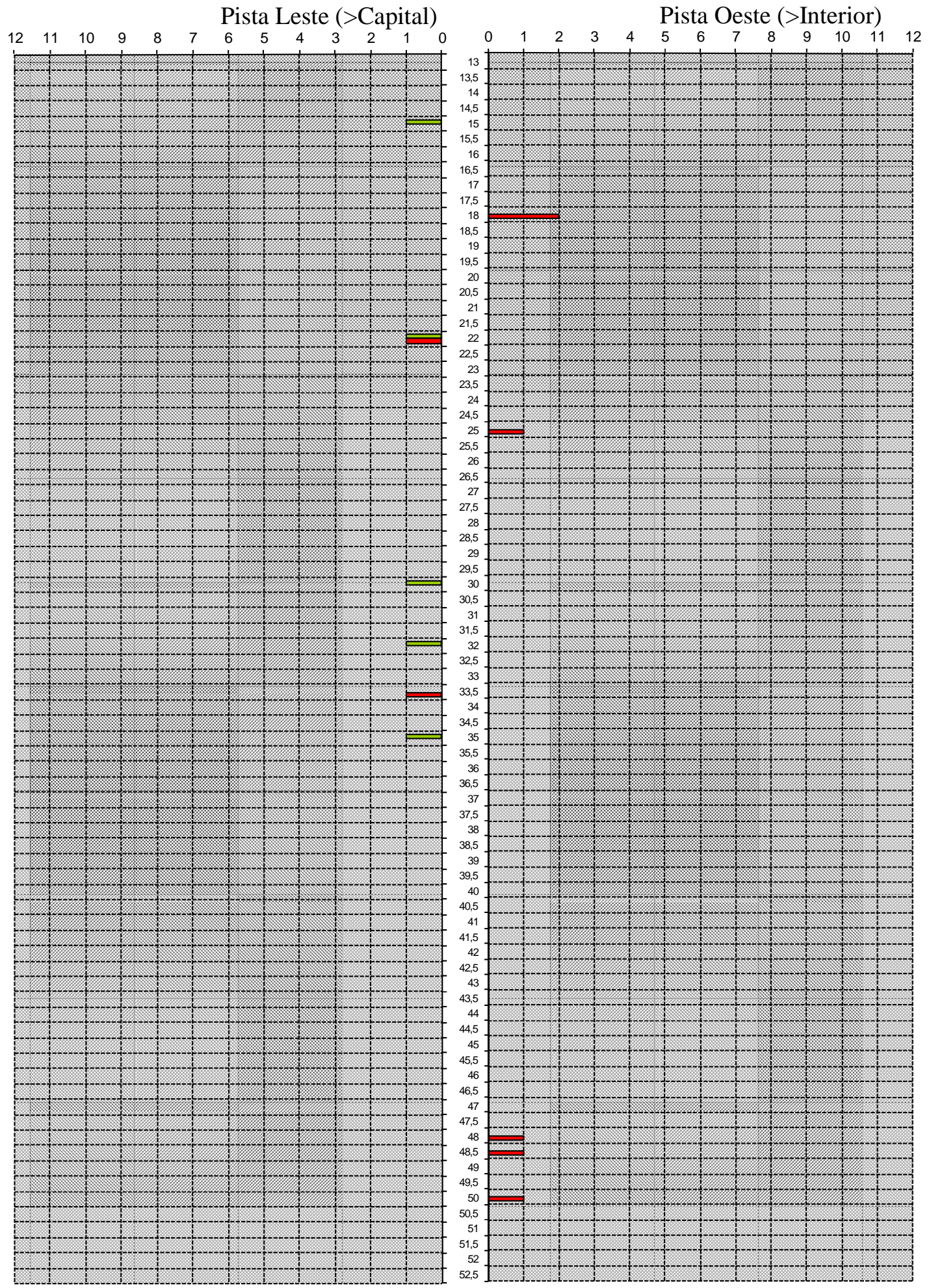
b) Acidentes com pedestres

Pista Leste (>Capital)

Pista Oeste (>Interior)
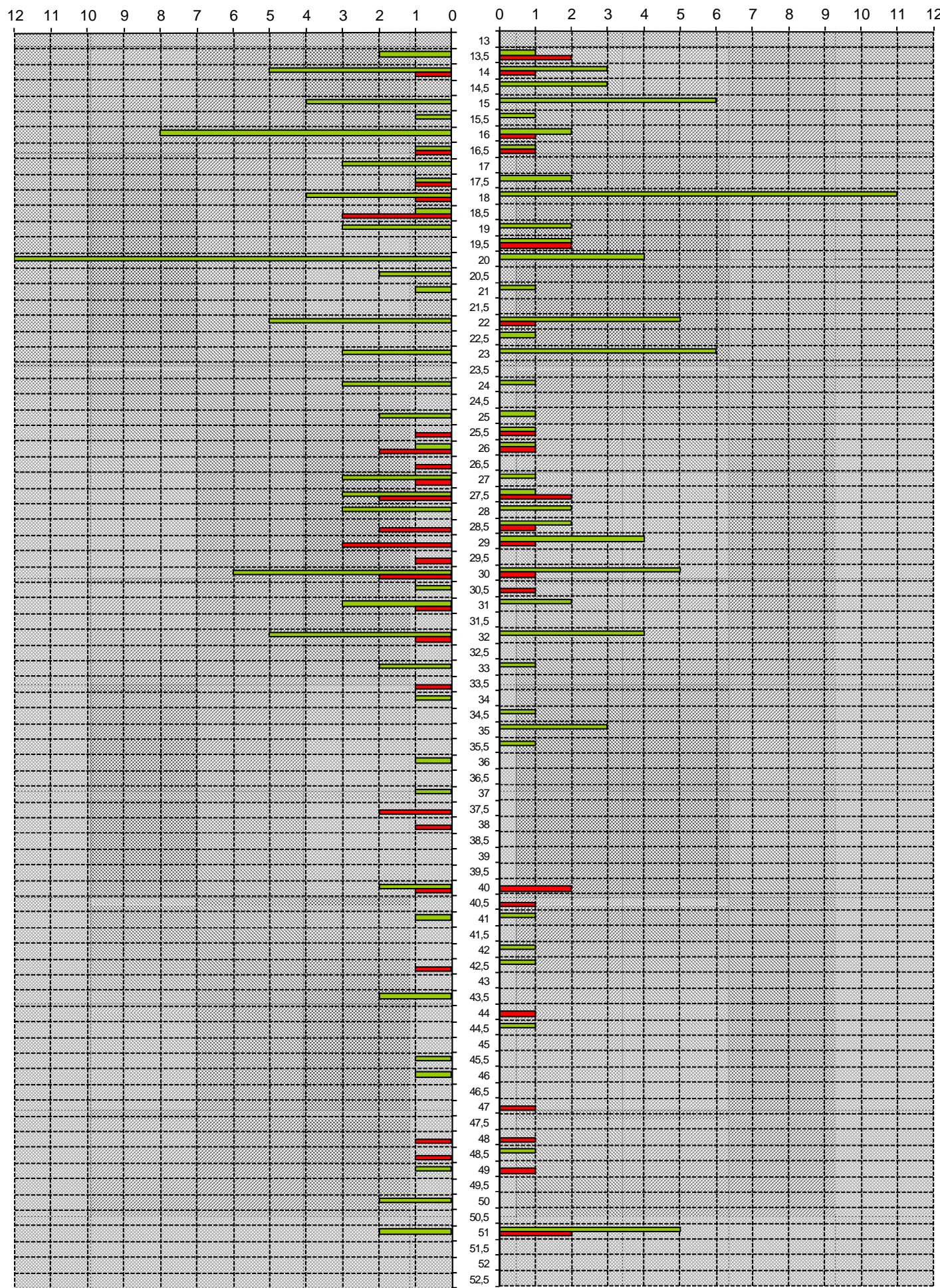

Figura 3-10 - Quadro dinâmico de acidentes - SP 280 
Na SP 270, Rodovia Raposo Tavares, os trechos críticos identificados no gráfico acima são: km 37 ao km 40 (duplicado em 2005) e km 63 ao km 65 (com pista simples). Os trechos finais, onde ocorre quantidade significativa de acidentes, estão sob influência das obras das marginais, e por esse motivo foram descartados como possíveis trechos para estudo.

Na SP 280, Rodovia Castello Branco, o trecho mais crítico é o início da rodovia, próximo à São Paulo, do km 13 ao km 33, sendo mais acentuado do km 18 ao 20. No entanto, notam-se diversos trechos com frequência persistente de atropelamentos adiante, normalmente associados a adensamentos ou empreendimentos lindeiros à rodovia.

Por fim, foram analisadas as intervenções realizadas pela Concessionária no período recente. A Figura 3-11 a seguir mostra o cronograma de todas as obras programadas nas rodovias sob concessão da ViaOeste, concluídas no período 2005 a 2010.

\begin{tabular}{|c|c|c|c|}
\hline \multirow{2}{*}{ Obra } & \multicolumn{2}{|c|}{ OBRAS PROGRAMADAS } & \multirow{2}{*}{$\begin{array}{l}\text { \% Avanço } \\
\text { Físico }\end{array}$} \\
\hline & Início & Fim & \\
\hline $\begin{array}{l}\text { Implantação do Entroncamento com a Estrada Municipal km } \\
104+130 \text { (antigo km 104+000) - Sorocaba }\end{array}$ & $10 / 01 / 05$ & 29/03/05 & 100,00 \\
\hline $\begin{array}{l}\text { Implantação de Entroncamento com Estrada Municipal km } \\
36+500 \text { - Cotia }\end{array}$ & 01/04/03 & $30 / 06 / 05$ & 100,00 \\
\hline $\begin{array}{l}\text { Implantação de Entroncamento com o Acesso a Caucáia do } \\
\text { Alto km 38+600 (antigo km 38+900) - Cotia }\end{array}$ & $01 / 04 / 03$ & $30 / 06 / 05$ & 100,00 \\
\hline $\begin{array}{l}\text { Melhorias no Dispositivo de Retorno do km 92+500 - } \\
\text { Sorocaba }\end{array}$ & 02/05/05 & $31 / 07 / 05$ & 100,00 \\
\hline $\begin{array}{l}\text { Recapeamento - } 1^{\text {a }} \text { Intervenção Pista Oeste no pavimento } \\
\text { entre os km } 48+000 \text { ao km 79+380 - } 2^{\text {a }} \text { Fase - } \\
\text { Araçariguama/ Itú }\end{array}$ & 01/09/00 & 29/09/05 & 100,00 \\
\hline $\begin{array}{l}\text { Recapeamento - } 2^{\mathrm{a}} \text { Intervenção do km 13+700 ao km } \\
33+000 \text { - Pista Leste e Pista Oeste - Osasco/ Itapevi }\end{array}$ & 01/07/02 & $30 / 12 / 05$ & 100,00 \\
\hline $\begin{array}{l}\text { Implantação de Entroncamento com a Estrada das Lajes } \\
\text { km 42+200 - Vargem Grande Paulista }\end{array}$ & $15 / 04 / 05$ & 29/03/06 & 100,00 \\
\hline Passarela - Implantação km 40+500 - Jardim Elias & $03 / 04 / 06$ & $20 / 09 / 06$ & 100,00 \\
\hline $\begin{array}{l}\text { Duplicação - km 34+000 ao km 45+200 - Sub-trecho1 - } \\
\text { Cotia/ Vargem Grande Paulista }\end{array}$ & 01/08/02 & $30 / 09 / 06$ & 100,00 \\
\hline $\begin{array}{l}\text { Implantação de Entroncamento com a SP } 250 \text { km 45+600 } \\
\text { (antigo km 45+200) - Vargem Grande Paulista }\end{array}$ & 01/07/05 & $30 / 09 / 06$ & 100,00 \\
\hline $\begin{array}{l}\text { Implantação de Ponte Sobre o Rib. V. Grande - km 46+000 - } \\
\text { Vargem Grande Paulista }\end{array}$ & 01/09/05 & $30 / 09 / 06$ & 100,00 \\
\hline $\begin{array}{l}\text { Implantação do Dispositivo Vargem Grande Paulista km } \\
43+700\end{array}$ & 01/09/05 & $30 / 09 / 06$ & 100,00 \\
\hline $\begin{array}{l}\text { Recapeamento - } 2^{\text {a }} \text { Intervenção do km 34+000 ao km } \\
45+200 \text { Pista Leste e Pista Oeste - Cotia/ Vargem Grande } \\
\text { Paulista }\end{array}$ & 01/08/02 & $30 / 09 / 06$ & 100,00 \\
\hline $\begin{array}{l}\text { Drenagem do Córrego Varjão entre o km 69+000 ao km } \\
71+0000\end{array}$ & $30 / 03 / 06$ & 29/03/07 & 100,00 \\
\hline 4 - Faixa - Implantação km 23+000 ao km 26+000 & $10 / 08 / 06$ & $29 / 03 / 07$ & 100,00 \\
\hline $\begin{array}{l}\text { Recapeamento - } 2^{\text {a }} \text { Intervenção do km 53+000 ao km } \\
58+500 \text { Pista Leste e Pista Oeste - São Roque }\end{array}$ & 01/09/05 & 29/03/07 & 100,00 \\
\hline
\end{tabular}


Continuação

\begin{tabular}{|c|c|c|c|}
\hline \multirow{2}{*}{ Obra } & \multicolumn{2}{|c|}{ OBRAS PROGRAMADAS } & \multirow{2}{*}{$\begin{array}{l}\text { \% Avanço } \\
\text { Físico }\end{array}$} \\
\hline & Início & Fim & \\
\hline $\begin{array}{l}\text { Recuperação do Pavimento e Sinalização da Av. dos } \\
\text { Bandeirantes - km 87+200 ao km 89+300 (trecho fora da } \\
\text { Concessão da Viaoeste) }\end{array}$ & $30 / 03 / 07$ & $29 / 06 / 07$ & 100,00 \\
\hline $\begin{array}{l}\text { Duplicação - km 89+300 ao km 90+490 - Sub-trecho } 7 \text { - } \\
\text { Sorocaba }\end{array}$ & $10 / 04 / 06$ & $30 / 06 / 07$ & 100,00 \\
\hline $\begin{array}{l}\text { Implantação da Transposição da linha Férrea da FEPASA } \\
\text { km } 87+200 \text { - Sorocaba }\end{array}$ & $01 / 08 / 06$ & $30 / 06 / 07$ & 100,00 \\
\hline Implantação do Contorno Provisório de Brigadeiro Tobias & $10 / 04 / 06$ & $15 / 07 / 07$ & 100,00 \\
\hline Implantação de Passarela - Brigadeiro Tobias km 88+430 & $30 / 03 / 07$ & $15 / 07 / 07$ & 100,00 \\
\hline $\begin{array}{l}\text { Melhorias das alças do dispositivo de retorno km 58+000 - } \\
\text { São Roque }\end{array}$ & $01 / 12 / 06$ & $29 / 07 / 07$ & 100,00 \\
\hline Implantação de Área de Descanso km 57+000 - São Roque & 01/07/06 & $29 / 07 / 07$ & 100,00 \\
\hline Implantação do Contorno Provisório de São Roque & $01 / 09 / 06$ & $30 / 07 / 07$ & 100,00 \\
\hline $\begin{array}{l}\text { 3's Faixas e Acostamentos - Implantação Pistas Leste e } \\
\text { Oeste }(18082 \mathrm{~m})\end{array}$ & 01/09/04 & $30 / 07 / 07$ & 100,00 \\
\hline $\begin{array}{l}\text { Recapeamento - 2a Intervenção do km 45+200 ao km } \\
\text { 53+000 Pista Leste e Pista Oeste - Vargem Grande } \\
\text { Paulista/ São Roque }\end{array}$ & 01/06/04 & $30 / 07 / 07$ & 100,00 \\
\hline $\begin{array}{l}\text { Recapeamento - } 2^{\mathrm{a}} \text { Intervenção do } \mathrm{km} 63+000 \text { ao km } \\
67+000 \text { Pista Leste e Pista Oeste - São Roque/ Mairinqui }\end{array}$ & 01/09/05 & $30 / 07 / 07$ & 100,00 \\
\hline $\begin{array}{l}\text { Recapeamento - } 2^{\mathrm{a}} \text { Intervenção do km } 67+000 \text { ao km } \\
87+200 \text { Pista Leste e Pista Oeste - Mairinqui/ Sorocaba }\end{array}$ & $15 / 03 / 03$ & $30 / 07 / 07$ & 100,00 \\
\hline $\begin{array}{l}\text { Base Operacional da Polícia Militar Rodoviária - PMRv km } \\
35+700 \text { Pista Oeste - Cotia }\end{array}$ & $01 / 04 / 07$ & $31 / 07 / 07$ & 100,00 \\
\hline $\begin{array}{l}\text { 1 Interv. pavimentos a serem implantados durante a } \\
\text { concessão - Complexo Maria Campos }\end{array}$ & $30 / 06 / 07$ & $30 / 09 / 07$ & 100,00 \\
\hline Passarela - Implantação km 72+600 - Itu & $15 / 05 / 07$ & $15 / 10 / 07$ & 100,00 \\
\hline Melhorias na Estrada do Marmeleiro & $01 / 03 / 07$ & $15 / 10 / 07$ & 100,00 \\
\hline Passarela - Implantação km 40+000 - Santana de Parnaíba & 01/06/07 & $18 / 12 / 07$ & 100,00 \\
\hline $\begin{array}{l}\text { Recapeamento - } 2^{\mathrm{a}} \text { Intervenção no pavimento entre os km } \\
92+000 \text { ao km } 115+500 \text { Pista Leste e Pista Oeste - } \\
\text { Sorocaba/ Araçoiaba da Serra }\end{array}$ & $19 / 04 / 06$ & $18 / 01 / 08$ & 100,00 \\
\hline $\begin{array}{l}\text { Passarela - Implantação km 42+500 - Vargem Grande } \\
\text { Paulista }\end{array}$ & $06 / 11 / 07$ & $29 / 03 / 08$ & 100,00 \\
\hline $\begin{array}{l}\text { Passarela - Implantação km 41+500 - Vargem Grande } \\
\text { Paulista }\end{array}$ & $27 / 08 / 07$ & $31 / 03 / 08$ & 100,00 \\
\hline $\begin{array}{l}\text { Implantação de Entroncamento com a Estrada do } \\
\text { Marmeleiro km } 63+600 \text { (antigo km 63+000) - São Roque }\end{array}$ & $15 / 12 / 06$ & $30 / 01 / 09$ & 100,00 \\
\hline $\begin{array}{l}\text { Melhorias nas interseções em níveis dos km } 50+300, \mathrm{~km} \\
62+800, \mathrm{~km} 65+800 \text { e km } 76+000\end{array}$ & $30 / 03 / 06$ & $29 / 03 / 09$ & 80,00 \\
\hline Melhoria do Pátio de Estacionamento km 74+000 (Fase 01) & $02 / 02 / 08$ & $30 / 07 / 09$ & 100,00 \\
\hline PGF - Implantação km 73+500 Pista Leste & $01 / 04 / 09$ & $30 / 11 / 09$ & 100,00 \\
\hline $\begin{array}{l}\text { Melhoria e Complementação do Dispositivo de Retorno km } \\
76+000 \text { - Itú }\end{array}$ & 01/04/08 & 04/12/09 & 100,00 \\
\hline $\begin{array}{l}\text { Melhorias Viárias na Marginal Tietê - Marginal Esquerda e } \\
\text { Direita }\end{array}$ & $06 / 05 / 09$ & $30 / 12 / 09$ & 100,00 \\
\hline $\begin{array}{l}\text { Complementação da Interseção com o Rodoanel no km } \\
\text { 19+300 (conforme projeto) }\end{array}$ & $22 / 04 / 09$ & $30 / 12 / 09$ & 100,00 \\
\hline $\begin{array}{l}\text { Melhorias no Trevo do km 31+950 - Acesso à Jandira, } \\
\text { Itapevi e Aldeia da Serra }\end{array}$ & $26 / 01 / 09$ & $08 / 02 / 10$ & 100,00 \\
\hline $\begin{array}{l}\text { Acostamento - Melhorias km 45+200 ao km 87+200 (Exceto } \\
\text { Contorno de São Roque) } 34.812 \mathrm{~m} \text { - Vargem Grande } \\
\text { Paulista/ Sorocaba }\end{array}$ & $21 / 07 / 04$ & $29 / 03 / 10$ & 100,00 \\
\hline 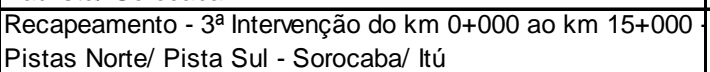 & $01 / 05 / 10$ & $01 / 10 / 10$ & 100,00 \\
\hline 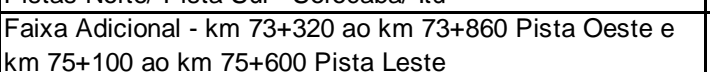 & $01 / 04 / 09$ & $30 / 12 / 10$ & 100,00 \\
\hline
\end{tabular}

Figura 3-11 - Cronograma de obras concluídas de 2005 a 2010 
Os trechos da SP 270, Rodovia Raposo Tavares, passaram por algumas intervenções no período em estudo (2005 a 2010), como pode ser observado na Figura 3-11.

Em 2008 foram realizadas melhorias nas interseções em níveis dos kms 62+800, 65+800 e km 76+000. O principal ganho para os pedestres foi justamente a instalação do dispositivo de proteção, chamados pela concessionária de "bullets", que incluem um refúgio central.

As principais intervenções foram a duplicação do trecho entre Cotia e Vargem Grande Paulista (incluindo passarelas para pedestres), o Contorno Urbano em São Roque e as Marginais nos trechos de Cotia, Vargem Grande e Sorocaba (a duplicação do trecho entre Sorocaba e Araçoiaba da Serra havia sido feita anteriormente). Em 2009 foi implantado também o entroncamento com a Estrada do Marmeleiro no km 63+000, em São Roque.

O trecho estudado da SP 280, Rodovia Castello Branco, do km 28 ao km 30 não sofreu grandes intervenções no período em estudo (2005 a 2010), com exceção dos trevos nos acessos próximos a São Paulo (como o de Jandira). Foram feitas alterações nas Marginais no trecho entre São Paulo e Alphaville, em Barueri (que haviam sido implantadas anteriormente).

Foram implantadas diversas passarelas para pedestres, adiante. Os trechos que deveriam ser estudados inicialmente foram o km 40+000 e o km 72+600 onde foram construídas passarelas, em 2007. Porém, as imagens das câmeras de segurança da concessionária não mostraram as passarelas em questão e foram, portanto, descartadas do estudo.

Com base nesta caracterização preliminar e no histórico de intervenções realizadas, definiu-se a seguinte diretriz para o estudo de campo:

- na SP 270 optou-se por analisar trechos de pista simples que tiveram a implantação de facilidades para travessias de pedestres e/ou ciclistas em nível;

- na SP 280 optou-se por analisar trechos (todos de pista dupla) que apresentaram elevados índices de acidentes;

- em ambos os casos, foram buscados locais que pudessem servir de grupo de comparação pelas características locais similares, mas sem um histórico de acidentes similar. 
Com estes critérios, foram pré-selecionados diversos trechos em ambas as rodovias e iniciouse o contato com a concessionária para obtenção de dados de campo. Em particular, face à disponibilidade de um amplo sistema de monitoração da operação com CFTV, onde seria possível obter imagens em filme da operação regular, decidiu-se por concentrar a observação، nos seguintes trechos: na SP 270, trechos de pista simples no km 60,5 (controle) e km 63; na SP 280, trechos de pista dupla no km 29,5 (controle) e km 30.

A Figura 3-12a relaciona as obras, por ordem, que influenciaram de alguma forma nos trechos estudados da SP 270, Rodovia Raposo Tavares. A Figura 3-12b, por sua vez, lista as obras que influenciaram nos trechos sob análise da SP 280, Rodovia Castello Branco.

a) SP 270

\begin{tabular}{|c|c|c|c|c|}
\hline \multirow{2}{*}{ Rodovia } & \multirow{2}{*}{ Item de Serviço } & \multirow{2}{*}{ Obra } & \multicolumn{2}{|c|}{ OBRAS PROGRAMADAS } \\
\hline & & & Início & Fim \\
\hline SP 270 & 050102020104 & $\begin{array}{l}\text { Recapeamento - } 2^{\mathrm{a}} \text { Intervenção do km 63+000 ao km } \\
67+000 \text { Pista Leste e Pista Oeste - São Roque/ Mairinqui }\end{array}$ & $01 / 09 / 05$ & $30 / 07 / 07$ \\
\hline SP 270 & 02040131 & $\begin{array}{l}\text { Melhorias nas interseções em níveis dos km 50+300, km } \\
62+800, \mathrm{~km} 65+800 \text { e km } 76+000\end{array}$ & $30 / 03 / 06$ & $29 / 03 / 09$ \\
\hline SP 270 & 010504 & Implantação do Contorno Provisório de São Roque & 01/09/06 & $30 / 07 / 07$ \\
\hline SP 270 & 02040108 & \begin{tabular}{|l} 
Implantação de Entroncamento com a Estrada do \\
Marmeleiro km 63+600 (antigo km 63+000) - São Roque
\end{tabular} & $15 / 12 / 06$ & $30 / 01 / 09$ \\
\hline SP 270 & 0204010801 & Melhorias na Estrada do Marmeleiro & $01 / 03 / 07$ & $15 / 10 / 07$ \\
\hline
\end{tabular}

b) SP 280

\begin{tabular}{|c|l|l|c|c|}
\hline \multirow{2}{*}{ Rodovia } & \multirow{2}{*}{ Item de Serviço } & \multicolumn{1}{|c|}{ Obra } & \multicolumn{2}{|c|}{ OBRAS PROGRAMADAS } \\
\cline { 3 - 5 } & & \multicolumn{1}{|c|}{ Início } & Fim \\
\hline SP 075 & 0202010106 & $\begin{array}{l}\text { Praça de Pedágio - Implantação km 12+500 Pista Sul } \\
\text { (antigo km 7+000) - Sorocaba }\end{array}$ & $01 / 04 / 98$ & $30 / 09 / 98$ \\
\hline SP 280 & 020607 & $\begin{array}{l}\text { Faixas de Aceleração/ Desaceleração km 18+000 Pista } \\
\text { Leste (Posto SAU a instalar). Substituída por Faixa de }\end{array}$ & $30 / 03 / 00$ & $29 / 09 / 00$ \\
\hline
\end{tabular}

Figura 3-12 - Cronograma com relação de obras que influenciaram de alguma forma os trechos em estudo

Considera-se que uma influência potencialmente relevante pode ter ocorrido nos trechos selecionados da SP 270. O contorno provisório fica entre os trechos estudados e pode ter efeito reduzido nos locais selecionados, mas o entroncamento com a Estrada do Marmeleiro certamente reduziu o fluxo no km 63 (uma melhor rota que busca o acesso à SP 280). 


\subsection{PREPARAÇÃO DO ESTUDO DE CAMPO}

Esse item apresenta as atividades desenvolvidas na preparação do estudo de campo, a saber:

- coleta de dados dos acidentes;

- filmagem da operação de tráfego no trecho;

- coleta de dados físicos e de tráfego;

- análise das condições locais e dos acidentes.

\subsubsection{Coleta de Dados sobre Acidentes nos Trechos para Estudo}

Nestes trechos selecionados, foi examinada a distribuição dos acidentes de trânsito envolvendo pedestres e ciclistas por dia da semana e por hora do dia, Tabela 3-4 e Tabela 3-6, de forma a garantir a cobertura de filmagens em períodos de maior frequência de acidentes. As Tabelas 3-5 e 3-7 trazem a distribuição dos acidentes por gravidade.

No km 60,5 da SP 270 não houve a ocorrência de acidentes e no km 29,5 ocorreu apenas 1 acidente no período analisado (2005 a 2011). Foram utilizados nesse estudo como controles dos demais kms em cada rodovia.

Com base na distribuição dos acidentes, foram programadas filmagens em um sábado e uma segunda-feira, em 3 períodos cada dia: pico da manhã (06:30 às 07:30), entre pico (12:00 às 13:00) e pico da tarde (18:30 às 19:30), em cada trecho sob análise. 
Tabela 3-4 - SP 270 - Acidentes por dia da semana

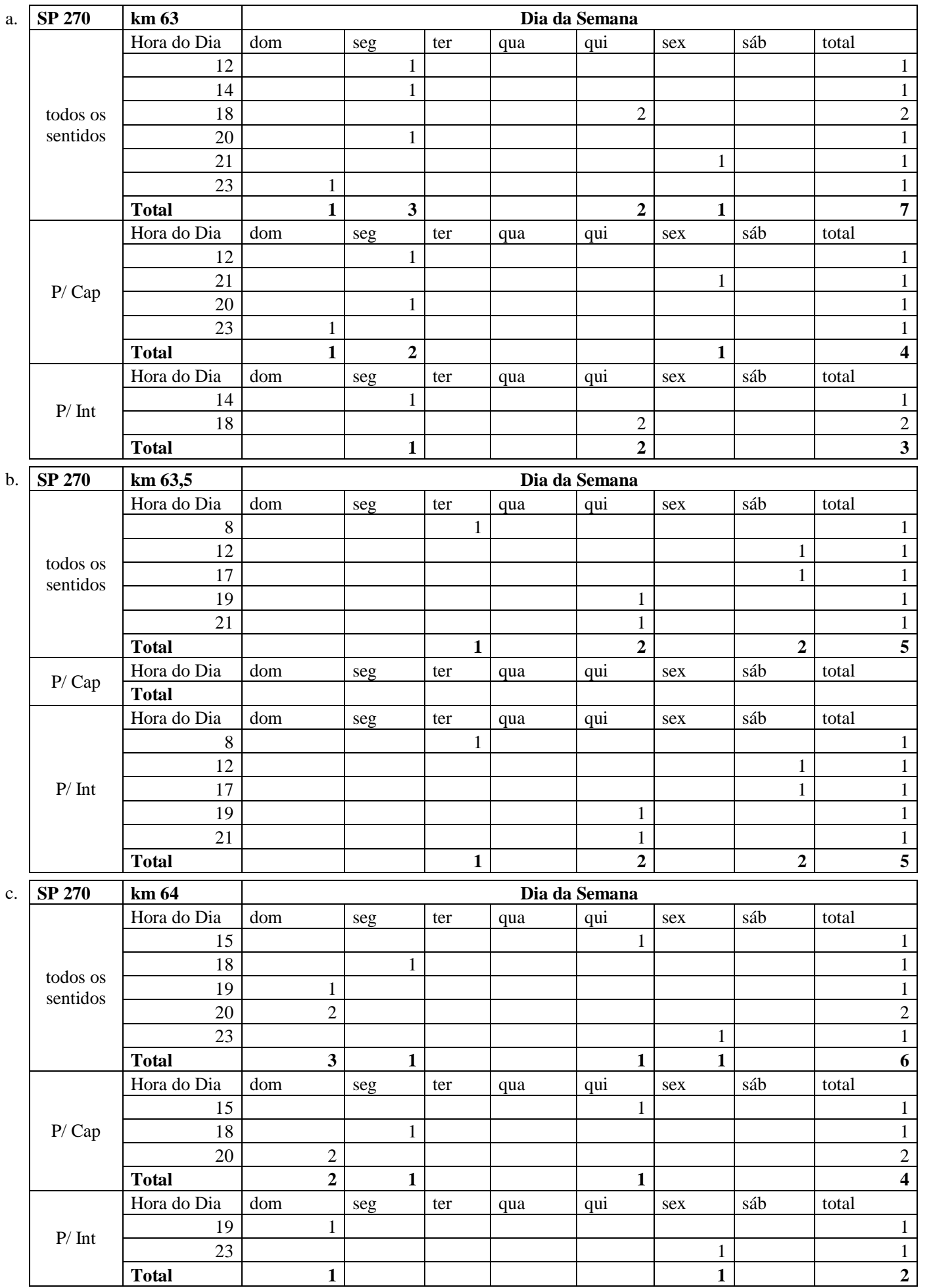


Tabela 3-5 - SP 270 - Acidentes por gravidade

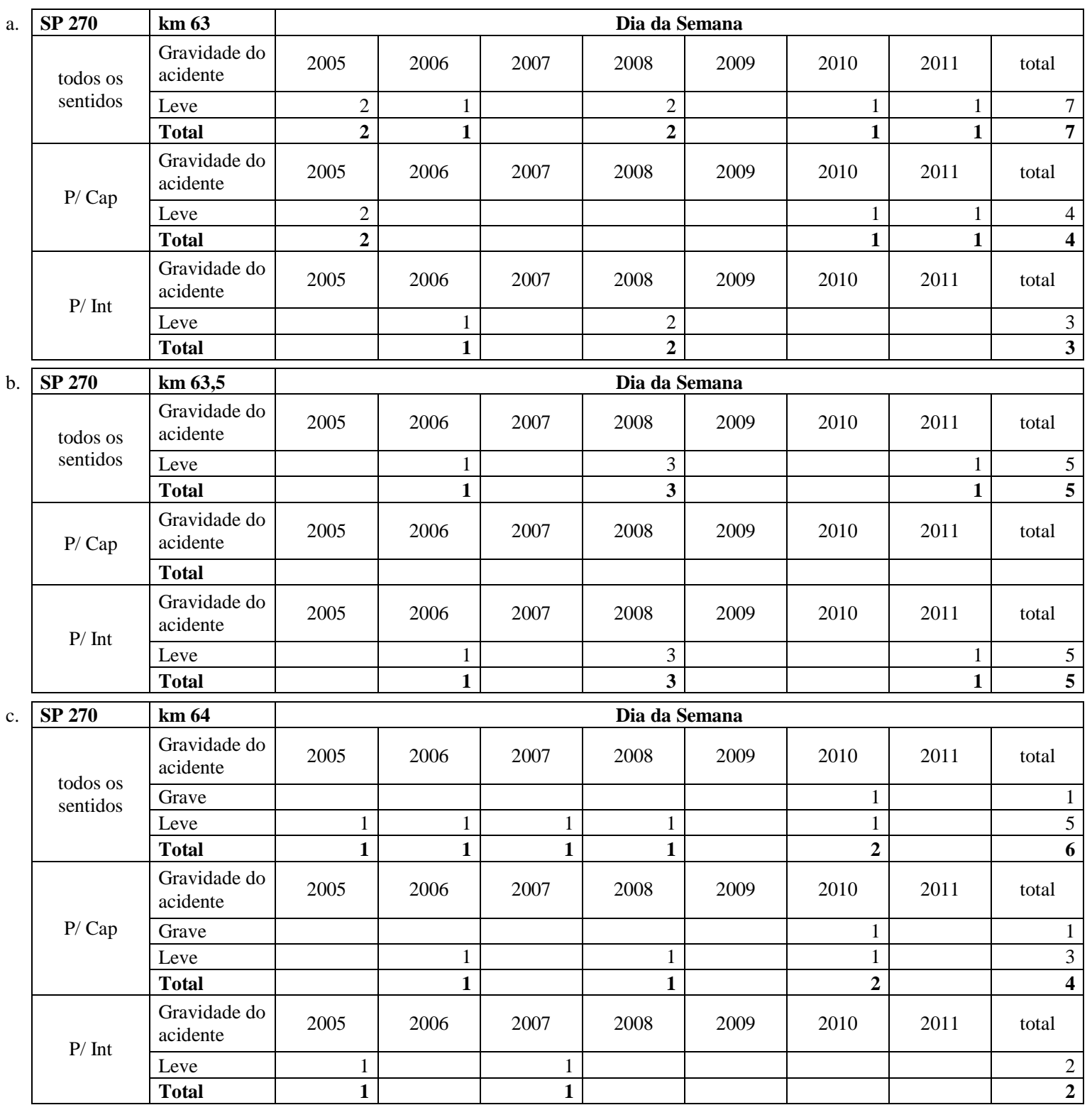


Tabela 3-6 - SP 280 - Acidentes por dia da semana

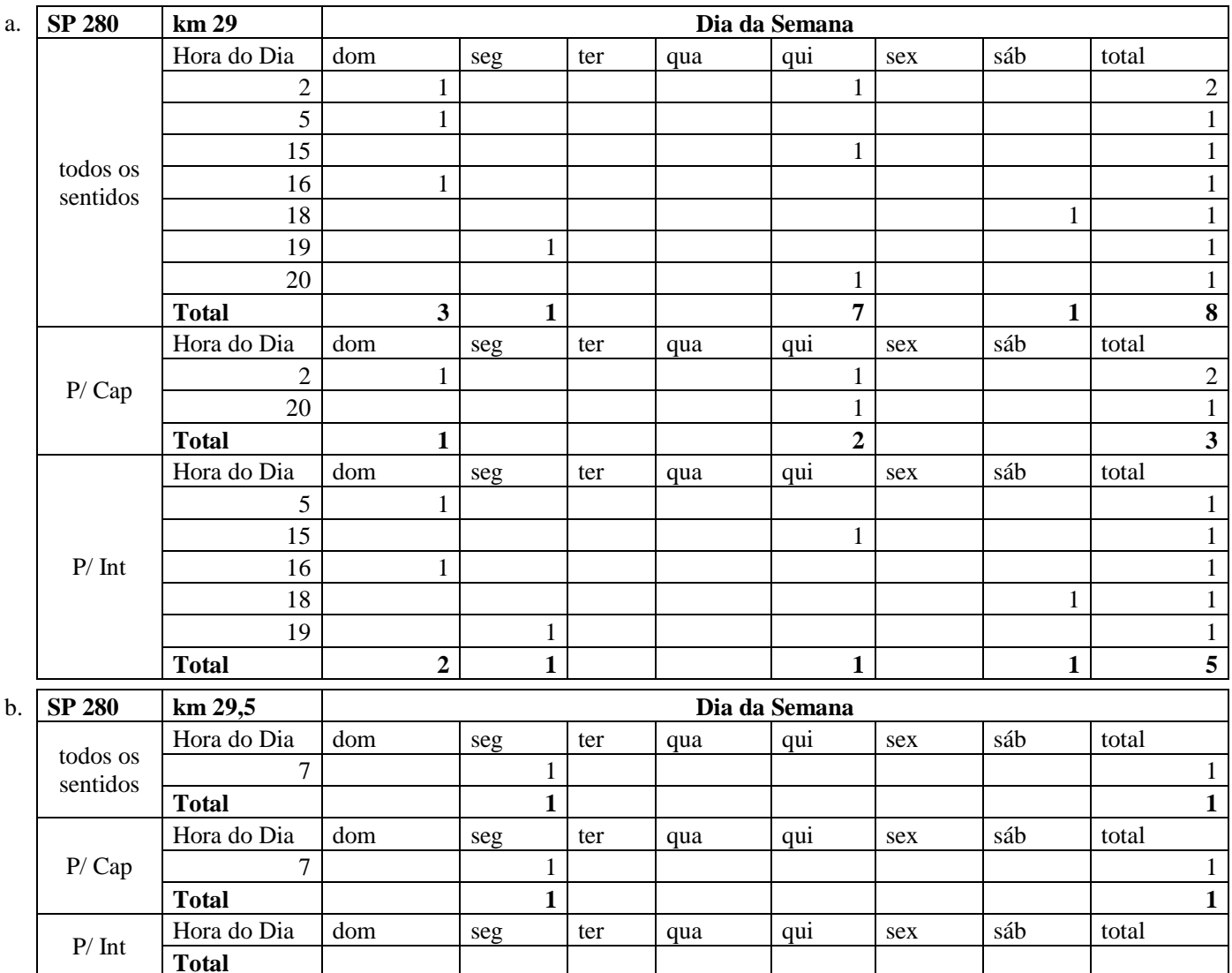

\begin{tabular}{|c|c|c|c|c|c|c|c|c|c|}
\hline SP 280 & km 30 & & & & Dia da & Semana & & & \\
\hline \multirow{11}{*}{$\begin{array}{l}\text { todos os } \\
\text { sentidos }\end{array}$} & Hora do Dia & dom & seg & ter & qua & qui & $\operatorname{sex}$ & sáb & total \\
\hline & 3 & & & & & & 1 & & 1 \\
\hline & 7 & & 1 & & & 2 & & & 3 \\
\hline & 8 & & & 1 & 1 & & & & 2 \\
\hline & 15 & 1 & & & & & & & 1 \\
\hline & 16 & & & 1 & & & & & 1 \\
\hline & 18 & & & 1 & & 2 & 1 & & 4 \\
\hline & 19 & & & & & & & 1 & 1 \\
\hline & 20 & & & & & 1 & & & 1 \\
\hline & 21 & 1 & & & & & & & 1 \\
\hline & Total & 2 & 1 & 3 & 1 & 5 & 2 & 1 & 15 \\
\hline \multirow{9}{*}{ P/ Cap } & Hora do Dia & dom & seg & ter & qua & qui & $\operatorname{sex}$ & sáb & total \\
\hline & 3 & & & & & & 1 & & 1 \\
\hline & 7 & & 1 & & & 2 & & & 3 \\
\hline & 8 & & & & 1 & & & & 1 \\
\hline & 18 & & & & & 1 & & & 1 \\
\hline & 19 & & & & & & & 1 & 1 \\
\hline & 20 & & & & & 1 & & & 1 \\
\hline & 21 & 1 & & & & & & & 1 \\
\hline & Total & 1 & 1 & & 1 & 4 & 1 & 1 & 9 \\
\hline \multirow{6}{*}{$\mathrm{P} /$ Int } & Hora do Dia & dom & seg & ter & qua & qui & sex & sáb & total \\
\hline & 8 & & & 1 & & & & & 1 \\
\hline & 15 & 1 & & & & & & & 1 \\
\hline & 16 & & & 1 & & & & & 1 \\
\hline & 18 & & & 1 & & 1 & 1 & & 3 \\
\hline & Total & 1 & & 3 & & 1 & 1 & & 6 \\
\hline
\end{tabular}


Tabela 3-7 - SP 280 - Acidentes por gravidade

\begin{tabular}{|c|c|c|c|c|c|c|c|c|c|}
\hline SP 280 & km 29 & & & & Dia da & nana & & & \\
\hline \multirow{5}{*}{$\begin{array}{l}\text { todos os } \\
\text { sentidos }\end{array}$} & $\begin{array}{l}\text { Gravidade do } \\
\text { acidente }\end{array}$ & 2005 & 2006 & 2007 & 2008 & 2009 & 2010 & 2011 & total \\
\hline & Fatal & & & & 1 & 1 & & 2 & 4 \\
\hline & Grave & & 1 & & & & 1 & & 2 \\
\hline & Leve & & 1 & & & 1 & & & 2 \\
\hline & Total & & 2 & & 1 & 2 & 1 & 2 & 8 \\
\hline \multirow{3}{*}{ P/ Cap } & $\begin{array}{l}\text { Gravidade do } \\
\text { acidente }\end{array}$ & 2005 & 2006 & 2007 & 2008 & 2009 & 2010 & 2011 & total \\
\hline & Fatal & & & & 1 & 1 & & 1 & 3 \\
\hline & Total & & & & 1 & 1 & & 1 & 3 \\
\hline \multirow{5}{*}{$\mathrm{P} / \mathrm{Int}$} & $\begin{array}{l}\text { Gravidade do } \\
\text { acidente }\end{array}$ & 2005 & 2006 & 2007 & 2008 & 2009 & 2010 & 2011 & total \\
\hline & Fatal & & & & & & & 1 & 1 \\
\hline & Grave & & 1 & & & & 1 & & 2 \\
\hline & Leve & & 1 & & & 1 & & & 2 \\
\hline & Total & & 2 & & & 1 & 1 & & 5 \\
\hline
\end{tabular}

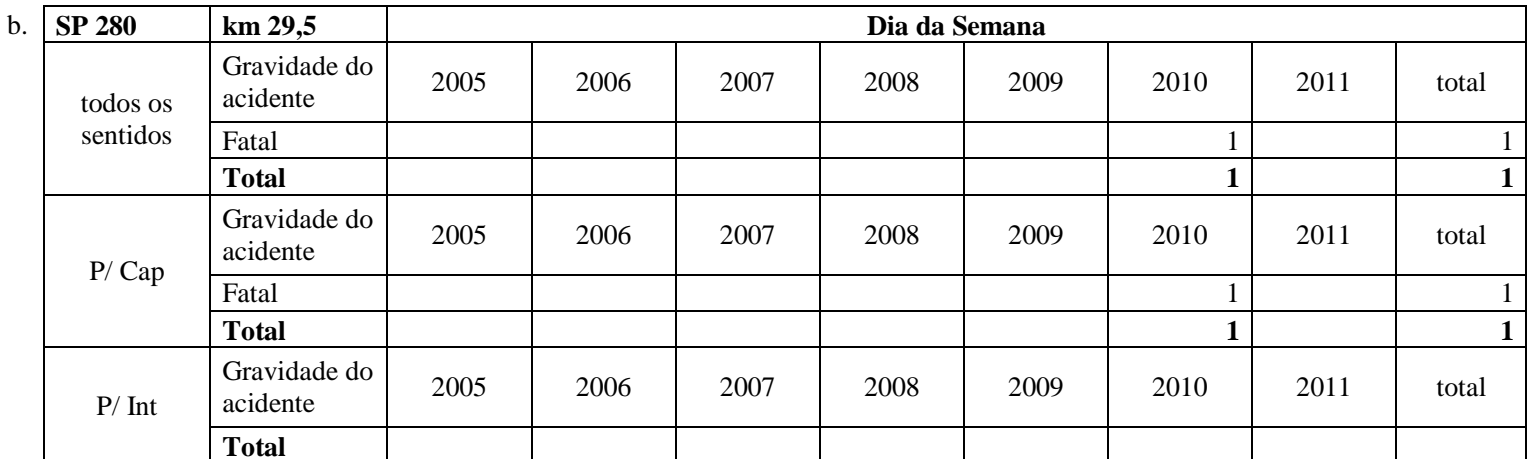

\begin{tabular}{|c|c|c|c|c|c|c|c|c|c|}
\hline SP 280 & km 30 & & & & Dia da $S$ & tana & & & \\
\hline \multirow{6}{*}{$\begin{array}{l}\text { todos os } \\
\text { sentidos }\end{array}$} & $\begin{array}{l}\text { Gravidade do } \\
\text { acidente }\end{array}$ & 2005 & 2006 & 2007 & 2008 & 2009 & 2010 & 2011 & total \\
\hline & Fatal & & & & 2 & & 1 & & 3 \\
\hline & Grave & & & 1 & 1 & & & 1 & 3 \\
\hline & Moderado & & & & & & & 3 & 3 \\
\hline & Leve & & 1 & 2 & 1 & 1 & & 1 & 6 \\
\hline & Total & & 1 & 3 & 4 & 1 & 1 & 5 & 15 \\
\hline \multirow{6}{*}{ P/ Cap } & $\begin{array}{l}\text { Gravidade do } \\
\text { acidente }\end{array}$ & 2005 & 2006 & 2007 & 2008 & 2009 & 2010 & 2011 & total \\
\hline & Fatal & & & & 1 & & 1 & & 2 \\
\hline & Grave & & & & & & & 1 & 1 \\
\hline & Moderado & & & & & & & 3 & 3 \\
\hline & Leve & & 1 & 1 & & & & 1 & 3 \\
\hline & Total & & 1 & 1 & 1 & & 1 & 5 & 9 \\
\hline \multirow{5}{*}{$\mathrm{P} / \mathrm{Int}$} & $\begin{array}{l}\text { Gravidade do } \\
\text { acidente }\end{array}$ & 2005 & 2006 & 2007 & 2008 & 2009 & 2010 & 2011 & total \\
\hline & Fatal & & & & 1 & & & & 1 \\
\hline & Grave & & & 1 & 1 & & & & 2 \\
\hline & Leve & & & 1 & 1 & 1 & & & 3 \\
\hline & Total & & & 2 & 3 & 1 & & & 6 \\
\hline
\end{tabular}




\subsubsection{Coleta de Dados sobre Operação nos Trechos para Estudo}

Nesse item primeiramente é apresentada a descrição geral de cada trecho estudado, e são então apresentados os dados básicos de operação nos trechos obtidos através da análise dos vídeos, conforme segue:

- Quantidade de veículos leves;

- Quantidade de veículos pesados;

- Quantidade de motos;

- Quantidade de ciclistas (ao longo da via e atravessando)

- Quantidade de pedestres (ao longo da via e atravessando)

- Velocidade veicular.

a. Descrição dos trechos

- km 60,5 da SP 270:

A Figura 3-13a mostra a imagem aérea do trecho em questão. A Figura 3-13b mostra a imagem da câmera de monitoração da concessionária, das imagens utilizadas nesse trabalho.

A Figura 3-14 mostra detalhes do trecho, sentido interior e sentido SP. O trecho é caracterizado por elevado fluxo de pedestres, devido à presença de pontos de ônibus em ambos os sentidos da rodovia, como pode ser observado.

A área lindeira é ocupada por bairros residenciais em ambos os sentidos e uma fábrica de móveis de escritório no sentido São Paulo. 
a. Imagem aérea

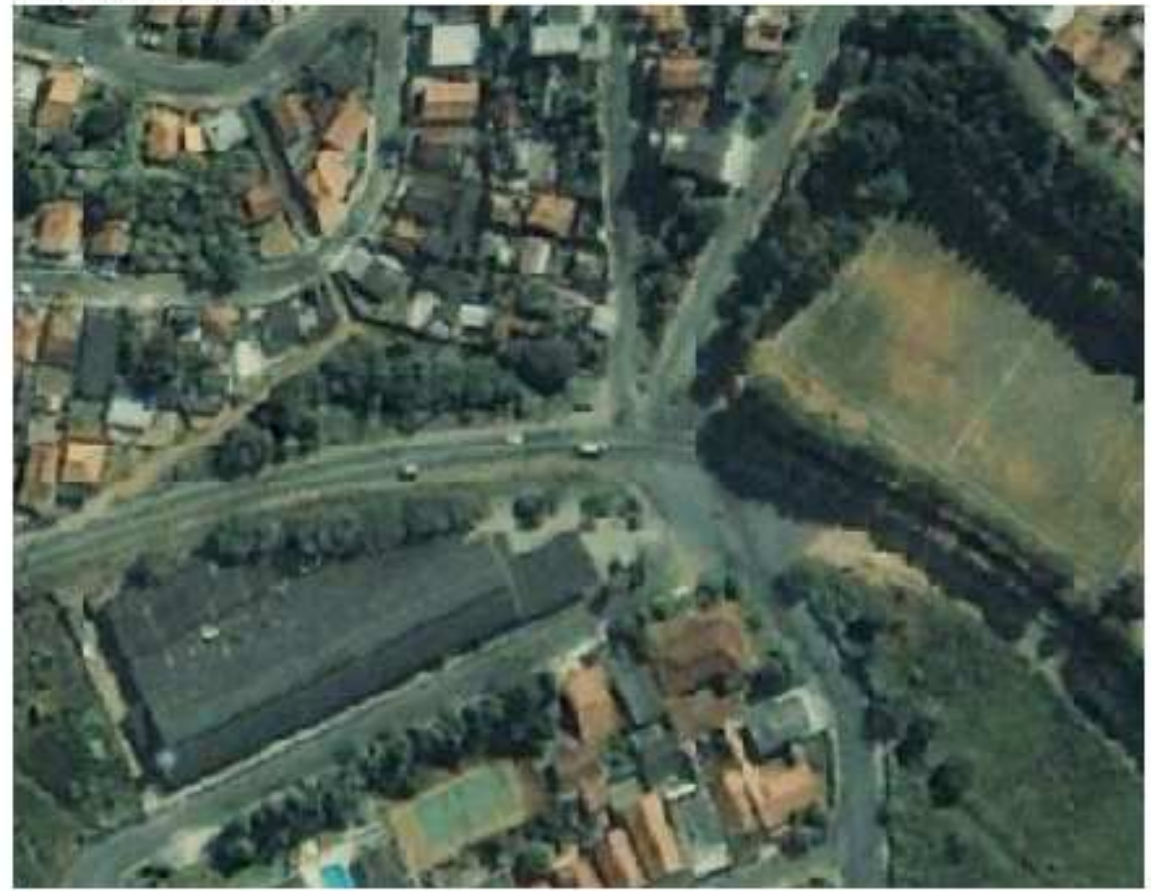

b. Câmera de segurança da concessionária

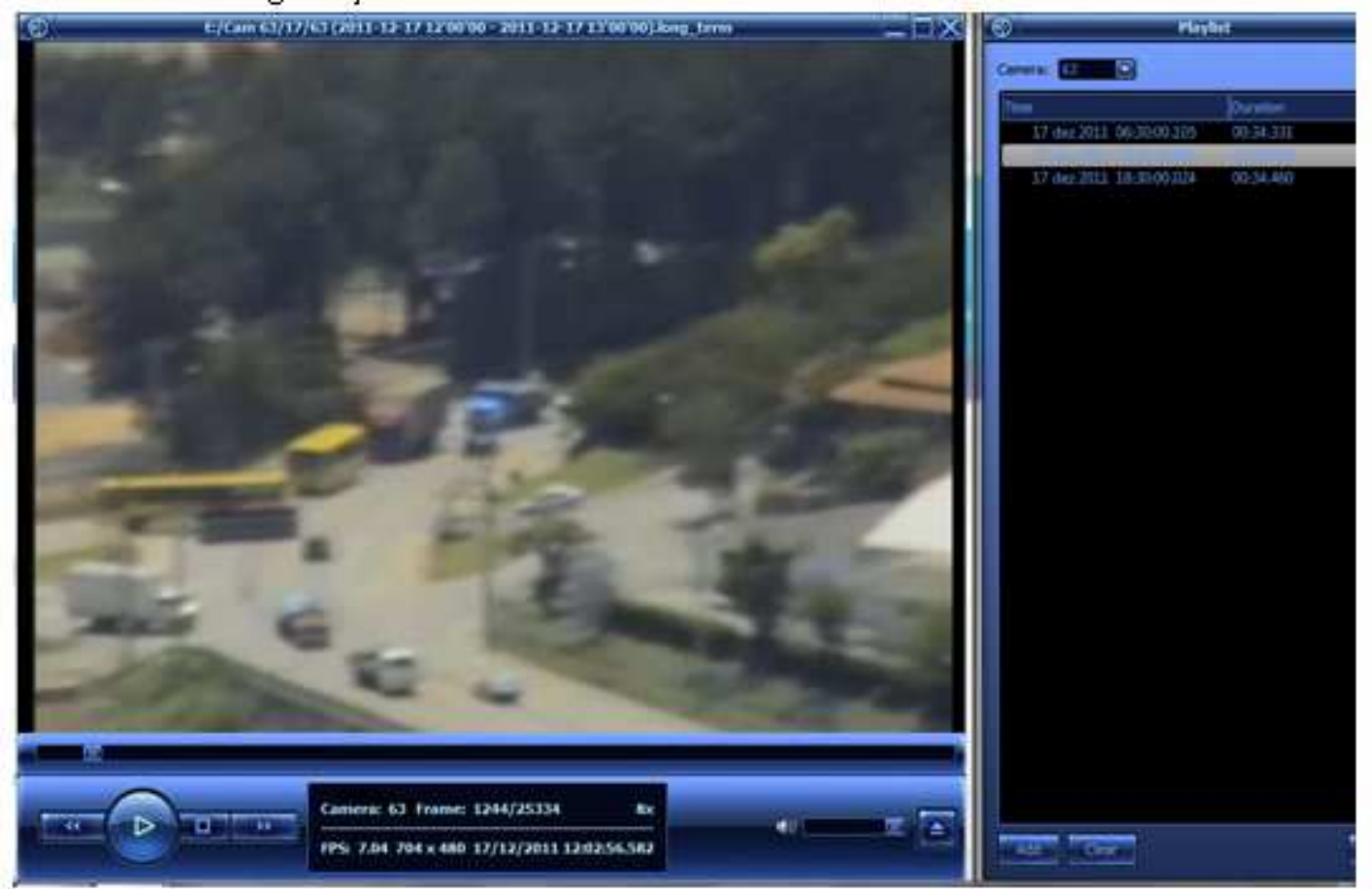

Figura 3-13 - km 60,5 da SP 270, imagem aérea (Google Earth) e câmera de segurança da concessionária 
a. Visão geral pontos de ônibus
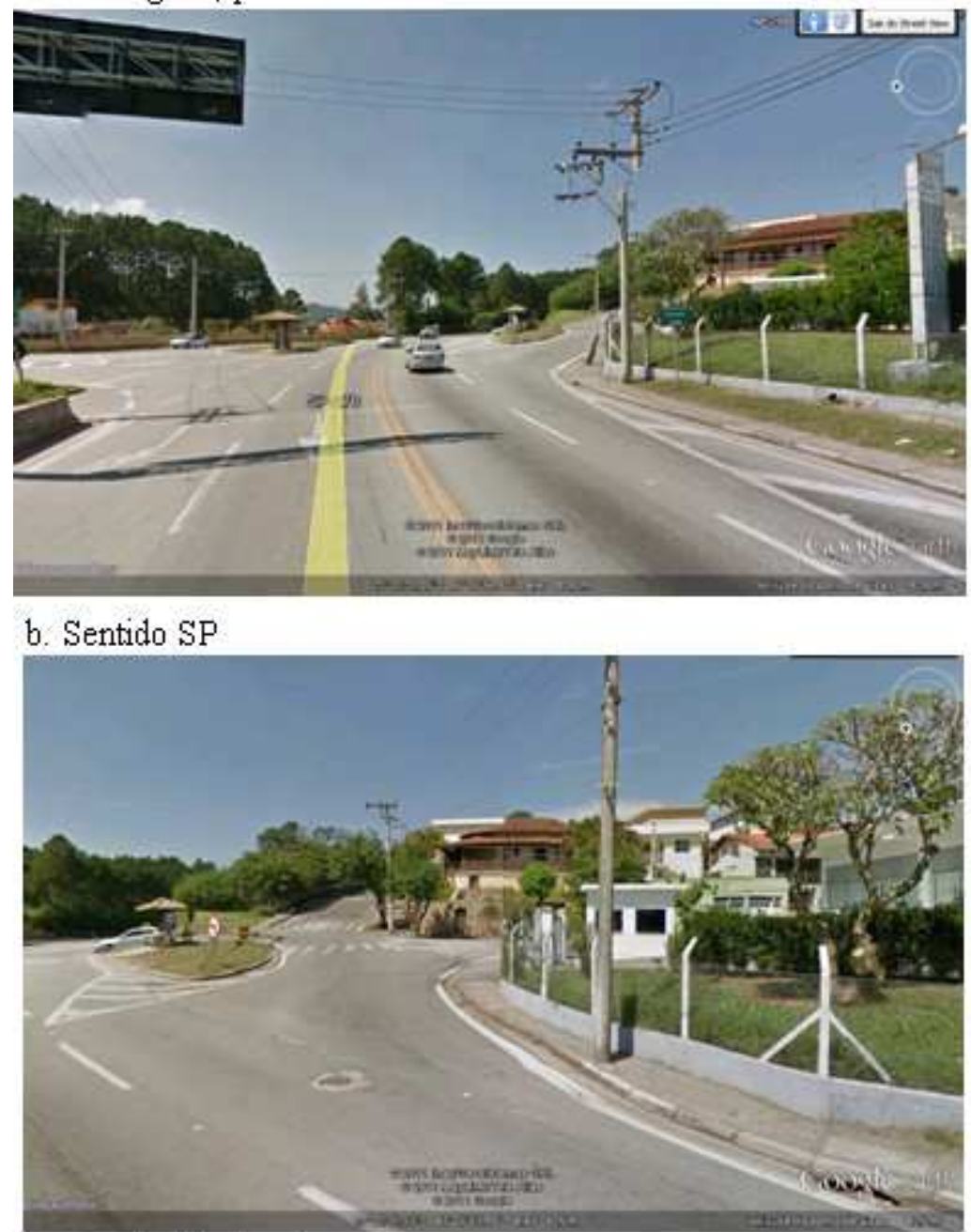

c. Sentido Interior

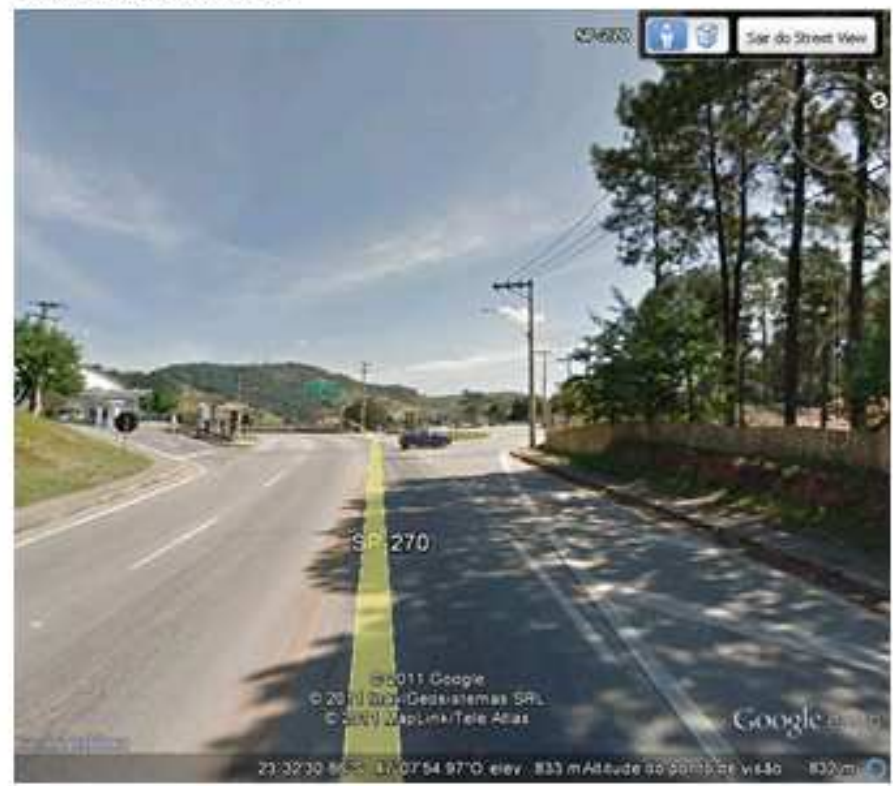

Figura 3-14 - km 60,5 da SP 270, detalhes (Street View - Google Earth) 
- km 63 da SP 270:

Esse trecho é caracterizado pela alta interferência urbana nas áreas lindeiras, tendo bairros mistos (residenciais e comerciais) em ambos os sentidos da rodovia. A Figura 3-15a mostra a vista aérea do local e a Figura 3-15b a imagem da câmera de monitoração da concessionária.

São utilizados dispositivos de travessia, como ilhas de refúgio, a fim de dividir a travessia, que pode ser realizada em um sentido de cada vez. A Figura 3-16 mostra fotos do local.

a. Imagem aérea

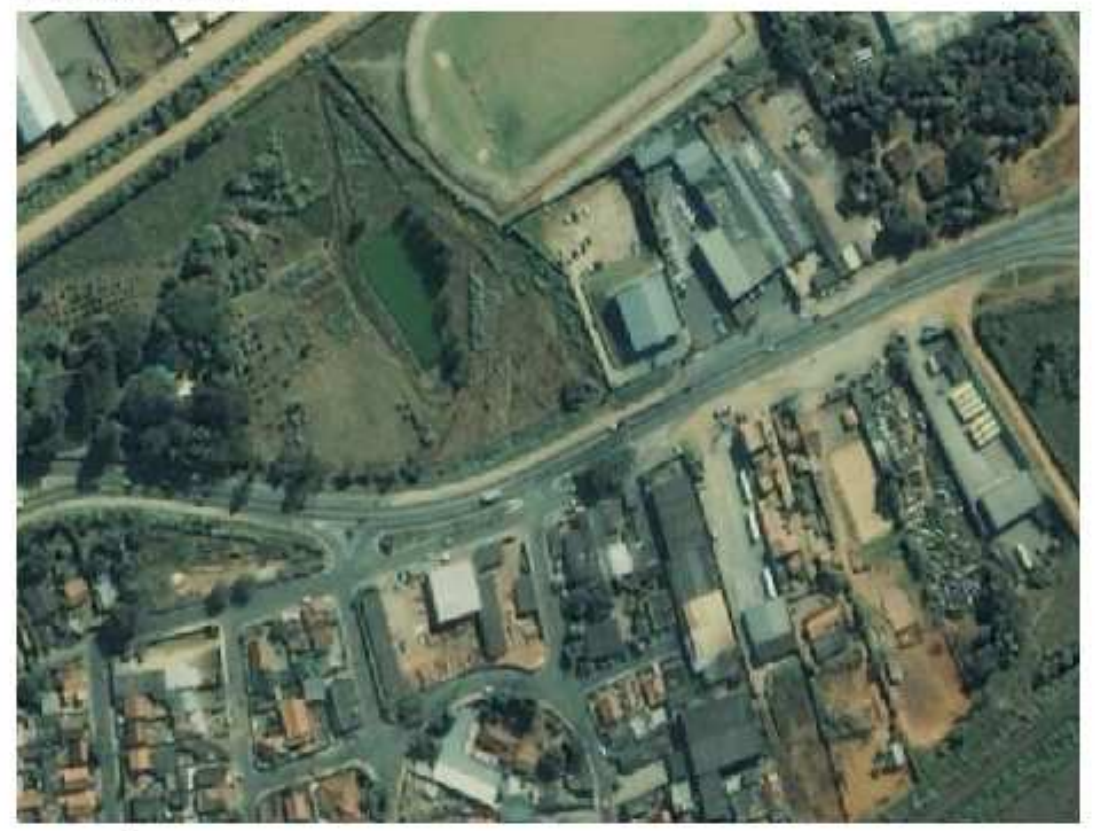

b. Câmera de Segurança

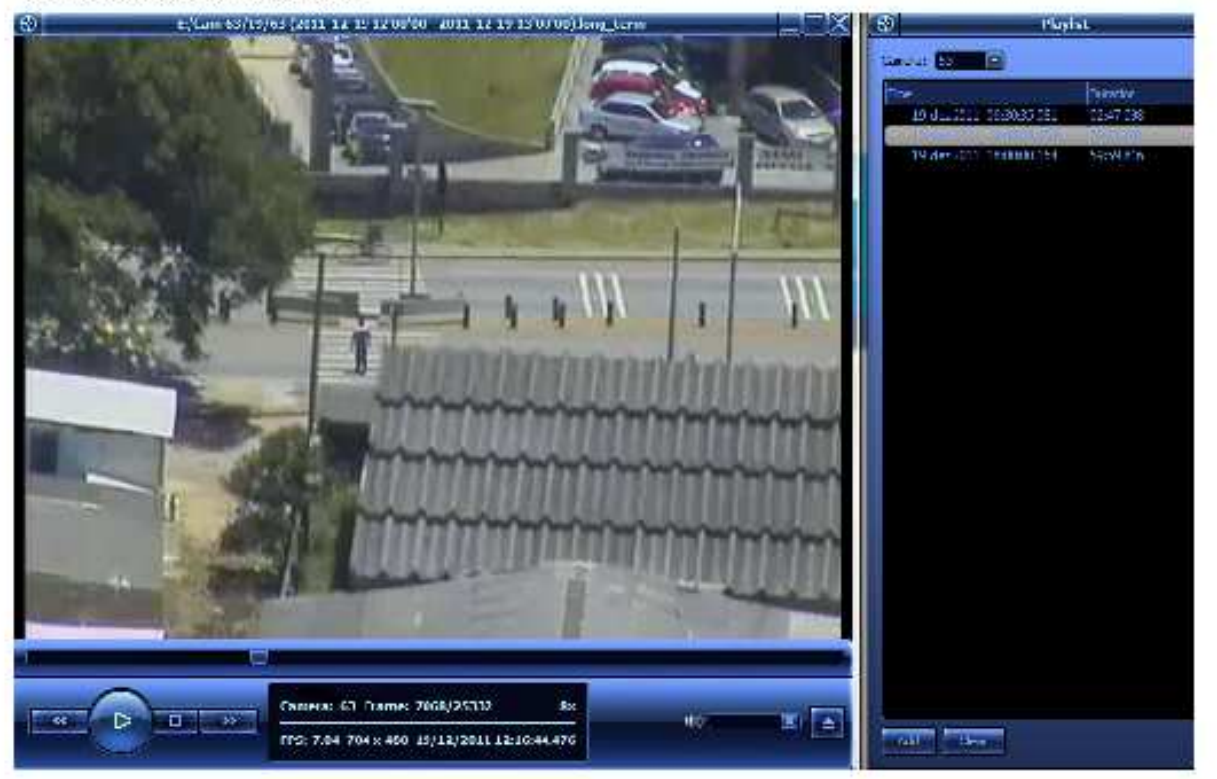

Figura 3-15 - km 63 da SP 270, imagem aérea (Google Earth) e câmera de segurança da concessionária 
a. Sentido SP

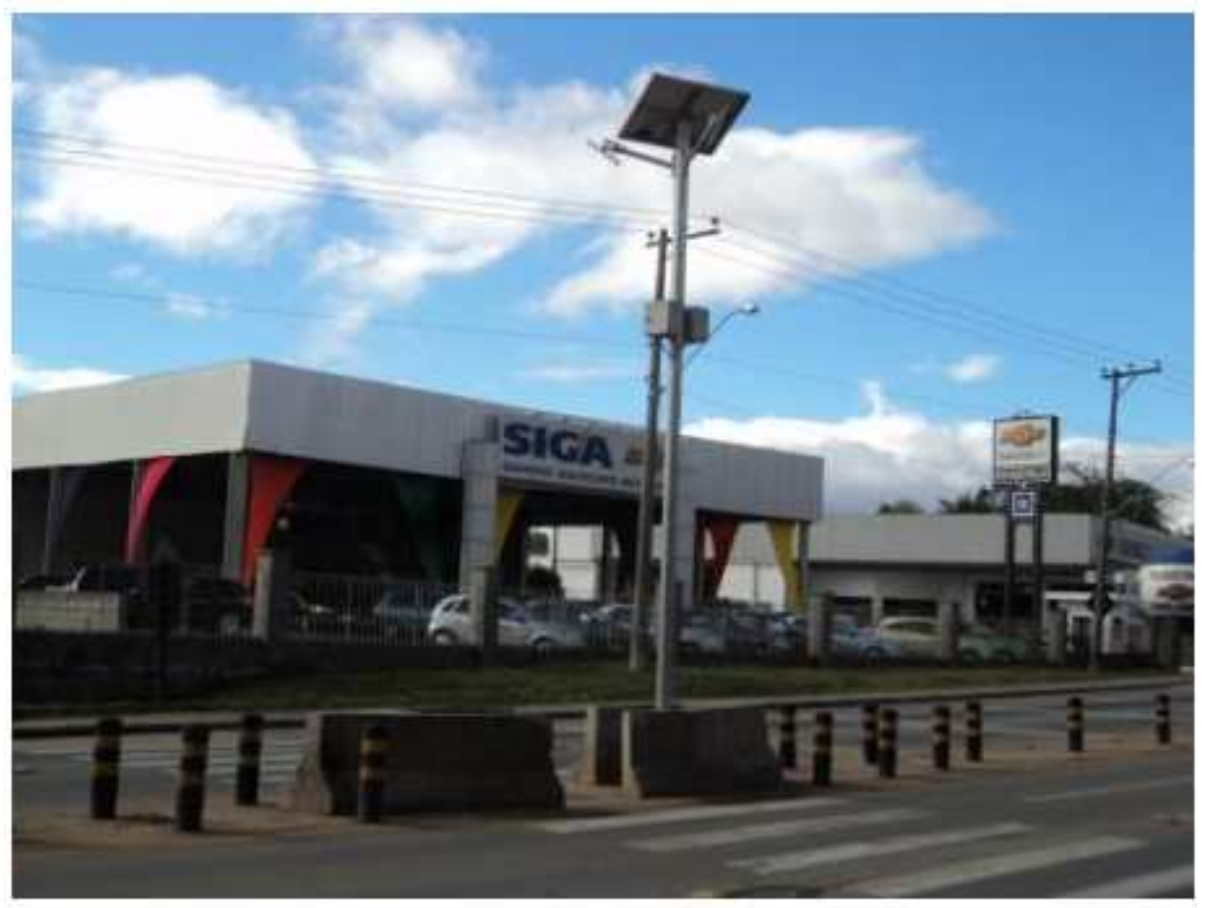

b. Dispositivo de proteção

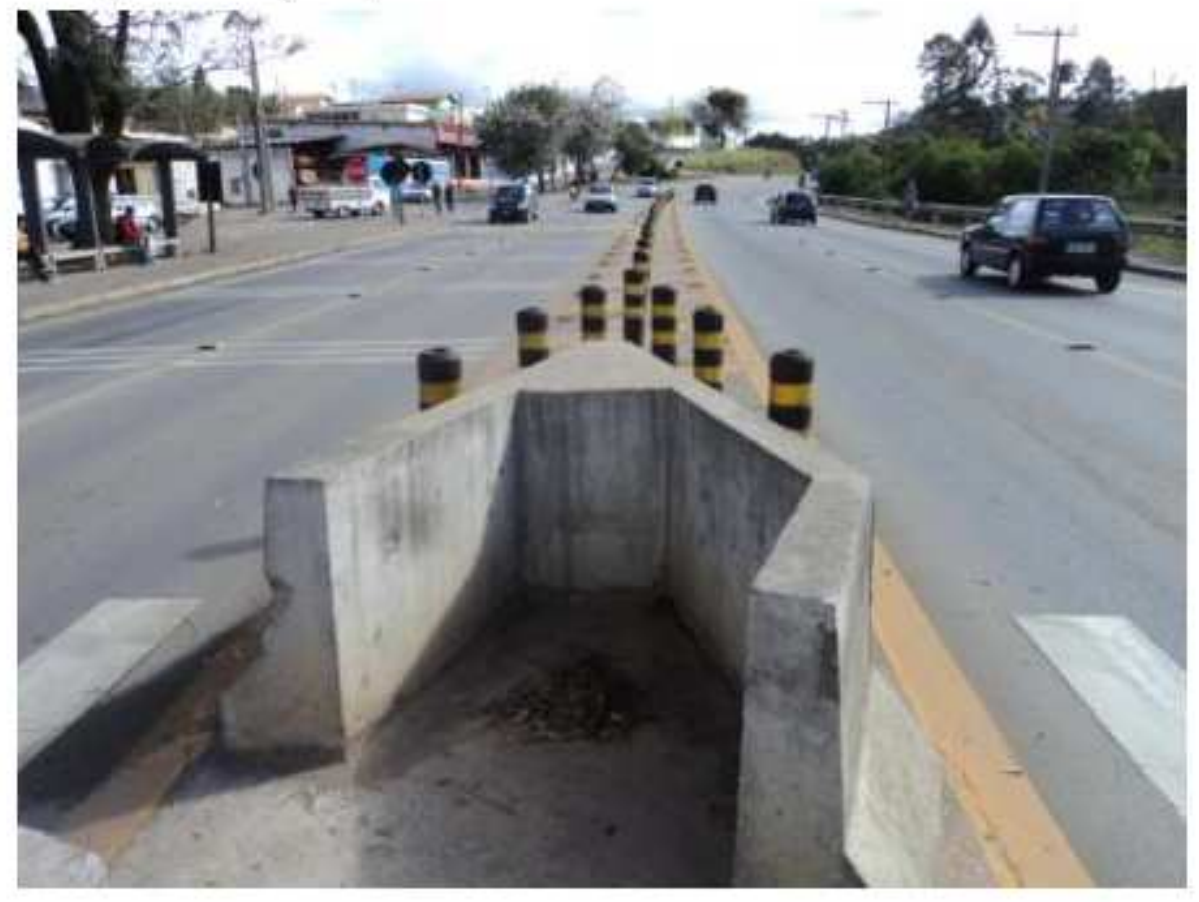

Figura 3-16 - km 63,5, detalhes 
- km 29,5 da SP 280:

O km 29,5, utilizado nesse trabalho como controle, é caracterizado pelo alto fluxo de veículos, principalmente nos períodos de pico da manhã e da tarde. Tem a área adjacente da pista sentido SP ocupada por fábricas, sem ocupação na área adjacente da pista sentido interior, como pode ser visto nas Figuras 3-17.

A Figura 3-18 mostra os detalhes do trecho, sentido SP e sentido interior.
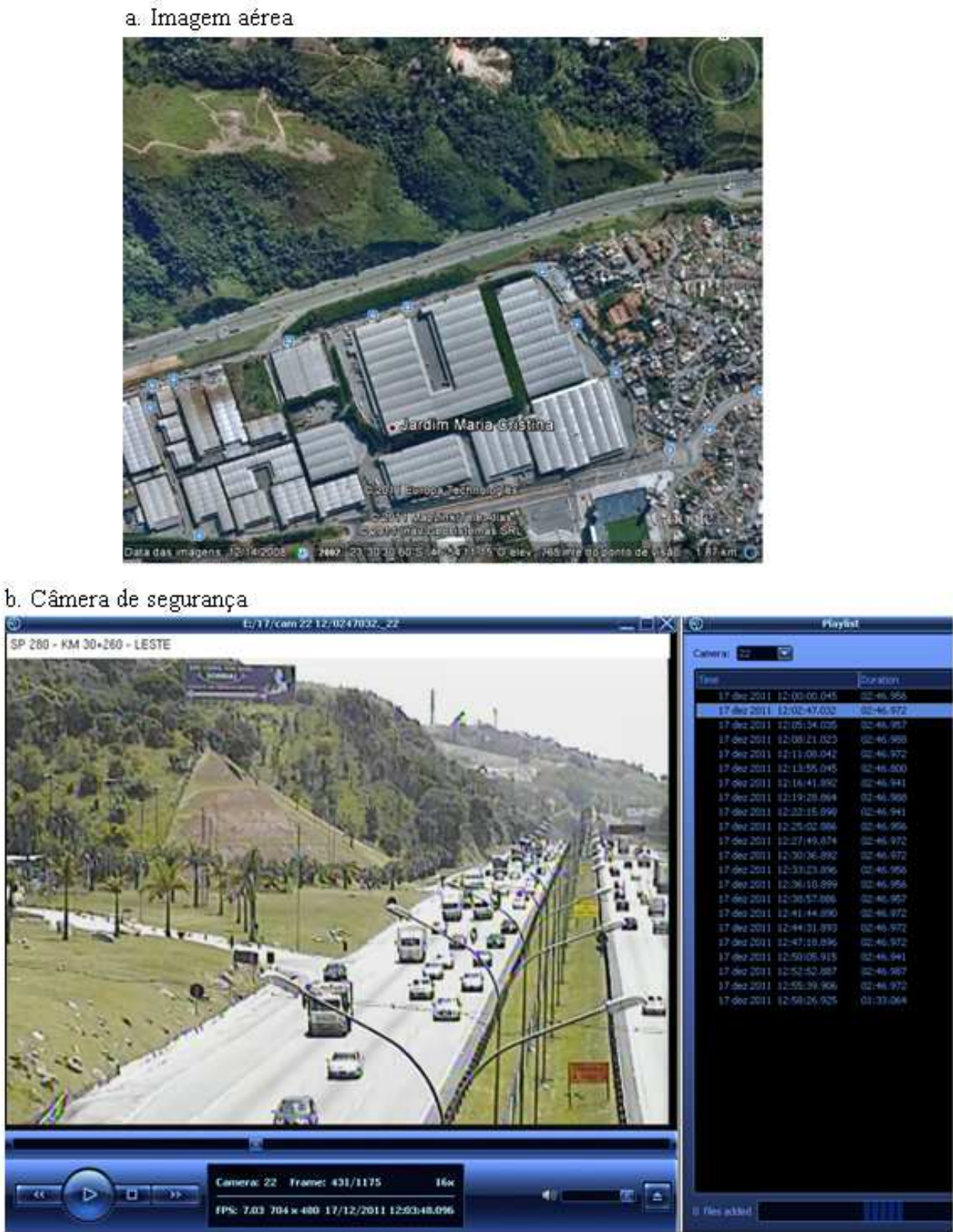

Figura 3-17 - km 29,5 da SP 280, imagem aérea (Google Earth) e câmera de segurança da concessionária 
a. Sentido interior

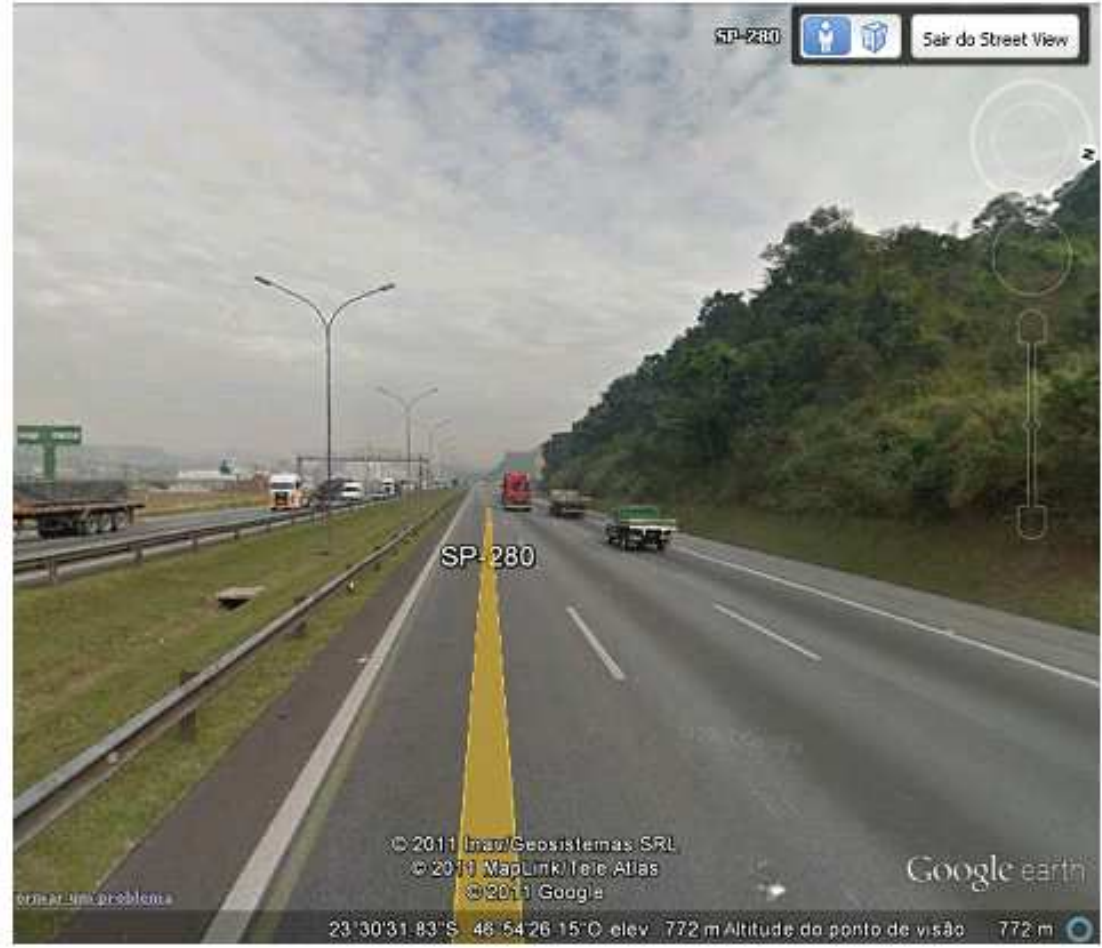

b. Sentido SP

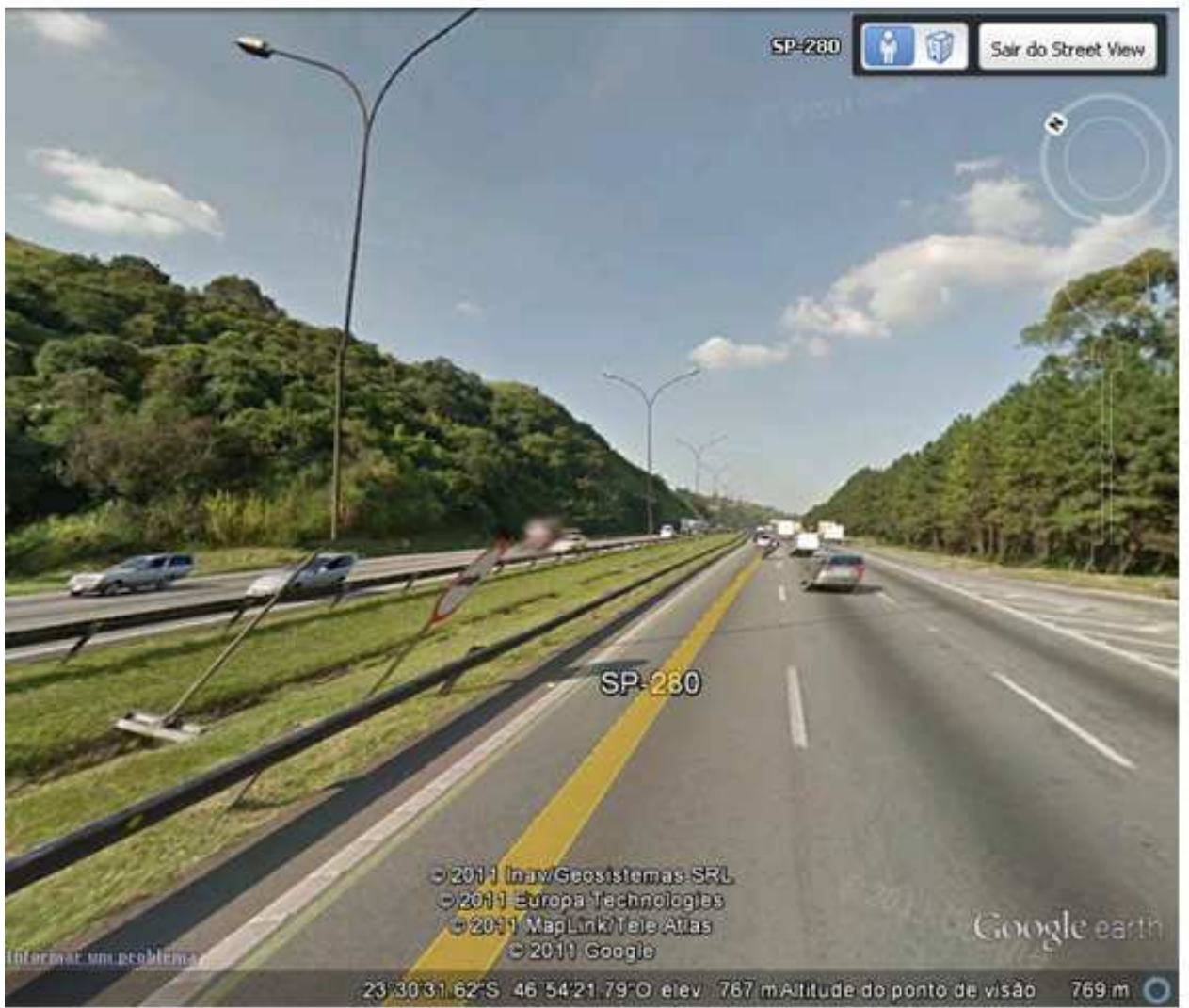

Figura 3-18 - km 29,5 da SP 280, detalhes (Street View - Google Earth) 
- km 30 da SP 280:

O km 30 da SP 280 tem elevado fluxo de veículos, tanto no sentido SP como no sentido interior. As áreas adjacentes são ocupadas, tendo um posto de serviços na pista sentido interior e um fábrica grande de produtos químicos na pista sentido SP. A Figura 3-19 mostra a imagem aérea da região e da câmera de segurança da concessionária.

A Figuras 3-20 mostra os detalhes do trecho.

a. Imagem aérea

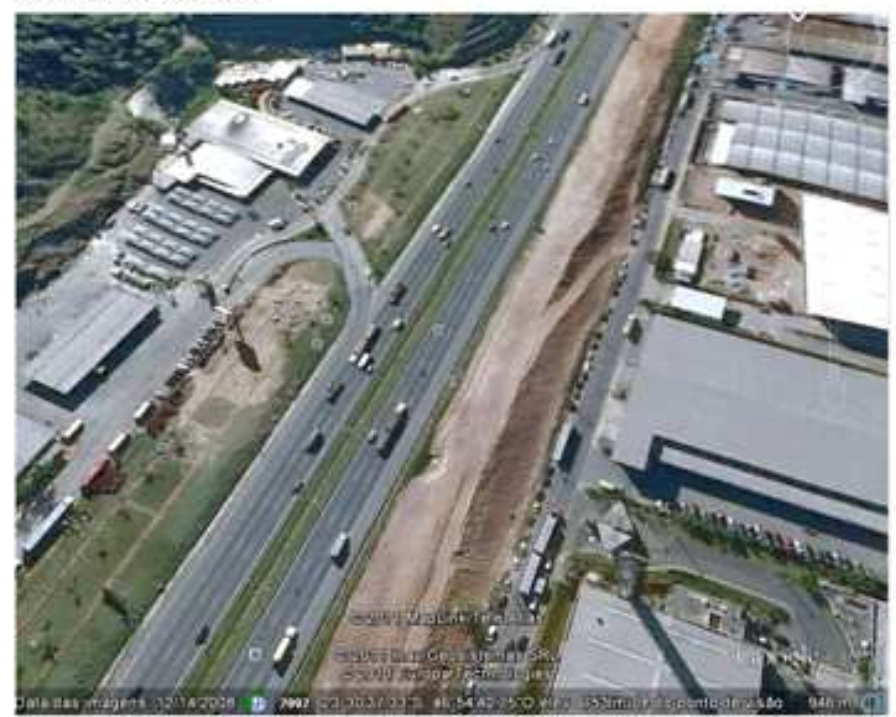

b. Câmera de segurança

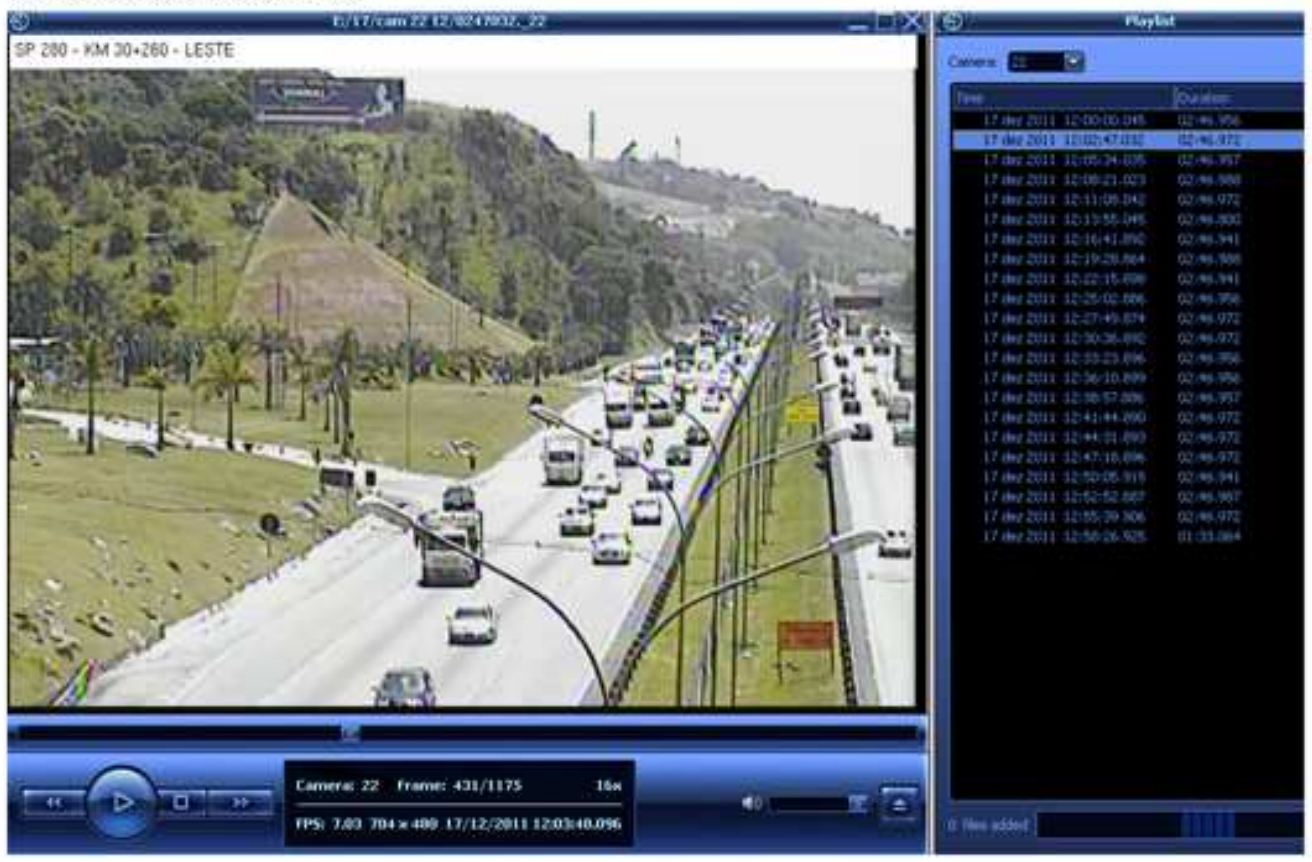

Figura 3-19 - km 30 da SP 280, imagem aérea (Google Earth) e câmera de segurança da concessionária 
a. Sentido interior

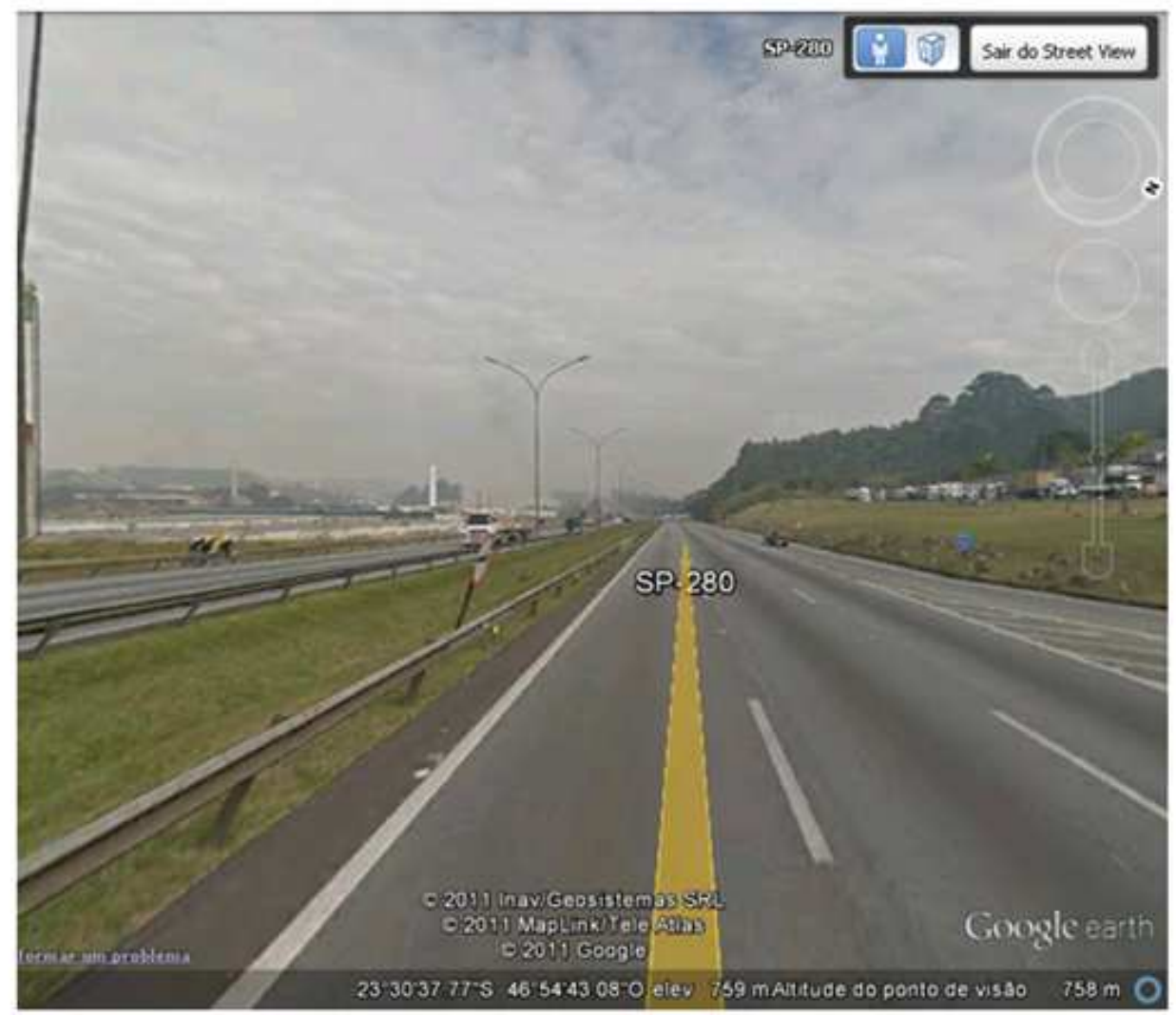

b. Sentido SP

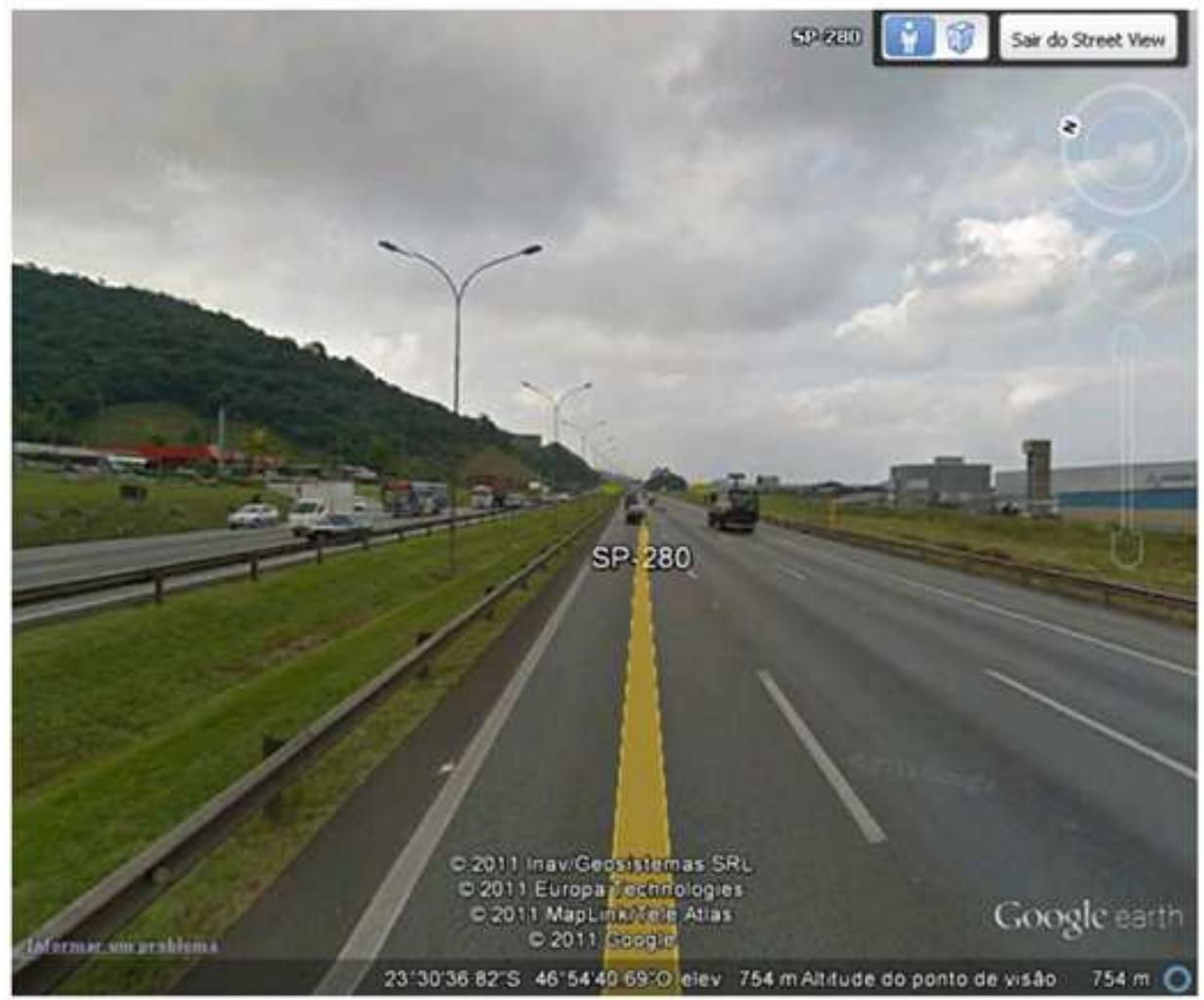

Figura 3-20 - km 30 da SP 280, detalhes (Street View - Google Earth) 
b. Resumo dos dados operacionais básicos

Nesse item são apresentados resumidamente os dados básicos de tráfego obtidos a partir do processamento das imagens das câmeras de segurança fornecidas pela concessionária.

No anexo A são apresentadas as planilhas utilizadas para esse levantamento, contendo as contagens feitas a cada 5 minutos de gravação.

No km 63 da SP 270, Rodovia Raposo Tavares, a filmagem do período da manhã apresentou problema e portanto não pode ser analisada. No período da tarde, a câmera estava posicionada bem distante da rodovia, e portanto foi possível realizar as contagens de tráfego, mas não foi possível identificar pedestres e ciclistas.

Foi levantada a composição do tráfego (quantidade de veículos leves, quantidade de veículos pesados e quantidade de motos), a velocidade de cada categoria, e os movimentos de pedestres e ciclistas, ao longo da via (no canteiro central ou nas laterais), e atravessando a via. 
- km 60,5 da SP 270:

Tabela 3-8 - Dados básicos de operação km 60,5 da SP 270

\begin{tabular}{|c|c|c|c|c|c|c|}
\hline \multirow{2}{*}{\multicolumn{2}{|c|}{ SP 270 - $\operatorname{lm} 60,5$}} & \multicolumn{2}{|c|}{ Sentido } & & \multicolumn{2}{|c|}{ Sentido } \\
\hline & & \multirow{2}{*}{$\begin{array}{c}\text { Int (O) } \\
213\end{array}$} & \multirow{2}{*}{$\frac{\mathbf{S P}(\mathbf{L})}{170}$} & & Int (O) & SP $(L)$ \\
\hline \multirow{4}{*}{$\begin{array}{c}06: 30- \\
07: 30\end{array}$} & Passeio (veículos/hora) & & & Ciclista ao longo da via (ciclistas/hora) & 0 & 3 \\
\hline & Comercial (veículos/hora) & 48 & 48 & Ciclista atravessando a via (ciclistas/hora) & 0 & 0 \\
\hline & Moto (veículos/hora) & 21 & 14 & Pedestre ao longo da via (pedestres/hora) & 13 & 15 \\
\hline & Velocidade $(\mathrm{km} / \mathrm{h})-(+/-15 \%)$ & 41 & 39 & Pedestre atravessando a via (pedestres/hora) & 22 & 19 \\
\hline \multirow{4}{*}{$\begin{array}{l}12: 00- \\
13: 00\end{array}$} & Passeio (veículos/hora) & 506 & 469 & Ciclista ao longo da via (ciclistas/hora) & 0 & 2 \\
\hline & Comercial (veículos/hora) & 60 & 45 & Ciclista atravessando a via (ciclistas/hora) & 0 & 0 \\
\hline & Moto (veículos/hora) & 36 & 48 & Pedestre ao longo da via (pedestres/hora) & 8 & 7 \\
\hline & Velocidade $(\mathrm{km} / \mathrm{h})-(+/-15 \%)$ & 40 & 32 & Pedestre atravessando a via (pedestres/hora) & 16 & 9 \\
\hline \multirow{4}{*}{$\begin{array}{l}18: 30- \\
19: 30\end{array}$} & Passeio (veículos/hora) & 377 & 419 & Ciclista ao longo da via (ciclistas/hora) & 1 & 0 \\
\hline & Comercial (veículos/hora) & 30 & 27 & Ciclista atravessando a via (ciclistas/hora) & 0 & 0 \\
\hline & Moto (veículos/hora) & 25 & 30 & Pedestre ao longo da via (pedestres/hora) & 8 & 7 \\
\hline & Velocidade $(\mathrm{km} / \mathrm{h})-(+/-15 \%)$ & 39 & 35 & Pedestre atravessando a via (pedestres/hora) & 16 & 17 \\
\hline
\end{tabular}

- km 63 da SP 270:

Tabela 3-9 - Dados básicos de operação km 63 da SP 270

\begin{tabular}{|c|c|c|c|c|c|c|}
\hline \multirow{2}{*}{\multicolumn{2}{|c|}{ SP 270 - $\operatorname{lm} 63$}} & \multicolumn{2}{|c|}{ Sentido } & & \multicolumn{2}{|c|}{ Sentido } \\
\hline & & \multirow{2}{*}{$\frac{\operatorname{Int}(\mathbf{O})}{-}$} & \multirow{2}{*}{$\frac{\mathbf{S P}(\mathrm{L})}{-}$} & & Int $(O)$ & SP $(\mathbf{L})$ \\
\hline \multirow{4}{*}{$\begin{array}{c}06: 30- \\
07: 30\end{array}$} & Passeio (veículos/hora) & & & Ciclista ao longo da via (ciclistas/hora) & - & - \\
\hline & Comercial (veículos/hora) & - & - & Ciclista atravessando a via (ciclistas/hora) & - & - \\
\hline & Moto (veículos/hora) & - & - & Pedestre ao longo da via (pedestres/hora) & - & - \\
\hline & Velocidade $(\mathrm{km} / \mathrm{h})-(+/-15 \%)$ & - & - & Pedestre atravessando a via (pedestres/hora) & - & - \\
\hline \multirow{4}{*}{$\begin{array}{l}12: 00- \\
13: 00\end{array}$} & Passeio (veículos/hora) & 489 & 517 & Ciclista ao longo da via (ciclistas/hora) & 3 & 0 \\
\hline & Comercial (veículos/hora) & 82 & 58 & Ciclista atravessando a via (ciclistas/hora) & 0 & 0 \\
\hline & Moto (veículos/hora) & 60 & 64 & Pedestre ao longo da via (pedestres/hora) & 24 & 10 \\
\hline & Velocidade $(\mathrm{km} / \mathrm{h})-(+/-15 \%)$ & 52 & 47 & Pedestre atravessando a via (pedestres/hora) & 3 & 9 \\
\hline \multirow{4}{*}{$\begin{array}{l}18: 30- \\
19: 30\end{array}$} & Passeio (veículos/hora) & 835 & 726 & Ciclista ao longo da via (ciclistas/hora) & - & - \\
\hline & Comercial (veículos/hora) & 45 & 42 & Ciclista atravessando a via (ciclistas/hora) & - & - \\
\hline & Moto (veículos/hora) & 90 & 51 & Pedestre ao longo da via (pedestres/hora) & - & - \\
\hline & Velocidade $(\mathrm{km} / \mathrm{h})-(+/-15 \%)$ & 48 & 46 & Pedestre atravessando a via (pedestres/hora) & - & - \\
\hline
\end{tabular}


- km 29,5 da SP 280:

Tabela 3-10 - Dados básicos de operação km 29,5 da SP 280

\begin{tabular}{|c|c|c|c|c|c|c|}
\hline \multirow{2}{*}{\multicolumn{2}{|c|}{ SP 280 - $\operatorname{lm} 29,5$}} & \multicolumn{2}{|c|}{ Sentido } & & \multicolumn{2}{|c|}{ Sentido } \\
\hline & & \multirow{2}{*}{$\frac{\text { Int }(\mathbf{O})}{1331}$} & \multirow{2}{*}{$\frac{\mathbf{S P}(\mathbf{L})}{1608}$} & & Int $(0)$ & SP (L) \\
\hline \multirow{4}{*}{$\begin{array}{c}\text { 06:30- } \\
07: 30\end{array}$} & Passeio (veículos/hora) & & & Ciclista ao longo da via (ciclistas/hora) & 0 & 1 \\
\hline & Comercial (veículos/hora) & 733 & 717 & Ciclista atravessando a via (ciclistas/hora) & 0 & 0 \\
\hline & Moto (veículos/hora) & 104 & 102 & Pedestre ao longo da via (pedestres/hora) & 0 & 2 \\
\hline & Velocidade $(\mathrm{km} / \mathrm{h})-(+/-15 \%)$ & 88 & 56 & Pedestre atravessando a via (pedestres/hora) & 0 & 0 \\
\hline \multirow{4}{*}{$\begin{array}{l}\text { 12:00- } \\
13: 00\end{array}$} & Passeio (veículos/hora) & 4772 & 2681 & Ciclista ao longo da via (ciclistas/hora) & 0 & 0 \\
\hline & Comercial (veículos/hora) & 698 & 847 & Ciclista atravessando a via (ciclistas/hora) & 0 & 0 \\
\hline & Moto (veículos/hora) & 205 & 138 & Pedestre ao longo da via (pedestres/hora) & 4 & 1 \\
\hline & Velocidade $(\mathrm{km} / \mathrm{h})-(+/-15 \%)$ & 78 & 64 & Pedestre atravessando a via (pedestres/hora) & 0 & 0 \\
\hline \multirow{4}{*}{$\begin{array}{l}18: 30- \\
19: 30\end{array}$} & Passeio (veículos/hora) & 2452 & 4717 & Ciclista ao longo da via (ciclistas/hora) & 0 & 0 \\
\hline & Comercial (veículos/hora) & 691 & 956 & Ciclista atravessando a via (ciclistas/hora) & 0 & 0 \\
\hline & Moto (veículos/hora) & 153 & 121 & Pedestre ao longo da via (pedestres/hora) & 0 & 1 \\
\hline & Velocidade $(\mathrm{km} / \mathrm{h})-(+/-15 \%)$ & 80 & 34 & Pedestre atravessando a via (pedestres/hora) & 0 & 0 \\
\hline
\end{tabular}

- km 30 da SP 280:

Tabela 3-11 - Dados básicos de operação km 30 da SP 280

\begin{tabular}{|c|c|c|c|c|c|c|}
\hline \multirow{2}{*}{\multicolumn{2}{|c|}{ SP 280 - $\operatorname{lm} 30$}} & \multicolumn{2}{|c|}{ Sentido } & & \multicolumn{2}{|c|}{ Sentido } \\
\hline & & \multirow{2}{*}{$\begin{array}{c}\text { Int }(\mathbf{O}) \\
1331 \\
\end{array}$} & \multirow{2}{*}{$\begin{array}{c}\text { SP (L) } \\
1608\end{array}$} & & Int (O) & SP $(\mathbf{L})$ \\
\hline \multirow{4}{*}{$\begin{array}{c}06: 30- \\
07: 30\end{array}$} & Passeio (veículos/hora) & & & Ciclista ao longo da via (ciclistas/hora) & 0 & 1 \\
\hline & Comercial (veículos/hora) & 733 & 717 & Ciclista atravessando a via (ciclistas/hora) & 0 & 0 \\
\hline & Moto (veículos/hora) & 104 & 102 & Pedestre ao longo da via (pedestres/hora) & 5 & 3 \\
\hline & Velocidade $(\mathrm{km} / \mathrm{h})-(+/-15 \%)$ & 88 & 56 & Pedestre atravessando a via (pedestres/hora) & 1 & 3 \\
\hline \multirow{4}{*}{$\begin{array}{l}12: 00- \\
13: 00\end{array}$} & Passeio (veículos/hora) & 4772 & 2681 & Ciclista ao longo da via (ciclistas/hora) & 0 & 0 \\
\hline & Comercial (veículos/hora) & 698 & 847 & Ciclista atravessando a via (ciclistas/hora) & 0 & 0 \\
\hline & Moto (veículos/hora) & 205 & 138 & Pedestre ao longo da via (pedestres/hora) & 6 & 1 \\
\hline & Velocidade $(\mathrm{km} / \mathrm{h})-(+/-15 \%)$ & 78 & 64 & Pedestre atravessando a via (pedestres/hora) & 4 & 2 \\
\hline \multirow{4}{*}{$\begin{array}{l}18: 30- \\
19: 30\end{array}$} & Passeio (veículos/hora) & 2452 & 4717 & Ciclista ao longo da via (ciclistas/hora) & 1 & 0 \\
\hline & Comercial (veículos/hora) & 691 & 956 & Ciclista atravessando a via (ciclistas/hora) & 0 & 0 \\
\hline & Moto (veículos/hora) & 153 & 121 & Pedestre ao longo da via (pedestres/hora) & 4 & 0 \\
\hline & Velocidade $(\mathrm{km} / \mathrm{h})-(+/-15 \%)$ & 80 & 34 & Pedestre atravessando a via (pedestres/hora) & 2 & 2 \\
\hline
\end{tabular}




\subsubsection{Análise das Condições Locais e dos Acidentes nos Trechos para Estudo}

A seguir são apresentados os diagramas de condição inicial dos trechos em estudo, $\mathrm{km}$ 60,5 e km 63 da SP 270 e km 29,5 e km 30 da SP 280. O atendimento às condições de projeto é também analisado, com atenção particular ao impacto de intervenções ocorridas no período.

a. Análise das Condições Locais

A Figura 3-21a mostra o trecho do km 60,5 da SP 270. Trata-se de um trecho com 1 faixa de tráfego veicular por sentido, sem acostamento. Há pontos de ônibus de ambos os lados, assim como baias de ônibus. Cerca de $50 \mathrm{~m}$ de cada lado há lombadas, que provocam a redução da velocidade dos veículos, gerando mais oportunidades de travessia para os pedestres no local. Nos trechos após a lombada, são 2 faixas de rolamento por sentido e acostamento, sendo que no sentido São Paulo há calçada para os pedestres que se deslocam ao longo da via antes e depois do trecho em questão, e no sentido interior há calçada apenas no trecho antes da lombada (para quem vai sentido interior).

A Figura 3-21b traz o diagrama de condição inicial do km 63 da SP 270. Nesse trecho são 2 faixas por sentido, sem acostamento, com calçada para pedestres que se deslocam ao longo da via em ambos os sentidos. No centro da pista, dividindo os dois sentidos do fluxo veicular, há o dispositivo de proteção para facilitar a travessia dos pedestres. 
a. Diagrama de condição local - SP 270, km 60,5

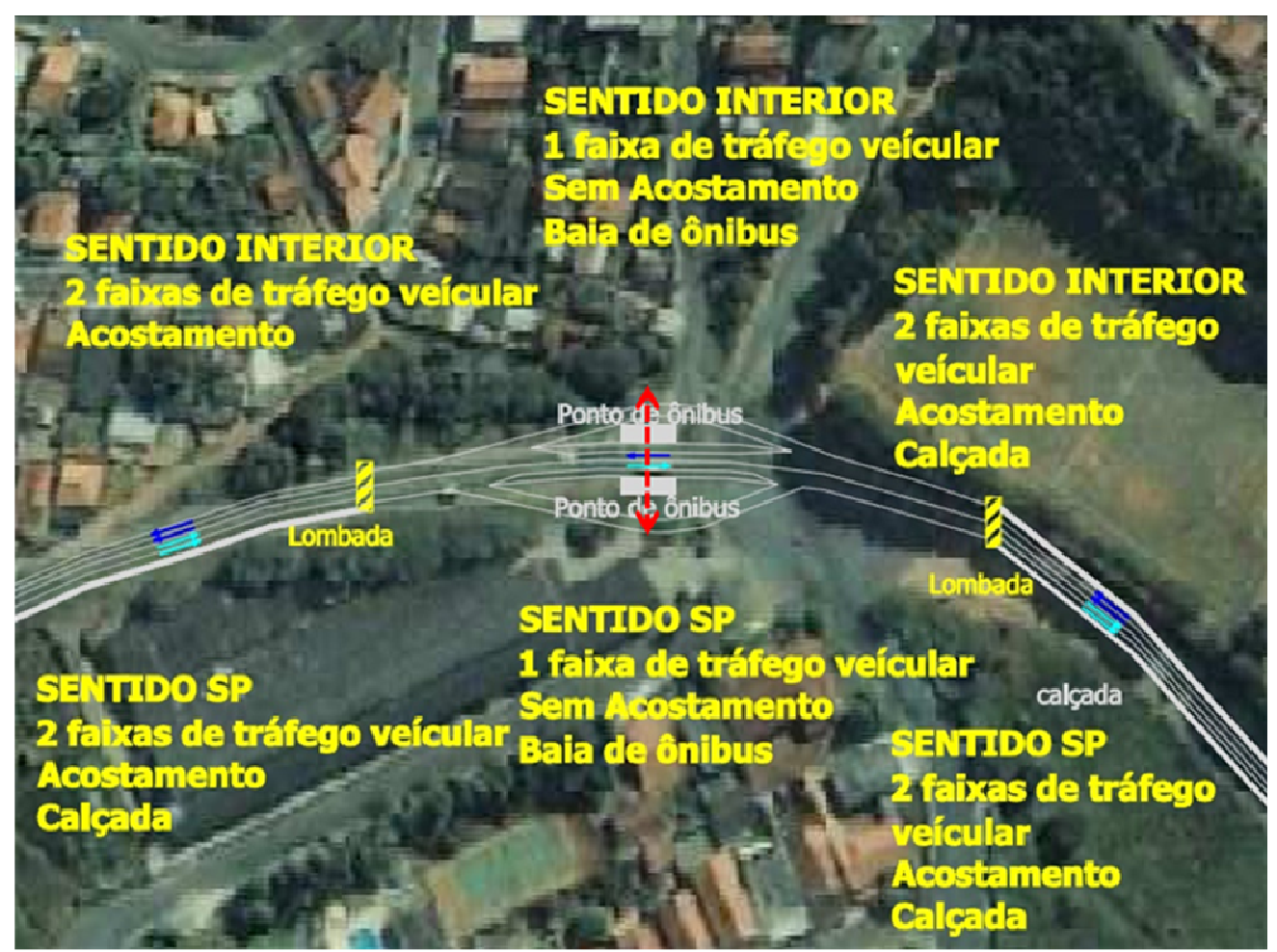

b. Diagrama de condição local - SP 270, km 63

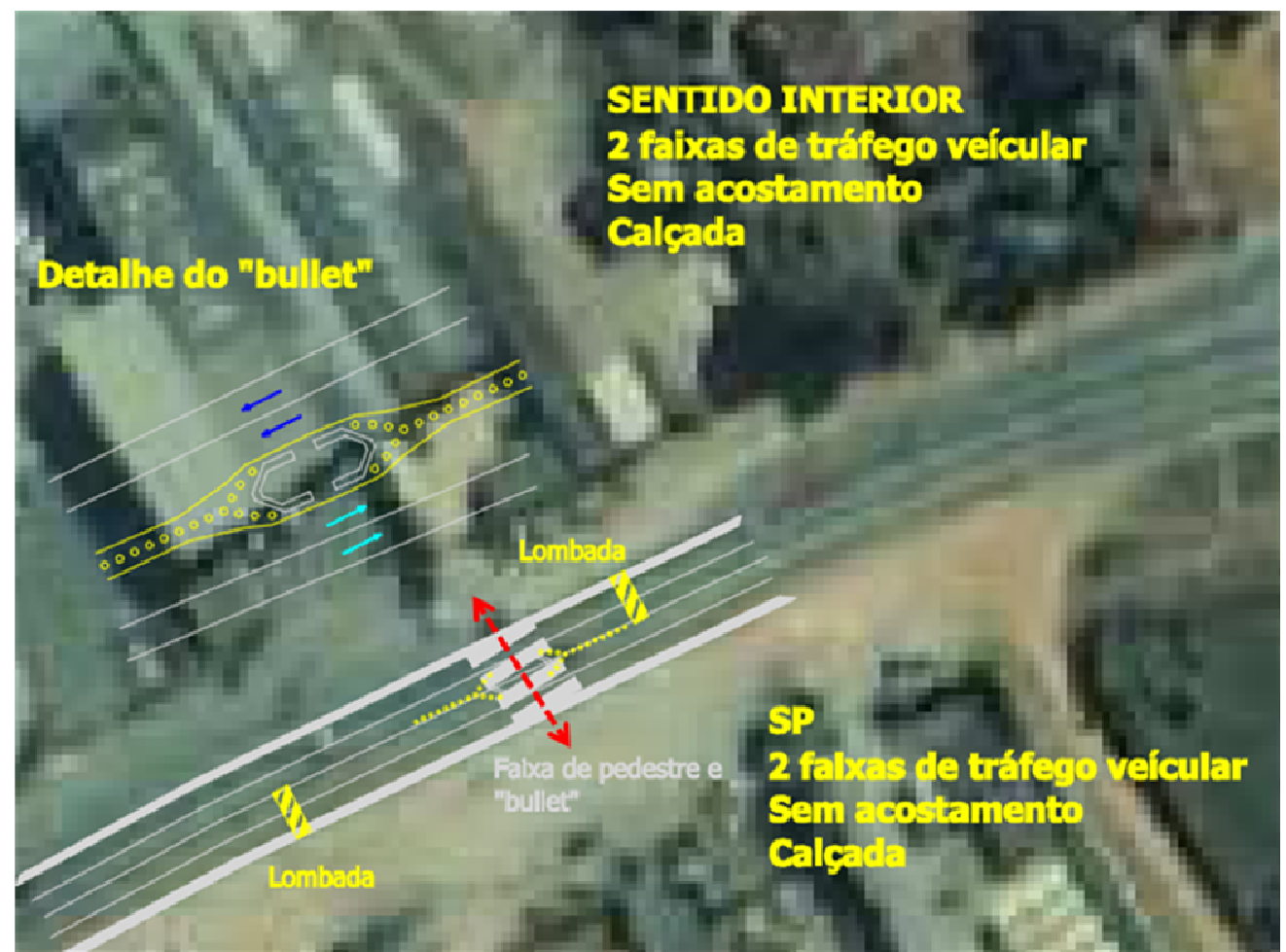

Figura 3-21 - Diagramas de condição inicial - SP 270 
A Figura 3-22a retrata as condições iniciais do km 29,5 da SP 280. São 3 faixas de rolamento por sentido, com acostamento no sentido interior e faixa de aceleração, para quem sai das fábricas no local, no sentido São Paulo.

Finalmente, a Figura 3-22b representa as condições locais do km 30 da SP 280. São 3 faixas de rolamento por sentido, com faixa de aceleração na saída do posto de serviços no sentido interior e acostamento no sentido São Paulo. Há também alambrado nesse local, que inibe a travessia de pedestres. 
a. Diagrama de condição local - SP 270, km 60,5

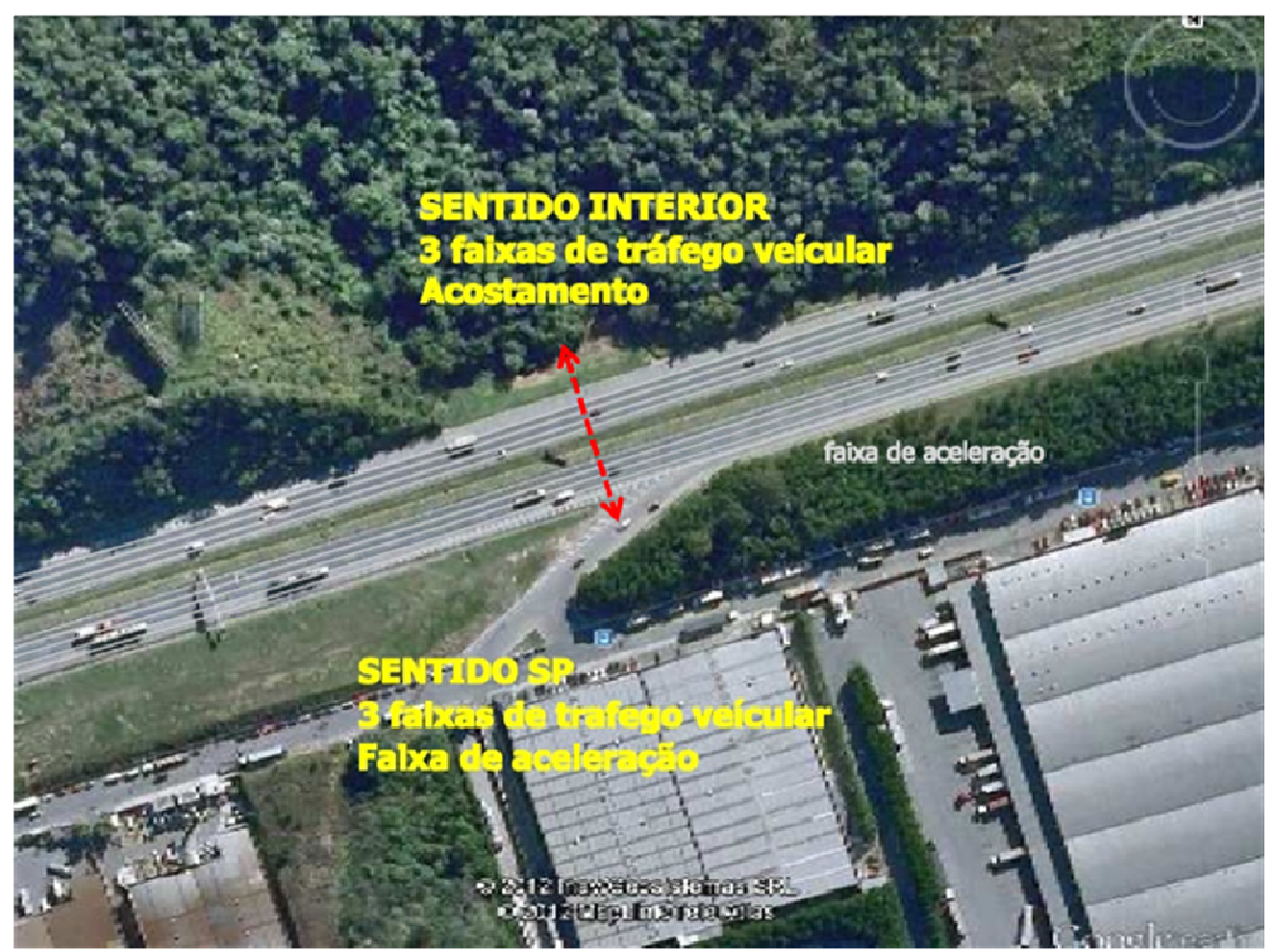

b. Diagrama de condição local - SP 270, km 63

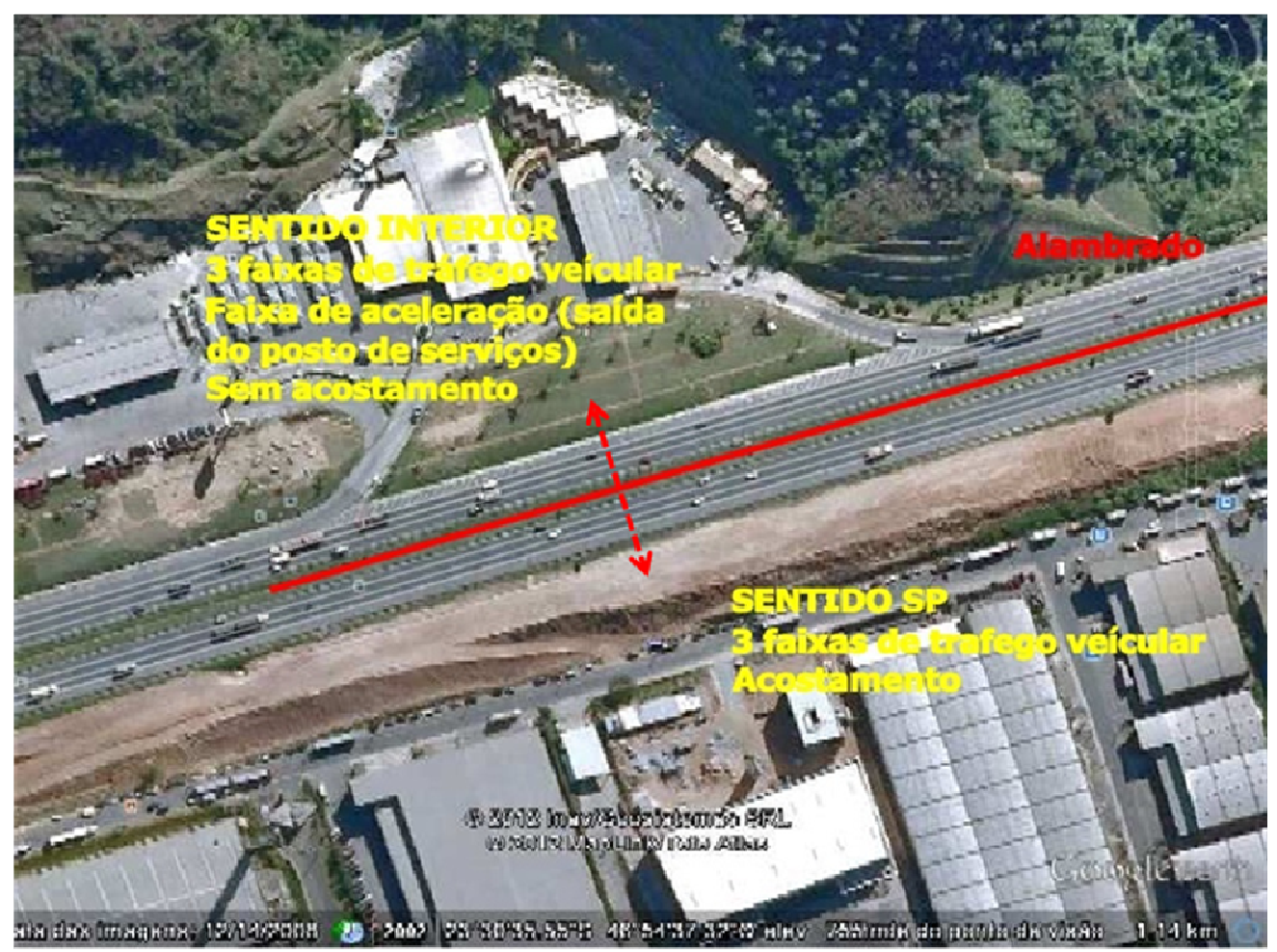

Figura 3-22 - Diagramas de Condição inicial - SP 280 
b. Análise do Atendimento às Condições de Projeto.

Visitas em campo e análises locais permitiram então fazer uma análise do atendimento das condições de projeto, considerando o que foi apresentado no capítulo 2 desse trabalho, onde foi apresentada a revisão bibliográfica, incluindo os manuais de projeto.

Conforme pode-se observar no diagrama de condição inicial apresentado na Figura 3-21a, o km 60,5 da Rodovia Raposo Tavares apresenta dispositivos que facilitam a travessia do pedestre. Primeiramente, as lombadas em ambos os sentidos, anteriores ao local de travessia, provocam a redução da velocidade dos veículos, ajudando também a formar brechas no fluxo, que facilitam a travessia. Os dois sentidos possuem ainda acostamentos e calçadas, que servem para o deslocamento ao longo da via de pedestres e ciclistas. A largura das faixas, 3,5 m está dentro do recomendado. A redução para 1 faixa por sentido e a inclusão da baia de ônibus no local da travessia também são positivos para a travessia. A configuração do retorno é também favorável para quem quer atravessar a rodovia, pois os veículos que realizam o movimento de conversão acabam servindo de "barreira" e formando brechas para a travessia.

Analisando o km 63 da SP 270, Rodovia Raposo Tavares, apresentado na Figura 3-21b, a travessia é esperada e facilitada pela existência da faixa de pedestres e do dispositivo de divisão da travessia, o "bullet". A própria canalização do "bullet", com sinalização horizontal e vertical, facilita a travessia do pedestre que escolhe atravessar fora da faixa de travessia. A situação anterior à instalação dos "bullets" era distinta: não havia a possibilidade de espera abrigada na travessia de cada sentido, mas havia acostamento e apenas 1 faixa por sentido. As lombadas também ajudam a tranquilizar o tráfego, conferindo aos veículos velocidades menores ao se aproximarem do local da travessia mas na configuração atual estão instaladas apenas na aproximação do trecho (a cerca de 50m). Há calçadas de ambos os lados na rodovia, possibilitando o deslocamento de pedestres ao longo desta. Porém, a ausência de acostamento leva os ciclistas a compartilharem o tráfego com os veículos na faixa de tráfego.

Já no caso dos locais estudados na SP 280, Rodovia Castello Branco, tanto o km 29,5 quanto o km 30 não possuem dispositivos adequados para a travessia do pedestre e/ou ciclista, face ao fluxo veicular intenso no local (não parece suficiente separar os fluxos de cada sentido). $\mathrm{Na}$ 
verdade, pela presença do alambrado, pode-se concluir que a travessia não é desejada, e de certa forma, desencorajado. Porém a presença de atividade lindeira, principalmente no $\mathrm{km} 30$, sugere que fosse necessário um tratamento alternativo, que atendesse a demanda de pedestres que precisam realizar a travessia. A presença de acostamento em ambos os sentido possibilita o deslocamento ao longo da via, tanto de ciclistas quanto de pedestres, que buscam evitar o alambrado para então realizar, com dificuldade, a travessia após seu término.

c. Análise da eficácia das condições existentes e das obras de melhoria

A fim de analisar a eficácia dos dispositivos de proteção para o pedestre instalados no km 63 da SP 270, Rodovia Raposo Tavares, é feita nesse item uma análise dos acidentes antes e depois da instalação dos dispositivos.

$\mathrm{O}$ anexo B traz as planilhas com os acidentes dos locais estudados na Rodovia Raposo Tavarez e na Rodovia Castello Branco, estando reproduzidos em forma de tabela os dados constantes no relatório de ocorrência de acidentes da concessionária.

A concessionária informou que esses dispositivos foram instalados em 2008, mas não precisamente em que mês. Considerando que há um período de adaptação da nova configuração, a análise foi feita excluindo o ano de 2008, considerando os anos de 2005, 2006 e 2007 como o período “antes" e os anos de 2009, 2010 e 2011, como o período "depois".

Os acidentes dos km 63 e 63,5 da SP270 foram somados nessa análise, pois os dois estão sob influência dos dispositivos e a localização é normalmente imprecisa. Na verdade, um dos acidentes anotado no $\mathrm{km} 63$ corresponde certamente a um trecho anterior e seria eliminado mas, como refere-se ao ano de 2008, foi desconsiderado também por este motivo. Todos os acidente foram leves, notando-se participação importante de atropelamentos por motos.

Na Figura 3-23 pode-se ver uma redução nos acidentes envolvendo pedestres após a instalação do dispositivo, tendo ocorrido 1 acidente a menos nos três anos seguintes ao ano da instalçao dos dispositivos quando comparado aos três anos anteriores. Apesar de se observar a redução 
ela não é tão significativa, pois o período de análise não é muito extenso. A mesma comparação para períodos maiores pode gerar dados mais interessantes.

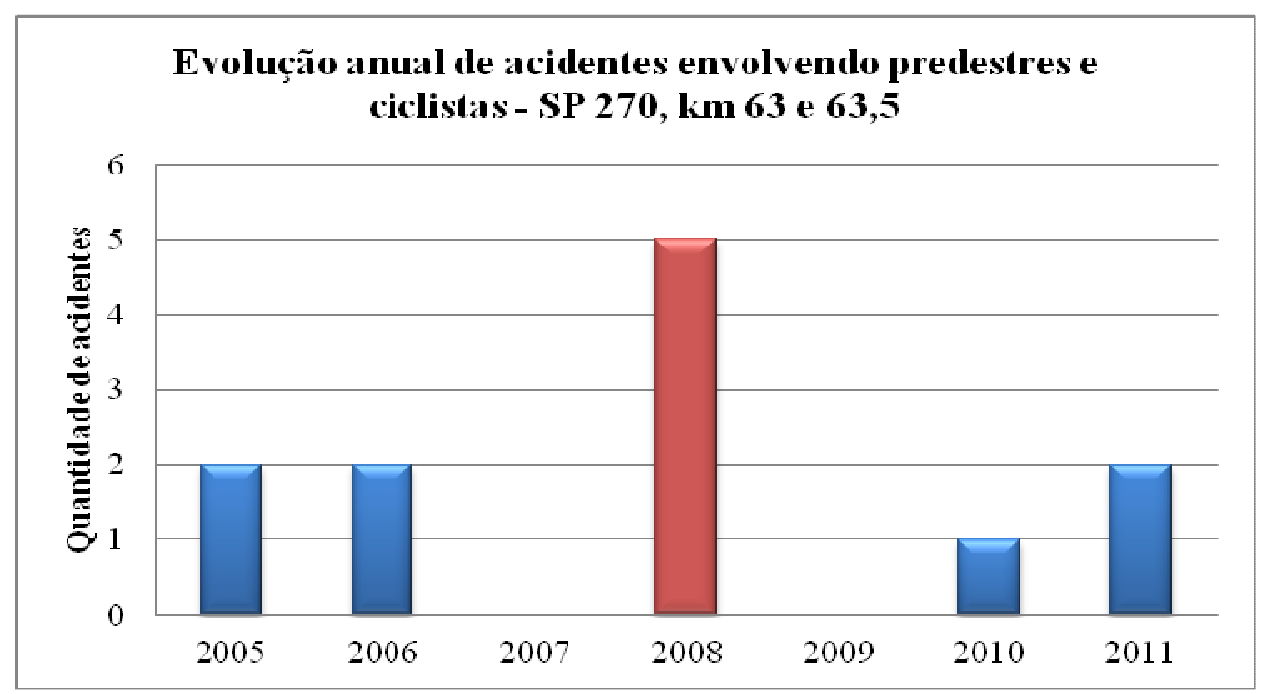

Figura 3-23 - Evolução anual de acidentes envolvendo pedestres e ciclistas na SP 270 , kms 63 e 63,5

Não há registro de acidentes referente ao km 60,5 da SP 270 (que foi selecionado por este motivo para servir de controle na aplicação das estimativas de OT e OC), o que sugere condições mais seguras neste local.

A análise dos acidentes nos trechos da SP 280 considerou todos os acidentes dos $\mathrm{km}$ 29,5, 30 e 30,5, em função da imprecisão na localização dos acidentes previamente mencionada. Apenas um dos acidentes refere-se a um acesso lindeiro e seria eliminado. Dos acidentes

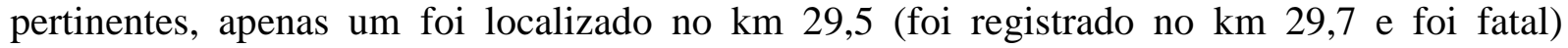
embora não haja qualquer menção que identifique o trecho com precisão. Os demais acidentes (15) foram localizados no $\mathrm{km} \mathrm{30,} \mathrm{sendo} 3$ fatais, 3 graves e 3 moderados (os demais leves), com 1 envolvendo pedestre empurrando bicicleta na travessia e 6 envolvendo motos ( 2 deles em condição de tráfego lento).

Portanto, os dados de acidentes sugerem maior risco no km 30 em relação ao km 29,5 (que foi selecionado por este motivo para servir de controle na aplicação das estimativas de OT e OC) na SP 280. Outro fator relevante é que a nálise dos acidentes mostra que uma parte representativa dos acidentes na SP280 ocorreram com motos. 


\subsection{RESULTADOS DO ESTUDO DE CAMPO}

Esse item apresenta os resultados obtidos no estudo de campo, a saber:

- obtenção das condições e medidas empíricas de oportunidade de travessia;

- obtenção e análise das medidas de oportunidade com os modelos de previsão;

- comparação dos diagnósticos com as medidas de oportunidades e com acidentes.

\subsubsection{Obtenção e Análise das Medidas de Oportunidades nos Trechos para Estudo}

É apresentado nesse item o resultado das medidas empíricas e teóricas de oportunidade obtidas através de análise dos vídeos das câmeras de segurança da concessionária.

a. Obtenção das medidas empíricas de oportunidade

Foram medidas as oportunidades de manobra ou travessia (OT) e de conflito (OC), por local estudado.

A oportunidade de manobra é função da brecha disponível, $T_{G}$, função da largura da via a ser atravessada $(\mathrm{L})$ e da velocidade do pedestre $\left(\mathrm{V}_{\mathrm{ped}}\right)$. A oportunidade de manobra acontece quanto a brecha é maior que $\mathrm{T}_{\mathrm{G}}$, dado por

$T_{G}=\frac{L}{V_{p e d}}+\delta_{\text {seg }}$ 
A margem de segurança $\delta_{\text {seg }}$ de 3 segundos foi utilizada por VASCONCELOS (2004) para distinguir oportunidades de travessia com risco aceitável (OTRA) ou inaceitável (OTRI).

Reconhece-se a questão levantada por VASCONCELOS (2004) de que a travessia ocorre, em grande parte das vezes, por faixa de rolamento. Essa questão foi também abordada por BREWER et al. (2006) que chamou o fenômeno de "rolling gap", podendo ser traduzido como brecha móvel. No entanto, os autores acabam desenvolvendo o estudo com o conceito tradicional, considerando a brecha na travessia total.

Para esse trabalho também foi considerado o conceito tradicional de brecha, sendo L a largura total a ser percorrida durante a travessia, ou seja, para a SP 270 (2 faixas), $\mathrm{L}=7,0 \mathrm{~m}$ tanto em pista simples ( $\mathrm{km} \mathrm{60,5)} \mathrm{quanto} \mathrm{em} \mathrm{pista} \mathrm{dupla} \mathrm{(} \mathrm{km} \mathrm{63,2}$ faixas em cada sentido) e para a SP 280 (3 faixas), $\mathrm{L}=10,5 \mathrm{~m}$ ( $\mathrm{km} \mathrm{29,5} \mathrm{e} \mathrm{km} \mathrm{30,} 3$ faixas em cada sentido).

A revisão bibliográfica mostrou valores recomendados para velocidade dos pedestres de 0,8 a $1,4 \mathrm{~m} / \mathrm{s}$, dependendo inclusive do tipo de pedestre, sendo $0,8 \mathrm{~m} / \mathrm{s}$ para pedestres mais lentos e $1,4 \mathrm{~m} / \mathrm{s}$ o pedestre andando bem rápido. A velocidade do pedestre aqui considerada foi de $1,2 \mathrm{~m} / \mathrm{s}$, valor típico geralmente utilizado para o pedestre adulto.

Dessa forma, a brecha crítica, $\mathrm{T}_{\mathrm{G}}$, pode ser calculada para cada rodovia:

- SP 270: Rodovia Raposo Tavares

$\mathrm{T}_{\mathrm{G}}=\left(\mathrm{L} / \mathrm{V}_{\text {ped }}\right)+3 \mathrm{seg}=(7 / 1,2)+3=8,83 \mathrm{seg}$ (etapa única para o $\mathrm{km} 60,5$, com 1 faixa por sentido, e por sentido para o $\mathrm{km} 63$, com 2 faixas por sentido)

- SP 280: Rodovia Castello Branco

$\mathrm{T}_{\mathrm{G}}=\left(\mathrm{L} / \mathrm{V}_{\mathrm{ped}}\right)+3 \operatorname{seg}=(10,5 / 1,2)+3=11,75 \operatorname{seg}(\operatorname{com} 3$ faixas por sentido $)$

As oportunidades de conflito são analisadas sempre que observada uma travessia e ocorre sempre que a separação no tempo do veículo que se aproxima até a linha de travessia do pedestre for menor que uma margem $(\delta)$ de segurança. $O$ valor utilizado nesse trabalho foi o utilizado por VASCONCELLOS (2004) na medida preferida OC3; também de 3 segundos. 
Definidos os conceitos operacionais de oportunidade de manobra e oportunidade de conflito nas travessias, foram analisadas mais uma vez as imagens das câmeras de segurança da concessionária, para cada km, para cada período estudado, pico da manhã, entre picos e pico da tarde. Estes resultados estão nas Tabelas 3-12, 3-13, 3-14 e 3-15 a seguir.

Para a obtenção da medidas empíricas, na análise dos vídeos foram buscadas, no caso das oportunidades de travessia, OT, as brechas entre dois veículos consideradas aceitáveis, ou seja, com margens maiores que $\mathrm{T}_{\mathrm{G}}$. No caso do trecho de pista simples, a travessia é em única etapa, e os valores são apresentados no total. Nos demais casos as oportunidades de travessia foram contadas para cada sentido, não sendo analisado um número de OT total, uma vez que a travessia, nesses casos, é sempre em etapas (uma opção seria associar à travessia integral um número de oportunidades de manobra igual ao da etapa crítica, com menor OT).

As oportunidades de conflito, foram obtidas de duas formas distintas. Primeiro as OC1, ou oportunidades de conflito única, que considera para uma travessia com conflito, uma OC1, independente do número de veículos que representaram oportunidade de conflito para o pedestres na travessia. As OC1s foram obtidas por etapa, e a composição do total foi obtida com a soma das probabilidades de cada sentido subtraído o produto (que corresponde ao evento união, simultâneo, e elimina a dupla contagem correspondente).

As aqui chamadas OC2, são as oportunidades de conflito múltiplas, onde para cada travessia, cada veículo que representa uma oportunidade de conflito é considerada uma OC, ou seja, para cada travessia podem existir mais de uma OC. As OC2s foram obtidas por sentido e a composição do total é soma das OC2s em cada sentido. 
Tabela 3-12 - Medidas empíricas de OTs e OCs - km 60,5 da SP 270

\begin{tabular}{|c|c|c|c|c|c|c|}
\hline $\begin{array}{l}\text { SP270- } \\
\text { Km60,5 }\end{array}$ & \multirow{2}{*}{$\begin{array}{l}\text { Fluxo de } \\
\text { Veículos } \\
\text { (Oposto, } \\
\text { v/h) }\end{array}$} & \multirow{2}{*}{$\begin{array}{c}\mathbf{L} \\
(\mathbf{m})\end{array}$} & \multirow{2}{*}{$\begin{array}{l}\text { Oportunidades } \\
\text { de Travessia } \\
\text { (OT) -Medida }\end{array}$} & \multirow{2}{*}{$\begin{array}{l}\text { Fluxo de } \\
\text { Pedestres } \\
(\mathrm{p} / \mathrm{h})\end{array}$} & \multirow{2}{*}{$\begin{array}{l}\text { Oportunidades } \\
\text { de Conflito } \\
\text { (OC1)-Medida }\end{array}$} & \multirow{2}{*}{$\begin{array}{l}\text { Oportunidades } \\
\text { de Conflito } \\
\text { (OC2)-Medida }\end{array}$} \\
\hline Período & & & & & & \\
\hline Manhã: >Sp & 282 & 3,5 & - & - & - & - \\
\hline$>\operatorname{Int}$ & 232 & 3,5 & - & - & - & - \\
\hline Total & 514 & 7,0 & $132(25,7 \%)$ & 41 & $9(22,0 \%)$ & $9(0,22)$ \\
\hline Meio : >Sp & 602 & 3,5 & - & - & - & - \\
\hline -Dia $>$ Int & 562 & 3,5 & - & - & - & - \\
\hline Total & 1164 & 7,0 & $84(7,2 \%)$ & 25 & $13(52,0 \%)$ & $15(0,60)$ \\
\hline Tarde: $>\mathrm{Sp}$ & 432 & 3,5 & - & - & - & - \\
\hline$>\operatorname{Int}$ & 476 & 3,5 & - & - & - & - \\
\hline Total & 908 & 7,0 & $48(5,3 \%)$ & 33 & $11(33,3 \%)$ & $12(0,36)$ \\
\hline Média/Hora & 862 & & $88(10,2 \%)$ & 33 & $11(33,3 \%)$ & $12(0,36)$ \\
\hline
\end{tabular}

Tabela 3-13 - Medidas empíricas de OTs e OCs - km 63 da SP 270

\begin{tabular}{|r|c|c|c|c|c|c|}
\hline $\begin{array}{l}\text { SP270- } \\
\text { Km63 }\end{array}$ & $\begin{array}{c}\text { Fluxo de } \\
\text { Veículos } \\
\text { (Oposto, } \\
\text { v/h) }\end{array}$ & $\begin{array}{c}\text { L } \\
\text { Período }\end{array}$ & $\begin{array}{c}\text { Oportunidades } \\
\text { de Travessia } \\
\text { (OT) -Medida }\end{array}$ & $\begin{array}{c}\text { Fluxo de } \\
\text { Pedestres } \\
(\mathbf{p} / \mathbf{h})\end{array}$ & $\begin{array}{c}\text { Oportunidades } \\
\text { de Conflito } \\
\text { (OC1)-Medida }\end{array}$ & $\begin{array}{c}\text { Oportunidades } \\
\text { de Conflito } \\
\text { (OC2)-Medida }\end{array}$ \\
\hline Manhã: $>$ Sp & - & 7,0 & - & - & - & - \\
\hline >Int & - & 7,0 & - & - & - & - \\
\hline Total & - & & - & - & - & - \\
\hline Meio : >Sp & 631 & 7,0 & $156(24,7 \%)$ & 12 & $2(16,7 \%)$ & $3(0,25)$ \\
\hline -Dia >Int & 639 & 7,0 & $180(28,2 \%)$ & 12 & $3(25,0 \%)$ & $3(0,25)$ \\
\hline Total & 1270 & & $156(12,3 \%)$ & 12 & $4,5(37,5 \%)$ & $6(0,50)$ \\
\hline Tarde: $>$ Sp & 970 & 7,0 & $108(11,1 \%)$ & - & - & - \\
\hline$>$ Int & 819 & 7,0 & $120(14,7 \%)$ & - & - & - \\
\hline Total & 1789 & & $108(6,1 \%)$ & - & - & - \\
\hline Média/Hora & $\mathbf{1 5 2 9 , 5}$ & & $\mathbf{1 3 2}(\mathbf{8 , 6 \%})$ & $\mathbf{1 2}$ & $\mathbf{4 , 5}(\mathbf{3 7 , 5 \%})$ & $\mathbf{6}(\mathbf{0 , 5 0})$ \\
\hline
\end{tabular}


Como exemplo, considere o período do meio-dia nos locais da SP 270:

- no $\mathrm{km}$ 60,5 ocorre a travessia de pista simples com um fluxo oposto de 1164v/h (soma dos dois sentidos); as OTs correspondem a brechas iguais ou superiores a 8,83seg e a frequência horária das suas ocorrências correspondem a 84 OT/h (7,2\% das brechas foram OTs); no mesmo período, ocorreram 25 travessias de pedestres (ambos os sentidos de travessia); as OCs corresponderam a travessias onde os veículos aproximaram-se a $3 \mathrm{seg}$ ou menos da trajetória dos pedestres e a frequência horária correspondente a estes casos foram iguais a 13 OC1/h (52,0\% dos pedestres) ou $15 \mathrm{OC} 2 / \mathrm{h}$ (considerando os casos em que houve mais de uma ameaça ao pedestre ao longo da mesma travessia, são 0,60 OC/ped); os dados correspondem à toda a travessia.

- no km 63 da SP 270 ocorre a travessia com refúgio (na situação atual); a travessia do sentido capital tem um fluxo oposto de $631 \mathrm{v} / \mathrm{h}$ e a do sentido interior de $639 \mathrm{v} / \mathrm{h}$; as OTs novamente correspondem a brechas iguais ou superiores a 8,83seg em cada caso (agora cada sentido tem 2 faixas) e a frequência horária de suas ocorrências correspondem a 156 OT/h (24,7\% das brechas foram OTs) no sentido capital e $180 \mathrm{OT} / \mathrm{h}$ no sentido interior (28,2\% das brechas foram OTs); considerando a etapa crítica, seriam $156 \mathrm{OT} / \mathrm{h}$ para a travessia integral; no mesmo período, ocorreram 12 travessias de pedestres (em ambas as etapas); as OCs corresponderam a travessias onde os veículos aproximaram-se a 3 seg ou menos da trajetória dos pedestres em cada etapa (avaliada separadamente) e a frequência horária correspondente a estes casos no sentido capital foram iguais a 2 OC1/h (16,7\% dos pedestres) ou 3 OCs/h (considerando os casos com ameaça múltipla na mesma travessia, são 0,25 OC/ped) e no sentido interior foram 3 OC1/h (25\% dos pedestres) ou $3 \mathrm{OC} 2 / \mathrm{h}$ (o mesmo valor, pois não houve casos com ameaça múltipla, é 0,25 OC/ped); considerando a travessia integral, a probabilidade de uma OC1 seria 0,167+0,250$0,167 * 0,250=37,5 \%$ (o que corresponderia a 4,5 pedestres) e o número de OC2/ped seria $0,25+0,25=0,50 \mathrm{OC} /$ ped (o que corresponderia a $6 \mathrm{OCs} / \mathrm{h}$ ).

A obtenção do valor médio horário foi calculado adotando uma ponderação específica para cada período. Preliminarmente, foi adotada a média simples dos valores horários de cada período analisado (manhã, meio-dia, tarde). 
Comparando os resultados dos trechos da SP 270, tem-se:

- km 60,5 da SP 270

O trecho em questão apresentou quantidade considerável de oportunidades de manobra e poucas oportunidades de conflito, considerando o alto fluxo de pedestres. As brechas geralmente são aceitáveis e o pedestre consegue efetuar a travessia sem grande dificuldade. No entanto, há uma razoável probabilidade de conflito durante a travessia (33\% na média).

- km 63 da SP 270

O trecho em questão, na situação atual (travessia em etapas), apresentou quantidade considerável de oportunidades de manobra e poucas oportunidades de conflito, de forma similar ao observado no local de controle (indicando que a intervenção teria sido capaz de eliminar a diferença na exposição a atropelamentos), ponderado o fluxo de travessias menor. 
Tabela 3-14 - Medidas empíricas de OTs e OCs - km 29,5 da SP 280

\begin{tabular}{|c|c|c|c|c|c|c|}
\hline $\begin{array}{l}\text { SP280- } \\
\text { Km29,5 } \\
\text { Período }\end{array}$ & $\begin{array}{c}\text { Fluxo de } \\
\text { Veículos } \\
\text { (Oposto, } \\
\text { v/h) }\end{array}$ & $\begin{array}{c}\mathbf{L} \\
(\mathbf{m})\end{array}$ & $\begin{array}{l}\text { Oportunidades } \\
\text { de Travessia } \\
\text { (OT) -Medida }\end{array}$ & $\begin{array}{l}\text { Fluxo de } \\
\text { Pedestres } \\
\quad(\mathrm{p} / \mathrm{h})\end{array}$ & $\begin{array}{l}\text { Oportunidades } \\
\text { de Conflito } \\
\text { (OC1)-Medida }\end{array}$ & $\begin{array}{l}\text { Oportunidades } \\
\text { de Conflito } \\
\text { (OC2)-Medida }\end{array}$ \\
\hline Manhã: >Sp & 2168 & 10,5 & $18(0,8 \%)$ & 0 & 0 & 0 \\
\hline$>\operatorname{Int}$ & 2427 & 10,5 & $12(0,5 \%)$ & 0 & 0 & 0 \\
\hline Total & 4595 & & $12(0,3 \%)$ & 0 & 0 & 0 \\
\hline Meio : >Sp & 5675 & 10,5 & $12(0,2 \%)$ & 0 & 0 & 0 \\
\hline -Dia >Int & 3666 & 10,5 & $0(0 \%)$ & 0 & 0 & 0 \\
\hline Total & 9341 & & $0(0 \%)$ & 0 & 0 & 0 \\
\hline Tarde: $>\mathrm{Sp}$ & 3296 & 10,5 & $12(0,4 \%)$ & 0 & 0 & 0 \\
\hline$>\operatorname{Int}$ & 5794 & 10,5 & $0(0 \%)$ & 0 & 0 & 0 \\
\hline Total & 9090 & & $0(0 \%)$ & 0 & 0 & 0 \\
\hline Média/Hora & 7675,3 & & $4(0,05 \%)$ & $\mathbf{0}$ & $-(-)$ & $-(-)$ \\
\hline
\end{tabular}

Tabela 3-15 - Medidas empíricas de OTs e OCs - km 30 da SP 280

\begin{tabular}{|r|c|c|c|c|c|c|}
\hline $\begin{array}{l}\text { SP280- } \\
\text { Km30 }\end{array}$ & $\begin{array}{c}\text { Fluxo de } \\
\text { Veículos } \\
\text { (Oposto, } \\
\text { Período }\end{array}$ & $\begin{array}{c}\mathbf{L} \\
\mathbf{( m )}\end{array}$ & $\begin{array}{c}\text { Oportunidades } \\
\text { de Travessia } \\
(\mathbf{O T}) \text {-Medida }\end{array}$ & $\begin{array}{c}\text { Fluxo de } \\
\text { Pedestres } \\
(\mathbf{p} / \mathbf{h})\end{array}$ & $\begin{array}{c}\text { Oportunidades } \\
\text { de Conflito } \\
\text { (OC1)-Medida }\end{array}$ & $\begin{array}{c}\text { Oportunidades } \\
\text { de Conflito } \\
\text { (OC2)-Medida }\end{array}$ \\
\hline Manhã: $>$ Sp & 2168 & 10,5 & $18(0,8 \%)$ & 3 & $0(0 \%)$ & $0(0)$ \\
\hline >Int & 2427 & 10,5 & $12(0,5 \%)$ & 1 & $1(100 \%)$ & $3(3)$ \\
\hline Total & 4595 & & $12(0,3 \%)$ & 4 & $4(100 \%)$ & $3(0,75)$ \\
\hline Meio : >Sp & 5675 & 10,5 & $12(0,2 \%)$ & 2 & $1(50 \%)$ & $2(1)$ \\
\hline -Dia $>$ Int & 3666 & 10,5 & $0(0 \%)$ & 4 & $0(0 \%)$ & $0(0)$ \\
\hline Tatal & 9341 & & $0(0 \%)$ & 6 & $3(50 \%)$ & $2(0,3 \%)$ \\
\hline Tarde: >Sp & 3296 & 10,5 & $12(0,4 \%)$ & 2 & $2(100 \%)$ & $6(3)$ \\
\hline TInt & 5794 & 10,5 & $0(0 \%)$ & 2 & $2(100 \%)$ & $5(2,5 \%)$ \\
\hline Média/Hora & 9090 & & $0(0 \%)$ & 4 & $4(100 \%)$ & $11(2,75)$ \\
\hline
\end{tabular}


Comparando os resultados dos trechos da SP280, tem-se:

- km 29,5 da SP 280

O trecho em questão apresentou poucas oportunidades de manobra, ainda menor no sentido interior, nos picos da manhã e da tarde. Não foram observadas travessias, e consequentemente não foram observadas oportunidades de conflito.

- km 30 da SP 280

O trecho apresenta iguais condições do trecho anterior, com poucas oportunidades de manobra, principalmente no sentido interior, nos picos da manhã e da tarde. A existência de travessias ocasiona a ocorrência de oportunidades de conflito, notando-se que a probabilidade de conflito em uma travessia é altíssima (quase certa nos picos).

Portanto, as medidas empíricas de oportunidades de manobra indicariam que os trechos de cada rodovia são essencialmente similares entre si. Os trechos da SP 280 seriam críticos pela inexistência de oportunidades de travessia. Os trechos da SP 270 tem uma frequência relevante de oportunidades de travessia (da ordem de 1 a 2 por minuto). Em termos de oportunidade de conflito, os trechos da SP 280 foram diferenciados pela presença de pedestres apenas, dado que a probabilidade de conflito na travessia é altíssima (quase certa). Este fato pode explicar a reduzida presença de pedestres. A maior presença de pedestres nos trechos da SP 270 indicaria um potencial de risco relevante, expresso pela quantidade de oportunidades de conflito (decorrência da quantidade de travessias e das condições locais), similar entre seus locais (bastante menor em termos relativos, se comparado com os locais da SP 280).

Notou-se também que a distinção da multiplicidade das COs não é empiricamente relevante (as medidas OC1 e OC2 são claramente similares). A seguir, adota-se o valor de OC2 visto que a multiplicidade é considerada nas fórmulas dos modelos de previsão discutidos adiante. 
b. Obtenção das medidas teórica de oportunidade

Nesse item são apresentadas as oportunidades de manobra, oportunidades de travessia (OT) e oportunidades de conflito (OC), calculadas através das expressões desenvolvidas por MING (2008) apresentadas anteriormente nesse trabalho.

Na expressão básica (modelo 1a), a oportunidade de conflito, calculada através da expressão básica desenvolvida por MING (2008), para movimentos de pedestres preferencial ou secundário, pode ser obtida considerando o fluxo total e a exposição total:

$$
O C=Q_{p e d}\left(1-e^{-Q v e i c . T G}\right)
$$

A expressão correspondente para oportunidade de manobra é obtida pelo produto do fluxo veicular (Qveic) pela probabilidade da brecha $\mathrm{H}$ ser maior que a brecha crítica $\left(T_{G}\right)$ :

$$
O T=Q_{\text {veic }} \cdot e^{-Q v e i c . T G}
$$

(esta expressão não está em MING, 2008, mas decorre de suas formulações).

MING (2008) também propõe expressões alternativas para os modelos de oportunidades de conflito com o fluxo por conflito ou faixa e a exposição por conflito ou faixa, além de uma expressão específica para movimentos de pedestres secundários, sem apresentar os modelos de oportunidades de travessia. As expressões foram reformuladas da seguinte maneira:

- por conflito (ou zona de conflito): espressão 1b de MING (2008):

$$
O C=Q_{p e d} \cdot\left(\sum_{c}\left(1-e^{-T_{c} \sum_{c} q l}\right)\right)
$$

onde $T_{C}=\frac{L_{C}}{V_{p e d}}+\delta_{\text {seg }}$ é o tempo de percurso e segurança no conflito C (a expressão correspondente para oportunidades de travessia é $O T=\left(\sum_{C} Q_{\text {veiC }}\right) \cdot\left(\prod_{C} e^{- \text {QveiC.TG }}\right)$, que usa a brecha integral $\mathrm{T}_{\mathrm{G}}$ e normalmente fornece a mesma estimativa que a fórmula básica; se $\mathrm{T}_{\mathrm{C}}=\mathrm{T}_{\mathrm{G}}$ 
em todas as zonas de conflito, a estimativa de oportunidades de conflito também é normalmente a mesma);

- por faixa: espressão 1c de MING (2008):

$$
O C=Q_{p e d} \cdot\left[\sum_{F}\left(1-e^{-T_{F} \cdot q_{l}}\right)\right]
$$

onde $T_{c l}=\frac{L_{c l}}{V_{p e d}}+\delta_{\text {seg }}$ é o tempo de percurso e segurança na faixa F (a expressão correspondente para oportunidades de travessia é $O T=\left(\sum_{F} Q_{\text {veiF }}\right) \cdot\left(\prod_{F} e^{- \text {QveiF.TG }}\right)$, que usa a brecha integral $T_{G}$ e normalmente fornece a mesma estimativa que a fórmula básica; se $T_{F}=T_{G}$ a estimativa de oportunidades de conflito também seria a mesma mas neste nível de análise as formulações com brecha móvel seriam normalmente necessárias para obter realismo maior).

A expressão para movimentos secundários de pedestres foram também reformuladas como:

$$
O C=Q_{p e d} \cdot\left(1-e^{-(a--t) \cdot \sum_{c l} q l}\right)
$$

onde $\tau \cong 0,5 . T_{G}$ (a expressão correspondente para oportunidades de travessia é a mesma fórmula básica $\left.O T=Q_{\text {veic }} \cdot e^{-Q v e i c . T G}\right)$.

Em todos os casos, a análise é feita por etapa de travessia (separadas por canteiros ou ilhas de refúgio, físicas ou pintadas). As expressões de MING (2008) são distintas porque consideram a possibilidade de OCs múltiplas em uma dada travessia (ao invés de simplesmente classificar as travessias em OC pela condição crítica de cada travessia). A fórmula utilizada corresponde melhor ao método utilizado na medida empírica de OC.

Os dados de fluxo veicular e fluxo de pedestre foram os obtidos na análise das imagens das câmeras de monitoração fornecidas pela concessionária. Da mesma forma, as oportunidades 
de manobra e oportunidades de conflito foram obtidas para os três períodos estudados, pico da manhã, entrepicos e pico da tarde.

A Tabela 3-16 mostra os cálculos das OTs e OCs, para cada km, período e sentido de tráfego, com base nos modelos 1a e 1b, 1c e 4. Como exemplo, serão apresentados a seguir o detalhamento dos cálculo para o período do meio-dia nos km 60,5 e 63 da SP 270.

a) Expressão $1 \mathrm{a}$

Segundo a expressão do MING (2008):

$$
O C=Q_{p e d} \cdot\left(1-e^{-Q v e i c . T G}\right)
$$

Dessa forma, no km 60,5, com:

$Q_{p e d}=25$ pedestres/hora

$Q_{\text {veic }}=(562+602)=1164$ veículos $/$ hora $=0,323$ veiculos $/$ segundo:

$\mathrm{T}_{\mathrm{G}}=8,83$ segundos

$$
O C=25 .\left(1-e^{-0,323.8,83}\right)=23,6 \text { OC/hora }
$$

A oportunidade de travessia é calculada conforme segue:

$$
\begin{gathered}
O T=Q_{\text {veic }} \cdot\left(e^{-Q v e i c . T G}\right) \\
O T=1164 \cdot\left(e^{-0,323.8,83}\right)=67 \text { OT/hora }
\end{gathered}
$$

No km 63, a travessia tem um refúgio central separando os sentidos, com:

- sentido capital: $Q_{p e d}=12$ pedestres/hora

$Q_{\text {veic }}=639$ veículos $/$ hora $=0,178$ veiculos/segundo:

$\mathrm{T}_{\mathrm{G}}=8,83$ segundos ( 2 faixas por sentido)

$$
O C=12 \cdot\left(1-e^{-0,178.8,83}\right)=9,5 \text { OC/hora }
$$


- sentido interior: $Q_{p e d}=12$ pedestres/hora

$Q_{\text {veic }}=631$ veículos $/$ hora $=0,175$ veiculos $/$ segundo:

$\mathrm{T}_{\mathrm{G}}=8,83$ segundos ( 2 faixas por sentido)

$$
O C=12 \cdot\left(1-e^{-0,175 \cdot 8,83}\right)=9,4 \text { OC/hora }
$$

- ambos os sentidos: $O C=9,5+9,4=18,9$ oC/hora

A oportunidade de travessia é calculada conforme segue:

$$
O T=Q_{\text {veic }} \cdot\left(e^{-Q v e i c \cdot T G}\right)
$$

- sentido capital:

$$
O T=639 \cdot\left(e^{-0,178.8,83}\right)=133,3 \text { OT/hora }
$$

- sentido interior:

$$
O T=631 .\left(e^{-0,175 \cdot 8,83}\right)=134,2 \text { OT/hora }
$$

- ambos os sentidos: 133,3 OT/hora (etapa crítica)

b) Expressão 1b: as zonas de conflito corresponde a cada um dos sentidos

$$
O C=Q_{p e d} \cdot\left(\sum_{c}\left(1-e^{-T_{c} \sum_{c} q l}\right)\right)
$$

Dessa forma, no km 60,5, com:

$Q_{p e d}=25$ pedestres/hora

$Q_{\text {veicl }}=562$ veículos $/$ hora $=0,156$ veiculos $/$ segundo

$Q_{\text {veic2 }}=602$ veículos $/$ hora $=0,167$ veiculos $/$ segundo 
$T_{C}=\frac{L_{C}}{V_{p e d}}+\delta_{s e g}$

$\mathrm{L}_{\mathrm{C}}=7,0 \mathrm{~m}$

$\mathrm{V}_{\text {ped }}=1,2 \mathrm{~m} / \mathrm{s}$

$\delta=3$ segundos

$\mathrm{T}_{\mathrm{C}}=8,83$ segundos

$$
\begin{aligned}
& O C=25 .\left(\left(e^{- \text {Qveic. } .(T C)}\right)_{\text {leste }}\right. \\
& O C=25 .\left(\left(e^{-Q \text { veic. } .(T C)}\right)_{\text {oeste }}\right.
\end{aligned}
$$

Com:

$$
\begin{aligned}
& O C=25 \cdot\left(\left(e^{-0,156.8,83}\right)=18,7\right. \text { OC/hora } \\
& O C=25\left(e^{-0,167.8,83}\right)=19,3 \text { OT/hora }
\end{aligned}
$$

A oportunidade de travessia é calculada conforme segue:

$\mathrm{T}_{\mathrm{G}}=8,83$ segundos

$$
\begin{aligned}
& O T=\left(\sum_{C} Q_{\text {veiC }}\right) \cdot\left(\prod_{C} e^{-Q v e i C . T G}\right) \\
& O T=(562+602) \cdot\left(e^{-Q v e i c .(T G)}\right) \cdot\left(e^{-Q v e i c .(T G)}\right) \\
& O T=(562+602) \cdot\left(e^{-0,156 \cdot 8,83}\right) \cdot\left(e^{-0,167.8,83}\right)=67 \text { OT/hora }
\end{aligned}
$$

(igual ao obtido com o modelo 1a).

No km 63, as zonas de conflito correspondem aos sentidos e os resultados são os mesmos do modelo 1a, tanto para oportunidades de conflito quanto para oportunidades de travessia. 
c) Expressão 1c: por faixa

$$
O C=Q_{p e d} \cdot\left[\sum_{F}\left(1-e^{-T_{F} \cdot q_{l}}\right)\right]
$$

Dessa forma, no km 60,5, os resultados são os mesmos do modelo 1b, pois há 1 faixa por sentido (ou zona de conflito).

No o km63, a travessia tem um refúgio central separando os sentidos e 2 faixas por sentido, com:

- sentido capital: $Q_{p e d}=12$ pedestres/hora

$Q_{\text {veic }}=639 / 2$ veículos $/$ hora $/$ faixa $=0,089$ veiculos $/$ segundo:

$\mathrm{T}_{\mathrm{cl}}=5,92$ segundos (cada uma das 2 faixas)

$$
O C=12 \cdot\left(\left(1-e^{-0,089.5,92}\right)+\left(1-e^{-0,089.5,92}\right)\right)=9,8 \text { OC/hora }
$$

- sentido interior: $Q_{p e d}=12$ pedestres/hora

$Q_{\text {veic }}=631 / 2$ veículos $/$ hora $=0,088$ veiculos/segundo:

$\mathrm{T}_{\mathrm{cl}}=5,92$ segundos (2 faixas por sentido)

$$
O C=12 \cdot\left(\left(1-e^{-0,088.5,92}\right)+\left(1-e^{-0,088.5,92}\right)\right)=9,7 \text { OC/hora }
$$

- ambos os sentidos: $O C=9,8+9,7=19,5$ OC/hora

A oportunidade de travessia é calculada conforme segue:

$$
O T=\left(\sum_{F} Q_{v e i F}\right) \cdot\left(\prod_{F} e^{-Q v e i F \cdot T G}\right)
$$

- sentido capital:

$$
O T=(639 / 2+639 / 2) \cdot\left(e^{-0,089.8,83} \cdot e^{-0,089.8,83}\right)=133,2 \text { OT/hora }
$$


- sentido interior:

$$
O T=(631 / 2+631 / 2) \cdot\left(. e^{-0,088.8,83} \cdot e^{-0,088.8,83}\right)=134,2 \text { OT/hora }
$$

- ambos os sentidos: 133,2 OT/hora (etapa crítica)

d) Expressão 4

$$
O C=Q_{p e d} \cdot\left(1-e^{-(\tau a-t) \cdot \sum_{c l} q l}\right)
$$

Dessa forma, no $\mathrm{km} \mathrm{60,5,} \mathrm{com:}$

$\tau \cong 0,5 . T_{G}$

$Q_{p e d}=25$ pedestres/hora

$Q_{\text {veicl }}=562$ veículos $/$ hora $=0,156$ veiculos $/$ segundo

$Q_{\text {veic2 }}=602$ veículos $/$ hora $=0,167$ veiculos $/$ segundo

$Q_{\text {veicT }}=(562+602)=1164$ veículos $/$ hora $=0,323$ veiculos $/$ segundo

$\mathrm{T}_{\mathrm{G}}=8,83$ segundos

$\tau=0,5 . \mathrm{T}_{\mathrm{G}}=0,5.8,83=4,42$ segundos

$$
O C=25 \cdot\left(1-e^{-\tau \cdot Q v e i c}\right)=25 \cdot\left(1-e^{-0,323.4,42}\right)=19 \text { OC/hora }
$$

A oportunidade de travessia é calculada como no modelo 1a.

No km63, na travessia tem um refúgio central separando os sentidos, com:

- sentido capital: $Q_{p e d}=12$ pedestres/hora

$Q_{\text {veic }}=639$ veículos $/$ hora $=0,178$ veiculos $/$ segundo: 
$\mathrm{T}_{\mathrm{G}}=8,83$ segundos (2 faixas por sentido)

$\tau=0,5 . \mathrm{T}_{\mathrm{G}}=0,5.8,83=4,42$ segundos

$$
O C=12 \cdot\left(1-e^{-0,178 \cdot 4,42}\right)=6,5 \text { OC/hora }
$$

- sentido interior: $Q_{p e d}=12$ pedestres/hora

$Q_{\text {veic }}=631$ veículos $/$ hora $=0,175$ veiculos $/$ segundo:

$\mathrm{T}_{\mathrm{G}}=8,83$ segundos ( 2 faixas por sentido)

$\tau=0,5 . \mathrm{T}_{\mathrm{G}}=0,5 \cdot 8,83=4,42$ segundos

$$
O C=12 \cdot\left(1-e^{-0,175.4,42}\right)=6,5 \text { OC/hora }
$$

- ambos os sentidos: $O C=6,5+6,5=13$ OC/hora

A oportunidade de travessia é calculada como no modelo 1a. 
Tabela 3-16 - Cálculo das OTs e OCs teóricas

a. SP $270 \quad$ Modelo 1a

\begin{tabular}{|c|c|c|c|c|c|c|}
\hline $\begin{array}{l}\text { SP270- } \\
\text { Km60,5 } \\
\text { Período } \\
\end{array}$ & $\begin{array}{c}\text { Fluxo de } \\
\text { Veículos } \\
(\mathbf{v} / \mathbf{h}) \\
\end{array}$ & $\begin{array}{c}\text { Fluxo de } \\
\text { Pedestres } \\
(\mathbf{p} / \mathbf{h}) \\
\end{array}$ & $\mathbf{L}(\mathbf{m})$ & TG (s) & OT & OC \\
\hline Manhã: >Sp & 232 & - & 3,5 & - & - & - \\
\hline$>\operatorname{Int}$ & 282 & - & 3,5 & - & - & - \\
\hline Total & 514 & 41 & 7,0 & 8,83 & 145,7 & 29,4 \\
\hline Meio : > Sp & 562 & - & 3,5 & - & - & - \\
\hline -Dia >Int & 602 & - & 3,5 & - & - & - \\
\hline Total & 1164 & 25 & 7,0 & 8,83 & 67 & 23,6 \\
\hline Tarde: >Sp & 476 & - & 3,5 & - & - & - \\
\hline$>\operatorname{Int}$ & 432 & - & 3,5 & - & - & - \\
\hline Total & 908 & 33 & 7,0 & 8,83 & 97,9 & 29,4 \\
\hline Média/Hora & 862 & 33 & - & - & 103,5 & 27,5 \\
\hline
\end{tabular}

\begin{tabular}{|c|c|c|c|c|c|c|}
\hline SP270-Km63 & & & & & & \\
\hline Período & $\begin{array}{c}\text { Veículos } \\
\text { (v/h) }\end{array}$ & $\begin{array}{c}\text { Pedestres } \\
(\mathbf{p} / \mathrm{h})\end{array}$ & $\mathbf{L}(\mathbf{m})$ & TG (s) & OT & OC \\
\hline Manhã: >Sp & - & - & 7,0 & 8,83 & - & - \\
\hline$>\operatorname{Int}$ & - & - & 7,0 & 8,83 & - & - \\
\hline Total & - & - & - & - & - & - \\
\hline Meio : >Sp & 639 & 12 & 7,0 & 8,83 & 133,3 & 9,5 \\
\hline -Dia $>$ Int & 631 & 12 & 7,0 & 8,83 & 134,2 & 9,4 \\
\hline Total & 1270 & 12 & & & 133,3 & 18,9 \\
\hline Tarde: $>\mathrm{Sp}$ & 819 & - & 7,0 & 8,83 & 109,9 & - \\
\hline$>\operatorname{Int}$ & 970 & - & 7,0 & 8,83 & 89,8 & - \\
\hline Total & 1789 & - & - & - & 89,8 & - \\
\hline Média/Hora & 1529,5 & 12 & - & - & 111,6 & 18,9 \\
\hline
\end{tabular}


Continuação da Tabela 3-16

a. SP $270 \quad$ Modelo 1b

\begin{tabular}{|l|c|c|c|c|c|c|c|}
\hline $\begin{array}{l}\text { SP270- } \\
\text { Km60,5 }\end{array}$ & $\begin{array}{c}\text { Fluxo de } \\
\text { Veículos } \\
(\mathbf{v} / \mathbf{h})\end{array}$ & $\begin{array}{c}\text { Fluxo de } \\
\text { Pedestres } \\
(\mathbf{p} / \mathbf{h})\end{array}$ & L (m) & TC (s) & TG (s) & OT & OC \\
\cline { 1 - 5 } Período & 232 & - & 3,5 & - & - & - & 17,8 \\
\hline Manhã: >Sp & 282 & - & 3,5 & - & - & - & 20,5 \\
\hline >Int & 514 & 41 & 7,0 & 8,83 & 8,83 & 145,7 & 38,3 \\
\hline Total & 562 & - & 3,5 & - & - & - & 18,7 \\
\hline Meio : >Sp & 602 & - & 3,5 & - & - & - & 19,3 \\
\hline -Dia >Int & 1164 & 25 & 7,0 & 8,83 & 8,83 & 67 & 38 \\
\hline Tarde: >Sp & 476 & - & 3,5 & - & - & - & 22,7 \\
\hline Total & 432 & - & 3,5 & - & - & - & 21,6 \\
\hline Total & 908 & 33 & 7,0 & 8,83 & 8,83 & 97,9 & 44,3 \\
\hline Média/Hora & $\mathbf{8 6 2}$ & $\mathbf{3 3}$ & - & - & - & $\mathbf{1 0 3 , 5}$ & $\mathbf{4 0 , 2}$ \\
\hline
\end{tabular}

\begin{tabular}{|r|c|c|c|c|c|c|c|}
\hline SP270-Km63 & $\begin{array}{c}\text { Fluxo de } \\
\text { Veículos } \\
\text { Período }\end{array}$ & $\begin{array}{c}\text { Fluxo de } \\
\text { Pedestres } \\
(\mathbf{p} / \mathbf{h})\end{array}$ & $\mathbf{L}(\mathbf{m})$ & TC (s) & TG (s) & OT & Oc \\
\cline { 1 - 7 } Manhã: >Sp & - & - & 7,0 & 8,83 & 8,83 & - & - \\
\hline$>$ Int & - & - & 7,0 & 8,83 & 8,83 & - & - \\
\hline Total & - & - & - & - & - & - & - \\
\hline Meio $:>$ Sp & 639 & 12 & 7,0 & 8,83 & 8,83 & 133,3 & 9,5 \\
\hline -Dia >Int & 631 & 12 & 7,0 & 8,83 & 8,83 & 134,2 & 9,4 \\
\hline Total & 1270 & 12 & - & - & - & 133,3 & 18,9 \\
\hline Tarde: $>$ Sp & 819 & - & 7,0 & 8,83 & 8,83 & 109,9 & - \\
\hline >Int & 970 & - & 7,0 & 8,83 & 8,83 & 89,8 & - \\
\hline Total & 1789 & - & - & - & - & 89,8 & - \\
\hline Média/Hora & $\mathbf{1 5 2 9 , 5}$ & $\mathbf{1 2}$ & - & - & - & $\mathbf{1 1 1 , 6}$ & $\mathbf{1 8 , 9}$ \\
\hline
\end{tabular}


Continuação da Tabela 3-16

a. SP $270 \quad$ Modelo 1c

\begin{tabular}{|c|c|c|c|c|c|c|c|c|}
\hline $\begin{array}{l}\text { SP270- } \\
\text { Km60,5 }\end{array}$ & $\begin{array}{l}\text { Fluxo de } \\
\text { Veículos }\end{array}$ & $\begin{array}{l}\text { Fluxo de } \\
\text { Pedestres }\end{array}$ & $\mathbf{N}(\mathbf{f x s})$ & $\mathbf{L f}(\mathbf{m})$ & $T_{c l}(s)$ & $T_{G}(s)$ & OT & OC \\
\hline Período & & & & & & & & \\
\hline Manhã: >Sp & 232 & - & 1 & 3,5 & - & - & - & - \\
\hline$>\operatorname{Int}$ & 282 & - & 1 & 3,5 & - & - & - & - \\
\hline Total & 514 & 41 & 2 & 7,0 & 8,83 & 8,83 & 145,6 & 38,3 \\
\hline Meio : >Sp & 562 & - & 1 & 3,5 & - & - & - & - \\
\hline -Dia $>$ Int & 602 & - & 1 & 3,5 & - & - & - & - \\
\hline Total & 1164 & 25 & - & 7,0 & 8,83 & 8,83 & 67 & 38 \\
\hline Tarde: $>\mathrm{Sp}$ & 476 & - & 1 & 3,5 & - & - & - & - \\
\hline$>\operatorname{Int}$ & 432 & - & 1 & 3,5 & - & - & - & - \\
\hline Total & 908 & 33 & - & 7,0 & 8,83 & 8,83 & 97,8 & 44,3 \\
\hline Média/Hora & 862 & 33 & - & - & - & - & 103,5 & 40,2 \\
\hline
\end{tabular}

\begin{tabular}{|c|c|c|c|c|c|c|c|c|}
\hline $\begin{array}{l}\text { SP270- } \\
\text { Km63 } \\
\text { Período } \\
\end{array}$ & $\begin{array}{c}\text { Fluxo de } \\
\text { Veículos } \\
(\mathbf{v} / \mathbf{h}) \\
\end{array}$ & $\begin{array}{c}\text { Fluxo de } \\
\text { Pedestres } \\
(\mathrm{p} / \mathrm{h}) \\
\end{array}$ & $\mathbf{N}(\mathbf{f x s})$ & $\mathbf{L f}(\mathbf{m})$ & $T_{c l}(s)$ & $T_{G}(s)$ & OT & OC \\
\hline Manhã: >Sp & - & - & 2 & 3,5 & 5,92 & 8,83 & - & - \\
\hline$>\operatorname{Int}$ & - & - & 2 & 3,5 & 5,92 & 8,83 & - & - \\
\hline Total & - & - & - & - & - & & - & - \\
\hline Meio : >Sp & 639 & 12 & 2 & 3,5 & 5,92 & 8,83 & 133,2 & 9,8 \\
\hline -Dia $>$ Int & 631 & 12 & 2 & 3,5 & 5,92 & 8,83 & 134,2 & 9,7 \\
\hline Total & 1270 & 12 & - & - & - & & 133,2 & 19,5 \\
\hline Tarde: $>\mathrm{Sp}$ & 819 & - & 2 & 3,5 & 5,92 & 8,83 & 109,8 & - \\
\hline$>\operatorname{Int}$ & 970 & - & 2 & 3,5 & 5,92 & 8,83 & 89,8 & - \\
\hline Total & 1789 & - & - & - & - & & 89,8 & - \\
\hline Média/Hora & 1529,5 & 12 & - & - & - & & 111,5 & 19,5 \\
\hline
\end{tabular}


Continuação da Tabela 3-16

a. SP $270 \quad$ Modelo 4

\begin{tabular}{|c|c|c|c|c|c|c|}
\hline $\begin{array}{l}\text { SP270- } \\
\text { Km60,5 }\end{array}$ & $\begin{array}{c}\text { Fluxo de } \\
\text { Veículos } \\
\text { Período }\end{array}$ & $\begin{array}{c}\text { Fluxo de } \\
\text { Pedestres } \\
(\mathbf{p} / \mathbf{h})\end{array}$ & $\mathbf{L}(\mathbf{m})$ & TG (s) & OT & OC \\
\hline Manhã: >Sp & 232 & - & 3,5 & - & - & - \\
\hline > Int & 282 & - & 3,5 & - & - & - \\
\hline Total & 514 & 41 & 7,0 & 8,83 & 145,7 & 19,2 \\
\hline Meio : >Sp & 562 & - & 3,5 & - & - & - \\
\hline -Dia >Int & 602 & - & 3,5 & - & - & - \\
\hline Total & 1164 & 25 & 7,0 & 8,83 & 67 & 19 \\
\hline Tarde: $>$ Sp & 476 & - & 3,5 & - & - & - \\
\hline >Int & 432 & - & 3,5 & - & - & - \\
\hline Total & 908 & 33 & 7,0 & 8,83 & 97,9 & 22,2 \\
\hline Média/Hora & $\mathbf{8 6 2}$ & $\mathbf{3 3}$ & - & - & $\mathbf{1 0 3 , 5}$ & $\mathbf{2 0 , 1}$ \\
\hline
\end{tabular}

\begin{tabular}{|c|c|c|c|c|c|c|}
\hline SP270-Km63 & Fluxo de & Fluxo de & & & & \\
\hline Período & $\begin{array}{c}\text { Veículos } \\
\text { (v/h) }\end{array}$ & $\begin{array}{c}\text { Pedestres } \\
(\mathbf{p} / \mathbf{h})\end{array}$ & $L(\mathbf{m})$ & Tc (s) & OT & OC \\
\hline Manhã: >Sp & - & - & 7,0 & 8,83 & - & - \\
\hline$>$ Int & - & - & 7,0 & 8,83 & - & - \\
\hline Total & - & - & - & - & - & - \\
\hline Meio : >Sp & 639 & 12 & 7,0 & 8,83 & 133,3 & 6,5 \\
\hline -Dia $\quad>$ Int & 631 & 12 & 7,0 & 8,83 & 134,2 & 6,5 \\
\hline Total & 1270 & 12 & - & - & 133,3 & 13 \\
\hline Tarde: $>\mathrm{Sp}$ & 819 & - & 7,0 & 8,83 & 109,9 & - \\
\hline$>\operatorname{Int}$ & 970 & - & 7,0 & 8,83 & 89,8 & - \\
\hline Total & 1789 & - & - & - & 89,8 & - \\
\hline Média/Hora & 1529,5 & 12 & - & - & 111,6 & 13 \\
\hline
\end{tabular}

Continua 
Continuação da Tabela 3-16

b. SP 280

Modelo 1a

\begin{tabular}{|l|c|c|c|c|c|c|}
\hline $\begin{array}{l}\text { SP280- } \\
\text { Km29,5 }\end{array}$ & $\begin{array}{c}\text { Fluxo de } \\
\text { Veículos } \\
(\mathbf{v} / \mathbf{h})\end{array}$ & $\begin{array}{c}\text { Fluxo de } \\
\text { Pedestres } \\
(\mathbf{p} / \mathbf{h})\end{array}$ & L (m) & TG (s) & OT & OC \\
\cline { 1 - 5 } Período & 2427 & 0 & 10,5 & 11,75 & 0,9 & 0 \\
\hline Manhã: >Sp & 2168 & 0 & 10,5 & 11,75 & 1,8 & 0 \\
\hline >Int & 4595 & 0 & - & - & 0,9 & 0 \\
\hline Total & 3665 & 0 & 10,5 & 11,75 & 0 & 0 \\
\hline Meio : >Sp & 5675 & 0 & 10,5 & 11,75 & 0 & 0 \\
\hline -Dia >Int & 9340 & 0 & - & - & 0 & 0 \\
\hline Tarde: >Sp & 5794 & 0 & 10,5 & 11,75 & 0 & 0 \\
\hline Total & 3296 & 0 & 10,5 & 11,75 & 0,1 & 0 \\
\hline Tnt & 9090 & 0 & - & - & 0 & 0 \\
\hline Média/Hora & $\mathbf{7 6 7 5}$ & $\mathbf{0}$ & - & - & $\mathbf{0 , 3}$ & $\mathbf{0}$ \\
\hline
\end{tabular}

\begin{tabular}{|c|c|c|c|c|c|c|}
\hline SP280-Km30 & & & & & & \\
\hline Período & $\begin{array}{c}\text { Veículos } \\
\text { (v/h) }\end{array}$ & $\begin{array}{c}\text { Pedestres } \\
(\mathbf{p} / \mathbf{h})\end{array}$ & $\mathbf{L}(\mathbf{m})$ & TG (s) & OT & OC \\
\hline Manhã: >Sp & 2427 & 4 & 10,5 & 11,75 & 0,9 & 4 \\
\hline$>\operatorname{Int}$ & 2168 & 4 & 10,5 & 11,75 & 1,8 & 4 \\
\hline Total & 4595 & 4 & - & - & 0,9 & 8 \\
\hline Meio : >Sp & 3665 & 6 & 10,5 & 11,75 & 0 & 6 \\
\hline -Dia $>$ Int & 5675 & 6 & 10,5 & 11,75 & 0 & 6 \\
\hline Total & 9340 & 6 & - & - & 0,0 & 12 \\
\hline Tarde: $>\mathrm{Sp}$ & 5794 & 4 & 10,5 & 11,75 & 0 & 4 \\
\hline$>\operatorname{Int}$ & 3296 & 4 & 10,5 & 11,75 & 0,1 & 4 \\
\hline Total & 9090 & 4 & - & - & 0 & 8 \\
\hline Média/Hora & 7675 & 4,7 & - & - & $\mathbf{0 , 3}$ & 9,3 \\
\hline
\end{tabular}

Continua 
Continuação da Tabela 3-16

b. SP $280 \quad$ Modelo 1b

\begin{tabular}{|c|c|c|c|c|c|c|c|}
\hline $\begin{array}{l}\text { SP280- } \\
\text { Km29,5 } \\
\text { Período }\end{array}$ & $\begin{array}{c}\text { Fluxo de } \\
\text { Veículos } \\
(\mathbf{v} / \mathbf{h}) \\
\end{array}$ & $\begin{array}{c}\text { Fluxo de } \\
\text { Pedestres } \\
(\mathbf{p} / \mathbf{h}) \\
\end{array}$ & $\mathbf{L}(\mathbf{m})$ & $\mathrm{TC}(\mathrm{s})$ & TG (s) & OT & OC \\
\hline Manhã: >Sp & 2427 & 0 & 10,5 & 11,75 & 11,75 & 0,9 & 0 \\
\hline$>\operatorname{Int}$ & 2168 & 0 & 10,5 & 11,75 & 11,75 & 1,8 & 0 \\
\hline Total & 4595 & 0 & - & - & - & 0,9 & 0 \\
\hline Meio : >Sp & 3665 & 0 & 10,5 & 11,75 & 11,75 & 0 & 0 \\
\hline -Dia $>$ Int & 5675 & 0 & 10,5 & 11,75 & 11,75 & 0 & 0 \\
\hline Total & 9340 & 0 & - & - & - & 0 & 0 \\
\hline Tarde: $>\mathrm{Sp}$ & 5794 & 0 & 10,5 & 11,75 & 11,75 & 0 & 0 \\
\hline$>\operatorname{Int}$ & 3296 & 0 & 10,5 & 11,75 & 11,75 & 0,1 & 0 \\
\hline Total & 9090 & 0 & - & - & - & 0 & 0 \\
\hline Média/Hora & 7675 & $\mathbf{0}$ & - & - & - & $\mathbf{0 , 3}$ & $\mathbf{0}$ \\
\hline
\end{tabular}

\begin{tabular}{|c|c|c|c|c|c|c|c|}
\hline SP280-Km30 & & & & & & & \\
\hline Período & $\begin{array}{c}\text { Veículos } \\
\text { (v/h) }\end{array}$ & $\begin{array}{c}\text { Pedestres } \\
(\mathbf{p} / \mathbf{h})\end{array}$ & $\mathbf{L}(\mathbf{m})$ & $\mathrm{TC}(\mathrm{s})$ & TG (s) & OT & OC \\
\hline Manhã: >Sp & 2427 & 4 & 10,5 & 11,75 & 11,75 & 0,9 & 4 \\
\hline$>\operatorname{Int}$ & 2168 & 4 & 10,5 & 11,75 & 11,75 & 1,8 & 4 \\
\hline Total & 4595 & 4 & - & - & - & 0,9 & 8 \\
\hline Meio : >Sp & 3665 & 6 & 10,5 & 11,75 & 11,75 & 0 & 6 \\
\hline -Dia $>$ Int & 5675 & 6 & 10,5 & 11,75 & 11,75 & 0 & 6 \\
\hline Total & 9340 & 6 & - & - & - & 0 & 12 \\
\hline Tarde: $>\mathrm{Sp}$ & 5794 & 4 & 10,5 & 11,75 & 11,75 & 0 & 4 \\
\hline$>\operatorname{Int}$ & 3296 & 4 & 10,5 & 11,75 & 11,75 & 0,1 & 4 \\
\hline Total & 9090 & 4 & - & - & - & 0 & 8 \\
\hline Média/Hora & 7675 & 4,7 & - & - & - & $\mathbf{0 , 3}$ & 9,3 \\
\hline
\end{tabular}


Continuação da Tabela 3-16

b. SP $280 \quad$ Modelo 1c

\begin{tabular}{|c|c|c|c|c|c|c|c|c|}
\hline $\begin{array}{l}\text { SP280- } \\
\text { Km29,5 } \\
\text { Período }\end{array}$ & $\begin{array}{c}\text { Fluxo de } \\
\text { Veículos } \\
(\mathbf{v} / \mathbf{h})\end{array}$ & $\begin{array}{c}\text { Fluxo de } \\
\text { Pedestres } \\
(p / h)\end{array}$ & $\mathbf{N}(\mathbf{f x s})$ & $\mathbf{L f}(\mathbf{m})$ & $\mathrm{T}_{\mathrm{cl}}(\mathrm{s})$ & $T_{G}(s)$ & От & OC \\
\hline Manhã: >Sp & 2427 & 0 & 3 & 3,5 & 5,92 & 11,75 & 0,9 & 0 \\
\hline$>\operatorname{Int}$ & 2168 & 0 & 3 & 3,5 & 5,92 & 11,75 & 1,8 & 0 \\
\hline Total & 4595 & 0 & - & - & - & - & 0,9 & 0 \\
\hline Meio : >Sp & 3665 & 0 & 3 & 3,5 & 5,92 & 11,75 & 0 & 0 \\
\hline -Dia $>$ Int & 5675 & 0 & 3 & 3,5 & 5,92 & 11,75 & 0 & 0 \\
\hline Total & 9340 & 0 & - & - & - & - & 0,0 & 0 \\
\hline Tarde: $>\mathrm{Sp}$ & 5794 & 0 & 3 & 3,5 & 5,92 & 11,75 & 0 & 0 \\
\hline$>\operatorname{Int}$ & 3296 & 0 & 3 & 3,5 & 5,92 & 11,75 & 0,1 & 0 \\
\hline Total & 9090 & 0 & - & - & - & - & 0 & 0 \\
\hline Média/Hora & 7675 & $\mathbf{0}$ & - & - & - & - & $\mathbf{0 , 3}$ & $\mathbf{0}$ \\
\hline
\end{tabular}

\begin{tabular}{|c|c|c|c|c|c|c|c|c|}
\hline $\begin{array}{l}\text { SP280- } \\
\text { Km30 } \\
\text { Período }\end{array}$ & $\begin{array}{c}\text { Fluxo de } \\
\text { Veículos } \\
(\mathrm{v} / \mathrm{h})\end{array}$ & $\begin{array}{c}\text { Fluxo de } \\
\text { Pedestres } \\
(\mathbf{p} / \mathbf{h})\end{array}$ & $\mathbf{N}(\mathbf{f x s})$ & $\mathbf{L f}(\mathbf{m})$ & $T_{c l}(s)$ & $T_{G}(s)$ & OT & OC \\
\hline Manhã: >Sp & 2427 & 4 & 3 & 3,5 & 5,92 & 11,75 & 0,9 & 10,4 \\
\hline$>$ Int & 2168 & 4 & 3 & 3,5 & 5,92 & 11,75 & 1,8 & 10 \\
\hline Total & 4595 & 4 & - & - & - & - & 0,9 & 20,3 \\
\hline Meio : >Sp & 3665 & 6 & 3 & 3,5 & 5,92 & 11,75 & 0 & 17,1 \\
\hline -Dia $>$ Int & 5675 & 6 & 3 & 3,5 & 5,92 & 11,75 & 0 & 17,8 \\
\hline Total & 9340 & 6 & - & - & - & - & 0 & 34,9 \\
\hline Tarde: $>\mathrm{Sp}$ & 5794 & 4 & 3 & 3,5 & 5,92 & 11,75 & 0 & 11,9 \\
\hline$>\operatorname{Int}$ & 3296 & 4 & 3 & 3,5 & 5,92 & 11,75 & 0,1 & 11,2 \\
\hline Total & 9090 & 4 & - & - & - & - & 0 & 23,1 \\
\hline Média/Hora & 7675 & 4,7 & - & - & - & - & $\mathbf{0 , 3}$ & 26,1 \\
\hline
\end{tabular}


Continuação da Tabela 3-16

b. SP 280

Modelo 4

\begin{tabular}{|l|c|c|c|c|c|c|}
\hline $\begin{array}{l}\text { SP280- } \\
\text { Km29,5 }\end{array}$ & $\begin{array}{c}\text { Fluxo de } \\
\text { Veículos } \\
(\mathbf{v} / \mathbf{h})\end{array}$ & $\begin{array}{c}\text { Fluxo de } \\
\text { Pedestres } \\
(\mathbf{p} / \mathbf{h})\end{array}$ & L (m) & Tc (s) & OT & Oc \\
\cline { 1 - 4 } Período & 2427 & 0 & 10,5 & 11,75 & 0,9 & 0 \\
\hline Manhã: >Sp & 2168 & 0 & 10,5 & 11,75 & 1,8 & 0 \\
\hline >Int & 4595 & 0 & - & - & 0,9 & 0 \\
\hline Total & 3665 & 0 & 10,5 & 11,75 & 0 & 0 \\
\hline Meio : >Sp & 5675 & 0 & 10,5 & 11,75 & 0 & 0 \\
\hline -Dia >Int & 9340 & 0 & - & - & 0 & 0 \\
\hline Total & 5794 & 0 & 10,5 & 11,75 & 0 & 0 \\
\hline Tarde: >Sp & 3296 & 0 & 10,5 & 11,75 & 0,1 & 0 \\
\hline >Int & 9090 & 0 & - & - & 0 & 0 \\
\hline Total & $\mathbf{7 6 7 5}$ & $\mathbf{0}$ & - & - & $\mathbf{0 , 3}$ & $\mathbf{0}$ \\
\hline
\end{tabular}

\begin{tabular}{|c|c|c|c|c|c|c|}
\hline SP280-Km30 & & & & & & \\
\hline Período & $\begin{array}{l}\text { Veículos } \\
\text { (v/h) }\end{array}$ & $\begin{array}{c}\text { Pedestres } \\
\text { (p/h) }\end{array}$ & $\mathbf{L}(\mathbf{m})$ & Tc (s) & OT & OC \\
\hline Manhã: >Sp & 2427 & 4 & 10,5 & 11,75 & 0,9 & 3,9 \\
\hline$>\operatorname{In} t$ & 2168 & 4 & 10,5 & 11,75 & 1,8 & 3,9 \\
\hline Total & 4595 & 4 & - & - & 0,9 & 7,8 \\
\hline Meio : >Sp & 3665 & 6 & 10,5 & 11,75 & 0 & 6 \\
\hline -Dia $>$ Int & 5675 & 6 & 10,5 & 11,75 & 0 & 6 \\
\hline Total & 9340 & 6 & - & - & 0,0 & 12 \\
\hline Tarde: >Sp & 5794 & 4 & 10,5 & 11,75 & 0 & 4 \\
\hline$>\operatorname{Int}$ & 3296 & 4 & 10,5 & 11,75 & 0,1 & 4 \\
\hline Total & 9090 & 4 & - & - & 0 & 8 \\
\hline Média/Hora & 7675 & 4,7 & - & - & $\mathbf{0 , 3}$ & 9,3 \\
\hline
\end{tabular}




\subsubsection{Análise e validação dos modelos de previsão das medidas de oportunidades}

Comparando as oportunidades de manobra e conflito obtidas teoricamente com as medidas empíricas, vemos que os valores estão muito próximos, principalmente para as medidas de oportunidades de conflito. A Tabela 3-20 mostra os valores empíricos e os valores calculados pelas expressões 1a, 1b, 1c e 4 do método proposto por MING (2008).

Podemos perceber que os valores obtidos a partir dos modelos 1 b e 4 são os que mais se aproximam dos valores obtidos empiricamente (particularmente a medida OC2).

Tabela 3-17 - Validação das medidas teóricas de oportunidade de manobra (OT) e oportunidade de conflito (OC)

\begin{tabular}{|c|c|c|c|c|c|c|c|c|c|c|}
\hline \multirow{2}{*}{$\begin{array}{c}\text { SP270- } \\
\text { Km60,5 }\end{array}$} & \multicolumn{2}{|c|}{ Modelo 1a } & \multicolumn{2}{|c|}{ Modelo 1b } & \multicolumn{2}{|c|}{ Modelo 1c } & \multicolumn{2}{|c|}{ Modelo 4} & \multicolumn{2}{|c|}{ Empíricas } \\
\hline & $\begin{array}{l}\text { OT/ } \\
\text { hora }\end{array}$ & $\begin{array}{l}\text { OC/ } \\
\text { hora }\end{array}$ & $\begin{array}{l}\text { OT/ } \\
\text { hora }\end{array}$ & $\begin{array}{l}\text { OC/ } \\
\text { hora }\end{array}$ & $\begin{array}{l}\text { OT/ } \\
\text { hora }\end{array}$ & $\begin{array}{l}\text { OC/ } \\
\text { hora }\end{array}$ & $\begin{array}{l}\text { OT/ } \\
\text { hora }\end{array}$ & $\begin{array}{l}\text { OC/ } \\
\text { hora }\end{array}$ & $\begin{array}{l}\text { OT/ } \\
\text { hora }\end{array}$ & $\begin{array}{l}\text { OC/ } \\
\text { hora }\end{array}$ \\
\hline Manhã: >Sp & - & - & - & - & - & - & - & - & - & - \\
\hline$>\operatorname{Int}$ & - & - & - & - & - & - & - & - & - & - \\
\hline Total & 145,7 & 29,4 & 145,7 & 38,3 & 145,6 & 38,3 & 145,7 & 19,2 & 132 & 9 \\
\hline Meio : >Sp & - & - & - & - & - & - & - & - & - & - \\
\hline -Dia $>$ Int & - & - & - & - & - & - & - & - & - & - \\
\hline Total & 67 & 23,6 & 67,0 & 38 & 66,9 & 38 & 67,0 & 19 & 84 & 15 \\
\hline Tarde: >Sp & - & - & - & - & - & - & - & - & - & - \\
\hline$>\operatorname{Int}$ & - & - & - & - & - & - & - & - & - & - \\
\hline Total & 97,9 & 29,4 & 97,9 & 44,3 & 97,8 & 44,3 & 97,9 & 22,2 & 48 & 12 \\
\hline Média/Hora & 103,5 & 27,5 & 103,5 & 40,2 & 103,5 & 40,2 & 103,5 & 20,1 & 88 & 12 \\
\hline
\end{tabular}

Continua 
Continuação Tabela 3-17

\begin{tabular}{|c|c|c|c|c|c|c|c|c|c|c|}
\hline \multirow[t]{2}{*}{ SP270-Km63 } & \multicolumn{2}{|c|}{ Modelo 1a } & \multicolumn{2}{|c|}{ Modelo 1b } & \multicolumn{2}{|c|}{ Modelo 1c } & \multicolumn{2}{|c|}{ Modelo 4} & \multicolumn{2}{|c|}{ Empíricas } \\
\hline & $\begin{array}{c}\text { OT/ } \\
\text { hora }\end{array}$ & $\begin{array}{c}\text { OC/ } \\
\text { hora }\end{array}$ & $\begin{array}{c}\text { OT/ } \\
\text { hora }\end{array}$ & $\begin{array}{c}\text { OCl } \\
\text { hora }\end{array}$ & $\begin{array}{c}\text { OT/ } \\
\text { hora }\end{array}$ & $\begin{array}{c}\text { OCl } \\
\text { hora }\end{array}$ & $\begin{array}{c}\text { OT/ } \\
\text { hora }\end{array}$ & $\begin{array}{l}\text { OC/ } \\
\text { hora }\end{array}$ & $\begin{array}{c}\text { OT/ } \\
\text { hora }\end{array}$ & $\begin{array}{l}\text { OC/ } \\
\text { hora }\end{array}$ \\
\hline Manhã: >Sp & - & - & - & - & - & - & - & - & - & - \\
\hline$>$ Int & - & - & - & - & - & - & - & - & - & - \\
\hline Total & - & - & - & - & - & - & - & - & - & - \\
\hline Meio : >Sp & 133,3 & 9,5 & 133,3 & 9,5 & 133,2 & 9,8 & 133,3 & 6,5 & 156 & 3 \\
\hline -Dia $>$ Int & 134,2 & 9,4 & 134,2 & 9,4 & 134,2 & 9,7 & 134,2 & 6,5 & 180 & 3 \\
\hline Total & 133,3 & 18,9 & 133,3 & 18,9 & 133,2 & 19,5 & 133,3 & 13 & 156 & 6 \\
\hline Tarde: $>\mathrm{Sp}$ & 109,9 & - & 109,9 & - & 109,8 & - & 109,9 & - & 108 & - \\
\hline$>$ Int & 89,8 & - & 89,8 & - & 89,8 & - & 89,8 & - & 120 & - \\
\hline Total & 89,8 & - & 89,8 & - & 89,8 & - & 89,8 & - & 108 & - \\
\hline Média/Hora & 111,6 & 18,9 & 111,6 & 18,9 & 111,5 & 19,5 & 111,6 & 13 & 132 & 6 \\
\hline SP280. & Mod & lo 1a & Mod & lo 1b & Mod & lo 1c & Mod & elo 4 & Emp & ricas \\
\hline Km29,5 & $\begin{array}{c}\text { OT/ } \\
\text { hora }\end{array}$ & $\begin{array}{l}\text { OCl } \\
\text { hora }\end{array}$ & $\begin{array}{c}\text { OT/ } \\
\text { hora }\end{array}$ & $\begin{array}{c}\text { OC/ } \\
\text { hora }\end{array}$ & $\begin{array}{l}\text { OT/ } \\
\text { hora }\end{array}$ & $\begin{array}{l}\text { OCl } \\
\text { hora }\end{array}$ & $\begin{array}{c}\text { OT/ } \\
\text { hora }\end{array}$ & $\begin{array}{l}\text { OCl } \\
\text { hora }\end{array}$ & $\begin{array}{l}\text { OT/ } \\
\text { hora }\end{array}$ & $\begin{array}{c}\text { OC/ } \\
\text { hora }\end{array}$ \\
\hline Manhã: >Sp & 0,9 & 0 & 0,9 & 0 & 0,9 & 0 & 0,9 & 0 & 18 & 0 \\
\hline$>$ Int & 1,8 & 0 & 1,8 & 0 & 1,8 & 0 & 1,8 & 0 & 12 & 0 \\
\hline Total & 0,9 & 0 & 0,9 & 0 & 0,9 & 0 & 0,9 & 0 & 12 & 0 \\
\hline Meio : >Sp & 0 & 0 & 0 & 0 & 0 & 0 & 0 & 0 & 12 & 0 \\
\hline -Dia $>$ Int & 0 & 0 & 0 & 0 & 0 & 0 & 0 & 0 & 0 & 0 \\
\hline Total & 0 & 0 & 0 & 0 & 0 & 0 & 0 & 0 & 0 & 0 \\
\hline Tarde: $>\mathrm{Sp}$ & 0 & 0 & 0 & 0 & 0 & 0 & 0 & 0 & 12 & 0 \\
\hline$>\operatorname{Int}$ & 0,1 & 0 & 0,1 & 0 & 0,1 & 0 & 0,1 & 0 & 0 & 0 \\
\hline Total & 0 & 0 & 0 & 0 & 0 & 0 & 0 & 0 & 0 & 0 \\
\hline Média/Hora & $\mathbf{0 , 3}$ & $\mathbf{0}$ & $\mathbf{0 , 3}$ & $\mathbf{0 , 0}$ & $\mathbf{0 , 3}$ & $\mathbf{0}$ & $\mathbf{0 , 3}$ & $\mathbf{0}$ & 4 & $\mathbf{0}$ \\
\hline
\end{tabular}


Continuação Tabela 3-17

\begin{tabular}{|c|c|c|c|c|c|c|c|c|c|c|}
\hline \multirow{2}{*}{ SP280-Km30 } & \multicolumn{2}{|c|}{ Modelo 1a } & \multicolumn{2}{|c|}{ Modelo 1b } & \multicolumn{2}{|c|}{ Modelo 1c } & \multicolumn{2}{|c|}{ Modelo 4} & \multicolumn{2}{|c|}{ Empíricas } \\
\hline & $\begin{array}{c}\text { OT/ } \\
\text { hora }\end{array}$ & $\begin{array}{l}\text { OC/ } \\
\text { hora }\end{array}$ & $\begin{array}{c}\text { OT/ } \\
\text { hora }\end{array}$ & $\begin{array}{l}\text { OC/ } \\
\text { hora }\end{array}$ & $\begin{array}{l}\text { OT/ } \\
\text { hora }\end{array}$ & $\begin{array}{l}\text { OC/ } \\
\text { hora }\end{array}$ & $\begin{array}{c}\text { OT/ } \\
\text { hora }\end{array}$ & $\begin{array}{l}\text { OC/ } \\
\text { hora }\end{array}$ & $\begin{array}{l}\text { OT/ } \\
\text { hora }\end{array}$ & $\begin{array}{l}\text { OC/ } \\
\text { hora }\end{array}$ \\
\hline Manhã: >Sp & 0,9 & 4 & 0,9 & 4 & 0,9 & 10,4 & 0,9 & 3,9 & 18 & 0 \\
\hline$>\operatorname{Int}$ & 1,8 & 4 & 1,8 & 4 & 1,8 & 10 & 1,8 & 3,9 & 12 & 3 \\
\hline Total & 0,9 & 8 & 0,9 & 8 & 0,9 & 20,3 & 0,9 & 7,8 & 12 & 3 \\
\hline Meio : >Sp & 0 & 6 & 0 & 6 & 0 & 17,1 & 0 & 6 & 12 & 2 \\
\hline -Dia $\quad>$ Int & 0 & 6 & 0 & 6 & 0 & 17,8 & 0 & 6 & 0 & 0 \\
\hline Total & 0 & 12 & 0 & 12 & 0 & 34,9 & 0 & 12 & 0 & 2 \\
\hline Tarde: $>\mathrm{Sp}$ & 0 & 4 & 0 & 4 & 0 & 11,9 & 0 & 4 & 12 & 6 \\
\hline$>\operatorname{Int}$ & 0,1 & 4 & 0,1 & 4 & 0,1 & 11,2 & 0,1 & 4 & 0 & 5 \\
\hline Total & 0 & 8 & 0 & 8 & 0 & 23,1 & 0 & 8 & 0 & 11 \\
\hline Média/Hora & $\mathbf{0 , 3}$ & 9,3 & $\mathbf{0 , 3}$ & 9,3 & $\mathbf{0 , 3}$ & 26,1 & $\mathbf{0 , 3}$ & 9,3 & 4 & 5,3 \\
\hline
\end{tabular}

Valores bastante semelhantes, tanto para oportunidades de travessia (OT) quanto para oportunidades de conflito (OC), permitem a validação preliminar dos modelos. Por ser o modelo mais simples que distingue os sentidos de tráfego, a análise a seguir preferirá utilizar o modelo $1 b$.

Para a situação atual, na qual também foram obtidas as medidas empíricas, o diagnóstico obtido seria basicamente o mesmo. No entanto, como discutido adiante, a utilização dos modelos de previsão permite examinar outros cenários e analisar a validade de outras conclusões. 
Os resultados foram analisados estatisticamente. Foram feitas regressões de OTmedida $\mathrm{x}$ OTprevista e OCmedida e OCprevista para cada modelo com Omedida = intercepto + coeficiente*Omodelo; por período (11 valores pra OT e 10 valores pra OC pela perda de dados da coleta).

A Tabela 3-18, a seguir, apresenta os resultados das regressões.

Tabela 3-18 - Análise estatística dos modelos de previsão

\begin{tabular}{|l|l|l|l|}
\hline Modelo & \multicolumn{1}{|c|}{ Int } & \multicolumn{1}{|c|}{ Coef } & \multicolumn{1}{|c|}{$\mathbf{R}^{\mathbf{2}}$} \\
\hline OT & $\begin{array}{l}5,98 \\
-0,71\end{array}$ & $\begin{array}{l}0,93 \\
(8,31)\end{array}$ & $88 \%$ \\
\hline OC1a & $\begin{array}{l}0,9 \\
-0,5\end{array}$ & $\begin{array}{l}0,38 \\
(3,68)\end{array}$ & $63 \%$ \\
\hline OC1b & $\begin{array}{l}1,3 \\
-0,86\end{array}$ & $\begin{array}{l}0,27 \\
(4,18)\end{array}$ & $69 \%$ \\
\hline OC1c & $\begin{array}{l}0,18 \\
-0,09\end{array}$ & $\begin{array}{l}0,26 \\
(3,60)\end{array}$ & $62 \%$ \\
\hline OC4 & $\begin{array}{l}0,22 \\
-0,13\end{array}$ & $\begin{array}{l}0,55 \\
(4,14)\end{array}$ & $68 \%$ \\
\hline
\end{tabular}

Por essa análise estatística o modelo 4 parece melhor, mas não foi considerado nesse trabalho por não distinguir os sentidos. 


\subsubsection{Comparação do Diagnóstico de Segurança com Medidas de Oportunidades e de Dados de Acidentes}

Nesse item é feita a comparação das medidas de oportunidades de manobra/travessia e de conflito obtidas empiricamente com o histórico de acidentes de cada local estudado.

Vale lembrar que as medidas de oportunidade de conflito consideram a multiplicidade (OC2) e as previsões de oportunidades de conflitos são aplicadas por zona de conflito (modelo 1b).

Também deve-se recordar que os locais com mais acidentes foram o km 63 na SP 270 (o km 60,5 é seu local de controle, sem registro de acidentes) e o km 30 na SP 280 (o km 29,5 é seu local de controle, com apenas 1 acidente registrado).

Por fim, deve-se notar que o km63 recebeu uma intervenção local em 2008 (a implantação dos "bullets") e teve os efeitos de uma intervenção estrutural que desviou parte do tráfego de passagem (destinado ao acesso para a SP 280). 
a. Diagnóstico Atual com Medidas Empíricas de Oportunidade

A Tabela 3-19 apresentam um sumário das OTs e OCs medidas para cada local.

Tabela 3-19 - Medidas empíricas de OTs e OCs

\begin{tabular}{|c|c|c|}
\hline $\begin{array}{l}\text { SP270- } \\
\text { Km60,5 }\end{array}$ & \multirow{2}{*}{$\begin{array}{l}\text { OT/hora } \\
\text { (empírica) }\end{array}$} & \multirow{2}{*}{$\begin{array}{l}\text { OC/hora } \\
\text { (empírica) }\end{array}$} \\
\hline Período & & \\
\hline Manhã: >Sp & - & - \\
\hline$>\operatorname{Int}$ & - & - \\
\hline Total & 132 & 9 \\
\hline Meio : $>\mathrm{Sp}$ & - & - \\
\hline -Dia $>$ Int & - & - \\
\hline Total & 84 & 13 \\
\hline Tarde: >Sp & - & - \\
\hline$>\operatorname{Int}$ & - & - \\
\hline Total & 48 & 11 \\
\hline Média/Hora & 88 & 11 \\
\hline
\end{tabular}

\begin{tabular}{|r|c|c|}
\hline SP270-Km63 & $\begin{array}{c}\text { oT/hora } \\
\text { (empírica) }\end{array}$ & $\begin{array}{c}\text { oc/hora } \\
\text { (empírica) }\end{array}$ \\
\cline { 1 - 2 } Período & - & - \\
\hline Manhã: >Sp & - & - \\
\hline >Int & - & - \\
\hline Total & - & 3 \\
\hline Meio : >Sp & 156 & 3 \\
\hline -Dia >Int & 180 & 6 \\
\hline Total & 156 & - \\
\hline Tarde: >Sp & 108 & - \\
\hline >Int & 120 & - \\
\hline Total & 108 & $\mathbf{6}$ \\
\hline Média/Hora & $\mathbf{1 3 2}$ & \\
\hline
\end{tabular}

\begin{tabular}{|c|c|c|}
\hline $\begin{array}{l}\text { SP280- } \\
\text { Km29,5 }\end{array}$ & \multirow[t]{2}{*}{$\begin{array}{c}\text { OT/hora } \\
\text { (empírica) }\end{array}$} & \multirow[t]{2}{*}{$\begin{array}{l}\text { oc/hora } \\
\text { (empírica) }\end{array}$} \\
\hline Período & & \\
\hline Manhã: >Sp & 18 & 0 \\
\hline$>\operatorname{Int}$ & 12 & 0 \\
\hline Total & 12 & 0 \\
\hline Meio : >Sp & 12 & 0 \\
\hline -Dia $>$ Int & 0 & 0 \\
\hline Total & 0 & 0 \\
\hline Tarde: $>\mathrm{Sp}$ & 12 & 0 \\
\hline$>\operatorname{Int}$ & 0 & 0 \\
\hline Total & 0 & 0 \\
\hline Média/Hora & 4 & $\overline{\mathbf{0}}$ \\
\hline
\end{tabular}

\begin{tabular}{|c|c|c|}
\hline SP280-Km30 & \multirow{2}{*}{$\begin{array}{l}\text { OT/hora } \\
\text { (empírica) }\end{array}$} & \multirow{2}{*}{$\begin{array}{l}\text { OC/hora } \\
\text { (empírica) }\end{array}$} \\
\hline Período & & \\
\hline Manhã: >Sp & 18 & 0 \\
\hline$>\operatorname{Int}$ & 12 & 3 \\
\hline Total & 12 & 3 \\
\hline Meio : $>\mathrm{Sp}$ & 12 & 2 \\
\hline -Dia $>$ Int & 0 & 0 \\
\hline Total & 0 & 2 \\
\hline Tarde: $>\mathrm{Sp}$ & 12 & 6 \\
\hline$>$ Int & 0 & 5 \\
\hline Total & 0 & 11 \\
\hline Média/Hora & 4 & 5 \\
\hline
\end{tabular}


É fácil perceber que as oportunidades de travessia e oportunidades de conflito avaliam aspectos complementares que devem ser considerados, ambos, ao avaliar se os locais são menos seguros.

Há locais onde a inexistência de OTs é o aspecto relevante que explica o risco de acidentes. É o caso do km 30: há poucas oportunidades de travessia e como visto no levantamento dos dados de acidentes mostrado no início do item 3.4, é um trecho com bastante ocorrência de acidentes. O mesmo ocorre no km 29,5 mas a avaliação relaciona a inexistência de acidentes à ausência de pedestres (apesar do alto risco).

Onde há OTs, a insegurança ainda pode estar presente. Na SP 270, Rodovia Raposo Tavares, a questão não pode ser avaliada na análise da relação caso/controle na situação atual (onde ambos tem registros de acidentes baixos, pouco maiores no $\mathrm{km} \mathrm{63).} \mathrm{Pode} \mathrm{ser} \mathrm{observado} \mathrm{nas}$ medidas de conflito empíricas que a situação atual é similar. O km 60,5 tem OTs em nível similar ao km 63, na situação atual. O local utilizado como controle apresenta número mais elevado de OCs do que o km 63, em função do maior fluxo de pedestres (em termos relativos, os locais também são similares, na situação atual).

A comparação com o histórico de acidentes nos locais da SP 270, Rodovia Raposo Tavares, (no período 2005 a 2011, a ocorrência de acidentes envolvendo pedestres e ciclistas é realmente bem mais elevada no $\mathrm{km} 63$, não tendo ocorrido nenhum acidente no km 60,5 no período estudado) somente poderá ser feita no estudo antes e depois, apresentado adiante.

Já no caso da SP 280, Rodovia Castello Branco, na comparação com o histórico de acidentes (bastante maior no $\mathrm{km} \mathrm{30),} \mathrm{essa} \mathrm{a} \mathrm{relação} \mathrm{caso/controle} \mathrm{é} \mathrm{menos} \mathrm{visível} \mathrm{na} \mathrm{análise} \mathrm{das}$ oportunidades de travessias, mas aparece aqui também, como nos acidentes, na ocorrência de oportunidades de conflito que no $\mathrm{km} 30$ é superior às do $\mathrm{km}$ 29,5 pela presença de pedestres. 
b. Diagnóstico com Medidas Teóricas de Oportunidade

Nesse item é feita a comparação das medidas de oportunidades de manobra/travessia e de conflito obtidas pelo modelo $1 \mathrm{~b}$ exposto por MING (2008).

A Tabela 3-20 sintetiza os resultados das previsões de OTs e OCs.

Tabela 3-20 - Medidas teóricas de OTs e OCs (1b)

\begin{tabular}{|c|c|c|}
\hline $\begin{array}{l}\text { SP270- } \\
\text { Km60.5 }\end{array}$ & \multicolumn{2}{|c|}{ Modelo 1b } \\
\hline Período & OT/hora & OC/hora \\
\hline Manhã: >Sp & - & - \\
\hline$>$ Int & - & - \\
\hline Total & 145,7 & 38,3 \\
\hline Meio : >Sp & - & - \\
\hline -Dia >Int & - & - \\
\hline Total & 67 & 38 \\
\hline Tarde: >Sp & - & - \\
\hline$>$ Int & - & - \\
\hline Total & 97,9 & 44,3 \\
\hline Média/Hora & 104 & 40 \\
\hline
\end{tabular}

\begin{tabular}{|r|c|c|}
\hline \multirow{2}{*}{ SP270-Km63 } & \multicolumn{2}{|c|}{ Modelo 1b } \\
\hline Período & OT/hora & OC/hora \\
\hline Manhã: >Sp & - & - \\
\hline >Int & - & - \\
\hline Total & - & - \\
\hline Meio : >Sp & 133,3 & 9,5 \\
\hline -Dia >Int & 134,2 & 9,4 \\
\hline Total & 133,3 & 18,9 \\
\hline Tarde: $>$ Sp & 109,9 & - \\
\hline >Int & 89,8 & - \\
\hline Total & 89,8 & - \\
\hline Média/Hora & $\mathbf{1 1 1 , 6}$ & $\mathbf{1 8 , 9}$ \\
\hline
\end{tabular}

\begin{tabular}{|c|c|c|}
\hline $\begin{array}{l}\text { SP280- } \\
\text { Km29,5 }\end{array}$ & \multicolumn{2}{|c|}{ Modelo 1b } \\
\hline Período & OT/hora & OC/hora \\
\hline Manhã: >Sp & 0,9 & 0 \\
\hline$>\operatorname{Int}$ & 1,8 & 0 \\
\hline Total & 0,9 & 0 \\
\hline Meio : >Sp & 0 & 0 \\
\hline -Dia >Int & 0 & 0 \\
\hline Total & 0,0 & 0 \\
\hline Tarde: $>\mathrm{Sp}$ & 0 & 0 \\
\hline$>$ Int & 0,1 & 0 \\
\hline Total & 0 & 0 \\
\hline Média/Hora & $\mathbf{0 , 3}$ & $\mathbf{0}$ \\
\hline
\end{tabular}

\begin{tabular}{|c|c|c|}
\hline SP280-Km30 & \multicolumn{2}{|c|}{ Modelo 1b } \\
\hline Período & OT/hora & OC/hora \\
\hline Manhã: >Sp & 0,9 & 4 \\
\hline$>\operatorname{Int}$ & 1,8 & 4 \\
\hline Total & 0,9 & 8 \\
\hline Meio : > Sp & 0 & 6 \\
\hline -Dia $>$ Int & 0 & 6 \\
\hline Total & 0 & 12 \\
\hline Tarde: >Sp & 0 & 4 \\
\hline$>$ Int & 0,1 & 4 \\
\hline Total & 0 & 8 \\
\hline Média/Hora & $\mathbf{0 , 3}$ & 9,3 \\
\hline
\end{tabular}


Nesse caso, como anteriormente comentado, os resultados são basicamente os mesmos da análise das medidas empíricas.

Foi possível prever que as oportunidades de travessia na SP 280, Rodovia Castello Branco, são praticamente nulas, o que mostra a impossibilidade da travessia segura de pedestres. Seria necessário algum tipo de tratamento para melhorar a segurança do pedestre na travessia, com segregação no tempo ou no espaço, ou a supressão da possibilidade física de travessia (com barreiras intransponíveis). A relação do maior risco efetivo com a presença de pedestres no km 30 também pode ser prevista.

A análise das oportunidades de travessia e de conflito na SP 270, Rodovia Raposo Tavares, também puderam ser replicadas. Na situação atual, as previsões demonstram a similaridade

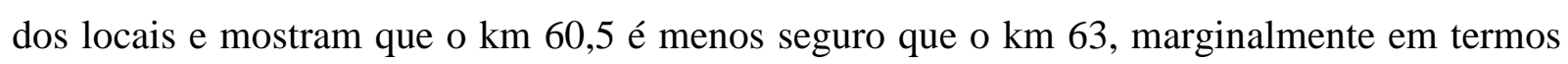
absolutos (mas sendo similares em termos relativos), pela maior presença de pedestres (o que não é coerente com os dados obtidos no levantamento dos dados de acidentes, enfraquecendo a relação caso/controle proposta inicialmente).

No entanto, os modelos de previsão permitem comparar também a situação antes e depois das intervenções que afetaram a frequência de acidentes no km 63, no item a seguir.

c. Diagnóstico do Impacto das Intervenções Observadas

Buscou-se então avaliar a eficácia dos dispositivos de proteção para o pedestre instalados no km 63 da SP 270, Rodovia Raposo Tavares, através de uma análise antes e depois da instalação dos dispositivos, com os cálculos de oportunidades de manobra e de conflito.

O modelo $1 \mathrm{~b}$ apresentado por MING é aplicado para os dados de tráfego do km 63, para pista simples (antes) e considerando o dispositivo de segurança (depois), a fim de desconsiderar o efeito do dispositivo instalado entre os dois sentidos de tráfego, para realização da travessia por etapa. Na situação antes, havia uma faixa por sentido com acostamento.

A Tabela 3-21a, na página 225, mostra essa comparação inicial. Percebe-se que não houve alteração nas oportunidade de conflito, já as oportunidade de travessia são consideravelmente 
reduzidas. A análise indica que o ganho da divisão da travessia em etapas teria sido parcialmente anulada pelo aumento do número de faixas por sentido (que prejudica a travessia dos pedestres).

Outro fator relevante ainda tem de ser considerado: o efeito do novo entroncamento com a Estrada do Marmeleiro (para acesso à Rodovia Castelo Branco, um pouco antes do local estudado, que entrou em operação em 2009), o que resultou em uma redução no fluxo que passa no $\mathrm{km} 63$.

A Figura 3-24, a seguir, mostra a situação atual. A fim de ilustrar essa mudança no fluxo, foram identificados os seguintes locais: i o ponto de interesse $(\mathrm{km} \mathrm{63),} \mathrm{R} \mathrm{a} \mathrm{rotatória,} \mathrm{A} \mathrm{o}$ acesso, RT o fluxo da Rodovia Raposo Tavares e CB o fluxo em direção à Rodovia Castello Branco. Anteriormente o acesso da Rodovia Raposo Tavares para a Rodovia Castello Branco era feito por RT-i-R-CB, e no sentido contrário CB-R-i-RT, ou seja o fluxo passava pelo local estudados (km 63, aqui chamado i). Com o entroncamento em desnível, esse fluxo é desviado e passa a faze ro seguinte trajeto: RT-A-CB ou CB-A-RT.

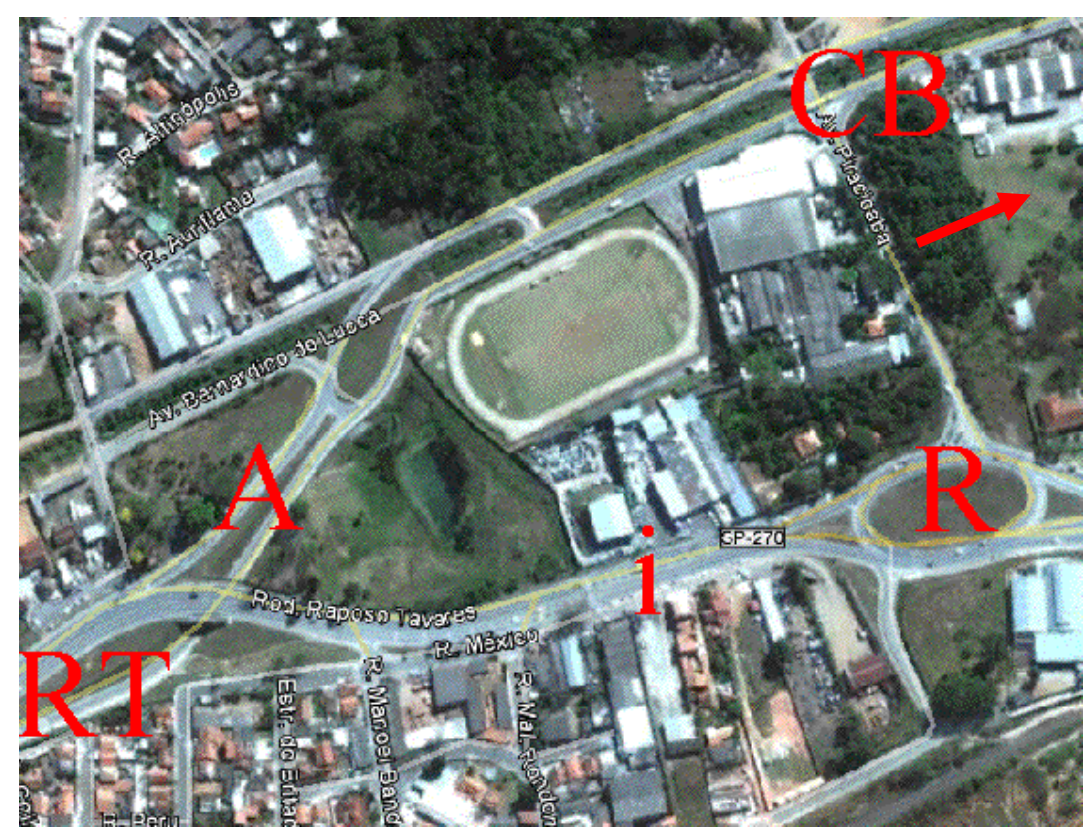

Figura 3-24 - Km 63 da SP 270 - Configuração atual 
Não foi possível obter as filmagens do entroncamento, para saber quanto do fluxo foi desviado, mas as vistorias em campo indicaram que o fluxo desviado é da ordem de 500 veículos/hora em cada sentido, com porcentagem de veículos pesados entre $5 \%$ e $20 \%$, pelo menos nos períodos de pico. Conservativamente, foi assumido um valor de 400 veículos/hora para estimar o fluxo antes. Essas considerações estão incorporadas na Tabela 3-21b, próxima página.

A comparação pertinente é com os resultados dos locais da SP 270 na Tabela 3-20 (ou os valores correspondentes, detalhados na Tabela 3-16a do modelo 1b). Nota-se que a situação sem dispositivo tem uma frequência bastante menor de oportunidades de travessia (agora em nível bastante inferior ao existente no local controle, o $\mathrm{km} 60,5$; cerca de $50 \%$ sem refúgio de pedestres e cerca de $10 \%$ sem refúgio de pedestres e sem entroncamento). A estimativa das oportunidades de conflitos, indica uma frequência cerca de $17 \%$ maior na situação sem dispositivo mas ainda menor que o valor absoluto observado no local controle (onde há mais pedestres). No entanto, a comparação com o local controle, o km 60,5, é agora ambígua pois a avaliação indica uma probabilidade de oportunidade de conflito simultâneo quase certa (risco relativo próximo a $100 \%$ de ambos os sentidos, dado que o fluxo de pedestres no período em que se obteve contagem é de $12 \mathrm{ped} / \mathrm{h}$ e tem-se $22,1 / 12=1,84 \mathrm{OC} /$ ped por travessia).

Os resultados apresentados permitem concluir que a situação antes é pior que a atual mas avalia que a eficácia dos dispositivos instalados poderia ser melhor, pelo menos no que diz respeito a segurança dos pedestres, se a travessia fosse não tivesse sido alongada. 
Tabela 3-21 - Análise das obras de melhoria - "antes" e "depois" para cálculos de oportunidade de manobra e de conflito

a. sem Refúgio de pedestres

Antes

\begin{tabular}{|c|c|c|c|c|c|c|c|}
\hline \begin{tabular}{|l|} 
SP270-Km63 \\
Período
\end{tabular} & $\begin{array}{c}\text { Fluxo de } \\
\text { Veículos (v/h) }\end{array}$ & $\begin{array}{c}\text { Fluxo de } \\
\text { Pedestres }(\mathrm{p} / \mathrm{h})\end{array}$ & $\mathbf{L}(\mathbf{m})$ & $\mathrm{TC}(\mathrm{s})$ & TG (s) & OT & OC \\
\hline Manhã: >Sp & - & - & 3,5 & - & - & - & - \\
\hline$>$ Int & - & - & 3,5 & - & - & - & - \\
\hline Total & - & - & 7,0 & - & - & - & - \\
\hline Meio : $>$ Sp & 639 & - & 3,5 & - & - & - & 9,5 \\
\hline -Dia $>$ Int & 631 & - & 3,5 & - & - & - & 9,4 \\
\hline Total & 1270 & 12 & 7,0 & 8,83 & 8,83 & 56,4 & 18,9 \\
\hline Tarde: $>\mathrm{Sp}$ & 819 & - & 3,5 & - & - & - & - \\
\hline$>\operatorname{Int}$ & 970 & - & 3,5 & - & - & - & - \\
\hline Total & 1789 & - & 7,0 & - & - & - & - \\
\hline Média/Hora & 1529,5 & 12 & - & - & - & 56,4 & 18,9 \\
\hline
\end{tabular}

b. sem Refúgio de pedestres e sem Entroncamento

Antes

\begin{tabular}{|l|c|c|c|c|c|c|c|}
\hline SP270-Km63 & $\begin{array}{c}\text { Fluxo de } \\
\text { Veículos (v/h) }\end{array}$ & $\begin{array}{c}\text { Fluxo de } \\
\text { Pedestres (p/h) }\end{array}$ & L (m) & TC (s) & TG (s) & OT & OC \\
\hline Manhã: >Sp & - & - & 3,5 & - & - & - & - \\
\hline$>$ Int & - & - & 3,5 & - & - & - & - \\
\hline Total & - & - & 7,0 & - & - & - & - \\
\hline Meio $:>$ Sp & 1039 & - & 3,5 & - & - & - & 11,0 \\
\hline -Dia >Int & 1031 & - & 3,5 & - & - & - & 11,1 \\
\hline Total & 2070 & 12 & 7,0 & 8,83 & 8,83 & 12,9 & 22,1 \\
\hline Tarde: $>$ Sp & 1219 & - & 3,5 & - & - & - & - \\
\hline >Int & 1370 & - & 3,5 & - & - & - & - \\
\hline Total & 2589 & - & 7,0 & - & - & - & - \\
\hline Média/Hora & $\mathbf{2 3 2 9 , 5}$ & $\mathbf{1 2}$ & - & - & - & $\mathbf{1 2 , 9}$ & $\mathbf{2 2 , 1}$ \\
\hline
\end{tabular}


d. Análise da Evitabilidade e Severidade das Oportunidade de Conflito

Os modelos de oportunidade de conflito foram extendidos para analisar também a questão da evitabilidade e severidade dos acidentes potenciais, aspecto analisado a seguir.

Calculadas as oportunidade de conflito, o valor em OT/hora e CO/hora é convertido para $\mathrm{OT} /$ ano e $\mathrm{CO} / \mathrm{ano}$ e então é corrigido pelo $\mathrm{P}_{\mathrm{SV}}$, mencionado anteriormente. Os valores depois da correção serão chamadas oportunidades de conflito efetiva $\left(\mathrm{OC}_{\mathrm{E}}\right)$.

A fim de se retratar de forma preliminar a diferença existente em termos de visibilidade noturna, a análise das restrições físicas foi complementada pela questão da dificuldade de deteção dos pedestres sob baixa luminosidade.

Segundo SCHNELL et al. (2001), para a visibilidade do pedestre em função da iluminação dos faróis sob condições normais e com farol baixo, o pedestre adulto é visto a uma distância de $109,9 \mathrm{~m}$ com roupas escuras (índice de refletividade 0,11) e 186,2m com roupas claras (índice de refletividade 0,81). Estes dados podem ser considerados como valores limites porque o estudo fez observações em um trecho experimental sem outras interferências.

Com base nestes valores, admitiu-se uma distância limite de visibilidade de 100m sem iluminação pública. Para locais com iluminação pública, admitiu-se uma distância limite de 200m (no mesmo trabalho, o efeito do uso do farol alto é avaliado em um aumento de 50\%, com base em outros estudos, mas o efeito da iluminação pública não é especificamente considerado). Em período diurno, adotou-se um valor limite de 400m.

As vistorias de campo mostram valores de visibilidade, considerando obstruções visuais e os limites mencionados acima, conforme a Tabela 3-22:

Tabela 3-22 - Distâncias de visibilidade considerando obstruções visuais

\begin{tabular}{|c|c|c|c|c|c|}
\hline & & \multicolumn{2}{|c|}{ Diurno } & \multicolumn{2}{c|}{ Noturno } \\
\hline $\mathbf{k m}$ & Rodovia & SP & Interior & SP & Interior \\
\hline 60,5 & 270 & $125 \mathrm{~m}$ & $130 \mathrm{~m}$ & $125 \mathrm{~m}$ & $130 \mathrm{~m}$ \\
\hline 63,5 & 270 & $140 \mathrm{~m}$ & $220 \mathrm{~m}$ & $140 \mathrm{~m}$ & $150 \mathrm{~m}$ \\
\hline 29,5 & 280 & $300 \mathrm{~m}$ & $300 \mathrm{~m}$ & $150 \mathrm{~m}$ & $150 \mathrm{~m}$ \\
\hline 30 & 280 & $300 \mathrm{~m}$ & $300 \mathrm{~m}$ & $150 \mathrm{~m}$ & $150 \mathrm{~m}$ \\
\hline
\end{tabular}


Os valores do tempo de reação foram considerados diferentes para as duas rodovias estudadas.

No caso dos trechos da SP 270, Rodovia Raposo Tavares, a travessia de pedestres é esperada, seja pela existência de pontos de ônibus no caso do $\mathrm{km} \mathrm{60,5}$ ou pela faixa de pedestres e dispositivo de proteção no canteiro central, no caso do $\mathrm{km} 63$. Nesse cado foi admitido um tempo de reação de 1 seg.

Já na SP 280, Rodovia Castello Branco, a travessia de pedestres não é esperada, e dessa forma o tempo de reação para o motorista foi considerado de $2,5 \mathrm{seg}$.

Adotou-se também frenagem igual a $10 \mathrm{~km} / \mathrm{h} / \mathrm{seg}$.

A Tabela 3-23, página 232, traz os valores de OC/ano e OCE/ano já com as considerações acima mencionadas. A aplicação foi feita com base no modelo $1 \mathrm{~b}$ pois este caso distingue os conflitos com distâncias de visibilidade específicas. Para avaliar a condição diurna e noturna, são utilizados fatores para cada período em análise. Preliminarmente, adotou-se o período (18:30-19:30) como noturno com um peso de 0,2 e os períodos (06:30-07:30) e (12:00-13:00) como diurno com um peso 0,4. A distância de visibilidade existente em cada local (em vista de obstruções visuais) é restrita por um valor limite distinto em cada período.

A distribuição de velocidades foi considerada a partir da velocidade média medida em campo, admitindo um coeficiente de variação de $20 \%$. Os valores adotados constam da Tabela 3-22.

Com esses dados pode-se então calcular também a probabilidade de acidente por severidade, como proposto anteriormente, onde as velocidades de impacto limite para acidentes leves e fatais seriam $V_{\mathrm{I}} \leq \mathrm{V}_{\mathrm{I} 1}=\frac{\alpha_{1}}{\beta}=\frac{4,678}{0,120}=39,0 \mathrm{~km} / \mathrm{h}$ e $\mathrm{V}_{\mathrm{I}} \geq \mathrm{V}_{\mathrm{I} 2}=\frac{\alpha_{2}}{\beta}=\frac{8,846}{0,120}=73,7 \mathrm{~km} / \mathrm{h}$.

A Tabela 3-23 traz os resultados correspondentes à severidade.

A sensibilidade às suposições foi avaliada adiante.

Como exemplo, considere novamente o km 60,5 da SP 270.

No local do km 60,5 são previstas 38,1 OC/hora nos períodos diurnos (média da contagem de manhã e meio-dia) e 44,3 OC/hora nos períodos noturnos (da contade de tarde); em termos 
anuais, o fator de expansão é 3650 (igual 365dias e 10\% da hora-pico/total diário), sendo 80\% $(0,4+0,4)$ em períodos diurnos e $20 \%(0,20)$ em períodos noturnos, ou seja, 111.327,4 OC/ano diurnos e 32.355,3 OC/ano noturnos.

No sentido capital, para o período diurno e noturno, $D_{V}=125 m$ (pela restrição física) e $\mathrm{V}_{\mathrm{A}}=\sqrt{\mathrm{b}^{2} \cdot \delta_{\mathrm{R}}^{2}+2 \cdot \mathrm{b} \cdot \mathrm{D}_{\mathrm{v}}}-\mathrm{b} \cdot \delta_{\mathrm{R}}=\sqrt{(10 / 3,6)^{2} \cdot 1^{2}+2 \cdot(10 / 3,6) \cdot 125}-(10 / 3,6) \cdot 1=85,4 \mathrm{~km} / \mathrm{h}$

para ambos os períodos. No entanto, o fator de correção é distinto em função da diferença de velocidades. No período diurno, $\mathrm{Pac}=P_{s v}=F\left[V>V_{A}\right\rfloor=0,0 \%$ na distribuição normal com velocidade média $35,5 \mathrm{~km} / \mathrm{h}$ e coeficiente de variação $20 \%$. No período noturno, Pac $=P_{s v}=F\left[V>V_{A}\right]=0,0 \%$ na distribuição normal com velocidade média $35,0 \mathrm{~km} / \mathrm{h}$ e coeficiente de variação $20 \%$

As velocidades limites de impacto, em ambos os períodos, indicam acidente leve se $V<V_{1}=\operatorname{máx}\left\{\sqrt{V_{I 1}^{2}+2 \cdot b \cdot D_{V}+\left(b \cdot \delta_{R}\right)^{2}}-b \cdot \delta_{R} ; 0\right\}$

$\mathrm{ou}$

$V<V_{1}=\operatorname{máx}\left\{\sqrt{(39 / 3,6)^{2}+2 .(10 / 3,6) \cdot 125+((10 / 3,6) .1)^{2}}-(10 / 3,6) .1 ; 0\right\}$

tendo-se $\mathrm{V}<\mathrm{V}_{1}=93,05 \mathrm{~km} / \mathrm{h}$,

e acidente fatal se $V \geq V_{2}=\operatorname{máx}\left\{\sqrt{V_{I 2}^{2}+2 \cdot b \cdot \delta_{R}-\left(b \cdot \delta_{R}\right)^{2}}-b \cdot \delta_{R} ; 0\right\}$ ou

$V \geq V_{2}=\operatorname{máx}\left\{\sqrt{(73,7 / 3,6)^{2}+2 \cdot(10 / 3,6) \cdot 125+((10 / 3,6) \cdot 1)^{2}}-(10 / 3,6) .1 ; 0\right\}$

tendo-se $\mathrm{V} \geq \mathrm{V} 2=110,56 \mathrm{~km} / \mathrm{h}$

A distribuição de severidade pode ser diferente em cada período (em função das velocidades) mas em ambos os períodos, para o sentido capital a previsão de Pac é desprezível, e portanto também torna desprezível a ocorrência de acidentes em cada nível de severidade. 
Para o sentido interior, $\mathrm{D}_{\mathrm{V}}=130 \mathrm{~m}$ e

$\mathrm{V}_{\mathrm{A}}=\sqrt{\mathrm{b}^{2} \cdot \delta_{\mathrm{R}}{ }^{2}+2 \cdot \mathrm{b} \cdot \mathrm{D}_{\mathrm{v}}}-\mathrm{b} \cdot \delta_{\mathrm{R}}=\sqrt{(10 / 3,6)^{2} \cdot 1^{2}+2 \cdot(10 / 3,6) \cdot 130}-(10 / 3,6) \cdot 1=87,3 \mathrm{~km} / \mathrm{h}$

para ambos os períodos. No entanto, novamente o fator de correção é distinto em função da diferença de velocidades. No período diurno, $\mathrm{Pac}=P_{s v}=F\left[V>V_{A}\right]=0,00000039 \%$ ou $0,0 \%$ (na distribuição normal com velocidade média $40,5 \mathrm{~km} / \mathrm{h}$ e coeficiente de variação $20 \%$ ). No período noturno, $\mathrm{Pac}=P_{s v}=F\left[V>V_{A}\right]=0,00000003 \%$ ou $0,0 \%$ (na distribuição normal com velocidade média $39 \mathrm{~km} / \mathrm{h}$ e coeficiente de variação $20 \%$ ).

As velocidades limites de impacto, em ambos os períodos, indicam acidente leve se $V<V_{1}=\operatorname{máx}\left\{\sqrt{V_{I 1}^{2}+2 \cdot b \cdot D_{V}+\left(b \cdot \delta_{R}\right)^{2}}-b \cdot \delta_{R} ; 0\right\}$

ou

$V<V_{1}=\operatorname{máx}\left\{\sqrt{(39 / 3,6)^{2}+2 .(10 / 3,6) \cdot 130+((10 / 3,6) \cdot 1)^{2}}-(10 / 3,6) .1 ; 0\right\}$

tendo-se $\mathrm{V}<\mathrm{V}_{1}=94,78 \mathrm{~km} / \mathrm{h}$,

e acidente fatal se $V \geq V_{2}=\operatorname{máx}\left\{\sqrt{V_{I 2}^{2}+2 \cdot b \cdot \delta_{R}-\left(b \cdot \delta_{R}\right)^{2}}-b \cdot \delta_{R} ; 0\right\}$ ou

$V \geq V_{2}=\operatorname{máx}\left\{\sqrt{(73,7 / 3,6)^{2}+2 \cdot(10 / 3,6) \cdot 130+((10 / 3,6) \cdot 1)^{2}}-(10 / 3,6) \cdot 1 ; 0\right\}$

tendo-se $\mathrm{V} \geq \mathrm{V} 2=112,04 \mathrm{~km} / \mathrm{h}$

A distribuição de severidade também é diferente em cada período (pelo efeito da velocidade).

No período diurno, a probabilidade de acidente leve é

$P_{a c}[$ Leve $]=F\left[V_{1}\right]-F\left[V_{A}\right]\left(0\right.$ se $\left.V_{1}<V_{A}\right)$, 
$\mathrm{P}_{\mathrm{ac}}[$ Leve $]=0,00000039 \%$ (quase $100 \%$ dos acidentes fatais) ou 0,0\% na distribuição normal com velocidade média 40,5 e coeficiente de variação $20 \%$; a probabilidade de acidente fatal é $P_{a c}[$ Fatal $]=1-F\left[V_{2}\right]\left(P_{a c}\right.$ se $\left.V_{2}<V_{A}\right)$

$\mathrm{P}_{\mathrm{ac}}[$ Fatal $]=0,0 \%$ na distribuição normal com velocidade média 40,5 e coeficiente de variação 20\%; e a probabilidade de acidente sério é $\mathrm{P}_{\mathrm{ac}}[$ Grave $]=0,0 \%$ (como complemento).

No período noturno, a probabilidade de acidente leve é

$P_{a c}[$ Leve $]=F\left[V_{1}\right]-F\left[V_{A}\right]\left(0\right.$ se $\left.V_{1}<V_{A}\right)$,

$\mathrm{P}_{\mathrm{ac}}[$ Leve $]=0,00000003 \%$ (quase $100 \%$ dos acidentes fatais) ou $0,0 \%$ na distribuição normal com velocidade média 39 e coeficiente de variação $20 \%$; a probabilidade de acidente fatal é

$P_{a c}[$ Fatal $]=1-F\left[V_{2}\right]\left(P_{a c}\right.$ se $\left.V_{2}<V_{A}\right)$

$\mathrm{P}_{\mathrm{ac}}[$ Fatal $]=0,0 \%$ na distribuição normal com velocidade média 39 e coeficiente de variação 20\%; e a probabilidade de acidente sério é $\mathrm{P}_{\mathrm{ac}}[$ Grave $]=0,0 \%$ (como complemento).

O potencial de acidentes, medido por OCE, seria relevante então apenas no sentido interior (pelo efeito da velocidade marginalmente maior), tendo-se:

No período diurno: $\mathrm{OC}_{\mathrm{E}}=0,0000000039 * 58048,8+0,00 * 53278,5=0,00000226 \mathrm{OC}_{\mathrm{E}} / \mathrm{ano}$ No período noturno: $\mathrm{OC}_{\mathrm{E}}=0,0000000003 * 15740,5+0,00 * 16594,7=0,00000005 \mathrm{OC}_{\mathrm{E}} /$ ano Total: $\mathrm{OC}_{\mathrm{E}}=0,00000226+0,00000005=0,00000231 \mathrm{OC}_{\mathrm{E}} /$ ano (uma estimativa desprezível, em termos práticos).

Note que a análise é sempre por sentido; desta forma, o exemplo não será detalhado também para o km 63. No entanto, há uma única diferença neste caso que consiste na obtenção das 
oportunidades de conflito considerando as situações antes e depois da intervenção. A obtenção do valor médio para o km63, considerou a situação antes representativa dos anos 2005, 2006 e 2007; a situação atual representativa dos anos 2009 e 2010 (repartindo-se o ano de 2008 igualmente). O valor global foi então obtido com a média ponderada pelo número de anos.

Dessa forma, no km 63, no período diurno (considerados os dados do meio dia, que são os únicos disponíveis), no sentido capital são previstas 11,0 OC/hora considerando o período anterior a instalação dos dispositivos e 9,5 OC/hora no período após a instalação. A média seria então $(11,0.3,5+9,5 * 2,5) / 6=10,4$ OC/hora, o fator de expansão é 3650 (igual 365dias e $10 \%$ da hora-pico/total diário), sendo $80 \%(0,4+0,4)$ em períodos diurnos, ou seja, 30291,1 OC/ano. No sentido capital são previstas 11,1 OC/hora considerando o período anterior a instalação dos dispositivos e 9,4 OC/hora no período após a instalação. A média seria então $(11,1.3,5+9,4 * 2,5) / 6=10,4$ OC/hora, o fator de expansão é 3650 (igual 365dias e 10\% da hora-pico/total diário), sendo 80\% $(0,4+0,4)$ em períodos diurnos, ou seja, 30401,1 OC/ano. Os demais procedimentos são similares.

Note-se que as restrições de visibilidade noturna somente tiveram influência nas estimativas da SP 280 (na SP 270, predominaram as restrições físicas à visibilidade). 
Tabela 3-23 - CO/ano e OCE/ano (efetiva) - (Modelo 1b)

\begin{tabular}{|c|c|c|c|c|c|c|c|c|c|c|}
\hline SP270-Km60,5 & \multirow{2}{*}{ OC/hora } & OC/ano & $\mathbf{V}$ & $\mathbf{V}_{\mathbf{1}}$ & $\mathbf{V}_{\mathbf{2}}$ & $\mathbf{P}_{\text {Sv }}$ & $\mathbf{P}_{\text {leve }}$ & $\mathbf{P}_{\text {grave }}$ & $\mathbf{P}_{\text {fatal }}$ & OC $_{\mathrm{E}} /$ ano \\
\hline Período & & & & & & & \\
\hline Diurno: $>$ Sp & 18,2 & 53278,5 & 35,5 & 93,05 & 110,56 & $0,00 \%$ & $0,00 \%$ & $0,00 \%$ & $0,00 \%$ & 0,00000000 \\
\hline >Int & 19,9 & 58048,8 & 40,5 & 94,78 & 112,04 & $0,00 \%$ & $0,00 \%$ & $0,00 \%$ & $0,00 \%$ & 0,00000226 \\
\hline Total & 38,1 & 111327,4 & & & & & & & & 0,00000226 \\
\hline Noturno: >Sp & 22,7 & 16594,7 & 35 & 93,05 & 110,56 & $0,00 \%$ & $0,00 \%$ & $0,00 \%$ & $0,00 \%$ & 0,00000000 \\
\hline >Int & 21,6 & 15740,5 & 39 & 94,78 & 112,04 & $0,00 \%$ & $0,00 \%$ & $0,00 \%$ & $0,00 \%$ & 0,00000005 \\
\hline Total & 44,3 & 32335,3 & & & & & & & & 0,00000005 \\
\hline Total Geral & 82,4 & 143662,6 & & & & & & & & 0,00000231 \\
\hline
\end{tabular}

\begin{tabular}{|c|c|c|c|c|c|c|c|c|c|c|}
\hline SP270-Km63 & \multirow{2}{*}{ OC/hora } & OC/ano & $\mathbf{V}$ & $\mathbf{V}_{\mathbf{1}}$ & $\mathbf{V}_{\mathbf{2}}$ & $\mathbf{P}_{\text {Sv }}$ & $\mathbf{P}_{\text {leve }}$ & $\mathbf{P}_{\text {grave }}$ & $\mathbf{P}_{\text {fatal }}$ & OC $_{\mathrm{E}}$ /ano \\
\hline Período & 10,4 & 30291,1 & 47 & 98,17 & 114,96 & $0,00 \%$ & $0,00 \%$ & $0,00 \%$ & $0,00 \%$ & 0,00045666 \\
\hline Diurno: $>$ Sp & 10,4 & 30401,1 & 52 & 122,14 & 136,20 & $0,00 \%$ & $0,00 \%$ & $0,00 \%$ & $0,00 \%$ & 0,00000010 \\
\hline >Int & 20,8 & 60692,1 & & & & & & & & 0,00045676 \\
\hline Total & - & - & 46 & 98,17 & 114,96 & $0,00 \%$ & $0,00 \%$ & $0,00 \%$ & $0,00 \%$ & - \\
\hline Noturno: $>$ Sp & - & - & 48 & 101,44 & 117,81 & $0,00 \%$ & $0,00 \%$ & $0,00 \%$ & $0,00 \%$ & - \\
\hline >Int & - & - & & & & & & & & - \\
\hline Total & - & & & & & & & & & 0,00045676 \\
\hline
\end{tabular}

\begin{tabular}{|c|c|c|c|c|c|c|c|c|c|c|}
\hline $\begin{array}{l}\text { SP280-Km29,5 } \\
\text { Período }\end{array}$ & OC/hora & OC/ano & $\mathbf{V}$ & $\mathbf{V}_{1}$ & $\mathbf{V}_{2}$ & $\mathbf{P}_{\mathrm{SV}}$ & $\mathbf{P}_{\text {leve }}$ & $\mathbf{P}_{\text {grave }}$ & $\mathbf{P}_{\text {fatal }}$ & $\mathrm{OC}_{\mathrm{E}} / \mathrm{ano}$ \\
\hline Diurno: $>\mathrm{Sp}$ & 0 & 0 & 60 & 129,09 & 141,31 & $0,00 \%$ & $0,00 \%$ & $0,00 \%$ & $0,00 \%$ & 0,00000000 \\
\hline$>$ Int & 0 & 0 & 83 & 129,09 & 141,31 & $0,67 \%$ & $0,39 \%$ & $0,25 \%$ & $0,02 \%$ & 0,00000000 \\
\hline Total & 0 & 0 & & & & & & & & 0,00000000 \\
\hline Noturno: >Sp & 0 & 0 & 34 & 88,77 & 104,84 & $0,00 \%$ & $0,00 \%$ & $0,00 \%$ & $0,00 \%$ & 0,00000000 \\
\hline >Int & 0 & 0 & 80 & 88,77 & 104,84 & $45,30 \%$ & $16,13 \%$ & $23,14 \%$ & $6,03 \%$ & 0,00000000 \\
\hline Total & 0 & 0 & & & & & & & & 0,00000000 \\
\hline Total Geral & 0 & 0 & & & & & & & & 0,00000000 \\
\hline
\end{tabular}

\begin{tabular}{|c|c|c|c|c|c|c|c|c|c|c|}
\hline $\begin{array}{l}\text { SP280-Km30 } \\
\text { Período }\end{array}$ & OC/hora & OC/ano & V & $\mathbf{V}_{1}$ & $\mathbf{V}_{2}$ & $\mathbf{P}_{\mathrm{Sv}}$ & $\mathbf{P}_{\text {leve }}$ & $\mathbf{P}_{\text {grave }}$ & $\mathbf{P}_{\text {fatal }}$ & $\mathrm{OC}_{\mathrm{E}} / \mathrm{ano}$ \\
\hline Diurno: >Sp & 5 & 14597,8 & 60 & 129,09 & 141,31 & $0,00 \%$ & $0,00 \%$ & $0,00 \%$ & $0,00 \%$ & 0,00000000 \\
\hline$>$ Int & 5 & 14595,1 & 83 & 129,09 & 141,31 & $0,00 \%$ & $0,00 \%$ & $0,00 \%$ & $0,00 \%$ & 0,00005431 \\
\hline Total & 10 & 29192,9 & & & & & & & & 0,00005431 \\
\hline Noturno: >Sp & 4 & 2920,0 & 60 & 88,77 & 104,84 & $0,01 \%$ & $0,01 \%$ & $0,00 \%$ & $0,00 \%$ & 0,00385915 \\
\hline$>$ Int & 4 & 2919,9 & 90 & 88,77 & 104,84 & $81,63 \%$ & $26,22 \%$ & $50,46 \%$ & $4,96 \%$ & 23,83547016 \\
\hline Total & 8 & 5839,9 & & & & & & & & 23,83932931 \\
\hline Total Geral & 18 & 35032,8 & & & & & & & & 23,83938362 \\
\hline
\end{tabular}


Analisando-se os resultados da Tabela 3-22, nota-se que:

- no km 63 da SP 270, Rodovia Raposo Tavares, mostra-se a previsão de 0,00046 OC $_{\mathrm{E}}$ /ano no período diurno do sentido capital, sendo totalmente desprezível nos demais casos; portanto, indica uma maior insegurança em relação ao local controle, o $\mathrm{km} \mathrm{60,5}$ (onde todos os resultados são desprezíveis); há uma indicação de que o efeito incorporado (basicamente a diferença de velocidades, na comparação do km 63 e km 60,5) aproxima a conclusão da acidentalidade observada; a ordem de grandeza da estimativa está, no entanto, claramente incorreta e indica a necessidade de melhor calibração do modelo ou seus dados;

- no km 30 da SP 280, Rodovia Castello Branco, mostra-se a previsão de 23,84 OC E/ano nos períodos noturnos do sentido interior, sendo desprezível nos demais casos; embora possa-se considerar que a deficiência noturna é uma indicação real, não se pode dizer o mesmo da atribuição desprezível de acidentalidade ao sentido capital; o resultado pode ser explicado pela velocidade média obtida em campo (muito inferior no sentido capital); embora uma diferença real, o efeito pode ter sido exagerado pela seleção dos períodos de observação em campo.

A análise de sensibilidade dos parâmetros assumidos nos cálulos apresentados anteriormente mostrou maior sensibilidade à velocidade média (não ao coeficiente de variação) e à distância de visibilidade (menos ao tempo de reação e à frenagem). Portanto, a indicação é de que estes são os dados a serem obtidos de forma cuidadosa na observação de campo. 
e. Avaliação Geral dos Resultados Preliminares

A análise dos resultados permite concluir que as medidas de oportunidade de manobra e conflito empíricas são válidas e complementares para avaliar a segurança de pedestres em rodovias, uma vez que se aproximou do histórico de acidentes estudados e do efeito antes e depois da intervenção ocorrida em um dos trechos.

As medidas teóricas também retrataram a mesma situação, por terem produzido estimativas aceitáveis das medidas observadas em campo.

Um exemplo de implicação desta análise pode ser vista ao criticar a recomendação adotada pelo DNIT (2010), como mostrada na Figura 2-26. Vê-se que o gráfico não recomenda intervenção no Km 30 da SP 280 (no caso, implantar passarelas, em função do baixo fluxo de pedestres). No entanto, a análise realizada mostra claramente que não há oportunidades de travessia e que todos os pedestres experimentam um risco potencial no local. Portanto, o critério sugerido seria segregar ou impedir as travessias. Na SP 270, o gráfico também não recomenda intervenção em ambos os locais (no caso, implantar passarelas, para os fluxos de pedestres observados) mas falha em não considerar alternativas (como as ilhas de refúgio). A análise proposta mostrou ambos os aspectos.

Por fim, a análise da evitabilidade e da severidade indicou que os modelos e dados utilizados precisam ser adequadamente calibrados para obter resultados precisos. No entanto, obteve-se indicações que apontam preliminarmente na direção correta para ponderar efeitos relevantes como a velocidade do tráfego e as retrições de visibilidade.

É importante comentar que em relação aos locais da SP 270, existem peculiaridades que não parecem adequadamente representadas nos modelos de previsão; dois deles são o efeito de proteção aos pedestres dos fluxos veiculares que cruzam o $\mathrm{km} \mathrm{60,5} \mathrm{e} \mathrm{o} \mathrm{efeito} \mathrm{do} \mathrm{número} \mathrm{e}$ localização dos redutores de velocidade (1 no km 63 e 2 no km 60,5); o primeiro aspecto poderia levar a categorizar as travessias por tipo de condição (com ou sem proteção) e o segundo poderia justificar um procedimento de previsão da velocidade local em função da velocidade de aproximação e dos fatores locais (como os redutores). Na SP 280, o efeito das 
motos não foi adequadamente representado no modelo de previsão. Uma solução seria utilizar velocidades diferentes por tipo de veículo nos cálculos de $\mathrm{OC}_{\mathrm{E}}$.

Os modelos de previsão também podem ser criticados por conter apenas os efeitos das condições físicas e operacionais, sem incorporar fatores outros que podem gerar conflitos e acidentes; dois exemplos seriam a ocorrência de erros humanos (falha ao detectar pedestres, por exemplo) ou a existência de comportamento aberrante (como motoristas alcoolizados ou em velocidade excessiva). Esse aspecto está discutido preliminarmente no trabalho de PIETRANTONIO e VASCONCELOS (2006).

\subsection{Método para análise de segurança de pedestres e ciclistas em rodovias}

O método proposto par aanálise de segurança de pedestres e ciclistas em rodovias, pode ser então resumido conforme o diagrama da Figura 3-24, contento os passos de análise de atendimentos às condições de projeto, análise de oportunidades e finalmente o diagnóstico integrado.

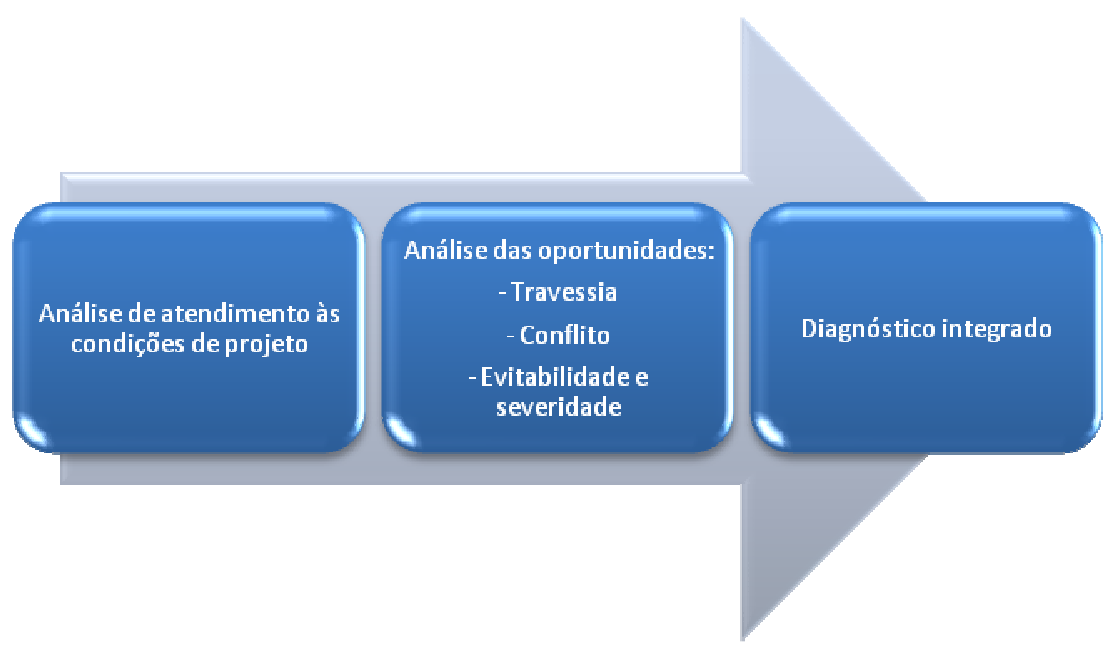

Figura 3-24 - Método proposto para análise de segurança de pedestres e ciclistas 


\section{CONCLUSÕES E RECOMENDAÇÕES}

Nesse item são apresentadas as conclusões referentes ao estudo de segurança de pedestre e ciclistas em rodovias concessionadas do Estado de São Paulo utilizando os conceitos de oportunidade de manobra e oportunidade de conflito. São também apresentados aspectos relevantes que não foram considerados e que podem ser considerados em estudos futuros.

A revisão dos trabalhos clássicos, manuais de projeto e trabalhos técnicos mostrou vários aspectos que devem ser considerados a fim de aumentar a segurança dos pedestres e ciclistas. A premissa da pesquisa bibliográfica foi identificar quais tipos de facilidades podem atender às necessidades de cada usuário; ao longo da via, em travessias, para proteção e canalização. A questão básica complementar é a definição de critérios que recomendam um ou outro tipo de facilidade.

Para pedestres e ciclistas, foram apresentados portanto, a infra-estrutura disponível e os parâmetros de projeto dessas infra-estruturas. Para esses aspectos a referência principal são os manuais da AASHTO, o Green Book e os manuais específicos de pedestre se ciclistas. As referências nacionais geralmente repetem os critérios da AASHTO, adicionando pouca coisa. As características básicas dos pedestres e ciclistas estão claramente documentadas, incluindo pedestres com necessidades especiais. Faltam, no entanto, diretrizes sobre a provisão do 
atendimento aos diferentes tipos de usuários (ou a categorização da infra-estrutura pelo atendimento).

Nos manuais nacionais, em particular, existe pouco conteúdo específico (assim como existe pouca informação sobre eventuais estudos que motivaram a adoção das recomendações da AASHTO, ou outra fonte, para o Brasil). No caso dos pedestres, uma adição relevante do DNIT (2010) é o método prático para estimar se a travessia de determinado local deve ser em nível ou desnível, em função do fluxo de pedestres e do fluxo veicular, conforme apresentado na Figura 2-26. Entretanto, a aplicação desse critério não é claramente discutida e disseminada.

No caso dos ciclistas, as recomendações do manual específico da AASHTO foram adotadas pelo DNIT (2010) para o Brasil. Estas recomendações parecem ter lacunas importantes. A revisão buscou algumas fontes complementares, em particular sobre a necessidade de tratamentos diversos. Cabe ressaltar os métodos estrangeiros para seleção do dispositivo a ser adotado, ou mesmo se há necessidade de algum dispositivo, em função do volume diário médio anual e da velocidade média de operação, separando ainda por tipo de ciclista (experientes ou comuns). Foram apresentados os critérios americano, Tabelas 2-13 e 2-14 (não adotado pela AASHTO ou recomendado pelo DNIT, 2010), e inglês, Tabela 2-15 (que é decorrente da tradição européia, onde os ciclistas são melhor atendidos).

Para a análise da operação foi revisado o HCM (2000), que busca avaliar o nível de serviço para pedestres e ciclistas com base no conceito de impedância, avaliando a frequência de encontros e ultrapassagens. Discutiu-se que estas variáveis poderiam ser melhor utilizadas na formulação dos critérios de projeto ou seleção de tratamentos. Observou-se que o conceito de impedância é relevante também para a segurança dos usuários (por representar eventos próximos a conflitos), embora esta relação não esteja formulada. Notou-se também a lacuna relativa às interações entre ciclistas e veículos (atualmente, a impedância considera ciclistas e pedestres).

A revisão abrangeu tanto a esfera urbana quanto rural. Especificamente no caso das rodovias, o acostamento é o dispositivo recomendado para o deslocamento de pedestres e ciclista ao longo do eixo (as calçadas são menos comuns) e, para a travessia, os dispositivos de 
segregação de nível como passarelas e passagens subterrâneas são recomendados. Há também alguns dispositivos que buscam minimizar os conflitos encontrados nas travessias como ilhas de refúgio centrais, cuja utilização é menos discutida. Além disso, notou-se a falta de recomendações para provisão de infra-estrutura complementar quando inexiste acostamento.

A análise do atendimento às condições de projeto foi praticada como forma de diagnóstico dos problemas de segurança para pedestres e ciclistas. Em linhas gerais, notou-se que diversos aspectos puderam ser apontados.

Na SP 270 - Rodovia Raposo Tavares, o km 60,5 apresenta pequena quantidade de acidentes quando comparado ao km 63, mesmo tendo fluxo de pedestres maior. Analisando o projeto viário dos dois locais, comparando com o que foi encontrado na revisão bibliográfica, o $\mathrm{km}$ 60,5 tem condições apropriadas para a travessia segura do pedestre, que atravessa 2 faixas ( 1 em cada sentido), a velocidade dos veículos é reduzida pela presença de lombadas em cada sentido, além dos próprios movimentos de conversão que acabam formando uma barreira

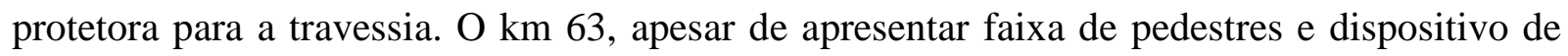
proteção e divisão da travessia, acaba tendo maior ocorrência de acidentes, provavelmente devido a largura da travessia; são 2 faixas em cada sentido, para um fluxo baixo de veículos. Isso encoraja também os veículos a desenvolverem maior velocidade, dificultando ainda mais a travessia para o pedestre. Apesar de possuir calçada, não há acostamento nesse trecho, o que prejudica principalmente a circulação de bicicletas no local.

Na SP 280 - Rodovia Castello Branco, os dois kms analisados são bastante próximos, km 29,5 e $\mathrm{km} 30$ e tem características operacionais também bastante semelhantes. O principal fator observado foi a presença de tela no canteiro central, a fim de evitar a travessia dos pedestres, entre os kms 29,2 e km 30. Dessa forma os pedestres acabam atravessando logo após o término da tela, no km 30, não tendo movimento de travessia no km 29,5.

A relação destes aspectos com os acidentes observados pode ser considerada parcial.

A revisão do aspecto metodológico a respeito de métodos de medir a segurança, mostrou as oportunidades de manobra e oportunidades de conflito como medidas promissoras e complementares, buscando validá-las no estudo de campo desenvolvido nesse trabalho, através de medidas empíricas e dos dados de acidentes dos locais estudados. 
As medidas empíricas, assim como os dados básicos operacionais utilizados nos modelos teóricos de oportunidade de manobra e oportunidade de conflito foram obtidos através de filmagens dos locais escolhidos para estudo. Esses locais, por sua vez, foram escolhidos tendo por base o histórico de acidente de 6 anos, de 2005 a 2011 (um caso e um controle).

Os resultados do estudo de campo têm de ser considerados preliminares em função da pequena amostra de observações examinadas (os problemas ocorridos na coleta de dados também limitam a análise realizada). A seguir, estes resultados preliminares serão divididos em 4 aspectos: viabilidade dos procedimentos; validade dos modelos de previsão; validade da análise de oportunidades e validade da análise de evitabilidade e severidade.

No que se refere à viabilidade dos procedimentos, o estudo de campo mostrou que os conceitos e modelos atuais são facilmente aplicados com análise de vídeo (pode-se considerar que também a observação direta em campo seria praticável). No entanto, os resultados foram sensíveis a diversos fatores que indicam a necessidade de levantamentos em campo mais detalhados. Este comentário aplica-se à observação de uma ampla variedade de períodos de operação característicos (para evitar a adoção de dados operacionais viesados) e à mensuração de parâmetros muito sensíveis (como a distância de visibilidade, particularmente na deteção dos pedestres em horários noturnos ou outras condições adversas).

No que se refere à validade dos modelos de previsão, a comparação de medidas de oportunidades de manobra e conflito obtidas através dos modelos teóricos com os valores obtidos empiricamente permitiu avaliar as estimativas de cada modelo proposto. As estimativas de oportunidades de travessia, iguais em todas as versões, tiveram boa aderência em relação aos valores medidos (notando-se uma tendência a sub-estimativa no caso dos locais da SP 280, com previsões ainda menores que os baixos valores observados). As estimativas de oportunidades de conflito indicaram corretamente as mudanças observadas mas mostraram uma aderência pior aos dados (com uma tendência a super-estimativa) que deveria motivar a busca de melhorias adicionais nos modelos propostos (a melhor representação das brechas reduzidas e a representação das diferentes condições de travessia foram indicadas pelo estudo de campo como aspectos que poderiam ser melhorados). 
No que se refere à validade da análise de oportunidades, a comparação de medidas de oportunidades de manobra e conflito obtidas com o levantamento do histórico de acidentes possibilitou a validação das conclusões da análise para avaliar a segurança de pedestres em rodovias. Em linhas gerais, pode-se dizer que muitos aspectos foram adequadamente apontados.

As medidas de oportunidades de travessia na SP 270 e na SP 280, por exemplo, diferenciaram de forma adequada as condições locais e mostraram a clara necessidade de se ter algum tratamento específico adicional na SP 280 para a travessia de pedestres nos locais estudados, com segregação no tempo ou espaço dos fluxos de veículos e pedestres ou obstrução física para impedir a travessia de pedestres nos locais inseguros (provendo naturalmente alguma opção segura e acessível para atender a sua necessidade de deslocamento). As medidas de oportunidades de conflito na SP 270 e SP 280 exibiram a óbvia dependência da presença de pedestres e da magnitude do fluxo oposto na travessia mas parecem exigir ponderações adicionais. Destacou-se a existência de condições de travessia específicas não claramente representadas (como o número e localização dos redutores de velocidade) e a necessidade de uma melhor represetação do ocmportamento na travessia, aspecto esse importante por relacionar as oportunidades de travessia e oportunidades de conflito.

A análise da evitabilidade e da severidade das oportunidades de conflito teve esta motivação. Buscou-se verificar a inclusão ao modelo de cálculo de oportunidade de conflito proposto anteriormente (em função dos fluxos de pedestre e de veículos) o efeito da velocidade média do fluxo veicular e da distância de visibilidade, fatores que são bastante importantes no caso de acidentes envolvendo pedestres e ciclistas. Tendo calculados esses parâmetros buscou-se ainda verificar a inclusão da estimativa da probabilidade da gravidade do acidente, considerado leve, grave ou fatal. Ambos os pontos apontaram relações importantes mas com uma escala de variação inadequada, sugerindo a necessidade de aprimorar as formulações e calibrar melhor seus parâmetros e dados de entrada.

Um aspecto que seria também muito interessante incluir em formulações futuras seria a influência de erros humanos e comportamentos aberrantes dos condutores ou pedestres, como apontado na análise dos resultados preliminares da validação. 
Recomenda-se ainda para estudos futuros o desenvolvimento de modelos para ciclistas e sua validação para a análise de segurança desses usuários, que não foi estudado devido a pouca incidência de acidentes envolvendo esses usuários nas rodovias estudadas.

Finalmente, uma adição futura interessante seria a transferência da análise de projeto em um procedimento de auditoria de segurança viária. 


\section{REFERÊNCIAS BIBLIOGRÁFICAS}

AASHTO - A Policy on Geometric Design of Highways and Streets, American Association of state Highway and Transportation Officials, 2004.

AASHTO - Guide for Development of Bicycle Facilities, American Association of state Highway and Transportation Officials, 2004.

AASHTO - Guide for the Planning, Design and Operation of Pedestrian Facilities, American Association of state Highway and Transportation Officials, 2004.

ALDUÁN, A. S. - Calmar El tráfico, Serie monografías, Ministerio de Fomento, 1998.

ARAUJO, G.P.; BRAGA, M.G.C. - Methodology for the Qualitative Evaluation of Pedestrian Crossings at Road junctions with Traffic Lights, in Transportation, vol.35, pp.539-557, 2008

BASILE, O.; PERSIA, L.; USAMI, D. - A Methodology to Assess Pedestrian Crossing Safety, European Transportation Research Review, vol.2, pp.129-137; 2010

BOtMA, H. - Method to Determine Levels of Service for Bicycle Paths and Pedestrian-Bicycle Paths, Transportation Research Record 1502, TRB, Nacional Research Council, Washington, D.C., 1995

BOVY - Reseaux et Espaces Piétonniers, Institut de Technique des Transports, 1973

BREWER M. A., FITZPATRICK K., WHITACRE J. A. e LORD D. - Exploration of Pedestrian GapAcceptance Behavior at Selected Locations, Transportation Research Record, 1982, pp 132-140, 2006

Marcus A. Brewer, Kay Fitzpatrick, Jeffrey A. Whitacre,

and Dominique Lord

CET - Segurança Viária e dos Pedestres, Notas Técnicas NT 020/78, Companhia de Engenharia de Tráfego, 1978.

CUCCI NETO, J. - Aplicações de Engenharia de Tráfego na Segurança dos Pedestres - Dissertação apresentada à Escola Politécnica da Universidade de São Paulo, São Paulo, Brasil, 1996.

DAVIS, G. A. - Relating Severity of Pedestrian Injury to Impact Speed in Vehicle-Pedestrian Crashes, Transportation Research Record, 1773, pp 108-113, 2007.

DER/PR - Manual de Segurança Rodoviária, Departamento de Estradas de Rodagem do Paraná, 1988.

DNER - Guia para Redução de Acidentes de Trânsito, Departamento Nacional de Estradas de Rodagem, 2001.

DNER - Manual de Projeto Viário, Departamento Nacional de Estradas de Rodagem, 1999.

DENATRAN - Manual Brasileiro de Sinalização de Trânsito, Departamento Nacional de Trânsito, 2007

DENATRAN - Manual de Identificação, Análise e Tratamento de Pontos Negros, Departamento Nacional de Trânsito, 1982.

DENATRAN - Manual de Projeto de Interseções em Nível Não Semaforizadas em Áreas Urbanas, Departamento Nacional de Trânsito, 1984.

DENATRAN - Manual de Segurança de Pedestres, Departamento Nacional de Trânsito, 1983;

DENATRAN - Manual de Semáforos, Departamento Nacional de Trânsito, 1979.

DNIT - Manual de Projeto de Interseções, Departamento Nacional de Infraestrutura de Transporte, 2005.

DNIT - Manual de Travessias Urbanas, Departamento Nacional de Infraestrutura de Transporte, 2010. 
GEIPOT - Manual de Planejamento Cicloviário, GEIPOT, 2001.

FHWA - Manual of Uniform Traffic Control Devices (MUTCD), Federal Highway Administration, U.S. Department of Transportation. Washington, DC, 2009.

FHWA - Pedestrian Facilities User Guide - Providing Safety and Mobility, Federal Highway Administration, U.S. Department of Transportation. Washington, DC, 2002.

FHWA - Selecting Roadway Design Treatments to Acommodate Bicycles, Federal Highway Administration, U.S. Department of Transportation. Washington, DC, 1992.

FRUIN, J. - Pedestrian Planning and Design, Elevator World, Mobile, Ala., 1990

GOLD, P., A. - Segurança de Trânsito: Aplicação da Engenharia para Reduzir de Acidentes, Banco Interamericano de Desenvolvimento, Brasil, 1998.

INGLATERRA - Cycling Centre for Excellence, London Cycling Design Standards, 2005.

ITE - Manual of Transportation Engineering Studies, Institute of Transportation Engineers, 2000.

KHISTY, C.J. - Evaluation of Pedestrian Facilities: Beyond the Level-of-Service Concept, Transportation Research Record 1438, pp.45-50; 1994

MING, S. H. - Oportunidades de Conflito de Tráfego - Modelos de Previsão - Dissertação apresentada à Escola Politécnica da Universidade de São Paulo, São Paulo, Brasil, 2008.

OGDEN, K.. W. - Safer Roads: A Guide to Road Safety Engineering, Avebury Technical, 1996.

PIETRANTONIO, H. e VASCONCELO, V.M.A. (2006) - Searching for Operational Measures of Road Safety: New Concepts and a Case Study, Relatório de Trabalho No.08/06, LEMT-Laboratório de Estudos Metodológicos em Tráfego e Transportes, Departamento de Engenharia de Transportes, Escola Politécnica, Universidade de São Paulo, Brasil (em revisão).

SCHNELl. T., AKTAN F., MCGEHEE D.V., DVORAK M., HUNT J., REYES A. e SORAK D. - Pedestrian Visibility Under Automobile Low-Beam Headlight Illumination, Transportation Research Record, 1773, pp 114-124, 2001.

SPECIAL REPORT 209 - Highway Capacity Manual. TRB. National Research Council, Washington, D.C.,2000.

TAC - Geometric Design Guide for Canadian Roads, Transportation Association of Canada, 1999.

VASCONCElOS, V. M. A. - Oportunidades de Travessia e Oportunidades de Conflito para Pedestres em Interseções Semaforizadas - Dissertação apresentada à Escola Politécnica da Universidade de São Paulo, São Paulo, Brasil, 2004. 


\section{APÊNDICA A - ANÁLISE DA OPERAÇÃO PARA PEDESTRES DO HCM (2000)}

\section{A.1. Nível de Serviço em Calçadas e Vias Exclusivas para Pedestres}

O cálculo do nível de serviço está no HCM (2000), definindo a largura efetiva da via como sendo:

$$
W_{E}=W_{T}-W_{o}
$$

$W_{E} \quad=$ largura efetiva da via de pedestre (m)

$W_{T} \quad=$ largura total da via de pedestre (m)

$W_{O}=$ soma das larguras e distância das obstruções na via (m)

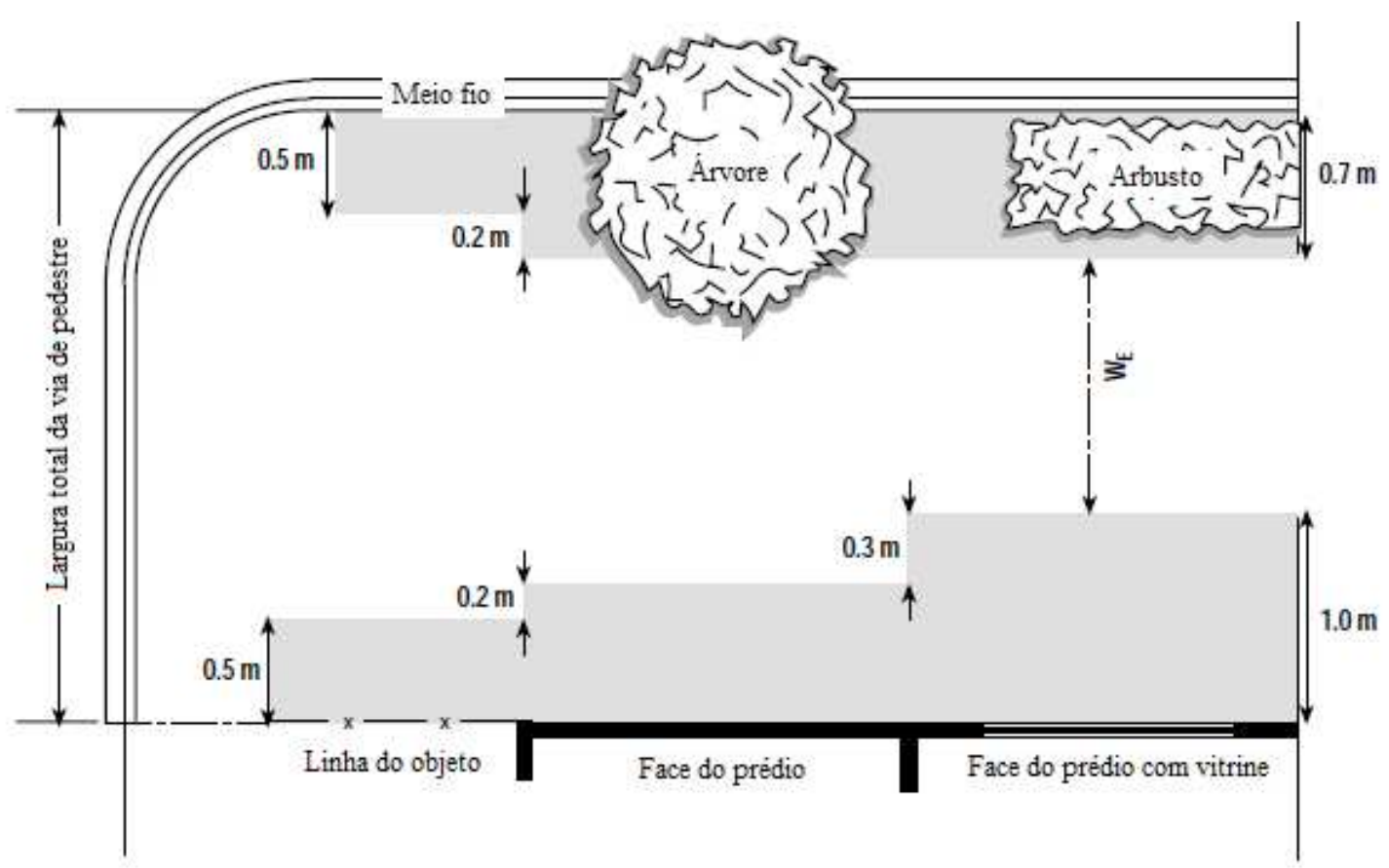

Figura A- 1 - Largura efetiva de pedestres (Fonte: Special Report 209: Highway Capacity Manual, TRB. National Research Council, Washington, D.C., 2000) 
Quando a configuração da via não está disponível, a tabela seguinte pode ser utilizada:

Tabela A- 1 - Largura efetiva (Fonte: Special Report 209: Highway Capacity Manual, TRB. National Research Council, Washington, D.C., 2000)

\begin{tabular}{|c|c|}
\hline Obstáculo & Largura adequada (m) \\
\hline \multicolumn{2}{|c|}{ Mobiliário } \\
\hline Poste fino & $0.8-1.1$ \\
\hline Postes de semáforos e caixas & $0.9-1.2$ \\
\hline Caixas de alarm de incêndio & $0.8-1.1$ \\
\hline Hidrantes & $0.8-0.9$ \\
\hline Placas de trânsito & $0.6-0.8$ \\
\hline Estacionamento & 0.6 \\
\hline Caixas de correio $(0,5 \mathrm{~m} \times 0,5 \mathrm{~m})$ & $1.0-1.1$ \\
\hline Cabines telefônicas $(0,8 \mathrm{~m} \times 0,8 \mathrm{~m})$ & 1.2 \\
\hline Bancos & 0.9 \\
\hline \multirow{2}{*}{\multicolumn{2}{|c|}{ Acesso público subterrâneo }} \\
\hline & \\
\hline Escadas de metrô & $1.7-2.1$ \\
\hline Saidas de ventilação de metrô & $1.8+$ \\
\hline Cúpula de ventilação do metrô & $1.5+$ \\
\hline \multicolumn{2}{|c|}{ Paisagismo } \\
\hline Árvores & $0.6-1.2$ \\
\hline Vasos & 1.5 \\
\hline \multicolumn{2}{|c|}{ Usuários comerciais } \\
\hline Bancas de jornais & $1.2-4.0$ \\
\hline Estandes de venda & variảvel \\
\hline Placas de advertência & variävel \\
\hline Vitrines de lojas & variävel \\
\hline Cafés de calçada & 2.1 \\
\hline \multicolumn{2}{|c|}{ Protusões de edificações } \\
\hline Colunas & $0.8-0.9$ \\
\hline Inclinações & $0.6-1.8$ \\
\hline Portas de porões & $1.5-2.1$ \\
\hline Conexoes de canos & 0.3 \\
\hline Postes de toldos & 0.8 \\
\hline Garagens de caminhões & variável \\
\hline Entrada/saida de garagens & variável \\
\hline Vias de tráfego veicular & variável \\
\hline \multicolumn{2}{|c|}{$\begin{array}{l}\text { Nota: } \\
\text { a. Para consideras a distância entre pedestres e obstáculos, } 0,3 \text { a } 0,5 \mathrm{~m} \\
\text { deve ser acrecido a largura recomendada. } \\
\text { Fonte: Pushkarev e Zupan }\end{array}$} \\
\hline
\end{tabular}


A taxa de fluxo de pedestres é a medida de serviço para pedestres em calçadas. Em um pico de 15 minutos, essa taxa pode ser obtida com a seguinte expressão:

$$
\mathrm{v}_{\mathrm{p}}=\frac{\mathrm{v}_{15}}{15 * \mathrm{~W}_{\mathrm{E}}} \quad \begin{aligned}
v_{p} & =\text { taxa de fluxo de pedestres }(\mathrm{p} / \mathrm{min} / \mathrm{m}) \\
v_{15} & =\text { taxa de fluxo de pico de } 15 \mathrm{~min}(\mathrm{p} / 15 \mathrm{~min}) \\
W_{E} & =\text { largura efetiva da via de pedestre }
\end{aligned}
$$

Taxas de volume por capacidade (v/c) podem ser obtidas considerando como capacidade $75 \mathrm{p} / \mathrm{min} / \mathrm{m}$. Dessa forma, o HCM traz a seguinte tabela para o nível de serviço:

Tabela A- 2 - Critério de fluxo médio para NS em caminhos e calçadas (Fonte: Special Report 209: Highway Capacity Manual, TRB. National Research Council, Washington, D.C., 2000)

\begin{tabular}{c|c|c|c|c}
\hline Nivel de Serviço & Espaço $\left(\mathrm{m}^{2} / \mathrm{p}\right)$ & Taxa de Fluxo $(\mathrm{p} / \mathrm{min} / \mathrm{m})$ & Velocidade $(\mathrm{m} / \mathrm{s})$ & $\mathrm{v} / \mathrm{c}$ \\
\hline A & $>5.6$ & $\leq 16$ & $>1.30$ & $\leq 0.21$ \\
B & $>3.7-5.6$ & $>16-23$ & $>1.27-1.30$ & $>0.21-0.31$ \\
C & $>2.2-3.7$ & $>23-33$ & $>1.22-1.27$ & $>0.31-0.44$ \\
D & $>1.4-2.2$ & $>33-49$ & $>1.14-1.22$ & $>0.44-0.65$ \\
E & $>0.75-1.4$ & $>49-75$ & $>0.75-1.14$ & $>0.65-1.0$ \\
F & $\leq 0.75$ & variável & $\leq 0.75$ & variável \\
\hline
\end{tabular}

Efeito de pelotões também está tabelado, levando em conta que o flui normal é impedido com $49 \mathrm{~m}^{2} / \mathrm{p}$ o que equivale a $1,6 \mathrm{p} / \mathrm{min} / \mathrm{m}$. Esse valor é utilizado como base para nível de serviço A.

Tabela A- 3 - Critério de NS para caminhos e calçadas com o eleito de pelotões (Fonte: Special Report 209: Highway Capacity Manual, TRB. National Research Council, Washington, D.C., 2000)

\begin{tabular}{l|c|c}
\hline Nivel de Serviço & Espaço $\left(\mathrm{m}^{2} / \mathrm{p}\right)$ & Taxa de Fluxo $(\mathrm{p} / \mathrm{min} / \mathrm{m})$ \\
\hline A & $>49$ & $\leq 1.6$ \\
B & $>8-49$ & $>1.6-10$ \\
C & $>4-8$ & $>10-20$ \\
D & $>2-4$ & $>20-36$ \\
E & $>1-2$ & $>36-59$ \\
F & $\leq 1$ & $>59$ \\
\hline
\end{tabular}

Em escada a tabela de NS também é apresentada pelo HCM, sendo que taxas de volume por capacidade (v/c) são baseados numa capacidade da escada de $49 \mathrm{p} / \mathrm{min} / \mathrm{m}$. 
Quando dois fluxos de pedestres se cruzam, o menor desses fluxos é chamado de cross flow. Para esse fluxo, níveis de serviço de A a D são obtidos pelas tabelas já mencionadas. O NS E é listado em outra tabela:

Tabela A- 4 - Critério de NS para fluxo de pedestres atravessando (Fonte: Special Report 209: Highway Capacity Manual, TRB. National Research Council, Washington, D.C., 2000)

\begin{tabular}{c|c|c|c|c}
\hline Nivel de Serviço & Espaço $\left(\mathrm{m}^{2} / \mathrm{p}\right)$ & \multicolumn{1}{|c|}{ Taxa de Fluxo $(\mathrm{p} / \mathrm{min} / \mathrm{m})$} & Velocidade $(\mathrm{m} / \mathrm{s})$ & Densidade $\left(\mathrm{p} / \mathrm{m}^{2}\right)$ \\
\hline $\mathrm{E}$ & $\geq 1.25$ & $\leq 75$ & $\geq 1.0$ & $\leq 0.8$ \\
\hline
\end{tabular}

Nota:

a. Total do fluxo principal e secundário

\section{A.2. Nível de Serviço em Calçadas Compartilhadas}

Segundo o HCM (2000), os pedestres tendem a ter o nível de serviço prejudicado devido a presença de bicicletas. Nesses casos, o nível de serviço é baseado no conceito de impedimento; considerando frequência de ultrapassagens e encontros entre pedestres e ciclistas. A frequência de encontros (meetings), $F m$, e a frequência de ultrapassagens (passings), $F p$, são então calculadas em função do fluxo de bicicletas em direção oposta, ou na mesma direção respectivamente; e das velocidades médias dos pedestres e dos ciclistas na via.

$$
\begin{aligned}
& F_{p}=Q_{s b}\left(1-\frac{S_{p}}{S_{b}}\right) \quad \begin{array}{l}
F p=\text { número de eventos de ultrapassagem (eventos/h) } \\
F m=\text { número de eventos opostos (eventos } / h \text { ) }
\end{array} \\
& \text { Qsb = taxa de fluxo de bicicletas no mesmo sentido (bicicletas/h) } \\
& F_{m}=Q_{o b}\left(1+\frac{S_{p}}{S_{b}}\right) \begin{array}{l}
Q 0 b=\text { taxa de fluxo de bicicletas no sentido oposto } \\
S p=\text { velocidade média do pedestre na via (m/s) } \\
\mathrm{Sb}=\text { velocidade média da bicicleta na via ( } \mathrm{m} / \mathrm{s})
\end{array}
\end{aligned}
$$

A frequência total de eventos é então calculada considerando que encontros causando geralmente menos impedimento, devido ao contato visual. 


$$
F=F_{p}+0.5 F_{m} \begin{aligned}
& \mathrm{F}=\text { número total de eventos na via (eventosih), } \\
& \mathrm{Fp}=\text { número de eventos de ultrapassagens (eventos } / h \text { ) } \\
& \mathrm{Fm}=\text { número de eventos de encontro (eventos } / \mathrm{h} \text { ) }
\end{aligned}
$$

Para cálculo no nível de serviço para uma via bidirecional, considerando velocidade média dos pedestres de $1,5 \mathrm{~m} / \mathrm{s}$ e velocidade média dos ciclistas de $6,0 \mathrm{~m} / \mathrm{s}$, com volume de bicicletas para via bidirecional (50/50) e largura de $2,4 \mathrm{~m}$ :

Tabela A- 5 - Critério de NS para pedestres em caminhos compatilhados (Fonte: Special Report 209: Highway Capacity Manual, TRB. National Research Council, Washington, D.C., 2000)

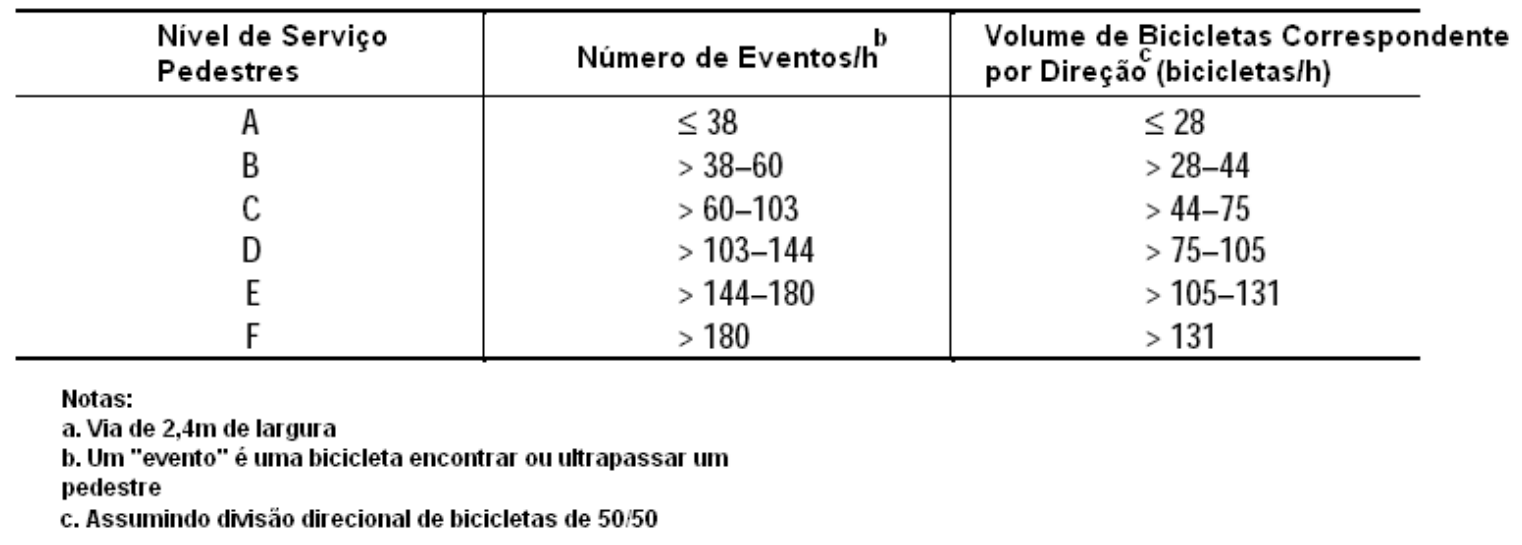

\section{A.3. Nível de Serviço em Áreas de Espera}

Em áreas de espera, o nível de serviço para o pedestre é relacionado ao espaço disponível para cada pedestre e ao grau de mobilidade permitido: 
Tabela A- 6 - Critério de NS para áreas de espera de pedestres (Fonte: Special Report 209: Highway Capacity Manual, TRB. National Research Council, Washington, D.C., 2000)

\begin{tabular}{c|c}
\hline Nivel de Serviço & Espaço $\left(\mathrm{m}^{2} / \mathrm{p}\right)$ \\
\hline A & $>1.2$ \\
B & $>0.9-1.2$ \\
C & $>0.6-0.9$ \\
D & $>0.3-0.6$ \\
E & $>0.2-0.3$ \\
F & $\leq 0.2$ \\
\hline
\end{tabular}

\section{A.4. Nível de Serviço em Travessias Semaforizadas}

A medida de nível de serviço no caso de interseções semaforizadas é o atraso médio sofrido pelo pedestre, calculado em função do tempo de verde efetivo para pedestres e comprimento do ciclo:

$$
\mathrm{d}_{\mathrm{p}}=\frac{0.5(\mathrm{C}-\mathrm{g})^{2}}{\mathrm{C}} \quad \begin{aligned}
& \mathrm{dp}=\text { atraso médio do pedestre } \\
& \mathrm{g}=\text { tempo efetivo de verde (para pedestres) }
\end{aligned}
$$

O nível de serviço é então obtido e é observado que para tempos de espera maiores que $30 \mathrm{seg}$, muitos pedestres assumem um comportamento de risco desobedecendo ao semáforo.

Tabela A- 7 - Critério de NS para pedestres em interseções semaforizadas (Fonte: Special Report 209: Highway Capacity Manual, TRB. National Research Council, Washington, D.C., 2000)

\begin{tabular}{c|c|c}
\hline Nivel de Serviço & Atraso do Pedestre (s/p) & Probabilidade de Desobediência \\
\hline A & $<10$ & Low \\
B & $\geq 10-20$ & Moderate \\
C & $>20-30$ & \\
D & $>30-40$ & High \\
E & $>40-60$ & Very High \\
F & $>60$ & \\
\hline
\end{tabular}


A área de pedestres requerida em esquinas compreende uma área de circulação (pedestres atravessando na fase verde, pedestres se juntando para atravessar na fase vermelha e pedestres circulando na calçada atravessar) e uma área para os pedestres esperando para atravessar na fase vermelha. A análise do HCM compara tempo e espaço disponível com a demanda de pedestres.

O tempo-espaço disponível (TS) para circulação e fila em uma esquina é o produto da área da esquina pelo tempo do ciclo analisado.

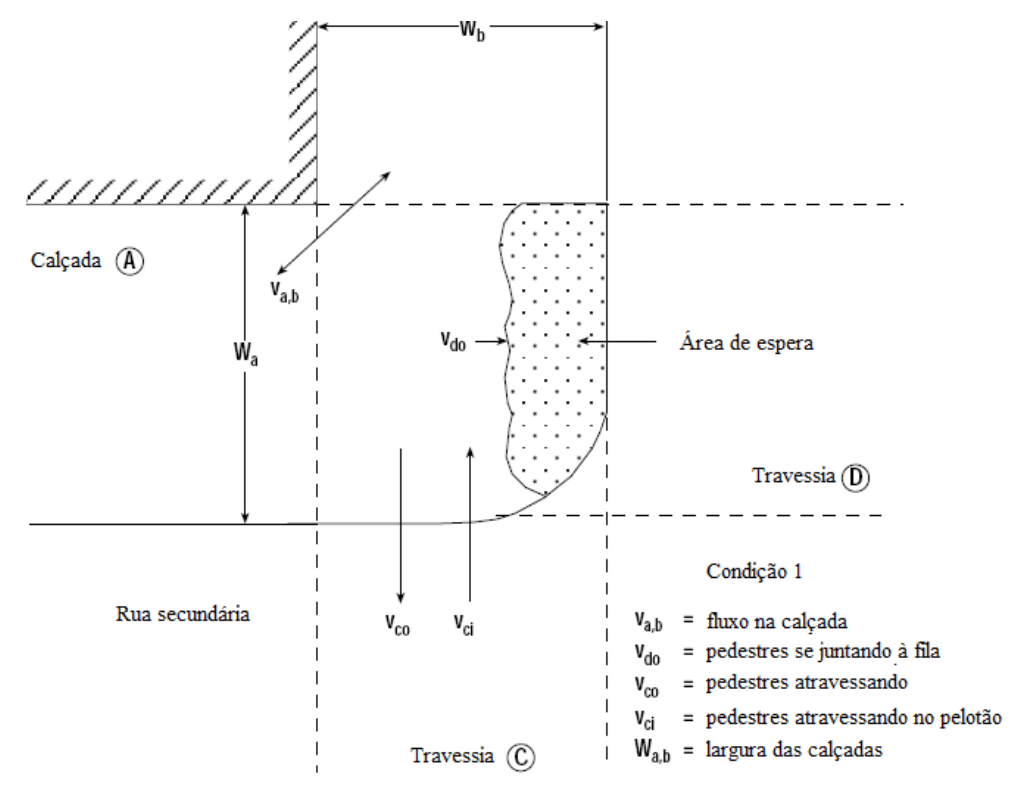

Figura A- 2 - Travessia de via secundária (Fonte: Special Report 209: Highway Capacity Manual, TRB. National Research Council, Washington, D.C., 2000)

$$
\mathrm{TS}=\mathrm{C}\left(\mathrm{W}_{\mathrm{a}} \mathrm{W}_{\mathrm{b}}-0.215 \mathrm{R}^{2}\right)
$$

Considerando que a chegada de pedestres na fila é uniforme, o tempo de espera do pedestre pode ser calculado conforme segue:

$$
Q_{\text {tdo }}=\frac{v_{\text {do }} R_{\mathrm{mi}}{ }^{2}}{2 \mathrm{C}}
$$



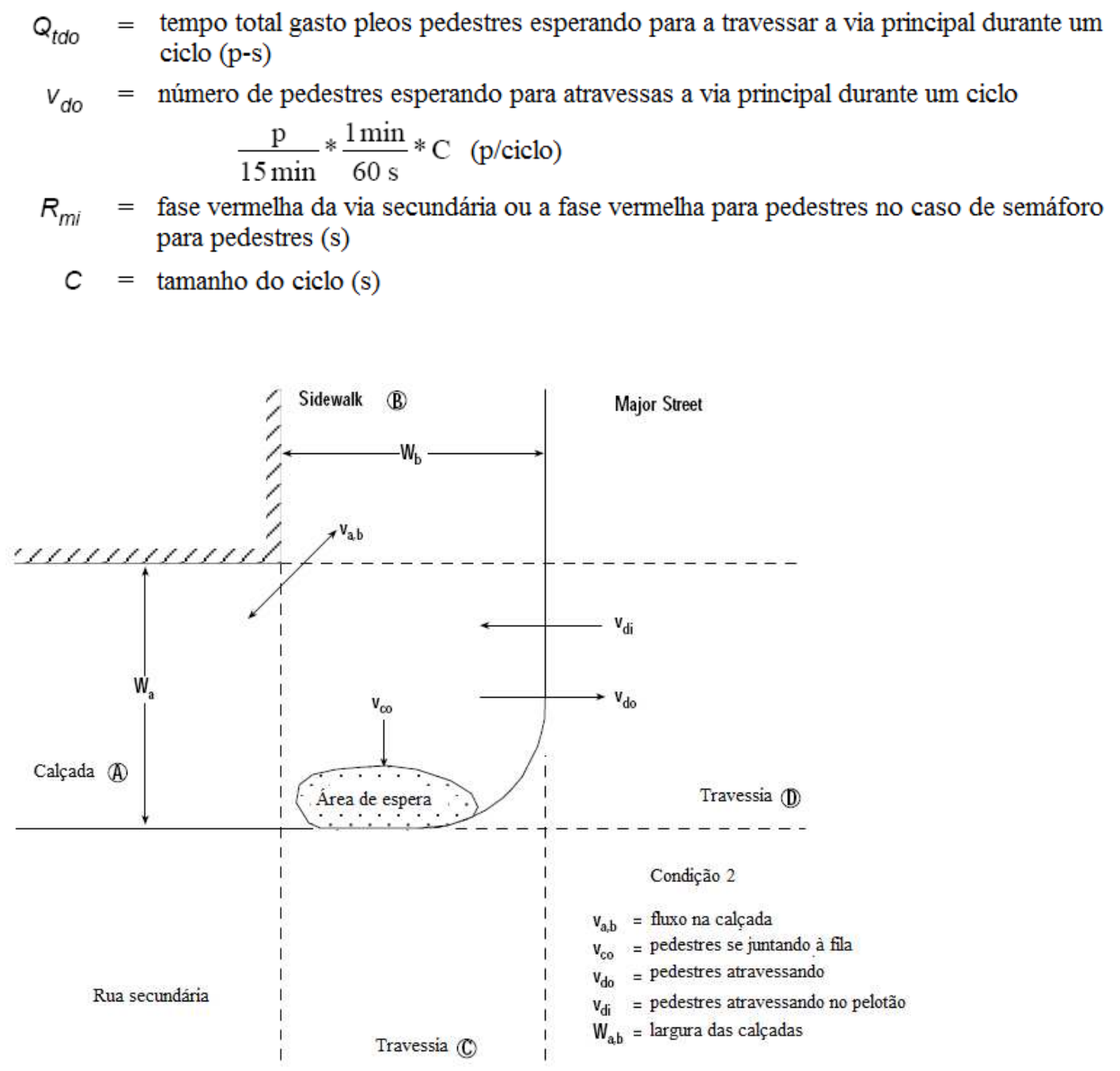

Figura A- 3 - Travessia de via principal (Fonte: Special Report 209: Highway Capacity Manual, TRB. National Research Council, Washington, D.C., 2000)

$$
\begin{aligned}
& Q_{t c o}=\frac{v_{c o} R_{m j}^{2}}{2 C} \\
& Q_{t d o}=\begin{array}{l}
\text { tempo total gasto pleos pedestres esperando para a travessar a via principal durante um } \\
\text { ciclo (p-s) }
\end{array} \\
& v_{\text {do }}=\text { número de pedestres esperando para atravessas a via principal durante um ciclo } \\
& \frac{\mathrm{p}}{15 \mathrm{~min}} * \frac{1 \mathrm{~min}}{60 \mathrm{~s}} * \mathrm{C} \quad(\mathrm{p} / \mathrm{ciclo}) \\
& R_{m i}=\text { fase vermelha da via secundária ou a fase vermelha para pedestres no caso de semáforo } \\
& \text { para pedestres (s) } \\
& C=\text { tamanho do ciclo (s) }
\end{aligned}
$$


O tempo espaço de circulação para pedestres pode ser então calculado:

$$
\begin{aligned}
T_{\mathrm{c}}= & T S-\left[0.5\left(Q_{\mathrm{tdo}}+Q_{\mathrm{tco}}\right)\right] \\
T S_{C}= & \text { espaço-tempo total disponível para circulação de pedestres }\left(\mathrm{m}^{2}-\mathrm{s}\right) \\
T S= & \text { espaço-tempo total disponível } \\
Q_{t d o}= & \text { tempo total gasto pelos pedestres para atravessar a via principal durante um } \\
& \text { ciclo (p-s) } \\
Q_{t c o}= & \text { tempo total gasto pelos pedestres esperando para atravessar a via secundária } \\
& \text { durante um ciclo (p-s) }
\end{aligned}
$$

Finalmente, o espaço requerido para circulação de pedestres é computado dividindo o tempoespaço total disponível para circulação de pedestres pelo tempo que os pedestres levam para andar pela área da esquina, que é a soma do volume total de circulação multiplicado por $4 \mathrm{~s}$, que é o tempo médio de circulação assumido:

$$
\begin{aligned}
& \begin{aligned}
M & =\text { área de circulação por pedestre }\left(\mathrm{m}^{2} / \mathrm{p}\right) \\
\mathrm{T}=\frac{\mathrm{TS}_{\mathrm{C}}}{4 \mathrm{v}_{\text {tot }}} \quad T \mathrm{~S}_{C} & =\text { tempo-espaco total disponível para a circulacão de pedestres }\left(\mathrm{m}^{2}-\mathrm{s}\right)
\end{aligned} \\
& v_{\text {tot }}=\text { número total de pedestres circulando em um ciclo } \quad=\mathrm{v}_{\mathrm{ri}}+\mathrm{v}_{\mathrm{co}}+\mathrm{v}_{\mathrm{di}}+ \\
& \mathrm{v}_{\mathrm{do}}+\mathrm{v}_{\mathrm{a}, \mathrm{b}}
\end{aligned}
$$

O tempo espaço de travessia em uma esquina é calculado como:

$$
\begin{gathered}
\text { TS } \left.=L_{E}(\text { WALK }+F D W)-\frac{L}{2 S_{p}}\right) \quad \text { ou } \\
T S=L W_{E}\left(G-\frac{L}{2 S_{p}}\right)
\end{gathered}
$$

where

$$
\begin{aligned}
T S & =\text { tempo-espaço }\left(\mathrm{m}^{2}-\mathrm{s}\right) \\
L & =\text { comprimento da travessia }(\mathrm{m}) \\
W_{E} & =\text { largura efetiva da travessia }(\mathrm{m}) \\
W A L K+F D W & =\text { tempo efetivo de verde para pedestres na travessia }(\mathrm{s}) \\
S_{p} & =\text { velocidade média dos pedestres }(\mathrm{m} / \mathrm{s}) \\
G & =\text { tempo de verde }
\end{aligned}
$$


A análise de tempo-espaço disponível para a travessia requer uma taxa de fluxo de pedestres durante o comprimento do intervalo do ciclo.

$$
\begin{aligned}
& \qquad N_{\text {ped }}=\frac{v(C-G)}{C} \\
& N_{\text {ped }}=\text { número de pedestres atravessando durante um intervalo }(\mathrm{p}) \\
& V=\text { volume de pedestres na via de pedestres }(\mathrm{p} / 15 \mathrm{~min}) \\
& G \quad=\text { tempo de verde }
\end{aligned}
$$

O tempo total de travessia ou tempo de verde efetivo requerido para totalizar a travessia numa interseção, é então:

$$
\begin{aligned}
& t=3.2+\frac{L}{S_{p}}+\left(0.81 \frac{N_{\text {ped }}}{W}\right) \text { para } W>3.0 m \\
& t=3.2+\frac{L}{S_{p}}+\left(0.27 N_{\text {ped }}\right) \text { para } W \leq 3.0 m
\end{aligned}
$$

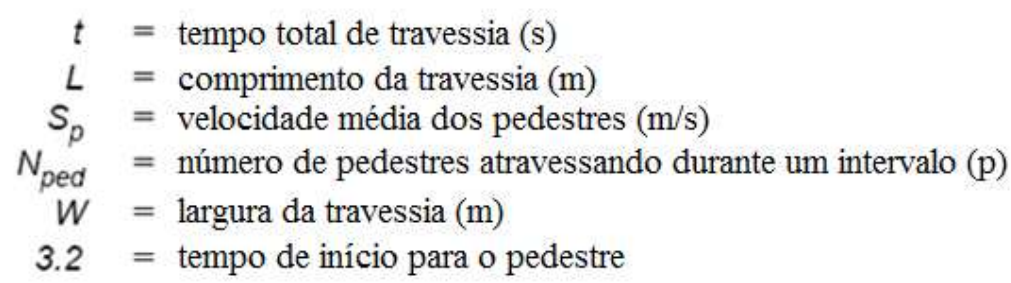

O tempo de ocupância da calçada é dado então como produto do tempo médio de travessia e o número de pedestres utilizando a travessia durante um ciclo do semáforo:

$$
T=\left(v_{i}+v_{0}\right) t
$$

$T=$ tempo total de ocupação da travessia (p-s)

$v_{i} \quad=$ volume de chegada para a travessia em questão (p/ciclo)

$v_{O}=$ volume de saída para a travessia em questão (p/ciclo)

$t$ = tempo total de travessia

O espaço de circulação para cada pedestre é então determinado dividindo o tempo-espaço disponível para a travessia pelo tempo de ocupância total, o que fornece a área disponível para cada pedestre, e pode ser relacionada ao nível de serviço discutido inicialmente para calçadas. 


$$
\begin{aligned}
& \mathrm{M}=\frac{\mathrm{TS}}{\mathrm{T}} \quad \mathrm{M}=\text { área de circulação por pedestre }\left(\mathrm{m}^{2} / \mathrm{p}\right) \\
& T S=\text { tempo-espaço }\left(\mathrm{m}^{2}-\mathrm{s}\right) \\
& T=\text { tempo total de ocupação da travessia }
\end{aligned}
$$

Esse método permite uma estimativa apropriada do efeito de veículos fazendo conversão no nível de serviço dos pedestres atravessando durante uma fase verde. Assumindo uma área ocupada por um veículo na travessia baseada no produto do veículo sweptpath $(2,4 \mathrm{~m}$ para a maioria dos veículos), largura da travessia e estimativa do tempo em que o veículo ocupa esse espaço (assumindo que seja $5 \mathrm{~s}$ ).

$$
\begin{aligned}
T S_{t V} & =\text { tempo-espaço ocupado por veículos em conversão }\left(\mathrm{m}^{2}-\mathrm{s}\right) \\
\mathrm{TS}_{\mathrm{tv}}=12 \mathrm{~N}_{\mathrm{tv}} \mathrm{W}_{\mathrm{E}} \quad N_{t V} & =\text { número de veículos durante a fase de verde (veic) } \\
W_{E} & =\text { largura efetiva da travessia }(\mathrm{m})
\end{aligned}
$$

\section{A.4. Nível de Serviço em Travessias Não-Semaforizadas}

E interseções não semaforizadas a oportunidade de travessia é função da brecha entre veículos. Os procedimentos recomendados pelo HCM (2000) são os seguintes:

\section{Cálculo da brecha crítica (para um único pedestre)}

$$
t_{c}=\frac{L}{S_{p}}+t_{S}
$$

\footnotetext{
$t_{c}=$ brecha crítica para um único pedestre (s)

$S_{p}=$ velocidade média do pedestre $(\mathrm{m} / \mathrm{s})$

$L \quad=$ comprimento da travessia $(\mathrm{m})$

$t_{s}=$ tempo de início do pedestre e final da visibilidade (s)
}

Distribuição espacial de pedestres 


$$
\mathrm{N}_{\mathrm{p}}=\operatorname{INT}\left[\frac{0.75\left(\mathrm{~N}_{\mathrm{c}}-1\right)}{\mathrm{W}_{\mathrm{E}}}\right]+1
$$

$N_{p}=$ distribuição espacial de pedestres (p)

$N_{c}=$ número toal de pedestres no pelotão atravessando (p)

$W_{E}=$ largura efetiva da travessia $(\mathrm{m})$

$0.75=$ largura efetiva utilizada por um único pedestre para evitar interferência quando passando por outros pedestres

$$
N_{c}=\frac{v_{p} e^{v_{p} t_{c}}+v e^{-v t_{c}}}{\left(v_{p}+v\right) e^{\left(v_{p}-v\right) t_{c}}}
$$

$N_{c}=$ tamanho de um pelotão típico de pedestres atravessando (p)

$v_{p}=$ taxa de fluxo de pedestres $(\mathrm{p} / \mathrm{s})$

$v=$ taxa de fluxo veicular (veic/h)

$t_{r} \quad=$ brecha crítica para um único pedestre (s)

$$
t_{G}=t_{c}+2\left(N_{p}-1\right)
$$

$t_{G}=$ brecha típica para um grupo de pedestres (s)

$t_{c}=$ brecha crítica para um único pedestre (s)

$N_{p}=$ distribuição espacial de pedestres (p)

$\underline{\text { Atraso }}$

$$
d_{p}=\frac{1}{v}\left(e^{v t_{G}}-v t_{G}-1\right)
$$

$d_{p} \quad=$ atraso médio para o pedestre (s)

$v=$ taxa de fluxo veicular $(\mathrm{veic} / \mathrm{h})$

$t_{G}=$ brecha crítica para grupo de pedestres (s) 
Tabela A- 8- Critério de NS para pedestres em interseções não semaforizadas (Fonte: Special Report 209: Highway Capacity Manual, TRB. National Research Council, Washington, D.C., 2000)

\begin{tabular}{c|c|c}
\hline Nivel de Serviço & Atraso Médio/Pedestres (s) & Probabilidade de Comportamento de Risco \\
\hline A & $<5$ & Baixa \\
B & $\geq 5-10$ & \\
C & $>10-20$ & Moderada \\
D & $>20-30$ & Alta \\
E & $>30-45$ & Muito Alta \\
F & $>45$ & \\
\hline
\end{tabular}

A.5. Nível de Serviço para Pedestres em Vias Urbanas 


\section{APÊNDICE B - ANÁLISE DA OPERAÇÃO PARA CICLISTAS DO HCM (2000)}

\section{B.1. Nível de Serviço em Vias Exclusivas}

Considerando dispositivos unidirecionais, a velocidade inicial, $\mathrm{v}_{0}$, é igual a 0 . Assumindo distribuição normal da velocidade das bicicletas com velocidade média de $18 \mathrm{~km} / \mathrm{h}$ e desvio padrão de $3 \mathrm{~km} / \mathrm{h}$, a frequiência de encontros, $f_{m}$, e de ultrapassagens $f_{p}$, é calculada conforme segue:

$$
\begin{gathered}
F_{p}=0.188 v_{s} \\
F_{m}=2 v_{o} \\
F=0.5 F_{m}+F_{p}
\end{gathered}
$$

\footnotetext{
$F_{p}=$ número de eventos de ultrapassagem (com ciclistas na mesma direção) (eventos/h);

$F_{m}=$ número de eventos opostos (com ciclistas na direção oposta) (eventos/h);

$F=$ número total de eventos na via (eventos $/ \mathbf{h})$, com um fator de peso de 0,5 para eventos de encontro;

$v_{s}=$ taxa de fluxo de bicicletas na direção avaliada (bicicletas/h);

$v_{0}=$ taxa de fluxo de bicicletas na direção oposta (bicicletas $/ \mathbf{h}$ )
}

E a seguinte tabela traz o critério de NS para bicicletas em vias exclusivas: 
Tabela B- 1 - Critério de NS para bicicletas em vias exclusivas (Fonte: Special Report 209: Highway Capacity Manual, TRB. National Research Council, Washington, D.C., 2000)

\begin{tabular}{c|c|c}
\hline Nivel de Serviço & $\begin{array}{c}\text { Frequência de Eventos, 2 sentidos, 2 faixas a } \\
\text { (eventos/h) }\end{array}$ & $\begin{array}{c}\text { Frequência de Eventos, 2 sentidos, } 3 \text { faixas } b \\
\text { (eventos/h) }\end{array}$ \\
\hline A & $\leq 40$ & $\leq 90$ \\
B & $>40-60$ & $>90-140$ \\
C & $>60-100$ & $>140-210$ \\
D & $>100-150$ & $>210-300$ \\
E & $>150-195$ & $>300-375$ \\
F & $>195$ & $>375$ \\
\hline
\end{tabular}

Notas:

a. vias de $2,4 \mathrm{~m}$ de largura. Também utilizado para bicicletas na via

b. vias de $3,0 \mathrm{~m}$ de largura

\section{B.2. Nível de Serviço em Vias de Uso Compartilhado Segregadas do Fluxo Motorizado}

A presença de pedestres prejudica a capacidade e NS para os ciclistas. Assumindo distribuição normal com médias: $18 \mathrm{~km} / \mathrm{h}$ para pedestres e $4,5 \mathrm{~km} / \mathrm{h}$ para ciclistas:

$$
\begin{aligned}
& F_{p}=3 v_{p s}+0.188 v_{b s} \\
& F_{m}=5 v_{p o}+2 v_{b o} \\
& F=0.5 F_{m}+F_{p} \\
& F, F_{p}, F_{m} \text { definidos anteriormente } \\
& v_{p s}=\text { taxa de fluxo de pedestres na direcão analisada }(\mathrm{p} / \mathrm{h}) \\
& v_{b s}=\text { taxa de fluxo de bicicletas na direção analisada }(\mathrm{bicicletas} / \mathrm{h}) \\
& v_{p o}=\text { taxa de fluxo de pedestres na direção oposta }(\mathrm{p} / \mathrm{h}) \\
& v_{b o}=\text { taxa de fluxo de bicicletas na direção oposta }(\text { bicicletas } / \mathbf{h})
\end{aligned}
$$


Tabela B- 2 - Critério de NS para ciclistas em vias de uso compartilhado segregadas do tráfego motorizado (Fonte: Special Report 209: Highway Capacity Manual, TRB. National Research Council, Washington, D.C., 2000)

\begin{tabular}{c|c|c}
\hline Nivel de Serviço & $\begin{array}{c}\text { Frequência de Eventos, 2 sentidos, 2 faixas a } \\
\text { (eventos/h) }\end{array}$ & $\begin{array}{c}\text { Frequência de Eventos, 2 sentidos, } 3 \text { faixas }{ }^{b} \\
\text { (eventos/h) }\end{array}$ \\
\hline A & $\leq 40$ & $\leq 90$ \\
B & $>40-60$ & $>90-140$ \\
C & $>60-100$ & $>140-210$ \\
D & $>100-150$ & $>210-300$ \\
E & $>150-195$ & $>300-375$ \\
F & $>195$ & $>375$ \\
\hline
\end{tabular}

\section{B.3. Nível de Serviço em Ciclofaixas}

Segundo o HCM (2000) a ciclofaixa deve ser separada das demais por pintura no pavimento com fluxo em uma direção. Quando há acostamento disponível, as bicicletas podem utilizá-lo como faixa exclusiva. A largura varia entre 1,2 m (faixas) e 3,0 (acostamento pavimentado). $\mathrm{O}$ NS das bicicletas é afetado pelo tráfego adjacente de veículos motorizados, tráfego de veículos pesados, estacionamento, entre outros.

\section{B.4. Nível de Serviço em Interseções Semaforizadas}

A capacidade e o atraso são calculados conforme segue:

$$
\mathrm{c}_{\mathrm{b}}=\mathrm{s}_{\mathrm{b}} \frac{\mathrm{g}}{\mathrm{C}}=2000 \frac{\mathrm{g}}{\mathrm{C}} \quad \begin{aligned}
c_{b} & =\text { capacidade da ciclofaixa (bicicletas/h) } \\
s_{b} & =\text { fluxo de saturação da ciclofaixa (bicicletas; } \mathbf{h} \text { ) } \\
\mathrm{g} & =\text { verde efetivo para a ciclofaixa } \\
\mathrm{C} & =\text { tempo de ciclo do semáforo }
\end{aligned}
$$




$$
\begin{gathered}
d_{b}=\frac{0.5 C\left(1-\frac{g}{C}\right)^{2}}{1-\left[\frac{g}{C} \min \left(\frac{v_{b}}{c_{b}}, 1.0\right)\right]} \\
d_{b}=\text { atraso (seg/bicicleta) } \\
v_{b}=\text { taxa de fluxo na ciclofaixa unidirecional (bicicletas/h) }
\end{gathered}
$$

Assim, o NS para ciclistas em interseções semaforizadas:

Tabela B- 3 - NS para bicicletas em interseções semaforizadas (Fonte: Special Report 209: Highway Capacity Manual, TRB. National Research Council, Washington, D.C., 2000)

\begin{tabular}{c|c}
\hline Nivel de Serviço & Atraso (seg/bicicleta) \\
\hline A & $<10$ \\
B & $\geq 10-20$ \\
C & $>20-30$ \\
D & $>30-40$ \\
E & $>40-60$ \\
F & $>60$ \\
\hline
\end{tabular}

\section{B.5. Nível de Serviço em Interseções Não Semaforizadas}

O HCM (2000) recomenda fórmula poissoniana para capacidade, mas não fornece brechas críticas. Para atraso, recomenda usar as mesmas expressões adotadas para veículos, advertindo que ciclistas não formam fila nas aproximações. É recomendado desprezar atrasos nas conversões à direita e usar critério de nível de serviço de interseção semaforizada. Adverte ainda sobre as manobras com entrelaçamento com veículos. 


\section{B.6. Nível de Serviço para Ciclistas em Vias Urbanas}

Efeito combinado dos trechos em fluxo contínuo e atrasos nas travessias:

$$
\overline{\mathrm{V}}_{\text {med }}=\frac{\mathrm{L}_{\mathrm{T}}}{\sum\left(\frac{\mathrm{L}_{\mathrm{i}}}{\mathrm{V}_{\text {bici }}}+\mathrm{d}_{\text {bici }}\right)}
$$

Tabela B- 4 - Critério de NS para bicicletas em vias urbanas (Fonte: Special Report 209: Highway Capacity Manual, TRB. National Research Council, Washington, D.C., 2000)

\begin{tabular}{c|c}
\hline Nivel de Serviço & Velocidade da bicicleta $(\mathrm{km} / \mathrm{h})$ \\
\hline A & $>22$ \\
B & $>15-22$ \\
C & $>11-15$ \\
D & $>8-11$ \\
E & $\geq 7-8$ \\
F & $<7$ \\
\hline
\end{tabular}




\section{ANEXO A - PLANILHAS DE LEVANTAMENTO DO DADOS OPERACIONAIS}

A seguir são reproduzidas as tabelas utilizadas no levantamento dos dados operacionais básico, de cada trecho, por dia, hora e sentido. 


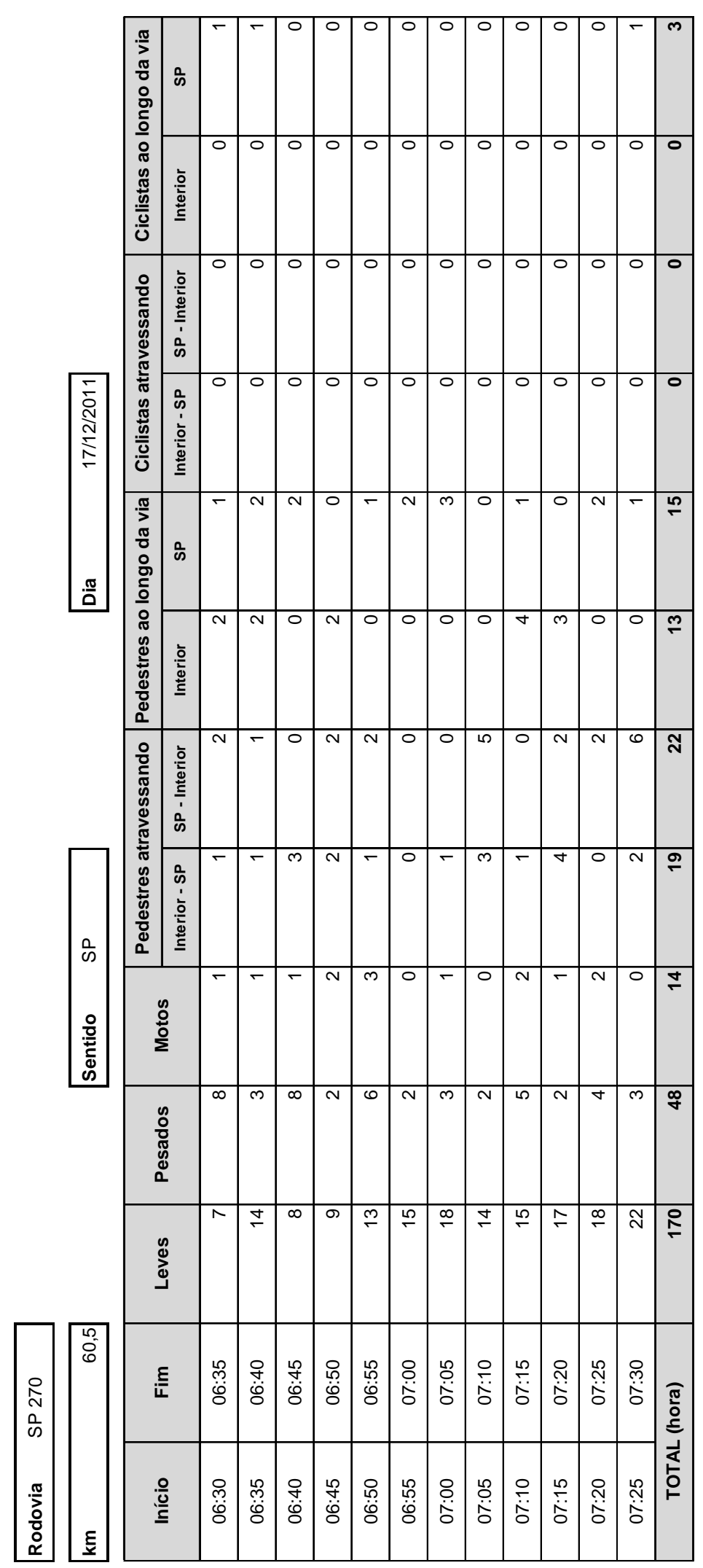




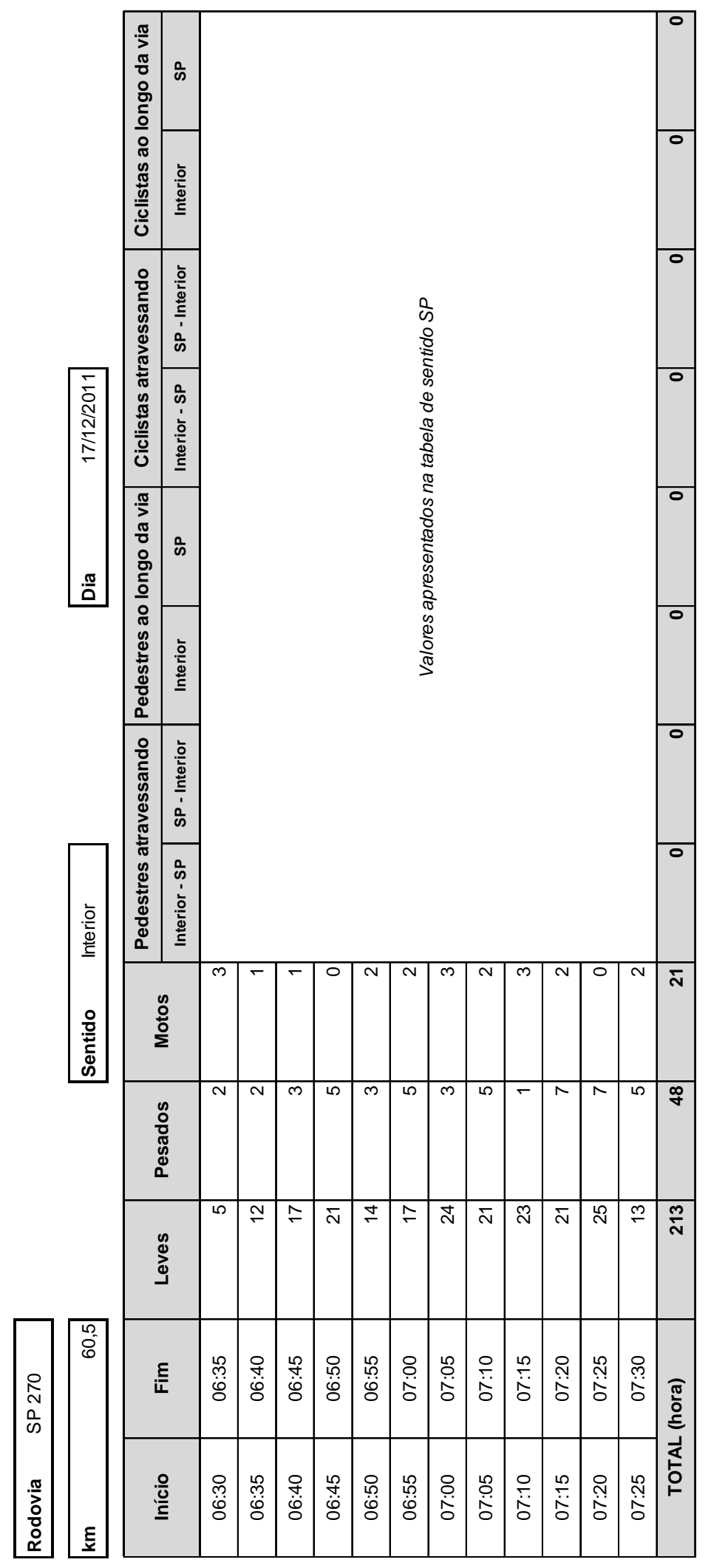




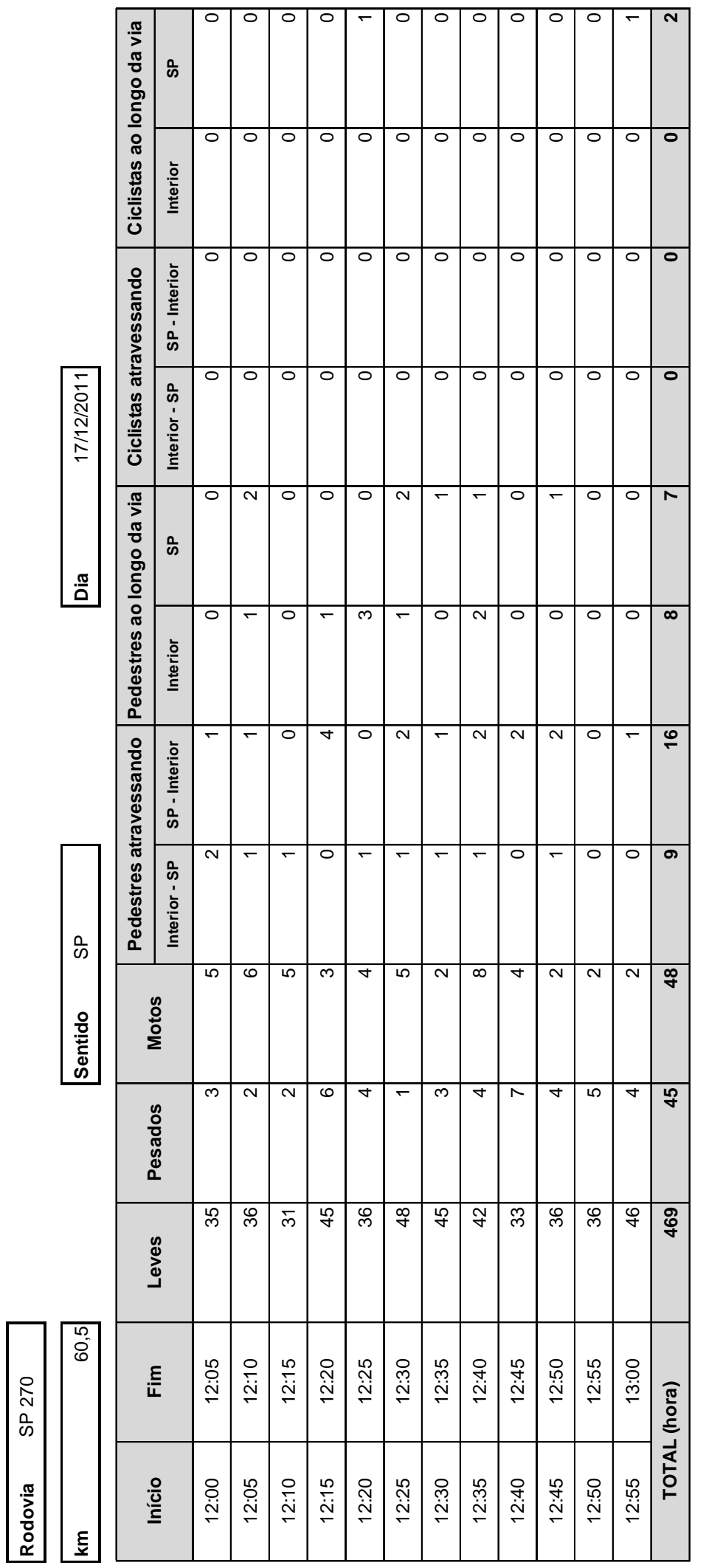




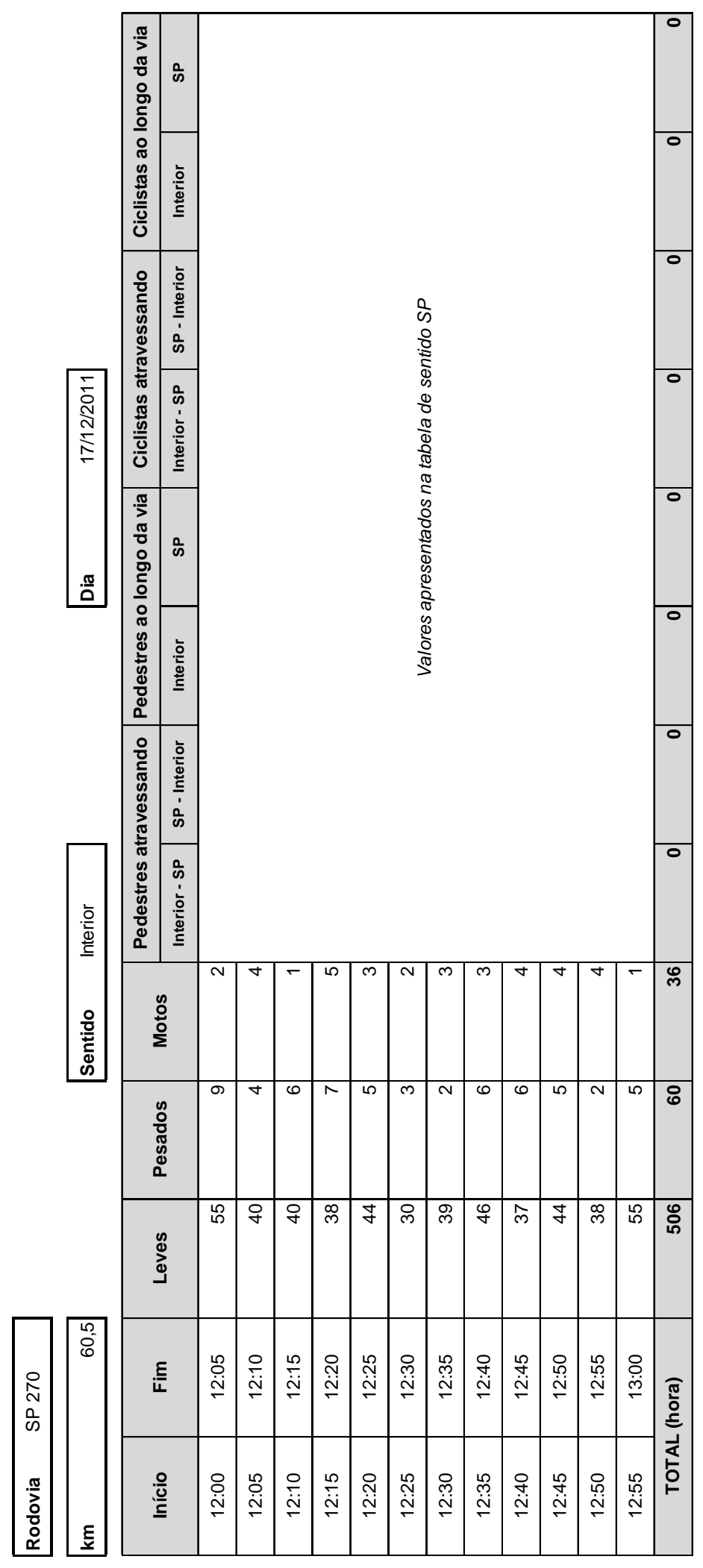




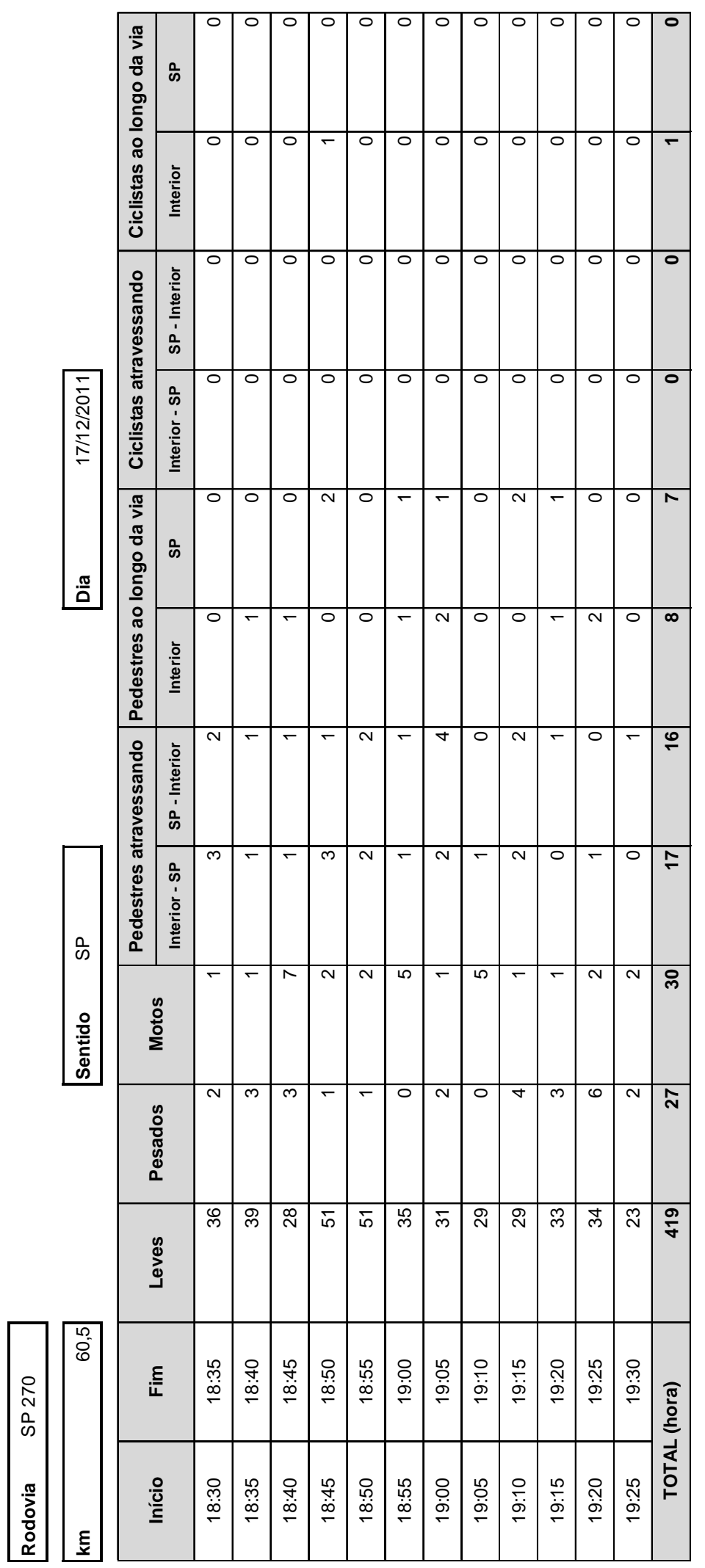




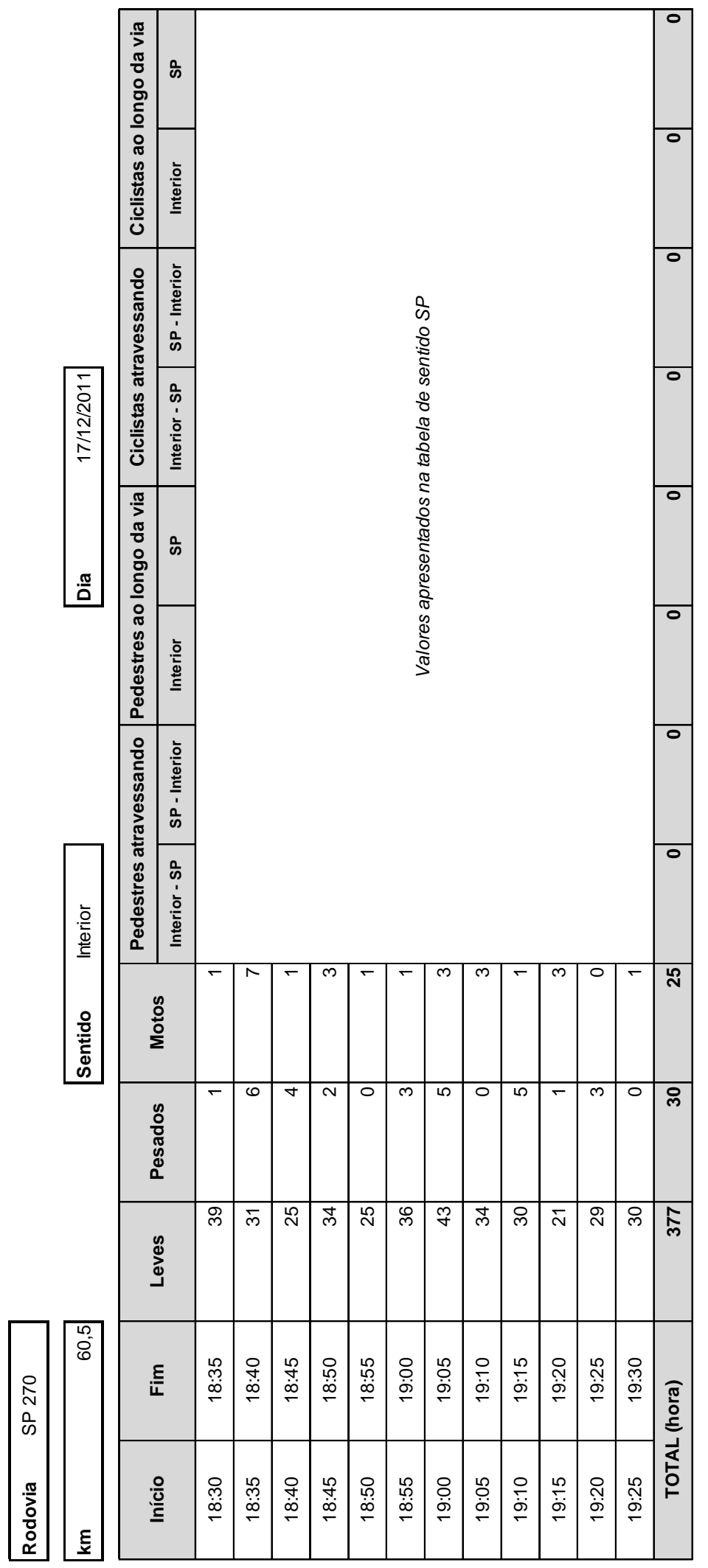




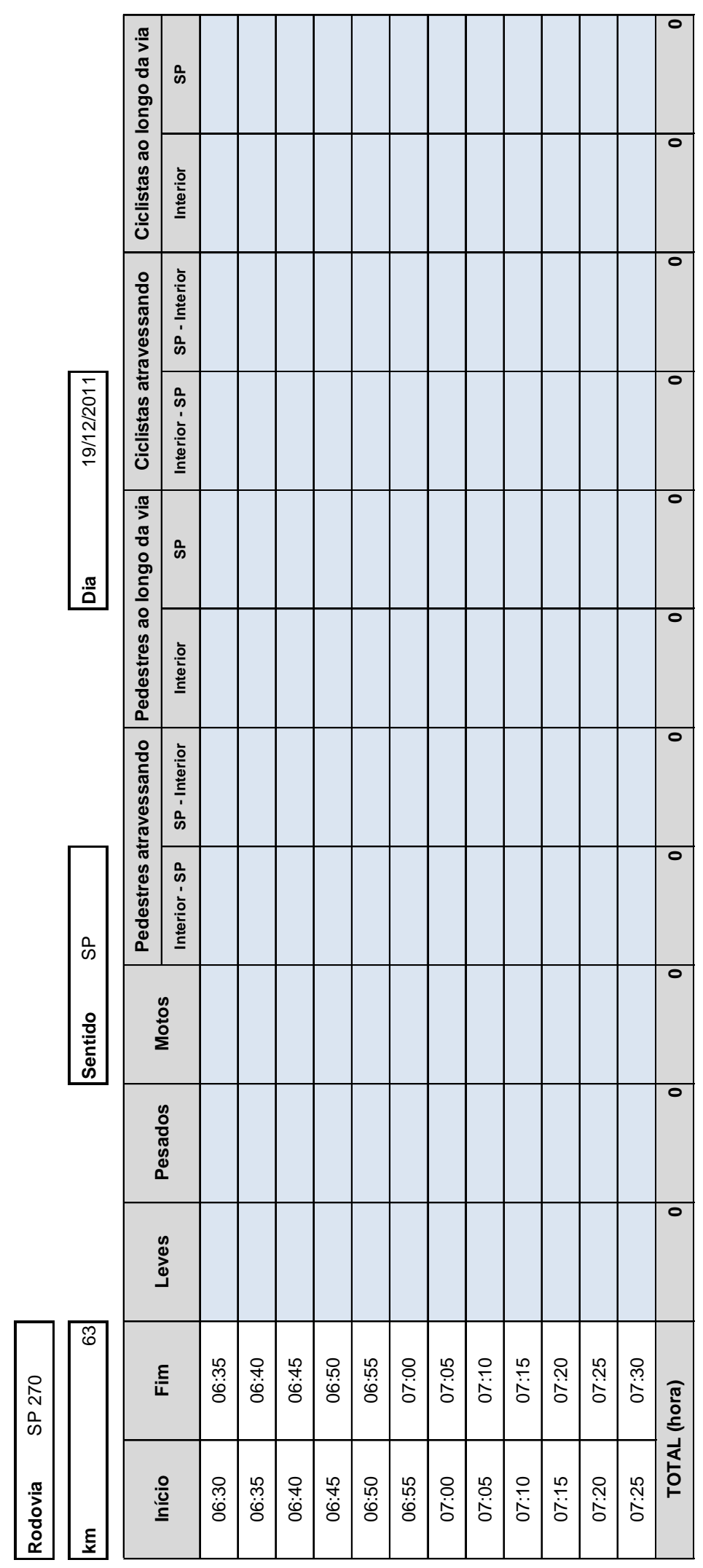




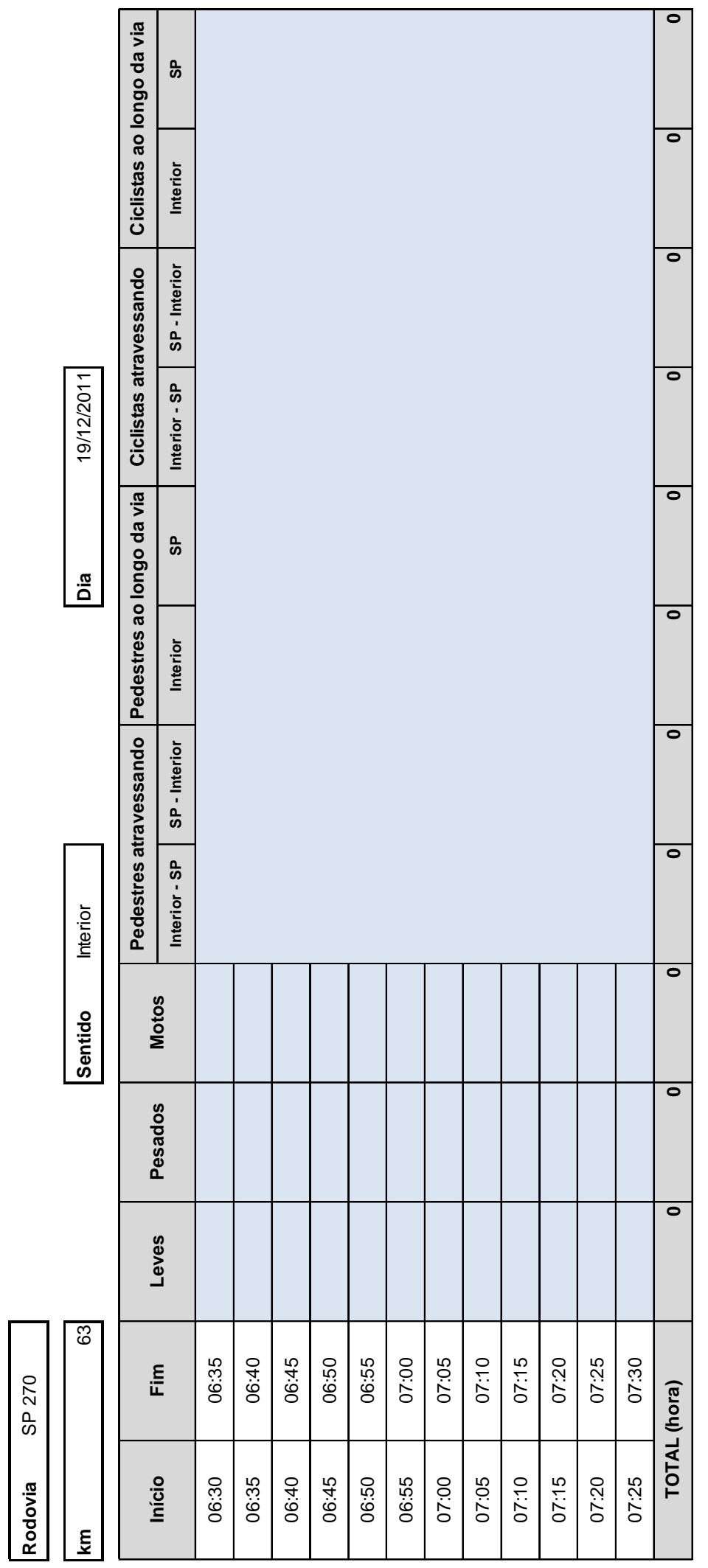




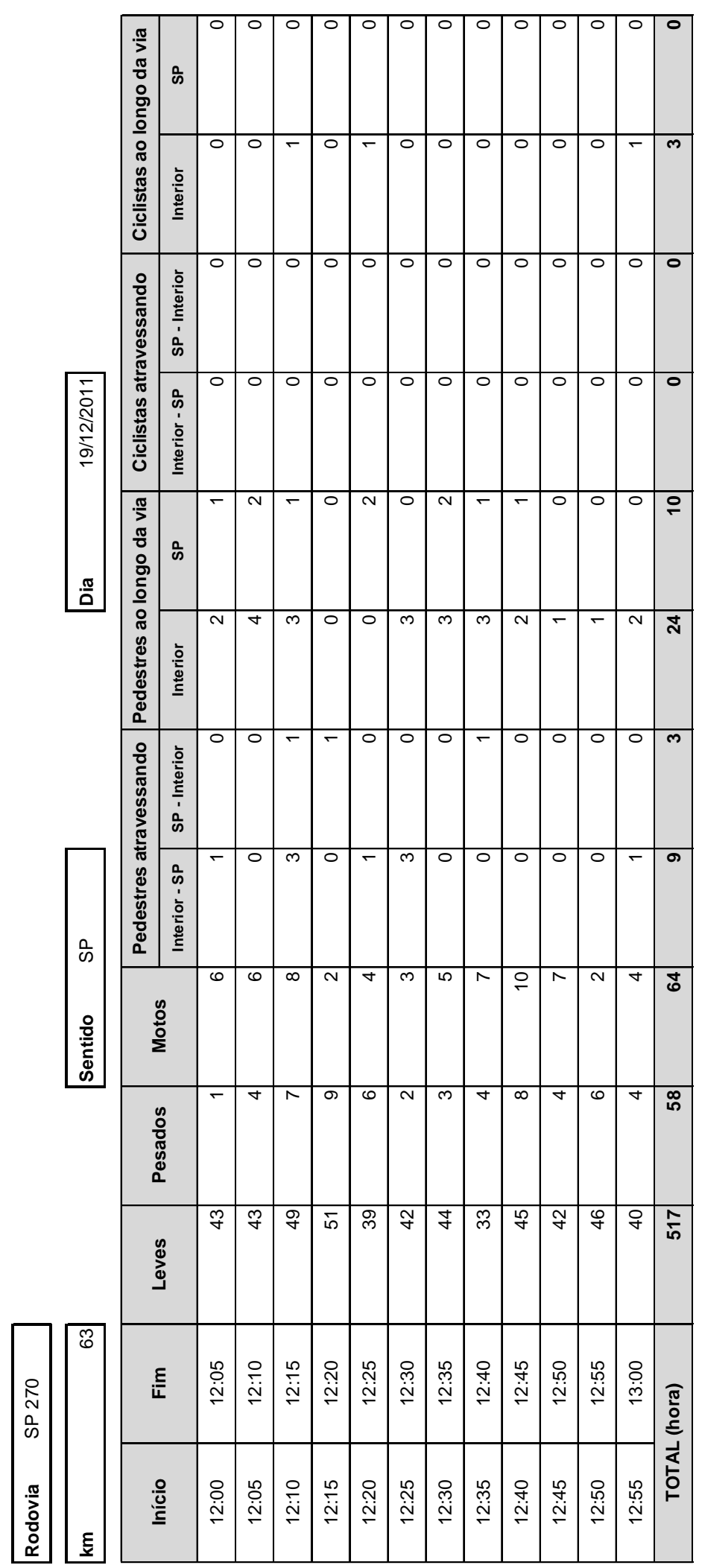




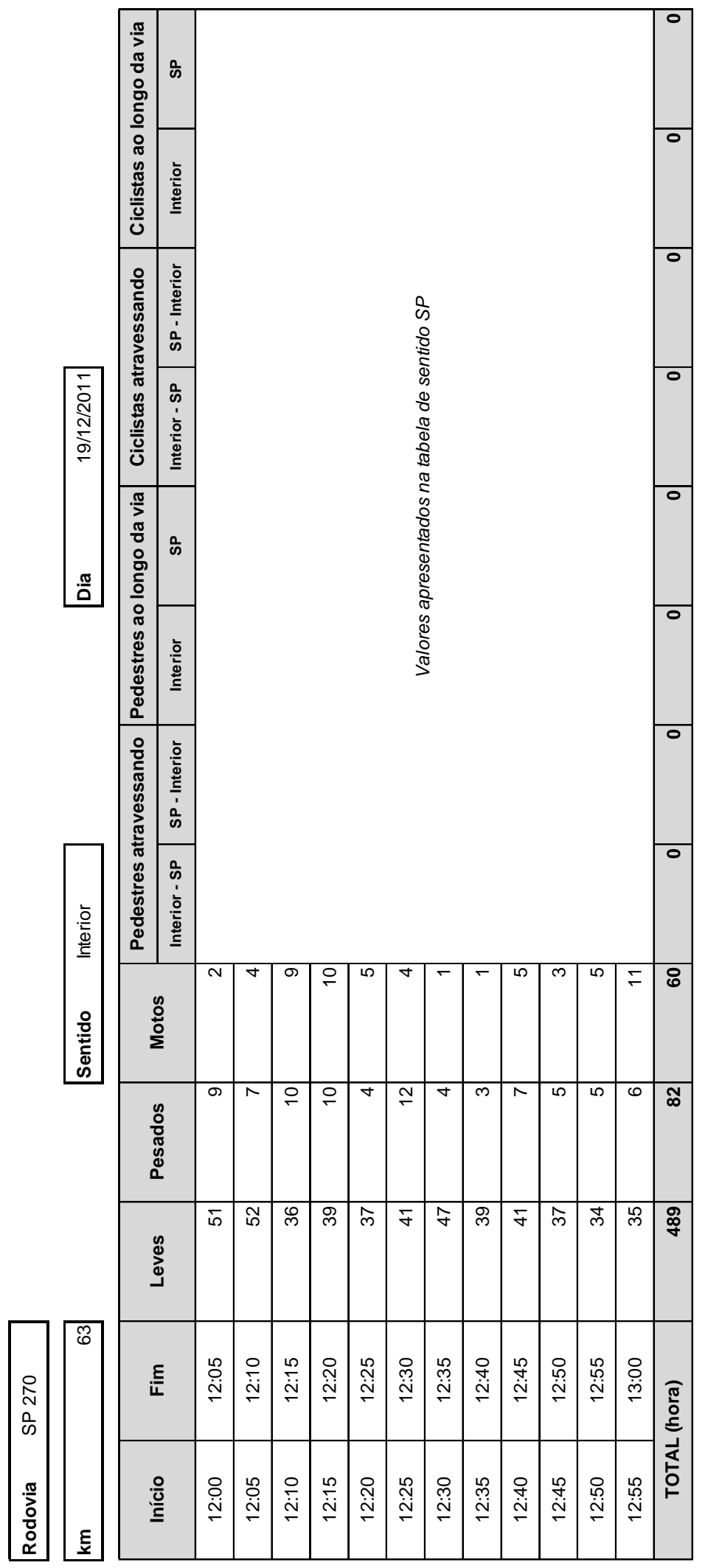




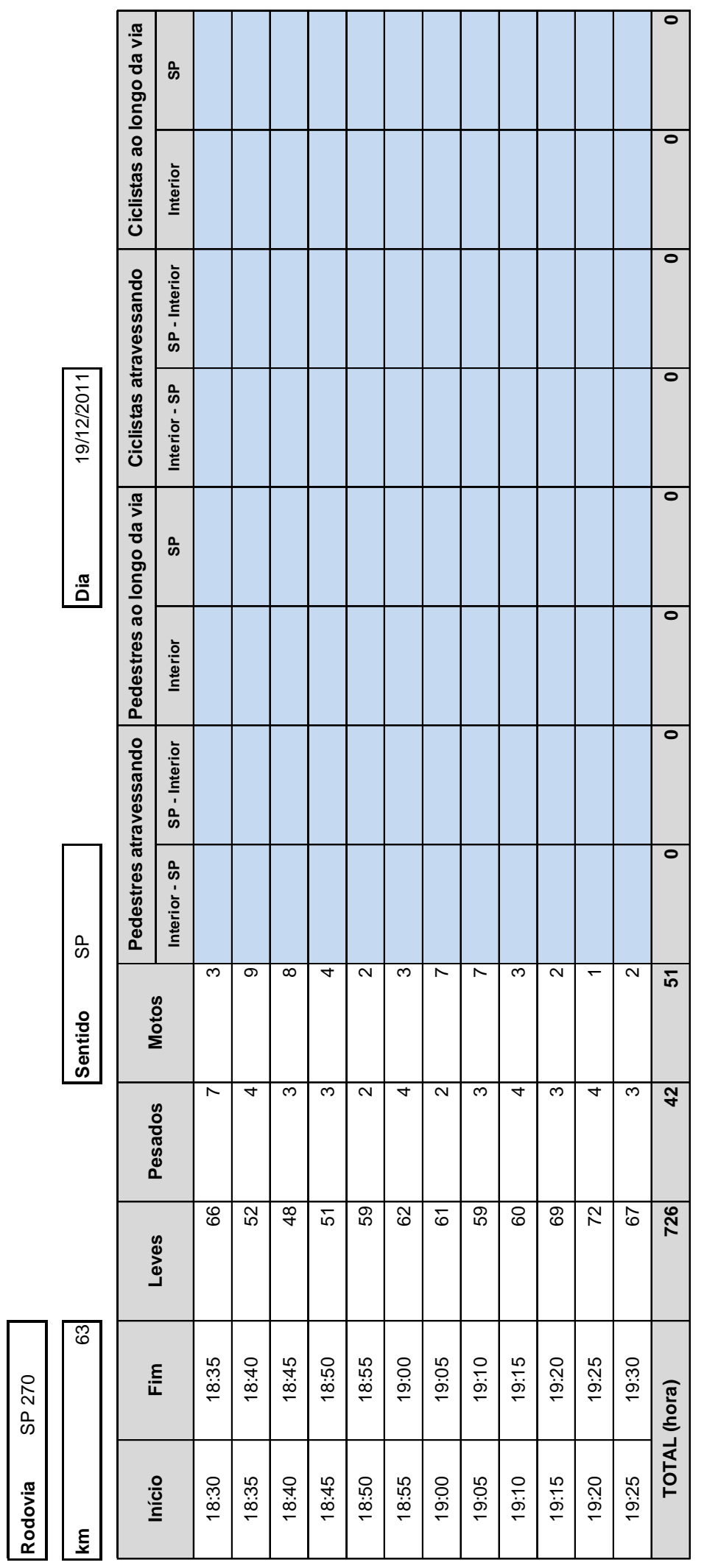




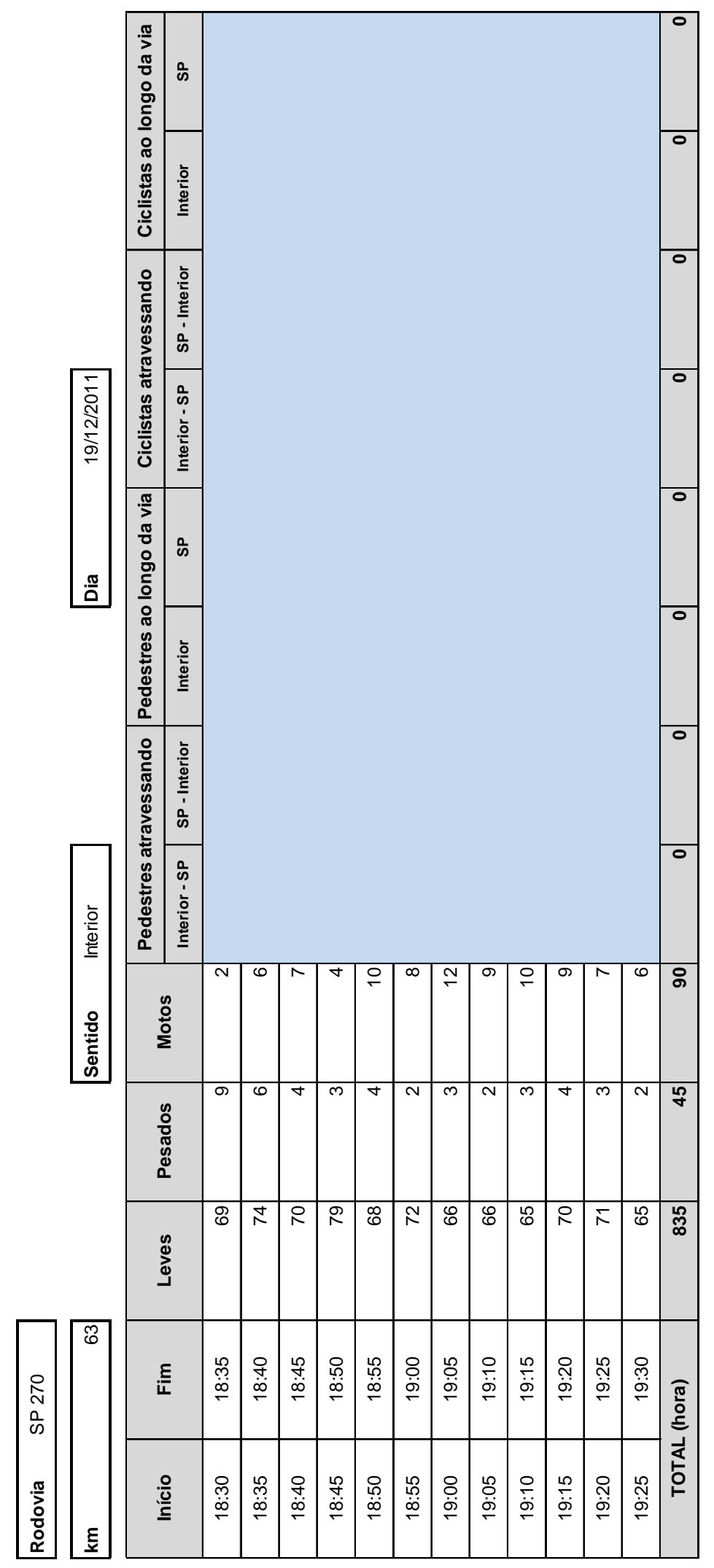




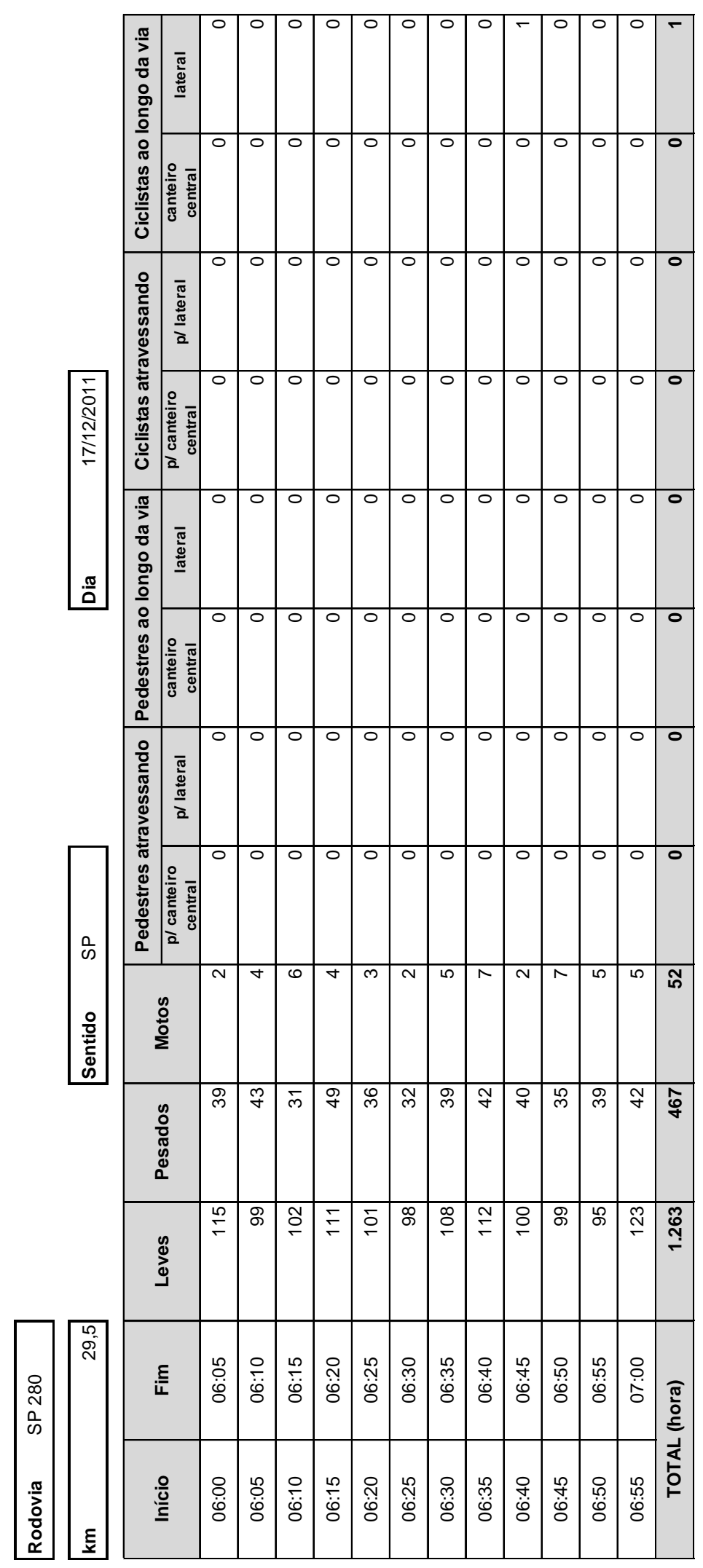




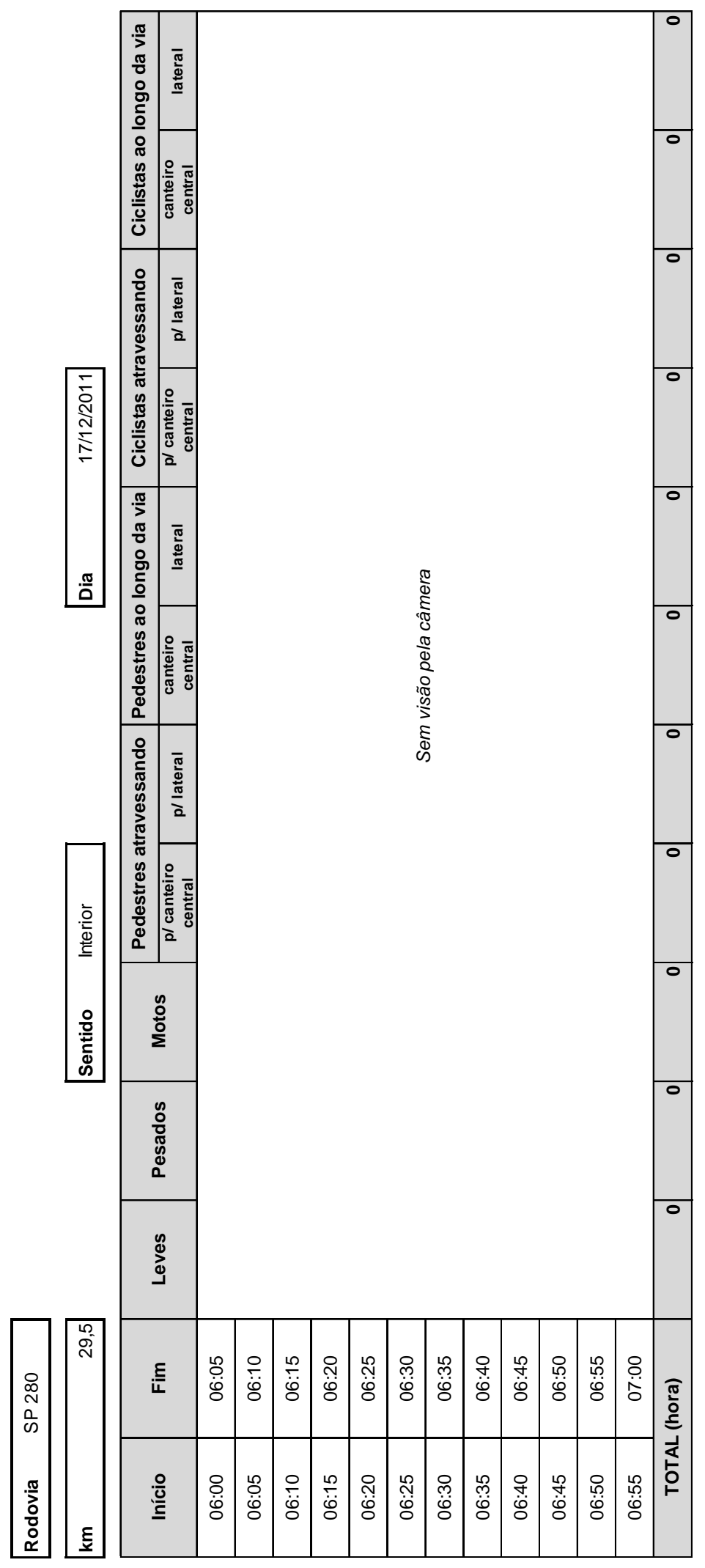




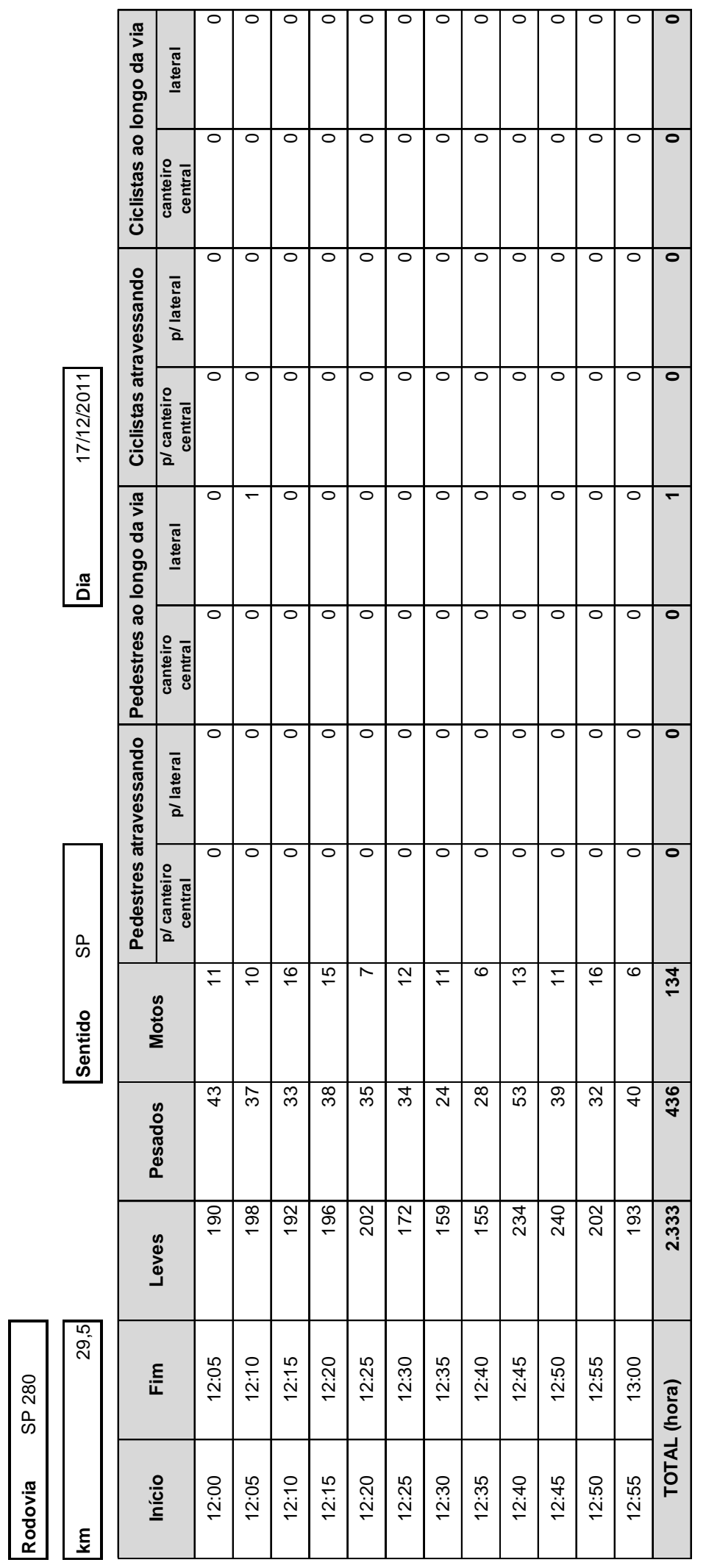




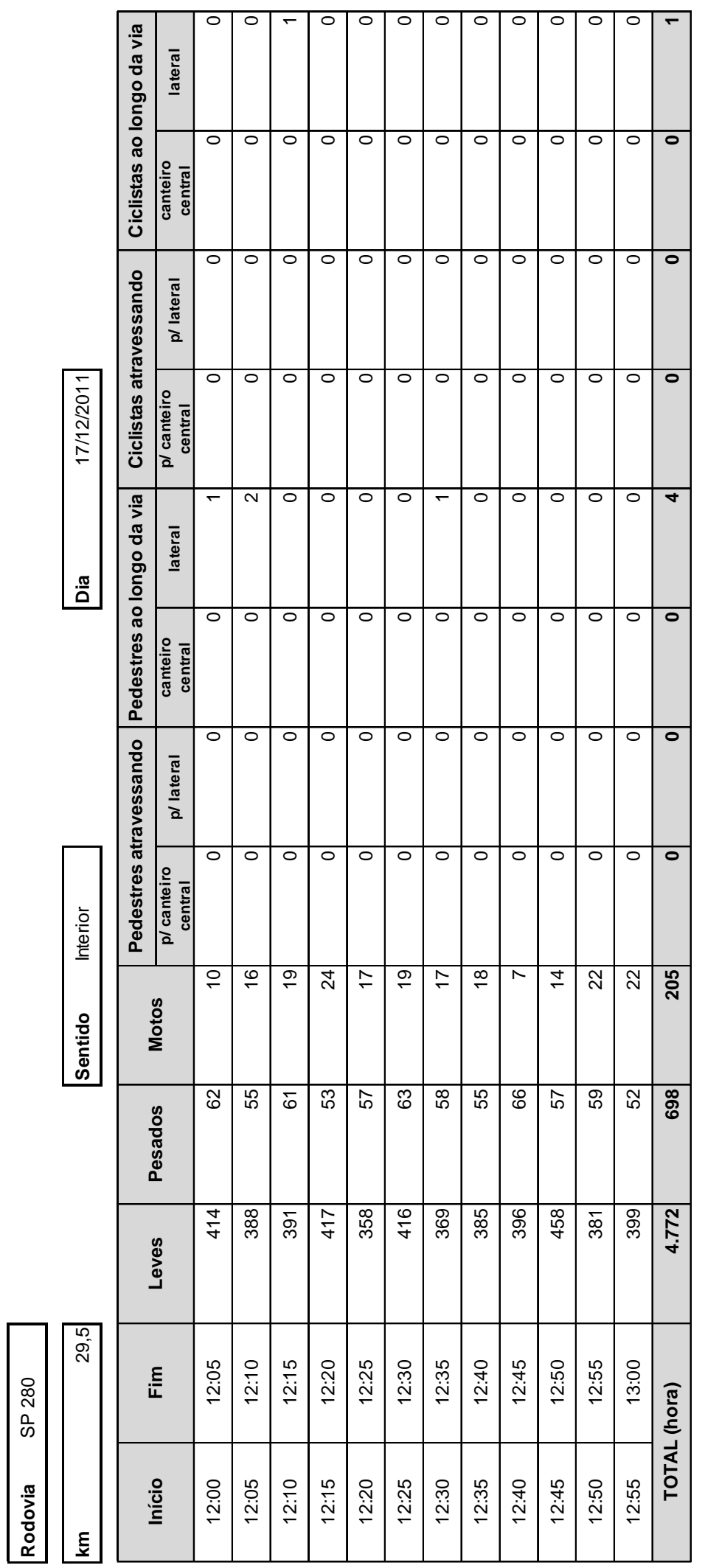




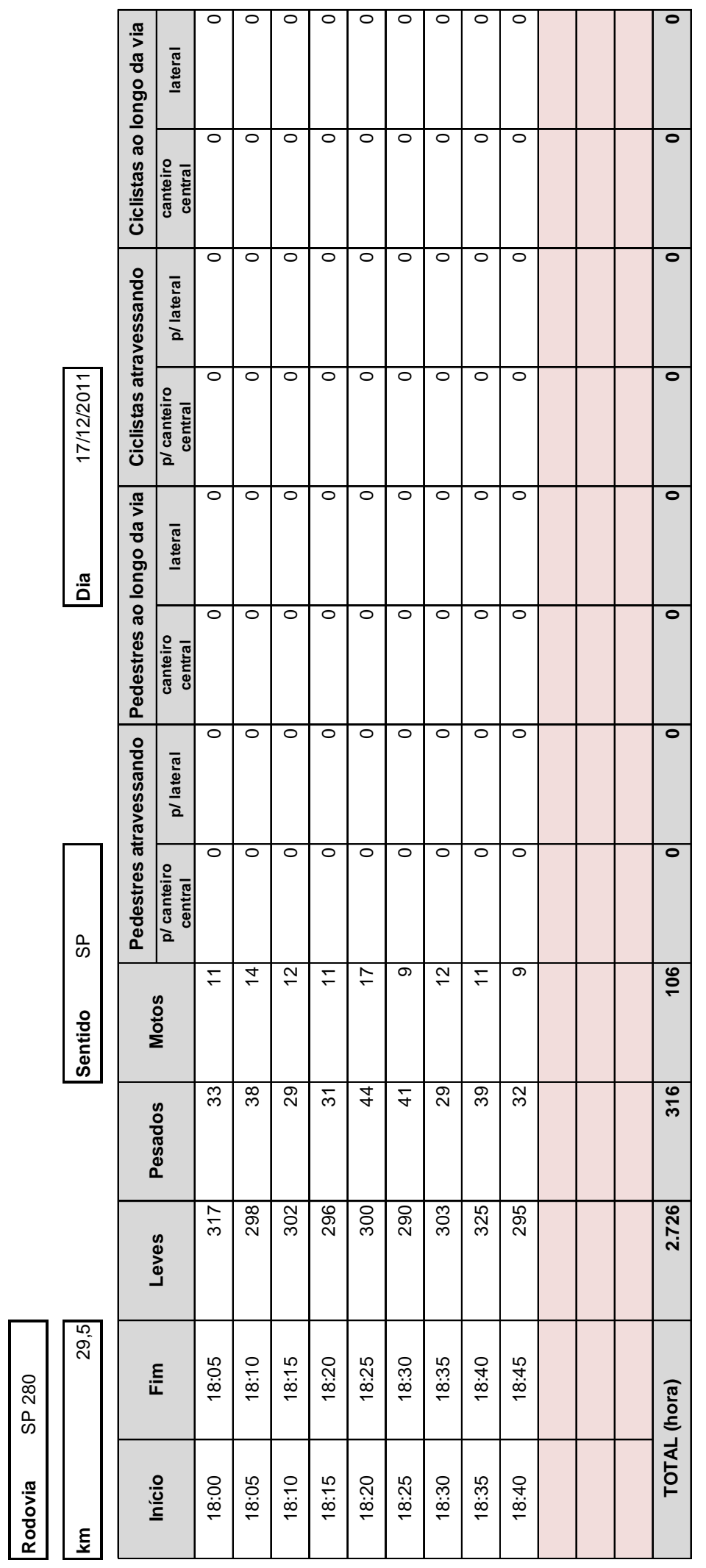




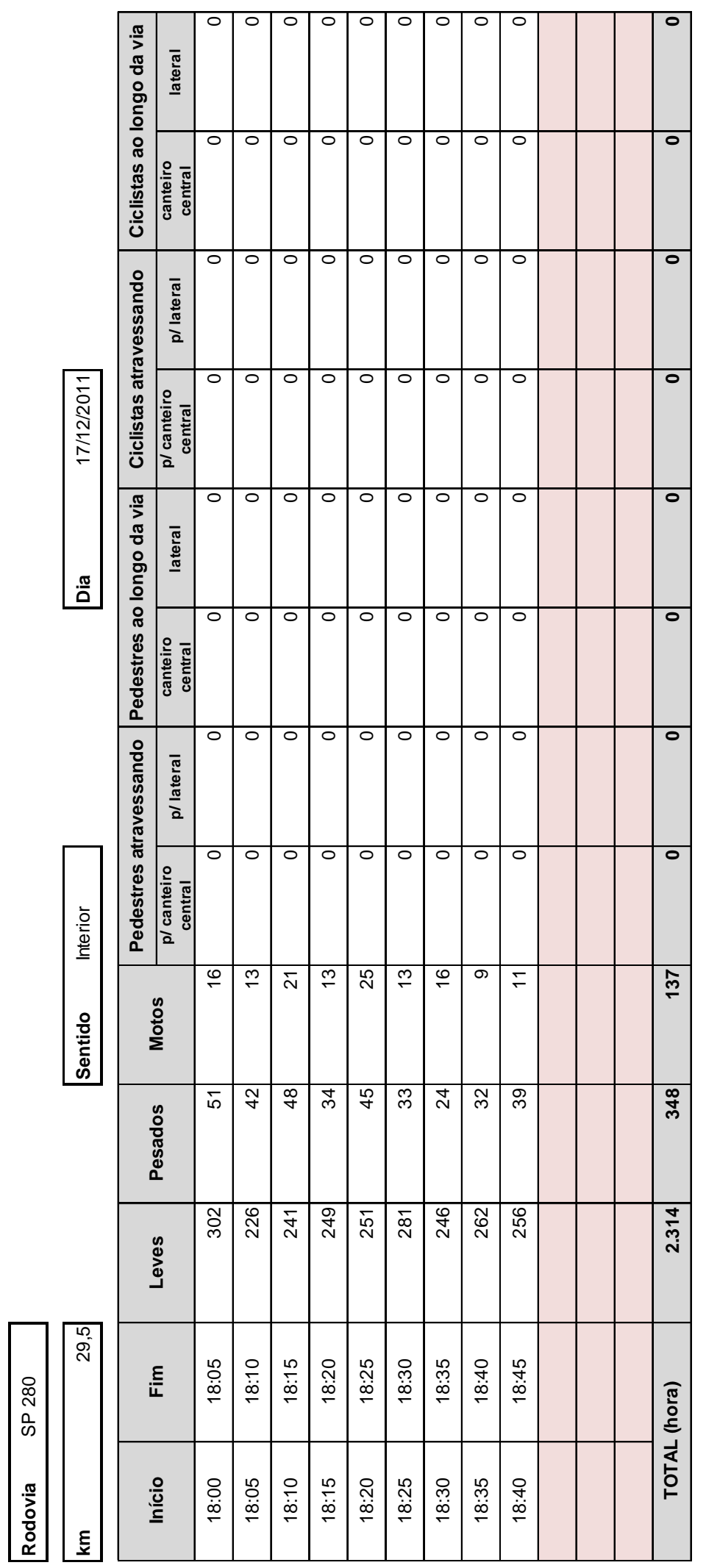




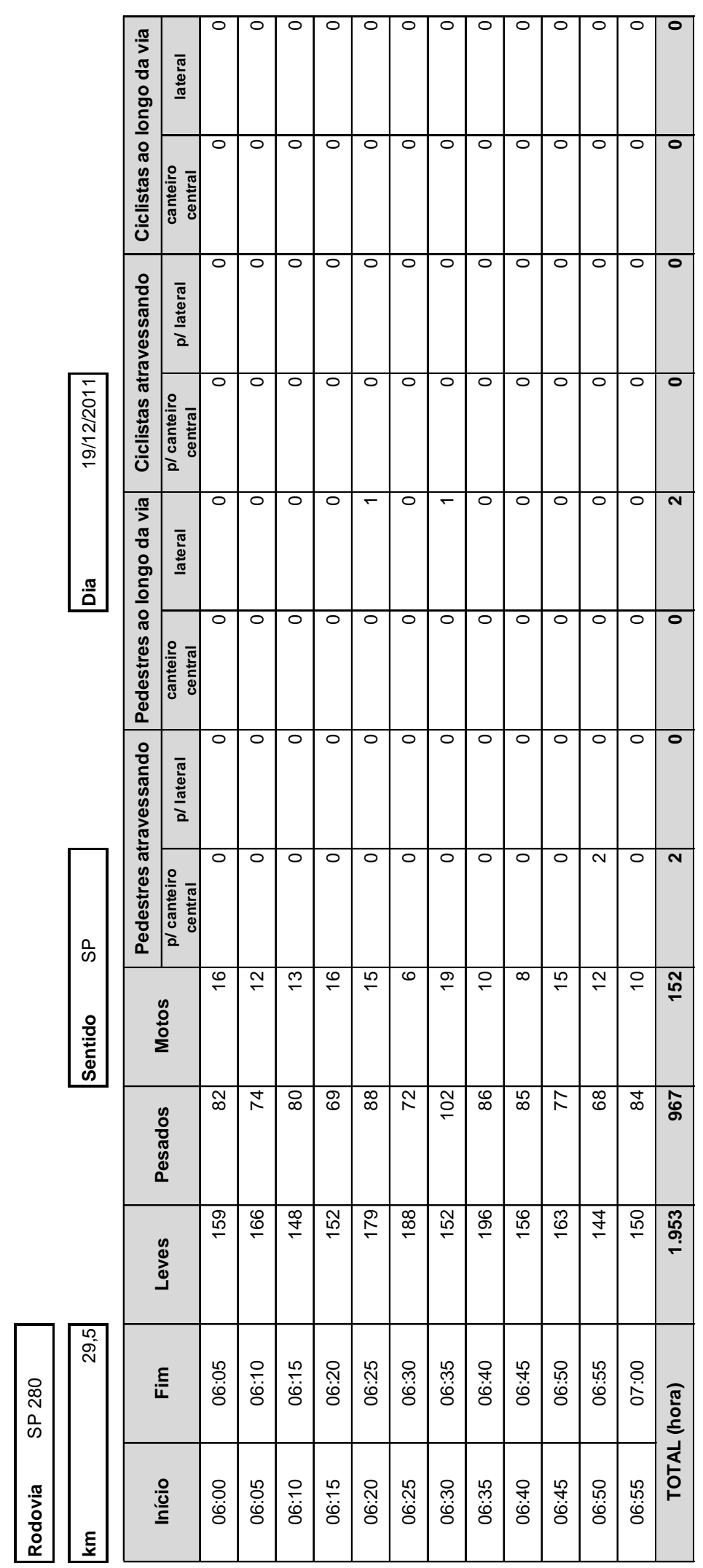




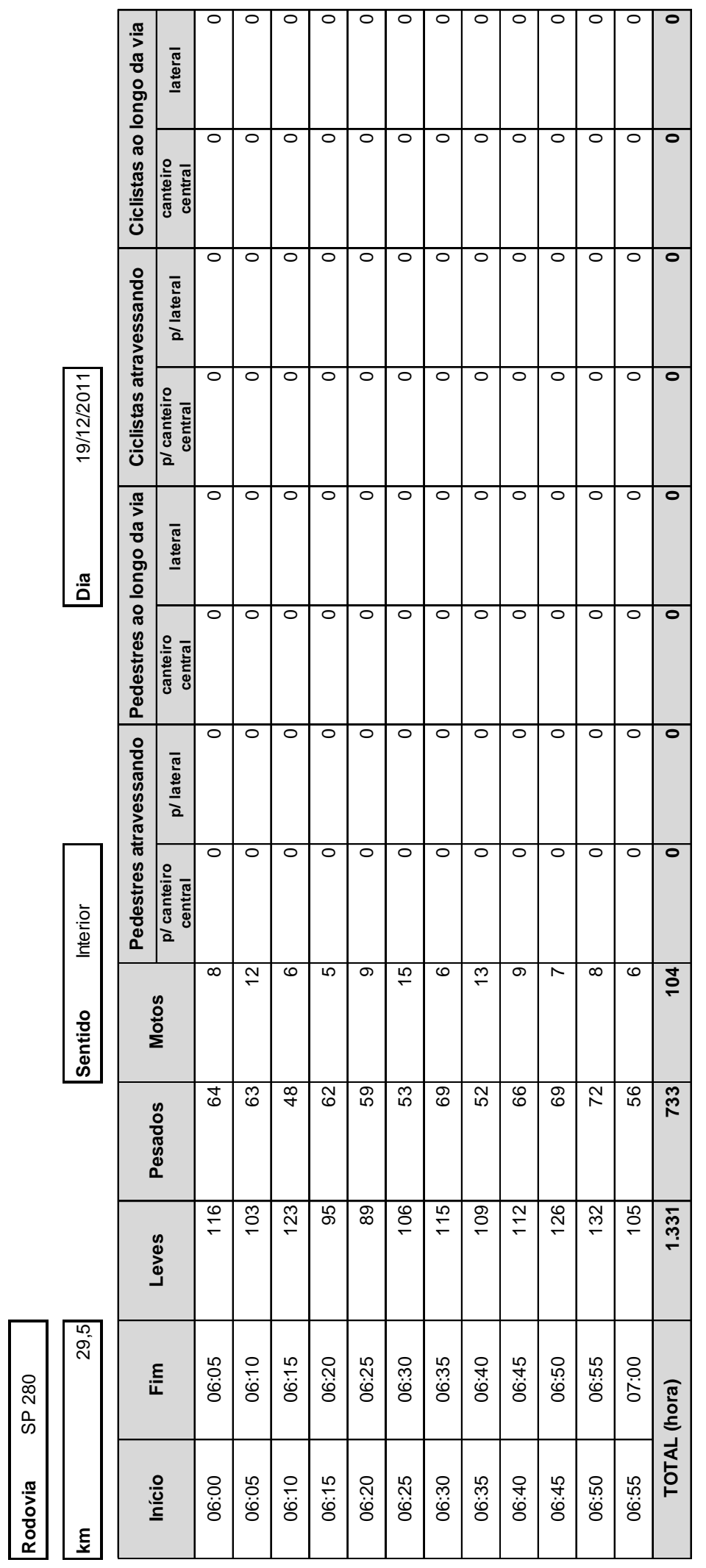




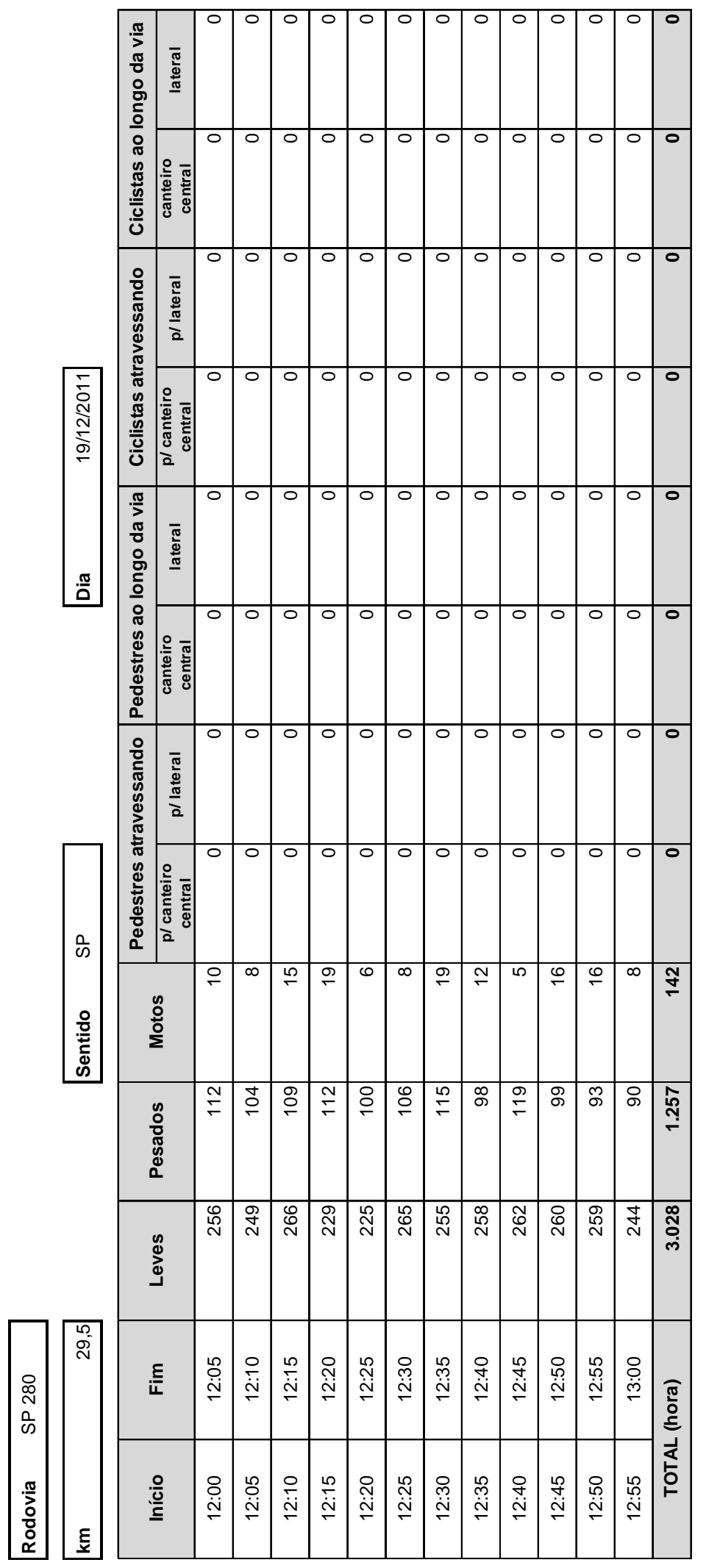




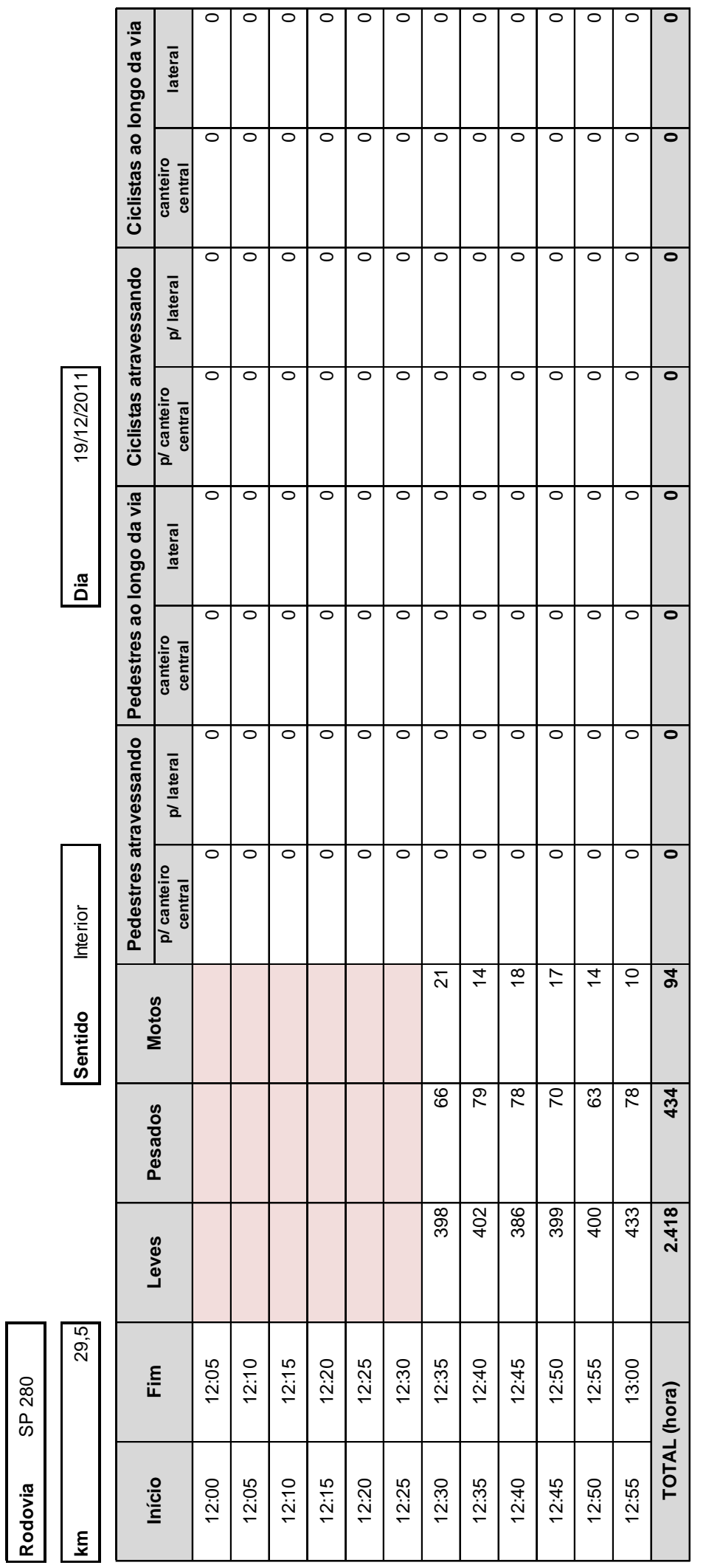




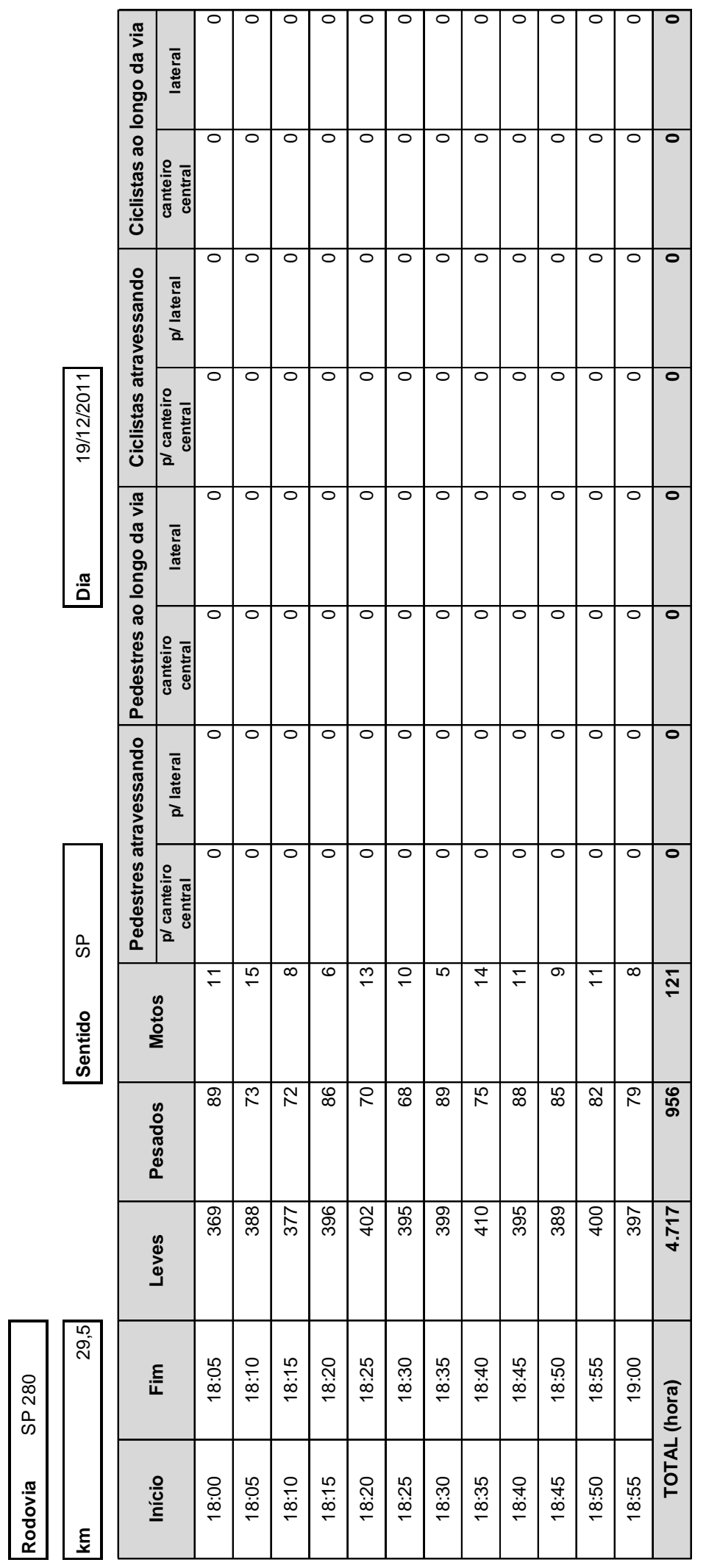




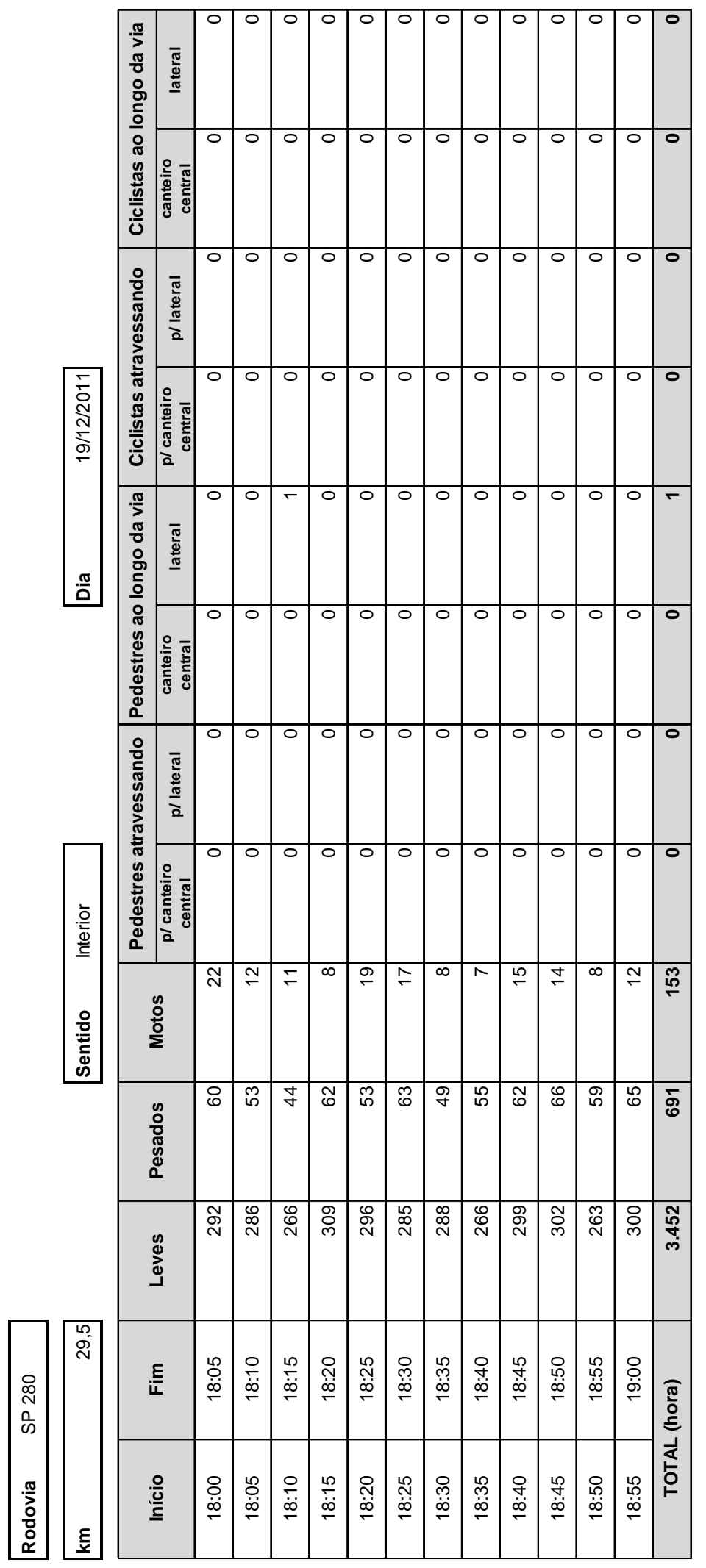




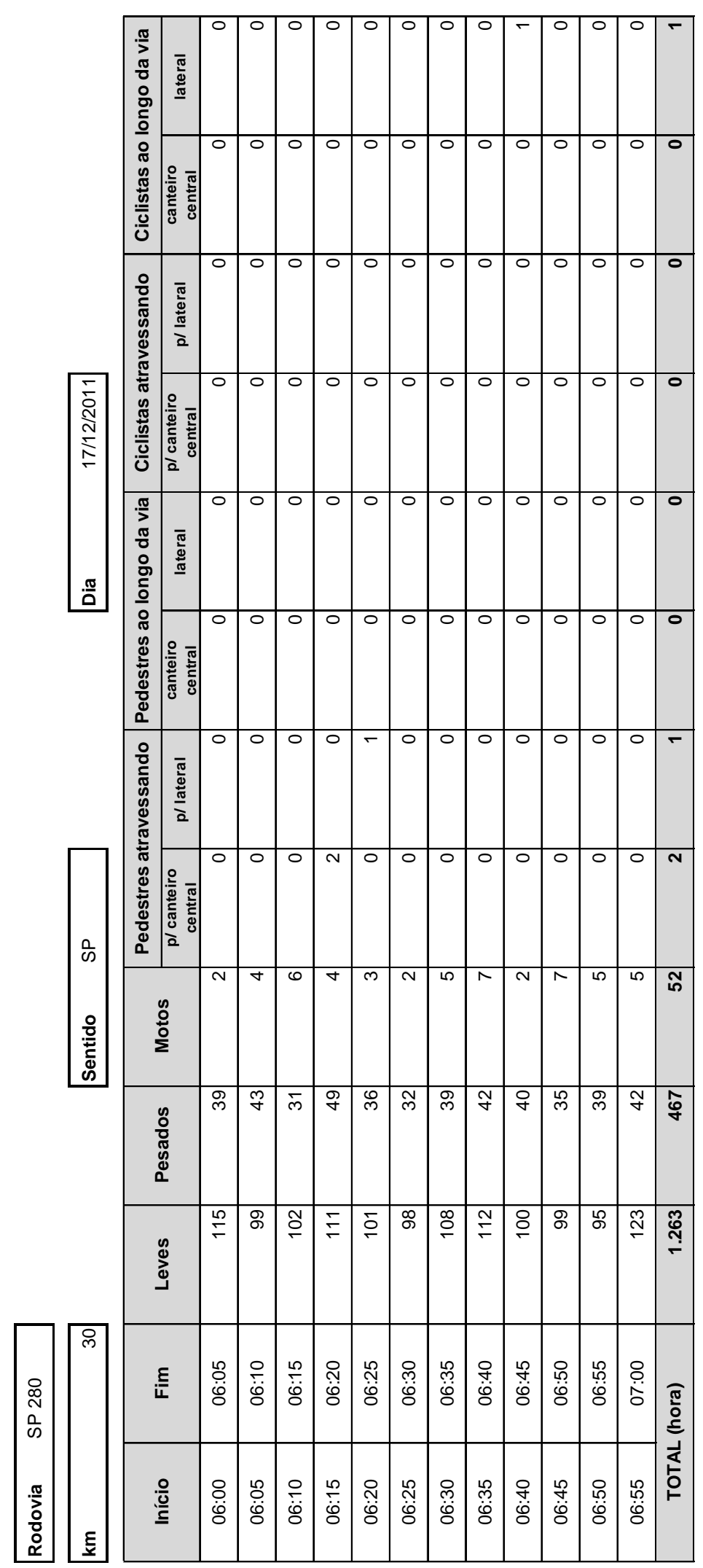




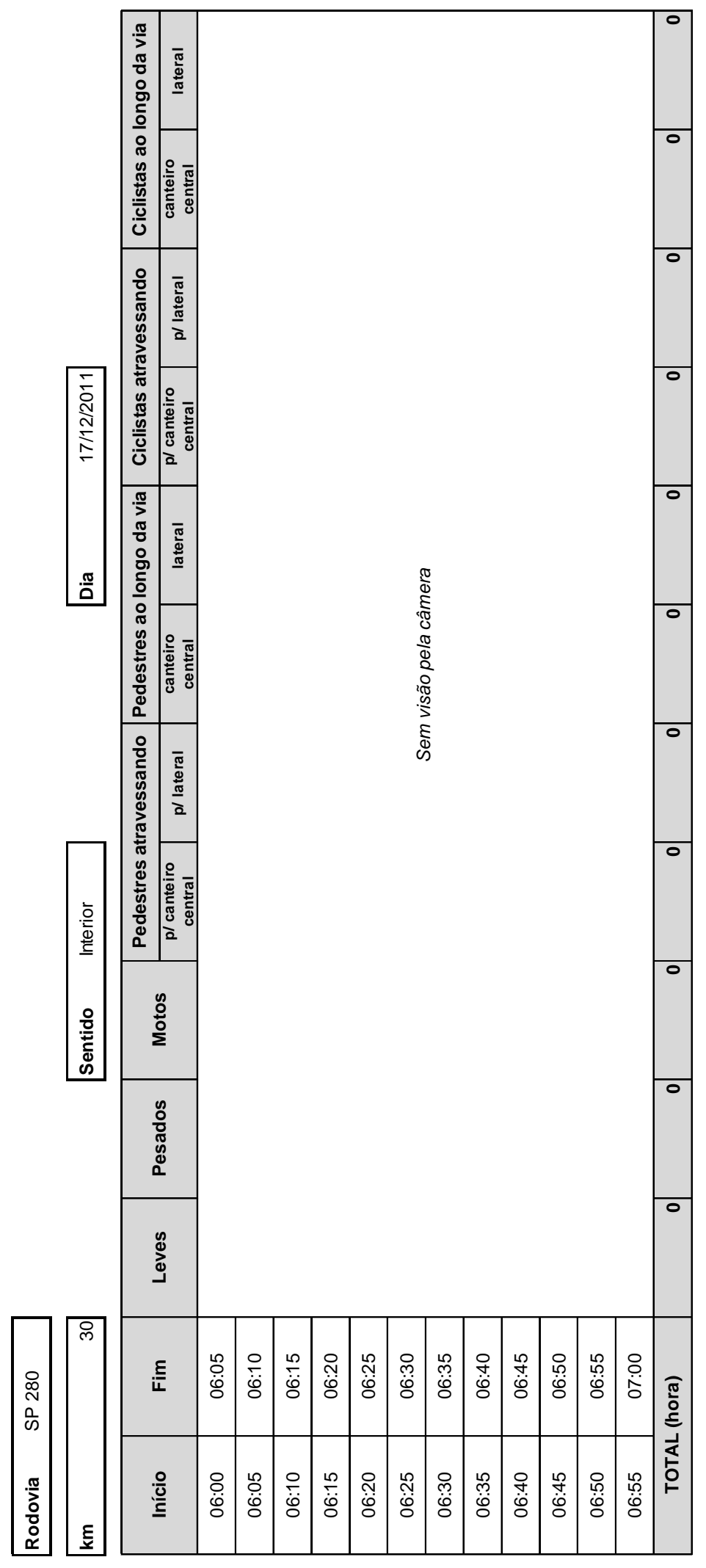




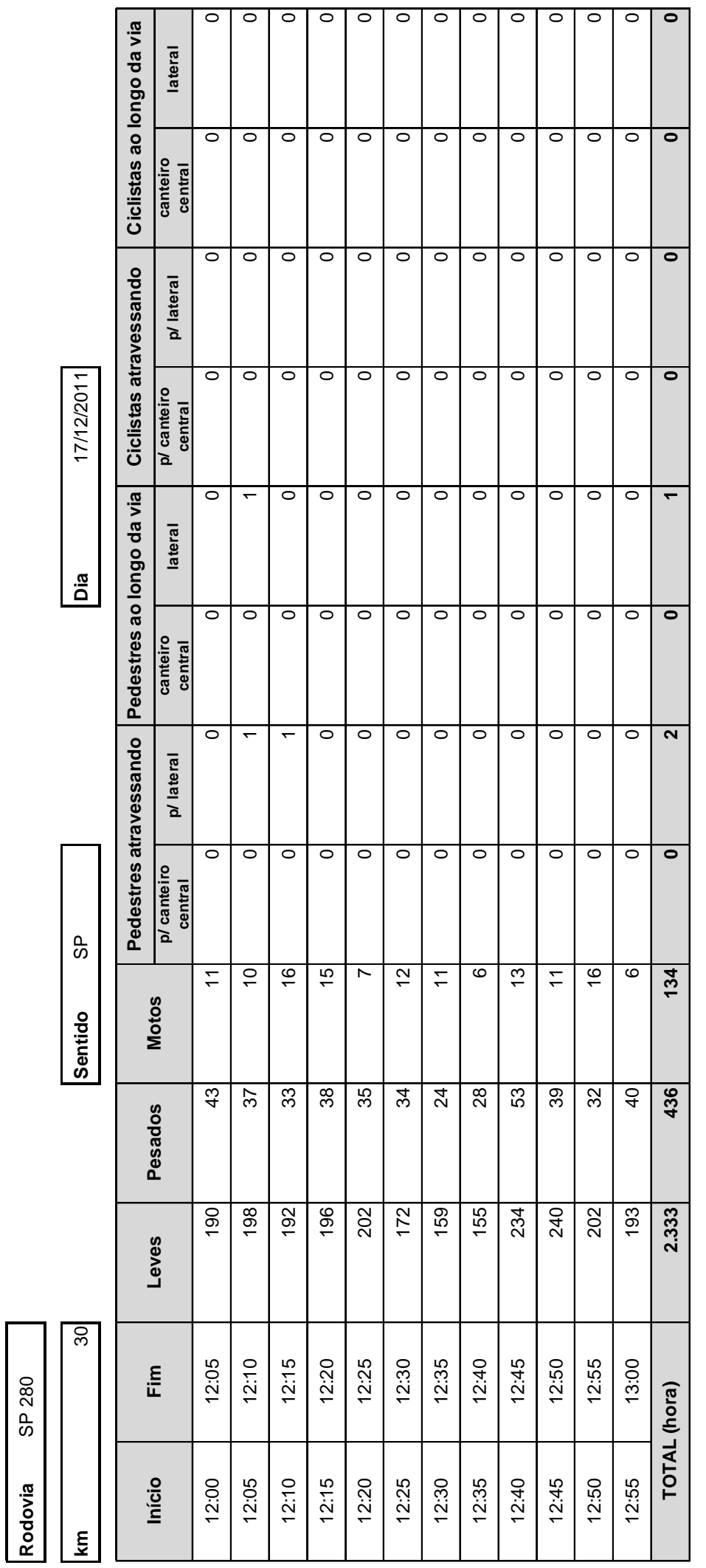




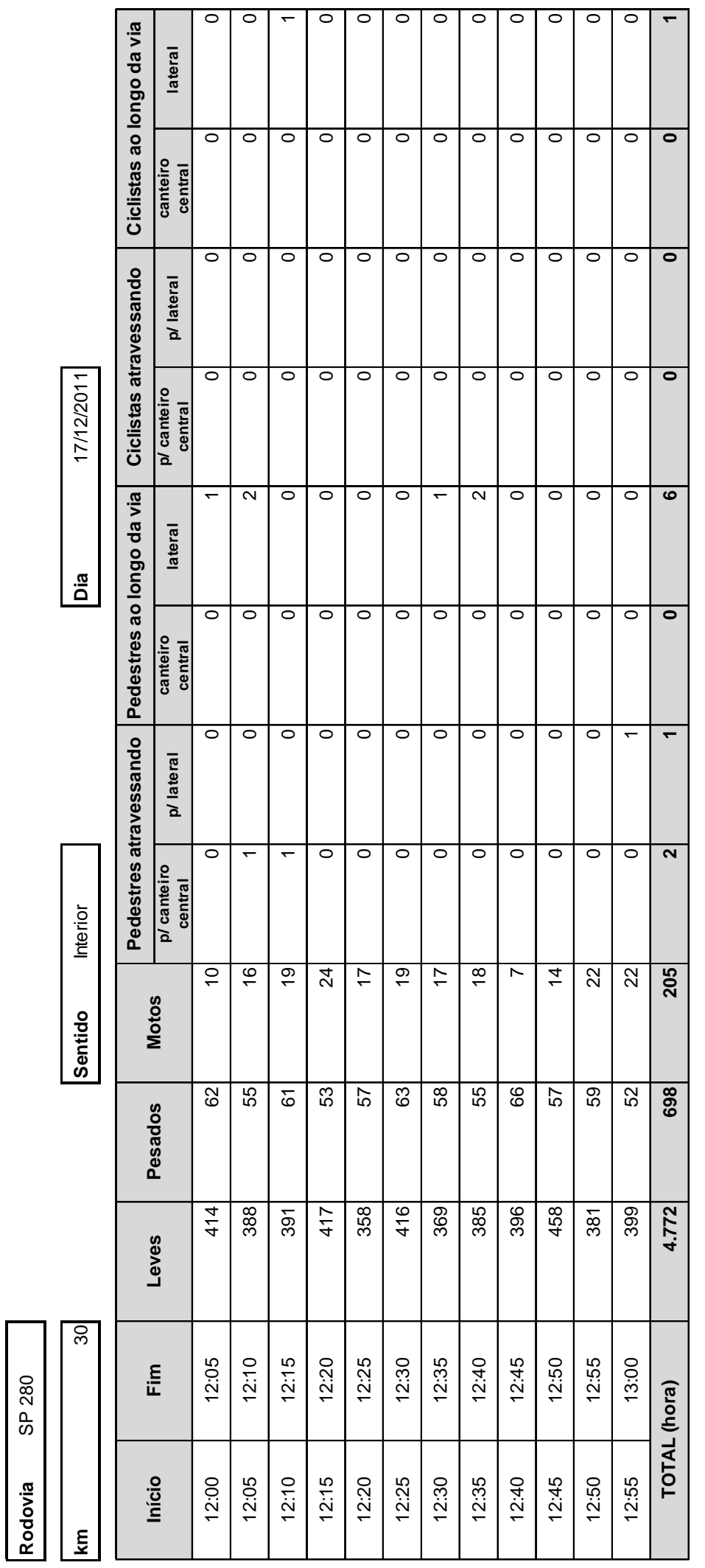




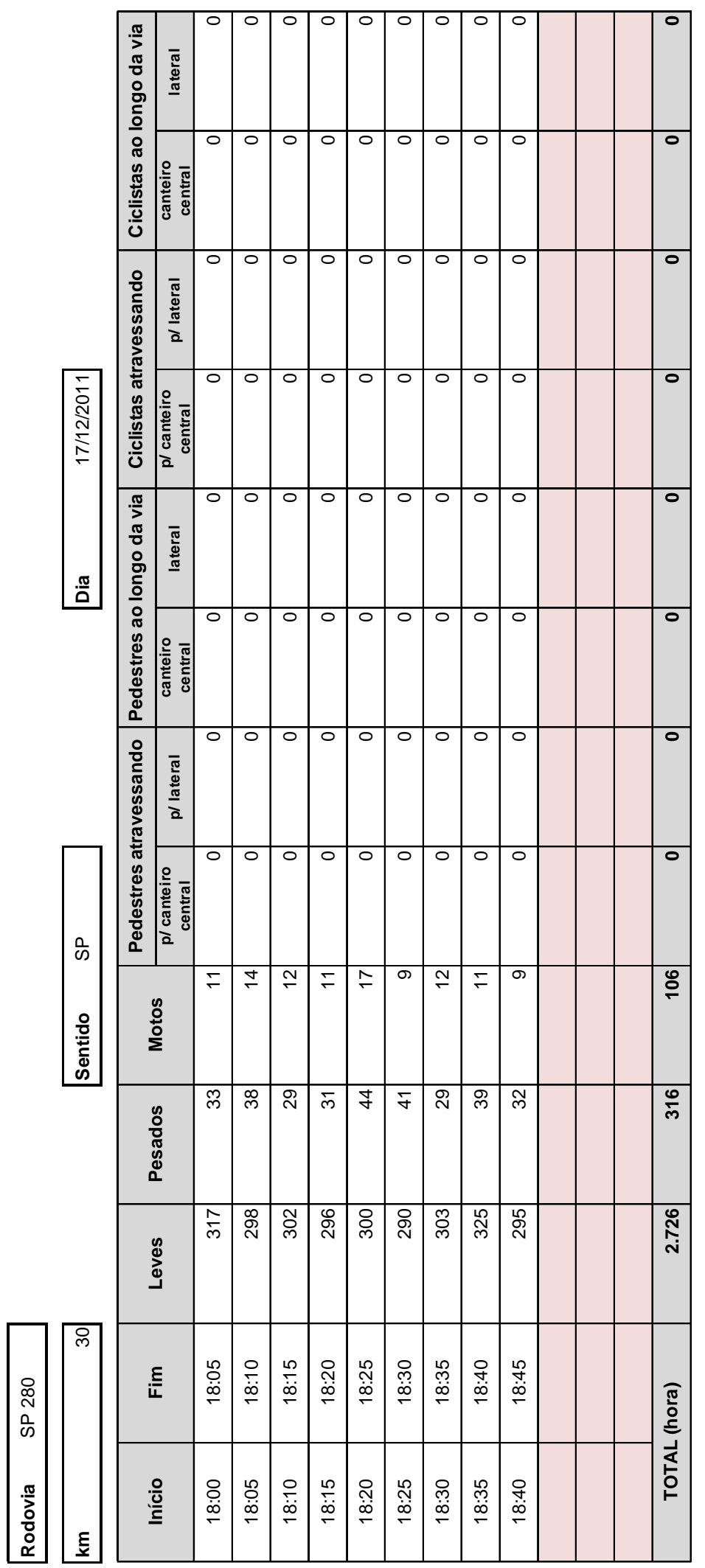




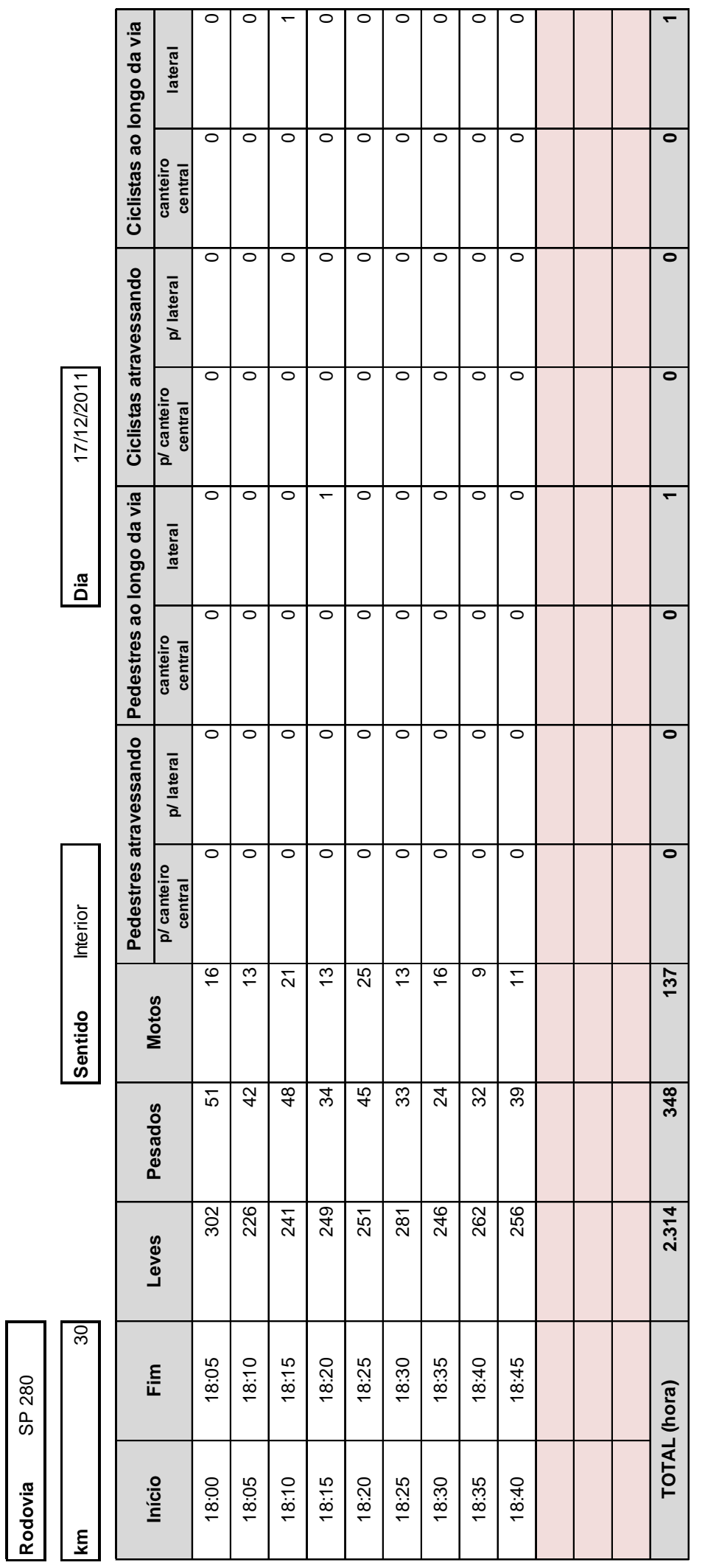




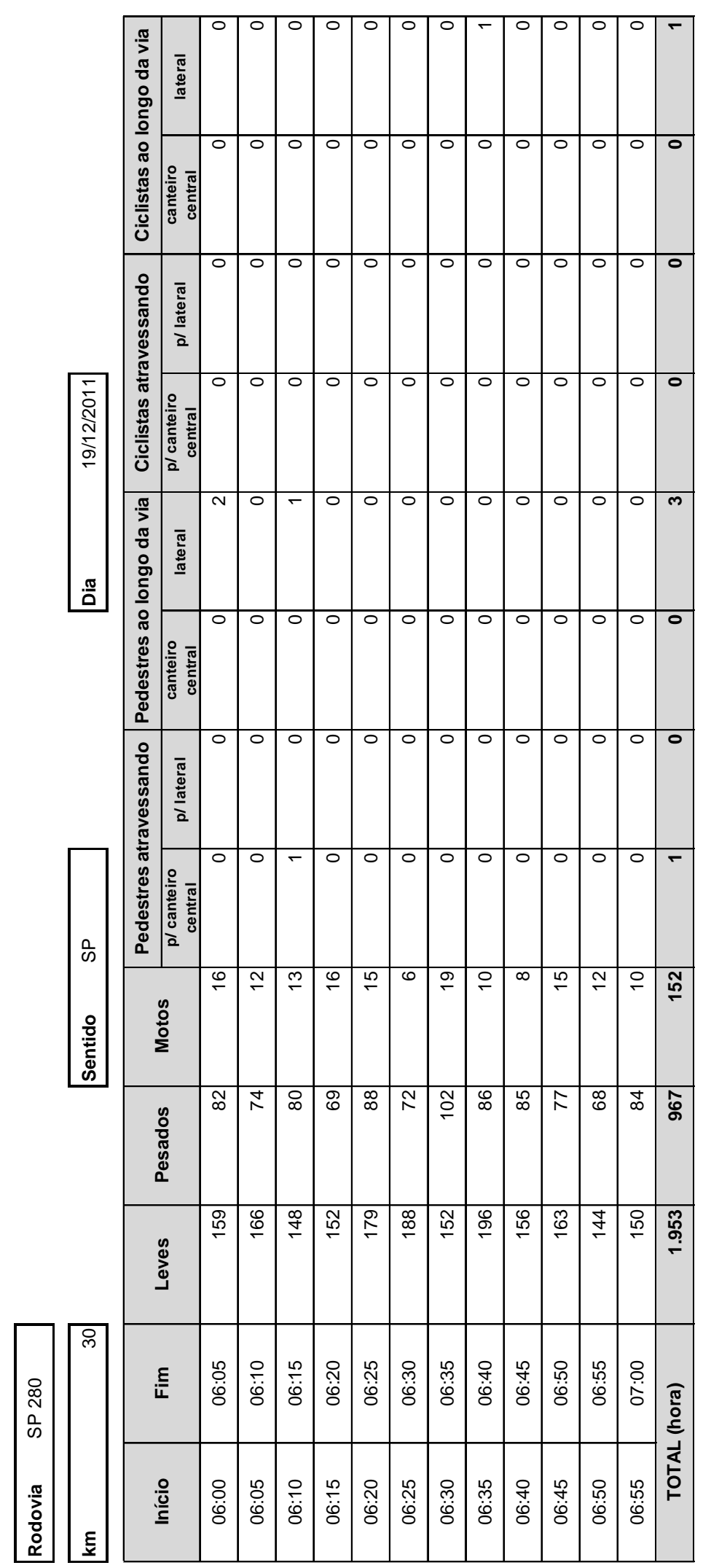




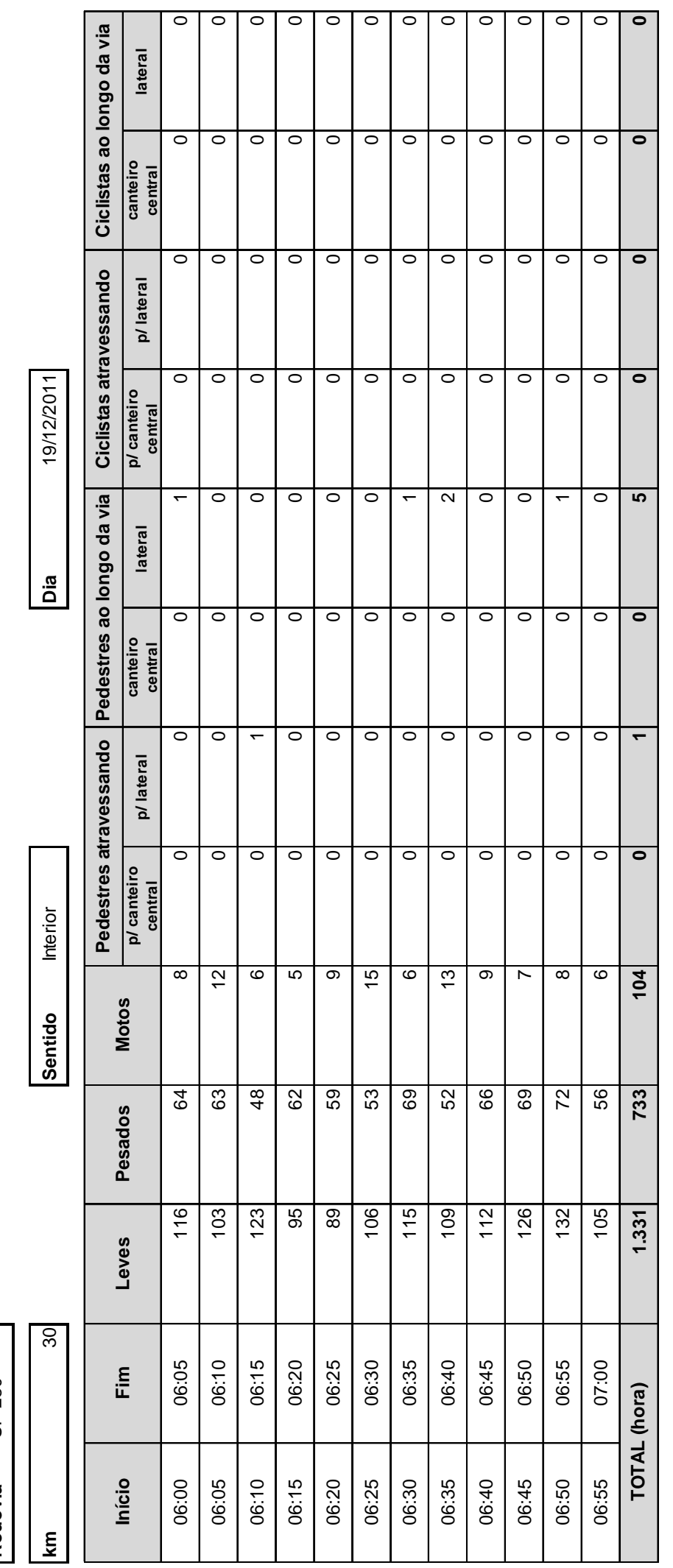




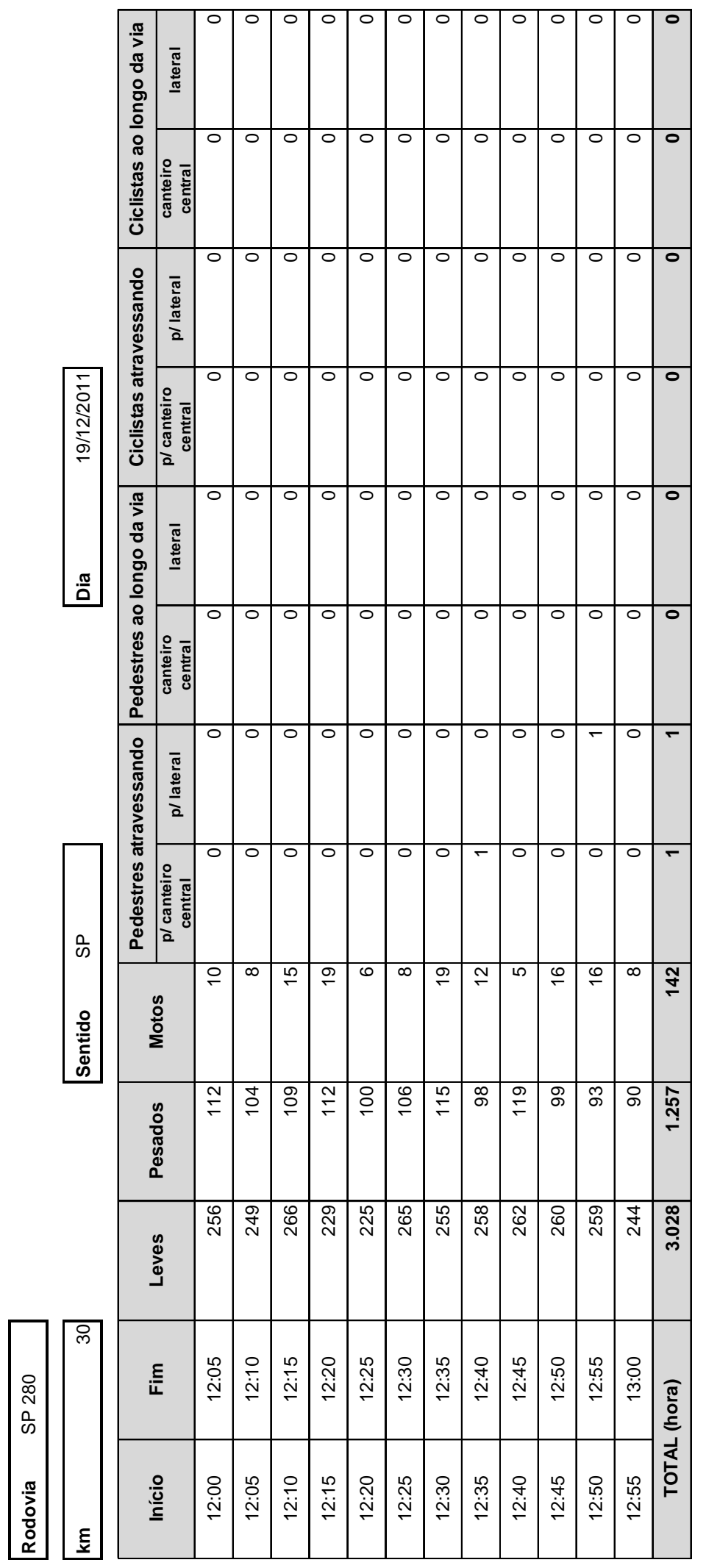




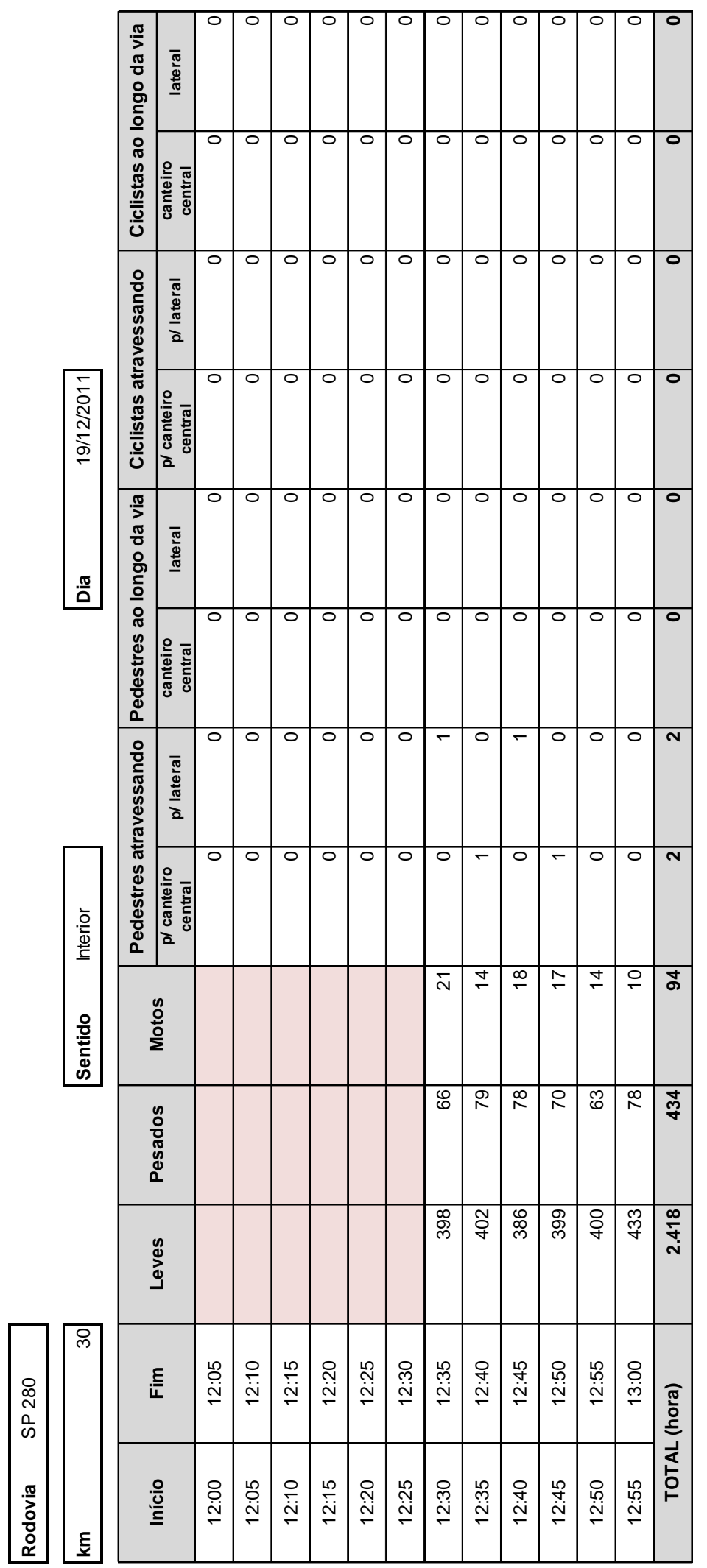




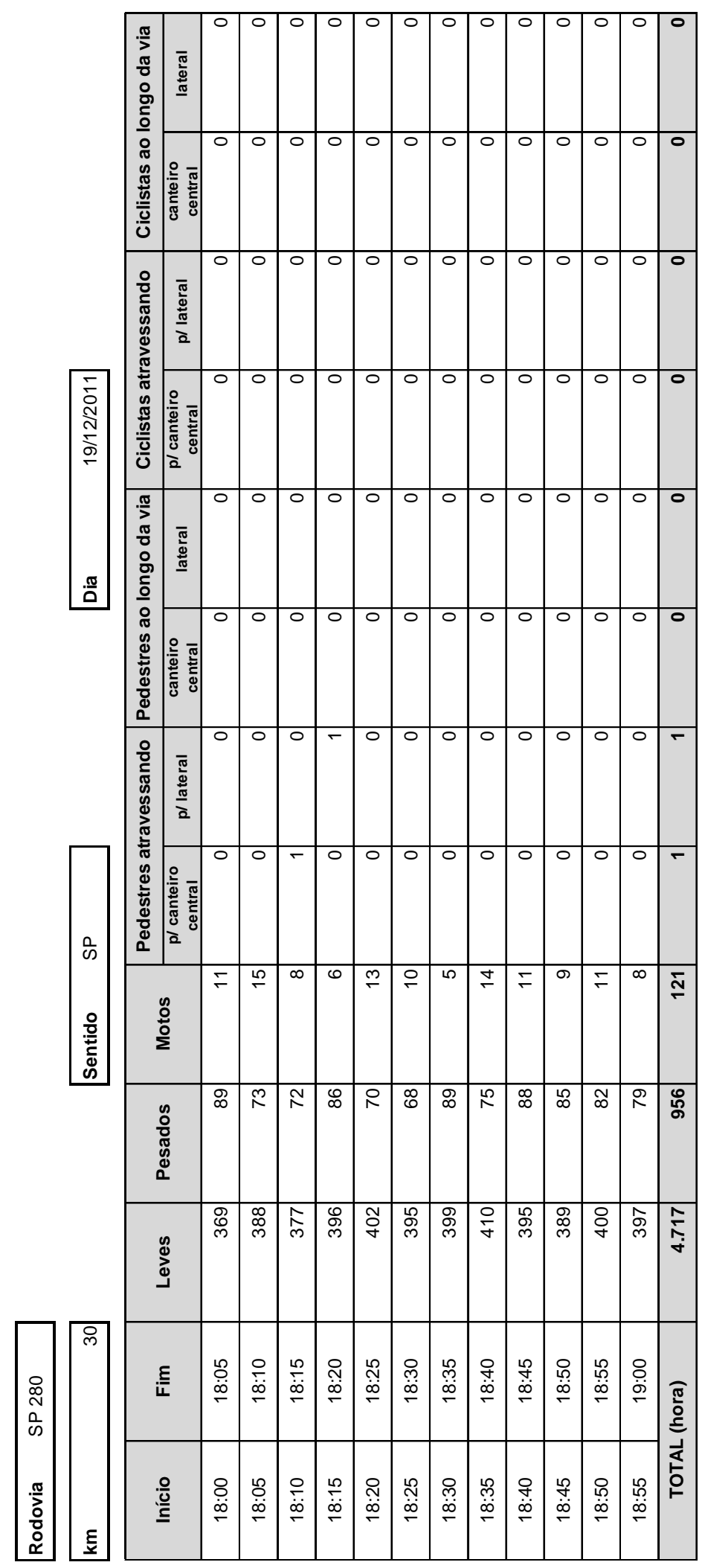




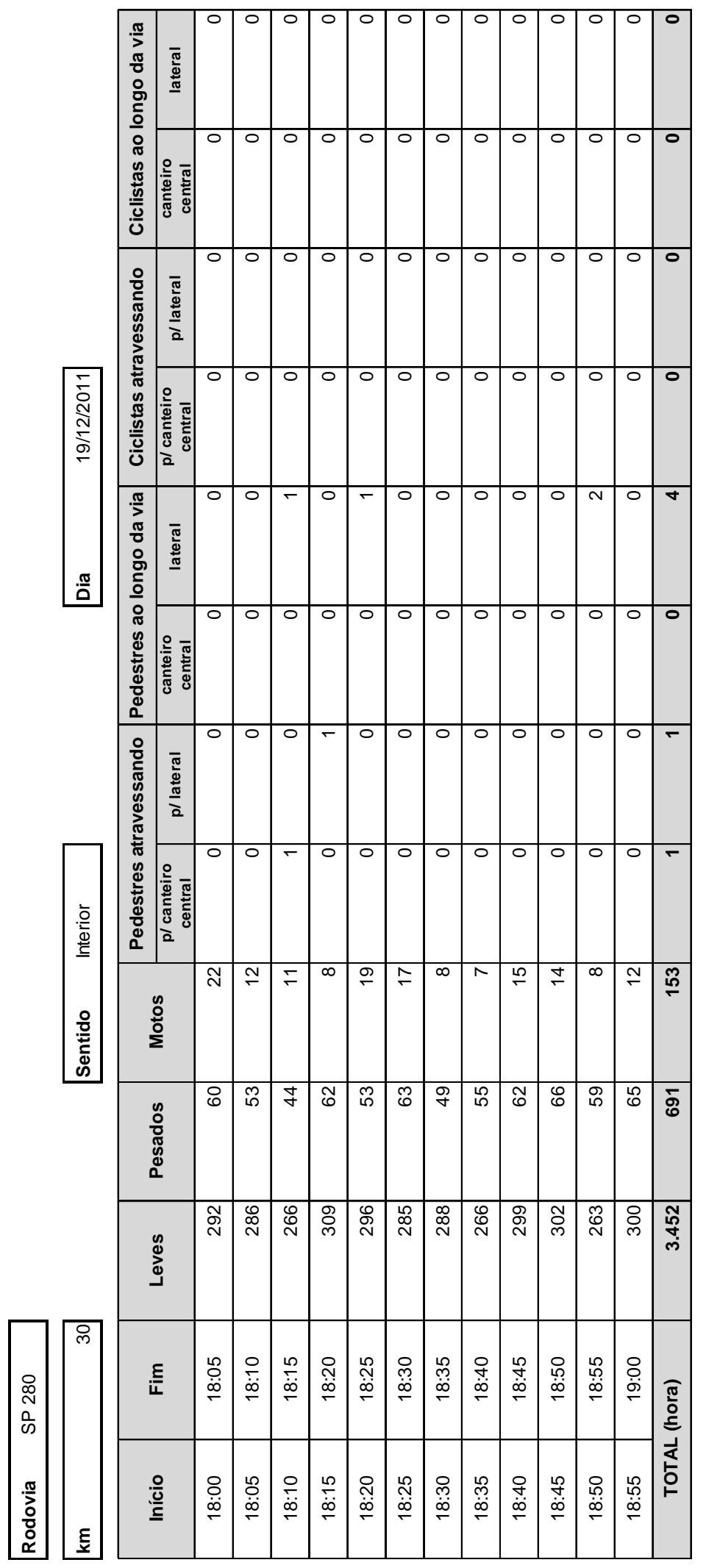




\section{ANEXO B - DADOS DE ACIDENTES}

A seguir é apresentada a tabela com os acidentes envolvendo pedestres e ciclistas nos locais estudados na Rodovia Raposo Tavares, SP 270, do km55 a 65, e na Rodovia Castelo Branco, SP 280, do km25 a 35, ambos nos anos de 2005 a 2011, com as informações retiradas dos relatórios de ocorrência da concessionária, inclusive a descrição do acidente. 


\begin{tabular}{|c|c|c|c|c|c|c|c|c|c|c|c|}
\hline Data & $\begin{array}{c}\text { Dia da } \\
\text { Semana }\end{array}$ & Hora & $\begin{array}{c}\text { Tipo de } \\
\text { acidente }\end{array}$ & $\begin{array}{l}\text { Gravidade } \\
\text { do acidente }\end{array}$ & Concessionária & Rod & km & Sentido & $\begin{array}{l}\text { Tipo de } \\
\text { área }\end{array}$ & Pista & Detalhe do Acidente \\
\hline $15 / 4 / 2005$ & sex & $23: 13$ & PED & Leve & ViaOeste & 270 & 64 & Oeste & P.Simples & principal & $\begin{array}{l}\text { SEGUNDO INFORMAÇOES, O PEDESTRE } \\
\text { APARENTEMENTE EMBRIAGADO, } \\
\text { ADENTROU A PISTA SEM A DEVIDA } \\
\text { ATENÇAO VINDO A SER ATROPELADO PELA } \\
\text { MOTO. }\end{array}$ \\
\hline $27 / 6 / 2005$ & seg & $12: 03$ & PED & Leve & ViaOeste & 270 & 63 & Leste & P.Simples & principal & $\begin{array}{l}\text { SEGUNDO INFORMAÇÕES COLHIDAS PELO } \\
\text { LOCAL POR MOTIVOS IGNORADOS V01 VEIO } \\
\text { A ATROPELAR A PEDESTRE. }\end{array}$ \\
\hline $4 / 8 / 2005$ & qui & 19:11 & PED & Leve & ViaOeste & 270 & 65 & Oeste & P.Simples & principal & $\begin{array}{l}\text { CONFORME INFORMADO POR } \\
\text { TESTEMUNHAS DA OCORRENCIA QUE O } \\
\text { USUARIO VEIO A ATRAVESSAR A RODOVIA } \\
\text { DE OESTE PARA LESTE SEM A DEVIDA } \\
\text { ATENÇÃO À FRENTE DE V1 QUE EVADIU-SE; }\end{array}$ \\
\hline 20/8/2005 & sab & $16: 27$ & PED & Leve & ViaOeste & 270 & 55 & Leste & P.Simples & principal & $\begin{array}{l}\text { NÃO FOI POSSIVEL OBTER DADOS DO } \\
\text { ACIDENTE POIS QUANDO AS VIATURAS } \\
\text { CHEGARAM AO LOCAL ESTAVA SOMENTE A } \\
\text { VITIMA SENDO QUE O VEICULO } \\
\text { ATROPELANTE FUGIU; }\end{array}$ \\
\hline $23 / 9 / 2005$ & sex & $21: 49$ & PED & Leve & ViaOeste & 270 & 63 & Leste & P.Simples & principal & $\begin{array}{l}\text { DADOS PREJUDICADOS. VEÍCULO } \\
\text { ATROPELANTE EVADIU-SE DO LOCAL E } \\
\text { VÍTIMA INCONSCIENTE ENCONTRADA PELA } \\
\text { PISTA REMOVIDA AO HOSPITAL REGIONAL } \\
\text { DE OSASCO PELA VIATURA DA VIAOESTE. }\end{array}$ \\
\hline $18 / 11 / 2005$ & sex & $10: 20$ & PED & Leve & ViaOeste & 270 & 56 & Oeste & P.Simples & principal & $\begin{array}{l}\text { CONFORME INFORMAÇÕES NO LOCAL, O AP } \\
\text { ATROPELANTE (EVADIU-SE) O MESMO } \\
\text { TRAFEGAVA SENTIDO LESTE QUANDO FOI } \\
\text { FAZER UMA ULTRAPASSAGEM PERDENDO } \\
\text { CONTROLE VINDO A ATROPELAR O } \\
\text { PEDESTRE PELO ACOSTAMENTO DA PISTA } \\
\text { OESTE. }\end{array}$ \\
\hline
\end{tabular}




\begin{tabular}{|c|c|c|c|c|c|c|c|c|c|c|c|}
\hline Data & $\begin{array}{c}\text { Dia da } \\
\text { Semana }\end{array}$ & Hora & $\begin{array}{l}\text { Tipo de } \\
\text { acidente }\end{array}$ & $\begin{array}{l}\text { Gravidade } \\
\text { do acidente }\end{array}$ & Concessionária & Rod & $\mathbf{k m}$ & Sentido & $\begin{array}{l}\text { Tipo de } \\
\text { área }\end{array}$ & Pista & Detalhe do Acidente \\
\hline $12 / 1 / 2006$ & qui & $21: 56$ & PED & Leve & ViaOeste & 270 & 63,5 & Oeste & P.Simples & principal & $\begin{array}{l}\text { SEGUNDO INFORMAÇÕES COLHIDAS NO } \\
\text { LOCAL, O CONDUTOR DA MOTO REALIZOU } \\
\text { UMA CONVERÇÃO IRREGULAR, } \\
\text { ACESSANDO A PISTA OESTE NA CONTRA- } \\
\text { MÃO, VINDO A ATROPELAR O PEDESTRE NA } \\
\text { FAIXA ZEBRADA. }\end{array}$ \\
\hline $6 / 2 / 2006$ & seg & $14: 45$ & PED & Leve & ViaOeste & 270 & 63 & Oeste & P.Simples & principal & $\begin{array}{l}\text { SEGUNDO INFORMAÇÕES COLHIDAS PELO } \\
\text { LOCAL V01 DESLOCAVA SENTIDO LESTE } \\
\text { QUANDO PEDESTRE ATRAVESSOU A PISTA } \\
\text { DA OESTE PARA LESTE SEM DEVIDA } \\
\text { ATENÇÃO PASSANDO A FRENTE DE V01. } \\
\text { CONDUTOR DE V01 TENTOU DESVIAR } \\
\text { PORÉM VEIO A ATROPELAR PEDESTRE PELO } \\
\text { ACOSTAMENTO DA PISTA LESTE. }\end{array}$ \\
\hline $16 / 10 / 2006$ & seg & 18:56 & PED & Leve & ViaOeste & 270 & 63,95 & Leste & P.Simples & principal & $\begin{array}{l}\text { SEGUNDO INFORMAÇÕES COLHIDAS PELO } \\
\text { LOCAL V01 DESLOCAVA PELA PISTA LESTE } \\
\text { QUANDO DEPAROU-SE COM PEDESTRE } \\
\text { ATRAVESSANDO A PISTA, SEM TEMPO PARA } \\
\text { FREIAR OU DESVIAR, VEIO ATROPELÁ-LO. }\end{array}$ \\
\hline $5 / 11 / 2006$ & dom & $21: 52$ & PED & Fatal & ViaOeste & 270 & 57 & Leste & P.Simples & principal & $\begin{array}{l}\text { SEGUNDO INFORMA O CONDUTOR DO V1, } \\
\text { TRAFEGAVA NA FAIXA ADICIONAL } \\
\text { QUANDO SE DEPAROU COM O PEDESTRE E, } \\
\text { NA TENTATIVA DE DESVIAR, VEIO A } \\
\text { CHOCAR-SE LATERALMENTE COM O } \\
\text { PEDESTRE. }\end{array}$ \\
\hline
\end{tabular}




\begin{tabular}{|c|c|c|c|c|c|c|c|c|c|c|c|}
\hline Data & $\begin{array}{c}\text { Dia da } \\
\text { Semana }\end{array}$ & Hora & $\begin{array}{c}\text { Tipo de } \\
\text { acidente }\end{array}$ & $\begin{array}{l}\text { Gravidade } \\
\text { do acidente }\end{array}$ & Concessionária & Rod & km & Sentido & $\begin{array}{l}\text { Tipo de } \\
\text { área }\end{array}$ & Pista & Detalhe do Acidente \\
\hline $7 / 10 / 2007$ & dom & 19:59 & PED & Leve & ViaOeste & 270 & 63,8 & Oeste & P.Simples & principal & $\begin{array}{l}\text { CONFORME INFORMAÇÕES DO CONDUTOR } \\
\text { DO AP, TRAFEGAVA SENTIDO LESTE E PELO } \\
\text { CITADO KM, A VÍTIMA SAIU DA CALÇADA E } \\
\text { ADENTROU A FAIXA DE ROLAMENTO, } \\
\text { VINDO A DESVIAR, NO ENTANTO, NÃO } \\
\text { CONSEGUIU EVITAR O ATROPELAMENTO, } \\
\text { VINDO A LATERAL DIREITA DO VEÍCULO A } \\
\text { COLHER A VÍTIMA QUE VEIO A CAIR SOBRE } \\
\text { A FAIXA DE ROLAMENTO. A VÍTIMA FOI } \\
\text { RETIRADA POR POPULARES PARA A } \\
\text { CALÇADA. }\end{array}$ \\
\hline
\end{tabular}




\begin{tabular}{|c|c|c|c|c|c|c|c|c|c|c|c|}
\hline Data & $\begin{array}{c}\text { Dia da } \\
\text { Semana }\end{array}$ & Hora & $\begin{array}{c}\text { Tipo de } \\
\text { acidente }\end{array}$ & $\begin{array}{l}\text { Gravidade } \\
\text { do acidente }\end{array}$ & Concessionária & Rod & $\mathbf{k m}$ & Sentido & $\begin{array}{l}\text { Tipo de } \\
\text { área }\end{array}$ & Pista & Detalhe do Acidente \\
\hline $28 / 4 / 2008$ & seg & $10: 54$ & PED & Leve & ViaOeste & 270 & 64,3 & Leste & P.Simples & principal & $\begin{array}{l}\text { CONFORME INFORMADO V1 DE DADOS } \\
\text { IGNORADOS E QUE SE EVADIU DO LOCAL } \\
\text { VEIO A ATROPELAR O PEDESTRE QUE NA } \\
\text { SEQUENCIA VEIO A SER LANÇADO CONTRA } \\
\text { V3 (MOTO) CAUSANDO A QUEDA DOS } \\
\text { OCUPANTES. }\end{array}$ \\
\hline $3 / 5 / 2008$ & sab & $17: 04$ & PED & Leve & ViaOeste & 270 & 63,5 & Oeste & P.Simples & principal & $\begin{array}{l}\text { CONFORME INFORMADO A PEDESTRE } \\
\text { ESTARIA CAMINHANDO PELO } \\
\text { ACOSTAMENTO QUANDO O AP OPALA } \\
\text { INVADIU O ACOSTAMENTO PROVOCANDO O } \\
\text { ATROPELAMENTO E EM SEGUIDA EVADIU- } \\
\text { SE DO LOCAL. }\end{array}$ \\
\hline $31 / 5 / 2008$ & sab & 12:02 & PED & Leve & ViaOeste & 270 & 63,7 & Oeste & P.Simples & principal & $\begin{array}{l}\text { CONFORME INFORMAÇÕES, V01 } \\
\text { TRAFEGAVA PELA FX DA DIREITA, QUANDO } \\
\text { O PEDESTRE VEIO A ATRAVESSAR A PISTA } \\
\text { CORRENDO, E SEM TEMPO DE FREIAR VEIO } \\
\text { A ATROPELAR O MESMO. }\end{array}$ \\
\hline $3 / 6 / 2008$ & ter & $8: 47$ & PED & Leve & ViaOeste & 270 & 63,5 & Oeste & P.Simples & principal & $\begin{array}{l}\text { CONFORME INFORMADO V1 VEIO A PERDER } \\
\text { O CONTROLE CAUSANDO O } \\
\text { ATROPELAMENTO DO PEDESTRE E NA } \\
\text { SEQUENCIA SOFRENDO QUEDA PELA FAIXA } \\
\text { DE ROLAMENTO. }\end{array}$ \\
\hline
\end{tabular}




\begin{tabular}{|c|c|c|c|c|c|c|c|c|c|c|c|}
\hline Data & $\begin{array}{c}\text { Dia da } \\
\text { Semana }\end{array}$ & Hora & $\begin{array}{l}\text { Tipo de } \\
\text { acidente }\end{array}$ & $\begin{array}{l}\text { Gravidade } \\
\text { do acidente }\end{array}$ & Concessionária & Rod & km & Sentido & $\begin{array}{l}\text { Tipo de } \\
\text { área }\end{array}$ & Pista & Detalhe do Acidente \\
\hline $7 / 6 / 2008$ & sab & $17: 59$ & PED & Leve & ViaOeste & 270 & 65 & Oeste & P.Simples & principal & $\begin{array}{l}\text { CONFORME INFORMADO A PEDESTRE VEIO } \\
\text { A TENTAR FAZER A TRAVESSIA FORA DA } \\
\text { FAIXA DE PEDESTRE À FRENTE DO V1 QUE } \\
\text { NÃO TEVE TEMPO DE EVITAR O } \\
\text { ATROPELAMENTO. VITIMA LEVE } \\
\text { REMOVIDA PARA A SANTA CASA DE SÃO } \\
\text { ROQUE. }\end{array}$ \\
\hline $17 / 7 / 2008$ & qui & $18: 42$ & PED & Leve & ViaOeste & 270 & 63 & Oeste & P.Simples & principal & $\begin{array}{l}\text { SEGUNDO INFORMAÇÕES DO SOLDADO } \\
\text { ROBSON DO CORPO DE BOMBEIRO DE SÃO } \\
\text { ROQUE, USUÁRIO TENTAVA ATRAVESSAR A } \\
\text { RODOVIA NO MOMENTO EM QUE FOI } \\
\text { ATROPELADO PELO V2. V2 EVADIU-SE DO } \\
\text { LOCAL. }\end{array}$ \\
\hline $23 / 10 / 2008$ & qui & $18: 27$ & PED & Leve & ViaOeste & 270 & 63 & Oeste & P.Simples & entrada & $\begin{array}{l}\text { SEGUNDO INFORMAÇÕES PELO LOCAL,V1 } \\
\text { SUBIA A ALÇA DO KM } 63 \text { EMPRESA ENAU } \\
\text { QUANDO AO PERMANECER OLHANDO PARA } \\
\text { O FLUXO QUE VINHA ATRÁS, SEGUIU COM O } \\
\text { VEICULO NÃO VENDO A PEDESTRE } \\
\text { CAUSANDO O ATROPELAMENTO. }\end{array}$ \\
\hline $26 / 10 / 2008$ & dom & $20: 12$ & PED & Leve & ViaOeste & 270 & 64 & Leste & P.Simples & principal & \begin{tabular}{|l|} 
CONFORME INFORMAÇÕES COLHIDAS NO \\
LOCAL, V01 TRAFEGAVA SENTIDO OESTE \\
QUENDO DEPAROU-SE COM PEDESTRE \\
ATRAVESSANDO A PISTA, SEM TEMPO PARA \\
DESVIAR VEIO ATROPELA-LO, PEDESTRE \\
FOI REMOVIDO PELOS BOMBEIROS. \\
\end{tabular} \\
\hline
\end{tabular}




\begin{tabular}{|c|c|c|c|c|c|c|c|c|c|c|c|}
\hline Data & $\begin{array}{c}\text { Dia da } \\
\text { Semana }\end{array}$ & Hora & $\begin{array}{l}\text { Tipo de } \\
\text { acidente }\end{array}$ & $\begin{array}{l}\text { Gravidade } \\
\text { do acidente }\end{array}$ & Concessionária & Rod & km & Sentido & $\begin{array}{l}\text { Tipo de } \\
\text { área }\end{array}$ & Pista & Detalhe do Acidente \\
\hline $14 / 3 / 2009$ & sab & $18: 04$ & PED & Leve & ViaOeste & 270 & 64,5 & Oeste & P.Simples & principal & \begin{tabular}{|l|} 
SEGUNDO INFORMAÇÕES COLHIDAS NO \\
LOCAL, O VEÍCULO TRAFEGAVA NA SP-270 \\
QUANDO AO ATINGIR O REFERIDO KM \\
DEPAROU-SE COM O PEDESTRE \\
ATRAVESSANDO A RODOVIA E NÃO \\
CONSEGUIU EVITAR O ATROPELAMENTO.
\end{tabular} \\
\hline $24 / 12 / 2009$ & qui & $16: 53$ & PED & Leve & ViaOeste & 270 & 58 & Oeste & P.Simples & principal & $\begin{array}{l}\text { INFORMAÇÕES PRESTADAS PELA PMRV, V1 } \\
\text { TRAFEGAVA SENTIDO CAPITAL, MOMENTO } \\
\text { EM QUE PAROU NO PONTO DE ONIBUS, V2 } \\
\text { DESCEU DO ONIBUAS SE DESEQUILIBROU E } \\
\text { CAIU EMBAIXO DA RODA DO V1 } \\
\text { OCORRENDO O ATROPELAMENTO.;Causa } \\
\text { Provável: } 410 \text { Pedestre na pista }\end{array}$ \\
\hline
\end{tabular}




\begin{tabular}{|c|c|c|c|c|c|c|c|c|c|c|c|}
\hline Data & $\begin{array}{c}\text { Dia da } \\
\text { Semana }\end{array}$ & Hora & $\begin{array}{l}\text { Tipo de } \\
\text { acidente }\end{array}$ & $\begin{array}{c}\text { Gravidade } \\
\text { do acidente }\end{array}$ & Concessionária & Rod & km & Sentido & $\begin{array}{l}\text { Tipo de } \\
\text { área }\end{array}$ & Pista & Detalhe do Acidente \\
\hline $31 / 1 / 2010$ & dom & $20: 13$ & PED & Grave & ViaOeste & 270 & 64 & Leste & P.Simples & principal & $\begin{array}{l}\text { CONFORME INFORMADO POR MOTIVOS } \\
\text { IGNORADOS O PEDESTRE VEIO A } \\
\text { ATRAVESSAR A FRENTE DE V1 CAUSANDO } \\
\text { O ATROPELAMENTO. NA SEQUENCIA O V1 } \\
\text { VEIO A EVADIR-SE DO LOCAL.;Causa Provável: } \\
410 \text { Pedestre na pista }\end{array}$ \\
\hline $7 / 3 / 2010$ & dom & $23: 16$ & PED & Leve & ViaOeste & 270 & 63 & Leste & P.Simples & principal & $\begin{array}{l}\text { CONFOME INFORMAÇÕES PRESTADAS PELA } \\
\text { PMRV, O V01 FOI ATRAVESSAR A PISTA E } \\
\text { V02 SEM TEMPO PARA DESVIAR VEIO } \\
\text { ATROPELÁ-LO.;Causa Provável: } 410 \text { Pedestre na } \\
\text { pista }\end{array}$ \\
\hline $10 / 9 / 2010$ & $\operatorname{sex}$ & $18: 07$ & PED & Leve & ViaOeste & 270 & 65 & Leste & P.Simples & principal & $\begin{array}{l}\text { SEGUNDO INFORMAÇÕES COLHIDAS NO } \\
\text { LOCAL, O USUARIO AO FAZER A TENTATIVA } \\
\text { DE TRAVESSIA DA PISTA NÃO VISUALIZOU } \\
\text { V1, VINDO A SER ATROPELADA PELA FAIXA } \\
\text { DE ROLAMENTO.;Causa Provável: } 410 \text { Pedestre } \\
\text { na pista }\end{array}$ \\
\hline 25/11/2010 & qui & $15: 56$ & PED & Leve & ViaOeste & 270 & 64 & Leste & P.Simples & principal & $\begin{array}{l}\text { SEGUNDO INFORMAÇOES DO CONDUTOR DE } \\
\text { V2 PELO REFERIDO KM VEIO A SE DEPARAR } \\
\text { COM PEDESTRE ATRAVESSANDO A PISTA } \\
\text { CARREGANDO UM COLCHÃO NOS BRAÇOS, } \\
\text { CONDUTOR NÃO TEVE TEMPO DE FRENAR E } \\
\text { MESMO AO TENTAR DESVIO ATINGIU } \\
\text { LATERAL TRASEIRA DO VEICULO NO } \\
\text { PEDRESTRE CAUSANDO O } \\
\text { ATROPELAMENTO.;Causa Provável: } 410 \text { Pedestre } \\
\text { na pista }\end{array}$ \\
\hline 19/12/2010 & dom & $18: 10$ & PED & Grave & ViaOeste & 270 & 64,7 & Leste & P.Simples & principal & $\begin{array}{l}\text { Conforme informações colhida no local V02 } \\
\text { trafegava pela pista leste quando no referido km } \\
\text { deparou-se com o pedestre e sem tempo hábil } \\
\text { parafrenagem veio atropela-lo e ambos ficaram } \\
\text { caidos sobre faixa em seguida V03 colidiu contra } \\
\text { V02. }\end{array}$ \\
\hline
\end{tabular}




\begin{tabular}{|c|l|l|l|l|l|l|l|l|l|l|l|}
\hline Data & $\begin{array}{c}\text { Dia da } \\
\text { Semana }\end{array}$ & Hora & $\begin{array}{c}\text { Tipo de } \\
\text { acidente }\end{array}$ & $\begin{array}{c}\text { Gravidade } \\
\text { do acidente }\end{array}$ & Concessionária & Rod & km & Sentido & $\begin{array}{l}\text { Tipo de } \\
\text { área }\end{array}$ & Pista & Detalhe do Acidente \\
\hline 13/1/2011 & qui & $19: 01$ & PED & Leve & ViaOeste & 270 & 63,5 & Oeste & P.Simples & $\begin{array}{l}\text { segundo informações colhidas no local, v1 ao atingir } \\
\text { o citado km, veio a se deparar com a usuaria fazendo } \\
\text { a travessia da pista sem tempo habil para } \\
\text { a frenagem ou desvio, veio a atropelar a mesma. }\end{array}$ \\
\hline $23 / 3 / 2011$ & qua & $21: 41$ & PED & Fatal & ViaOeste & 270 & 64,6 & Oeste & P.Simples & $\begin{array}{l}\text { Conforme informações da PMR, por motivo a serem } \\
\text { apurados, a vitima deslocava entre faixa 02 e } \\
\text { acostamento, quando veio a ser atropelado por } \\
\text { um veículo de dados ignorados que evadiu-se do } \\
\text { local. }\end{array}$ \\
\hline 2/5/2011 & seg & $23: 36$ & PED & Grave & ViaOeste & 270 & 57 & Oeste & P.Simples & $\begin{array}{l}\text { CONFORME INFORMAÇÕES COLHIDAS NO } \\
\text { LOCAL, V2 TRAFEGAVA PISTA OESTE } \\
\text { QUANDO NO CITADO KM SER DEPAROU } \\
\text { COM A PEDESTRE ANDANDO SOBRE FAIXA E } \\
\text { SEM } \\
\text { TEMPO HÁBIL DE FREAR OU DESVIAR VEIO } \\
\text { A ATROPELAR A PEDESTRE.;Causa Provável: } \\
\text { 4110 Pedestre na pista }\end{array}$ \\
\hline
\end{tabular}




\begin{tabular}{|c|l|l|l|l|l|l|l|l|l|l|l|}
\hline Data & $\begin{array}{c}\text { Dia da } \\
\text { Semana }\end{array}$ & Hora & $\begin{array}{c}\text { Tipo de } \\
\text { acidente }\end{array}$ & $\begin{array}{c}\text { Gravidade } \\
\text { do acidente }\end{array}$ & Concessionária & Rod & km & Sentido & $\begin{array}{l}\text { Tipo de } \\
\text { área }\end{array}$ & Pista & Detalhe do Acidente \\
\hline $29 / 8 / 2011$ & seg & $20: 37$ & PED & Grave & ViaOeste & 270 & 63 & Leste & P.Simples & $\begin{array}{l}\text { Conforme informação colhidas com os envolvidos, } \\
\text { v02 trafegava sobre faixa 01 momento que se } \\
\text { deparou com v01(pedestre) atravessando de leste } \\
\text { para oeste, não tendo tempo hábil para a frenagem, } \\
\text { veio a atropelar o v01 e na sequencia sofrer o } \\
\text { tombamento sobre faixa. }\end{array}$ \\
\hline $14 / 9 / 2011$ & qua & $22: 20$ & PED & Leve & ViaOeste & 270 & 65 & Oeste & P.Simples & $\begin{array}{l}\text { Conforme informação prestada pelo condutor do v02 } \\
\text { (moto), trafegava sobre faixa 02 momento que v01 } \\
\text { (pedestre) atravessou a pista sem a devida } \\
\text { atenção, v02 não tendo tempo hábil para frenagem } \\
\text { vindo a atropelar v02 que caiu sobre faixa 02. }\end{array}$ \\
\hline 22/9/2011 & qui & $17: 48$ & PED & Moderado & ViaOeste & 270 & 58 & Oeste & P.Simples & $\begin{array}{l}\text { Conforme informações prestadas pelos envolvidos, } \\
\text { v02 (pedestre) trafegava pelo acostamento e v01 } \\
\text { (motocicleta) trafega sobre faixa 01 momento } \\
\text { que v01 realizou uma ultrapassagem pela direita } \\
\text { utilizando o acostamento, quando se deparou com } \\
\text { v02 e não tendo tempo hábil para a frenagem } \\
\text { vindo a atropelar v02. }\end{array}$ \\
\hline
\end{tabular}




\begin{tabular}{|c|c|c|c|c|c|c|c|c|c|c|c|}
\hline Data & $\begin{array}{c}\text { Dia da } \\
\text { Semana }\end{array}$ & Hora & $\begin{array}{c}\text { Tipo de } \\
\text { acidente }\end{array}$ & $\begin{array}{l}\text { Gravidade } \\
\text { do acidente }\end{array}$ & Concessionária & Rod & km & Sentido & $\begin{array}{l}\text { Tipo de } \\
\text { área }\end{array}$ & Pista & Detalhe do Acidente \\
\hline $14 / 3 / 2005$ & seg & 6:54 & PED & Leve & ViaOeste & 280 & 25 & Leste & P.Dupla & principal & $\begin{array}{l}\text { INFORMAÇÕES OBTIDAS NO LOCAL, QUE O } \\
\text { CONDUTOR DO V1 TRAFEGANDO NA FAIXA } \\
\text { DE BORDO AO LADO DA FAIXA 0 1, NÃO } \\
\text { VISUALIZOU O PEDESTRE NA FAIXA DE } \\
\text { BORDO VINDO A COLHER O MESMO, } \\
\text { SENDO OS INDIVIDUOS ARREMESSADO NA } \\
\text { FAIXA 01 JUNTAMENTE COM A MOTO. } \\
\end{array}$ \\
\hline $12 / 5 / 2005$ & qui & $7: 37$ & PED & Grave & ViaOeste & 280 & 27 & Leste & P.Dupla & principal & $\begin{array}{l}\text { SEGUNDO INFORMAÇÕES COLHIDAS NO } \\
\text { LOCAL, O PEDESTRE TENTOU CRUZAR A } \\
\text { RODOVIA SEM A DEVIDA ATENÇÃO E VEIO } \\
\text { A SER COLHIDO NA FAIXA 1 DE } \\
\text { ROLAMENTO PELA MOTOCICLETA, QUE } \\
\text { NÃO TEVE TEMPO HÁBIL PARA DESVIO OU } \\
\text { FRENAGEM. }\end{array}$ \\
\hline 30/9/2005 & $\operatorname{sex}$ & $17: 12$ & PED & Grave & ViaOeste & 280 & 32 & Oeste & P.Dupla & principal & $\begin{array}{l}\text { ???? DADOS PREJUDICADOS. VEÍCULO } \\
\text { ATROPELANTE EVADIU-SE DO LOCAL E } \\
\text { VÍTIMA INCONSCIENTE ENCONTRADA } \\
\text { PELA PISTA REMOVIDA AO HOSPITAL } \\
\text { REGIONAL DE OSASCO PELA VIATURA DA } \\
\text { VIAOESTE. } \\
\end{array}$ \\
\hline
\end{tabular}




\begin{tabular}{|c|c|c|c|c|c|c|c|c|c|c|c|}
\hline Data & $\begin{array}{c}\text { Dia da } \\
\text { Semana }\end{array}$ & Hora & $\begin{array}{c}\text { Tipo de } \\
\text { acidente }\end{array}$ & $\begin{array}{l}\text { Gravidade } \\
\text { do acidente }\end{array}$ & Concessionária & Rod & km & Sentido & $\begin{array}{l}\text { Tipo de } \\
\text { área }\end{array}$ & Pista & Detalhe do Acidente \\
\hline $10 / 10 / 2005$ & seg & $1: 17$ & PED & Grave & ViaOeste & 280 & 32 & Leste & P.Dupla & principal & $\begin{array}{l}\text { INFORMAÇÕES PRESTADAS PELO } \\
\text { CONDUTOR DA CARRETA, TRAFEGAVA } \\
\text { FAIXA 3, MOMENTO EM QUE VISUALIZOU O } \\
\text { PEDESTRE NO ACOSTAMENTO E SEM } \\
\text { MOTIVO APARENTE, O PEDESTRE } \\
\text { AVANÇOU PARA A FAIXA 3 SENDO } \\
\text { COLHIDO PELA CARRETA, PARANDO } \\
\text { ENVOLVIDOS NO ACOSTAMENTO. } \\
\end{array}$ \\
\hline $20 / 11 / 2005$ & dom & $12: 42$ & PED & Leve & ViaOeste & 280 & 34 & Leste & P.Dupla & principal & $\begin{array}{l}\text { O CONDUTOR DO VEÍCULO ATROPELANTE } \\
\text { INFORMA QUE ESTAVA DESLOCANDO PELA } \\
\text { FAIXA 03, E QUE, UM VEÍCULO MODELO } \\
\text { KADETT Â SUA FRENTE DESVIOU DE UM } \\
\text { PEDESTRE QUE ESTAVA NA FAIXA 03, ELE } \\
\text { NÃO TENDO TEMPO HÁBIL PARA DESVIAR } \\
\text { DO PEDESTRE VEIO ATROPELÁ-LO } \\
\text { FICANDO O PEDESTRE ENTRE A FAIXA } 03 \text { E } \\
\text { ACOSTAMENTO. }\end{array}$ \\
\hline
\end{tabular}




\begin{tabular}{|c|c|c|c|c|c|c|c|c|c|c|c|}
\hline Data & $\begin{array}{c}\text { Dia da } \\
\text { Semana }\end{array}$ & Hora & $\begin{array}{l}\text { Tipo de } \\
\text { acidente }\end{array}$ & $\begin{array}{l}\text { Gravidade } \\
\text { do acidente }\end{array}$ & Concessionária & Rod & km & Sentido & $\begin{array}{l}\text { Tipo de } \\
\text { área }\end{array}$ & Pista & Detalhe do Acidente \\
\hline $22 / 2 / 2006$ & qua & $11: 42$ & PED & Leve & ViaOeste & 280 & 28 & Oeste & P.Dupla & principal & $\begin{array}{l}\text { INFORMAÇÕES NO LOCAL QUE O PEDESTRE } \\
\text { ESTAVA NO CANTEIRO CENTRAL E AO } \\
\text { TENTAR ATRAVESSAR FOI COLHIDO NA } \\
\text { FAIXA 02, ONDE O PILOTO DA MOTO } \\
\text { SOFREU A QUEDA NA FAIXA 01. } \\
\end{array}$ \\
\hline $2 / 3 / 2006$ & qui & 18:37 & PED & Leve & ViaOeste & 280 & 32 & Oeste & P.Dupla & principal & $\begin{array}{l}\text { CONFORME INFORMAÇÕES DO CONDUTOR } \\
\text { DO V1, TRAFEGAVA PELO CITADO LOCAL, } \\
\text { SENTIDO ITAPEVI, QUANDO A VÍTIMA, SEM } \\
\text { OS DEVIDOS CUIDADOS ADENTROU A } \\
\text { FAIXA DE ROLAMENTO E MESMO AO } \\
\text { DESVIAR A LATERAL DO VEÍCULO VEIO A } \\
\text { ATROPELAR A VÍTIMA. }\end{array}$ \\
\hline $5 / 3 / 2006$ & dom & $5: 11$ & PED & Grave & ViaOeste & 280 & 29 & Oeste & P.Dupla & principal & $\begin{array}{l}\text { SEGUNDO INFORMADO, O VEÍCULO ÚNICO } \\
\text { TRAFEGAVA SENTIDO INTERIOR QUANDO } \\
\text { AO ATINGIR O REFERIDO KM DEPAROU-SE } \\
\text { COM O PEDESTRE ATRAVESSANDO A VIA E, } \\
\text { SEM TEMPO HÁBIL PARA DESVIO OU } \\
\text { FRENAGEM, VEIO A COLHÊ-LO NA FAIXA } 3 .\end{array}$ \\
\hline $15 / 4 / 2006$ & sab & $10: 29$ & PED & Grave & ViaOeste & 280 & 27 & Leste & P.Dupla & principal & $\begin{array}{l}\text { SEGUNDO INFORMAÇÕES COLHIDAS NO } \\
\text { LOCAL, A PEDESTRE E SEU NAMORADO } \\
\text { ATRAVESSAVAM DO CANTEIRO CENTRAL } \\
\text { PARA O ACOSTAMENTO E ELA DEIXOU SEU } \\
\text { CELULAR CAIR NA FAIXA 2; AO VOLTAR } \\
\text { PARA PEGÁ-LO, FOI COLHIDA PELO } \\
\text { VEÍCULO. }\end{array}$ \\
\hline $21 / 4 / 2006$ & $\operatorname{sex}$ & 19:43 & PED & Fatal & ViaOeste & 280 & 31 & Leste & P.Dupla & principal & $\begin{array}{l}\text { CONFORME INFORMAÇÕES DO CONDUTOR, } \\
\text { TRAFEGAVA PELA FAIXA } 1 \text { DE } \\
\text { ROLAMENTO E A VÍTIMA VEIO A } \\
\text { ADENTRAR A FAIXA } 1 \text { REPENTINAMENTE, } \\
\text { NÃO CONSEGUINDO FREIAR OU DESVIAR } \\
\text { OCORRENDO O ATROPELAMENTO. A } \\
\text { VÍTIMA JÁ CAÍDO SOBRE A PISTA FOI } \\
\text { ATROPELADO POR OUTROS VEÍCULOS QUE } \\
\text { SE EVADIRAM DO LOCAL. }\end{array}$ \\
\hline
\end{tabular}




\begin{tabular}{|c|c|c|c|c|c|c|c|c|c|c|c|}
\hline Data & $\begin{array}{c}\text { Dia da } \\
\text { Semana }\end{array}$ & Hora & $\begin{array}{c}\text { Tipo de } \\
\text { acidente }\end{array}$ & $\begin{array}{l}\text { Gravidade } \\
\text { do acidente }\end{array}$ & Concessionária & Rod & km & Sentido & $\begin{array}{l}\text { Tipo de } \\
\text { área }\end{array}$ & Pista & Detalhe do Acidente \\
\hline $12 / 5 / 2006$ & sex & $6: 48$ & PED & Leve & ViaOeste & 280 & 28 & Leste & P.Dupla & principal & $\begin{array}{l}\text { CONFORME INFORMAÇÕES DO CONDUTOR } \\
\text { DO VEÍCULO ATROPELANTE ELE ESTAVA } \\
\text { DESLOCANDO SENTIDO BAIRROX } \\
\text { CASTELLO MOMENTO QUE O PEDESTRE } \\
\text { SEM A DEVIDA ATENÇÃO VEIO A } \\
\text { ATRAVESSAR A PISTA SENDO } \\
\text { ATROPELADO E PROJETADO PARA O } \\
\text { ACOSTAMENTO, A VITIMA FOI REMOVIDA } \\
\text { EM ESTADO MODERADO PARA O REGINAL } \\
\text { DE OSASCO. }\end{array}$ \\
\hline $13 / 5 / 2006$ & sab & $18: 27$ & PED & Leve & ViaOeste & 280 & 29 & Oeste & P.Dupla & principal & $\begin{array}{l}\text { SEGUNDO INFORMADO, O VEÍCULO ÚNICO } \\
\text { TRAFEGAVA SENTIDO INTERIOR NA FAIXA } \\
1 \text { DE ROLAMENTO QUANDO AO ATINGIR O } \\
\text { REFERIDO KM DEPAROU-SE COM O } \\
\text { ANDARILHO NA FAIXA } 1 \text { E, SEM TEMPO } \\
\text { PARA DESVIO OU FRENAGEM, VEIO A } \\
\text { ATROPELÁ-LO, PROJETANDO-O PARA O } \\
\text { CANTEIRO CENTRAL.; }\end{array}$ \\
\hline $18 / 5 / 2006$ & qui & 18:57 & PED & Leve & ViaOeste & 280 & 35 & Oeste & P.Dupla & principal & $\begin{array}{l}\text { DESCRIÇÃO IGNORADA - INFORMAÇÕES } \\
\text { SOMENTE DO ACOMPANHANTE DA VÍTIMA } \\
\text { QUE DESLOCAVAM PARA O POSTO DO KM } \\
\text { 38 PELA PISTA LESTE E DECIDIRAM } \\
\text { ATRAVESSAR PARA PISTA OESTE E A } \\
\text { VÍTIMA FOI ATROPELADA POR UM } \\
\text { VEÍCULO, O QUAL NÃO SOUBE INFORMAR } \\
\text { SE FOI AP OU CA. }\end{array}$ \\
\hline
\end{tabular}




\begin{tabular}{|c|c|c|c|c|c|c|c|c|c|c|c|}
\hline Data & $\begin{array}{l}\text { Dia da } \\
\text { Semana }\end{array}$ & Hora & $\begin{array}{c}\text { Tipo de } \\
\text { acidente }\end{array}$ & $\begin{array}{l}\text { Gravidade } \\
\text { do acidente }\end{array}$ & Concessionária & Rod & km & Sentido & $\begin{array}{l}\text { Tipo de } \\
\text { área }\end{array}$ & Pista & Detalhe do Acidente \\
\hline 6/9/2006 & qua & $5: 52$ & PED & Grave & ViaOeste & 280 & 25 & Leste & P.Dupla & principal & $\begin{array}{l}\text { INFORMAÇÕES COLHIDAS NO LOCAL QUE } \\
\text { O ANDARILHO SAIU DO ACOSTAMENTO E } \\
\text { CRUZOU A PISTA REPENTINAMENTE } \\
\text { SENDO ATINGIDO PELO VEÍCULO NA FAIXA } \\
1 .\end{array}$ \\
\hline 6/9/2006 & qua & $8: 13$ & PED & Leve & ViaOeste & 280 & 30 & Leste & P.Dupla & principal & $\begin{array}{l}\text { CONFORME INFORMAÇÕES DOS } \\
\text { ENVOLVIDOS NO LOCAL O ANDARILHO } \\
\text { SAIU DO ACOSTAMENTO SENTIDO CANT. } \\
\text { CENTRAL E FOI ATINGIDO PELA MOTO NA } \\
\text { FAIXA } 2 .\end{array}$ \\
\hline $10 / 9 / 2006$ & dom & $12: 56$ & CIC & Leve & ViaOeste & 280 & 35 & Leste & P.Dupla & principal & $\begin{array}{l}\text { SEGUNDO INFORMAÇÕES, O CICLISTA } \\
\text { ENCONTRAVA-SE PELO ACOSTAMENTO, } \\
\text { QUANDO FOI ATINGIDO POR UM VEICULO } \\
\text { DE DADOS IGNORADOS ; }\end{array}$ \\
\hline $4 / 10 / 2006$ & qua & 18:11 & PED & Grave & ViaOeste & 280 & 27,5 & Leste & P.Dupla & principal & $\begin{array}{l}\text { SEGUNDO INFORMAÇÕES COLHIDAS NO } \\
\text { LOCAL, A MOTOCICLETA TRAFEGAVA } \\
\text { SENTIDO LESTE NA FAIXA } 1 \text { DE } \\
\text { ROLAMENTO QUANDO AO ATINGIR O } \\
\text { REFERIDO KM DEPAROU-SE COM O } \\
\text { PEDESTRE NA FAIXA ESQUERDA } \\
\text { REALIZANDO TRAVESSIA DO CANTEIRO } \\
\text { CENTRAL PARA O ACOSTAMENTO, ONDE } \\
\text { VEIO A COLHÊ-LO E SOFRER QUEDA. } \\
\end{array}$ \\
\hline $7 / 10 / 2006$ & sab & $18: 33$ & PED & Grave & ViaOeste & 280 & 27,4 & Leste & P.Dupla & principal & $\begin{array}{l}\text { DESCRIÇÃO PREJUDICADA, LOCALIZADO } \\
\text { PEDESTRE PELO ACOSTAMENTO VÍTIMA } \\
\text { DE ATROPELAMENTO. REMOVIDO AO } \\
\text { REGIONAL DE OSASCO EM ESTADO GRAVE. }\end{array}$ \\
\hline
\end{tabular}




\begin{tabular}{|c|c|c|c|c|c|c|c|c|c|c|c|}
\hline Data & $\begin{array}{c}\text { Dia da } \\
\text { Semana }\end{array}$ & Hora & $\begin{array}{c}\text { Tipo de } \\
\text { acidente }\end{array}$ & $\begin{array}{l}\text { Gravidade } \\
\text { do acidente }\end{array}$ & Concessionária & Rod & km & Sentido & $\begin{array}{l}\text { Tipo de } \\
\text { área }\end{array}$ & Pista & Detalhe do Acidente \\
\hline $11 / 10 / 2006$ & qua & $8: 35$ & PED & Leve & ViaOeste & 280 & 30,9 & Leste & P.Dupla & principal & $\begin{array}{l}\text { SEGUNDO INFORMAÇÕES NO LOCAL O } \\
\text { MOTOQUEIRO ATROPELOU O PEDESTRE NA } \\
\text { FAIXA } 1 .\end{array}$ \\
\hline $19 / 10 / 2006$ & qui & $21: 45$ & PED & Fatal & ViaOeste & 280 & 32 & Leste & P.Dupla & principal & $\begin{array}{l}\text { INFORMAÇÕES PRESTADAS PELO } \\
\text { CONDUTOR DO V1, TRÁFEGAVA PISTA } \\
\text { LESTE PELA FAIXA UM DE ROLAMENTO, } \\
\text { MOMENTO EM QUE DEPAROU-SE COM O } \\
\text { PEDESTRE ATRAVESSANDO A RODOVIA, } \\
\text { SEM TEMPO HÁBIL DE FRENAGEM OU } \\
\text { DESVIO, OCORRENDO O ATROPELAMENTO, } \\
\text { SENDO PEDESTRE LANÇADO NO CANTEIRO } \\
\text { CENTRAL E VEÍCULO ATROPELANTE } \\
\text { PARANDO NO ACOSTAMENTO. } \\
\end{array}$ \\
\hline $29 / 10 / 2006$ & dom & 19:15 & PED & Fatal & ViaOeste & 280 & 27,5 & Leste & P.Dupla & principal & $\begin{array}{l}\text { SEGUNDO INFORMAÇÕES NO LOCAL, V01 } \\
\text { TRAFEGAVA PELA FAIXA } 1 \text { QUANDO } \\
\text { DEPAROU-SE COM PEDESTRES TENTANDO } \\
\text { ATRAVESSAR A RODOVIA. SEM TEMPO } \\
\text { HÁBIL PARA FREIAR VEIO A ATROPELAR A } \\
\text { VÍTIMA QUE FOI ARREMESSADA PARA O } \\
\text { CANTEIRO CENTRAL. MULHER DA VÍTIMA } \\
\text { QUE TENTAVA ATRAVESSAR JUNTO NADA } \\
\text { SOFREU. V01 PAROU PELA CASA DO } \\
\text { USUÁRIO. }\end{array}$ \\
\hline
\end{tabular}




\begin{tabular}{|c|c|c|c|c|c|c|c|c|c|c|c|}
\hline Data & $\begin{array}{l}\text { Dia da } \\
\text { Semana }\end{array}$ & Hora & $\begin{array}{c}\text { Tipo de } \\
\text { acidente }\end{array}$ & $\begin{array}{l}\text { Gravidade } \\
\text { do acidente }\end{array}$ & Concessionária & Rod & km & Sentido & $\begin{array}{l}\text { Tipo de } \\
\text { área }\end{array}$ & Pista & Detalhe do Acidente \\
\hline $11 / 11 / 2006$ & sab & $1: 10$ & PED & Leve & ViaOeste & 280 & 27 & Leste & P.Dupla & principal & $\begin{array}{l}\text { INFORMADO PELO CONDUTOR DO V1, } \\
\text { TRAFEGAVA PELA FAIXA } 2 \text { DE } \\
\text { ROLAMENTO, MOMENTO EM QUE } \\
\text { DEPAROU-SE COM PEDESTRE } \\
\text { ATRAVESSANDO A PISTA, FREIANDO } \\
\text { BRUSCAMENTE, PORÉM AINDA ATINGIU O } \\
\text { PEDESTRE QUE TEVE SOMENTE ALGUMAS } \\
\text { ESCORIAÇÕES. }\end{array}$ \\
\hline $4 / 12 / 2006$ & seg & $0: 52$ & PED & Fatal & ViaOeste & 280 & 27,7 & Leste & P.Dupla & principal & \begin{tabular}{|l|} 
CONFORME INFORMADO POR \\
TESTEMUNHAS, VÍTIMA FOI ATROPELADA \\
NA FAIXA 3 POR UM CAMINHÃO BRANCO \\
DE DADOS IGNORADOS.
\end{tabular} \\
\hline
\end{tabular}




\begin{tabular}{|c|c|c|c|c|c|c|c|c|c|c|c|}
\hline Data & $\begin{array}{c}\text { Dia da } \\
\text { Semana }\end{array}$ & Hora & $\begin{array}{l}\text { Tipo de } \\
\text { acidente }\end{array}$ & $\begin{array}{l}\text { Gravidade } \\
\text { do acidente }\end{array}$ & Concessionária & Rod & km & Sentido & $\begin{array}{l}\text { Tipo de } \\
\text { área }\end{array}$ & Pista & Detalhe do Acidente \\
\hline $4 / 1 / 2007$ & qui & $8: 35$ & PED & Leve & ViaOeste & 280 & 28 & Oeste & P.Dupla & principal & $\begin{array}{l}\text { ALEGA O FUNCIONÁRIO DA EMPRESA } \\
\text { VERDYCON, ELE TENTAVA ATRAVESSAR } \\
\text { AS FAIXAS DE ROLAMENTO DO } \\
\text { ACOSTAMENTO PARA O } \\
\text { CANTEIROCENTRAL, QUANDO FOI } \\
\text { COLHIDO NA FAIXA 01 POR UM VEÍCULO } \\
\text { DE DADOS IGNORADOS, O QUAL EM } \\
\text { SEGUIDA EVADIU-SE DO LOCAL. }\end{array}$ \\
\hline $26 / 1 / 2007$ & $\operatorname{sex}$ & $21: 12$ & PED & Grave & ViaOeste & 280 & 27,5 & Leste & P.Dupla & principal & $\begin{array}{l}\text { INFORMAÇÕES PRESTADAS PELA PMRV, } \\
\text { PEDESTRE TENTOU CRUZAR DO SENTIDO } \\
\text { LESTE PARA OESTE, MOMENTO EM QUE FOI } \\
\text { SURPREENDIDO NAFAIXA } 1 \text { DE } \\
\text { ROLAMENTO DA PISTA LESTE PELA PICK } \\
\text { UP QUE SEM TEMPO HÁBIL DE FRENAGEM } \\
\text { OU DESVIO VEIO A ATROPELAR O } \\
\text { PEDESTRE. }\end{array}$ \\
\hline $30 / 1 / 2007$ & ter & $14: 57$ & PED & Grave & ViaOeste & 280 & 35 & Oeste & P.Dupla & principal & $\begin{array}{l}\text { SEGUNDO INFORMAÇÕES COLHIDAS PELO } \\
\text { LOCAL, O PEDESTRE ATRAVESSAVA A } \\
\text { RODOVIA DA OESTE PARA A LESTE } \\
\text { QUANDO FOI COLHIDO PORUM CA DE } \\
\text { DADOS IGNORADOS PELA FAIXA 3. O CA } \\
\text { EVADIU-SE E O PEDESTRE ESTAVA SEM } \\
\text { DOCUMENTOS E NÃO APARENTAVA SER } \\
\text { ANDARILHO,PORÉM POSTERIORMENTE } \\
\text { CONFESSOU AO MÉDICO QUE HAVIA } \\
\text { BEBIDO. }\end{array}$ \\
\hline $16 / 2 / 2007$ & $\operatorname{sex}$ & $12: 07$ & PED & Grave & ViaOeste & 280 & 27 & Oeste & P.Dupla & principal & $\begin{array}{l}\text { SEGUNDO INFORMADO, O PEDESTRE } \\
\text { (CATADOR DE LATINHAS) ESTAVA NO } \\
\text { CANTEIRO CENTRAL E PULOU A DEFENSA } \\
\text { PARA A FAIXA } 1 \text { ONDE FOICOLHIDO PELO } \\
\text { VW GOLF. }\end{array}$ \\
\hline
\end{tabular}




\begin{tabular}{|c|c|c|c|c|c|c|c|c|c|c|c|}
\hline Data & $\begin{array}{c}\text { Dia da } \\
\text { Semana }\end{array}$ & Hora & $\begin{array}{l}\text { Tipo de } \\
\text { acidente }\end{array}$ & $\begin{array}{l}\text { Gravidade } \\
\text { do acidente }\end{array}$ & Concessionária & Rod & km & Sentido & $\begin{array}{c}\text { Tipo de } \\
\text { área }\end{array}$ & Pista & Detalhe do Acidente \\
\hline 6/3/2007 & ter & 7:36 & PED & Leve & ViaOeste & 280 & 30,5 & Leste & P.Dupla & principal & $\begin{array}{l}\text { CONFORME INFORMAÇÕES DO PILOTO DA } \\
\text { MOTO O CONDUTOR SAIU DO CANTEIRO } \\
\text { PARA A FAIXA } 1 \text { NA FRENTE DA MOTO, } \\
\text { VINDO A SER ATROPELADO. } \\
\end{array}$ \\
\hline $23 / 3 / 2007$ & sex & $21: 24$ & CIC & Fatal & ViaOeste & 280 & 25 & Oeste & P.Dupla & principal & $\begin{array}{l}\text { INFORMAÇÕES PRESTADAS PELA PMRV, O } \\
\text { CICLISTA TRAFEGAVA PELO } \\
\text { ACOSTAMENTO, MOMENTO QUE POR } \\
\text { MOTIVOS IGNORADOS, UM CAMINHÃO } \\
\text { ADENTROU O ACOSTAMENTO } \\
\text { ATROPELANDO O PEDESTRE. }\end{array}$ \\
\hline $25 / 4 / 2007$ & qua & $5: 20$ & PED & Leve & ViaOeste & 280 & 32 & Leste & P.Dupla & principal & $\begin{array}{l}\text { Informações prestadas pela PMR'v, Condutor do v1 } \\
\text { não percebeu que v2 caminhava pela faixa de bordo } \\
\text { da pista do retorno, vindo a ocorrer o } \\
\text { atropelamento. }\end{array}$ \\
\hline 8/7/2007 & dom & $8: 23$ & PED & Leve & ViaOeste & 280 & 28,4 & Oeste & P.Dupla & principal & $\begin{array}{l}\text { SEGUNDO INFORMAÇÕES COLHIDAS NO } \\
\text { LOCAL, O V2 ESTAVA PARADO NO } \\
\text { ACOSTAMENTO ONDE UM DOS } \\
\text { PASSAGEIROS FECHAVA A TAMPA } \\
\text { TRASEIRA DO AUTOMÓVEL QUE HAVIA } \\
\text { ABERTO ESPONTANEAMENTE. O V1, QUE } \\
\text { TRAFEGAVA SENTIDO INTERIOR NA FAIXA } \\
\text { 2 DE ROLAMENTO, TEVE UM PNEU } \\
\text { TRASEIRO FURADO E SEM CONTROLE DE } \\
\text { DIREÇÃO, INVADIU O ACOSTAMENTO E } \\
\text { ATROPELOU O PASSAGEIRO DO V2. }\end{array}$ \\
\hline
\end{tabular}




\begin{tabular}{|c|c|c|c|c|c|c|c|c|c|c|c|}
\hline Data & $\begin{array}{l}\text { Dia da } \\
\text { Semana }\end{array}$ & Hora & $\begin{array}{c}\text { Tipo de } \\
\text { acidente }\end{array}$ & $\begin{array}{l}\text { Gravidade } \\
\text { do acidente }\end{array}$ & Concessionária & Rod & km & Sentido & $\begin{array}{l}\text { Tipo de } \\
\text { área }\end{array}$ & Pista & Detalhe do Acidente \\
\hline $5 / 8 / 2007$ & dom & $15: 37$ & PED & Leve & ViaOeste & 280 & 30 & Oeste & P.Dupla & principal & $\begin{array}{l}\text { CONFORME INFORMAÇÕES DO CONDUTOR, } \\
\text { TRAFEGAVA PELA FAIXA } 2 \text { DE } \\
\text { ROLAMENTO, MOMENTO EM QUE } \\
\text { SURPREENDEU-SE COM A VÍTIMA } \\
\text { ATRAVESSANDO A PISTA E NA TENTATIVA } \\
\text { DE EVITAR O ATROPELAMENTO, DESVIOU } \\
\text { PARA A FAIXA } 1 \text { DE ROLAMENTO, MESMO } \\
\text { TRAJETO REALIZADO PELA VÍTIMA, VINDO } \\
\text { A OCORRER O ATROPELAMENTO. }\end{array}$ \\
\hline 4/9/2007 & ter & $16: 49$ & PED & Grave & ViaOeste & 280 & 30 & Oeste & P.Dupla & principal & $\begin{array}{l}\text { SEGUNDO INFORMA O CONDUTOR DO V1, } \\
\text { TRANSITAVA NA FAIXA } 1 \text { QUANDO, } \\
\text { DEPAROU-SE COM O PEDESTRE NA FAIXA } 1 \\
\text { E, SEM TEMPO HÁBIL PARA FRENAR, VEIO } \\
\text { A CHOCAR-SE CONTRA. }\end{array}$ \\
\hline 7/9/2007 & sex & $0: 23$ & PED & Grave & ViaOeste & 280 & 34,4 & Oeste & P.Dupla & principal & $\begin{array}{l}\text { ALEGAÇÃO DO CONDUTOR DO VEÍCULO } \\
\text { QUE PEDESTRE ATRAVESSAVA DO } \\
\text { CANTEIRO CENTRAL PARA ACOSTAMENTO } \\
\text { SENDO COLHIDO NA FAIXA 03 E } \\
\text { ARREMESSADO PARA ACOSTAMENTO. } \\
\end{array}$ \\
\hline $15 / 9 / 2007$ & sab & 19:39 & PED & Fatal & ViaOeste & 280 & 28,5 & Oeste & P.Dupla & principal & $\begin{array}{l}\text { SEGUNDO INFORMAÇÕES, A VITIMA } \\
\text { ATRAVESSAVA DO ACOSTAMENTO PARA O } \\
\text { CANTEIRO CENTRAL, MOMENTO EM QUE } \\
\text { FOI COLHIDA POR UM VEÍCULO QUE } \\
\text { EVADIU-SE. EM SEGUIDA OUTROS } \\
\text { VEÍ́CULOS TAMBÉM PASSARAM SOBRE O } \\
\text { CORPO, E NÃO PARARAM. (APENAS OS } 2 \\
\text { VEÍCULOS REGISTRADOS PARARAM NO } \\
\text { LOCAL). }\end{array}$ \\
\hline
\end{tabular}




\begin{tabular}{|c|c|c|c|c|c|c|c|c|c|c|c|}
\hline Data & $\begin{array}{c}\text { Dia da } \\
\text { Semana }\end{array}$ & Hora & $\begin{array}{c}\text { Tipo de } \\
\text { acidente }\end{array}$ & $\begin{array}{l}\text { Gravidade } \\
\text { do acidente }\end{array}$ & Concessionária & Rod & km & Sentido & $\begin{array}{l}\text { Tipo de } \\
\text { área }\end{array}$ & Pista & Detalhe do Acidente \\
\hline $25 / 10 / 2007$ & qui & 7:34 & PED & Leve & ViaOeste & 280 & 30 & Leste & P.Dupla & principal & $\begin{array}{l}\text { SEGUNDO INFORMA O CONDUTOR DO V1, } \\
\text { TRANSITAVA ENTRE FAXA } 1 \text { E BORDO } \\
\text { QUANDO, O PEDESTRE ADENTROU A } \\
\text { FAIXA de BORDO PARA TENTATIVA DE } \\
\text { TRAVESSIA E V1, SEM TEMPO HÁBIL PARA } \\
\text { FRENAR VEIO A ATROPELAR O PEDESTRE, } \\
\text { PERDENDO O CONTROLE DO VEÍCULO E } \\
\text { COLIDINDO NA LATERAL DO V3. } \\
\end{array}$ \\
\hline $30 / 10 / 2007$ & ter & $7: 16$ & PED & Leve & ViaOeste & 280 & 25 & Oeste & P.Dupla & principal & $\begin{array}{l}\text { INFORMAÇÕES DA PMRV QUE USUÁRIO AO } \\
\text { TENTAR ATRAVESSAR } 200 \text { MTS PRÓXIMO } \\
\text { DA PASSARELA FOI COLHIDO POR UM } \\
\text { VEICULO IGNORADO NA FAIXA 03. } \\
\end{array}$ \\
\hline $21 / 12 / 2007$ & sex & $6: 34$ & PED & Fatal & ViaOeste & 280 & 25,8 & Oeste & P.Dupla & principal & $\begin{array}{l}\text { SEGUNDO INFORMA O AJUDANTE NO } \\
\text { LOCAL, ESTAVAM PARADO NO } \\
\text { ACOSTAMENTO COM O V3 ARRUMANDO A } \\
\text { LONA QUANDO, V1 VEIO A ATROPELAR O } \\
\text { CONDUTOR DO V3 NO ACOSTAMENTO, } \\
\text { EVADINDO-SE DO LOCAL LANÇANDO O } \\
\text { CONDUTOR NA FAIXA } 4 .\end{array}$ \\
\hline
\end{tabular}




\begin{tabular}{|c|c|c|c|c|c|c|c|c|c|c|c|}
\hline Data & $\begin{array}{c}\text { Dia da } \\
\text { Semana }\end{array}$ & Hora & $\begin{array}{l}\text { Tipo de } \\
\text { acidente }\end{array}$ & $\begin{array}{c}\text { Gravidade } \\
\text { do acidente }\end{array}$ & Concessionária & Rod & km & Sentido & $\begin{array}{c}\text { Tipo de } \\
\text { área }\end{array}$ & Pista & Detalhe do Acidente \\
\hline $13 / 4 / 2008$ & dom & $20: 34$ & PED & Leve & ViaOeste & 280 & 35 & Oeste & P.Dupla & principal & $\begin{array}{l}\text { SEGUNDO INFORMAÇÕES COLHIDAS NO } \\
\text { LOCAL, A VÍTIMA (TIAGO CERQUEIRA), } \\
\text { ESTAVA A PRINCÍPIO DENTRO DE UM } \\
\text { VEÍCULO QUE TRAFEGAVA SENTIDO } \\
\text { LESTE, NO INTERIOR DO QUAL ELE } \\
\text { DISCUTIU COM A NAMORADA. AO ATINGIR } \\
\text { O KM 35, ELES PARARAM NO } \\
\text { ACOSTAMENTO, E ELE, ETILIZADO, SAIU } \\
\text { DO VEÍCULO E TENTAVA ATRAVESSAR A } \\
\text { PISTA OESTE NO MOMENTO EM QUE FOI } \\
\text { COLHIDO PELO FIAT UNO. }\end{array}$ \\
\hline $17 / 4 / 2008$ & qui & $17: 55$ & PED & Grave & ViaOeste & 280 & 27,8 & Leste & P.Dupla & principal & $\begin{array}{l}\text { SEGUNDO INFORMAÇÕES COLHIDAS NO } \\
\text { LOCAL, O V1 TRAFEGAVA SENTIDO LESTE } \\
\text { NA FAIXA } 2 \text { QUANDO AO ATINGIR O } \\
\text { REFERIDO KM DEPAROU-SE COM O } \\
\text { PEDESTRE ATRAVESSANDO A PISTA DO } \\
\text { CANTEIRO CENTRAL PARA O } \\
\text { ACOSTAMENTO E, SEM TEMPO PARA } \\
\text { DESVIO OU FRENAGEM, VEIO A COLHÊ-LO } \\
\text { E PROJETÁ-LO PARA O ACOSTAMENTO. }\end{array}$ \\
\hline $7 / 6 / 2008$ & sab & $11: 46$ & PED & Fatal & ViaOeste & 280 & 26 & Leste & P.Dupla & principal & $\begin{array}{l}\text { INFORMAÇÕES DA TESTEMUNHA QUE } \\
\text { ESTAVA NO LOCAL, QUE A VÍTIMA ESTAVA } \\
\text { NO ACOSTAMENTO E QUE EM CERTO } \\
\text { MOMENTO SE JOGOU NA FRENTE DE UMA } \\
\text { CARRETA NA FAIXA 03, QUANDO O } \\
\text { CONDUTOR CONSEGUIU DESVIAR E O } \\
\text { VEICULO QUE SEGUIA ATRÁS DA CARRETA } \\
\text { SEM TEMPO PARA DESVIAR VEIO A } \\
\text { COLHER A VÍTIMA PELA FAIXA 03, } \\
\text { ENTRANDO EM ÓBITO NO LOCAL. }\end{array}$ \\
\hline
\end{tabular}




\begin{tabular}{|c|c|c|c|c|c|c|c|c|c|c|c|}
\hline Data & $\begin{array}{c}\text { Dia da } \\
\text { Semana }\end{array}$ & Hora & $\begin{array}{c}\text { Tipo de } \\
\text { acidente }\end{array}$ & $\begin{array}{l}\text { Gravidade } \\
\text { do acidente }\end{array}$ & Concessionária & Rod & km & Sentido & $\begin{array}{l}\text { Tipo de } \\
\text { área }\end{array}$ & Pista & Detalhe do Acidente \\
\hline $26 / 6 / 2008$ & qui & 18:57 & PED & Grave & ViaOeste & 280 & 29,8 & Oeste & P.Dupla & principal & $\begin{array}{l}\text { INFORMAÇÕES COLHIDAS NO LOCAL, } \\
\text { PEDESTRE TENTOU ATRAVESSAR A PISTA } \\
\text { OESTE DO CANTEIRO CENTRAL PARA O } \\
\text { CANTEIRO LATERAL, SENDO COLHIDO } \\
\text { PELO CAMINHÃO NA FAIXA } 3 \text { DE } \\
\text { ROLAMENTO. }\end{array}$ \\
\hline $8 / 7 / 2008$ & ter & $18: 20$ & PED & Fatal & ViaOeste & 280 & 30 & Oeste & P.Dupla & principal & $\begin{array}{l}\text { SEGUNDO INFORMAÇÕES, O PEDESTRE } \\
\text { ATRAVESSAVA A PISTA DO CANTEIRO } \\
\text { CENTRAL PARA O ACOSTAMENTO, } \\
\text { QUANDO FOI COLHIDO PELA MOTO NA } \\
\text { FAIXA 1. EM SEGUIDA O PILOTO DA MOTO } \\
\text { CAIU ENTRE O EIXO TRASEIRO DA CAR, E O } \\
\text { GARUPA NA FAIXA } 2 . \\
\end{array}$ \\
\hline $26 / 8 / 2008$ & ter & $8: 35$ & PED & Leve & ViaOeste & 280 & 30 & Oeste & P.Dupla & entrada & $\begin{array}{l}\text { INFORMAÇÕES NO LOCAL QUE O } \\
\text { PEDESTRE FOI AVISADO PARA FAZER A } \\
\text { TRAVESSIA POR UM USUÁRIO DE UMA } \\
\text { CARRETA DE DADOS IGNORADOS, } \\
\text { QUANDO O VEÍCULO QUE ESTAVA SAINDO } \\
\text { DA ALCCA DO POSTO DO KM } 30 \text { VEIO A } \\
\text { COLHER O PEDESTRE PELO } \\
\text { ACOSTAMENTO. }\end{array}$ \\
\hline $25 / 10 / 2008$ & sab & $4: 16$ & PED & Leve & ViaOeste & 280 & 25,5 & Oeste & P.Dupla & principal & \begin{tabular}{|l} 
SEGUNDO INFORMADO PELO SR. \\
FERNANDO, RESPONSÁVEL DA MANO \\
SINAL, ELEE E SUA EQUIPE INICIAVAM \\
LIBERAÇÃO DAS FAIXAS 3 E 4 QUANDO \\
MOTOCICLISTA INVADIU A SINALIZAÇÃO \\
VINDO A ATROPELAR 2 ( DOIS ) DE SEUS \\
FUNCIONÁRIOS. CONDUTOR DA MOTO EM \\
SEGUIDA SOFREU QUEDA SOBRE FAIXA 3.
\end{tabular} \\
\hline
\end{tabular}




\begin{tabular}{|c|c|c|c|c|c|c|c|c|c|c|c|}
\hline Data & $\begin{array}{c}\text { Dia da } \\
\text { Semana }\end{array}$ & Hora & $\begin{array}{c}\text { Tipo de } \\
\text { acidente }\end{array}$ & $\begin{array}{l}\text { Gravidade } \\
\text { do acidente }\end{array}$ & Concessionária & Rod & km & Sentido & $\begin{array}{l}\text { Tipo de } \\
\text { área }\end{array}$ & Pista & Detalhe do Acidente \\
\hline 20/11/2008 & qui & 20:54 & PED & Fatal & ViaOeste & 280 & 29 & Leste & P.Dupla & principal & $\begin{array}{l}\text { CONFORME INFORMAÇÕES DO CONDUTOR } \\
\text { DO V01, ELE TRAFEGAVA SENTIDO LESTE } \\
\text { NA FAIXA } 1 \text { QUANDO DEPAROU-SE COM } \\
\text { PEDESTRE E SEM TEMPO DE FREIAR OU } \\
\text { DESVIAR O ATROPELOU. }\end{array}$ \\
\hline $28 / 11 / 2008$ & sex & $17: 11$ & PED & Leve & ViaOeste & 280 & 31 & Oeste & P.Dupla & principal & $\begin{array}{l}\text { SEGUNDO INFORMAÇÕES COLHIDAS PELO } \\
\text { LOCAL PEDESTRE ATRAVESSAVA A PISTA, } \\
\text { QUANDO FOI COLHIDO PELO V01 PELA } \\
\text { FAIXA } 3 .\end{array}$ \\
\hline 20/12/2008 & sab & $19: 38$ & PED & Fatal & ViaOeste & 280 & 29,95 & Leste & P.Dupla & principal & $\begin{array}{l}\text { INFORMAÇÕES DO LOCAL QUE A SRA. } \\
\text { TELMA HAVIA DEIXADO SEU AUTOMÓVEL } \\
\text { NO POSTO GRAAL E FOI PARA UMA FESTA } \\
\text { DE CARONA. NA VOLTA, A CARONA } \\
\text { DEIXOU-A NA PISTA LESTE E QUANDO ELA } \\
\text { TENTOU ATRAVESSAR EM DIREÇÃO AO } \\
\text { POSTO, FOI COLHIDA NA FAIXA } 1 .\end{array}$ \\
\hline $21 / 12 / 2008$ & dom & $20: 26$ & PED & Grave & ViaOeste & 280 & 31,1 & Leste & P.Dupla & principal & $\begin{array}{l}\text { SEGUNDO INFORMAÇÕES COLHIDAS NO } \\
\text { LOCAL, O PEDESTRE TENTAVA } \\
\text { ATRAVESSAR DO CANTEIRO CENTRAL } \\
\text { PARA O ACOSTAMENTO DA PISTA LESTE } \\
\text { MOMENTO EM QUE FOI COLHIDO PELO V2 } \\
\text { NA FAIXA ESQUERDA. EM SEGUIDA, V3 } \\
\text { TAMBÉM O ATROPELOU. } \\
\end{array}$ \\
\hline $27 / 12 / 2008$ & sab & $21: 10$ & PED & Leve & ViaOeste & 280 & 33 & Oeste & P.Dupla & principal & $\begin{array}{l}\text { SEGUNDO INFORMAÇÕES COLHIDAS NO } \\
\text { LOCAL, A ARRECADADORA AO } \\
\text { ATRAVESSAR A PISTA DE MOTOS VEIO A } \\
\text { SER ATROPELADA POR V1. }\end{array}$ \\
\hline
\end{tabular}




\begin{tabular}{|c|c|c|c|c|c|c|c|c|c|c|c|}
\hline Data & $\begin{array}{l}\text { Dia da } \\
\text { Semana }\end{array}$ & Hora & $\begin{array}{c}\text { Tipo de } \\
\text { acidente }\end{array}$ & $\begin{array}{l}\text { Gravidade } \\
\text { do acidente }\end{array}$ & Concessionária & Rod & km & Sentido & $\begin{array}{l}\text { Tipo de } \\
\text { área }\end{array}$ & Pista & Detalhe do Acidente \\
\hline $10 / 1 / 2009$ & sab & $21: 31$ & PED & Fatal & ViaOeste & 280 & 27,5 & Oeste & P.Dupla & principal & $\begin{array}{l}\text { SEGUNDO INFORMAÇÕES COLHIDAS NO } \\
\text { LOCAL, O V1 TRAFGAVA SENTIDO } \\
\text { INTERIOR QUANDO AO ATINGIR O } \\
\text { REFERIDO KM DEPAROU-SE COM O } \\
\text { PEDESTRE NA FAIXA } 1 \text { E SEM TEMPO PARA } \\
\text { DESVIOU OU FRENAGEM, VEIO A } \\
\text { ATROPELÁ-LO. } \\
\end{array}$ \\
\hline $31 / 1 / 2009$ & sab & 6:51 & PED & Fatal & ViaOeste & 280 & 28,5 & Leste & P.Dupla & principal & $\begin{array}{l}\text { SEGUNDO INFORMAÇÕES COLHIDAS PELO } \\
\text { LOCAL V01 TRAFEGAVA FAIXA 1, QUANDO } \\
\text { DEPAROU-SE COM PEDESTRE } \\
\text { ATRAVESSANDO A RODOVIA, SEM TEMPO } \\
\text { PARA DESVIAR OU FREIAR VEIO } \\
\text { ATROPELÁ-LO, VÍTIMA FOI ARREMESSADA } \\
\text { PELO CANTEIRO CENTRAL. }\end{array}$ \\
\hline $26 / 2 / 2009$ & qui & $15: 18$ & PED & Leve & ViaOeste & 280 & 29 & Oeste & P.Dupla & principal & $\begin{array}{l}\text { INFORMAÇÕES COLHIDAS NO LOCAL QUE } \\
\text { O MORADOR ESTAVA NAS PROXIMIDADES } \\
\text { DO CANTEIRO LATERAL CONSUMINDO } \\
\text { BEBIDA ALCOÓLICA AO LADO DE UMA } \\
\text { CACHOEIRA E NA TENTATIVA DE } \\
\text { ATRAVESSAR DO ACOSTAMENTO PARA O } \\
\text { CANTEIRO CENTRAL FOI COLHIDO NA } \\
\text { FAIXA } 1 .\end{array}$ \\
\hline 3/3/2009 & ter & $20: 48$ & PED & Grave & ViaOeste & 280 & 25,8 & Oeste & P.Dupla & principal & $\begin{array}{l}\text { SEGUNDO INFORMADO PELO MOTORISTA } \\
\text { DO VEÍCULO ATROPELADOR, ELE } \\
\text { TRAFEGAVA SENTIDO OESTE NA FAIXA } 3 \\
\text { DE ROLAMENTO QUANDO AO ATINGIR O } \\
\text { REFERIDO KM ELE VISUALIZOU A } \\
\text { PEDESTRE PULAR A TELA DA BARREIRA } \\
\text { CENTRAL E ENTRAR NO MEIO DA PISTA, } \\
\text { UM CAMINHÃO DESVIO DELA PORÉM ELE, } \\
\text { QUE VINHA LOGO ATRÁS, NÃO ONSEGUIU } \\
\text { SAIR E VEIO A ATROPELÁ-LA. }\end{array}$ \\
\hline
\end{tabular}




\begin{tabular}{|c|c|c|c|c|c|c|c|c|c|c|c|}
\hline Data & $\begin{array}{c}\text { Dia da } \\
\text { Semana }\end{array}$ & Hora & $\begin{array}{l}\text { Tipo de } \\
\text { acidente }\end{array}$ & $\begin{array}{c}\text { Gravidade } \\
\text { do acidente }\end{array}$ & Concessionária & Rod & km & Sentido & $\begin{array}{l}\text { Tipo de } \\
\text { área }\end{array}$ & Pista & Detalhe do Acidente \\
\hline $3 / 4 / 2009$ & sex & $18: 55$ & PED & Leve & ViaOeste & 280 & 29,9 & Oeste & P.Dupla & principal & $\begin{array}{l}\text { SEGUNDO INFORMAÇÕES COLHIDAS NO } \\
\text { LOCAL, O TRÁFEGO ESTAVA LENTO NO } \\
\text { REFERIDO TRECHO E O PEDESTRE TENTOU } \\
\text { ATRAVESSAR DO CANTEIRO CENTRAL } \\
\text { PARA ACOSTAMENTO E APÓS PASSAR A } \\
\text { FAIXA 1, PAROU SOBRE A FAIXA } \\
\text { SECCIONADA. NESSE MOMENTO, ELE FOI } \\
\text { ATINGIDO PELA MOTO QUE TRANSITAVA } \\
\text { NO CORREDOR E NÃO CONSEGUIU } \\
\text { DESVIAR. APÓS O ATROPELAMENTO, A } \\
\text { VÍTIMA FOI PROJETADA CONTRA A } \\
\text { LATERAL DO ÔNIBUS QUE TAMBÉM FOI } \\
\text { COLIDIDO NA TRASEIRA PELO } \\
\text { MOTOQUEIRO QUE AINDA SOFREU QUEDA } \\
\text { AO SOLO. }\end{array}$ \\
\hline $27 / 5 / 2009$ & qua & $7: 32$ & PED & Leve & ViaOeste & 280 & 31 & Oeste & P.Dupla & principal & $\begin{array}{l}\text { SEGUNDO INFORMAÇÕES COLHIDAS PELO } \\
\text { LOCAL V01 TRAFEGAVA FAIXA } 2 \text { QUANDO } \\
\text { DEPAROU-SE COM PEDESTRE } \\
\text { ATRAVESSANDO A PISTA, SEM TEMPO } \\
\text { PARA DESVIAR OU FREIAR VEIO } \\
\text { ATROPELÁ-LO.;Causa Provável: } 410 \text { Pedestre na } \\
\text { pista }\end{array}$ \\
\hline $24 / 6 / 2009$ & qua & $19: 28$ & CIC & Fatal & ViaOeste & 280 & 33,5 & Leste & P.Dupla & principal & $\begin{array}{l}\text { CONFORME ALEGA O CONDUTOR DO V1, } \\
\text { UM CA DE DADOS IGNORADOS VEIO A } \\
\text { PASSAR PELO CICLISTA E AO BUZINAR, O } \\
\text { CICLISTA PERDEU O CONTROLE VINDO A } \\
\text { ADENTRAR A FAIXA } 3 \text { À FRENTE DE V1 } \\
\text { CAUSANDO O ATROPELAMENTO. VITIMA } \\
\text { LANÇADA PARA O CANTEIRO LATERAL } \\
\text { FICANDO A BICICLETA PELO } \\
\text { ACOSTAMENTO ;Causa Provável: } 601 \text { Ignorado }\end{array}$ \\
\hline
\end{tabular}




\begin{tabular}{|c|c|c|c|c|c|c|c|c|c|c|c|}
\hline Data & $\begin{array}{c}\text { Dia da } \\
\text { Semana }\end{array}$ & Hora & $\begin{array}{c}\text { Tipo de } \\
\text { acidente }\end{array}$ & $\begin{array}{l}\text { Gravidade } \\
\text { do acidente }\end{array}$ & Concessionária & Rod & km & Sentido & $\begin{array}{l}\text { Tipo de } \\
\text { área }\end{array}$ & Pista & Detalhe do Acidente \\
\hline $30 / 6 / 2009$ & ter & $0: 12$ & PED & Fatal & ViaOeste & 280 & 25,5 & Leste & P.Dupla & saída & $\begin{array}{l}\text { NESTE QTR FOI INFORMADO POR } \\
\text { USUARIOS, UMA PESSOA CAIDA PELA FX } \\
\text { DE DESACELERAÇÃO NA ALÇA DE ACESSO } \\
\text { PARA A SP280 NO KM 26. NO LOCAL UMA } \\
\text { VTR DO SAMU E DA GM DE BARUERI. } \\
\text { GAMA3 PELO LOCAL CONSTATOU ÓBITO } \\
\text { APÓS APROXIMADAMENTE 1H30 DE } \\
\text { ATENDIMENTO. CONSTATADO VITIMA DO } \\
\text { SEXO MASCULINO APARENTEMENTE } 22 \\
\text { ANOS VITIMA DE ATROPELAMENTO EM } \\
\text { QUE O VEICULO ATROPELANTE EVADIU-SE } \\
\text { DO LOCAL.;Causa Provável: } 601 \text { Ignorado }\end{array}$ \\
\hline $5 / 7 / 2009$ & dom & $0: 22$ & PED & Fatal & ViaOeste & 280 & 25,9 & Leste & P.Dupla & principal & $\begin{array}{l}\text { SEGUNDO INFORMAÇÕES COLHIDAS NO } \\
\text { LOCAL, O VEÍCULO FUSION TRAFEGAVA } \\
\text { NA SP-280 SENTIDO SÃO PAULO NA FAIXA } 1 \\
\text { DE ROLAMENTO QUANDO AO ATINGIR O } \\
\text { REFERIDO DEPAROU-SE COM O PEDESTRE } \\
\text { SOBRE A PISTA E, SEM TEMPO HÁBIL PARA } \\
\text { DESVIO OU FRENAGEM, VEIO A COLHÊ-LO. } \\
\text { A VÍTIMA ESTAVA JUNTO COM DOIS } \\
\text { PARENTES QUE ESTAVAM MUITO } \\
\text { ALTERADOS E NÃO SOUBERAM EXPLICAR } \\
\text { EXATAMENTE O QUE ELES FAZIAM NA } \\
\text { RODOVIA. ACIDENTE OCORRIDO A 50 } \\
\text { METROS DA PASSARELA. NÃO HAVIA } \\
\text { MARCAS DE FRENAGEM.;Causa Provável: } 410 \\
\text { Pedestre na pista } \\
\end{array}$ \\
\hline 18/7/2009 & sab & $6: 25$ & PED & Leve & ViaOeste & 280 & 32 & Leste & P.Dupla & saída & $\begin{array}{l}\text { SEGUNDO INFORMAÇÕES O PEDESTRE } \\
\text { SEGUIA ATRAVESSANDO A PISTA PELO } \\
\text { RETORNO, QUANDO POR MOTIVOS A } \\
\text { SEREM APURADOS, PAROU SOBRE A FAIXA } \\
\text { DE ROLAMENTO E V2 SEM TEMPO DE } \\
\text { FREAR ATROPELOU O PEDESTRE.;Causa } \\
\text { Provável: 410 Pedestre na pista } \\
\end{array}$ \\
\hline
\end{tabular}




\begin{tabular}{|c|c|c|c|c|c|c|c|c|c|c|c|}
\hline Data & $\begin{array}{c}\text { Dia da } \\
\text { Semana }\end{array}$ & Hora & $\begin{array}{l}\text { Tipo de } \\
\text { acidente }\end{array}$ & $\begin{array}{l}\text { Gravidade } \\
\text { do acidente }\end{array}$ & Concessionária & Rod & km & Sentido & $\begin{array}{l}\text { Tipo de } \\
\text { área }\end{array}$ & Pista & Detalhe do Acidente \\
\hline $11 / 9 / 2009$ & sex & $19: 46$ & PED & Fatal & ViaOeste & 280 & 26,7 & Leste & P.Dupla & principal & $\begin{array}{l}\text { SEGUNDO INFORMAÇÕES COLHIDAS NO } \\
\text { LOCAL, O VEÍCULO UNNICO TRAFEGAVA } \\
\text { SENTIDO SÃO PAULO NA FAIXA } 2 \text { DE } \\
\text { ROLAMENTO QUANDO AO ATINGIR O } \\
\text { REFERIDO KM A CONDUTORA DEPAROU-SE } \\
\text { COM O PEDESTRE ATRAVESSANDO A PISTA } \\
\text { E, SEM TEMPO HÁBIL PARA DESVIO OU } \\
\text { FRENAGEM, VEIO A ATROPELÁ-LO.;Causa } \\
\text { Provável: } 410 \text { Pedestre na pista } \\
\end{array}$ \\
\hline $8 / 10 / 2009$ & qui & $5: 20$ & PED & Grave & ViaOeste & 280 & 32 & Oeste & P.Dupla & principal & $\begin{array}{l}\text { SEGUNDO INFORMAÇÕ்ES COLHIDAS PELO } \\
\text { LOCAL PEDESTRE ATRAVESSOU A PISTA } \\
\text { DO ACOSTAMENTO LESTE SENTIDO A } \\
\text { PISTA OESTE, SENDO COLHIDA NA FAIXA } 1 \\
\text { DA PISTA LESTE PRÓXIMO A FAIXA DE } \\
\text { BORDO AO LADO DA BARREIRA DE } \\
\text { CONCRETO QUE DIVIDE A PISTA OESTE DA } \\
\text { PISTA LESTE.;Causa }\end{array}$ \\
\hline $2 / 12 / 2009$ & qua & $17: 25$ & PED & Leve & ViaOeste & 280 & 32 & Oeste & P.Dupla & principal & $\begin{array}{l}\text { SEGUNDO INFORMAÇÕES COLHIDAS PELO } \\
\text { LOCAL, O FUNCIONARIO QUE DIRIGIA O } \\
\text { ROLO COMPRESSOR NÃO VISUALIZOU, O } \\
\text { FUNCIONARIO QUE EXECUTAVA A OBRA } \\
\text { DEVIDO AO DESCUIDO VEIO A ATROPELAR } \\
\text { O MESMO.;Causa Provável: } 415 \text { Descuido do } \\
\text { motorista }\end{array}$ \\
\hline $20 / 12 / 2009$ & dom & $2: 00$ & PED & Fatal & ViaOeste & 280 & 29,1 & Leste & P.Dupla & principal & $\begin{array}{l}\text { SEGUNDO INFORMAÇÕES COLHIDAS NO } \\
\text { LOCAL, V02 TRAFEGAVA PELA FAIXA } 2 \text { AO } \\
\text { SE DEPARAR COM O PEDESTRE TENTANDO } \\
\text { FAZER A TRAVESSIA DO ACOSTAMENTO } \\
\text { PARA O CANTEIRO CENTRAL NÃO TEVE } \\
\text { TEMPO HABIL PARA O DESVIO } \\
\text { ATROPELANDO O MESMO.;Causa Provável: } \\
\text { 601 Ignorado }\end{array}$ \\
\hline
\end{tabular}




\begin{tabular}{|c|c|c|c|c|c|c|c|c|c|c|c|}
\hline Data & $\begin{array}{c}\text { Dia da } \\
\text { Semana }\end{array}$ & Hora & $\begin{array}{c}\text { Tipo de } \\
\text { acidente }\end{array}$ & $\begin{array}{l}\text { Gravidade } \\
\text { do acidente }\end{array}$ & Concessionária & Rod & km & Sentido & $\begin{array}{l}\text { Tipo de } \\
\text { área }\end{array}$ & Pista & Detalhe do Acidente \\
\hline $8 / 1 / 2010$ & sex & $21: 43$ & CIC & Leve & ViaOeste & 280 & 32 & Leste & P.Dupla & principal & $\begin{array}{l}\text { SEGUNDO INFORMAÇÕES DE USUARIO, AO } \\
\text { FAZER A TENTATIVA PARA TRAVESSIA O } \\
\text { MESMO VEIO A SER ATROPELADOPOR V1 } \\
\text { NA SEQUENCIA A PMR PELO LOCAL } \\
\text { DESLOCOU COM O CICLISTA E A } \\
\text { BICICLETA DISPENSANDO O V1.;Causa } \\
\text { Provável: } 603 \text { Ciclista na Pista } \\
\end{array}$ \\
\hline $17 / 1 / 2010$ & dom & $16: 39$ & PED & Grave & ViaOeste & 280 & 29 & Oeste & P.Dupla & principal & $\begin{array}{l}\text { SEGUNDO INFORMAÇÕES COLHIDAS NO } \\
\text { LOCAL, A CRIANÇA ESTAVA COM UM } \\
\text { GRUPO DE AMIGOS BRINCANDO EM UMA } \\
\text { CACHOEIRA LOCALIZADA PRÓXIMO DA } \\
\text { RODOVIA NAQUELE KM. NO MOMENTO EM } \\
\text { QUE RETORNAVA PARA CASA } \\
\text { ACOMPANHADA PELOS AMIGOS, TENTOU } \\
\text { ATRAVESSAR A RODOVIA } \\
\text { INADVERTIDAMENTE E VEIO A SER } \\
\text { COLHIDA PELO VEÍCULO PUNTO NA FAIXA } \\
1 \text { DE ROLAMENTO.;Causa Provável: } 410 \\
\text { Pedestre na pista }\end{array}$ \\
\hline $6 / 2 / 2010$ & sab & $13: 13$ & PED & Fatal & ViaOeste & 280 & 28,5 & Leste & P.Dupla & principal & $\begin{array}{l}\text { INFORMAÇÕES NO LOCAL JUNTO AO } \\
\text { POLICIAL RODOVIÁRIO SD FRIEDMAN, } \\
\text { COLHIDAS PELOS CONDUTORES DOS } \\
\text { VEÍCULOS ENVOLVIDO NO ACIDENTE, QUE } \\
\text { O VEÍCULO ATROPELANTE V1 TRAFEGAVA } \\
\text { NA FAIXA } 1 \text { E AO MUDAR DE FAIXA } \\
\text { PASSANDO PARA FAIXA } 2 \text { NÃO } \\
\text { VISUALIZOU O ANDARILHO A FRENTE, } \\
\text { VINDO A ATROPELAR-LO, EM SEGUIDA } \\
\text { ARREMESSANDO A VÍTIMA EM OUTRO } \\
\text { VEÍCULO V2 QUE TRAFEGAVA NA FAIXA } 1 \\
\text { QUE ARRASTOU A VÍTIMA } \\
\text { APROXIMADAMENTE } 50 \text { METROS A } \\
\text { FRENTE. ;Causa Provável: } 408 \text { Mudança de faixa }\end{array}$ \\
\hline
\end{tabular}




\begin{tabular}{|c|c|c|c|c|c|c|c|c|c|c|c|}
\hline Data & $\begin{array}{c}\text { Dia da } \\
\text { Semana }\end{array}$ & Hora & $\begin{array}{c}\text { Tipo de } \\
\text { acidente }\end{array}$ & $\begin{array}{c}\text { Gravidade } \\
\text { do acidente }\end{array}$ & Concessionária & Rod & km & Sentido & $\begin{array}{l}\text { Tipo de } \\
\text { área }\end{array}$ & Pista & Detalhe do Acidente \\
\hline $7 / 2 / 2010$ & dom & $21: 40$ & PED & Leve & ViaOeste & 280 & 32 & Leste & P.Dupla & principal & $\begin{array}{l}\text { SEGUNDO INFORMAÇÕES COLHIDAS NO } \\
\text { LOCAL, O PEDESTRE CAMINHAVA SOBRE } \\
\text { FAIXA } 2 \text { DE ROLAMENTO NO RETORNO KM } \\
\text { 32, SOB A CASTELLO SENTIDO } \\
\text { ITAPEVI/JANDIRA, QUANDO EM DADO } \\
\text { MOMENTO FOI ATINGIDO PELO } \\
\text { MOTOCICLISTA QUE TAMBÉM SOFREU } \\
\text { QUEDA AO SOLO.;Causa Provável: } 410 \text { Pedestre } \\
\text { na pista }\end{array}$ \\
\hline $12 / 3 / 2010$ & sex & $20: 57$ & PED & Fatal & ViaOeste & 280 & 25,6 & Oeste & P.Dupla & principal & $\begin{array}{l}\text { CONFORME INFORMAÇÕES DA PMR O } \\
\text { ATROPELAMENTO OCORREU PELA FAIXA } 3 \\
\text { DE ROLAMENTO E O VEICULO } \\
\text { ATROPELANTE EVADIU-SE DO LOCAL, } \\
\text {;Causa Provável: } 601 \text { Ignorado }\end{array}$ \\
\hline $6 / 5 / 2010$ & qui & $17: 00$ & PED & Fatal & ViaOeste & 280 & 30,5 & Oeste & P.Dupla & principal & $\begin{array}{l}\text { SEGUNDO INFORMAÇÕES PRESTADAS POR } \\
\text { LINDEIROS NO LOCAL, O V1 TRANSITAVA } \\
\text { NO SENTIDO OESTE QUANDO DEPAROU-SE } \\
\text { COM O PEDESTRE ATRAVESSANDO A VIA E } \\
\text { SEM TEMPO HÁBIL PARA DESVIAR, } \\
\text { ATINGIU O PEDESTRE NA FAIXA 2, } \\
\text { EVADINDO-SE DO LOCAL.;Causa Provável: } 601 \\
\text { Ignorado }\end{array}$ \\
\hline $7 / 5 / 2010$ & sex & 22:06 & PED & Fatal & ViaOeste & 280 & 33,5 & Leste & P.Dupla & principal & $\begin{array}{l}\text { SEGUNDO INFORMAÇÕES COLHIDAS NO } \\
\text { LOCAL O PEDESTRE ATRAVESSOU A VIA } \\
\text { DA PISTA LESTE PARA OESTE, NO INTUITO } \\
\text { DE INICIAR ATIVIDADES NO CENTRO DE } \\
\text { DISTRIBUIÇÃO DO CARREFOUR, QUANDO } \\
\text { FOI COLHIDO PELO V01 NA FAIXA 1 DA } \\
\text { PISTA LESTE. ;Causa Provável: } 410 \text { Pedestre na } \\
\text { pista }\end{array}$ \\
\hline
\end{tabular}




\begin{tabular}{|c|c|c|c|c|c|c|c|c|c|c|c|}
\hline Data & $\begin{array}{l}\text { Dia da } \\
\text { Semana }\end{array}$ & Hora & $\begin{array}{l}\text { Tipo de } \\
\text { acidente }\end{array}$ & $\begin{array}{l}\text { Gravidade } \\
\text { do acidente }\end{array}$ & Concessionária & Rod & km & Sentido & $\begin{array}{l}\text { Tipo de } \\
\text { área }\end{array}$ & Pista & Detalhe do Acidente \\
\hline $17 / 5 / 2010$ & seg & $7: 04$ & PED & Fatal & ViaOeste & 280 & 29,7 & Leste & P.Dupla & principal & $\begin{array}{l}\text { INFORMAÇÕES PRESTADAS PELA PMRV, O } \\
\text { PEDESTRE TENTAVA ATRAVESSAR A PISTA } \\
\text { LESTE DO CANTEIRO CENTRAL PARA O } \\
\text { ACOSTAMENTO, MOMENTO EM QUE PULOU } \\
\text { A DEFENSA METÁLICA NÃO PERCEBEU A } \\
\text { PRESENÇA DA MOTOCICLETA QUE } \\
\text { TRAFEGAVA PELA FAIXA } 1 \text { DE } \\
\text { ROLAMENTO OCORRENDO O } \\
\text { ATROPELAMENTO DO PEDESTRE E QUEDA } \\
\text { DO PILOTO DA MOTOCICLETA, PARANDO } \\
\text { ENVOLVIDOS ENTRE FAIXAS } 1 \text { E } 2 \text { DE } \\
\text { ROLAMENTO.;Causa Provável: } 410 \text { Pedestre na } \\
\text { pista }\end{array}$ \\
\hline $22 / 5 / 2010$ & sab & $7: 53$ & PED & Leve & ViaOeste & 280 & 32 & Leste & P.Dupla & principal & $\begin{array}{l}\text { SEGUNDO INFORMAÇÕES COLHIDAS NO } \\
\text { LOCAL O V01 SEGUIA DE ITAPEVI PARA A } \\
\text { SP280 QUANDO NO ACESSO AO VIADUTO } \\
\text { DO RETORNO O PEDESTRE FICOU INDECISO } \\
\text { ENTRE FAIXAS } 1 \text { E } 2 \text { E FOI COLHIDO POR } \\
\text { V01 QUE NÃO CONSEGUIU DESVIAR.;Causa } \\
\text { Provável: } 410 \text { Pedestre na pista }\end{array}$ \\
\hline $1 / 6 / 2010$ & ter & $21: 26$ & PED & Grave & ViaOeste & 280 & 27,5 & Oeste & P.Dupla & principal & $\begin{array}{l}\text { SEGUNDO INFORMAÇÕ̃ES COLHIDAS PELO } \\
\text { LOCAL PEDESTRE FOI LOCALIZADO } \\
\text { ATROPELADO PELO CANTEIRO } \\
\text { CENTRAL.;Causa Provável: } 601 \text { Ignorado }\end{array}$ \\
\hline $10 / 7 / 2010$ & sab & $18: 47$ & PED & Fatal & ViaOeste & 280 & 27,5 & Oeste & P.Dupla & principal & $\begin{array}{l}\text { SEGUNDO INFORMAÇÕES COLHIDAS PELO } \\
\text { LOCAL V01 TRAFEGAVA PELA FAIXA 1, } \\
\text { QUANDO DEPAROU-SE COM PEDESTRE } \\
\text { ATRAVESSANDO A PISTA, SEM TEMPO } \\
\text { PARA DESVIAR OU FREAR, VEIO } \\
\text { ATROPELÁ-LO.;Causa Provável: } 410 \text { Pedestre na } \\
\text { pista }\end{array}$ \\
\hline
\end{tabular}




\begin{tabular}{|c|c|c|c|c|c|c|c|c|c|c|c|}
\hline Data & $\begin{array}{c}\text { Dia da } \\
\text { Semana }\end{array}$ & Hora & $\begin{array}{c}\text { Tipo de } \\
\text { acidente }\end{array}$ & $\begin{array}{l}\text { Gravidade } \\
\text { do acidente }\end{array}$ & Concessionária & Rod & km & Sentido & $\begin{array}{l}\text { Tipo de } \\
\text { área }\end{array}$ & Pista & Detalhe do Acidente \\
\hline $27 / 8 / 2010$ & sex & 7:53 & PED & Leve & ViaOeste & 280 & 33 & Leste & P.Dupla & principal & \begin{tabular}{|l|} 
SEGUNDO INFORMAÇÕES COLHIDAS NO \\
LOCAL, O PEDESTRE ATRAVESSAVA A \\
PISTA ENTRE OS VEICULOS, V2 QUE \\
SEGUIA PELO CORREDOR AO DEPARAR-SE \\
COM O PEDESTRE NÃO CONSEGUIU \\
FRENAR OU DESVIAR E CHOCOU-SE \\
CONTRA O MESMO.;Causa Provável: 410 \\
Pedestre na pista \\
\end{tabular} \\
\hline $8 / 9 / 2010$ & qua & 7:21 & PED & Leve & ViaOeste & 280 & 27,8 & Leste & P.Dupla & principal & $\begin{array}{l}\text { SEGUNDO INFORMAÇÕES COLHIDAS NO } \\
\text { LOCAL, V1 SEGUIA PELO CORREDOR DE } \\
\text { MOTOS ENTRE AS FAIXAS 01 E 02, } \\
\text { MOMENTO EM QUE DEPAROU-SE COM } \\
\text { PEDESTRE ATRAVESSANDO A PISTA, SEM } \\
\text { TEMPO HÁBIL DE FRENAR OU DESVIAR } \\
\text { CHOCOU-SE CONTRA O PEDESTRE } \\
\text { ARREMEÇANDO-O PARA O BORDO DA } \\
\text { FAIXA 01.;Causa Provável: } 410 \text { Pedestre na pista } \\
\end{array}$ \\
\hline $4 / 11 / 2010$ & qui & $18: 13$ & PED & Leve & ViaOeste & 280 & 28,5 & Oeste & P.Dupla & principal & $\begin{array}{l}\text { SEGUNDO INFORMAÇÕES COLHIDAS PELO } \\
\text { LOCAL V01 TRAFEGAVA FAIXA 1, QUANDO } \\
\text { DEPAROU-SE COM PEDESTRE } \\
\text { ATRAVESSANDO A PISTA, SEM TEMPO } \\
\text { PARA FREAR OU DESVIAR, VEIO } \\
\text { ATROPELÁ-LO.;Causa Provável: } 410 \text { Pedestre na } \\
\text { pista }\end{array}$ \\
\hline $13 / 12 / 2010$ & seg & $7: 12$ & PED & Fatal & ViaOeste & 280 & 30 & Leste & P.Dupla & principal & $\begin{array}{l}\text { SEGUNDO INFORMAÇÕES COLHIDAS COM } \\
\text { UMA DAS VITIMAS, ELE E SEU } \\
\text { COMPANHEIRO DESCERAM DE ONIBUS NO } \\
\text { KM } 30 \text { LESTE, VINDO DE ASSIS, NO INTUITO } \\
\text { DE PEGAR CAMINHÃO DA EMPRESA QUE } \\
\text { ESTAVA ESTACIONADO NO POSTO KM } 30 \\
\text { OESTE. NATRAVESSIA ELE E SEU } \\
\text { COMPANHEIRO FORAM COLHIDOS PELO } \\
\text { V01,QUE SEGUIA NO CORREDOR ENTRE } \\
\text { FAIXA } 1 \text { E } 2 \text { DEVIDO AOTRAFEGO LENTO. }\end{array}$ \\
\hline
\end{tabular}




\begin{tabular}{|c|c|c|c|c|c|c|c|c|c|c|c|}
\hline Data & $\begin{array}{c}\text { Dia da } \\
\text { Semana }\end{array}$ & Hora & $\begin{array}{l}\text { Tipo de } \\
\text { acidente }\end{array}$ & $\begin{array}{c}\text { Gravidade } \\
\text { do acidente }\end{array}$ & Concessionária & Rod & km & Sentido & $\begin{array}{l}\text { Tipo de } \\
\text { área }\end{array}$ & Pista & Detalhe do Acidente \\
\hline $19 / 12 / 2010$ & dom & $21: 18$ & PED & Grave & ViaOeste & 280 & 26,1 & Leste & P.Dupla & principal & $\begin{array}{l}\text { segundo informações colhidas no local, } \mathrm{v} 2 \\
\text { trafegava pela faixa } 02 \text {, ao atingir o citado km veio } \\
\text { a se deparar com o usuario atravessando a pista } \\
\text { nosentido leste para oeste, sem tempo habil para a } \\
\text { frenagem ou desvio veio a atropelar o mesmo, } \\
\text { parando entre faixa } 01 \text { e } 02 \text {. }\end{array}$ \\
\hline $20 / 12 / 2010$ & seg & $17: 26$ & PED & Moderado & ViaOeste & 280 & 31 & Leste & P.Dupla & principal & $\begin{array}{l}\text { segundo informações colhidas no local, v01 } \\
\text { trafegava pela faixa } 01 \text {, ao atingir o citado km veio } \\
\text { a se deparar com o pedestre fazendo a travessia } \\
\text { dapista, sem tempo habil para a frenagem ou desvio } \\
\text { veio a atropela-lo. }\end{array}$ \\
\hline $20 / 12 / 2010$ & seg & 7:01 & PED & Grave & ViaOeste & 280 & 32,8 & Leste & P.Dupla & principal & $\begin{array}{l}\text { SEGUNDO INFORMAÇÕES COLHIDAS NO } \\
\text { LOCAL, A VÍTIMA TRATA-SE DE UM CHAPA } \\
\text { E ESTAVA DE PÉ NO ACOSTAMENTO } \\
\text { SINALIZANDOPARA OS CAMINHONEIROS, } \\
\text { QUANDO EM DADO MOMENTO O VEÍCULO } \\
\text { ATROPELADOR INVADIU O ACOSTAMENTO, } \\
\text { O ATINGIU EEVADIU-SE DO LOCAL. }\end{array}$ \\
\hline
\end{tabular}




\begin{tabular}{|c|c|c|c|c|c|c|c|c|c|c|c|}
\hline Data & $\begin{array}{l}\text { Dia da } \\
\text { Semana }\end{array}$ & Hora & $\begin{array}{c}\text { Tipo de } \\
\text { acidente }\end{array}$ & $\begin{array}{l}\text { Gravidade } \\
\text { do acidente }\end{array}$ & Concessionária & Rod & km & Sentido & $\begin{array}{l}\text { Tipo de } \\
\text { área }\end{array}$ & Pista & Detalhe do Acidente \\
\hline $20 / 1 / 2011$ & qui & $2: 13$ & PED & Fatal & ViaOeste & 280 & 29 & Leste & P.Dupla & principal & $\begin{array}{l}\text { SEGUNDO INFORMAÇÕES COLHIDAS COM } \\
\text { A PMRV O PEDESTRE ADENTROU A FAIXA } \\
\text { 03 GESTICULANDO COM AS MÃOS } \\
\text { SOLICITANDO } \\
\text { A PARADA DO V2, O V2 SEM TEMPO PARA } \\
\text { DESVIAR OU PARAR VEIO ATROPELÁ-LO. }\end{array}$ \\
\hline $2 / 6 / 2011$ & qui & $18: 38$ & CIC & Leve & ViaOeste & 280 & 30 & Leste & P.Dupla & principal & $\begin{array}{l}\text { SEGUNDO INFORMAÇÕES COLHIDAS NO } \\
\text { LOCAL, V1 TRAEGAVA PELA FAIXA 03, NÃO } \\
\text { VISUALIZOU O PEDESTRE QUE FAZIA A } \\
\text { TRAVESSIA EMPURRANDO UMA } \\
\text { BICICLETA, SEM TEMPO HABIL PARA O } \\
\text { DESVIO VEIO A ATROPELAR O } \\
\text { MESMO.;Causa Provável: } 410 \text { Pedestre na pista }\end{array}$ \\
\hline $26 / 6 / 2011$ & dom & $21: 26$ & PED & Moderado & ViaOeste & 280 & 30 & Leste & P.Dupla & principal & $\begin{array}{l}\text { SEGUNDO INFORMAÇÕES PRESTADA PELO } \\
\text { CONDUTOR DO V2, TRAFEGAVA PELA } \\
\text { FAIXA 01 QUANDO DEPAROU-SE COM O } \\
\text { PEDESTRE ATRAVESSANDO A PISTA, SEM } \\
\text { TEMPO HÁBIL DE FRENAR OU DESVIAR } \\
\text { CHOCOU O RETROVISSOR DO SEU VEICULO } \\
\text { CONTRA O PEDESTRE QUE CAIU SOBRE A } \\
\text { FAIXA 01.;Causa Provável: } 410 \text { Pedestre na pista }\end{array}$ \\
\hline $11 / 7 / 2011$ & seg & 19:29 & PED & Fatal & ViaOeste & 280 & 28,9 & Oeste & P.Dupla & principal & $\begin{array}{l}\text { SEGUNDO INFORMAÇÃO COLHIDA COM A } \\
\text { PMR, O V2 TRAFEGAVA PELA FAIXA 01, } \\
\text { QUANDO DEPAROU-SE COM O PEDESTRE } \\
\text { PELA MESMA FAIXA, NÃO CONSEGUIU } \\
\text { FRENAR OU DESVIAR E ATINGIU O } \\
\text { PEDESTRE, ARREMEÇANDO-O PARA O } \\
\text { BORDO DA FAIXA 01.;Causa Provável: } 410 \\
\text { Pedestre na pista }\end{array}$ \\
\hline
\end{tabular}




\begin{tabular}{|c|c|c|c|c|c|c|c|c|c|c|c|}
\hline Data & $\begin{array}{c}\text { Dia da } \\
\text { Semana }\end{array}$ & Hora & $\begin{array}{c}\text { Tipo de } \\
\text { acidente }\end{array}$ & $\begin{array}{c}\text { Gravidade } \\
\text { do acidente }\end{array}$ & Concessionária & Rod & km & Sentido & $\begin{array}{l}\text { Tipo de } \\
\text { área }\end{array}$ & Pista & Detalhe do Acidente \\
\hline 28/7/2011 & qui & $20: 18$ & PED & Moderado & ViaOeste & 280 & 29,8 & Leste & P.Dupla & principal & $\begin{array}{l}\text { SEGUNDO INFORMOU O CONDUTOR DO V2, } \\
\text { TRAFEGAVA PELA FAIXA 01 EM } \\
\text { VELOCIDADE MÉDIA DE } 90 \text { KM/H, } \\
\text {,MOMENTO EM QUE DEPAROU-SE COM O } \\
\text { PEDESTRE PELA MESMA FAIXA, SEM } \\
\text { TEMPO HÁBIL PARA FRENAR OU DESVIAR } \\
\text { VEIO A ATROPELÁ-LO, ARREMEÇANDO-O } \\
\text { PARA O BORDO DA FAIXA 01.;Causa Provável } \\
\text { 410 Pedestre na pista } \\
\end{array}$ \\
\hline $12 / 8 / 2011$ & $\operatorname{sex}$ & $3: 30$ & PED & Grave & ViaOeste & 280 & 30 & Leste & P.Dupla & principal & $\begin{array}{l}\text { SEGUNDO INFORMAÇÕES COLHIDAS NO } \\
\text { LOCAL V1 TRAFEGAVA PELA FAIXA 03 AO } \\
\text { SER FECHADO POR UM OUTRO CAMINHÃO } \\
\text { (DADOS } \\
\text { IGNORADOS) VEIO A PERDER O CONTROLE } \\
\text { CHOCANDO -SE CONTRA A DEFENSA } \\
\text { ATROPELANDO O PEDESTRE. }\end{array}$ \\
\hline $15 / 9 / 2011$ & qui & 7:16 & PED & Moderado & ViaOeste & 280 & 30 & Leste & P.Dupla & principal & $\begin{array}{l}\text { Segundo informações dos envolvidos, v2 seguia } \\
\text { pela faixa } 02 \text { quando no referido km, se deparou } \\
\text { com pedestre que após pular a tela de proteção } \\
\text { iniciava travessia da pista, fazendo então v2 não } \\
\text { conseguir o desvio e sofrer o atropelamento. }\end{array}$ \\
\hline $15 / 12 / 2011$ & qui & $15: 03$ & PED & Fatal & ViaOeste & 280 & 27 & Leste & P.Dupla & principal & $\begin{array}{l}\text { SEGUNDO INFORMAÇÃO COLHIDAS PELO } \\
\text { LOCAL,O VEICULO TRAFEGAVA SENTIDO } \\
\text { SÃO PAULO NA FAIXA } 1 \text { MOMENTO EM } \\
\text { QUE, POR } \\
\text { MOTIVO IGNORADO, ADENTROU } \\
\text { BRUSCAMENTE O CANTEIRO DE OBRAS } \\
\text { CHOCANDO SE CONTRA UMA MÁQUINA }\end{array}$ \\
\hline
\end{tabular}

